\title{
La América española: entre el Pacífico
}

y el Atlántico GLOBALIZACIÓN MERCANTIL Y ECONOMÍA POLÍTICA,

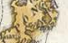

\section{I580-I840}
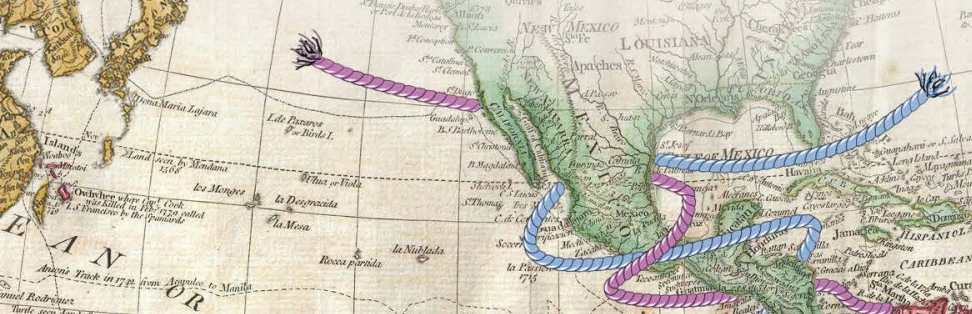




\section{LA AMÉRICA ESPAÑOLA: \\ ENTRE EL PACÍFICO Y EL ATLÁNTICO}

GLOBALIZACIÓN MERCANTIL Y ECONOMÍA POLÍTICA, 1580-1840 
CENTRO DE ESTUDIOS HISTÓRICOS 


\section{LA AMÉRICA ESPAÑOLA: ENTRE EL PACÍFICO Y EL ATLÁNTICO \\ GLOBALIZACIÓN MERCANTIL Y ECONOMÍA POLÍTICA, 1580-1840}

Mariano Alberto Bonialian

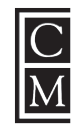

EL COLEGIO DE MÉXICO 
381.09809034

B7151a

Bonialian, Mariano Alberto

La América española : entre el Pacífico y el Atlántico : globalización mercantil y economía política, 1580-1840 / Mariano Alberto Bonialian. 1a ed. - Ciudad de México, México : El Colegio de México, Centro de Estudios Históricos, 2019.

446 p. : il. ; $22 \mathrm{~cm}$.

Incluye bibliografía.

ISBN 978-607-628-674-6

1. América Latina - Comercio - Historia - Hasta 1830. 2. Perú Comercio - Historia - Siglo Xvi. 3. Perú - Comercio - Historia Siglo XVII. 4. América Latina - Comercio - Siglo XVII. 5. América Latina - Comercio - Siglo xviri. 6. América Latina - Política económica Siglo XVII. 7. América Latina - Política económica - Siglo XVIII.

Primera edición, 2019

D.R. (C) El Colegio de México, A. C.

Carretera Picacho Ajusco núm. 20

Ampliación Fuentes del Pedregal

Alcaldía Tlalpan

14110, Ciudad de México, México

www.colmex.mx

ISBN: 978-607-628-674-6

Impreso en México 


\section{ÍNDICE}

Agradecimientos . . . . . . . . . . . . . . 11

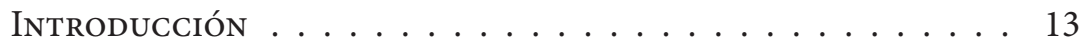

La América española en la Historia

Global del Atlántico y del Pacífico. . . . . . . . . . . . . . . 15

Los ejes geohistóricos hispanoamericanos . . . . . . . . 20

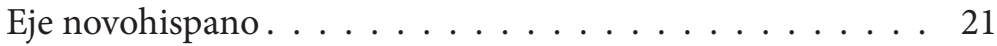

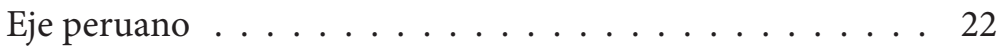

El eje del Cabo de Hornos . . . . . . . . . . . . . . . . 23

Eje Jamaica-Panamá-San Blas . . . . . . . . . . . . . . 24

\section{El Atlántico paCificado}

I. La (in)dependencia económica del Perú, 1580-1620:

circuitos del Pacífico, autosuficiencia y movilidad perulera. . 35

Dependencia e independencia económica

del Perú en los informes oficiales . . . . . . . . . . . . . . 46

Política peninsular asimétrica sobre el virreinato

del Perú . . . . . . . . . . . . . . . . 57

Comercio por el Pacífico: excedentes y autosuficiencia . . . . . 64

La relación con la Nueva España y la crisis de Portobelo . . . 65

1) México: almacén y redistribución de textiles

extranjeros y novohispanos hacia el Perú. . . . . . . . 69

2) Los escapes de metálico peruano hacia México . . . . . 81

3) Los excedentes de productos peruanos

por el Pacífico: vino, azogue y cacao . . . . . . . . . . . 103

Mercado interno y autosuficiencia del Perú . . . . . . . . 117

Emancipación y movilidad espacial: peruleros

en los mercados globales . . . . . . . . . . . . . 128 
Eje transatlántico . . . . . . . . . . . . . . . . 131

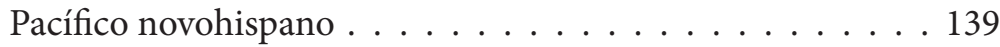

China y las Islas Filipinas. . . . . . . . . . . . . . . 148

II. Nueva España y la segunda pacificación del Atlántico,

1680-1740 . . . . . . . . . . . . . . . . 155

México: "corazón" de la economía marítima

de la Monarquía . . . . . . . . . . . . . . . . . . . . . . 159

Intento de Nueva España por oficializar

su centralidad y la del Pacífico . . . . . . . . . . . . . . 167

El Atlántico pacificado y la garantía

de las corporaciones mercantiles . . . . . . . . . . . 173

\section{El Pacífico atlantizado}

III. Geopolítica y economía mercantil en la América española, $1740-1840$. . . . . . . . . . . . . . . . . 201

El Pacífico en las postrimerías del siglo xvini ¿bautismo global o atlantización? . . . . . . . . . . . . 201

Crisis y descomposición del Pacífico indiano . . . . . . . . . 205

Agonía del galeón de Manila y de la feria de Acapulco . . . . 206 Una nueva relación entre México y el Pacífico sudamericano. . . . . . . . . . . . . . . . . . 222

El tráfico de producciones locales: primer nivel comercial . . . . . . . . . . . . . . . . . . 224

La atlantización del Pacífico sudamericano y mexicano . . . . . . 238

El eje Europa-Cabo de Hornos-Pacífico sudamericano . . . . 239

Primera fase: navíos de registro españoles desde 1749 . . . 239

Segunda fase: balleneros ingleses y angloamericanos desde 1790 . . . . . . . . . . . . . . . 256

El eje Jamaica-Panamá-San Blas, 1810-1820 . . . . . . . . . 276

La extensión del flujo hacia el septentrión mexicano . . . 298

La occidentalización de los circuitos de plata del Pacífico . . . 304

La rotación del comercio oriental: del Pacífico al Atlántico. . 313 Fragmentación y disputa corporativa

por los mercados regionales . . . . . . . . . . . . 330 
Nuevo patrón de consumo: población, textiles británicos y consumo masivo . . . . . . . . . . . 345

Apéndice documental. . . . . . . . . . . . . . . . 367

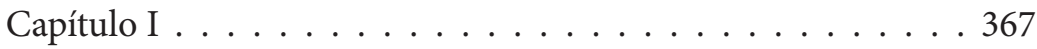

Capítulo III . . . . . . . . . . . . . . . . . 376

Referencias......................... 411

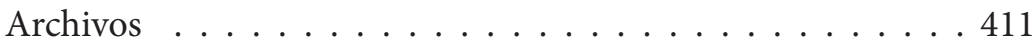

Fuentes primarias y bibliografía $\ldots \ldots \ldots 411$ 
A mi madre

María Tania Assadourian 


\section{AGRADECIMIENTOS}

Quiero brindar mi sincero agradecimiento al Centro de Estudios Históricos de El Colegio de México y a su directora, la doctora Érika Pani, por ofrecerme todas las condiciones necesarias para realizar la investigación. Fueron de enorme utilidad las conversaciones mantenidas con mis colegas Carlos Marichal y Bernd Hausberger. Ellos me brindaron su valioso tiempo para discutir hipótesis y desafíos metodológicos. No puedo dejar de mencionar las amistosas charlas durante la realización del trabajo, con apreciados colegas de la casa de estudios: Graciela Márquez, Sandra Kuntz, Aurora Gómez Galvarriato, Juan Pedro Viqueira y Óscar Mazín. El intercambio de ideas y opiniones que mantuve con colegas peruanos también resultó estimulante: menciono aquí a Carlos Contreras, a Margarita Suárez y a Cristina Mazzeo. Por último, quiero agradecer a Emelina Nava García y a Tania Ochoa Postillo por realizar la versión digital de los mapas del libro. 



\section{INTRODUCCIÓN}

El presente libro es un proyecto editorial finalizado, pero de ninguna manera podría pensarse como una investigación acabada. Gran parte de las ideas que aquí compartimos con el lector son provisorias y abiertas a la discusión. Que el libro impulse el debate no resulta, en principio, un mal síntoma. En razón de la amplitud de la problemática aquí tratada, es inevitable encontrarse con vacíos, desacuerdos y planteamientos arriesgados. Al tomar el ambicioso proyecto de emprender una historia de la globalización mercantil y de la economía política por la América española en la larga duración (1580-1840), tuvimos que estar atentos a todas las áreas, espacios y horizontes de análisis posibles. Las ventanas que nos abre el fenómeno histórico global presentan desafíos metodológicos, conceptuales y analíticos que no siempre encuentran respuestas y soluciones en la presente investigación.

Aun reconociendo sus límites, creemos que vale la pena el estudio. La historia económica de la América española desde sus dos frentes marítimos, el Pacífico y el Atlántico, nos recuerda a la rutinaria advertencia que en la vida diaria se le presenta al peatón cuando se dispone a cruzar una ancha avenida con carriles de dirección opuesta. Las precauciones no tardan en aparecer: "mira para ambos lados" o "debes tener ojos también en la espalda". Una analogía similar aparece con el principio de abordaje que busca atender ambas laterales costeras; desde y hacia ambos océanos. El estudio global de la historia mercantil de la América española incita a reflexionar sobre su singular y privilegiada posición geoespacial, la cual - como veremos- deriva en transformaciones geopolíticas. La América hispana se encuentra en medio de los dos océanos más amplios del globo. El dato no es nada 
insignificante, si la tarea inicial es la de inscribir el bloque continental en la historia de la globalización temprana.

Entendemos la globalización en su historicidad y no como un suceso brusco, de alto impacto y de tiempo reciente. Definimos este hecho como la constitución de un entramado de relaciones económicas, marítimas, de personas, ideas y objetos entre macrorregiones que cubren el globo. La navegación marítima a larga distancia es la herramienta fundamental que hace posible la interacción y la relación económica, política, religiosa y cultural entre los espacios. ${ }^{1}$ Por lo que nos preguntamos: ¿acaso lo que ocurre en el universo marítimo no es tan importante como lo que sucede en tierra?, ¿qué responsabilidad adquiere la América española para que sea posible hablar de globalización temprana? La expansión española y portuguesa que alcanzó a América a través del Atlántico hacia finales del siglo XV y principios del Xvi es una pieza del tablero global que comenzó a gestarse con anterioridad, a partir de las conexiones euroasiáticas que realizan los agentes europeos entre Europa, Asia y África. La relación transpacífica es el hilo faltante de la telaraña global. Hacia el último cuarto del siglo XVI, con la inauguración de la nao de China, que conecta el puerto de Acapulco con Cantón vía Islas Filipinas, se enlazan definitivamente los espacios de Asia y América, dando lugar a la primera red verdaderamente global. ${ }^{2}$ A medida que avanza el tiempo, se anexan nuevos espacios a la red. Hacia finales del siglo XVIII se integrarán al concierto mundial los actuales países de Canadá y Estados Unidos y también lo hará, casi al mismo tiempo, el Pacífico australiano. Por lo dicho, el inicio de la globalización temprana lo ubicamos en el siglo XVI.

Desde entonces, la América española es receptora de los impulsos marítimos procedentes del Atlántico europeo e impulsora de la conexión transpacífica. Pero la movilidad de bienes y personas entre las dos áreas marítimas será de ida y vuelta, conforme

${ }^{1}$ Compartimos aquí la definición amplia que nos brinda un reciente libro: Hausberger, 2018, pp. 1-20.

2 Flynn y Giráldez, 2014, pp. 29-76. 
avance el proceso global. Es más, la ratio de movilidad se reducirá a las fronteras de los océanos. En cada periodo o fase de la globalización, la América española presentará puntos de confluencia para conectar ambos universos marítimos. El presente libro es un análisis de los ejes geohistóricos hispanoamericanos, cuyo modus operandi es la interacción, en clara tensión y conflictos, entre las economías del Atlántico y del Pacifico.

\section{LA AMÉRICA ESPAÑOla EN LA Historia Global del Atrántico y del Pacífico}

No hay duda de que la historiografía dedicada a los temas de la Global History, World History, Atlantic History, incluso los de más reciente difusión de la llamada Pacific History, ha hecho importantes avances. Quisiéramos hacer énfasis en el que quizá fuera el más sobresaliente: la superación de los límites que la historia nacional, hegemónica desde el siglo xix y con actual vigencia, ha impuesto en la comprensión e interpretación de procesos globalizadores previos a la construcción de los Estados nacionales. No obstante, las nuevas historias supranacionales o transnacionales, como actualmente se les denomina, terminan por reemplazar un marco espacial y analítico (el del Estado-nación) por otra suerte de paradigma que también alienta a la crítica y a la revisión.

El carácter eurocéntrico ${ }^{3}$ o sinocéntrico ${ }^{4}$ marca la pauta de la agenda de discusión de la Global History o World History. ${ }^{5}$ Aun validando la idea de que Europa y Asia (particularmente China) fungen como impulsores y centros de desarrollo de los procesos globalizadores tempranos y modernos, la globalización bipolar está lejos todavía de asumir la precisa trascendencia que adquiere en ella la América española. El libro de Hausberger publica-

3 Wallerstein, 1979-99; Duchesne, 2002, pp. 428-463.

4 Pérez García, 2014, pp. 337-352.

5 Gunder Frank, 1998; Pomeranz y Topik, 2006; Hopkins, 2002; Findlay y O’Rourke, 2007. 
do en 2018 discute el carácter bipolar del fenómeno planetario. Nos propone una globalización temprana multipolar que tiende a valorar las restantes macrorregiones del globo, India, África y la propia América, tanto la hispánica como la portuguesa. ${ }^{6} \mathrm{La}$ pregunta central radica en qué entendemos por polo. ¿América es un polo o un centro de la globalización temprana? Enseguida haremos algunos comentarios al respecto. Nos sumergimos en un debate que da sus primeros pasos en la academia hispanoamericana. De momento el presente libro hará referencia al perfil bipolar de la globalización, pero vale la pena presentar las posibles perspectivas para su discusión.

Gran parte de la literatura global define el papel de la Améri$\mathrm{ca}$, tanto la española como la portuguesa, como un espacio pasivo, proveedor de plata y oro que alimenta la monetización de las "verdaderas" economías desarrolladas. Nadie podría cuestionar esta premisa básica y tradicional, pero su aceptación acrítica esconde un supuesto arriesgado: que la expulsión del metal hacia el exterior es automática, es decir, sin que operen o sean decisivas las redes económicas y políticas impulsadas desde el interior por las elites locales. En otros términos, existe una agencia propia en Hispanoamérica que no es reconocida en la historia global. ¿A qué se debe la omisión o, cuando menos, su marginación en los

${ }^{6}$ Historia de la temprana globalización es un libro ensayístico con ideas sugerentes, pero no menos provocadoras. Hausberger parece aceptar la idea de la América hispana como polo de la globalización temprana. Según el autor, desde la segunda mitad del siglo XVI, la América española se convierte en un "potente" mercado de consumo de productos importados que da como resultado una estructura productiva y de exportación minera en México y Perú, lo cual permite la monetización de los mercados asiáticos y europeos. Las primeras elites de México y Perú tuvieron la necesidad de crear una unidad de cambio para pagar las importaciones de productos externos (textiles, vino, hierro, acero, armas, fuego, etcétera), y así garantizar su prestigio social y sus hábitos de consumo. Al no disponer de bienes locales apreciados en el exterior, las elites españolas de México y del Perú encontraron en la exportación de metálico el remedio ideal. La producción a gran escala de la plata hispanoamericana, que permitió proveer al mundo de un medio con valor de cambio, tendría su justificación en la necesidad de los primeros núcleos de españoles en suelo americano por mantener sus hábitos elitistas de consumo; asimismo, esto dio lugar a la diferenciación social. El libro de Hausberger además señala por qué nos parece una hipótesis arriesgada y discutible. Hausberger, 2018, pp. 129-133. 
estudios globales?, ¿a la indiferencia?, ¿al poco peso que la historia global tiene dentro de los círculos académicos de los países hispanoamericanos y de España? Respuestas todas posibles. Con todo, en calidad de historiadores hispanos e hispanoamericanos nos preguntamos si es posible sortear toda mirada eurocéntrica o sinocéntrica para el estudio de la globalización. ${ }^{7}$

Vale cierta mesura en nuestras observaciones. Estamos lejos de pregonar por un américa-centrismo en la temprana globalización. Desde el siglo XVI hasta inicios del XIX Hispanoamérica no es, ni por mucho, un espacio productor de mercancías de exportación, menos aún de productos con valor agregado. Además, su aparato manufacturero, obrajero o "industrial" no tiene un desarrollo avanzado si se le compara con el de centros industriales de China o Europa. Tampoco podría sobreestimarse su mercado consumidor, dado que la población de sus principales ciudades o centros urbanos durante el siglo xvi y hasta finales del XviII es reducida, poco significante en relación con la densidad de algunas urbes europeas o de China. En definitiva, creemos que la singularidad en el mapa global de la América española se visualiza al atender su singular posición geoespacial en el marco planetario, en la evolución de las economías por sus dos frentes oceánicos, que en última instancia están sujetas a los cambios y transformaciones que la globalización asume en su historicidad.

¿Qué podemos decir de la convocante Historia Atlántica? ${ }^{8} \mathrm{Su}$ volatilidad y carácter cambiante se debe a que se alimenta de mu-

7 Deben reconocerse los nuevos desafíos que hoy tiene la historiografía hispanoamericana para incorporarse en los debates actuales de la literatura sobre la globalización histórica: a) los historiadores hispanos deberían apropiarse y desarrollar una agenda propia de problemas sobre la Historia Global, lo cual aún se encuentra lejos o, cuando menos, en embrión, y $b$ ) un mayor conocimiento y trabajo sobre los archivos de los países hispanoamericanos que salvo raras excepciones, no son materia de trabajo por parte de los historiadores globales europeos y asiáticos. Es necesario releer los expedientes y documentos hispanoamericanos con nuevas y viejas preguntas que configuren poco a poco el marco de estudio de nuestra agenda historiográfica. Es evidente que ambas condiciones se encuentran pendientes, pero aún estamos a tiempo para remediarlo

8 Cañizares-Esguerra y Seeman, 2006; Armitage, 2002, pp. 11-27; Pieper y Schmidt, 2005; Aram y Yun-Casalilla, 2014. 
chas historias, de "muchos Atlánticos". Usualmente, la Atlantic History construye un relato histórico desde la ventana propiamente británica o angloamericana, ${ }^{9}$ poco difiere aquí de los problemas derivados de la tan criticada historia nacional. Se puede hablar de un Atlántico americano, uno hispánico, un inglés, otro portugués, etcétera. Habría muchas historias del Atlántico según la época y a qué espacio o área histórica nos estemos refiriendo. En este sentido, cabe preguntar si la clásica definición del Atlántico como un espacio lleno de interacciones, permeable y con otras consideraciones transitorias, no explica nuestra dificultad por descubrir su cohesión, un hilo conductor del espacio histórico. Por ejemplo, la monarquía española construyó parte del Atlántico, pero resulta inaceptable pensar que sólo con una perspectiva imperial se puede comprender una historia atlántica total. Lo "poroso", lo permeable de sus fronteras, así como la notable movilidad de los agentes históricos, supera los límites institucionales de la Monarquía hispánica y ello obliga a un análisis contextual del espacio en un cuadro global.

Parecería acertado concebir al Atlántico como un excelente marco espacial de trabajo; pero nos resistimos a otorgarle una entidad propia y a considerarlo como unidad histórica independiente. En su afán de buscar cierta totalidad, ¿no termina dicha escuela por generar el efecto contrario, es decir, de recortar acontecimientos o problemáticas que en la realidad superan sus fronteras marítimas? ¿La Atlantic History no sería más bien un producto histórico, una importante pieza europea de la oleada discursiva de la Global History?, ¿acaso el comercio transatlántico no es incomprensible sin considerar el universo transpacífico? La movilidad de agentes en la Monarquía y en los mercados globales, ¿sólo puede analizarse bajo los límites atlánticos? Lo dudamos. Más adelante comentaremos al respecto.

La historia del Pacífico, con vida más reciente, presenta similitudes y diferencias con la del Atlántico. ${ }^{10} \mathrm{Su}$ historia se construye

9 Hausberger, 2007, pp. 279-291.

10 Véanse los clásicos ensayos de Matsuda, 2006, pp. 758-780; Gulliver, 2011, pp. 83-100; Dirlik, 1992, pp. 55-79. 
a partir de múltiples identidades: Spanish Lake, Pacífico hispanoamericano, extranjero, y el menos recordado por los hispanistas o americanos: Mar de la China. ${ }^{11}$ Lo cierto es que la historia del Pacífico, comprendida entre el siglo xvi y el momento previo de las independencias americanas, se presenta como un "artefacto europeo" (sea español o no español). ${ }^{12}$ Valga la similitud con el Atlántico: existen "muchos Pacíficos" en el plano geoespacial, como también existen muchos "pacíficos" conforme a su historicidad. Dicha similitud deviene en un relato semejante porque la reconstrucción de su historia no puede evitar en su fragmentación referirse a los "pedazos" de ese gran Pacífico, recortando o enalteciendo determinadas fronteras.

Aun siendo una historia más “joven” que la atlántica, la del Pacífico sufre un similar dilema: dónde colocar sus fronteras, sus límites o márgenes geográficos. La historia del Pacífico entre el siglo XVI e inicios del XIX también cuenta con visiones eurocéntricas o hispanistas que intentan caracterizar su identidad dentro de la Monarquía hispánica, aun reconociendo las distancias espaciales entre sí. Pero, últimamente, han aparecido trabajos muy sugerentes que señalan su verdadero sentido histórico con relación al otro polo global del momento: China, con la mediación de las Islas Filipinas. La lectura Pacífico-China ha llegado a sostener que la inauguración del galeón de Manila (1565) y la fundación de la ciudad de Manila (1571) terminaron por integrar de manera completa el mundo: el intercambio de ideas, bienes, flora, cultura, personas, etcétera, entre el México novohispano y el imperio de los Ming. ${ }^{13}$ La mirada del Pacífico americano hacia China tiene un gran valor en los capítulos de este libro, particularmente en los dos primeros.

11 Spate, 1979-1988; Schurz, 1992; Bonialian, 2012.

12 Spate, 1978, pp. 32-45.

13 Flynn y Giráldez, 2014, pp. 29-76. 


\section{LOS EJES GEOHISTÓRICOS HISPANOAMERICANOS}

¿Por qué nuestra insistencia de presentar los vacíos y límites de la Atlantic History y de la Pacific History? La razón es que dichas perspectivas no parecen ser suficientes a la hora de vincular la economía hispanoamericana con la globalización temprana. Lo que para estas literaturas aparece como fronteras o límites marginales de su análisis, en este libro son problemas medulares. De forma más precisa, descubrimos una historia con sentido propio en los puntos de conexión, en las uniones de esos márgenes. Se trata de "encadenar" fenómenos que suceden de uno a otro lado de las costas de la América española para reubicarla en el centro del escenario global. Creo que existe una magnífica "caja de herramientas" para comprender los nudos, puentes y vinculaciones que se tejen entre el Atlántico y el Pacífico, permitiendo ponderar la importancia de la participación de los espacios hispanoamericanos en los fenómenos de la globalización mercantil. Nos referimos a los denominados ejes geohistóricos (cuadro 1). ${ }^{14}$

¿Qué entendemos por el eje geohistórico? La existencia de estructuras suprarregionales, poco cambiantes. En estas plataformas que combinan lo terrestre con lo marítimo se asienta la movilización de personas, bienes y elementos culturales. Dicha movilización revela, a la vez, los espacios donde se desarrollan las prácticas sociales, económicas y políticas de los agentes históricos. Son difíciles de descubrir a simple vista, en una primera aproximación que sólo perciba un fenómeno local, regional o nacional. Más bien, se descubren con la sumatoria de dinámicas micro, que dan por resultado regularidades históricas de carácter global o transnacional. De esta manera, los ejes geohistóricos construidos desde, hacia o entre los espacios americanos ilustran los modos de su incorporación a la Monarquía y a la misma globalización. Desde mediados del siglo xvi se distinguen dos ejes transoceánicos que permiten contactar los grandes espacios ame-

14 Véase la definición del término en Braudel, 1991, pp. 39-74; Chaunu, 1960, pp. 521-557; Carmagnani, 2012a, pp. 331-356. 
ricanos con el exterior: el novohispano y el peruano. Hemos realizado una detallada caracterización de estos ejes geohistóricos en anteriores investigaciones, por lo que mencionamos aquí sus elementos más sustanciales. ${ }^{15}$

Cuadro 1. Ejes transoceánicos hispanoamericanos

\begin{tabular}{|c|c|c|}
\hline Periodo & Eje & Ruta \\
\hline $1 / 2$ XVI- 1740 & Peruano & $\begin{array}{l}\text { España-Portobelo-Panamá-El Callao- } \\
\text { Lima }\end{array}$ \\
\hline $1 / 2$ XVI- 1789 & Novohispano & $\begin{array}{l}\text { España-Veracruz-Ciudad de México- } \\
\text { Acapulco-Islas Filipinas }\end{array}$ \\
\hline 1750-1850 & Cabo de Hornos & $\begin{array}{l}\text { Europa-Estados Unidos-Río de } \\
\text { Janeiro-Buenos Aires-Cabo de } \\
\text { Hornos-Pacífico sudamericano- } \\
\text { México-China }\end{array}$ \\
\hline $1800 \rightarrow$ & Panamá & $\begin{array}{l}\text { Gran Bretaña /Norteamérica-Jamaica- } \\
\text { Panamá-San Blas-Septentrión } \\
\text { novohispano }\end{array}$ \\
\hline $1848 \rightarrow$ & Panamá & $\begin{array}{l}\text { Europa-Norteamérica-Colón-Ciudad } \\
\text { de Panamá-Pacífico-San Francisco- } \\
\text { China }\end{array}$ \\
\hline
\end{tabular}

Fuente: Elaboración propia.

Eje novohispano

Presenta a la Ciudad de México como nodo central que ramifica su extensión a través de dos vías: hacia el Atlántico (Ciudad de México-Veracruz-España) y hacia el Pacífico (Ciudad de México-Acapulco-Islas Filipinas). La Ciudad de México logra unir el Atlántico con el Pacífico: el primero con la flota de Veracruz y el segundo con el galeón de Manila. ¿Cómo funciona económicamente el eje? El poder de los notables novohispanos, amparados

15 Bonialian, 2014, pp. 27-55. 
con su órgano rector del Consulado de la Ciudad de México, es la razón de fondo que dinamiza el eje. La corporación capitalina monopoliza la distribución de los bienes europeos y asiáticos por el mercado interno virreinal y controla la circulación por el espacio de la plata, que es la principal forma de pago de las importaciones. Los agentes, como el espacio, adquieren una posición geopolítica privilegiada en el comercio global, en el centro económico hispanoamericano para los contactos directos con Asia y Europa.

\section{Eje peruano}

Un eje transoceánico fundamental que estructura gran parte del espacio meridional hispanoamericano entre mediados del siglo XVI y la del XVIII tiene como centro de confluencia a Panamá. La movilización por sus 80 kilómetros de ruta terrestre posibilita la conexión del Atlántico, gracias al galeón de Portobelo que proviene de España, y su extensión con la Armada del Sur, que enlaza a través del Pacífico el puerto peruano de el Callao. Al igual que el novohispano, el eje peruano se encuentra bajo control de los notables mercaderes limeños, responsables de distribuir los bienes internacionales por los mercados locales y regionales del espacio virreinal. ${ }^{16}$ Mientras la vida del eje peruano se desvanece hacia 1740, con el abandono y la suspensión oficial de las ferias de Portobelo, el novohispano se prolonga hasta finales del siglo XVIII, pues la flota de Veracruz continúa funcionando hasta el año 1789 y el galeón de Manila hasta 1815.

Sin embargo, como daremos a conocer en el tercer capítulo, el eje novohispano, con cabecera en la Ciudad de México, ingresa en una profunda crisis casi al mismo tiempo en que desaparece el eje peruano. Ahora bien, estos dos ejes que estructuran la espacialidad hispanoamericana a través de sus centros capitalinos (Ciudad de México y Lima, respectivamente) logran romper sus distancias con un fuerte y prolongado enlace construido entre

16 Tandeter, 1991, pp. 185-201. 
los puertos del espacio peruano con Acapulco por el Pacífico. El contacto entre virreinatos por el Mar del Sur resulta trascendental porque, como veremos en los dos primeros capítulos, crea influjos, mezclas, condicionamientos y alteraciones en los dos ejes transoceánicos mencionados.

\section{El eje del Cabo de Hornos}

A mediados del siglo xviII un nuevo eje transoceánico aparece con potencia en escena. Antes de esa fecha, el paso austral fue un punto de confluencia marítima circunstancial y esporádico. Luego del descubrimiento del estrecho por Fernando de Magallanes hacia 1521 y cinco años después con la expedición del fraile José García de Loaysa (1525-1526) por el Cabo de Hornos para llegar a las Molucas y participar en el tráfico de la especiería, España nunca logró convertir al estrecho ni al cabo en una ruta oficial para intervenir en el universo del Pacífico, ni en el sueño de acceder a las sedas y especias del Oriente. La piratería holandesa estuvo presente a principios del siglo xvir y los mercaderes franceses de Saint Maló gozaron de un auge comercial a principios del siglo XviII. Las inclemencias climáticas y geográficas, aunado a las limitaciones técnicas de la navegación, resultaron factores importantes para la pasividad del circuito. Pero no habría que subestimar la resistencia de los agentes locales hispanoamericanos con el fin de mantener un alto grado de autonomía política y económica sobre el área.

El paso por el Cabo de Hornos comenzó a operar sistemáticamente a partir de 1750, en las comunicaciones entre España y el Pacífico sudamericano, estimulando la fragmentación de los mercados de la América meridional tanto por su frente Atlántico (Río de Janeiro, Montevideo o Buenos Aires) como por la franja del Pacífico (Santiago, Lima, Guayaquil, etcétera). El flamante derrotero austral, institucionalizado con la paz firmada con Inglaterra (1748), no sólo suplantó al eje Portobelo-el Callao, también propició que el perfil internacional con el que gozaba el enlace Perú y México hasta la mitad de ese siglo por el Mar del Sur se convir- 
tiera, a partir de entonces, en un mero enlace de cabotaje. Veremos, también, que su institucionalización alcanzó a comprometer el tradicional y monopólico eje novohispano. El eje por el Cabo de Hornos cobró un carácter aún más global desde 1790, cuando los balleneros ingleses y estadounidenses se apropiaron de él para emprender un verdadero comercio globalizador con la Gran Bretaña, las costas del este de Norteamérica, el Atlántico caribeño, mexicano y sudamericano, Pacífico sudamericano, mexicano, y China. Las costas de la flamante nación estadounidense se incorporaron al eje unas décadas después, hacia finales del siglo XVIII.

\section{Eje Jamaica-Panamá-San Blas}

Hasta 1740 el punto de confluencia centroamericana de Portobelo-Panamá respondía a la economía del Pacífico sudamericano, es decir, a la economía peruana. Hacia la segunda mitad del siglo XVIII, pero con mayor fuerza a principios del siglo XIX, Panamá cambia su orientación hacia el norte del Pacífico hispanoamericano. En contextos de libre comercio y la catarata de autorizaciones para ser "puerto franco" en las islas y costas del Caribe mexicano y antillano, se gesta un nuevo encadenamiento espacial entre Jamaica, Panamá y San Blas, con influencia directa sobre Tepic y del mercado de Guadalajara. Es probable que estas sean las instancias históricas iniciales en que Panamá, como punto transoceánico, se orienta decididamente hacia el norte del Pacífico mexicano, de manera que el nuevo eje termina por comprometer seriamente el tradicional corredor entre Acapulco y las Islas Filipinas. Puede resultar sorprendente, pero quizá estemos en presencia del basamento geohistórico de consolidación de Panamá en 1855, con la construcción de sus vías férreas, su mediación con los puertos mexicanos (particularmente Mazatlán) y su vinculación hacia el polo metalífero en la costa oeste de Estados Unidos; nos referimos a la famosa "fiebre del oro" de California. ${ }^{17}$ 
Los mencionados ejes geohistóricos son los puentes que conectan las economías de los universos del Pacífico y del Atlántico. En el juego de sus interacciones se perciben las gravitaciones y complementariedades. Los capítulos del libro exponen la evolución de esas relaciones de influencias y condicionamientos. Dicho fenómeno manifiesta, en una escala mayor, los efectos de expansión o contracción de los frentes asiáticos y occidentales en las diferentes fases que asume globalización histórica. En pocas líneas, anticipamos el problema fundamental que estudiamos en el libro concentrando la mirada en los ejes:

a) El Atlántico pacificado: cuando la economía mercantil del Pacífico está en condiciones y con capacidad para influir sobre el mundo atlántico, globalización bipolar o multipolar.

b) La atlantización del Pacífico: cuando la economía mercantil noratlántica europea se expande y controla las redes de circuitos, agentes, puertos e intercambios del universo pacífico, globalización unipolar occidental.

Estas dos caracterizaciones son útiles para la división libro. ${ }^{18}$ La primera sección, El Atlántico pacificado, ilustra la conformación de economías virreinales del Pacífico capaces de influir, ya sea condicionando o alentando, la red de flujos transatlánticos que enlazan a Hispanoamérica con España. La influencia se percibe en un tiempo prolongado, de 1580 a 1750, y son claramente distinguibles la naturaleza y las características de ambos universos económicos. En otros términos, si bien el Atlántico y el Pacífico se conectan gracias a los ejes geohistóricos, éstos contienen identidades, es decir, lógicas de funcionamiento disímiles y con dinámica propia.

18 El lector tiene la posibilidad de atender los capítulos de manera independiente o en conjunto. Si bien cada uno de ellos atiende a una específica problemática, tenemos el convencimiento de que resulta más sugerente atender el hilo conductor general que los relaciona. 
¿Qué entendemos por economía marítima? Todo el universo económico oceánico y portuario que gira en torno a un determinado espacio. Esta amplia definición del concepto nos remite a cuestiones de los flujos comerciales, a la cultura del consumo, al plano de la producción, a los agentes participantes y a la evolución de los mercados. Claro está, los universos dependen del juego de escalas. La intención es articular los universos que se configuran por cada espacio hispanoamericano, para luego inscribirlos en forma conjunta en el marco de la mundialización mercantil del momento.

En este sentido, vemos una economía marítima del Occidente americano que alcanza plena autonomía en su desenvolvimiento. La economía del Pacífico, primero con epicentro en el espacio peruano a raíz de su auge minero y luego en la Ciudad de México con la notable autonomía de su consulado de comercio, se presenta con una vida económica en sí y para sí, que le permite desarrollarse lejos de las pulsaciones transatlánticas e, incluso, le genera efectos significativos a la economía europea que se desarrolla por el Atlántico. Cabe aclarar que de ninguna manera estamos proponiendo un Pacífico más importante que el Atlántico, o sea, uno donde habría una mayor intensidad o cantidad de plata, de bienes, y de personas que por los conductos transatlánticos. De lo que se trata aquí son de gravitaciones, efectos y condicionantes; en este sentido, lo que genera el Pacífico sobre otras áreas marítimas (operando de manera autónoma y lejos de las lógicas de las economías europeas) resulta sorprendente.

La influencia del Pacífico sobre el Atlántico se sustancia en dos periodos de ese largo tiempo histórico. La primera fase va de 1580 a 1620 y la segunda de 1680 a 1740 . La periodicidad se corresponde a los dos primeros capítulos del libro. El capítulo inicial, "La (in)dependencia económica del Perú, 1580-1620: circuitos del Pacífico, autosuficiencia y movilidad perulera", da cuenta de los principales elementos que marcan la temprana "tentación” de expansión de la economía peruana hacia el Pacífico novohispano y China. Según los testimonios de la época, dirigirse hacia el Oriente compromete lo que en su época adjudicaban a la 
"forzada dependencia" del espacio andino con España por la vía transatlántica. El peligro de que se cortara la relación transatlántica se debe a una economía andina exuberante, donde la notable producción de plata y la existencia de excedente productivos se "desvían" por conductos que no tienen como destino Panamá para finalizar en España. Sin embargo, el notable desarrollo de los flujos mercantiles por el Pacífico no es el único elemento por el que avizoramos una influencia determinante sobre el Atlántico. Los efectos de gravitación alcanzan su cota máxima con la movilidad de los agentes peruanos sobre rutas transatlánticas que en principio le correspondían al cargador sevillano.

El capítulo que le sigue presenta la segunda ola de un Atlántico pacificado con epicentro en la Ciudad de México. Con similar perspectiva que con el primero, se analiza la función trascendental que cumple la Ciudad de México entre 1680 y 1740 para promocionar un gran esquema de comercio con perfil imperial y global, cuyo cuerpo tiene como "nervio principal" la relación económica con el virreinato del Perú. Estamos en presencia del segundo momento de auge, de reimpulso, en la orientación de la economía hispanoamericana hacia el universo del Pacífico.

La postulación de una economía del Pacífico fuerte, autónoma y con potencial para influir en el mundo mercantil atlántico obliga a revisar aquella visión occidental-eurocéntrica que sostiene un Pacífico débil, de nula participación en los circuitos internacionales y, sobre todo, sumiso a los ritmos de la razón hispánica transatlántica. Quizá el principal exponente de esa interpretación sea Chaunu, con su monumental obra El Pacífico y las Filipinas. El autor sostiene que, desde la inauguración del Galeón de Manila hasta su desaparición en tiempos de las emancipaciones americanas, el Pacífico era un "Pacífico de los ibéricos", que carece de movilidad, de autonomía, y por lo tanto, se encuentra sujeto a los ritmos dictados por el Atlántico peninsular. El postulado de Chaunu choca con nuestras premisas. Según él, estamos en presencia de un Atlántico que arrasa y domina el área del Pacífico. Niega un proceso de autonomía mercantil del Pacífico que dentro de la economía mundial: "no pasa de ser una importante 
fracción de las divisiones de un Atlántico que ha devorado todo [...] una simple prolongación de los intercambios del Atlántico sevillano". ${ }^{19}$

¡Qué tan alejado estamos de estas interpretaciones! Es difícil aceptar su objetivo cumplido de "haber incorporado al Galeón de Manila en esa economía mundial con polo en Sevilla”. Para nosotros, durante la primera fase de una globalización bipolar (1580-1740), el Pacífico no sólo arremete sobre piezas de la estructura mercantil del Atlántico, sino que cumple funciones vitales, como la de ser una fracción importante de la economía asiática. Más que incorporarse, la economía del Pacífico parece alejarse del polo global europeo. En anteriores investigaciones ya hemos ofrecido argumentos para sugerir que hasta la mitad del siglo xviII, el Pacífico representa un lago indiano, es decir, una economía marítima que se encuentra monitoreada por los agentes comerciales de la Ciudad de México y de Lima, el otro polo político, comercial y administrativo situado en la América meridional. La temprana economía del Pacífico logra repercutir en la economía transatlántica; participa y se incorpora a los circuitos mercantiles de la mundialización temprana alejada de la rada occidental hispánica. ${ }^{20}$ Con excepción de la función transpacífica que goza Acapulco con el galeón de Manila, los trabajos referidos al Pacífico hispanoamericano sugieren conceptualizar al conjunto de las economías marítimas del occidente americano como unidades y zonas de escaso desarrollo, reducido a un comercio de cabotaje y de poca resonancia en economías externas. La visión peca de simplismo y anula la complejidad del escenario.

Ciertamente, la potencia económica que despliega el Pacífico en esta primera etapa se corresponde y actúa dentro del bipolarismo de la globalización temprana que, insistimos, presenta a China como uno de sus centros. Como una fuente de atracción, el espacio del Perú y el de la Nueva España (utilizando como pun-

19 Chaunu, 1974, pp. 22-23.

20 Bonialian, 2012 y 2014. 
tos mediadores a Panamá y Centroamérica) drenan capitales, agentes y parte de sus riquezas hacia China y el extremo Oriente. El Pacífico de los siglos XVI, XVII y gran parte del XVIII se desarrolla en una constante tensión: con una pertenencia jurídica e institucional al mapa de Occidente, pero con una realidad que sólo se comprende al ver su relación con el polo asiático. El Pacífico hispanoamericano se relacionó con la economía china más de lo que suponemos, incluso más de lo que supuso en su momento España.

Los ejes transoceánicos como el novohispano y el peruano (más la relación informal que tienen entre sí) constituyen las ventanas analíticas de la primera parte del libro. El eje por el Cabo de Hornos sólo operará hasta la primera mitad del siglo XVIII, principalmente por medio del pillaje, la piratería, el contrabando o las exploraciones científicas cartográficas. Son estas tibias modalidades e intervenciones europeas las que le inyectan vida al eje transoceánico. Será hasta 1750 cuando el Cabo de Hornos asuma un notable protagonismo como vía de confluencia marítima. A partir de ahí, el juego de las fuerzas oceánicas que rodean a la América española se invierte. La economía atlántica comienza a apropiarse de un Pacífico que hasta entonces sólo conocía de forma difusa o poco precisa. En otros términos, si antes de 1750 presenciábamos un Pacífico americano con gran cuota de autonomía orientado hacia China, posteriormente esa área mercantil se encuentra profundamente dependiente de la economía transatlántica británica-angloamericana, que fungirá desde entonces como el exclusivo polo de la globalización económica. Comienza, en efecto, la segunda parte del libro, El Pacífico atlantizado, cuyo contenido se presenta en el tercer capítulo: "Economía y geopolítica mercantil en la América española, 1740-1840”. Nos encontramos lejos de brindar un modelo integral y completo de la política económica y el escenario comercial marítimo que se construye en la América española desde la segunda mitad del siglo XVIII. Nuestra intención es justificar las razones de la agonía de los ejes transoceánicos tradicionales, la crisis y desaparición del Pacífico autónomo y con vida propia, que explicamos en los primeros dos 
capítulos, y la emergencia de centros económicos y geopolíticos que sirven de trampolín para el expansionismo de la economía europea sobre el mapa económico hispanoamericano.

Al inicio de la segunda mitad del siglo XVIII se registra un parteaguas, una suerte de revolución en el comercio, en la cultura del consumo y un proceso de fragmentación de sus mercados que son los basamentos para el surgimiento de los Estados nacionales. Conocer los nuevos ejes transoceánicos de la segunda mitad del siglo XVIII y principios del XIX que conducen a la crisis de los tradicionales y monopólicos ejes será el hilo conductor de nuestras reflexiones. La primera avanzada del Atlántico sobre el Pacífico se gestará por la ruta del Cabo de Hornos; el segundo embate vendrá décadas más tarde, en los primeros años del siglo XIX, a través del eje transoceánico de Panamá, que será vital en conectar el enclave inglés de Jamaica con el mercado occidental mexicano. La nueva dirección que toma Panamá por el Pacífico contribuirá a la agonía de la relación transpacífica que enlazaba directamente a México con el Oriente.

Desde la segunda mitad del siglo XVIII, la economía atlántica impondrá su hegemonía en el Pacífico. Agentes europeos (primero españoles y luego ingleses), norteamericanos y, en menor medida, franceses y alemanes comenzarán a controlar los circuitos comerciales y mercados de la economía occidental hispanoamericana. El fenómeno comienza a vislumbrarse con las políticas económicas del reformismo borbónico; un proceso de apropiación espacial que se intensificará en los últimos años del siglo XVIII. En este sentido, más que un cambio, la consolidación europea y norteamericana por el Pacífico expresa una continuidad histórica con las políticas económicas gestadas en el periodo de las reformas de los Borbones. La expansión de la economía atlántica derivó en un proceso de descomposición de todas las características que habían convertido al Pacífico en un área marítima indiana e independiente. La transformación ilustra una nueva etapa en el proceso histórico de la globalización: por un lado, el dominio de Occidente, materializado con la revolución industrial inglesa y, por el otro, el retroceso de China. Estamos en presencia 
de la transición de una fase histórica, de la globalización de carácter bipolar al unipolar; un único polo, Europa: Gran Bretaña. ${ }^{21}$

En primer lugar, el proceso de occidentalización de los mercados del Pacífico hispanoamericano, con el simultáneo retraimiento de China como polo en la globalización, nos puede ofrecer algunas pistas sobre "la gran divergencia"; es decir, sobre los caminos disímiles que toma el desarrollo económico europeo con respecto al chino hacia finales del siglo XVIII y principios del XIX..$^{22}$ En segundo, la atlantización del Pacífico es un fenómeno en paralelo a la emergencia del Empire of Cotton; cuando Occidente, particularmente los ingleses que, con la vía libre para abastecer los mercados del Pacífico hispanoamericano, tienen mucho que ofertar: el textil de algodón británico y de sus colonias. Aquí vale compartir una reflexión del historiador Beckert que vemos aplicarse en la América española: ${ }^{23}$ "El verdadero auge de la industria británica del algodón fue el de la exportación. Para 1800, la manufactura inglesa del algodón se había convertido en una de las de mayor presencia en los mercados mundiales". ${ }^{24} \mathrm{Su}$ importación en un contexto de libre comercio altera el patrón de consumo en la América española, quebrando los principios consumistas y de producción que reinaban en América, en momentos de globalización bipolar.

21 Findlay y O’Rourke, 2007; Vries, 2015.

22 Pomeranz, 2000.

23 Beckert, 2014, pp. 74-75.

24 "The true boom of the British cotton industry was thus an export boom. By 1800 British manufactured cottons had become a major presence on world markets". 



\section{1 \\ EL ATLÁNTICO PACIFICADO}





\title{
I. LA (IN)DEPENDENCIA ECONÓMICA DEL PERÚ, 1580-1620: CIRCUITOS DEL PACÍFICO, AUTOSUFICIENCIA Y MOVILIDAD PERULERA
}

\author{
"todo el alivio y riqueza de España \\ depende del buen gobierno del Perú” (1629) \\ Benito Peñaloza, \\ $5^{\circ}$ excelencia, XxI, p. 146
}

"para que las Indias no se pierdan conviene estén pendientes y subordinadas a España” (1605)

Martín Ignacio de Loyola AGI, Filipinas 35, núm. 47, f. 824.

"Independencia”, “emancipación”, “autonomía”, o sus antagonismos: "dependencia” y "subordinación", no suelen ser términos que los actuales estudios históricos sobre las sociedades de Antiguo Régimen utilicen. Apuntados en los círculos académicos como anacrónicos, ahistóricos o políticamente incorrectos, estas categorías nos parecen remitir a una escuela historiográfica clásica, más cercana al materialismo histórico, que a un adecuado corpus conceptual que emerge de las propias fuentes históricas. Si su utilización es al menos excepcional en los trabajos ocupados en la historia hispanoamericana, más extraño resulta verlos en ensayos dedicados a periodos tan tempranos como los momentos de conquista y colonización de América.

Sin embargo, al revisar con atención las fuentes oficiales de finales del siglo XVI y de las primeras décadas del siglo XVII, los términos "forzosa dependencia", "subordinación" o "independencia" son frecuentemente utilizados. Esquivamos el debate historiográfico de aquellas corrientes, de gran vigencia y muy extendidas en 
los círculos académicos, que consideran estos conceptos ligados a una mirada "ideologizada", o "colonialista" de la realidad histórica. ${ }^{1}$ Tomamos el riesgo de que el ensayo sea etiquetado como un estudio "desactualizado", pero tenemos la certeza de que al colocar los conceptos sobre la mesa y revalorizarlos, somos respetuosos y transparentes con la terminología que utilizan los contemporáneos para explicar la realidad de su momento, al tiempo que ofrecemos una lectura e interpretación desde nuestro presente.

Ahora bien, ¿qué debe entenderse por "dependencia” en los manuscritos de la época? Desde una óptica amplia y general, la dependencia implica la subordinación de un reino indiano al poder central. Sus defensores piensan que el quiebre de la relación de dependencia económica derivaría en la falta de una política "espiritual y temporal", es decir, en la ausencia de un dominio político de la metrópoli hacia el reino. Otros perciben una concepción organicista del imperio, donde cada reino o espacio cumple una función particular, muy necesaria para la vida y el desarrollo de la unidad del "cuerpo" monárquico. En este sentido, la "dependencia" es una conexión "natural", al mismo tiempo que minimiza los evidentes conflictos que conlleva la relación económica entre la metrópoli y los dominios americanos. Pero es desde una clara perspectiva comercial-monopólica, desde el axioma mercantilista, donde los significados de "dependencia", "independencia" o "subordinación" adquieren pleno sentido. El diagnóstico de un estado de debilidad da cuenta de una coyuntura e inestabilidad en el comercio ultramarino y en la estructura fiscal de la Monarquía. Lejos estamos aún del pensamiento fisiócrata, en el que la tierra, la producción agrícola y los recursos naturales cobrarán una particular significancia en la segunda mitad del siglo XVIII.

El caso del Perú para el periodo 1580-1620 es emblemático al respecto, tanto por el discurso oficial que describe su momento, como la realidad que experimenta. Algunos manuscritos de carácter político o económico emitidos en diferentes rincones del imperio acuden a tales calificativos para explicar la situación

${ }^{1}$ Lempérière, 2005. 
del Virreinato del Perú, en la posibilidad de que logre abandonar su relación económica "de dependencia" con España. Existen fundados elementos para sostener que estamos en presencia de un momento de máxima tensión entre España y los agentes económicos y políticos del Perú, donde, como dirían las fuentes, la relación de "subordinación" está por quebrarse. El Consejo de Indias, los mercaderes peninsulares, los funcionarios políticos y religiosos del cuerpo monárquico nos hablan del peligro de que se quiebre la "forzada dependencia" que todo reino debería mantener con España. El propio reino del Perú parece estar viviendo en esos tiempos una emancipación económica, alejándose de la órbita peninsular. Puede que estemos en presencia de un escenario económico inédito, que no volvería a repetirse hasta la independencia política acaecida en la tercera década del siglo XIX (1821).

El estado de autonomía económica que reina en el espacio entre 1580 y 1620 parece comprenderse de manera más cabal si se conecta con el tensísimo clima político que el espacio andino experimenta décadas atrás, particularmente entre 1540 y 1560. A partir de la conquista del Tawantinsuyu, el faccionalismo, el motín, la revuelta y el conflicto son los rasgos dominantes de la vida política y administrativa en el Perú. Las guerras civiles iniciadas en 1537 entre los grupos de Francisco Pizarro y de Diego de Almagro constituyen la chispa de la fragilidad de gobierno que se afinca en la región en las décadas posteriores. El conflicto se agudizará con la controversia sobre la perpetuidad de las encomiendas entre los primeros conquistadores y pobladores, y el poder regio. Los encomenderos mostrarán una fuerte resistencia a cumplir con las Leyes Nuevas de 1542 que intentan suprimir la perpetuidad de las encomiendas. En este contexto se gestan los alzamientos y las rebeliones contra el poder de la Corona. La primera de éstas, y de corte más radical, es la encabezada por Gonzalo Pizarro (1544-1548). Le seguirá la comandada desde el Cuzco por Francisco Hernández de Girón (1553-1554). Hemos mencionado los más sobresalientes acontecimientos que ilustran la dificultad que tiene la Monarquía hispana para subordinar políticamente al reino del Perú. Los encomenderos, con años de 
haber acumulado grandes riquezas a partir de su dominio sobre los indígenas y el fruto de su trabajo, y de acumular tierras por merced, compra o apropiación directa no muestran disposición de ceder su poder ante el avance de la autoridad real. Entre guerras y violencia permanente, en el Perú se juega la posibilidad de que los encomenderos forjen un régimen político autónomo, independiente del poder monárquico. Si existe un momento histórico donde Perú se encontró muy cerca de independizarse políticamente de la Corona española, no hay dudas que esa coyuntura singular está comprendida entre 1540 y 1560; en el temprano periodo colonial y previo al virrey Toledo. ${ }^{2}$

En las primeras décadas del proceso de colonización, los encomenderos representan la elite socioeconómica; el poderoso grupo que, como brevemente sintetizamos, busca consagrar su poder político con la posibilidad de independizar políticamente al espacio peruano de la monarquía. El fracaso de la tendencia hacia la autonomía política responde a un abanico de cuestiones que exceden el objetivo del capítulo. Pero hay un factor que vale la pena subrayar: la declinación del poder económico de los encomenderos. Al momento de llegar al Perú para analizar la posible perpetuidad de las encomiendas, los comisarios reales notan su debilidad. La correlación de fuerzas favorece a los intereses reales. Muy pocos encomenderos están en situación de comprar la perpetuidad y esto inclina a los comisarios a convencer a la Corona para dar marcha atrás con la decisión. Hacia la década de 1560, la perpetuidad deja de ser un asunto de primer orden en la agenda del poder real y los propios encomenderos parecen conformarse con el cumplimiento de la ley de sucesión de dos vidas, establecida entre 1535 y $1536 .^{3}$

2 Goldwert, 1957-58, pp. 207-245; Bakewell, 1989a, pp. 41-70; Noejovich, 2009, pp. 23-208.

3 Dice Bakewell: "la rapidez y la aparente tranquilidad con que los encomenderos abandonaron sus pretensiones a la perpetuidad y a la jurisdicción indicaba que, para 1562-1563, su verdadero poder en el Perú había disminuido en un grado notable”. Bakewell, 1989a, p. 48. 
Desde entonces, una estabilidad política parece reinar en el espacio y aunque la hacienda real cuenta, de ese momento en adelante, con más ingresos provenientes de los repartimientos de indios en cabeza de su majestad, no logran solventar los apremios financieros de la corona. Para la Corona, el peligro de una independencia política alentada por los encomenderos es sólo un mal recuerdo del pasado. ¿Continúan siendo la elite del Perú en el último cuarto del siglo Xvi? La emergencia de un nuevo sector económico comercial viene a reemplazar a los encomenderos. Sobre esta nueva elite económica, que cristaliza su consolidación con la creación del Tribunal del Consulado de Lima en 1593, la Monarquía y los funcionarios reales posarán su atención para no caer en la amarga experiencia que les causó el grupo de los encomenderos. La preocupación se agudizará cuando perciban una segunda posibilidad de quiebre de la sujeción y dependencia del Perú con la península; en este caso una emancipación de corte económica más que política.

En este contexto que los manuscritos de finales del siglo xvi y primeros años del XVII ponen al descubierto, en pos de garantizar la "relación de dependencia" económica, dos condiciones básicas deben cumplirse:

1) La apropiación de excedentes en forma de metales preciosos con posibilidad de ser transferidos para su acumulación a la metrópoli. El énfasis sobre la exportación de plata de Potosí, determinada por el fetiche del mercantilismo metálico-comercial, debería asentarse bajo una estricta fiscalización que sólo lo puede otorgar el monopolio concretizado en Panamá; zona de tránsito por excelencia para la celebración de ferias y llegada de las flotas peninsulares.

2) Que el mercado consumidor del Perú y del resto de las posesiones indianas estén dispuestos a ingerir de manera exclusiva los bienes elaborados en España o producidos por otras naciones europeas, pero siempre por medio del canal monopólico de las flotas españolas. La circulación mercantil por canales exclusivos es la herramienta principal para la obten- 
ción de ganancias de España. Tal objetivo requiere frustrar toda aspiración para el desarrollo de actividades productivas internas, como precisos cultivos agrícolas que abundan en España o de productos industriales elaborados en ella o en Europa. Por lo que la "relación de dependencia" alcanzaría su logro cuando su economía no es capaz de alcanzar un régimen de autoabastecimiento, cuando no puede valerse por sí misma y necesita indefectiblemente surtirse por canales oficiales de bienes desde España.

Los usos interpretativos que los manuscritos de la época hacen sobre los términos "independencia" o "quiebre de dependencia" requieren detenimiento. Lo que en la época se menciona como una suerte de independencia económica del Perú está muy distante del pensamiento moderno del desarrollo económico, o más específicamente de la conocida "teoría de la dependencia", que corresponde ciertamente a otra circunstancia histórica, donde la producción, la transferencia de capital, de tecnología y de servicios son determinantes para definir el grado de autonomía económica de un determinado espacio. La advertencia sobre el peligro de verse cortada la "relación de dependencia" sólo puede comprenderse en el marco del pensamiento mercantilista. Desde una aproximación circulacionista y no productiva se asientan los argumentos del término. La notable disponibilidad de plata en su economía interna y las salidas de sus excedentes productivos son los argumentos para suponer una economía peruana independiente. ${ }^{4}$ Sólo así puede comprenderse que el Perú se encuentre al borde de romper su relación con la metrópoli: reteniendo metálico o desviándolo por otros conductos externos que no son los que se inician o finalizan en la Península Ibérica. Perú expande su economía, maximizando su capacidad exportadora y reduciendo al mínimo el ingreso de productos del exterior que proceden desde España por el camino de Tierra Firme.

\footnotetext{
${ }^{4}$ Heckscher, 1943.
} 
El diagnóstico de una economía peruana con relativa autonomía no debería suponerse como una situación "normal", es decir, como el estado natural de un reino de las Indias formando parte de una monarquía policéntrica o compuesta. En este caso, la autonomía económica del Perú no es resultado de una hipotética concesión de la Corona, por un movimiento flexible y delegado. Lo que se vive en el virreinato del Perú entre 1580-1620 no podría inscribirse como una instancia de negociación o pacto político. Visto desde la ventana peninsular, la situación parece más compleja, hasta alarmante: los actores limeños experimentan una "independencia económica” que, según algunos testimonios que veremos enseguida, podría devenir en una "independencia política”.

Pero, ¿cuáles son los argumentos que suponen una gran autonomía económica del Perú entre 1580 y 1620?, ¿qué señales sugieren su posible desprendimiento de la cabecera ibérica de la Monarquía? Son varios fenómenos que al relacionarlos pintan un cuadro cercano a la realidad histórica: 1) la autosuficiencia del espacio peruano, comunicado hace tiempo por Carlos Assadourian, que tiene en su interior prácticamente todo lo que necesita; 2) el espectacular crecimiento de la producción de plata con el correspondiente aumento de numerario líquido disponible en el interior del espacio y que les permite a los comerciantes más reconocidos de Lima contar con el medio de cambio más preciado en diferentes mercados externos y emprender iniciativas de inversiones comerciales que superan el cuadro formal del comercio monopólico; 3) Perú es responsable de la primera gran crisis del intercambio oficial por Portobelo, al disminuir los envíos de remesas a España y consumir una mínima porción de lo enviado por los cargadores peninsulares por medio de los galeones de Portobelo. Los agentes sevillanos se ven desplazados en la plaza de recambio de Panamá y de cualquier intervención y participación en el mercado peruano; 4) muy relacionado al anterior factor, el drenaje promovido por los mercaderes limeños de los excedentes económicos desprendidos del espacio hacia el Pacífico novohispano (plata, vino, azogue, cacao) y China (plata), y 5) la notable movilidad que evidencian los peruleros por los 
circuitos comerciales y mercados globales de la época; una suerte de factores y comisionistas de grandes comerciantes limeños que apuestan su capital, esquivando cualquier agente mediador. Todos estos fenómenos constituyen, en su conjunto, los elementos más representativos del proceso de autonomía y emancipación económica del Perú.

Desde 1580 hasta por lo menos 1640 la plata del Perú representa aproximadamente $70 \%$ del total de metálico importado a España (gráfica II.4). El centro de intercambio en Portobelo funge como la exclusiva vía de captación del metálico andino para su circulación y destino a la Península. Dos condiciones se deben cumplir para que España acapare y obtenga la plata peruana en Portobelo: 1) cerrar los flujos ilegales de salida del metálico por el espacio (contrabando extranjero y local), y 2) que los cargadores peninsulares ofrezcan a cambio mercancías de consumo o de insumo en el virreinato andino. Estos dos principios se encuentran profundamente alterados en el periodo analizado.

El marco temporal requiere una breve justificación. A partir de 1580, precisamente con las reformas implementadas por el virrey Toledo, la producción de plata potosina inicia un boom, cuyo pico máximo se registra entre 1590 y $1592 .{ }^{5}$ Desde entonces, se genera una ola de documentación oficial que, de manera reiterada, expresa una crisis de los intercambios oficiales por la feria de Portobelo, que tiene como principales responsables a los agentes del Perú que se resisten a participar en la feria de Portobelo y el comercio ultramarino transatlántico. Desde el último cuarto del siglo XVI se registran elevados niveles de comercialización de los excedentes mercantiles peruanos a través de la costa del Pacífico hispanoamericano, extendiéndose hacia el eje transpacífico con destino a China; una circulación que no se repetirá durante el

${ }^{5}$ El cambio de técnica que se realiza por estos años del método indígena de la huayra (hornillos de fundición) al método de amalgama con azogue de Huancavelica resulta fundamental para la explosión de la producción de plata en Potosí. Assadourian, 1979, pp. 223-292; Bakewell, 1989 b. 
largo periodo del Antiguo Régimen. Pero, ¿cuáles son los niveles de las exportaciones peruanas? Resulta imposible presentar tal información con exactitud debido a la ausencia de documentación seria y oficial. Recordemos que estamos en presencia de un tráfico ilícito que sus agentes se ocupan de silenciar. Ante la debilidad de la evidencia, aquí consideramos fuentes cualitativas y los casos concretos que se conocen. Lo cierto es que la "expulsión" de los excedentes producidos del espacio peruano se inscriben en un modelo económico de autosuficiencia, en el que pocos o escasos productos se requieren del exterior: síntoma representativo del diagnóstico de autonomía económica. Por lo tanto, el escenario histórico analizado comienza en la década de 1570, con dos hechos trascendentes: a) el inicio del crecimiento de la producción de plata en Perú, dada la combinación exitosa del proceso de amalgama de plata potosina con el mercurio de Huancavelica, y b) la inauguración oficial del sistema del galeón de Manila, que conecta y articula las economías de China, de las Islas Filipinas, de la Nueva España y del virreinato del Perú.

El corte final lo ubicamos hacia 1620, pero podría extenderse hasta los inicios de la cuarta década del siglo. En esa primera fecha, la producción de plata de Potosí inicia su declinación. Otros centros mineros del Perú mantienen o incluso aumentan su producción hasta 1640 como Oruro, Arequipa o Cailloma. La tendencia muestra un descenso ininterrumpido desde esa fecha y su recuperación será en las últimas décadas del siglo xviII, pero lejos de los niveles alcanzados en el periodo que nos ocupa (gráfica II.4). ${ }^{6} \mathrm{Al}$ mismo tiempo durante el segundo cuarto del siglo XVII las exportaciones de excedentes mercantiles no mineros del espacio peruano descienden de manera significativa. Su estancamiento productivo conduce a que el espacio peruano inicie un proceso de fragmentación regional, con la correspondiente desaparición del atributo que lo posicionaba independientemente de la economía española: la autosuficiencia. La desmonetización del mercado interno y la ruralización de las economías locales hace

6 TePaske y Brown, 2010, pp. 150-158. 
disminuir el nivel de productos locales destinados a mercados externos. No es casual que desde 1640, la participación del Perú en el comercio del Pacífico y transpacífico se minimiza notoriamente. La caída de la producción de plata incidirá en una reducción del movimiento comercial hacia México, con la consecuencia directa de su disminución en la participación del comercio del galeón de Manila. Aunque a partir de 1640 comience a reencauzarse la relación de dependencia transatlántica del Perú con España. Los reclamos, conflictos corporativos y la salida de riqueza peruana hacia el Pacífico y el Oriente serán un recuerdo en las décadas siguientes. Recién retomarán impulso, como veremos en el capítulo II, a partir del último cuarto del siglo XVII.

El capítulo I contiene tres apartados. En el primero, se presenta la correspondencia oficial elaborada por virreyes, religiosos, organismos y corporaciones de España, de Perú y otros lugares bajo la órbita de la Monarquía, manifestando la situación terminal que sufre el lazo de "dependencia" del Perú. En un principio, la atención recae en identificar los motivos que hacen a los contemporáneos hablar de "frágil dependencia", "crisis de la subordinación" o aun de "independencia". Visualizamos dos grandes motivos: la tragedia que sufre la relación ultramarina en las primeras décadas del siglo XVII, como de la situación económica emancipadora del reino peruano en las últimas décadas del siglo XVI y primer cuarto del XVII. El análisis nos obliga a precisar e identificar las razones que permitieron tal diagnóstico.

El segundo apartado traslada hacia la realidad concreta todo lo que el discurso oficial delibera. Nos detenemos a identificar los factores responsables del quiebre de la relación transatlántica y que propiciaron a "liberar" económicamente al Perú, para ello rescatamos el proceso que comunica Assadourian sobre la autosuficiencia del espacio peruano. Sin embargo, nos detenemos a repensar el postulado sobre si la autosuficiencia económica del Perú fue posible sólo a condición de un elevado "control exterior" peninsular de su excedente. La necesidad de revisar la premisa relacional crecimiento interno $=$ control exterior surge cuando 
nos detenemos a evaluar la magnitud que alcanza la circulación del excedente peruano por cauces no oficiales, promovidos por sus agentes; una red de circuitos locales, monárquicos y globales que no están controlados por España. En efecto, la producción de bienes que produce el modelo de autosuficiencia peruana y su drenaje por circuitos ilegales en el amplio espacio del Pacífico hispanoamericano sugieren un crecimiento de la economía peruana que late a ritmo propio, reconfigurando sus propias estrategias de inserción espacial en economías exteriores. En el amplio mapa global de intercambio comercial que se desarrolla por las aguas del occidente de las Indias, se atiende, con particularidad, al proceso de crisis de la relación transatlántica que atrae Perú al priorizar la contratación asiática-novohispana.

El último apartado analiza la movilidad espacial de los agentes peruleros como actores representativos del momento de emancipación. Comúnmente, la historiografía estudia las prácticas económicas de los agentes americanos dentro de sus propias fronteras locales. Lo que observamos y subrayamos en el caso del Perú es una notable movilidad de sus actores hacia espacios externos, gravitando fuertemente en mercados distantes. Los peruleros se definen, ante todo, como comisionistas, agentes o representantes de los grandes comerciantes de Lima, que viajan hacia mercados externos para adquirir mercancía estimada en las plazas consumidoras del Perú; son verdaderos agentes globalizadores en la época. Su actividad y movilidad los lleva a cuestionar desde sus estructuras los principios de la economía monopólica diseñados desde España. Con disposición de metálico, intervienen en mercados globales; con prácticas no institucionalizadas más cercanas a los principios de libre comercio y alteran los mecanismos regulatorios y monopólicos del comercio imperial. Tres campos de acción se visibilizan y se distinguen: en el mercado hispalense, en la Nueva España y aun en las Islas Filipinas. En suma, estas tres grandes problemáticas nos inducen a pensar que estamos en presencia de la primera gravitación e influencia que provoca el área marítima del Pacífico sobre el Atlántico europeo: ese gran fenómeno que llamamos el Atlántico pacificado. 
El capítulo se nutre de un abanico de investigaciones dedicadas a los grandes problemas de la temprana economía peruana. La obra de Carlos Assadourian cobra significancia a la hora de reflexionar sobre la formación del mercado interno. ${ }^{7}$ Asimismo, se consideran los más trascendentales estudios que abordan el movimiento comercial de larga distancia del espacio peruano, ya sea en la orientación transatlántica, transpacífica y sus contactos con México. Se consultan los clásicos trabajos sobre la historia económica del galeón de Manila; indispensables para rastrear la gravitación de la economía del Perú en el eje transpacífico con epicentro en Acapulco. ${ }^{8}$ En cuanto a las fuentes primarias que sostienen el trabajo, cabe mencionar los diarios, informes, cartas de testigos oculares que describen la realidad peruana de finales del siglo XVI y principios del siglo XVII. Se rescata también otro tipo de documentación: cartas, memoriales, informes políticos y económicos de personajes y corporaciones de la Monarquía y protocolos notariales que se encuentran, en diferentes ramos y fondos del Archivo General de Indias (AGI), del Archivo General de la Nación de México (AGNM) y del Archivo General de la Nación de Perú (AgNL).

\section{DEPENDENCIA E INDEPENDENCIA ECONÓMICA Del Perú en los informes oficiales}

Al menos en los primeros años del siglo XVII, la aplicación del concepto "dependencia forzosa" es frecuentemente utilizado. La aparición del término casi siempre se ve acompañado de calificativos negativos: "crisis", "frágil sujeción" o, aún más significativa, "falta de dependencia". La combinación de las palabras sintetiza la preocupante realidad que está viviendo el virreinato del Perú entre 1580 y 1620 dentro de la Monarquía. La preocupación del poder

\section{Assadourian, 1982.}

8 Sería muy extensa la lista para citar aquí todos los estudios. El lector podrá reconocerlos en citas posteriores o en el listado bibliográfico que aparece al final del libro. 
peninsular por verse cortada la "dependencia" con el Perú tiene sus argumentos. Ciertamente, el virreinato andino constituye la pieza económica fundamental del imperio hispánico en la segunda mitad del siglo XVI y gran parte del xviI. Como lo advierte la cita de Peñaloza que aparece al principio del capítulo: el devenir de España "depende" de las riquezas del Perú, en particular de su plata. Sus riquezas metalíferas son indispensables para solventar las guerras y las finanzas en la Península. De ahí, la preocupación que denotan los escritos por la reducción de los envíos de plata, de la "desmonetización" del circuito Portobelo-Sevilla. El declive de la ruta transatlántica del metal va a contramano con la espectacular producción de plata en el Perú.

Un breve recorrido por un puñado de manuscritos oficiales advirtiendo del inminente rompimiento del lazo comercial entre Perú y España nos puede ofrecer, como introducción, los factores responsables del quiebre. El 21 de septiembre de 1603, el rey Felipe II le solicita al cardenal arzobispo de Sevilla una relación sobre el "mejor remedio" para conservar la "dependencia que conviene que haya de las Indias con estos reinos y que éste se conserve y aumente". ${ }^{\text {El }}$ cardenal Fernando Niño de Guevara responde de manera inmediata, el 28 de octubre, recomendando atender las cinco más importantes razones, que si se dejan de lado, "se puede en verdad creer que dentro de pocos años se acabará de todo punto la relación de dependencia" " ${ }^{10}$ Dos de ellas son simplemente enunciadas en el manuscrito: "la poca seguridad que ha habido en el mar", dada la presencia de piratas y el contrabando europeo y, por otra parte, "los excesivos derechos que se pagan en el comercio [reglamentado]", que llevan a la baja la rentabilidad obtenida por los comerciantes. Los tres restantes factores que el cardenal atiende enfáticamente para explicar el distanciamiento de la "relación de dependencia" del Perú hacia la Monarquía son:

9 "Copia de carta original del Cardenal Arzobispo de Sevilla", [1603] 1845, pp. 565-572. Por su importancia, se transcribe gran parte del documento en el apéndice documental, capítulo I, documento III.

10 "Copia de carta original del Cardenal Arzobispo de Sevilla", [1603] 1845, p. 572. 
a) "el trato y comercio de las Indias con las Filipinas"

b) "en haberse dejar plantar viñas en el Perú"

c) "en haber tolerado los navíos de comercio por fuera de las flotas de Portobelo".

El arzobispo de Sevilla avizora que, si el comercio entre Perú y México continúa con el esplendor que el galeón de Manila le inyecta, peligrará no sólo el comercio transatlántico sino la propia integridad del imperio hispánico. El comercio de vino peruano a México es un elemento más que refuerza la potencia de autonomía mercantil peruana. Ya no es sólo los bienes asiáticos y europeos que fluyen desde Acapulco hacia el Perú, sino que la comercialización de los vinos producidos en el espacio andino hacia el norte de Hispanoamérica aminora los envíos de la bebida producida en los viñedos españoles hacia Veracruz. El prelado explicita la raíz del problema para la Corona: incuba el fenómeno de "independencia económica" que inevitablemente terminará en ideas de independencia política.

Niño de Guevara acierta al reconocer los factores del quiebre de la relación de dependencia peruana con España. Esto se puede confirmar no sólo al notar que esos postulados se reiteran en los demás escritos oficiales de la época, sino que, como veremos, la realidad histórica lo confirma. La salida de plata peruana hacia el Oriente, con el correspondiente ingreso de telas asiáticas al mercado regional, la comercialización de vinos del Perú por todas las Indias y la crisis del centro de intercambio oficial por Portobelo aparecen como piezas plenamente articuladas de un nuevo mapa económico peruano, cuya órbita se encuentra bien distante de los intereses españoles.

Aunque el movimiento de bienes entre Filipinas, México y Perú se encuentra prohibido desde 1582, el área de navegación triangular por el Pacífico muestra una gran actividad en las décadas de esplendor de la economía peruana. Con la oficializa-

11 "Copia de carta original del Cardenal Arzobispo de Sevilla", [1603] 1845, pp. 565-572. 
ción del galeón de Manila (1573) y las autorizaciones para las libres y directas vinculaciones entre el Oriente con la América hispana (1579), la Corona se ve en la necesidad de dictar la prohibición a toda contratación asiática que se desarrolle por fuera del radio novohispano. La economía peruana queda marginada de todo comercio con el Oriente y negada a cualquier trato de productos orientales y europeos con Nueva España. Como veremos enseguida, la realidad demostró que la disposición tuvo poco resultado. Por su parte, la producción de vino peruano no sólo captura el mercado de consumo de todo el virreinato, sino que al ingresar con mucho peso en los mercados de Centroamérica y la Nueva España, no hace más que desplazar y tornar invendibles los vinos españoles que llegan a Portobelo.

Otros escritos de diferentes rincones del imperio también advierten sobre el camino peligroso que ha tomado la economía del Perú. En 1605, dos años después del escrito del arzobispo de Sevilla, aparecen dos figuras destacadas de la política imperial emitiendo su juicio sobre el peligro de verse cortada la "relación de dependencia”. Uno de ellos es el gobernador de Panamá, Francisco Valverde de Mercado, quizá el más agudo testigo ocular y conocedor de la economía panameña del temprano periodo colonial. El gobernador relaciona el "miserable y nunca visto estado de ruina de los intercambios en Portobelo" con la inclinación de los agentes peruanos hacia Acapulco y su extensión de trato hacia Filipinas y el Oriente. En sus líneas señala que la "dependencia comercial” transatlántica está prácticamente quebrada por la indiferencia de los comerciantes de Lima al centro de intercambio de Portobelo, dada su inclinación hacia la economía novohispana y del Oriente. ${ }^{12}$

Para los primeros años del siglo XVII sobresale el abanico de cartas y documentos del fraile Martín Ignacio de Loyola. El religioso es una de las personas más viajeras y conocedoras del mun-

12 "Carta del presidente Francisco Valverde de Mercado, 9 de octubre de 1605", AGI, Panamá, 15, r. 6, núm. 52, f. 1; "Carta del presidente de Panamá Francisco Valverde de Mercado, 25 de junio de 1610”, Agi, Panamá, 16, r. 2, núm. 23, f. 14. 
do tempranamente globalizado. ${ }^{13}$ Luego de vivir y visitar varios lugares de China, India y África, desde 1596 se le encuentra en la Gobernación de Paraguay, cumpliendo la función de Obispo de Buenos Aires. Más que un pensamiento uniforme y formal, sus percepciones sobre la economía del Perú aparecen en contadas y breves cartas que envía al Consejo de Indias. ${ }^{14}$ Loyola presenta ideas más radicales y determinantes que sus contemporáneos sobre el estado de independencia que entonces vive el reino andino. Ante la negativa real de abrir el puerto de Buenos Aires al comercio portugués, el franciscano, defensor de los intereses porteños, se anima a denunciar la corriente sistemática de "ropa de China" que alimenta a Lima vía Acapulco. ${ }^{15}$ Incluso llega a decir que la "conexión china" se ramifica por las plazas de la gobernación de Tucumán, Chile y Buenos Aires. La apertura clandestina de los puertos del Perú hacia el polo oriental que presenta la globalización temprana no sólo produce una inestabilidad de la conexión Portobelo-Sevilla, también alienta, con relación al Perú, "una grande independencia [...] de España y llegará el momento en que las Indias no estuvieren pendientes de España en todo". ${ }^{16} \mathrm{Al}$ denunciar lo que ocurre por el Pacífico de la América meridional,

13 Sugerentes estudios culturales hacen mención al concepto de mediadores culturales, como una suerte de correas humanas que contribuyen a la interacción cultural en la temprana globalización. Véase al respecto, Gruzinski, 2010, pp. 234-274. Posiblemente, el abordaje de redes mercantiles es una herramienta ideal para comenzar a rastrear la movilidad de los agentes en la conexión de los continentes. Los peruleros, una problemática que analizamos en el último apartado, es una aproximación al tema.

14 "Que se tripliquen los despachos tocantes a la contratación con las Filipinas y a la mercadería y ropa de la China que se prohíben en el Perú", 6 de mayo de 1605, AGI, Sevilla AGI, Charcas, leg. 135, exp. s/n, f. 1. Fragmentos importantes de este documento aparecen transcritos en el apéndice documental.

15 Dice Loyola que "muchos millones de pesos que van a las Filipinas y esto que digo no es cosa sabida por relación, sino como testigo de vista, que vi una vez en el Callao una nao con mercaderías de la China que valía más que cuanto ha entrado por este puerto de Buenos Aires en cincuenta años y más que vale toda esta provincia. Y como ven que con estos abusos tan grandes quiebra el comercio de España a las Indias echan la culpa a este puerto de Buenos Aires, siendo ello muy al revés”. AGI, Charcas, leg. 135 , exp. s/n, f. 1.

16 AGI, Charcas, 135, exp. s/n: 1. 
Loyola logra en 1602 el permiso real para que el puerto de Buenos Aires movilice productos de la tierra (a excepción de la plata potosina y de esclavos) con el Brasil lusitano y con la costa africana de Guinea. Sorprendente explicación de corte global que asume gravitaciones entre las fuerzas económicas oceánicas: para solicitar la apertura del puerto atlántico rioplatense, Loyola apunta al tráfico de contrabando por el Pacífico.

Martín Ignacio de Loyola ofrece un discurso más extremista que sus pares. Desliza que el Perú vive una verdadera “independencia” económica, superando el diagnóstico más común de sus contemporáneos que apuntan a una "débil" o "crisis de dependencia”. Su visión radical se reluce en su terminología: "conviene que las Indias estén pendientes y subordinadas a España.. ${ }^{17} \mathrm{La}$ "subordinación" resulta ser un concepto utilizado para reforzar un principio innegociable: la relación de dominación peninsular sobre el espacio andino. Advierte que el crecimiento exponencial de la economía peruana podría devenir muy pronto en una independencia política del reino: "y tal que el día que [en] el Perú no estuvieren pendientes de España en todo sin duda se destruirá toda la política espiritual y temporal". ${ }^{18}$

Las voces de los funcionarios de las Indias repercuten en los círculos de poder peninsular. El Consejo de Indias se apropió de la conexión triangular entre Perú, México y las Islas Filipinas para ubicarla en un primer orden de la agenda de discusión. En 1608, aparece el arbitrio de un gran defensor de los intereses mercantiles sevillanos, el comisario consular Pedro de Avendaño Villela. ${ }^{19}$ Según Avendaño, la ruina y quiebra que se registran en la feria de Portobelo es una clara manifestación de un Perú que había roto el lazo de dependencia con España. Nos dice que, si la puerta del comercio con Asia y México continúa abierta y no se toman medidas al respecto, Perú se alejará de la influencia monárquica. Era

17 AGI, Filipinas 35, núm. 47, f. 824.

18 AGI, Charcas, 135, exp. s/n: 1.

19 "Discurso de Pedro de Avendaño Villela sobre la decadencia del comercio y forma de remediarlo, 14 de abril 1608”, AGI, Consulados, 93, 4/n de fs.; Suárez, 2015, pp. 107-108. 
necesario restablecer los mecanismos para que las Indias se vean "necesitadas a la dependencia de España [...] de lo contrario se han experimentado notables inconvenientes y daños y se podrán esperar mayores". ${ }^{20}$ Su recomendación es una medida tan radical como ingenua en materia diplomática: que la Corona castellana trueque con Portugal las Islas Filipinas por el Brasil. ${ }^{21}$ La defensa a los intereses de los cargadores sevillanos lleva a Avendaño a buscar por todos los caminos la desaparición del eje China-Filipinas-Nueva España-Perú en el mapa de la Monarquía hispánica, y a eliminar cualquier inclinación del Perú hacia uno de los polos de la globalización policéntrica: la economía china.

El quiebre de la relación de dependencia entre España y Perú, dado el "escape" de los excedentes comerciales del virreinato hacia México y Filipinas en perjuicio del eje transatlántico, es una razón que aparece de manera recurrente en los testimonios de queja emitidos por los cargadores sevillanos. La corporación mercantil se encuentra comprometida por el desenvolvimiento mercantil autónomo del espacio peruano. En uno publicado en 1610 se sugiere trasladar la contratación asiática de México, como venía ejecutándose a través del galeón de Manila, hacia España, para así minimizar el papel fundamental que gozan los agentes de Nueva España y del Perú en el comercio por el Pacífico. ${ }^{22}$ Hay que desplazar a México de la centralidad mercantil que logró asumir en el imperio y volver a otorgarle esa función a España.

Una de las más expresivas manifestaciones metropolitanas para "subordinar" al Perú aparece en la Memoria de 1615, del virrey Juan de Mendoza y Luna, marqués de Montesclaros. Allí se establecen explícitamente cada una de las prohibiciones que pe-

20 AGI, Consulados, 93, fs. 4.

${ }^{21}$ Avendaño nota el contrabando portugués por Sacramento y Buenos Aires, para poder canalizar por vías de comercio formales la plata andina que se escapa por el Atlántico sur. La propuesta de negociación expresa la actuación de los comerciantes peninsulares en los límites del espacio atlántico y de su nula gravitación en los flujos del Pacífico.

22 "Real Cédula al marqués de Salinas, virrey de Nueva España”, 1610, AGI, Filipinas, vol. 329, leg. 2: 18-120. 
san sobre el Perú para evitar un desarrollo económico autónomo. Vale reproducir las líneas más elocuentes:

Hay disposiciones generales para el Gobierno de estos Reinos que miran a hacerlos enteramente dependientes de los de España; como no haya obrajes, no se planten viñas ni olivares, no se traiga ropa de China, para que los paños, el vino y el aceite y las sedas vengan de Castilla, muy conveniente es tal dependencia, y el clavo más firme con que se afija la fidelidad y sujeción; alguna vez he dicho a Su Majestad por mis cartas el tiento con que se debe proceder a esta razón de estado, y cuán peligroso es tomar de ella más que lo muy preciso para conseguir el fin principal. Digo peligroso en la justicia, que rigor parece vedar a los moradores lo que naturalmente les concede la tierra que habitan, peligroso aun para los mismo que se desea, que ya podría el apresurar a buscar salida, quebrantando los grillos y rompiendo las cadenas del precepto. ${ }^{23}$

Para el virrey, la "razón de estado" español pasa por vedar cualquier proceso industrial, comercial y consumidor peruano que no pase por la economía peninsular. Como en los restantes manuscritos revisados, la "sujeción" económica del Perú está en privar el desarrollo de obrajes locales y reprimir el cultivo y la comercialización de sus vinos y aceites hacia los mercados de Centroamérica y de México. Asimismo que sus habitantes no deben consumir telas y sedas del Oriente con el objetivo de vender el textil peninsular que llega a Panamá. En definitiva, un conjunto de medidas que hacen de la dependencia con España para la garantía del eje transatlántico Portobelo-Sevilla. Vale aclarar que las disposiciones prohibitivas del virrey Montesclaros no son nuevas: al margen de su cumplimiento o no, están vigentes desde el mandato del virrey Toledo (1569-1581). ${ }^{24}$

23 Bailly, 1859, p. 47.

24 "Real Cédula al Conde del Villar, nombrado virrey del Perú, para que se informe acerca de lo que se ordenó a Don Francisco de Toledo sobre la prohibición de fabricación del vino y de paños finos y de cobres y asimismo ordene que no se traigan vinos de Chile ni de otra provincia”, 1584, AGI, Indiferente, 606, 1. 1, fs. 10-11. 
Años antes, cuando la política se alía con los poderosos de la economía, Montesclaros termina por apoyar los intereses de las elites económicas del Perú. En 1612, defiende la posición de los comerciantes limeños al sugerir la reapertura oficial del tráfico entre Perú, México y Filipinas que se encuentra oficialmente cerrada desde 1580. Una nueva oficialización del eje, con el consecuente peso impositivo que se aplicaría al circuito por el área terminaría por disminuir, según el virrey, la inclinación de los limeños sobre la ruta y renovarían el movimiento de sus capitales hacia la contratación de Tierra Firme. Al "blanquear" el eje, se alentaría a reforzar "la relación de dependencia" del Perú con España. Montesclaros es consciente de que la principal preocupación de la Corona es que México provoque la pérdida de la "relación de dependencia" de Perú hacia España; un punto fundamental de la controversia establecida con la corporación mercantil sevillana. Por ello, intenta convencer a la Corona que si:

la principal cargazón de España a México es vino, aceite y algo de lencería [...] por lo que toca al vino, México es incapaz de consumir más vino y aceite del que a la presente gasta y ya queda conseguida la forzosa dependencia. Que lo que toca al lienzo lo podría suplir en parte sirviéndose del que los indios hacen de algodón y de las sedas que provee Manila para beneficiar y labrar admirablemente en la Mixteca. ${ }^{25}$

La visión del virrey, sugestiva y parcial por donde se la mire, esconde, no obstante, lo que ocurre en los circuitos mercantiles de la Monarquía. No le tiembla el pulso en ocultar los flujos clandestinos que, como veremos enseguida, funcionan por el Pacífico y que son promovidos con capitales peruanos. El caso del vino peruano movilizándose por todos los puertos del Pacífico hispa-

25 "Carta en respuesta al informe sobre mudar a España la contratación de México a Filipinas", 12 de abril de 1612, Papeles referentes al gobierno del Marqués de Montesclaros, virrey del Perú, y otros documentos sobre el estado de Filipinas y su comercio con México, BDHE, signatura Mss/8990, f. 74. 
noamericano es un fenómeno que no menciona el virrey y que, dos años antes de que escriba la carta, el 14 de agosto de 1610, la Corona le ordena a Montesclaros cortar la emisión de licencias para el cultivo de viñas y la renovación de las existentes para garantizar la "dependencia” del Perú: "que no se den licencias para plantarlas ni para reparar las que se fueran acabando, para que se conserve la dependencia que conviene que tengan estos reinos de estos, y por la contratación y comercio". ${ }^{26}$

En suma, vino, plata y sedas de China: un mar de productos y mercancías que fluyen por el Pacífico expresando una economía peruana reluciente y emancipada. La contratación asiática termina por adecuarse muy bien a las mercancías del espacio andino que se ofrecen en el exterior. El virrey no sólo es indiferente a la orden real, sino que oculta la realidad. En primer lugar, minimiza el peso de los textiles europeos que se envían hacia México en las flotas transatlánticas de Veracruz. En las décadas que nos ocupamos, las flotas novohispanas funcionan con regularidad y dicho rubro comercial es plenamente aceptado en el mercado novohispano. Al mismo tiempo, otorga un énfasis particular a la comercialización al vino y al aceite español que se destina al mercado novohispano. No duda en afirmar que "la Nueva España es incapaz de consumir más vino y aceite del que a la presente gasta”. O que los vinos que se beben en México "siempre los ha de recibir de España y no hay otra parte que se los pueda dar" ${ }^{27}$ Aquí intenta ocultar lo que es un hecho de público conocimiento; la existencia de un excedente en la producción vitivinícola del Perú para su exportación hacia

26 Hasta el jesuita e historiador hispanista de finales del siglo xIx, Ricardo Cappa, defendió a ultranza la política restrictiva que pesó sobre el comercio del Pacífico. Poca simpatía muestra a la emancipación americana del momento. Dice al respecto: "Yo no me arredro por ir hasta las últimas consecuencias las cédulas que defiendo, porque no permitiéndose el plantar viñas se mantendrá América dependiente de España”. Cappa, 1890, vol. vi, p. 19.

27 "Carta en respuesta al informe sobre mudar a España la contratación de México a Filipinas", 12 de abril de 1612, Papeles referentes al gobierno del Marqués de Montesclaros, virrey del Perú, y otros documentos sobre el estado de Filipinas y su comercio con México, BDHE, signatura Mss/8990, f. 75. 
México, Panamá y Guatemala. ${ }^{28}$ En este sentido, se inscribe el Parecer de un arbitrista, el contador Hernando de Valencia, explicitando los daños que ocasiona la continua expansión de las plantaciones de viñas en el Perú, por lo que aconseja retornar a su prohibición para aumentar el consumo de los vinos que vienen desde España. ${ }^{29}$ Para esos años, el comercio del vino español por Panamá no sólo pierde terreno ante la expansión vitivinícola peruana, sino que su circulación hacia las plazas de Nueva España y más en Centroamérica le genera una férrea competencia.

Abundan los memoriales de similar perfil que terminan por inundar la mesa del Consejo de Indias y de la Monarquía durante las dos primeras décadas del siglo XVII. Valdría mencionar un último caso. Se trata del Memorial y Apuntalamiento del arbitrista, comerciante y matemático aragonés Joan de Belveder, que al menos desde 1584 residía en el Perú. ${ }^{30}$ A diferencia de la mayoría de los arbitristas peninsulares, Belveder comunica, en calidad de testigo ocular, la necesidad de "reformar, ordenar y hacer concierto", pues de otro modo caería en serio cuestionamiento el dominio de España sobre el reino. El Memorial se compone de 38 puntos que sintetizan los daños y remedios para reforzar el lazo. Para el arbitrista aragonés, el Perú de principios del siglo XVII podría definirse sobre cuatro grandes postulados: lo habitan españoles que no habían nacido en la Península; dispone de un mercado autosuficiente de insumos, alimentos y textiles que lo hacen depender mínimamente del exterior; genera un notable fraude fiscal en su lazo transatlántico a través de Panamá, gozando, al mismo tiempo, de un intenso flujo de nulo registro con China y México, y en detrimento de España.

28 Ramos Pérez, 1970, p. 236.

29 Suárez, 2014, p. 27.

30 "Memorial y apuntamiento sumario de algunos casos muy importantes al reparo y aumento de las rentas reales de su majestad para estos reinos del Perú y España que piden reformación, orden y concierto en su administración”, 1612; AGI, Lima, 143. Agradezco a la historiadora Margarita Suárez el haberme compartido la transcripción completa del manuscrito. Suárez realizó un excelente ensayo sobre el pensamiento de Belveder: Suárez, 2014, pp. 25-46. 
La Península debe reformular su enlace con el reino andino, obligándola a acudir a ella. La "dependencia" comercial no es posible si el Perú continúa plantando viñedos, olivares, cañaverales de azúcar; si persiste en la fundación de obrajes para la fábrica de ropas compuestas de paños, sedas y otros textiles, y si el trato con México y China sigue en pleno desarrollo, escapando "a esta parte más de 130 millones de pesos de tesoro [español]”. El hilo mercantil con España está por soltarse, pues su vino ya no tiene consumo en el Perú, como tampoco el aceite, el cobre ni los textiles de Castilla; una canasta de productos que no puede competir con los tejidos de China y los labrados en México. La llegada de las flotas españolas a la plaza de recambio en Panamá, según registra el aragonés, son las últimas pulsaciones de su vida. ${ }^{31}$

\section{Política peninsular asimétrica sobre el virreinato del Perú}

En su clásica obra Spanish under the Habsburgs, John Lynch nos dice que el gobierno imperial hispánico se encuentra plenamente consciente de la existencia de una economía peruana independiente para las tempranas décadas del siglo XVII. ${ }^{32}$ El monopolio español resiente hondamente la inclinación del Perú hacia el Pacífico, en particular hacia México y Filipinas. La Corona, presionada por los intereses privados de los mercaderes peninsulares, busca por todos los medios preservar el mercado peruano, el más importante por esos tiempos en Hispanoamérica, cerrando, prohibiendo y regulando la natural inclinación del espacio andino hacia la economía del Pacífico hispanoamericano y del Extremo Oriente.

¿Qué conclusiones generales (explícitas y subyacentes) se desprenden de las advertencias oficiales sobre una realidad emancipadora de la economía peruana? Ante todo, la existencia de un estado peninsular que marca claramente cuál es la política económica que debe implementarse en los espacios indianos. Los me-

31 “Memorial”, AGI, Lima, 143, s/n de fs.

32 Lynch, 1969, pp. 225-226. 
moriales e informes oficiales dilucidan la "rebeldía" de Perú por cumplir con esa política. Es decir, los escritos expresan un contexto histórico donde el poder español aspira a institucionalizar la relación de subordinación económica con los espacios americanos. El periodo comprendido entre 1580 y 1630, momentos en que la producción minera de Potosí vive su apogeo, la política metropolitana tiende a esforzarse por encuadrar para su beneficio el crecimiento del espacio que a todas luces parece superar los límites impuestos. Desde una perspectiva económica, estamos lejos de pensar en un ejercicio libre de pactos y negociaciones entre el rey y el poder local del Perú. Si tal "pacto" existe, tanto los propósitos que aparecen en las cartas y memoriales revisados, como la propia realidad económica que germina en el Perú lo comprometen. Más bien, lo que manifiestan estos escritos es consolidar una marcada relación asimétrica, de explícita subordinación donde el Perú se muestre económicamente necesitada de España.

$\mathrm{Si}$ aceptamos la premisa, debemos revisar el renovado concepto de reino que utiliza la historiografía contemporánea para comprender lo que suele denominarse como el proceso de incorporación de los reinos indianos a la "Monarquía universal". En efecto, la nueva corriente de interpretación institucional y jurídica propone desechar el concepto colonia o colonial, postulando en sus reemplazos la de reino o de Antiguo Régimen. ¿Es válido plantearse la dicotomía entre colonia y reino? Al menos desde la historia económica vemos una completa compatibilidad entre los usos del término "reino del Perú" o "reinos de las Indias" y las políticas metropolitanas que marcan, en esencia, una relación colonial. ${ }^{33}$ Podría ser correcto hablar de Antiguo Régimen o reino cuando se intenta trazar un análisis desde la historia jurídica, administrativa y aun desde el plano normativo de la institucionalidad. Pero la relación colonial aparece en su máxima manifes-

33 Remitimos aquí al debate "en torno al colonialismo" que cristaliza el ensayo de Lempérière, 2005. En el dossier aparecen importantes apreciaciones sobre la pertinente utilización de los conceptos "colonia" o "reino" para los siglos anteriores al xix. Recomendamos el ensayo "La cuestión colonial” de Garavaglia, 2005. 
tación de forma muy temprana, en momentos que Perú intentaba emanciparse comercialmente. La subordinación del Perú a la política económica impuesta por la Corona pasa a ser el rasgo fundamental de los escritos oficiales.

Quisiéramos ser más claros para evitar confusiones que puede provocar la discusión conceptual pregonada por la actual historiografía jurídica-institucionalista. La política discrecional y asimétrica aparece con nitidez desde el último cuarto del siglo XVI; una suerte de "batería" de medidas económicas metropolitanas que buscan la sujeción o control de los espacios del Perú y de la Nueva España en aras del desarrollo económico metropolitano (la razón de su fracaso constituye otro gran problema de análisis que supera nuestro objetivo). Tres grandes directrices de la política económica manifestarían la aspiración peninsular de "subordinar” al Perú y a todas las Indias.

1) Subordinación industrial y consumidora: Desde 1530 hasta 1570, la Corona otorga libertades a la producción textil en las Indias. Ante el temor de que los obrajes españoles se vean incapaces de responder de manera simultánea al mercado interno y ultramarino, el Consejo de Indias decide el cierre a la exportación de los tejidos producidos en la Península. La industria española, dependiente de la producción inglesa, francesa y holandesa, no se encuentra capacitada en esos tiempos para abastecer su mercado interno y menos aún el de las colonias hispanoamericanas. La decisión redunda en un claro beneficio hacia las Indias y, en especial, para los centros productivos de seda y lana en la ciudad de México y Puebla. Desde 1570 hasta 1630, la política económica cambia rotundamente de sentido: se emiten medidas restrictivas y de prohibición para frenar la expansión de la industria textil hispanoamericana. Mediante disposición real, España reconoce que la dependencia sólo puede mantenerse si los mercados hispanoamericanos son abastecidos de productos españoles y europeos. De esa manera, se deja sin efecto la medida de libertad para producir textiles manufacturados, particularmente de paños y sedas, que estuvieran destinados a los grupos socialmente pri- 
vilegiados de españoles. El objetivo es claro: que Perú (y todas las Indias) se vea obligado a consumir los textiles de seda, paño y algodón producidos en España y en otros “pulmones" industriales de Europa. ${ }^{34}$

2) Sujeción al sistema comercial de monopolio. El rígido esquema mercantil concentrado en los puertos exclusivos de Sevilla, Veracruz y Portobelo resulta la herramienta más adecuada para captar la plata de Potosí y de las minas novohispanas, al intercambiarla por los productos elaborados provenientes de España. Las ferias de Veracruz y Portobelo se erigen como las únicas plazas de recambio autorizadas por la Corona, donde deberían acudir los comerciantes de México y del Perú para celebrar los intercambios. La política económica implementada sobre el área del Pacífico es la más clara manifestación de los intentos de subordinación económica de las Indias a España. Entre 1580 y 1630, el espacio del Pacífico sufre la más férrea política de prohibición y regulación, la cual busca impedir que las economías de la Nueva España y del Perú transiten por un desarrollo económico distante a sus intereses. En 1582, la política metropolitana busca marginar a la economía del Perú de todo trato directo, o mediado por Acapulco, con la economía del Imperio chino. Se busca que la ascendente producción de plata de Potosí sea canalizada únicamente por la ruta de Panamá. Hasta entonces, la economía peruana disfrutaba de un libre tráfico con el Oriente. ${ }^{35}$ El galeón de Manila, navío que en 1573 inaugura de manera formal las travesías entre Filipinas y Acapulco, desde 1593 llevará el peso de una serie de restricciones comerciales para los envíos de plata e importación de bienes orientales. En la Disposición se subraya la exclusividad del virreinato de la Nueva España para consumir los bienes orientales que se importan por la única plaza de recam-

34 Miño Grijalva, 1988, pp. 283-321.

35 AGI, Filipinas, 339, libro 1, fs. 210-211; "Consultas sobre la contratación de Filipinas", cit., AGI, Filipinas, 1, núm. 66, s/n de fs. También "Cartas y expedientes de gobernadores de Filipinas”, 1565-1601, AGI, Filipinas, 6, s/n de fs. 
bio autorizada: Acapulco. ${ }^{36}$ Los topes que establece el poder real buscan minimizar las perturbaciones que podrían derivarse en el comercio transatlántico de un libre comercio con el Oriente. Las medidas de restricción sobre el espacio peruano se agudizarán en los años siguientes. En 1604, el Consejo de Indias, a través de una real cédula, permite que sólo tres naves peruanas por año realicen comercio con la Nueva España de productos locales, "de la tierra”. En 1630, se llega a la decisión real de prohibir todo trato comercial entre la Nueva España y el Perú. ${ }^{37}$ Será en estos años cuando el vino peruano encuentra limitaciones importantes para su producción y comercialización por el Pacífico, dada la necesidad peninsular de expender su vino y aceite en las Indias. Entre 1614 y 1615, se decreta la prohibición de su ingreso al mercado de Panamá y Guatemala, y en 1620 se desautoriza su consumo en la Nueva España. Recién hacia la década de 1640 gozará de permisiones oficiales para su comercio. ${ }^{38}$

\section{3) Limites a la movilidad espacial de los agentes hispanoamerica-} nos. No hemos encontrado ninguna normativa o ley que fije espacialmente el radio de acción de los grupos mercantiles o de sus corporaciones en el sistema de monopolio comercial. Todo

${ }^{36}$ Las cédulas reales con sus respectivas prohibiciones para todos los espacios americanos aparecen en los siguientes libros de asiento con la fecha 11 de enero de 1593. "Real Cédula al marqués de Cañete, virrey del Perú, prohibiendo el comercio de las Indias occidentales a la China y Filipinas, y a su vez el de estas islas con Nueva España", AGI, Filipinas, 339, libro 2, fs. 70-71; "Asiento de despacho de una Real Cédula a la Audiencia de Panamá sobre la prohibición del comercio de las Indias occidentales con China y Filipinas, y a su vez el de estas islas con Nueva España”, AGI, Filipinas, 339, libro 2, f. 71; "Real Cédula prohibiendo el comercio de las Indias occidentales con las Islas Filipinas y dictando reglas para el que se había de hacer entre éstas y Nueva España", AGI, Filipinas, 339, libro 2, fs. 72-73; "Real Cédula a los virreyes del Perú y Nueva España, Marqués de Cañete y Luis de Velasco, al gobernador de las Filipinas, Gómez Pérez das Mariñas, y a los presidentes y oidores de las Audiencias de las Indias, prohibiendo el comercio de las Indias occidentales con las Islas Filipinas, y dictando reglas para el que se había de hacer entre éstas y Nueva España”, AGI, Filipinas, 339, libro 2, fs. 73-74. Véase también: Álvarez, 2013, pp. 25-84; Yuste, 2013, pp. 85-106.

37 Borah, 1975, pp. 227-236; Rodríguez, 1960, pp. 235-237.

38 Encinas, [1596] 1946, pp. 243-265. 
indica que una práctica secundada en la costumbre, en lo consuetudinario, termina por ser percibida como una ley. En ese sentido, las reiteradas "internaciones" de los flotistas o galeonistas son denunciadas por los mercaderes novohispanos o limeños como una violación o interferencia a su facultad de exclusividad en sus respectivos mercados internos. Al mismo tiempo, los flotistas españoles esperan que los frecuentes viajes transatlánticos de mexicanos o peruleros hacia el mercado peninsular también sea una práctica censurada por la Corona. Sea un principio asentado en la costumbre o una temprana disposición oficial, lo cierto es que cada grupo de mercaderes dispone de un espacio de exclusividad comercial.

La autorización metropolitana para las fundaciones de los Reales Tribunales del Consulado de Lima y de la Ciudad de México en 1593 y 1592, respectivamente, no sólo es una concesión de facultades jurídicas y de derechos mercantiles, es también la obligación de sus miembros por respetar y sujetar sus prácticas y operaciones comerciales a determinados límites espaciales. En el caso de la corporación mercantil novohispana, su actuación tiene como fronteras y límites las ferias de Acapulco y Veracruz. Estas puertas comunicantes son los límites fronterizos de su accionar. Los notables mercaderes de la Ciudad de México fungen como los únicos receptores de las mercancías enviadas ya sea desde España con los flotistas o las remitidas por los "vecinos" filipinos asentados por siete o más años en las islas. Estos últimos agentes tienen, en teoría, el derecho a la carga del galeón de Manila. Los beneficios que obtienen del sistema los almaceneros novohispanos es que cuentan con el monopolio para redistribuir los productos asiáticos y europeos en el mercado interno virreinal.

En el caso peruano la situación es muy similar. Los grandes comerciantes de Lima deben participar únicamente en la feria de Portobelo, movilizándose por medio de la Armada del Sur que navega entre el Callao, Guayaquil y Panamá. Deben contentarse con esperar el galeón español y de esa manera abastecer los mercados del espacio peruano de mercancías adquiridas durante la celebración 
de la feria del Istmo. El principio teórico aparece de manera muy clara en el clásico trabajo de Loosley:

La influencia de la feria [de Portobelo] era el resultado de un convenio entre los mercaderes españoles y peruanos, sancionado por la Corona e impuesto por ella. Así los mercaderes españoles podían comerciar sólo hasta Portobelo y los peruanos sólo hasta el Istmo. Actuaban como si fueran dos compañías mercantes. En Sevilla estaban los miembros de una y en Perú los de otra. En las ferias, los sevillanos eran representados por el Almirante de la flota, y los peruanos por el presidente de Panamá. ${ }^{39}$

A nuestro entender, los tres postulados constituyen los pilares que definen institucionalmente una relación económica discrecional y de subordinación de las Indias con España. Nuestro análisis debe partir de un hecho fundamental: en el periodo que va desde 1580 a 1620 , por lo menos, todos esos lineamientos son violados o, al menos incapaces de frenar el crecimiento de Perú; un espacio que a partir de la práctica de sus agentes históricos se encuentra desafiando y poniendo en serio riesgo la relación asimétrica. Si la subordinación es resistida, el camino a transitar es el de la emancipación y el de una posible independencia económica. Se abastece de productos europeos y se drena su plata por otras vías, circuitos y espacios que no se trazan exclusivamente por la plaza de recambio oficial de Portobelo.

La economía peruana alcanza a crear un modelo de autosuficiencia, el cual requiere escasos productos del exterior, y dispone de excedentes mercantiles (sean mineros o no) que terminan por destinarse hacia otros mercados hispanoamericanos (Nueva España, Guatemala y Centroamérica). Los excedentes que salen de su economía interna ahondan la crisis de la relación económica transatlántica, que se manifiesta en Portobelo, bastión de la relación entre España y el virreinato del Perú.

39 Loosley, 1933, pp. 316-317. Los límites de la movilidad espacial pueden también rastrearse en Veitia Linage, 1945, pp. 314-369; Haring, 1939, pp. 171-173. 


\section{COMERCiO POR El PACÍfico: EXCEDENTES y AUtosuficiencia}

Pasemos de la pluma a datos concretos y veamos cómo los elementos reseñados por los funcionarios y pensadores se encuentran muy cerca de expresar la realidad. La emancipación económica del espacio peruano entre 1580 y 1620, que genera la primera crisis de la "relación de dependencia" con España, podría esbozarse en dos grandes niveles de análisis: por un lado, atendiendo el movimiento económico entre el Perú con el otro gran centro de Hispanoamérica, Nueva España, y, por otro lado, los lineamientos generales de su economía interna hasta alcanzar, en términos de Assadourian, el modelo de autosuficiencia y de integración regional que lo hace poco dependiente del exterior. Estos dos planos de análisis pueden ofrecer respuestas sobre nuestro interrogante fundamental: si la metrópoli logra mantener o no la "relación de dependencia" en pleno auge de la economía peruana. Comencemos con ese gran impulso que establece Perú con el polo novohispano y con la economía mercantil transpacífica, que llega incluso hasta Filipinas.

El análisis de la emancipación de la economía peruana, circunscrito a Nueva España por el Pacífico, no debe hacernos perder de vista que, en una coyuntura precisa de su crecimiento y expansión mercantil, Perú establece una comunicación directa con la economía asiática-filipina. Al margen de su corta vida, la relación directa Perú-Filipinas es una clara expresión de una economía peruana pujante y con gran iniciativa, que reconoce los beneficios y costos que implica prescindir de la relación novohispana para llegar al Oriente. Hacia 1580, desde las Islas Filipinas se muestran muy dispuestos a aprovechar el boom de la producción de plata peruana y la atracción de las sedas chinas que evidencia su mercado regional. El caso más emblemático de la navegación directa entre las Islas Filipinas con el puerto del Callao es el del navío Nuestra Señora de la Cinta que lo promueve el propio gobernador del archipiélago, Gonzalo Ronquillo. Junto con su sobrino, Ronquillo aprovecha su poder político para construir un comercio directo y clandestino con Lima. La nave lleva en sus 
bodegas, entre otros productos, grandes cantidades de seda china y hierro: dos de las pocas mercancías con las que no dispone el Perú. Las fuentes no permiten saber mucho más sobre esta navegación directa, pero la circulación de seda asiática sin mediación de Acapulco y, como enseguida veremos, el asentamiento de peruanos en las Islas Filipinas durante esas décadas hace suponer que el circuito funciona clandestinamente hasta las primeras décadas del siglo XVII, esquivando las prohibiciones legislativas. ${ }^{40}$

La relación con la Nueva España y la crisis de Portobelo

"hay gran comercio de todos estos reinos de Perú y de los de México y China" [1590]

De Morua, 1946, p. 188.

En 1607, la Audiencia de Panamá envía al Consejo de Indias un detallado informe relativo a las causas que provocan la dramática situación comercial por Portobelo. El documento es un excelente punto de partida para nuestro análisis. La Audiencia relata que "pocos años atrás, los vecinos de Panamá tuvieron grandes ganancias por la frecuencia de las flotas"; pero desde la última década del siglo xvi, "las flotas comenzaron a tardar dos años y a veces más y venir menores en número de navíos e importancia de la cargazón" ${ }^{41}$ La gráfica I.1 recupera las cifras presentadas por la Audiencia. Allí se ve claramente la tendencia de caída de los intercambios por el centro oficial de Portobelo.

El ritmo regular (trianual o bianual) de la llegada de los galeones a Portobelo parece no poder simular el desplome del núme-

40 "Real Cédula a Gonzalo Ronquillo de Peñalosa, gobernador de Filipinas, comunicándole que ha sabido que en 1580 envió a Perú un navío cargado de especiería, y que en 1581 envió otro con mercaderías a cargo de su sobrino Gonzalo Ronquillo de Ballesteros; que había dado órdenes de cobro de almojarifazgo y fletes sin dar aviso al rey" (11-6-1582), AGI, Filipinas, 339, leg. 1, fs. 210-211. También: Iwasaki Cauti, 1992 y del mismo autor, 1990, pp. 123-169.

41 “Descripción de Panamá", [1607] 1908, pp. 174-175. 
ro de navíos que salen desde la costa panameña en búsqueda de las mercaderías que trae la escuadra oficial. Cae en picada entre 1585 y 1605: de 94 navíos al mando del capitán Diego de Ribera, que descargan las mercaderías en 1589, se despachan en 1605 por Portobelo tan sólo 17 con la flota de Francisco del Corral. ${ }^{42}$

Gráfica I.1. Barcos despachados en Panamá en búsqueda de mercanías traídas por el Galeón

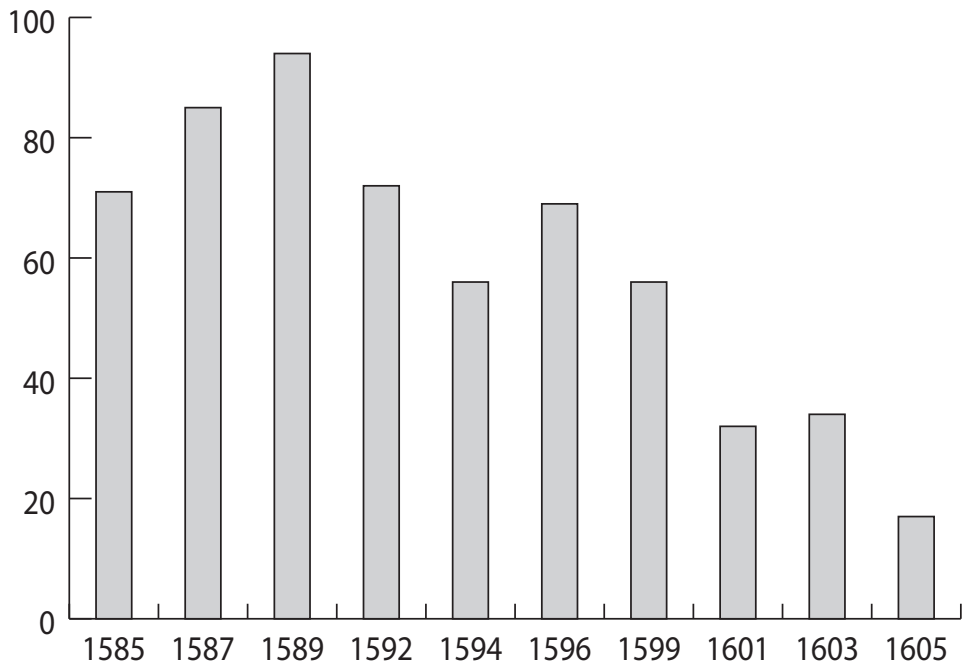

Fuente: “Descripción de Panamá", [1607] 1908, p. 174.

La crisis de Panamá tiene su espejo en el Pacífico, en el número de navíos que conectan los puertos de Guayaquil, Manta y Santa Elena con el Istmo centroamericano. Mientras, en el periodo 1569-1592 salen desde las costas ecuatorianas un promedio anual de siete navíos hacia Panamá, desde 1593 hasta 1638 las unidades navales descienden estrepitosamente a un promedio de dos barcos y medio al año. ${ }^{43}$ Estos cálculos deben contextualizarse en una

42 1585, 71 navíos; 1587, 85; 1589, 94; 1592, 72; 1594, 56; 1596, 69; 1599, 56; 1601, 32; 1603, 34 y 1605, 17. “Descripción de Panamá”, [1607] 1908, p. 174.

43 El brusco descenso de navíos ecuatorianos al Pacífico panameño obedece a la decisión de desviarse hacia Nueva España para vender su cacao y adquirir textiles asiáticos y europeos. Chaunu, 1955-59, vili, pp. 960-1000. 
marcada inclinación de la economía marítima peruana hacia el comercio del Pacífico. En 1590, se estima que la marina mercante del Perú cuenta con entre 40 y 50 navíos en servicio, de los que tan sólo cuatro o cinco son utilizados anualmente para el trayecto formal Callao-Panamá. ${ }^{44}$ Evidentemente, estamos en presencia de una economía peruana que de manera natural se orienta con mayor interés a un mundo del Pacífico más "libre" y cómodo que al forzoso eje administrativo y regulador transatlántico.

La imagen de Portobelo que se desprende de los escritos de los funcionarios y testigos es la de un espacio socioeconómico francamente miserable; muy lejos de la apreciación realizada décadas antes por el cronista Cieza de León, cuando compara Portobelo con la famosa plaza de recambio de Venecia. ${ }^{45}$ Bartolomé Churruca, procurador de la ciudad, se muestra consciente de lo que está aconteciendo. En 1604 le notifica a la Audiencia "del estado ruinoso del reino, la falta de contrataciones y comercio, y la huida de sus vecinos". Tres años después, en 1607, el Cabildo suplica "que se ejecute lo ordenado sobre el cese del trato de las mercadurías de la China en Perú". En ese mismo año, la Audiencia se lamenta de los pocos mercaderes asentados en Panamá, del mísero trato e intercambio y de su estado de abandono. ${ }^{46}$ Todavía en 1610, los miembros del Cabildo insisten que "se está despoblando la ciudad", y que es conveniente "cerrar la puerta de todo punto para que no vaya plata alguna a Acapulco" ${ }^{47}$ Por esos años, Por-

44 Clayton, 1975, pp. 1-6.

45 Una reluciente Portobelo de mitad del siglo xvi se desprende del escrito de Cieza de León: "Toda la más de esta ciudad está poblada, como yo dije, de muchos y muy honrados mercaderes de todas partes, trata en ella y en el Nombre de Dios, porque el trato es tan grande, que casi se puede comparar con la ciudad de Venecia. Porque muchas veces acaece venir navíos por la mar del Sur a desembarcar a esta ciudad cargados de oro y plata, por la mar del Norte es muy grande el número de las flotas que allegan al Nombre de Dios, de las cuales gran parte de las mercaderías viene a este reino por el río que llaman de Chagres en barcos y del que está cinco leguas de Panamá los traen en grandes y muchas recuas que los mercaderes tienen para este efecto". Cieza de León, [1871] 2005, pp. 16-17.

46 Para mayor detalle véase el apéndice documental, capítulo I, documento IV.

${ }^{47}$ Los testimonios citados se encuentran en Torres, 1978, pp. 45-50. 
tobelo estaría contando tan sólo con dos tiendas públicas pertenecientes a " 4 o 6 mercaderes" de la ciudad. Estas tiendas venden mercancía europea a precios irrisorios por la tardanza y espacialidad de la llegada de flota. Otras tiendas informales operan en un más activo comercio al menudeo de productos de Nicaragua o del Perú. ${ }^{48}$ El escenario de bancarrota se ve profundizado porque la plata que llega del Perú se retiene en Panamá para saldar los magros sueldos de los funcionarios reales y en la reconstrucción de la ciudad en abandono. ${ }^{49}$

Con aguda percepción, los contemporáneos no dudan en focalizar los factores de su ruina por el opuesto escenario de esplendor que se vive por el Pacífico, en especial con los contactos que se tejen entre México y Perú. El informe de la Audiencia recoge mucho de lo ya notificado y sintetiza en cuatro principales razones la crisis del trato español por Portobelo. El contundente testimonio obliga a reproducir sus frases:

1) "una parte de las mercaderías que vienen de España para el Perú, toman su derrota por Nueva España".

2) "el haberse introducido la navegación de la China [...] que consume muchos millones de plata que se llevan a perder para siempre entre aquellos bárbaros".

3) "que el Perú tiene vino de cosecha para sí y para cargar a Nueva España [...] Nueva España da paños y sedas. De la China vienen sedas, lienzos, hierro y otros géneros".

4) "la plata que solía pasar por aquí [Panamá] para España se divide y divierte, parte a la China, parte a la Nueva España". ${ }^{50}$

Cada una de las causas, innegablemente vinculadas, encierra un mundo de problemas con elevada complejidad. Todas ellas podrían sintetizarse en tres niveles de análisis. En primer lugar,

48 "Descripción de la Ciudad de San Felipe de Portobelo. Relaciones sacadas en 1606 y 1607”, Descripción de Indias, t. I, BDHE, Mss/3064, fs. 138v.

49 AGI, Panamá, 33, núm. 180, s/fs.; Panamá, 33, núm. 163, s/f. Para una mayor evidencia documental del estado desolador de Portobelo, véase Vila Vilar, 1982, pp. 2-4.

50 “Descripción de Panamá”, [1607] 1908, pp. 175-176. 
nos remite a la función de la Ciudad de México como centro de acopio y redistribución de textiles extranjeros hacia los mercados de Hispanoamérica. Segundo, a los “escapes” del excedente en metálico que van desde el Perú hacia Nueva España y China propiciando la desmonetización de Portobelo, y, por último, nos obliga a valorar otros excedentes (agrarios y mineros) que fluyen por el Pacífico hacia la Nueva España como el vino, el azogue y el cacao de Guayaquil; un conjunto de exportaciones peruanas que reflejan una economía con gran capacidad exportadora y en plena expansión.

1) México: almacén y redistribución de textiles extranjeros y novohispanos hacia el Perú

El punto 1 y la última parte del punto 3 referidos en el informe de Panamá remite a la función de centro de almacenaje y acopio de mercaderías extranjeras de la Ciudad de México para su posterior redistribución hacia las plazas del sur hispanoamericano. Durante el apogeo de la economía peruana, México compite con el eje institucional entre España y Tierra Firme por el mercado peruano como espacio redistribuidor de telas y textiles internacionales. Los textiles elaborados, uno de los pocos productos que Perú requiere del exterior, se envían desde Nueva España.

Cuando la Audiencia se refiere a la derrota novohispana de las "mercaderías que vienen de España al Perú" apunta, en especial, a los textiles europeos y castellanos traídos al puerto de Veracruz en la flota española. Al ser descargadas en el puerto de Sotavento, la mercadería transita tierra adentro hasta la Ciudad de México, donde los grandes mercaderes novohispanos las almacenan en sus bodegas. Luego de dar respuesta al mercado interno, las sobrantes transitan hasta Acapulco, para su reenvío por el Mar del Sur al consumo del mercado peruano y centroamericano. Grandes porciones de los textiles castellanos y europeos que el Perú necesita llegan a los puertos de Guayaquil, Paita o el Callao con mediación de México, vía Acapulco (gráfica I.5). 
El sistema bipolar transatlántico presenta desigual fortuna dada la centralidad que asume la Ciudad de México como punto redistribuidor de mercancías internacionales hacia los mercados hispanoamericanos: vitalidad del eje Veracruz-Ciudad de México promoviendo su influencia hasta el Perú por la vía del Mar del Sur, y parálisis del eje transatlántico que conecta a Sevilla con Portobelo. ${ }^{51}$ La breve y contundente carta que le envía al Rey el alcalde mayor de "Nombre de Dios", Diego Suárez de Anaya, en 1592, pone al descubierto los nocivos efectos que vive la plaza de recambio oficial debido a los contactos de Perú con México. Su pedido es que se "cierre la puerta a no dar licencia a ningún virrey del Perú ni a otra persona que despache navío para las Filipinas o para México". Aunque aleguen que van por artillería o por socorro, "verdaderamente no lo es"; van en búsqueda de la ropa de China y de Castilla y "como los mercaderes ven que a sus casas les traen muchas mercaderías de allí, no se les levanta el ánimo a ir a España a emplear ni escribir a sus agentes que se las envíen, como entienden esto mismo los naturales de Sevilla que cargan por su cuenta para el Perú, van cada día aflojando y lo dejan de hacer" ${ }^{2}$

La reorientación del intercambio peruano hacia México nos remite a las movilidades de los agentes. ${ }^{53}$ Subrayemos por el momento que, según el alcalde mayor de Panamá, el interés peruano por el comercio con México no sólo detiene los envíos de capitales hacia Portobelo, sino que "afloja" la participación del cargador sevillano de viajar hacia el istmo centroamericano. Anaya recomienda dos cosas: fin a las permisiones por el Mar del Sur que "buscan ropa de la China", y que las flotas españolas "vengan

51 En ensayos anteriores nos ocupamos sobre la centralidad mercantil novohispana. Bonialian, 2014, pp. 27-55.

52 "Carta de Suárez de Anaya al Rey" (1592-9-15), AGI, Panamá, 43, núm. 56, f. 573.

${ }^{53}$ En el último apartado atendemos la apasionante problemática en torno a la movilidad de los agentes. Como modo de anticipo, digamos que los cargadores de flotas peninsulares priorizan invertir sus cargas en la escuadra de Veracruz ya que los comerciantes limeños, con sus mediadores peruleros, llegan a controlar en gran medida el comercio ultramarino por Portobelo. 
más a menudo", porque si no hay una respuesta al crecimiento de los centros consumidores de Lima, Huancavelica, Potosí o Quito desde el frente atlántico, los peruanos o sus comisionistas terminarán por acudir a plazas mercantiles alternativas.

Ahora bien, el testimonio de Anaya nos conduce al punto 3 del informe de la Audiencia de Panamá: esto es, las importaciones peruanas de "sedas, lienzos, hierro y otros géneros que vienen de la China", ${ }^{54}$ como los "paños y sedas" que se producen en México. No es para nada casual que a la par de la expansión de la minería peruana, el comercio a través del galeón de Manila registre un ciclo de apogeo; ambos procesos se retroalimentan. La economía del Perú tiene un espacio muy relevante en la composición de la canasta importadora de géneros asiáticos por el puerto de Acapulco y, como enseguida veremos, en la exportación de su plata hacia Filipinas y China.

Al menos desde 1570 las importaciones de textiles asiáticos por Acapulco evidencian un crecimiento sostenido. El alza tiene su razón por la estimación que tienen dichos géneros en los centros consumidores de la Nueva España, Centroamérica y del virreinato del Perú. El trabajo archivístico realizado no nos permite presentar una serie cuantitativa que confirme el apogeo del galeón en este temprano periodo. Sin embargo, contamos con datos económicos aislados y otros de carácter cualitativos. Dos pruebas para el año 1595: a) más de 400 mercaderes filipinos, mexicanos y peruanos llegan al puerto de Acapulco procedentes de Manila en la nao Santa Margarita y el San Pablo con un sorprendente cargamento de más de cinco mil fardos, cajones y bolsas; ${ }^{55}$ b) las "imposiciones que pagan las personas por las mercancías que mandan a Nueva España han aumentado excesivamente en los últimos años" ${ }^{56}$ Pero el caso más resonante ocurre en 1615, expresado en el cuadro I.1, cuando por el corredor transpacífico llegan

54 El caso del hierro merecerá una breve consideración más adelante.

55 "Cara del virrey Velasco a Su Majestad (12-1-1595), AGI, México, 23, núm. 30, fs. $1-27$.

56 AGI, Filipinas, 35, núm. 4, fs. 18. 
dos navíos que introducen un cargamento en número de piezas asiáticas que no se repetirá hasta los últimos días de vida del galeón de Manila (1815). ${ }^{57}$

Cuadro I.1. Galeón de Manila del año 1615. piezas importadas por Puerto de Acapulco

Capitana

llegada: 2 de enero de 1615

Almiranta San Andrés llegada: 20 de diciembre de 1614

Cajones 1422 Cajones 725

Fardos 964

Fardos 491

Fardillos 2504

Fardillos 828

Cajoncillos 99

Cajoncillos 49

Petacas 54

Petacas 31

Piezas de cera 231

Cajas 8

Cajas 19

Escribanías 9

Escritorios 19

Escritorios 5

Azogue quintales 36

Loza 871

Buyones de almizcle 5

Lienzos de ropa 6

Loza 1318

Baúles 2

Almizcle 10

Barriles de Camanguran [sic] 2

Total: 6671 piezas Total: 3037 piezas

Registro Alonso Pardo.

Total de piezas 9708 piezas

Fuente: “Carta del virrey marqués Guadalcázar", 31-1-1615, AGI, México 28, núm. 20, fs. 1-30.

Si la ley establecía que los navíos transpacíficos deben tener una capacidad de carga máxima de 200 toneladas, según el vi-

57 El galeón de Manila apunta más al derrotero o ruta transpacífica que a la propia embarcación. Para estos tempranos tiempos, dos navíos unen la ruta Acapulco-Manila (la Capitana y la Almiranta). Conforme avance el siglo Xvir y especialmente en el XVIII será una sola embarcación la que conecta esos puntos. 
rrey Guadalcázar, la Capitana de 1615 habría alcanzado las mil toneladas, "la carga mayor que se ha visto". ${ }^{58}$ El número de piezas registrado al momento de su arribo en Acapulco, el 2 de enero, es de 6671. Su par o navío acompañante, la almiranta San Andrés, llegó 12 días antes, el 20 de diciembre de 1614, manifestando el ingreso de 3037 piezas. Si se suma el número de piezas de ambas naves se llega a un total realmente sorprendente: 9708 piezas. En 1616, ante presiones ejercidas por la elite económica del archipiélago, una real cédula permite duplicar la carga del galeón de 200 a 400 toneladas. ${ }^{59}$ Como veremos en los próximos capítulos, estas cantidades superan los registros del segundo ciclo de apogeo del galeón (1680-1740), cuando el número de piezas anuales ingresadas por Acapulco alcanzan, como tope máximo, las $6000 .^{60}$ Creemos que este enorme cargamento de 1615 importado por Acapulco supera los niveles de consumo del mercado novohispano y debe comprenderse, a pesar del carácter clandestino, por las solicitudes gestionadas por y desde el Perú.

El diagnóstico consumidor de algunas ciudades importantes del Perú como Lima, Potosí y Huancavelica termina por ser ancho y diversificado. Tomemos el caso de Potosí: antes de su boom minero (1577) la población se estima en 2000 españoles y 20000 indígenas masculinos. Su revolución demográfica aparece a inicios del siglo XVII: 100000 habitantes en 1600 y, en 1610, 150000 . Es una verdadera metrópoli urbana que supera las ciudades europeas más pobladas como Ámsterdam, Londres, Sevilla o Venecia. ${ }^{61}$

En aquellas tres ciudades del Perú (por nombrar las más importantes) se consume todo tipo de textiles del mundo donde

58 “Carta del virrey marqués Guadalcázar”, 31-1-1615, AGI, México 28, núm. 20, f. 6.

59 "Aviso y orden sobre carga de la armada de socorro", 10-10-1616, AGI, Filipinas, 340, 1. 3, f. 155.

${ }^{60} \mathrm{Al}$ respecto, véase el cuadro III.1 y la gráfica III.1 del tercer y último capítulo.

61 Salazar-Soler, 2009, pp. 109-228. Lima cuenta por esos años con una población de poco más de 25000 almas, mientras que Huancavelica se estima en 10000 habitantes. Si bien el caso de Potosí es excepcional, todos estos centros podrían clasificarse como puntos consumidores. Para Lima: Cook, 1968, p. 2. Para Huancavelica: Contreras, 1982, p. 42. Véase el cuadro II.4 al final del segundo capítulo. 
destacan las sedas y paños orientales. Abundantes testimonios que ya hemos comunicado en anteriores trabajos dan cuenta del ingreso masivo de diferentes tipos y formatos de sedas asiáticas en un abanico de ciudades y regiones adyacentes a Lima: Quito, Santiago de Chile, Córdoba e incluso Buenos Aires. ${ }^{62}$ El textil asiático reúne todas las condiciones para ser estimado en las altas esferas sociales y en las capas más bajas, como "mulatos, negros, indios y mestizos". Hacia 1590, la seda china barata se destina a lo que las fuentes se refieren como "gente pobre". La seda china se cotiza en el Perú a 10\% del valor de la seda española, lo cual permite ser consumida por grupos sociales de escaso capital. Los testimonios abundan. ${ }^{63}$ Uno de los pocos y contados productos que el Perú necesita del exterior en razón de su autosuficiencia es la seda procedente de China, a través del camino Filipinas-México-Mar del Sur. Junto con los comerciantes mexicanos, la consiguen a corto plazo y con excelentes beneficios de rentabilidad; muy diferente a los procesos administrativos, legales y de mayores costos de comercialización que pesan sobre la ruta transatlántica Sevilla-Portobelo.

Al prohibirse en 1596 la producción y cría del gusano de seda en suelo novohispano para garantizar el consumo de seda española, la Corona genera el efecto opuesto: potencia la entrada de la seda china en madeja, rollos de seda bruta, sin elaboración. El Memorial sobre el trato de la China con Nueva España y estos reinos, es-

62 Remito aquí a varios de los trabajos propios que aparecen en el apartado bibliográfico. En Assadourian, 1982, pp. 59-64, se analizan numerosos casos de compañías mercantiles ubicadas en Chile a finales del siglo xiv comercializando bienes chinos.

63 En 1594, el virrey Hurtado de Mendoza llega a decir que "las mercancías chinas son tan baratas y las españolas tan caras que me parece imposible recortar ese comercio hasta el punto que en este reino se deje de consumir productos chinos, ya que un hombre puede vestir a su mujer con sedas chinas por doscientos reales [25 pesos] mientras que no podría proporcionarle vestidos con seda española por doscientos pesos", Cartas y expedientes de virreyes del Perú (1593-1599), AGI, Lima, 33, f. 43. También el informe de los mercaderes del Perú de 1602, mencionan que "de esta ropa de China no se visten sino los muy pobres y negros y negras y mulatas y mulatos, muchos indios y mestizos y es tan en gran multitud de gente que tan bien gastan las sedas de la China”, AgI, Filipinas, 35, núm. 47, f. 825 v. Para mayores pruebas documentales: Bonialian, 2014, pp. 27-106. 
crito entre los años 1620 y 1622 por Horacio de Levanto, da cuenta de la composición de la canasta importadora del galeón de Manila. Conocedor como pocos de las lógicas comerciales de la Monarquía por participar en el comercio de flotas y en el galeón de Manila, Levanto informa que, en pleno contexto de expansión de la economía peruana, el cargamento importado por la nao de China se divide, en jerarquía de importancia, de la siguiente manera: $a$ ) la seda, en madeja, peso y trama, $b$ ) los tejidos de seda, $c$ ) los tejidos de algodón, d) frutos de la isla, y e) brujerías y regalos.

La seda de China es, sin duda, el producto de excelencia que llega al Perú desde Acapulco. Además de sus condiciones climáticas ideales, China dispone de un avanzado proceso tecnológico para su elaboración, lo que la hace inigualable ante cualquier intento de imitación europea. ${ }^{64}$ Pero la seda china llega al Perú en diferentes formatos e instancias de elaboración. Ante todo, es la seda en madeja, un insumo de tela, sin elaborar, el bien más preciado y estimado en Hispanoamérica y supera a los artículos asiáticos que presentan un perfil suntuoso, exquisito y de mayor valor elaborado. No olvidemos que sólo a estas últimas mercaderías atendió de forma insistente y destacada la historiografía especializada. ${ }^{65}$ Similar jerarquía en la composición importadora expuesta por Levanto es la que brinda Antonio de Morga, gobernador de Filipinas en los primeros años del siglo XVI y presidente de la Audiencia de Quito entre 1615 a 1636. En su obra Sucesos de las Islas Filipinas, publicada en el año 1609, en pleno contexto de emancipación económica peruana, dice que la seda cruda o en mazo de baja ley es lo más grueso que ingresa a Hispanoamérica. ${ }^{66}$

Entonces vale preguntarse: ¿no habría que revisar la tradicional premisa que sostiene una importación de seda china com-

64 Supera los límites de la comunicación un estudio específico del sistema tecnológico chino en la elaboración de la seda. Al respecto Zanier, 2004, pp.105-190.

65 Para una crítica sobre esta visión exclusivamente suntuaria de la contratación asiática y de una atención particular al memorial de Levanto, véase Bonialian, 2016c, pp. 1-25.

66 Morga presenta un notable detalle de los productos asiáticos movilizados desde Filipinas hacia Acapulco. Morga, [1609] 1890, pp. 351-353. 
prometiendo a la industria sedera novohispana? ${ }^{27}$ Cierto es que su entrada, junto con las políticas reales tendientes a reforzar el consumo de la seda procedente de Granada, provocan la caída del cultivo y la producción del hilo fino en suelo novohispano. Pero la importación de seda cruda o bruta de China no parece tan nociva al obraje virreinal que, en cierto modo, la aprovecha como insumo para confeccionar prendas y enviarlas al Perú. Cuando en 1640 se evalúa la reapertura del comercio entre México y Perú, los argumentos a favor atienden a la manutención de más de 14000 novohispanos que dependen de la confección de la seda china en los centros manufactureros del virreinato novohispano. La seda oriental en madeja: "tiene su saca para el Perú, porque en Nueva España hay poca". ${ }^{6}$ Aún con la carencia de fuentes concretas, hay indicios para pensar que el Perú vive una situación similar a la novohispana. El espacio andino dispondría de seda en madeja de China, seda bruta, para su confección en los propios obrajes peruanos. Joan de Belveder comunica en 1612 la existencia de telares en Lima dedicados a labrar la seda torcida de China que utilizan las "negras, mulatas e indias", y que evitan su sanción al definirlas como "seda de México"; un producto de la tierra autorizado. ${ }^{69}$ El Memorial del arbitrista confirmaría años después las definiciones de Levanto al referirse a la "ropa de la China"

67 Es la premisa que sostiene John Lynch: "Indeed one Mexican activity, silk raising and manufacture, was a victim of Chinese competition, which, combined with Indian labour shortage and crown policy, helped to ruin the industry". Lynch, 1969, p. 225.

68 "Petición de informe sobre abrir el comercio con Perú", 14-2-1640, AGI, Filipinas, $340,1.5$, fs. $36-40$.

69 AGI, Lima, 143, puntos 4 y 5, s/n de fs. Dice Belveder: "en este reino la ropa de la China se ha introducido el armarse tantos telares de seda y pasa manos de ella y de oro y plata so color de decir que es seda de México y en los pasa manos y toquería que con ella tejen consumen gran suma de marcos de plata y oro en hilo y hoja por quintar que por ser en tan grande numero lo que ansi se labró se venden baratos y por esta causa no tienen valor ni venta lo que de los dichos géneros se trae de Castilla y se han dejado de traer que es causa que negras, mulatas e indias vayan arreadas y costosas [...] contrabando de la ropa de la China como debiera se trae de cada día la grosedad que se ve y entiende ocultamente así en piezas tejidas como torcida cruda y en pelo que su labor de ella está ya tan fundada en esta ciudad como es notorio con tantos telares a donde se tejen todas suertes de sedas". Véase Suárez, 2014, pp. 41-42. 
como de consumo amplio, artículo de ingreso en estado bruto o semielaborado. La circulación de telas y tejidos que se hacen desde China y México hacia el espacio peruano encierra una enorme complejidad que todavía estamos lejos de descifrar con claridad. Baste por el momento reconocer los problemas que presenta.

Hemos visto que la Audiencia de Panamá no sólo reconoce la llegada al Perú del textil asiático, sino también lo confeccionado por los centros manufactureros de México. Ambas partidas se movilizan desde Acapulco hacia los puertos de Guayaquil, El Callao y otros puertos menores de la costa del Mar del Sur. Considerables cargas de textil novohispano llegan al espacio peruano (en particular el paño elaborado en la ciudad de Puebla). La producción pañera en la ciudad poblana alcanza un histórico apogeo entre 1570 y 1634 . ¿Es pura coincidencia que el tránsito de expansión comercial de Perú corra a la par de un obraje novohispano en su máxima expansión $?^{70}$ Es evidente su plena correspondencia. El número de obrajes en Puebla lo confirma: para el año 1579: 40 obrajes; 1603, 33; 1604, 35 y 1620, 37. Considerando el periodo 1570-1620, se estima un promedio de 102 trabajadores en cada obraje. Algunos de los establecimientos ocupan prácticamente una cuadra completa. ${ }^{71}$ Se ofrecen productos de alta y baja calidad para el mercado de la Nueva España y en especial al Perú. De hecho, el mercado consumidor peruano resulta ser fundamental a la hora de pensar el desarrollo de los establecimientos textiles de Puebla; así como para dar salida a su cerámica, sombrerería y cerrajería. En síntesis, una importante cantidad de los textiles de seda china llegados a Acapulco y de otros textiles confeccionados en la Mixteca, en Puebla o en la misma Ciudad de México terminan por despacharse hacia el Perú en compañía de las telas europeas que se encuentran en México luego de su descargo en la costa atlántica de Veracruz. ${ }^{72}$

70 Entre 1570 y 1634 se registra la máxima expansión de la industria manufacturera novohispana. Miño Grijalva, 1998, pp. 27-31.

71 Carabarín, 1984, pp. 17-19.

72 Los documentos del fondo de protocolos notariales ubicados en el Archivo General de la Nación de Perú (AGNL) mencionan reiteradamente la compra en conjunto 
Los registros realizados en los puertos de Paita, El Callao y Guayaquil hacen referencia a importantes ingresos de textiles con calificativo, no siempre verdadero, de "ropa de México". La referencia de "ropa de México" representa un mecanismo estratégico del agente mercantil para calificar un producto de la tierra novohispana (algo permitido) de un objeto que tiene algún componente castellano, europeo o asiático (algo ilícito desde 1582), ${ }^{73}$ pasando así completamente desapercibido. El más claro y contundente testimonio lo ofrece un reconocido judío mercader de Lima, Pedro León Portocarrero. En 1620 apunta que Perú obtiene "grande cantidad de sedas torcidas y flojas, beneficiadas en México y muchas sedas de Mixteca, provincia de México [...] todas las sedas de México son las mejores que se gastan en el Perú, porque tienen bon negro y están sanas y recias."74

En su Descripción del Perú añade una "Memoria de todos los géneros de mercadería que son necesarios en el Perú y sin ellas no pueden pasar porque no se fabrican en la tierra" ${ }^{75}$ Como diría Assadourian, casi $40 \%$ de los artículos de la lista son tejidos finos y lencería extranjera. ${ }^{76}$ Por supuesto, los testimonios de Levanto para el caso de México, como el ofrecido para el Perú por el arbitrista Belveder, relativizan el postulado de Portocarrero acerca de un exclusivo ingreso de ropa fina para un consumo reducido de la elite.

Los géneros procedentes de México y de China alcanzan, para el mercader limeño, mayores márgenes de ganancia que la ruta Sevilla-Tierra Firme. La ganancia mercantil es, claro está, un factor decisivo para entender la razón de la reorientación peruana hacia el Pacífico novohispano en detrimento de Portobelo.

por parte de los comisionistas o factores limeños residentes en Acapulco de "mercadería china, de Castilla y de México" para remitirse al Perú. Para mayor detalle véase el cuadro I. 6.

73 Para el caso de Paita: Glave, 1997, pp. 101-125.

74 León Portocarrero, [1620] 2009, pp. 106-107.

75 León Portocarrero, [1620] 2009, pp. 117-129.

76 Un 35\% corresponde a artículos de hierro y acero. Ambos rubros de bienes, medidos en valor, alcanzarían 90\% de los artículos que necesita Perú del exterior. Assadourian, 1982, p. 143. 
Margarita Suárez, especialista en la materia, comunica los márgenes de ganancia bruta que en 1617 presenta cada producto en el mercado limeño: tafetanes "de México", 22.3\%; sedas blancas y de colores de la China, 19.7; paños de Segovia, 18.1; raso con oro de Italia, 16.6; damasco de China, 16.4; damasco de Valencia, 11.1; rasos de China, 9.4; paños de Quito, 6.6; terciopelos, 2.9; chamelotes, 2.9, y resmas de papel, 2.2. Por su parte, los pasamanos de Sevilla, sombreros de tafetán y los pañuelos de Holanda no registran ganancia. ${ }^{77}$ Estamos en presencia de datos sorprendentes: la mayoría de las mercaderías con los más altos márgenes de ganancia se consiguen en Nueva España y muy pocos en la plaza de Portobelo. A eso se le debe sumar dos razones más que hacen preferible el comercio de textiles con México: los bajos precios de los textiles asiáticos y los cortos tiempos de retorno de las ganancias.

La complejidad que reviste el flujo de textiles procedentes de México hacia el Perú no se agota en lo enunciado. Existe un elemento, quizá más gravitante aún, de lo que podríamos llamar un proceso de occidentalización de lo oriental. ¿A qué nos estamos refiriendo? En China o en la propia Filipinas se reproducen, se copian o se imitan textiles y otros bienes castellanos o europeos que son de gran demanda en México y en Perú. Los peruleros, agentes o factores de mercaderes limeños que viajan hacia el Oriente para realizar operaciones mercantiles, llevan consigo los diseños occidentales muy demandados en el mercado peruano. En China se logran imitar las prendas europeas a un costo laboral mucho menor. El obispo Salazar, quien está en Filipinas en 1590, informa al rey que varios artículos de formato occidental que se encuentran de "moda" en la Nueva España y el Perú son fabricados en China y Filipinas: "los sangleyes, que son muy buenos artesanos en la moda española, y hacen todo a muy bajo costo son [...] tan hábil y listo que, tan pronto como vean objetos hechos por un obrero español, lo reproducen con exactitud". ${ }^{78}$

78 Testimonio recogido de Iaccarino, 2011, pp. 108-109; Bonialian, 2014, pp. 172-183. 
Con todo, la catarata de textiles que llegan al Perú, el principal ramo importador y uno de los pocos objetos que su mercado necesita del exterior, presentan un origen productivo plenamente global: se hacen en China, en la Nueva España, España, Italia, Francia, Alemania y en otras regiones europeas. Todos los textiles confluyen en Acapulco para enviarse hacia los puertos del Perú. Por su notable capacidad importadora y por ser el principal nodo de almacenamiento y redistribución, la Ciudad de México logra forzar a su máxima tensión la "crisis de dependencia” entre Perú y España a través de la plaza de Portobelo (gráfica I.5 y mapa II.1). Posiblemente, Acapulco se presenta en estas décadas, y de manera clandestina e informal, como plaza de recambio competitiva a la oficial de Portobelo. El principal bastión y nudo de tránsito en el que se asienta la "relación de dependencia" está siendo amenazado por el flujo existente en el Pacífico hispanoamericano.

Lo cierto es que la reorientación de las funciones mercantiles, de los espacios y de los flujos hacia el Pacífico, constituye un reclamo recurrente en los pensadores y funcionarios de la época. El remedio para revitalizar el enlace transatlántico con Tierra Firme es retornar al equilibrio del principio bipolar centrado en Veracruz y en Panamá. En otras palabras, es necesario que México abandone la tarea clandestina de ingerir un número superior de bienes asiáticos y europeos de lo que su mercado interno necesita. Así lo dice en 1607 el presidente de la Audiencia de Panamá, Francisco Valverde: "México debe contentarse con las que puede gastar porque la contratación reducida a una honesta limitación dará lugar a que los vasallos que viven en Lima vuelvan a encaminar sus contrataciones con seguras ganancias por el camino ordinario". ${ }^{79}$

El restablecimiento del equilibrio de los flujos transatlánticos no es una tarea sencilla en razón de las múltiples causas que provocan el desbalance. No sólo requiere que la economía peruana vuelva a depositar interés en la plaza de Portobelo, también es un imperativo que los peruleros desistan de movilizarse por el circuito transatlántico que le compete al propio galeonista penin-

79 AGI, Panamá, 15, r. 8, num. 87, f. 1. 
sular. Todo indica que desde 1640, el comerciante peninsular logrará el cometido. El protagonismo perulero por el eje oceánico Portobelo-Sevilla tendrá peso hasta 1630. De eso nos ocuparemos más adelante.

\section{2) Los escapes de metálico peruano hacia México}

Salvo casos muy puntuales y tocantes a la historia global, la participación de la economía peruana y de su plata por el flujo transpacífico no mereció la atención suficiente por parte de la nutrida historiografía especializada. ${ }^{80}$ Usualmente, todo análisis sobre el comercio peruano con China aparece como un complemento secundario del enlace novohispano con las Islas Filipinas, donde la gravitación peruana es mínima, producto de un simple comercio de cabotaje, accesorio, por el Mar del Sur. El ejemplo más emblemático se encuentra en la obra de Chaunu. ${ }^{81}$ En Las Filipinas y los Ibéricos se da como supuesto que el Pacífico es el galeón de Manila; elementos utilizados como sinónimos, como si estuviéramos en presencia de un área marítima que sólo puede ser comprendida a partir de los pesados movimientos de las naos chinas. Chaunu no sólo es indiferente al contrabando por el Pacífico y al funcionamiento informal que adquiere el galeón de Manila, también a la participación de la economía marítima peruana. La primera lectura, en principio, no tendría objeción, mas al tener en cuenta que la literatura define al galeón de Manila como un galeón novohispano. ${ }^{82}$ Sin embargo, para la segunda reflexión y para el periodo que nos ocupa, la participación de la economía y de los mercaderes limeños en el eje transpacífico no debería desmerecerse, sino todo lo contrario.

${ }^{80}$ Nombremos tan sólo tres estudios de perfil global que atienden la economía asiática de la época atendiendo las entradas de plata potosina: Atwell, 1982, pp. 68-90; Flynn y Giráldez, 2002, pp. 391-427; Kindleberger, 1989, pp. 23-26.

${ }^{81}$ Chaunu, 1974, pp. 34-54.

82 Bernal, 2004, pp. 485-525. 
Recordemos lo que nos dice la Audiencia de Panamá en 1607, al combinar el análisis de los puntos 2 y 4 referidos al derrotero de metálico peruano y asociarlo con el tratado punto 1 . El informe reconoce que el excedente de metálico peruano no se ve obligado a transitar hacia Portobelo, sino que fluye hacia Nueva España. El corredor de metálico peruano hacia la Nueva España se "divide": una parte hacia China vía Manila y otra se sumerge tierra adentro en la Nueva España, para salir finalmente hacia España por el puerto de Veracruz. ${ }^{83}$ Ciertamente, los caminos del metal son para saldar, en gran parte, las compras de los textiles. Analicemos la primera bifurcación del metal peruano: su camino hacia China.

Los informes oficiales hablan de la conexión asiática-peruana como elemento determinante de la crisis de la "relación de dependencia”. Entre los factores más importantes que contribuyen a la demanda de plata hispanoamericana en China, sea el circuito transpacífico o euroasiático, las reformas políticas fiscales y monetarias que aplica. Quizá la más importante de ellas es la llamada "látigo simple", implementada hacia el decenio de 1580, que obliga a los campesinos, artesanos y mercaderes chinos a pagar los impuestos con plata. El comercio y la guerra del imperio también se financian con la moneda de plata producida en los virreinatos hispanoamericanos. Su ley, calidad y peso la convierten en el medio de intercambio y de pago más importante en China,

${ }^{83}$ La salida de plata peruana hacia México se inicia desde muy temprano, mucho antes de que el mercado peruano adquiriera autosuficiencia y capacidad de emancipación. De imposible cuantificación y estimación, lo destacable de este desconocido flujo exportador de plata peruana por Veracruz es su perdurabilidad. La primera señal aparece muy temprano, en una Cédula real emitida en 1538 por la Corona, a razón de un pago que se había generado por los envíos de productos de guerra y alimentos hacia el Perú del conquistador Cortés. "La reina. Nuestros oficiales de la Nueva España: yo soy informado que algunas personas en de servicio nuestro y en daño y perjuicio de nuestras rentas reales, e yédo $[s i c]$ y pasando contra lo que por nos está proveído y mandado por nuestras cartas y provisiones han llevado y llevan a esta tierra de las provincias e islas de nuestras Indias, especialmente del Perú cantidad de oro y plata y que vosotros con solo cobrar los derechos que de ello nos pertenecen, no les lleváis por eso otra pena alguna, y porque como ves esto es cosa a que no se ha dar lugar", "Cédula de la reina a los oficiales de la Real Hacienda en la Nueva España, Valladolid, 18 de enero de 1538", Encinas, [1596] 1946, t. III, pp. 366-367. 
desplazando al tradicional uso de papel moneda. Con todo, una gran porción de los 100000000 o 120000000 de habitantes que, por esos tiempos, habitarían en China, están con la necesidad de disponer de metálico para tributar al Estado ${ }^{84}$ Por otro lado, el arbitraje oro = plata resultaba más beneficioso en China que en Europa. Hacia mediados del siglo Xvi el coeficiente entre el oro y la plata ronda 1:11 y 1:12 en Europa, mientras que en China es de 1:6 y en la India 1:8. De tal manera, los beneficios de arbitraje para que los mercaderes europeos, mexicanos y peruanos operen en el Oriente son enormes. ${ }^{85} \mathrm{El}$ gigantesco cambio fiscal implementado por China obliga a una fuerte monetización de su economía interna donde la succión del metal hispanoamericano se presenta como una importante condición. Lo más importante para nuestro argumento es que la transformación y monetización de la estructura fiscal y económica de China, y el apogeo de la producción de plata de Potosí son fenómenos simultáneos. No sería nada apresurado concebir ambos acontecimientos como componentes de un único proceso de la temprana globalización mercantil: la América española como principal proveedora de plata hacia los mercados globales.

En efecto, al menos desde 1570 la moneda de plata peruana ingresa junto con la mexicana y la japonesa a los circuitos económicos de China con una fuerza considerable. El paralelismo entre lo que ocurre en China y la evolución de la plata en Perú no se ago-

84 Maddison, 1998, p. 169; Melitz, 2017, pp. 8-12.

85 Sobre el fenómeno de absorción de plata hacia China, Flynn y Giráldez, 1995, pp. 201-221; Flynn, 1996, pp. 309-338; Kindleberger, 1989, pp. 23-26. El propio Marx percibe el papel de China como "depósito" mundial de la plata americana. Pero no sólo desatiende lo que ocurre por el Pacífico, sino que también ubica en una época tardía la función de depósito de plata del Oriente: "Desde principios del siglo XviI Asia, y en particular la India y China, nunca dejaron de ejercer una importante influencia en el mercado de metales preciosos en Europa y América. La plata, como único medio de intercambio en esos países orientales, fue la causa de que el tesoro con que Hispanoamérica inundó a Europa se haya escapado parcialmente por los cauces del comercio oriental, y que la importación de plata de América que hizo Europa fuera absorbida por la exportación de Europa al Asia", "La crisis monetaria en Europa", en Marx y Engels, 1975, pp. 63-64. 
ta en esta precisa coincidencia. La historiografía presenta debates sobre su masiva presencia en la economía china en este temprano periodo de la globalización. La controversia no parece llegar a un acuerdo, ni consenso, más cuando estamos en presencia de flujos de plata que no se pueden cuantificar ni medir. En todo caso, se discute si la caída de la producción minera en el Perú desde 1640 tendría alguna explicación con la crisis política en China que devino en un trascendente cambio dinástico: de los Ming a los King. Richard von Glahn, por ejemplo, niega la influencia de una supuesta escasez de plata en la crisis de la China de los Ming. En cambio, William S. Atwell considera que la disminución de las entradas, desde las Filipinas y Japón, incide de manera indirecta en la caída dinástica. ${ }^{86}$ Como puede notarse, la temprana economía colonial del Perú no está al margen de las controversias que se desatan en la literatura ocupada en la historia global.

Hemos advertido que los modos en que se involucra la economía peruana en la contratación asiática se da, en gran medida, por la mediación de Acapulco. A pesar de sus prohibiciones para dicha contratación desde 1580, la red de corrupción entre funcionarios reales con los comerciantes peruanos y novohispanos permite que grandes volúmenes de bienes orientales sean expulsados desde Acapulco hacia el mercado peruano. Más aún, a pesar de la prohibición real de distanciar a la economía peruana de toda participación en el tráfico de bienes orientales, disponemos de un documento muy singular donde se explicita la permisión real para que, desde el año 1585, el mercader novohispano Baltasar Rodríguez, con su navío Santiago, trasladara "mercancías chinas y filipinas hacia el reino del Perú". ${ }^{77}$ El privilegio que se le concede a Baltasar Rodríguez tiene una simple explicación: es uno de los fundadores del Consulado de la Ciudad de México y quizá el mercader novohispano de mayor capital en ese tiempo. ${ }^{88}$ En

86 Atwell, 2005, pp. 467-489; Von Glahn, 1996, pp. 429-454.

87 Véase parte de la transcripción de la carta del virrey Villamanrique en el apéndice documental, capítulo I, documento $\mathrm{v}$.

88 Smith, 1944, p. 304. 
su patrimonio aparece el navío Santiago, quizá la embarcación más importante que circula por el Mar del Sur y el navío Nuestra Señora del Pilar, que opera por el espacio transatlántico junto a las flotas de la Nueva España. ${ }^{89}$ Todo indica que la concesión que se le ofreció en 1585 continúa vigente en los años posteriores. En 1591 lo vemos cargar y trasladar desde Acapulco hacia El Callao un notable cargamento de "mercancías de China y de Filipinas" hacia el Perú. ${ }^{90}$ A pesar de no contar con otras permisiones, el virrey Villamanrique explicita en su carta que así como le otorga la licencia a Rodríguez "se ha dado a otros pagando a V. M. los derechos de salida como los pagan los demás". ${ }^{91}$ Lo que pasa dos años después parece confirmar la afirmación de Villamanrique. El virrey del Perú, García de Hurtado, informa que durante todo el año 1593 y los primeros tres meses de 1594, una docena de barcos había zarpado rumbo a México, “dejando esta colonia [el Perú] limpia de plata". 92 El caso de Rodríguez y la apreciación ofrecida por el virrey Villamanrique resultan pruebas significativas de que no siempre es el comercio informal o de contrabando de bienes chinos el que se hace entre Acapulco y el Perú. Parece ser un acto regular y frecuente otorgar permisos en el marco de estrategias de redes mercantiles que llegan a tener el beneplácito de las autoridades (incluso del virrey). Con todo, Baltasar Rodríguez es muy consciente de la estima de los textiles orientales en el Perú; generó fortunas al gozar de este enorme privilegio real.

La plata de Potosí es el medio de cambio fundamental para saldar esas importaciones de mercancías. El crecimiento comercial del eje transpacífico es paralelo al incremento exponencial de

89 "Carta acordada del Consejo al general Garibay para que de visita a la nao 'Santa María del Pilar' de Baltasar Rodríguez para que pueda ir con la flota de Tierra Firme, con tal de que ésta no haya de detener ni una hora su partida por aquella" 28/4/1601, en AGI, indiferente, 1957, 1. 5, fs. 218-219.

90 "Para que pueda el navío Santiago de Baltasar Rodríguez, cargar y llevar mercaderías de China y Filipinas a las provincias del Perú, pagando los derechos conforme a las cédulas reales, 4 de marzo de 1591", AGNM, Instituciones coloniales, Gobierno Virreinal, General de Parte, vol. 4, exp. 294, fs. 1-82.

91 Apéndice documental, capítulo I, documento v.

92 Valle Pavón, 2005, p. 227. 
la producción y comercialización de la plata potosina. La simultaneidad de los fenómenos no es en absoluto casual. Hay evidencia para sugerir que los agentes del Perú y su plata adquieren por estas décadas una significativa trascendencia en el comercio de la nao de China. La irradiación de capitales y de peruleros en la Carrera filipina debería contextualizarse en el marco de la emancipación económica del Perú; problemática la de los agentes o comisionistas limeños que abordaremos al final del trabajo.

Algunos ejemplos pueden servir de argumentos para ponderar la participación de la plata peruana en la Carrera filipina. Entre 1597 y 1601 el galeón de Manila estaría cargando en el puerto de Acapulco rumbo a las Islas Filipinas la increíble suma total de 12000000 de pesos, de los cuales 8000000 pertenecerían a la economía peruana del cerro de Potosí. ${ }^{93}$ En 1602, el cabildo de México le informa a la Corona que la exportación de plata alcanza los 5000000 de pesos, ${ }^{94}$ cifra que se mantendría en la década siguiente con una alta participación de monedas del Perú. ${ }^{95}$ Hay que reconocerlo: documentación de carácter cualitativa más precisa y concreta sugiere un promedio anual de plata peruana inferior al caso de 1597-1601. Sin embargo, al considerar el total de plata americana exportada hacia China, el metal peruano seguirá teniendo un lugar destacado en los embarques de la nao de China.

Los testimonios indican que en una gran porción de años comprendidos entre 1590 y 1630 salen del puerto de Acapulco unos cuatro o cinco millones de pesos anuales; ${ }^{96}$ la moneda del Perú, restándole la que se interna en México, rondaría entre 30\% y 50\% del total del cargamento. El cálculo se desprende si consideramos que en esa coyuntura, la movilización de plata en barra, en pasta o en moneda enviada desde el Perú a la Nueva España alcanza entre los dos o tres millones de pesos anuales. ${ }^{97}$ El mencionado arbitris-

93 Borah, 1975, pp. 227-236.

94 Borah, 1975, p. 85; Lynch, 1969, t. II, p. 225; Iacarrino, 2011, p. 111.

95 Hoberman, 1991, p. 216.

96 Borah, 1975, pp. 235-236; Hoberman, 1991, pp. 216-219.

97 Borah, 1975, pp. 116-124; Ramos, 1970, p. 233; Suárez, 1995, p. 34; Valle Pavón 2005, pp. 213-240. 
ta, Joan de Belveder, comunica en su Memorial de 1612 que durante treinta años salen más de 60000000 de pesos "de este reino al de México para ocuparlos en mercaderías de la China", lo que arroja un promedio anual de 2000000 de pesos de plata peruana en Acapulco para la compra de ropa asiática. ${ }^{98}$ En ese contexto, se inscribe el caso particular que dio a conocer el historiador Ramiro Flores del navío peruano Ave María, que en 1602 arriba al puerto de Acapulco con más de 560000 pesos en plata peruana. ${ }^{99}$ Si bien el patrón común nos indica la salida entre 10 a 15 barcos anuales con cargas particulares que van entre los 100000 y 200000 pesos, probablemente el monto que moviliza la nave Ave María no fue un hecho aislado. ${ }^{100}$ Lo confirma Juan Antonio Suardo, quien en su Diario de Lima señala que en 1629 salieron dos navíos hacia México: en noviembre, el llamado San Francisco, del banquero Juan de la Cueva, donde "la común opinión es que llevará más de un millón" y, un segundo barco, en diciembre sale de el Callao el "navío de México" y se "dice por cosa muy cierta que lleva más de dos millones". ${ }^{101}$

Hasta aquí un breve repaso sobre fuentes cualitativas que indican el envío del excedente de metálico peruano hacia Acapulco y, gran parte, hacia las Islas Filipinas por medio del galeón de Manila. Resta ver la otra "división" que menciona la Audiencia de Panamá: la porción que se interna en suelo novohispano. Estamos en presencia de un flujo con escasísima evidencia documental e imposible de discernir al momento de cuantificarlo. Su existencia sólo puede descubrirse a partir de la revisión de notables testimonios. Uno de ellos lo ofrece en 1609 el virrey novohispano.

98 "Memorial y Apuntamiento", AGI, Lima, 143, s/n de fs.; véase también: Suárez, 2014, p. 41.

99 Flores, 1995, p. 403.

100 Existen casos de mayor trascendencia como el protagonizado por el propio virrey del Perú, marqués de Montesclaros, por permitir expedir un navío limeño hacia Acapulco con una carga de 1000000 de pesos en plata. Véase al respecto Hanke, 1979-80, t. III, p. 153. Para el patrón común, véase AGI, Panamá, 33, núm. 146, f. 3 y los ensayos de Valle Pavón, 2005, p. 227; Vila Vilar, 1982, pp. 294.

101 Suardo, [1629-1639] 1936, pp. 39 y 46. 
El “joven” Velasco dice que la plata peruana no labrada que llega a México "hincha de plata esta plaza", para que sea empleado "por géneros que esta tierra lleva de cosecha y en mercaderías de Castilla". ${ }^{102}$

Se debe considerar un fenómeno revelador en el caso tratado. Durante el gran periodo que va de 1580 a 1640 existe una enorme brecha entre la plata producida y registrada en las cajas del Alto Perú, y la plata acuñada en la Casa de la Moneda de Potosí; una casa que abastece de moneda al reino andino. La acuñación que hace Potosí llega a representar tan sólo $20 \%$ de la plata producida y registrada en el Perú. ${ }^{103}$ Una enorme masa de metálico no acuñado estaría fluyendo hacia la Nueva España para su amonedación. De esta manera, la moneda peruana viaja hacia China, mientras que el metal no labrado penetra en el propio corazón de la economía novohispana para ser labrada e incorporarse a sus circuitos internos del virreinato antes de partir hacia España: "Las barras de plata venden aquí los del Perú parte a los que labran moneda en esta casa donde pagan sus derechos y parte a mercaderes de esta ciudad que las envían por granjería a España para sus empleos". 104

El valioso testimonio del virrey novohispano se confirma en 1640 con las líneas del Memorial del procurador de las Islas Filipinas, Grau y Monfalcón. Insistiendo en lo beneficioso que sería reabrir el comercio entre México y Perú, prohibido desde 1604, coloca como fundamento que:

102 AGI, México, 27, núm. 66, fs. 5-6.

103 TePaske y Brown, 2010, pp. 258-259; Suárez, 2016, pp. 168-170.

104 AGI, México, 27, núm. 66, fs. 5-6. El excedente de metálico peruano que se dirige a Nueva España, esquivando el centro de Portobelo, se presenta con diferentes "formatos": monedas, en pasta o en barras. La plata amonedada es la preferida de China para la monetización de su mercado interno. Por su parte, la de pasta o en barras estaría internándose en México para que los ensayadores y fundidores de la Casa de la Moneda las labren y continúen su curso legal pagando los derechos correspondientes. "Carta sobre que forme el superintendente unas ordenanzas particulares para esta Real Casa de Moneda de suerte que puedan servir también para las del Perú", AGNM, Real Hacienda, Casa de La Moneda, vol. 143, exp. 25, fs. 180-191. 
cuando pasaba a Nueva España [los tres millones de pesos], era forzoso que engrosase ambos comercios, el de Castilla y el de Filipinas y que los dos participasen de mayor cantidad de plata, y que habiendo cesado lo sintieran ambos [Pero] el de Filipinas no ha tenido menos retorno de lo que solía [...] el comercio de Castilla tampoco baja considerable ni proporcionada a la falta de sus millones. ${ }^{105}$

Es necesario postular escalas de jerarquización de los circuitos del metálico peruano. En este ejercicio, el eje Perú-Acapulco-Asia prevalece sobre el eje Ciudad de México-Veracruz-Sevilla. Entre 1580 y 1630, el eje de abasto textil fino por el frente transpacífico compite exitosamente con las sedas de Granada, de Andalucía o de Valencia que se proveen con mayor costo a través del comercio transatlántico de las flotas de Veracruz. Es constante el reclamo de los cargadores sevillanos sobre la poca venta de sedas peninsulares en el mercado novohispano y peruano, dado el ingreso de seda exquisita del Oriente por Acapulco. El ataque peninsular hacia el comercio transpacífico no debería inscribirse exclusivamente en el dominio que tienen los comerciantes novohispanos en el trato de la contratación asiática, sino en que éstos logran configurar a la Nueva España como el espacio centralizador para el abasto y redistribución de los textiles en Hispanoamérica. ${ }^{106}$

Ahora bien, la gráfica I.2 ilustra el incremento de metal americano en la hacienda China. Se puede advertir que desde 1580 hasta 1604 las entradas de metálico al Imperio Celeste aumentan de manera sostenida. La tendencia también contempla los ingresos de metal nipón que, por cierto, no fueron nada despreciables. Sin embargo, no resulta casual que sea en 1580 el inicio de su repunte; año en que los caudales de plata potosina tienen vía libre para participar en el comercio del galeón de Manila. Vale la pena atender el notable aumento de las importaciones del metal durante el periodo

105 Grau y Monfalcón, 1640, pp. 79-80.

106 Sobre la controversia entre cargadores sevillanos y mercaderes novohispanos, véase Álvarez de Abreu, [1736] (1977), t. I. También Sales Colín, 2007, pp. 127-146. 
1590-1604, ciclo de crecimiento que se correspondería con el auge del comercio triangular entre Perú-Acapulco-Islas Filipinas.

\section{Gráfica I.2. Importaciones en plata a la hacienda China,} 1570-1617 (en pesos de a ocho reales)

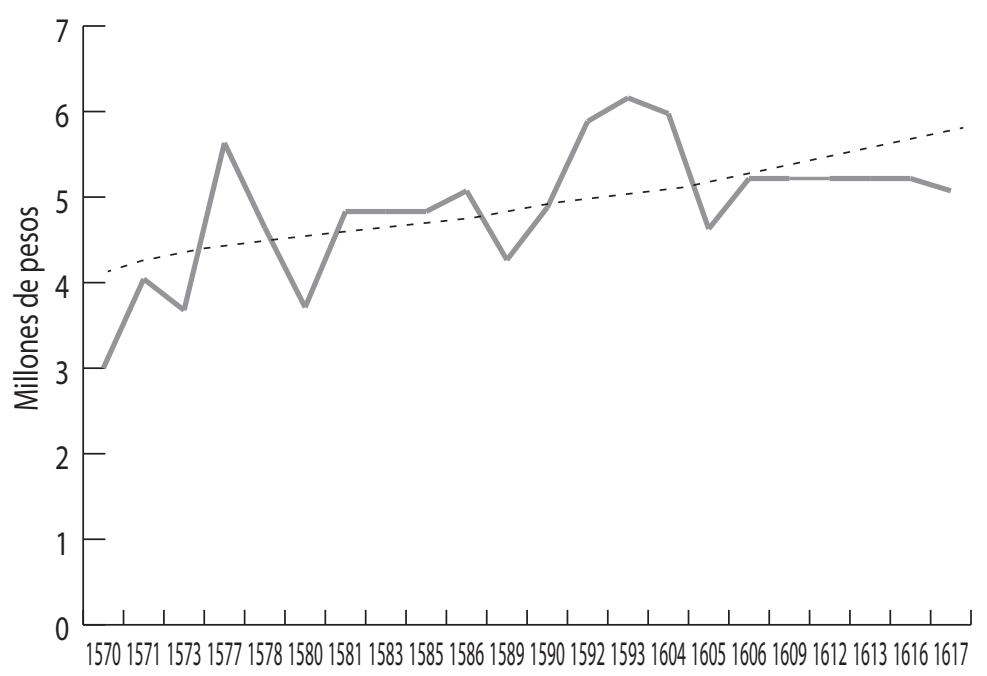

Fuente: Atwell, 2005, p. 80.

Enseguida veremos que en los primeros años del siglo XVII se registra un descenso de envíos de remesas de metálico por el eje transatlántico, que inscriben forzosamente en aquellas denuncias del peligro de romperse el lazo de "dependencia" entre Perú y España. En 1581, la plata que se importa a China supera los 4800000 pesos; en 1586 se eleva a 5070000 pesos y entre 1590 a 1604 las cifras arrojan un promedio de casi 6000000 de pesos. ${ }^{107}$ ¿Es posible saber, al menos como tendencia aproximada, qué porcentaje le corresponde a la plata que procede de la América española, particularmente, plata peruana? No conocemos ninguna

107 Atwell presenta los datos en kilogramos y en taels (unidad de medida de peso china, el taels. Aquí las hemos convertido a pesos de a 8 reales, tomando en consideración que un tael equivale aproximadamente a 1.3 pesos. Atwell, 2005, p. 80. 
evidencia cuantitativa que responda a este precisa cuestión. Sólo es posible "jugar" con ciertos datos generales y desprender una imagen de tendencia general. En este argumento hay que destacar las cifras que brinda el historiador chino Chuan Hang-Sheng. Si bien son aisladas, lo cual impide un ejercicio serial, tienen el atributo de contemplar el envío de metálico que viaja fuera de registro o en contrabando y que saltea el registro fiscal en el puerto de Acapulco. Según Hang-Sheng, antes de 1598 fluye hacia China un promedio anual de 1000000 de pesos desde Acapulco; entre 1599 y 1602, 2000000 ; entre 1604 y años posteriores, 2500000 pesos; en 1620, 3000000 , y finalizando la tercera década del siglo XVII: 2000000 de pesos. ${ }^{108} \mathrm{Si}$ aceptamos las referencias de fuentes cualitativas ofrecidas en páginas anteriores acerca de una participación de $40 \%$ de la economía del Perú en los cargamentos de la nao de China, estaríamos autorizados en suponer un promedio anual que gira en torno al millón o a 1.25 millones de pesos en plata peruana.

Estos volúmenes generales de plata americana que viajan hacia las Islas Filipinas superan, con creces, las estimaciones que se presentan en la reconocida y clásica literatura española e hispanoamericana. Veamos los datos brindados por Pierre Chaunu y TePaske y Klein (cuadro I.2).

Si se fraccionan por año los montos globales de cada déca$\mathrm{da}$, se obtienen cifras realmente nimias, respetando de manera impecable la normativa de regulación comercial que ordena un máximo de 500000 pesos anuales en salida de plata. De hecho, a excepción de la década 1611-1620, las salidas de plata para el resto de los años se ubican muy por debajo del tope legislativo. La limitación de considerar seriamente los datos de Chaunu es que margina al espacio peruano como una variable de cálculo en las exportaciones de plata hacia el Oriente, cuando sabemos (aún con la imposibilidad de saber con exactitud su escape) cuán determinante es dicho espacio a la hora de considerar los cargamentos de los galeones que salen desde Acapulco hacia Manila. 


\section{Cuadro I.2. Envíos de plata desde la Nueva España a las Islas Filipinas (por décadas)}

\begin{tabular}{cccc} 
Décadas & Remesas privadas & Remesas púbicas & Totales \\
\hline $1581-1590$ & - & 1259651 & 1259651 \\
$1591-1600$ & 578170 & 466016 & 1044186 \\
$1601-1610$ & 3516513 & 1174782 & 4691295 \\
$1611-1620$ & 5048118 & 2541652 & 7589770 \\
$1621-1630$ & 5423822 & 3620573 & 9044395 \\
$1631-1640$ & 3509871 & 3672874 & 7182745 \\
\hline
\end{tabular}

Fuentes: Remesas privadas: Chaunu, 1974, pp. 132-133; remesas públicas: TePaske y Klein, 1981, cuadro 4, p. 133.

Desde un principio, Chaunu define al comercio peruano por el Pacífico como un mero fenómeno de comercio de cabotaje. ${ }^{109}$ No hay otra alternativa que sostener su crítica. El comercio de cabotaje peruano por el Pacífico que llega a la costa occidental de la Nueva España es la plataforma ideal para participar en un juego comercial de escala internacional. La minimización de Chaunu sobre la participación de la economía peruana en el galeón de Manila explica las reducidas cifras de salidas de plata hacia el Oriente. Estas cantidades realmente bajas que salen desde Acapulco le permiten a Chaunu llegar a proponer una hipótesis que, en principio, requiere de cautela: "una correlación positiva entre el Atlántico y el Pacífico", donde el galeón de Manila no genera ninguna tensión en la economía transatlántica. ${ }^{10}$ Es evidente que nuestra posición está bastante lejos de los flujos compatibles y

109 Chaunu, 1974, pp. 78-80.

110 Vale recordar aquí la hipótesis fundamental de la obra de Chaunu: "El estudio del galeón de Manila, llevada a cabo gracias a las contadurías de las administraciones territoriales, conduce a una conclusión decepcionante: la negación del Pacífico en tanto que espacio económicamente autónomo, dotado de dinámica propia, susceptible de alterar y de influenciar el destino de la Europa del Atlántico [...] Pero también es cierto que esa misma hipótesis obliga a reencontrar lo que el Pacífico fue en realidad: simple prolongación, en el orden de intercambios, del Atlántico hispanoamericano de Sevilla”. Chaunu, 1974, pp. 22-23. 
armónicos entre ambos océanos, pregonados por Chaunu. Ahora bien, a pesar de la ausencia de la variable peruana y sujetar su interpretación a la documentación oficial y parcial, el ciclo referido a un alza del tráfico transpacífico desde 1600 hasta 1630 parece acertado. De eso nos ocuparemos enseguida.

Valdría ahora concentrar la atención en el área del Atlántico para un posterior cotejo entre los flujos oceánicos de larga distancia. Con lo arriesgado que resulta toda cuantificación, valen la pena ciertas observaciones sobre la cuantía de remesas en metálico que se estarían destinando desde Portobelo a España durante el periodo que nos ocupa. Estamos muy lejos de ofrecer explicaciones cuantitativas sobre un mundo económico realmente complejo, donde existen variables históricas que escapan al registro, al número oficial. El propósito puede resultar más humilde, si queremos contextualizar en periodos más precisos lo que venimos enunciando cualitativamente. La gráfica y el cuadro I.3 muestran el intento.

Para la producción de plata se consideran las cifras ofrecidas por TePaske y Kendall. ${ }^{111}$ Desde un principio hay que considerar que estamos en presencia de plata registrada, no así el metálico en barra o en pasta que esquiva cualquier registro oficial y que, de todas maneras, termina por incorporarse a flujos comerciales, en gran medida, a los que se generan por el Pacífico. Decidimos atender la caja dominante del periodo: Potosí, que brinda prácticamente toda la plata para su circulación interna y su posterior salida al exterior. Pero, vale advertir, que no dejamos de integrar a la serie las importantes cifras de producción que arrojan otros centros productivos: Lima, Cuzco, Castrovirreyna (para las últimas décadas del siglo XVI y primeros años de la centuria siguiente) y, en momentos en que la producción de Oruro adquiere verdadera significancia (1609-1627). Con todas las limitaciones que pueden suponerse, la serie ofrece una imagen por demás representativa del proceso de producción de plata por el espacio peruano.

Para el caso de las salidas de metálico hacia Sevilla, las cuatro series que presentamos sufren, hay que reconocerlo, importantes 
limitaciones (cuadro I.3). De acuerdo con nuestro rastreo, cuatro historiadores atendieron las exportaciones de plata peruana hacia Sevilla. La primera limitación es que las series no son completas ni exactas. Como tendencias mínimas, se dispone de las cifras de Chaunu $^{112}$ y por Moreyra y Paz-Soldán. ${ }^{113}$ Ambas series estarían considerando exclusivamente las remesas públicas enviadas por Portobelo. Chaunu logra identificar las cantidades exactas para cada año, mientras Paz-Soldán, consultando el libro de López de Caravantes, obtiene el número de las travesías y el monto general en ducados que Caravantes clasificó por nombre de virreyes o Audiencias. De tal manera, hemos decidido desprender, de los números de Moreyra y Paz-Soldán, un promedio anual de plata en pesos de cada galeón en concepto de plata de Su Majestad. Por lo tanto, ambas estadísticas deberían tomarse como piso, pero de ninguna manera como reflejo o tendencia general de los excedentes en metálicos enviados hacia Sevilla.

Otro escenario diferente arrojan las clásicas series presentadas por Hamilton y Morineau. El principal atributo de ambas estadísticas es que contemplan los envíos públicos y los cargamentos privados de remesas. En el clásico libro El tesoro americano, Hamilton publica las cantidades quinquenales que se habrían enviado desde todas las Indias hacia Sevilla. ${ }^{114} \mathrm{Al}$ evaluar el consenso que existe en la historiografía de la plata exportada, la plata de Tierra Firme rondó aproximadamente 66\%, hemos tomado la decisión de considerar los dos tercios de las cantidades totales de esos montos quinquenales y dividirlas entre cinco. Por su parte, las cifras de Morineau, que tradicionalmente han sido más aceptadas que las de Hamilton, plantean también ciertos inconvenientes. Son más sólidas y sistemáticas para el periodo posterior a 1620; año que, paradójicamente, estamos ante el cierre de nuestro ensayo. Para los años previos, los datos que suministra son parciales, de fuentes cualitativas y parciales que se 
apoyan en la administración castellana. ${ }^{115}$ En muy pocas ocasiones nos brinda datos de envíos de plata del galeón de Portobelo. En su mayoría, las cifras consideran los totales exportados desde la Nueva España y del Perú. En ese caso, aplicamos 66\% del total; porcentaje plenamente consensuado por los estudios especializados en la materia. Por otra parte, las cifras que ofrece no siempre consideran los envíos exclusivos del galeón de Tierra Firme; también estarían contemplando las salidas de plata por Buenos Aires o por diferentes puntos de la Hispanoamérica atlántica en navíos de registro o de permiso; problemática que supera nuestra atención sobre la evolución precisa de Portobelo. En definitiva, son las series que actualmente se manejan con cierta validez en la historiografía.

Cuadro I.3. Producción y salidas de plata peruana desde Portobelo hacia España

\begin{tabular}{cc|c|c|c|c|} 
& \multirow{5}{*}{$\begin{array}{c}\text { Producción } \\
\text { de plata registrada }\end{array}$} & & & & Envío de remesas de plata \\
Año & (TePaskey Kendall) & Chaunu & Morineau & Hamilton & $\begin{array}{c}\text { Moreyra y } \\
\text { Paz-Soldán }\end{array}$ \\
\hline 1581 & 6533352 & - & 3894151 & 6478676 & 832571 \\
1582 & 6889125 & - & & 6478676 & 832571 \\
1583 & 6150445 & - & - & 6478676 & 685425 \\
1584 & 6052582 & - & 4500000 & 6478676 & - \\
1585 & 7590772 & - & 7920000 & 6478676 & - \\
1586 & 6995831 & - & - & 5268226 & - \\
1587 & 3743289 & - & 8580000 & 5268226 & - \\
1588 & 5694363 & - & - & 5268226 & - \\
1589 & 7646767 & - & 9466000 & 5268226 & 911102 \\
1590 & 7350506 & - & - & 5268226 & 911102 \\
1591 & 7610589 & - & - & 7761365 & 911102 \\
1592 & 7662103 & - & - & 7761365 & 911102 \\
1593 & 7673779 & 2010175 & 6590000 & 7761365 & 911102 \\
1594 & 6867292 & - & - & 7761365 & 911102 \\
1595 & 7021354 & 3909022 & 16057000 & 7761365 & 911102
\end{tabular}




\begin{tabular}{|c|c|c|c|c|c|}
\hline \multirow[b]{2}{*}{ Año } & \multirow{2}{*}{$\begin{array}{c}\text { Producción } \\
\text { de plata registrada } \\
\text { (TePaske y Kendall) }\end{array}$} & \multicolumn{4}{|c|}{ Envío de remesas de plata } \\
\hline & & Chaunu & Morineau & Hamilton & $\begin{array}{l}\text { Moreyra y } \\
\text { Paz-Soldán }\end{array}$ \\
\hline 1596 & 7180758 & - & 10296000 & 7594520 & 1605099 \\
\hline 1597 & 6806478 & - & - & 7594520 & 1605099 \\
\hline 1598 & 6411445 & - & 7722000 & 7594520 & 1605099 \\
\hline 1599 & 6410927 & - & - & 7594520 & 1605099 \\
\hline 1600 & 6477036 & - & - & 7594520 & 1605099 \\
\hline 1601 & 7368083 & - & - & 5383085 & 1605099 \\
\hline 1602 & 7637320 & - & 10000000 & 5383085 & 1605099 \\
\hline 1603 & 7385619 & 1748399 & 6242234 & 5383085 & 1605099 \\
\hline 1604 & 6722977 & - & - & 5383085 & 1605099 \\
\hline 1605 & 7646961 & - & - & 5383085 & 1360568 \\
\hline 1606 & 7285291 & - & 4500000 & 6927617 & 3167559 \\
\hline 1607 & 7090166 & - & - & 6927617 & 1445223 \\
\hline 1608 & 5969649 & - & 6475260 & 6927617 & 1445223 \\
\hline 1609 & 6628291 & - & 6737908 & 6927617 & 1445223 \\
\hline 1610 & 8113188 & - & - & 6927617 & 1445223 \\
\hline 1611 & 5344250 & 1518576 & 5583000 & 5410614 & 1445223 \\
\hline 1612 & 7442096 & 1777284 & 6434134 & 5410614 & 1445223 \\
\hline 1613 & 7603556 & 1620912 & 6006000 & 5410614 & 1445223 \\
\hline 1614 & 8390524 & 1515498 & 5871984 & 5410614 & 1445223 \\
\hline 1615 & 8144596 & 1449213 & 5511816 & 5410614 & 1445223 \\
\hline 1616 & 7362307 & 1666473 & 7126742 & 6642453 & 878090 \\
\hline 1617 & 6829110 & 1302452 & 4788429 & 6642453 & 878090 \\
\hline 1618 & 6629162 & 2234761 & 8399857 & 6642453 & 878090 \\
\hline 1619 & 6973860 & 1920940 & 7062534 & 6642453 & 878090 \\
\hline 1620 & 6625900 & - & - & 6642453 & 878090 \\
\hline 1621 & 5626653 & - & - & 5958236 & 878090 \\
\hline 1622 & 5583105 & - & - & 5958236 & 1134672 \\
\hline 1623 & 5499318 & - & 8341095 & 5958236 & 875061 \\
\hline 1624 & 5484759 & 1903340 & - & 5958236 & 875061 \\
\hline 1625 & 5153673 & - & 736000 & 5958236 & 875061 \\
\hline 1626 & 5238492 & - & 12529026 & 5504674 & 875061 \\
\hline 1627 & 5414721 & - & 8497086 & 5504674 & - \\
\hline
\end{tabular}

Fuentes: TePaske y Kendall, 2010, pp. 56-122; Chaunu, 1955-59, t. vi, pp. 418-421; Morineau, 1985, pp. 71-77; Hamilton, 1975, pp. 47-55; Moreyra y Paz-Soldán, 1944, p. 71. 
Gráfica I.3. Producción de plata registrada en Perú y envíos de plata de Tierra Firme hacia Sevilla, 1581-1627 (por año en pesos de ocho reales)

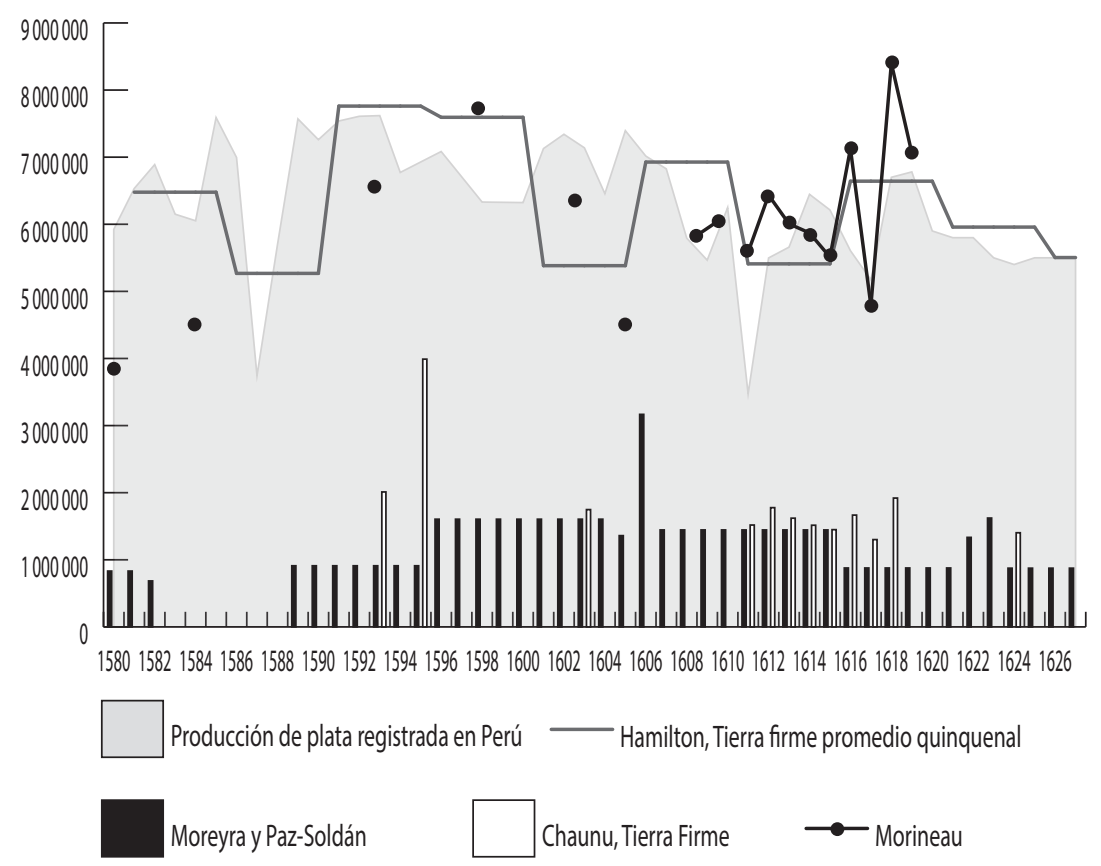

Fuente: Cuadro I.3.

Al realizar la tarea de promediar los datos aislados de Morineau que expresan los envíos en instancias de flota, aparece una sorprendente similitud con los cálculos de promedios quinquenales que arrojan las cifras de Hamilton. Una coincidencia que puede reforzar la validez de la serie para nuestro periodo. Las diferencias sustanciales entre ambos historiadores aparecen hacia mediados del siglo XVII, cuando la serie de Morineau expresa un sorprendente ascenso, muy pronunciado a partir de 1660, de los envíos no reportados de metálico hacia Europa. ${ }^{116}$ 
Ahora bien, hemos dicho que los datos sobre producción de plata consideran varios centros productivos y cajas de registro del espacio peruano (Potosí, Lima, Cuzco, Castrovirreyna, más tarde Oruro). Sin embargo, el papel dominante de Potosí durante las dos últimas décadas del siglo Xvi, abastecer el mercado interno y externo con más de $90 \%$ de la plata, no debería pasar inadvertido. Entre 1589 y 1607, la caja de Potosí registra los niveles de producción más elevados de toda su historia. En este contexto, no resulta casual ver, en primer lugar, que para 1595 y 1596, Morineau descubra los cargamentos de plata más importantes que se envían hacia Sevilla (16057000 y 10296000 pesos respectivamente). En segundo lugar, quizá un fenómeno más trascendente para nuestro estudio, las importaciones de plata en la hacienda China evidencian un incremento considerable durante el periodo comprendido entre 1592 y 1606; crecimiento exponencial donde gran parte de la responsabilidad, sin duda, recae en los envíos de plata peruana y novohispana a través del galeón de Manila.

Cuadro I.4. Producción de plata registrada en Potosí y remesas enviadas de Tierra Firme hacia España, 1580-1620 (en pesos de a ocho reales)

\begin{tabular}{cccc} 
Año & Producción Potosí & Hamilton & Morineau \\
\hline 1580 & 5923313 & - & 8250000 \\
1581 & 6533352 & 6478676 & 3894151 \\
1582 & 6889125 & 6478676 & - \\
1583 & 6150445 & 6478676 & - \\
1584 & 6052582 & 6478676 & 4500000 \\
1585 & 7590772 & 6478676 & - \\
1586 & 6995831 & 5268226 & - \\
1587 & 3743289 & 5268226 & - \\
1588 & 5694363 & 5268226 & - \\
1589 & 7570316 & 5268226 & - \\
1590 & 7260444 & 5268226 & -
\end{tabular}




\begin{tabular}{cccc} 
Año & Producción Potosí & Hamilton & Morineau \\
\hline 1591 & 7539975 & 7761365 & - \\
1592 & 7609023 & 7761365 & - \\
1593 & 7619776 & 7761365 & 6590000 \\
1594 & 6772630 & 7761365 & - \\
1595 & 6928690 & 7761365 & - \\
1596 & 7084749 & 7594520 & - \\
1597 & 6708061 & 7594520 & - \\
1598 & 6331373 & 7594520 & 7722000 \\
1599 & 6327261 & 7594520 & - \\
1600 & 6323148 & 7594520 & - \\
1601 & 7128997 & 5383085 & - \\
1602 & 7341142 & 5383085 & - \\
1603 & 7139571 & 5383085 & 6242234 \\
1604 & 6456772 & 5383085 & - \\
1605 & 7395816 & 5383085 & - \\
1606 & 7016357 & 6927617 & 4500000 \\
1607 & 6826468 & 6927617 & - \\
1608 & 5793069 & 6927617 & 6475260 \\
1609 & 5465786 & 6927617 & 6737908 \\
1610 & 6248165 & 6927617 & - \\
1611 & 3472679 & 5410614 & 5583000 \\
1612 & 5498490 & 5410614 & 6434134 \\
1613 & 5659950 & 5410614 & 6006000 \\
1614 & 6446918 & 5410614 & 5871984 \\
1615 & 6213586 & 5410614 & 5511816 \\
1616 & 5606319 & 6642453 & 7126742 \\
1617 & 5172630 & 6642453 & 4788429 \\
1618 & - & 6642453 & 8399857 \\
1619 & - & 6642453 & 7062534 \\
1620 & - & 6642453 & - \\
\hline & & &
\end{tabular}

Fuente: Cuadro I.3.

De esta manera, sostenemos que el inicio del auge de las salidas de plata peruana hacia México y las Islas Filipinas adquie- 
re un papel significativo desde la última década del siglo XVI. El boom del metálico peruano por el Pacífico ocurre de manera simultánea con los picos de máxima producción de plata de Potosí y, aunque en apariencia resulte paradójico, con los índices de salida más elevados desde Portobelo hacia Sevilla. Es cierto que, según las mediciones de Hamilton, en ciertos años del periodo 1593-1600 las exportaciones transatlánticas superan el registro de producción de Potosí. Pero debemos reconocer que desde 1588 hasta 1594, en su interior Perú retiene metálico que podría ser expulsado en años posteriores al momento de la llegada de una flota o, por el contrario, a través del Pacífico.

Gráfica I.4. Producción de plata registrada en Potosí y salidas por Portobelo (1589-1617)

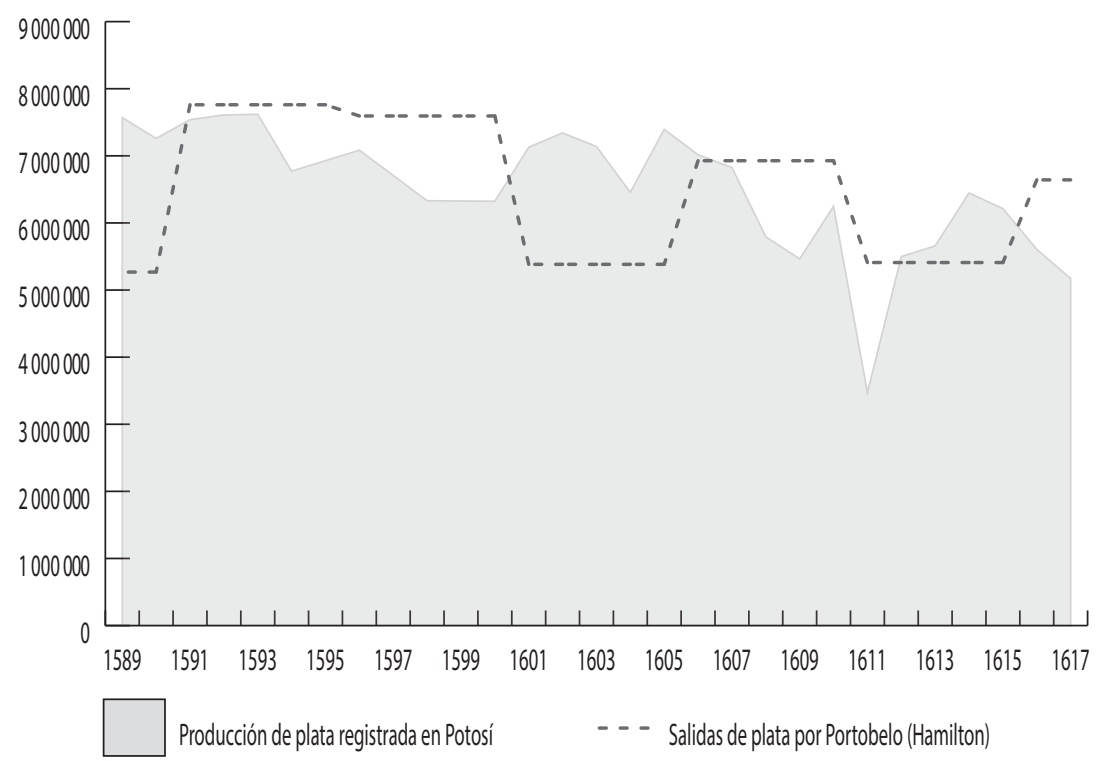

Fuente: Cuadro I.4.

Según Hamilton, la caída que ocurre en 1630 de los caudales en metálico que fluyen hacia España obedece "al incremento del 
comercio con Oriente". ${ }^{117}$ Aquí se propone una explicación alternativa. El aumento de los envíos de metálico hacia China es previo, desde 1590, a la par del ciclo ascendente del flujo metálico transatlántico. La notable producción de plata en Potosí permitiría que la corriente de salidas de metal por el Atlántico y por el Pacífico convivan, aún con tensiones menores, en tendencia a la alza durante la década. Ahora bien, esta suerte de compatibilidad de los flujos transoceánicos se puede explicar, en gran medida, por lo que ocurre en la economía peruana. El pico máximo que alcanzan las remesas en metálico por Portobelo entre 1590 y 1600 no podría entenderse como la relación inmediata de un supuesto éxito de los cargadores sevillanos. El envío de caudales vive su momento de esplendor en paralelo al reclamo que realiza la corporación sevillana. La explicación podría buscarse en la iniciativa que toman los agentes de la economía peruana. Gran parte de los capitales que circulan por el eje transatlántico pertenecen a peruleros, encargados de realizar operaciones directas para la compra de los productos en la propia Península y en otros mercados de Europa, esquivando el monopolio de los sevillanos en el cargamento del galeón. ${ }^{118}$

Ahora bien, un escenario distinto comienza a gestarse asomando el siglo XVII. Según Luis Alonso Álvarez, el proceso de desmonetización del flujo transatlántico, dado su escape a China, se inicia desde $1580 .{ }^{119}$ Para nosotros, el fenómeno recién se hace evidente a principios del siglo XVII. La expulsión de plata peruana por el galeón de Manila se mantiene con elevadas cifras durante las dos primeras décadas de este siglo, en un contexto donde las remesas enviadas de Portobelo sufren el inicio de dos breves fases de declive. Más precisamente, la gráfica I.4 atiende dos coyunturas críticas: 1600-1606 y 1612-1616. La primera de ellas expresa un desplome de los envíos de metálico peruano por el Atlántico, a pesar de la recuperación de los altos índices de producción de plata

117 Hamilton, 1975, pp. 48-49.

118 Sobre la precisa problemática acerca de la movilización espacial del perulero como elemento indicador de la emancipación económica peruana nos detendremos en la última parte del capítulo. Remitimos aquí al cuadro I.6.

119 Álvarez, 2016, pp. 288-289. 
en Potosí, que en los años anteriores manifiesta un declive no menor. El resultado es un sobrante de plata que, a nuestro entender, sale de manera sistemática hacia Nueva España, y que de manera insistente aparece denunciado en los escritos oficiales que hemos visto al inicio del capítulo.

Todo indica que aquella Relación de la Audiencia de Panamá de 1607 se inscribe en este marco de oposiciones de flujos metalíferos transatlánticos y transpacíficos. Asimismo, nuestras inferencias estadísticas obligan a revisar el postulado general de Chaunu, definido como "la correlación positiva simple pacífico-atlántica". Ese "sorprendente paralelismo" entre el tráfico pacífico y atlántico se desvanece hacia 1600; el primer conducto transoceánico mantiene su auge mientras que el segundo se comprime. ${ }^{120}$ Estamos ante un fenómeno que podemos sintetizar como un Atlántico pacificado; una Carrera de Indias condicionada por la informalidad del circuito del Mar del Sur y del galeón de Manila. Ahora bien, luego de un repunte de los envíos transatlánticos de la flota (1608-1610), el escenario de un aumento de producción de plata potosina con la simultánea caída de los envíos vuelve a reiterarse. El comercio de Perú con México y Filipinas, aún con la legislación prohibitiva, continuará con una actividad muy importante entre 1612 y 1616 . Ese sobrante o retención de metálico que dispone nuevamente el Perú en su interior será la punta de lanza para mantenerlo conectado con México y Filipinas.

Podríamos inscribir los cálculos ofrecidos por Kenneth Andrien de la distribución de los ingresos públicos de Lima durante esas décadas. En las primeras décadas del siglo gran parte de los recursos fiscales del virreinato son retenidos en su interior: una clara muestra fiscal de los inicios de la autonomía económica del espacio peruano. En la década 1591-1600, de un total de 31407730 pesos que entran a las arcas públicas de Perú, sólo $36 \%$ se retiene (11450254). Los ingresos públicos gozarán de un aumento en las décadas siguientes (37976256 para la década 1601-1610 y 33242788 para el periodo 1611-1620), lo retenido en el Perú será 
$55 \%$ (20 726 850) y 65\% (21323 078) respectivamente. ${ }^{121}$ Podría sugerirse que esos montos en aumento retenidos en el espacio interno constituyen parte de los capitales enviados de manera clandestina hacia el Pacífico. Asimismo, al considerar las claras diferencias que nos distancian con el esquema de Chaunu, estaríamos de acuerdo con su propuesta de la gran coyuntura del Pacífico: crecimiento acentuado del tráfico entre México y las Islas Filipinas desde 1590 hasta los primeros "signos [...] indiscutibles de fatiga y de debilitamientos a partir de los años 1616-1620". ${ }^{122}$

\section{3) Los excedentes de productos peruanos por el Pacífico: vino, azogue y cacao}

La plata no es el único producto que sale del Perú hacia los mercados del Pacífico hispanoamericano. El vino, el azogue y el cacao son excedentes o medio de cambio que desde el último cuarto del siglo XVI van hacia mercados exteriores desde el espacio peruano autosuficiente. ${ }^{123}$

El vino. Los viñedos constituyen el mayor de los cultivos comerciales del Perú. Después de la plata, es el medio de cambio fundamental en los mercados externos en esas décadas. ${ }^{124}$ Su espacio de producción se encuentra principalmente en los valles de Ica y Pisco, siguiéndole en orden de importancia Nazca, la franja del desierto costero, Chile y la región de Cuyo. Una característica que define la actividad de los viñedos peruanos en esta época es su so-

121 Andrien, 1985, p. 34.

122 Chaunu, 1974, p. 240.

123 Las harinas del Perú también son una mercancía de exportación. Pero todo indica que su flujo se limita hasta Panamá, sus vecinos gozan de la exención de impuesto a su circulación. La harina del Perú no alcanza el mercado novohispano, como sí lo hacen los tres productos que analizamos. Para su análisis remitimos a numerosos expedientes que se encuentran en el fondo Panamá del AGI.

124 Todo indica que el vino, como mercancía de cambio, se reproduce en el interior del espacio peruano, quedando una mínima retención para el uso doméstico. Assadourian, 1982, pp. 154-155. 
breproducción; una notable capacidad de producción que, según Assadourian, genera un proceso de sustitución de importaciones. ${ }^{125}$ En términos de mercado interno, la oferta de vino supera la demanda interna.

La captura prácticamente completa del vino local en el amplio mercado regional del Perú lleva a un desplazamiento de los vinos españoles, cuya importación en 1600 resulta insignificante. Nuestra fecha inicial de 1580 para ubicar el inicio de la expansión de la economía del Perú también parece corroborarse con el caso del vino. El contador de Madrid, Hernando de Valencia, calcula que hasta ese año habían ingresado al Perú 200000 botijas; una sorprendente cantidad que benefició al fisco real con un ingreso anual de 115000 pesos. El boom de la producción peruana contrae hasta tal punto el movimiento del vino español por la vía transatlántica que, según el contador, desde 1580 hasta 1633 el fisco perdió unos 6095000 pesos. ${ }^{126}$ Parece evidente que la ausencia de las botijas de vino español hacia el istmo explica esa estrepitosa caída de los intercambios por Portobelo ilustrados en la gráfica I.1 que presentamos en las primeras páginas. La caída del consumo de vino español tiene mucha responsabilidad en el descenso del número de barcos, recuas y casas de alquiler de los peruanos para asentarse en tiempo de feria en Panamá. Uno de los pilares en que se apoya el comercio transatlántico se encuentra en riesgo, debilitando lo que, a juicio de aquellos manuscritos analizados, garantizan la relación de "dependencia".

No es de extrañar que desde muy temprano, España vea la expansión productiva del vino en el Perú como una amenaza al comercio ultramarino. ¿Cómo frenar su circulación cuando los viñedos peruanos se encuentran en su máxima capacidad de funcionamiento? Un abanico de argumentos, algunos poco verídicos, aparecen en la legislación prohibitiva peninsular en su intento por frenar su circulación y consumo: a) es el causante de la ebriedad de los indígenas, lo cual compromete su productividad;

125 Assadourian, 1982, pp. 156-157.

126 Suárez, 2009, pp. 257-258. 
b) su pobre conservación y mala calidad contribuyen a generar enfermedades como "esquinencia”, viruelas, sarampión, "dolor de costado", tabardillo, "postemas" y "granos", ${ }^{127}$ y c) se falsifica, al etiquetarse el vino peruano como español, etcétera.

Desde principios del siglo XVII se inicia una verdadera "lucha legislativa” entre Perú, Panamá y España en torno a la autorización o prohibición del comercio y consumo de los vinos peruanos. No hay otra explicación para entender la ambigüedad y "el ida y vuelta" que expone la legislación peninsular sobre el caso. En 1600 una real cédula prohíbe la introducción de vinos peruanos a Panamá por sus efectos nocivos para la salud. La alianza entre Sevilla y el Cabildo de Panamá habría sido la causante del cierre. Pero en 1604, el propio rey Felipe III cambia de parecer, posiblemente ante la presión de la Audiencia y de los mercaderes del Perú, y autoriza que sus vinos puedan circular y consumirse en Panamá y Guatemala. ${ }^{128} \mathrm{La}$ autorización es efímera y ante la insistencia de los dueños de viñas españolas y mercaderes sevillanos, una nueva ordenanza vuelve a convertir al vino peruano en un producto ilegal. Para 1632 rige su absoluta prohibición y aún en 1640 una real orden desiste de la propuesta del gobernador de Tierra Firme en autorizar su entrada a condición de pagar un derecho extraordinario en Panamá que se destinaría a la construcción de casas reales. ${ }^{129}$ El tráfico de vinos peruanos hacia Centroamérica se clausura en 1615, cuando ven que opera para el tráfico de mercaderías asiáticas procedentes de la Nueva España. ${ }^{130}$ Para el caso novohispano, la prohibición de su circulación está presente, al menos, desde $1620 .{ }^{131}$ Pero suponemos que existe una ordenanza de prohibición simultánea al caso centroamericano. El 20 de mayo de 1631 se permite que la Nueva España comercie vino peruano a condición del pago de $2 \%$ del vino "que cogiesen y trajinasen embotijado". ${ }^{132}$

127 Suárez, 2009, p. 258.

128 Clayton, 1975, p. 8; Cappa, 1890, Iv, p. 33.

129 Para 1632, véase AgI, Panamá, 229, 1. 3, f. 51; para 1640, AGI, Panamá, 229, 1. 3, fs. 137-138.

130 Macleod, 1973, pp. 235-264.

131 Suárez, 1995, p. 103.

132 Cappa, 1890, IV, p. 37. 
Mapa I.1.

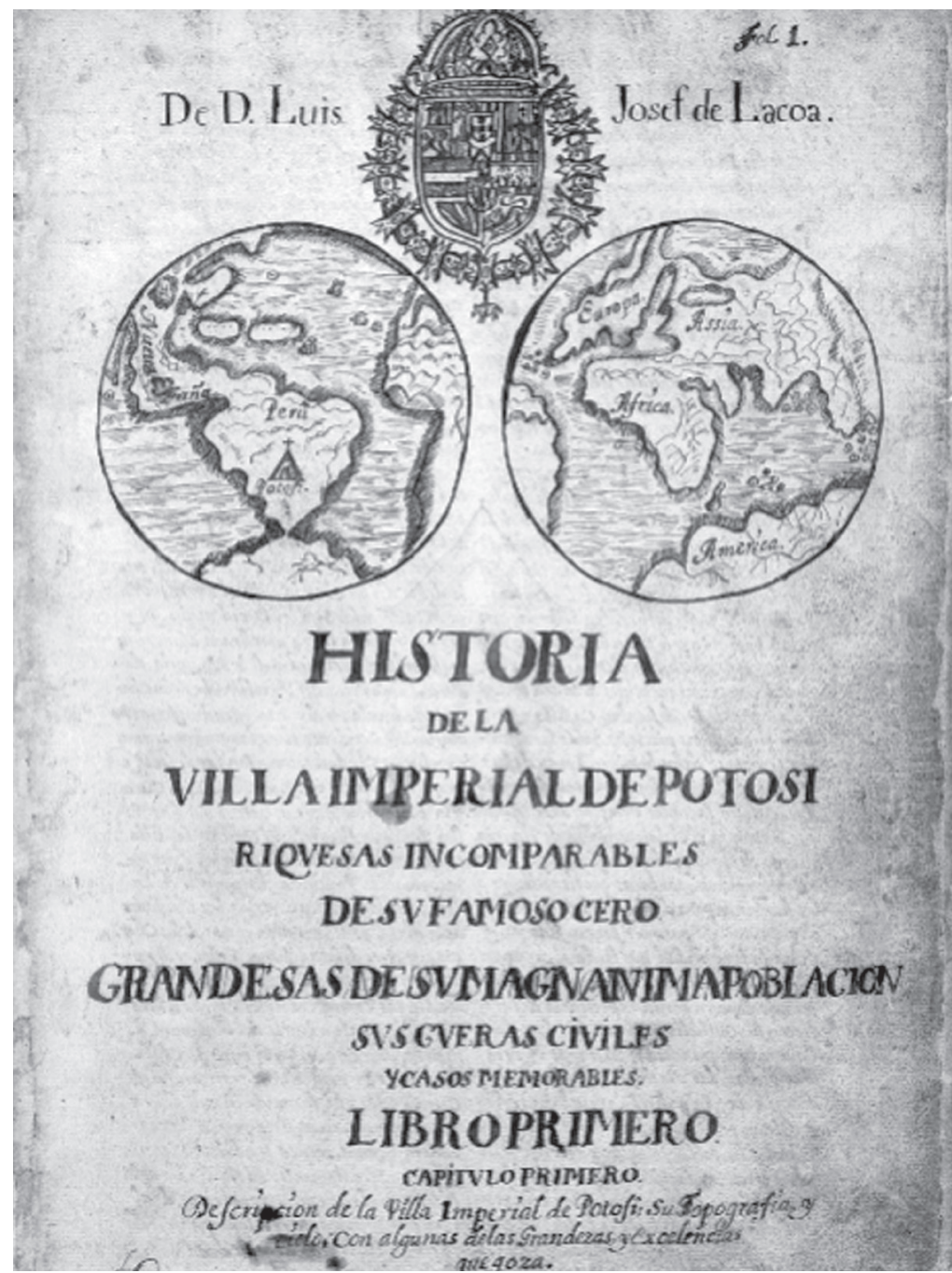

Ilustración interior que inaugura el "Libro primero" de Josef de Lacoa; texto que forma parte de la reconocida obra Historia de la villa imperial de Potosí de Bartolomé Arzans de Orsúa y Vela. La ilustración del lado izquierdo muestra la centralidad de Potosí en un Perú que comprende toda América del Sur. Se destaca en la imagen la Nueva España y el Mar del Sur, área marítima que adquiere tanta importancia como la atlántica. En la imagen derecha podría interpretarse cómo América, pilar de la plata de Potosí, participa con los restantes tres continentes de la globalización en la época: África, Asia y Europa. 
Lo cierto es que el paquete de disposiciones prohibitivas no tiene la capacidad para frenar el interés de su producción y su movilización hacia Centroamérica y la Nueva España. En 1597, personajes del Santo Oficio de la Inquisición de Perú, el fiscal Tomás de Solarana y su secretario Julián de Tudela le envían a Nicolás de Zabala, un importante comerciante limeño que por esos tiempos reside en la Ciudad de México como una suerte de perulero, 400 botijas de vino peruano para que ingrese por el puerto de Acapulco. ${ }^{133}$ En 1598, Amador de Antas, maestre del navío Nuestra Señora del Rosario, lleva hacia el puerto del Realejo 418 botijas de vino. ${ }^{134}$ En 1603, llega el navío San Luis a Acapulco procedente del puerto de el Callao con enormes cargas de vino y vinagre para el consumo novohispano. ${ }^{135}$ Creemos que es el Ave María estudiado por Ramiro Flores. Si es el caso, estamos en presencia de una notable cantidad: 11835 botijas de vino y 3268 botijas de vinagre. ${ }^{136} \mathrm{El}$ navío Santiago que llega a Acapulco procedente de Lima en diciembre de 1617 lleva en sus bodegas, sumado al cacao de Guayaquil, una enorme cantidad de botijas de vino al mercado novohispano. ${ }^{137}$

En 1629, los planteamientos testimoniales del fraile benedictino Benito de Peñalosa muestran no sólo una producción de vinos en el Perú que supera los niveles de consumo interno sino, ante todo, la circulación y el deseo de los mercados externos por contar en sus plazas internas de los excedentes vitícolas: "como ya hay tanto vino, todo es buscar trazas para expenderlo por mar y por tierra, y en muchos bajeles lo llevan por las costas del Mar del Sur a Panamá, Nicaragua, Guatemala, Realejo y otros puertos, hasta Acapulco y puertas de México". ${ }^{138}$ Su movilización asume una suerte de escalada ascendente hacia todos los puertos occidentales de Hispanoamérica. Es tan elevada su exportación

\footnotetext{
133 AGNL, Fondo Protocolos Notariales, Poder, JBE1, vol. 12, exp. 110, fs. 156 r y v. 134 AGNL, Fondo Protocolos Notariales, Recibo, FRB1, vol. 14, exp. 709, fs. 1967 r y v. 135 AGNM, gobierno virreinal, General de Parte, vol. 6, exp. 369, fs. 139.

136 Véase Flores, 1995, p. 403.

137 AGI, México, 29, núm. 21, fs. 30-32.

138 Peñaloza, 1629, 5 excelencia, capítulo viI, p. 123.
} 
que "de los sobredichos puertos lo llevan tierra adentro hasta los puertos del Mar del Norte" ${ }^{139}$ El vino peruano circula de forma notable del Pacífico al frente Atlántico del continente. Por estas décadas, grandes cantidades de botijas de vino peruano se depositan en los almacenes del puerto de Acapulco, dispuestos para su embarque en las naos de China. Parece ser un acto natural su consumo por parte de la tripulación en los viajes de Acapulco hacia Cavite. ${ }^{140}$

Pero lo que es aún más interesante del Memorial de Peñaloza es que la intensa circulación de la bebida arrastra nuevamente la plata hacia Lima, que antes se había exportado desde el Perú para la compra de textiles extranjeros en Nueva España. Nos dice Peñalosa: "Los vinos del Perú se llevan a muchos puertos del Mar del Sur, y de ahí se comunica a tantos lugares, hasta el Mar del Norte, por cuya razón chupan la plata que hay en dichos puertos y tierras y las vuelven al centro que es Lima, Potosí, y demás comarcas". ${ }^{141}$ Esta cita plantea lo complejo que resulta aplicar convencionalismos en las lógicas del intercambio. La circulación del vino hacia México minimiza los envíos de metálico peruano con vistas a la adquisición de los textiles chinos o europeos que hay en la Nueva España. El vino constituye un medio de cambio y no sólo un producto de consumo fuera del Perú. La plata que retorna a Lima busca nuevamente su salida, dado que en principio "el Perú no ha menester otra cosa que le sea necesario"; o que "los criollos que comúnmente tienen viñas no estiman la plata” para gastarla en "costosas telas de Italia, delgada lencería de reinos extraños y toda brujería y curiosidad extranjera. Y con gran abundancia gastan sedas venidas por la vía de Acapulco, de China, y labradas en México, y otra ropa de contrabando". ${ }^{142}$

Es cierto que el Perú no necesita mucho del exterior, pero la referencia de Peñaloza a que "solo traen alguna brea" ${ }^{143}$ no

\footnotetext{
139 Peñaloza, $1629,5^{\circ}$ excelencia, capítulo viI, p. 123

140 AGI, Contaduría, 899, exps. 1-3, s/n de fs.

141 Peñaloza, $1629,5^{\circ}$ excelencia, capítulo x, p. 130.

142 Peñaloza, $1629,5^{\circ}$ excelencia, capítulo x, p. 130.

143 Peñaloza, 1629, $5^{\circ}$ excelencia, capítulo x, p. 130.
} 
hace más que desconocer su necesidad en el Perú para la conservación de las botijas de vino o como insumo indispensable en la construcción de navíos. ${ }^{144}$ Ahora bien, el vino del Perú no sólo se constituye en un medio de cambio en el interior del espacio peruano. También cumple esa función en la Nueva España para que los agentes limeños dispongan nuevamente de metálico en vistas de adquirir textiles asiáticos, europeos y mexicanos. Peñaloza remata su planteamiento sobre los efectos de "remolino" que vive la plata y el vino peruano por el Pacífico, que está impidiendo la captación del excedente mercantil por España: “y todo esto es fuerza quitarle a la dicha plata su común derrota que es España, que ya venía caminando, y el vino la revuelve [sic] al Perú para que se gaste de esta manera, y la lleven a reinos extraños sin registro". 145

En sus Memorias de 1621, el virrey Francisco de Borja realiza un planteamiento muy similar sobre lo que abunda en el Perú y lo que se necesita. A pesar de la prohibición para su ingreso al Perú, el príncipe de Esquilache le comunica al rey que en su mandato permitió el comercio de vinos por sedas orientales "beneficiadas en México" cobrando reales derechos. Resulta necesario permitir la comercialización de la bebida etílica hacia la Nueva España porque "sin ello no hay fletes bastantes para que ningún navío vaya a emplear a México en seda beneficiada y tejidos que es lo poco que estas provincias ha menester de ellas". ${ }^{146}$

Para el mercader peruano es más conveniente llevar los vinos hacia México porque es un producto aceptado en el intercambio de los textiles europeos y asiáticos. El comercio español sufre una doble alteración: no se venden los textiles europeos que lleva a Portobelo ni su vino. Esta relación de intercambio afecta no sólo el espacio peruano, sino en otros frentes exteriores donde gravita la circulación vitícola peruana se expande hacia Panamá, Guatemala y la misma Nueva España. Aquí cobra sentido el mencio-

144 Rodríguez, 1960, p. 243.

145 Peñaloza, 1629, 5 excelencia, capítulo x, p. 130.

146 Bailly, 1859, p. 133. 
nado punto 3 del informe de Panamá que anotamos al inicio del capítulo: "el Perú tiene vino de cosecha para sí y para cargar a Nueva España”.

Azogue de Huancavelica. El mercurio peruano constituye otro excedente mercantil de importancia que sale hacia el mercado novohispano. Quizá sea en tiempos del marqués de Cañete, a inicios de la última década del siglo XVI, cuando alcanza su máxima prosperidad productiva y comercial. En 1578 el volumen de la producción en promedio quinquenal es de 65 quintales, en 1588 asciende a 97, en 1593 a 95, en 1603 decae a 48 para recuperarse en 1613 a $85 .{ }^{147}$ Son cifras elevadas que nos remiten no sólo a un abastecimiento interno que cubre a Potosí, sino también los asientos de Castrovirreina, Zaruma, Quito y Huaylas. El mercurio de Huancavelica fue un elemento indispensable para la producción de plata en el Perú. Sin embargo, vemos un artículo que, a fin de cuentas, goza de una Corona permisiva para su exportación; al promover su salida de los puertos de Paita, Arica y el Callao para el abasto de las minas de Culiacán, Zamalpán y Taxco en la Nueva España. Las dificultades que presenta el yacimiento en Almadén y el inviable plan de importar mercurio de China ${ }^{148}$ para los centros metalíferos novohispanos, obliga a planificar abastos sistemáticos y de grandes magnitudes desde Huancavelica hacia Nueva España por el Pacífico. Al margen de estas dificultades de movilización, lo cierto es que el mineral peruano compite exitosamente con el de Almadén en el mercado novohispano, no sólo por su menor precio sino por su mayor pureza. ${ }^{149}$

147 Contreras, 1982, p. 62.

148 Numerosos proyectos, todos truncados, proyectan desde 1590 hasta 1640 la movilización de mercurio asiático para el mercado novohispano. Los altos costos de comercialización, el precio y la cantidad de lo que era posible importar desde el Oriente llevan a desistir de la posibilidad. Pero el contrabando de sedas y tejidos asiáticos, que encubría el tráfico de azogues, resultaba el obstáculo principal. AGI, Lima, 572, núm. 20, fs. 195-233. Bakewell, 1976, pp. 152-153; Valdés Lakowsky, 1987, pp. 62-63.

149 Borah, 1975, pp. 174-175; Bakewell, 1976, pp. 237-238. 
Al menos desde 1573 llegan al puerto de Huatulco 1500 quintales de azogue de Huancavelica con el navío San Sebastián que había partido del puerto de Huanchaco, cercano a Trujillo. ${ }^{150}$ Pero quizás el circuito se formaliza con fuerza hacia 1591, cuando, por medio de una real cédula, se le ordena al virrey peruano Marqués de Cañete la exportación anual de 1500 a 2000 quintales de azogue a la Nueva España por tres o cuatro años, sea por cuenta de la hacienda pública o por manos privadas. En aquel año, la producción de Huancavelica alcanza su cota máxima en toda su historia: 11522 quintales. ${ }^{151}$ En 1592, se remiten 3500 quintales y al año siguiente le siguen $2000 .{ }^{152}$ En los primeros años del siglo XVII, la producción de Huancavelica declina pavorosamente, hasta el punto en que las cantidades enviadas en los años de auge pasan a ser los niveles productivos totales del yacimiento. ${ }^{153}$

Cacao de Guayaquil. Un último producto mercantil del espacio peruano que se expulsa hacia la Nueva España es el cacao producido en la región norte del virreinato, en Guayaquil. Existen dos razones para comprender el efecto de arrastre que cumple la Nueva España para la evolución productiva del fruto guayaquileño: a) la atracción que le genera a un mercado consumidor novohispano en expansión, donde los centros productores locales, como Tabasco y Soconusco, no tienen la capacidad suficiente para responder, y b) el elemento o la vía de acceso de los comerciantes guayaquileños para disponer de la ropa de China que se encuentra disponible en el Pacífico novohispano. Para León Borja y Szászdi Nagy, la razón de fondo que da nacimiento a la producción de cacao obedece a la necesidad de la región de disponer de un producto propio que contribuya a equilibrar la balanza comercial y así saldar los estimados bienes asiáticos procedentes de la Nueva España. ${ }^{154}$ Sin embargo, Manuel Miño Grijalva desacre-

\footnotetext{
150 AGI, Patronato, 239, r. 4-3, fs. 57-58.

151 TePaske y Brown, 2010, p. 210.

152 Lohmann, 1999, pp. 164-165.

153 Lohmann, 1999, cuadro V, pp. 484-485.

${ }^{154}$ Léon de Borja y Szásdy Nagy, 1964, p. 2.
} 
dita la idea, pues "era poco lo que el cacao podía hacer para enfrentar tan poderoso desequilibrio". ${ }^{155}$ Acuerda, no obstante, que para entonces Guayaquil es una región productora importante de Hispanoamérica, generando efectos tanto en su economía interna como fuera de su espacio. De hecho, en 1627 el corregidor del puerto ecuatoriano reconstruye la ciudad, luego de un ataque sufrido por corsarios, con la ayuda del cacao que por entonces se encuentra vendiendo en el mercado de la Nueva España. ${ }^{156}$ El consumo novohispano, al fin de cuentas, incentiva la producción cacaotera en Guayaquil.

En tanto que la yerba mate y la coca son las infusiones de consumo popular más arraigadas en el mercado interno peruano, el cacao de Guayaquil encuentra en el exterior, concretamente en la Nueva España, el verdadero disparador para su producción, al menos hasta 1630. Para Assadourian, el éxito del cacao ecuatoriano en México se debe al proceso de democratización del consumo; un producto que antes de la Conquista era reservado a la nobleza azteca y que en la época colonial despega por toda la sociedad. ${ }^{157}$

La bienvenida novohispana al cacao de Guayaquil tiene, desde muy temprano, frentes conflictivos no menores. Uno de ellos es la temprana producción local de Tabasco, Zacatula, Igualapa y Xicayán. Sin embargo, la capacidad competitiva de estos centros productivos para la plaza de consumo virreinal tiene una vida muy breve; cuando mucho, hasta 1580 . El desplome de la población indígena en la región, la falta de mano de obra y el aumento de los costos productivos que elevan los precios, hacen que el cacao de producción local no pueda responder a un mercado consumidor cada vez más numeroso. El segundo y más importante conflicto se desata con la región productora de cacao que se encuentra ubicada cerca de la costa del otro gran océano: Caracas. El cacao venezolano tiene, desde las primeras décadas del siglo XVII, el apoyo y la promoción real para ser el grano de consumo del mercado novohispano. Por el contrario, Guayaquil sufre las

155 Miño Grijalva, 2013, p. 52.

156 Miño Grijalva, 2013, pp. 52-53.

157 Assadourian, 1982, pp. 235-237. 
prohibiciones o, cuando menos, restricciones comerciales para su envío hacia el norte.

La decisión política de privilegiar el fruto caraqueño por sobre el ecuatoriano se manifiesta en 1634, con la prohibición absoluta para el comercio de bienes locales entre la Nueva España y el virreinato peruano. Previo a esos años, los excedentes mercantiles de grano ecuatoriano son elevados, siendo su consumo y comercio en Nueva España a gran escala a partir de $1593 .{ }^{158}$ El interés del mercado novohispano por el cacao de Guayaquil es tan alto que hace descender el movimiento de navíos hacia el istmo centroamericano. Según el Memorial de Antonio de León Pinelo del año 1623, de nueve barcos por año que llegaban a Panamá entre 1593 y 1600, hacia 1620 sólo se registran un promedio anual de cuatro embarcaciones procedentes de Guayaquil. La navegación mercantil del Perú se desvía hacia la Nueva España con cargamentos de cacao para lograr retornar tafetanes y sedas novohispanas y asiáticas. ${ }^{159}$

La gráfica I.5 ilustra los lineamientos básicos del escenario histórico descrito hasta aquí. Se identifican cuatro principales espacios con sus determinadas funciones y características. La primera geografía que resalta es el virreinato del Perú, un área espacial que abarca prácticamente toda la porción hispánica de Sudamérica. Como espacio autosuficiente e integrado, Perú muestra como principales polos urbanos y económicos a Potosí y Lima. En segundo nivel aparecen puertos y ciudades: Guayaquil con su centro de Quito, Paita-Piura, el Callao como puerto dominante del espacio, Santiago, Córdoba, Paraguay y el puerto atlántico de Buenos Aires. El segundo gran espacio le pertenece a la Ciudad de México, principal centro de acopio y redistribución de productos asiáticos, europeos y novohispanos a centros consumidores de Hispanoamérica. Las puertas comunicantes de la ciudad novohispana son Veracruz por el Atlántico y Acapulco por el Pacífico.

158 Léon de Borja y Szásdi Nagy, 1964, p. 4. Según el ensayo de Jesús Hernández, la gravitación del cacao de Guayaquil en la Nueva España es evidente hacia la segunda década del siglo xVII, momentos de una altísima conflictividad entre el cacao de Venezuela y el ecuatoriano por el mercado novohispano. Hernández, 2008, pp. 43-79.

159 Molina, 1962, pp. 37-112. 


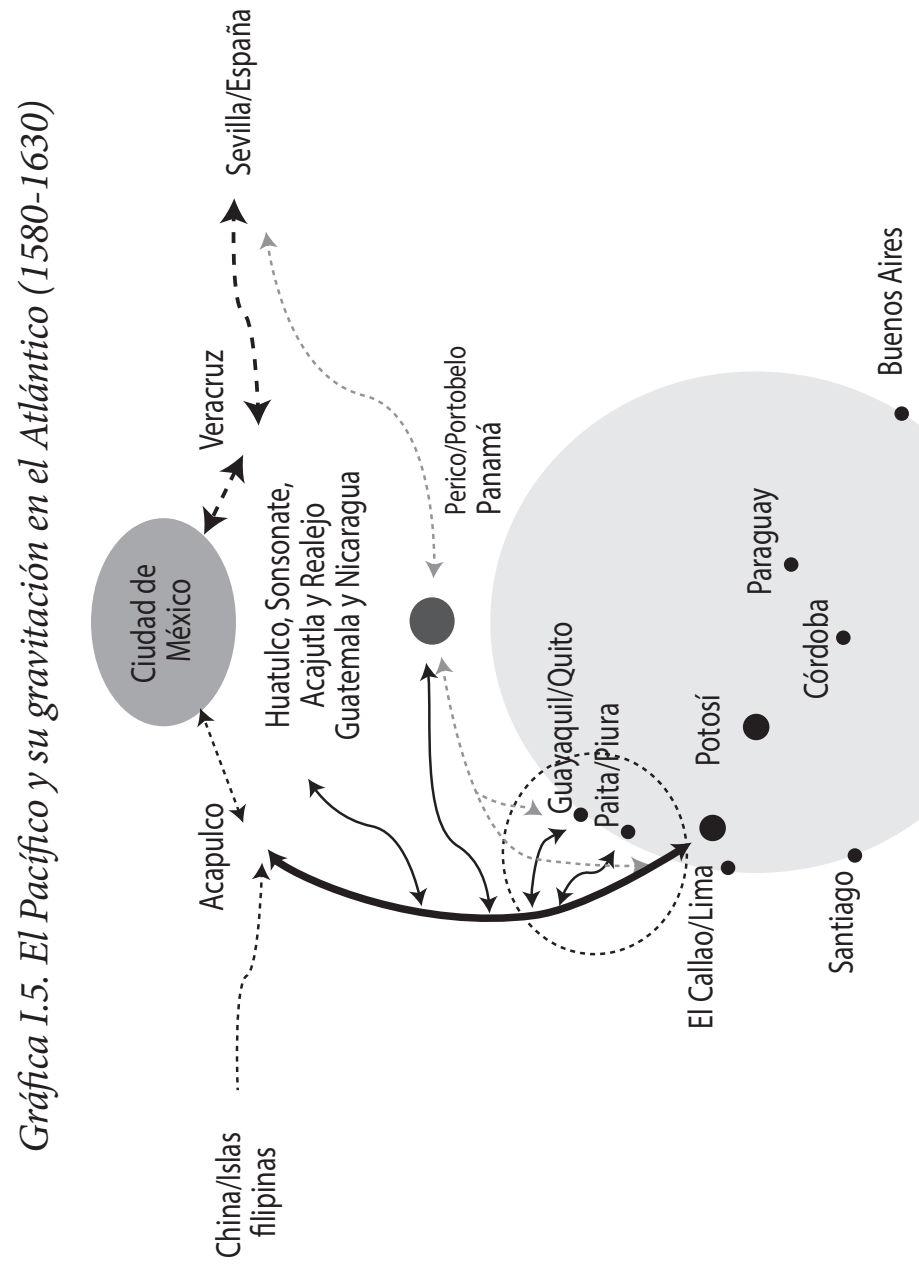




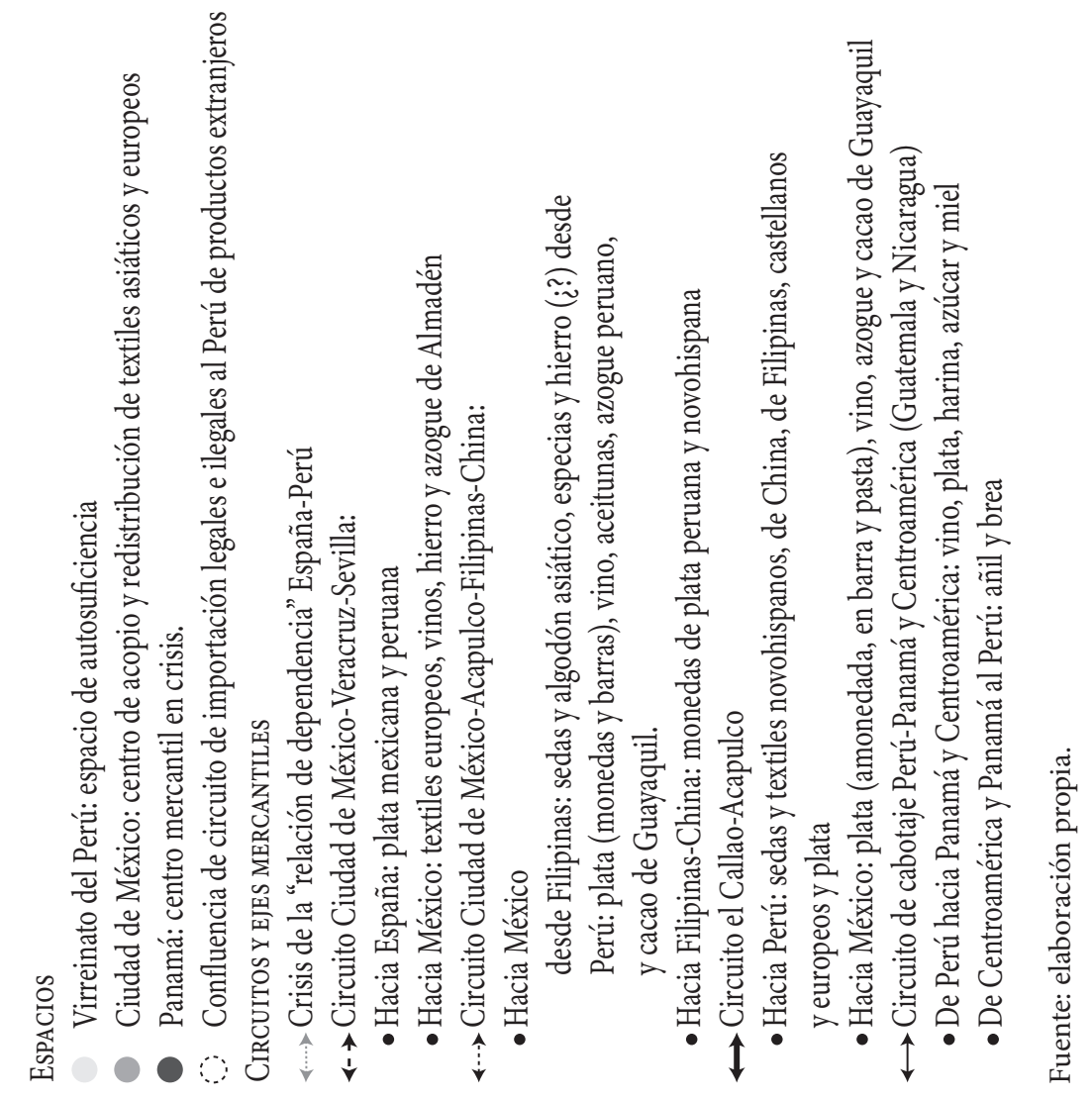




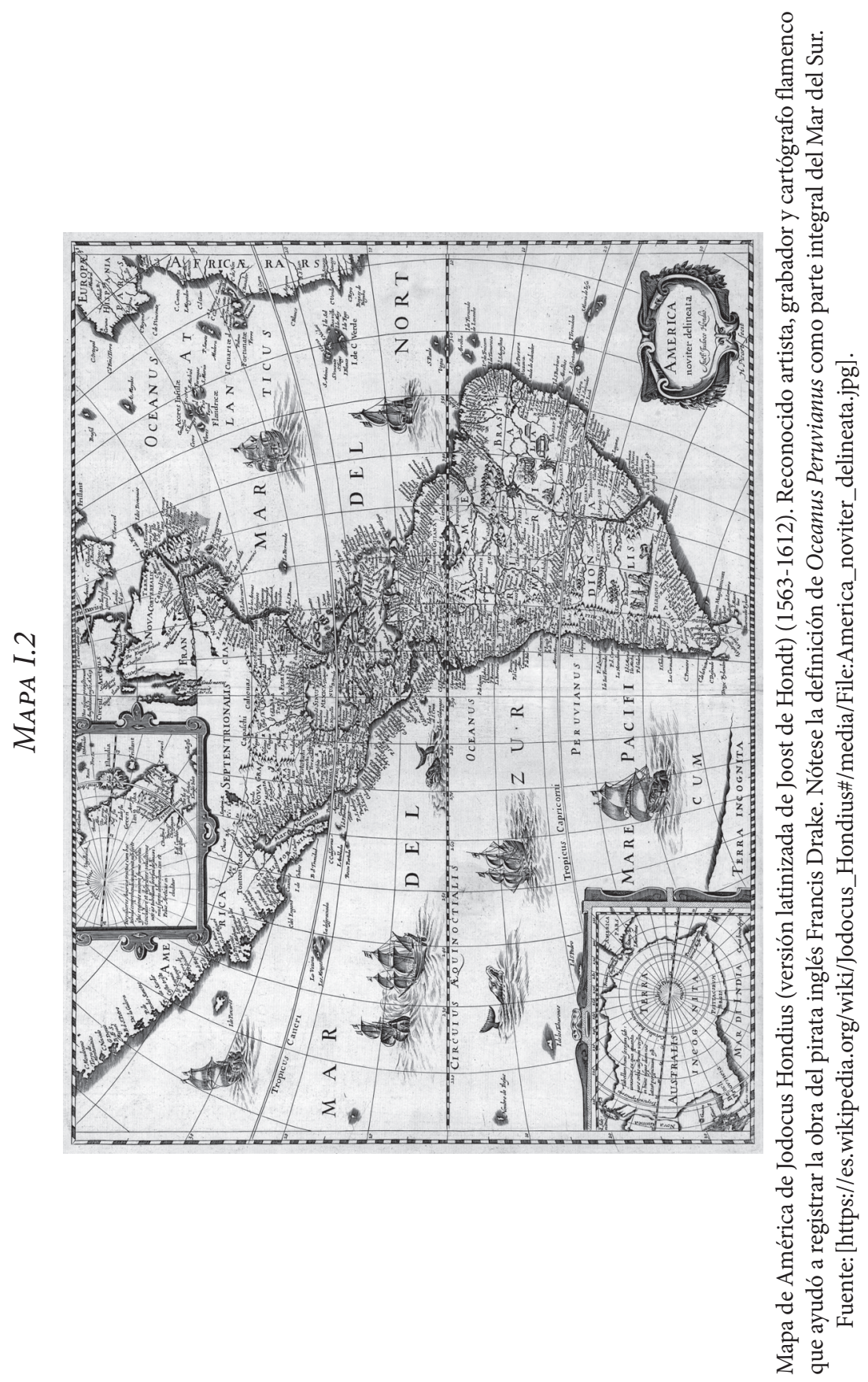


La tercera área identificada es, claro está, Panamá: una plaza oficial de recambio que se encuentra comprometida por los envíos de plata peruana hacia México. Una última y cuarta zona predominantemente marítima y poco comentada hasta el momento confluye en el circuito oficial que enlaza a Panamá con el puerto de el Callao, y el que une los puertos peruanos con las puertas costeras del Pacífico hispanoamericano (Panamá, Realejo, Sonsonate, Acajutla, Huatulco y el puerto de Acapulco). Allí confluyen circuitos legales e ilícitos de difícil distinción.

El grabador y cartógrafo flamenco, Jodocus Hondius (mapa I.2), no duda en calificar esta área de navegación como un verdadero Oceanus peruvianus. Zona radial de ambigua demarcación institucional pero decisoria, en tanto que en ella irrumpen los desvíos de excedentes peruanos hacia México, con la correspondiente entrada ilícita de bienes procedentes de la Nueva España.

\section{Mercado interno y autosuficiencia del Perú}

La obra de Assadourian es, sin duda, el "trampolín" que permite mantener las siguientes reflexiones. Su enfoque histórico sobre la realidad del Perú, combinado con un sólido cuerpo teórico de trabajo de archivo, nos obliga a inscribir el problema de la situación de emancipación comercial del Perú en el pensamiento del historiador. ${ }^{160}$ Las salidas de los excedentes peruanos por el eje del Pacífico hacia la Nueva España ocurren a condición y simultáneamente con lo que Assadourian denominó un espacio peruano, en alto grado de autosuficiencia económica y en su máximo nivel de integración regional. ${ }^{161}$ ¿Cuál es la naturaleza y las principales características de este gran mercado interno? Potosí, centro de la minería de plata, y Lima, centro político y de la economía mer-

160 Corre por mi exclusiva responsabilidad la manera de interpretar sus hipótesis.

161 Según Assadourian, el espacio peruano es una zona económica que se corresponde con la unidad política del momento: el virreinato del Perú del siglo XVI y XVII. Lo que actualmente comprendería Ecuador, Perú, Bolivia, Chile, Argentina y Paraguay. Assadourian, 1982, pp. 109-110. 
cantil monopólica, se posicionan como los "polos de crecimiento" del espacio, no sólo por su capacidad de consumo de bienes elaborados o de insumos, sino también porque originan efectos de especialización y división del trabajo sobre otras regiones del espacio peruano.

Si bien se sitúa más allá de nuestras prioridades de análisis, es necesario presentar de manera breve los planteamientos de Assadourian sobre los modos de integración y la división del trabajo que asume cada región en el gran espacio peruano. El sector dominante y nodo central es la minería de plata de Potosí, al tener la capacidad para cohesionar y monetizar las regiones del espacio. El trigo y el maíz de Jauja y Loja, los más importantes productos en el rubro de cereales y granos, buscan los mercados de Potosí, Lima y en menor dimensión, los centros de las minas de Zamora y Huancavelica. El trigo chileno sólo parece llegar a mercados de corta distancia. La producción de azúcar en los Andes, junto a la de Lima, centro productor y de efecto de arrastre consumidor de producciones aledañas, adquiere significancia. El vino de Ica y Pisco, y en menor dimensión de Arequipa, se dirigen al mercado de Potosí, Huancavelica y Cuzco, no sólo para su consumo, sino también como puntos de redistribución hacia mercados menores al llegar hasta Concepción. Acompaña por similares canales de comercialización el aceite de Coquimbo, La Rioja y el Valle de Lima y la aceituna de Ilo, Moquegua, Locumba, Chala y Arica. Arequipa provee ají y la papa de las altas tierras también baja a los centros del valle y centros mineros para su consumo. La coca de Cuzco y de los Andes meridionales nutre la vida de la mano de obra indígena por el casi completo mapa del espacio. El tabaco y la yerba mate de Paraguay alcanza significancia en la primera mitad del siglo XVII. La yerba mate engarza definitivamente el litoral con el resto del espacio peruano. El cacao de Guayaquil se distribuye por el interior de Lima, Arica y Chile pero, como vimos, su salida hacia el exterior es su razón productiva. La madera de Guayaquil es el principal insumo para la construcción de barcos en su navegación por el Pacífico y del trascendente astillero que se hará en Guayaquil. Assadourian subraya la importancia de la 
madera de Guayaquil como necesario medio de producción para las minas. Finalmente, del sector ganadero, los productos comercializados son la cabra y en su derivado de sebo, jabón y cordobanes, cueros, las llamas y mulas, que se transforman en el principal medio ambulante y de circulación a partir de 1600. Por supuesto, también está la carne y el pescado para el alimento de los centros urbanos y mineros. ${ }^{162}$ La relación de Lima y Potosí con regiones polarizadas se recrea en grados diversos sobre una nueva relación entre estas últimas con otras nuevas regiones secundarias y más distantes de los polos de desarrollo.

Dicha autosuficiencia significa que Perú deja de necesitar productos del exterior. Abandona la necesidad de comprar vino, azúcar, harina, tejidos de lana, algodón, vidrios, cueros y otros productos mencionados procedentes de España y Europa. No sólo eso, como hemos visto con el caso del vino, el mercurio y el cacao, Perú se convierte en una gran economía de exportación de los mercados centroamericanos y, en especial, del novohispano. Su economía interna genera excedentes para responder a mercados distantes y fuera de su espacio. Los productos de primera necesidad ya no serán un rubro que el Perú requiera del exterior. Su necesidad se limita a insumos esenciales para las minas, como el hierro, las armas, el papel y las mercancías de elite, en especial textiles, con alto valor agregado. ${ }^{163}$ En este contexto histórico, de un Perú comercialmente independiente, se inscribe la elocuente

162 Por su densidad poblacional y polea urbana de la plata, Potosí es durante esa época una esponja consumidora de bienes internacionales; como una villa que goza de los efectos de la mundialización mercantil. Sus tiendas y mercados se encuentran colmados de objetos de diferentes partes del mundo. Llegan a la ciudad tafetanes y sedas de Granada, medias y espadas de Toledo, paños y rajas de Segovia, sedas y rasos de Valencia y Murcia, abanicos y otras "curiosidades de Madrid", mantas de Sevilla, hierro de Vizcaya, tejidos de Portugal, sedas, sombreros y otros productos de Francia, tapicería, escritorios y espejos de Flandes, Lienzos y paños de Holanda, mantelería, acero y espadas de Alemania, papel y sedas de Génova, medias y tejidos de Nápoles, telas ricas de Milán, laminas y levantes de pintura de Roma, bayetas y sombreros de Inglaterra, cera blanca de África, grana, cristales, loza y seda de China, etcétera. Orsúa y Vela, 1965, t. I, pp. 8-9.

163 Clayton, 1975 , p. 7. 
frase de un cronista indiano en el año 1590, fray Martín Murúa: "Sólo le falta al Perú seda y lino, para con ello tenerlo todo de sobra, y no haber necesidad de mendigar ni esperar nada de otro ningún reino ni provincia del mundo (porque hierro, si lo buscasen, sin duda, hallarían minerales de ello)". ${ }^{164}$

La seda y los artículos textiles son uno de los rubros fundamentales que enlazan como un hilo fino la conexión transatlántica. Pero la estrecha dependencia comercial con España se verá afectada por dos razones fundamentales: a) la seda y la ropa de Castilla y Europa ingresarán al mercado interno del Perú por la vía de Acapulco procedente de México, y b) el funcionamiento del comercio transatlántico por Portobelo ya no será abastecido mayoritariamente por los mercaderes españoles, sino por sus pares peruanos, más conocido como peruleros.

Con elevada rentabilidad, el mercado peruano autosuficiente cobra pleno sentido y se enmarca en lo que los citados manuscritos nos hablan de "relación de dependencia", esto es: la imposición peninsular de generar una corriente de excedentes para garantizar el financiamiento de la administración, la defensa y las aspiraciones sociales y económicas de los grupos de elite de la Península Ibérica. Ahora bien, para que tenga éxito la "relación de dependencia”, es necesario que España logre canalizar de manera monopólica los excedentes del integrado espacio peruano, en especial de las remesas en metálico. Para ello, a decir de Assadourian, la política metropolitana esboza cuatro mecanismos: a) Lima como único punto de entrada y salida de productos del espacio; b) vedar todo tipo de relación hacia el Atlántico portugués; c) la prohibición al circuito de metales hacia la Nueva España, con su escape a China e India, y d) la estricta regulación a las relaciones de intercambio con otros espacios de la América hispana. ${ }^{165}$

Nada hemos comentado sobre la advertencia $b$ que anota Assadourian. ¿La Corona puede vedar las salidas de plata potosina 
en manos de los portugueses? Todo indica que el monopolio español se nutre y se ve superado por la participación portuguesa. Se los encuentra invirtiendo sus capitales en los galeones y dinamizando, gracias a que disponen de plata potosina y a que residían en Lima o Potosí, los circuitos metalíferos que tienen salida por Buenos Aires, Sacramento, costas de Brasil y por la misma Portobelo. A pesar de lo difícil que resulta calcular el comercio de estos puertos del Atlántico sur, no hay dudas de que por esas décadas se convierten en verdaderas ferias para intercambiar la plata potosina por los bienes de la India o de China y por esclavos que traen los navíos portugueses luego de pasar por África y cruzar el Atlántico. ${ }^{166}$ El comercio de bienes orientales por manos lusas, problemática poco atendida en la historiografía especializada, forma parte de la importante presencia portuguesa en el espacio peruano. Con todo, las salidas de metálico potosino para el pago de esclavos y mercaderías ingresadas por los mercaderes portugueses por el puerto de Buenos Aires se denuncia fervientemente desde Lima. ${ }^{167}$

Los restantes puntos tendientes al encuadre dependiente se ven profundamente cuestionados desde el propio centro de Lima entre 1580-1620. Ello es posible porque, en primer lugar, el Callao no se posiciona tan sólo como único puerto oficial mercantil del espacio; no es, en definitiva, la exclusiva puerta comunicante con el exterior. Considerando incluso el puerto limeño, hay que mencionar a Paita, Guayaquil y Trujillo que funcionan como puertas de escape de los excedentes mercantiles, en las navegaciones autorizadas e ilícitas con orientación hacia el norte del Pacífico. El puerto de Paita requiere un especial comentario. A pesar de ser un desolado paraje en el norte costero peruano, la entrada y salida de barcos hacia y desde México, Huatulco, Realejo y Sonsonate resulta significativa para los años iniciales del siglo XVII. Miguel Glave contabiliza un total de 21 navíos que tocan Paita

166 Boxer, 1970, pp. 457-478; Canabrava, 1984; Santaella Stella, 1997, pp. 16-22.

167 Sobre esta problemática: Canabrava, 1984; Saguier, 1985, pp. 43-166; Moutoukias, 1988; Perusset, 2005, pp. 285-304. 
procedentes de "México, Acapulco o Huatulco" para el periodo $1600-1606{ }^{168}$

¿Qué más decir sobre las salidas de excedente metálico y de productos hacia la Nueva España? Creemos que se ofrecieron suficientes argumentos para pensar que los puntos $c$ y $d$ enunciados por Assadourian también están alterados por la propia movilidad de los agentes peruanos y por el propio desenvolvimiento de su economía. Hay que reconocer la aproximación verdaderamente globalizadora del estudio de Assadourian, innovadora para el momento historiográfico de su tiempo. Se muestra muy dispuesto a considerar la relación del espacio peruano con lo que nosotros llamamos el Pacífico indiano. Nuestra pregunta es si la conexión Perú-Acapulco-Asia es tan sólo una salida interdicta, con mínimos efectos de intervención sobre la "puerta comunicante legal" que es la plaza de recambio de Panamá. ${ }^{169}$ ¿No hemos presentado elementos para revisar el problema?

Assadourian pone a la luz los flancos riesgosos que supone este conjunto de políticas tendientes a la dependencia del Perú con España. Nos dice que, si bien la lógica intrínseca del modelo de autosuficiencia aparece como condición para maximizar los envíos de los excedentes peruanos hacia España, son esos mismos mecanismos de subordinación los que abren camino a conflictos con los grupos de poder local, surgidos al calor del propio desarrollo de la economía peruana. En otros términos, si la Corona exprime al máximo la producción de plata del cerro de Potosí con el propósito de enviar más remesa de metálico desde Portobelo, esa misma política económica ocasiona que los hacendados, mineros y comerciantes locales se enriquezcan y acumulen poder. De ahí, explica Assadourian, las concesiones de la política metropolitana, de sus medidas intermedias, flexibles y lejos de rígidas ataduras que propicien una situación no deseada:

168 Habría que sumar los navíos registrados en Paita que hacen escalas y tejen su navegación con los puertos de Panamá, Realejo o Sonsonate para alcanzar la costa novohispana. Glave, 1997, p. 113.

169 Véase especialmente la gráfica 5 que elabora Assadourian en su estudio, 1982, p. 142. 
"hacer estallar la estructura de la relación de dominación". ${ }^{170} \mathrm{De}$ todos modos, una política metropolitana flexible y de coyuntura requerida no parece ser el único remedio español para evitar el desprendimiento del espacio peruano, su camino hacia la "independencia económica”. Es el propio Assadourian quien advierte sobre los límites estructurales que imposibilitan ese final: "transferencia del excedente metálico, el desplazamiento de la siderurgia y los límites de represión impuestos al desarrollo local de la producción de tejidos". ${ }^{171}$

Desde el plano de las relaciones productivas, estos tres elementos se sitúan como los pilares de la relación asimétrica, en tanto límites constitutivos al desarrollo moderno de la economía. Vale insistir aquí que la "dependencia" entendida en términos de transferencia de capital, de tecnología o incluso de servicios financieros no se encuentra cuestionada. Pero si entendemos la "dependencia" en términos mercantilistas, circulacionistas, o en una suerte de autonomía mercantil, como los propios contemporáneos la comprenden, la posibilidad del quiebre entre España y el espacio peruano resulta comprensible.

Los testimonios ofrecidos al inicio del capítulo hablan de una "independencia" del reino del Perú en momentos que el flujo de metal destinado a España alcanza niveles altos entre 1580 y 1600 , cifras que no volverán a registrarse en su historia. Pero dos elementos marcan, en esencia, la capacidad del espacio peruano para reforzar o condicionar el flujo transatlántico. Primero: las enormes cantidades de capital líquido que viajan a Sevilla no pasan siempre por mediación de los cargadores españoles. Como se verá en páginas siguientes, desde finales del siglo XVI y el primer cuarto del siglo XVII, grandes porciones de plata peruana que circulan por la vía transatlántica pertenecen a los comerciantes limeños, a través de la figura del perulero, evitando la intervención del español. Segundo: esa corriente de metálico por el Atlántico tiene como vía competidora la ruta del Pacífico-China, a través

170 Assadourian, 1982, pp. 131-132.

171 Assadourian, 1982, p. 144. 
de Nueva España, que como vimos moviliza una ingente cantidad de plata por el Pacífico en detrimento del Atlántico.

El caso de la producción de textiles y de la siderurgia remite necesariamente al plano productivo; nivel económico donde los límites de un posible curso a la independencia económica peruana quedan, con razón, expuestos. Puede pensarse que la obstrucción metropolitana de desplazar la producción de tejidos en el espacio del Perú sea la medida más determinante que le impide recorrer un camino a su definitiva emancipación. Pero hay que ser cautelosos y precisar qué tipo de desarrollo asume el obraje en el Perú. Assadourian lo expresó con claridad: mientras que España combate la producción de tejidos de alta calidad en el Perú para cautivar con productos españoles al consumo de elite, la Corona tolera, sino es que promueve, los obrajes locales ocupados en géneros de inferior y mediana calidad destinados a la sociedad media o pobre. ${ }^{172}$ La región de Quito es el ejemplo a resaltar: un "bolsón" obrajero de fabricación de paños con vida prolongada para el consumo "popular" de todo el espacio peruano. ${ }^{173}$

Pero, si se trata de revisar los mecanismos de la relación de subordinación o de los medios para captar el excedente de metálico peruano, la atención debería concentrarse en los textiles finos, de alto valor agregado llevados con las flotas para su venta en Panamá. Aquí retomamos un punto analizado: la vía novohispana de abasto de tejidos finos, ya sean asiáticos, castellanos, europeos e incluso elaborados por los centros obrajeros de Puebla y México. Nueva España compite con éxito con el canal oficial de abastecimiento español con polo en Portobelo; no lo reemplaza, pero el universo informal del Pacífico muestra una fuerza con capacidad para cuestionarlo y tornarlo inestable. La autosuficiencia del espacio peruano demuestra los precisos rubros de mercadería que México puede ofrecer al mercado: textiles extranjeros y los realizados en sus obrajes. A excepción de los textiles, ningún producto local novohispano es solicitado desde el virreinato andino. 
Una de las columnas que sostienen la "relación de dependencia" es la venta monopólica de textiles finos, la cual vive una verdadera pesadilla que a la vez, merma la salida de metálico peruano por dicho circuito.

¿Qué comentarios se pueden agregar sobre el caso del hierro y la dependencia peruana de la siderurgia española? No se podría discutir que uno de los rubros importados desde España al Perú es el hierro, en barra y manufacturado. El hierro es uno de los pocos artículos que se envían desde España para garantizar la "relación de dependencia" transatlántica. Los testimonios recogidos por Assadourian hablan de la presencia del mineral de hierro en el espacio peruano, aunque su extracción y elaboración, en clara competencia con la producción de plata, es inexistente. Pero debemos recordar aquí el ya citado informe de la Audiencia de Panamá (1607), donde se menciona la llegada de hierro chino al Perú por la vía de Acapulco. ${ }^{174}$ Hay testimonios difusos y poco consistentes que hablan de una importante producción de hierro en China y su exportación hacia México y Perú entre 1580 y 1620. En 1580 los oficiales de la Real Hacienda de Filipinas relatan la llegada a las islas de varios navíos chinos cargados con hierro para llevarlo a los mercados de Hispanoamérica. ${ }^{175}$ En 1626, el gobernador interino de Filipinas, Fernando Silva, comunica de la abundancia de hierro chino y de las grandes posibilidades de enviarlo al Perú. ${ }^{176}$ Un suceso más consistente es lo que ocurrió en 1581, con el navío Nuestra Señora de la Cinta procedente de Filipinas, que arriba al puerto de el Callao. Su registro arroja 400 quintales de hierro chino. ${ }^{177}$ Consideremos con seriedad este cargamento, pues en 1585, en su Historia de las cosas más notables de China, el padre Juan González de Mendoza apunta el frecuente envío desde el espacio asiático hacia el archi-

174 "De la China vienen sedas, lienzos, hierro y otros géneros", "Descripción de Panamá”, [1607] 1908, p. 176.

175 AGI, Filipinas, 29, núm. 33.

176 "Carta de Fernando Silva sobre asuntos de gobierno", AGI, Filipinas, 7, r. 6, núm. 85 .

177 Iwasaki Cauti, 1992, pp. 37-38. 
piélago hispánico de "hierro, acero y mucho azogue". ${ }^{178}$ ¿Qué tan sistemática es esta exportación de azogue desde las Islas Filipinas hacia México? Las fuentes impiden conocer la realidad concreta del fenómeno. El gobernador del archipiélago de 1605, Acuña, anota la escasez de hierro en las islas dada la prohibición del gobierno chino de exportarlo. ${ }^{179}$ Posiblemente, en los primeros años de la emancipación peruana una pequeña porción entra en circulación por el Pacífico, pero habría menguado rápidamente. El caso del hierro, ausente en las investigaciones, requiere un análisis más profundo.

Aun con la imposibilidad de su cuantificación, si se le otorga la debida importancia al canal que moviliza excedentes peruanos hacia la Nueva España (ya sean de la actividad minera o agrícola), lo que en un principio se enuncia como un proceso de "captación de excedente", termina por dilucidarse como la manifestación de un espacio que no sólo busca romper y desprenderse de las imposiciones de sujeción metropolitana sino que, sobre todo, aspira a modelar independientemente un sistema de crecimiento mercantil con otros espacios económicos externos, sobre la base de su economía interna autosuficiente. De todo lo enunciado hasta aquí, estamos en condiciones de retomar una de las principales hipótesis de Assadourian: "Si es indiscutible pensar que el conjunto regional manifiesta una diversificación productiva de gran amplitud, la mesura lleva a calificarla de autosuficiencia desequilibrada, con alto grado de control del exterior. Dicha autonomía no contradice, o sólo genera contradicciones secundarias, con el sistema de dominación metropolitana”. ${ }^{180}$

178 González de Mendoza, 1585, p. 341.

179 "Carta de Acuña al virrey de Nueva España, marqués de Montesclaros", AGI, Filipinas, 29, núm. 83.

180 Assadourian, 1982, p. 144. En varios pasajes de su obra, insiste en que la "autosuficiencia desequilibrada" no hace peligrar el control exterior, la dependencia. Descubre en documentación la presencia de compañías comerciales de mercaderes chilenos en expediciones hacia China y México. Sin embargo: "el hecho de que comerciantes de Santiago participen financieramente en expediciones hacia Tierra Firme, México o China no presupone quebrar la dependencia, ya que siempre se realiza por conducto de gestores o intermediarios limeños", Assadourian, 1982, p. 59. 
La apertura interpretativa de Assadourian obliga a no pensar en ideas determinantes y cerradas. Se muestra consciente de que, "trabajando sobre modelos cerrados" se podría arribar al supuesto de "independencia relativa" del espacio peruano. La autosuficiencia, como estructura en sí misma o en tanto visión analítica aislada, podría concebirse como la expresión más cabal de un espacio económicamente independiente. Pero, para Assadourian, el modelo peruano, que necesita realmente poco de economías externas, cobrará su pleno sentido por el alto control externo generado por la vía de Panamá. Vaya paradoja: el concepto de "autosuficiencia" tiene su razón de ser al estar subordinado desde el exterior; de ahí el calificativo independencia "desequilibrada”. De esta manera, la emancipación económica tiene un techo incuestionable: la innegable "dominación" peninsular en la que se ve contextualizada. ${ }^{181}$ La autosuficiencia económica del Perú es la condición necesaria para que las remesas circulen a través del método fiscal y el comercio oficial por el circuito Lima-Callao-Portobelo-Sevilla. En definitiva, estaríamos en presencia de un modelo de crecimiento peruano alentado desde el centro peninsular, en vista a su canalización del excedente primario: la plata andina. Según esta interpretación, la autosuficiencia se muestra así compatible con el sistema de dominación metropolitana; su emancipación sólo estaría creando "contradicciones secundarias, menores", en las columnas inalterables y primarias que hacen al envío de sus excedentes.

¿La relación peruana con la Nueva España y China sólo crea efectos secundarios, perturbaciones mínimas, que no alteran la relación de dependencia? Si recordamos las advertencias de los manuscritos oficiales y la intensa relación que el espacio peruano supo generar con la Nueva España, aun con la fuerza de la legislación prohibitiva para los contactos intercoloniales, los efectos suscitados en la relación de dominación no parecen, en definitiva, nimios o menores. La autosuficiencia del espacio peruano bien podría adecuarse a las exigencias de la Península por captar

181 Assadourian, 1982, p. 140. 
la corriente del excedente del amplio reino del Perú. Si bien el eje Lima-el Callao-Portobelo se posiciona como el canal de circulación monopólico que refuerza la "dependencia forzosa", la crisis y decadencia del centro de intercambio situado en Portobelo, por varios periodos de esas cuatro décadas (1580-1620), manifiesta no sólo las grietas y debilidades de esa relación de dominación $\mathrm{y}$, ante todo, la canalización del excedente económico peruano por vías alternativas. De allí nuestra enfática atención sobre el otro gran eje comercial que - no de manera única- es alentado y promocionado por los agentes peruanos: Pacífico peruano-Nueva España-Filipinas-China. Sobre la iniciativa que toma el agente peruano en esta economía emancipada trata el próximo y último apartado.

EMANCIPACIÓN Y MOVILIDAD ESPACIAL:

PERULEROS EN LOS MERCADOS GLOBALES

La canalización del excedente en metálico es uno de los elementos para analizar qué tan dependiente o independiente es el espacio peruano con relación a la Península. Pero no es el único parámetro de medición. Resulta incompleto el diagnóstico de una expansión de la economía peruana entre 1580 y por lo menos 1620 sin considerar la movilidad de sus agentes y capitales por los mercados externos. El concepto de emancipación adquiere su pleno sentido cuando vemos que los llamados peruleros logran un fuerte protagonismo en el comercio internacional. Reconocidos como "pasajeros", "factores del Perú", "comisionistas" o simplemente "indianos" los encontramos en las Islas Filipinas, Nueva España, Centroamérica, Sevilla e incluso por otros importantes mercados de Europa. La presencia de los peruleros en el mapa global sin duda demuestra la clara proyección de una economía peruana pujante y la de alcanzar su punto máximo de emancipación, gravitando en mercados distantes.

Los peruleros viajan con capital por los circuitos marítimos para participar en los intercambios por los mercados externos. 
Así como fueron concebidos como mediadores culturales ${ }^{182}$ también se les puede definir como agentes globales, conectando economías distantes con la movilización internacional de sus capitales. Llevan consigo una considerable cantidad de plata para adquirir mercancías de procedencia europea o asiática. El caso de los peruleros manifiesta las dos caras de la misma moneda: por un lado, la cuasiindependencia económica que desde la informalidad asumen los más importantes mercaderes del Perú y de las Indias; por el otro, el cuestionamiento limeño al statu quo imperial, su resistencia para subordinarse a los tiempos, intereses y productos que pasan por la unilateral decisión del cargador español.

La circulación y los viajes de los peruleros van a contramano de los principios estipulados por la disposición española. Como se subrayó al inicio del capítulo, la ley ordena que cada corporación mercantil de la Monarquía se vea beneficiada con el control exclusivo del comercio en su propia jurisdicción. En palabras más precisas: ¿Qué instrucciones ordena la ley mercantil? A los cargadores peninsulares o los llamados galeonistas, la ley peninsular les concede el monopolio del comercio transatlántico y del mercado hispalense para la exportación e importación de bienes y plata con las Indias. El consulado de México, por su parte, obtiene el derecho exclusivo para la redistribución de los bienes y salida de plata en su propio mercado interno. Así, los almaceneros novohispanos son los agentes dominantes para los intercambios realizados en las ferias celebradas en los puertos de Acapulco y Veracruz. Los vecinos de las Islas Filipinas que cuentan con una residencia no menor a ocho años son beneficiados con la repartición de los espacios de carga del galeón de Manila en su rumbo a México. Siempre según la ley, los comerciantes de Lima controla-

182 Rueda Ramírez saca a la luz la participación de los peruleros en el tráfico de libros por la vía transatlántica de España y Panamá entre 1590 y 1620 . Llevan los pedidos de los lectores peruanos hacia Sevilla para adquirirlos por su cuenta ante el librero sevillano. Evidentemente, el rótulo de perulero no se define exclusivamente como un agente exclusivo del terreno económico; es también un verdadero mediador cultural. Rueda Ramírez, 2014, pp. 447-478. 
rían la distribución de bienes por el interior del espacio virreinal y serían responsables, luego de operar en Portobelo, de responder a la demanda de los mercados internos y locales del Perú.

Ahora bien, entre 1580 y 1630 los peruleros se movilizan, superando y violando las rígidas fronteras que impone el monopolio. Sus viajes de larga distancia por el Pacífico y el Atlántico sortean las facultades de exclusividad comercial que la Corona delega a cada corporación mercantil para el manejo de un determinado eje y espacio de comercialización; alteran, modifican y obstruyen el planificado juego entre la oferta y demanda del principio de monopolio. Recordemos aquí un hecho mencionado al inicio del apartado: el estado de abandono de Panamá; ¿la escasez de mercaderes, tiendas y actividad comercial por el istmo no obedecería a la movilidad y residencia de peruleros en otras plazas de recambio? Nos referimos a Filipinas, la Nueva España o en la misma Sevilla.

Gráfica I.6. Movilidad espacial de los peruleros

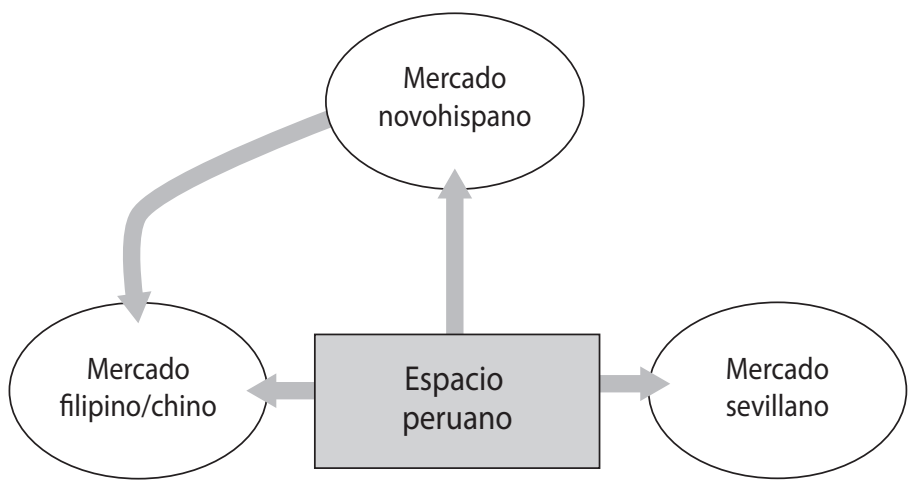

Fuente: Elaboración propia.

La interferencia de los peruleros en mercados externos genera dos grandes alteraciones en los patrones económicos: a) al inyectar la plata que llevan consigo en las distantes plazas de recambio, no hacen más que incrementar los precios de los productos que se ofertan en ellos, provocando que los agentes mercantiles 
que disponen el derecho de monopolizar los intercambios se vean cuestionados e impedidos de concretar sus operaciones. Es decir, el perulero rompe con la regulación de precios a la que aspira el método de monopolio; $b$ ) el consumo como polea de arrastre de la demanda. Si el principio monopólico que promueve el sistema de las flotas y ferias coloca a la oferta por encima del consumo, la movilidad perulera revierte dicho principio, ubicando a la demanda como fuerza de arrastre de la producción y de la oferta de bienes. El régimen de monopolio de flotas se asienta en una economía de escasez en los mercados americanos, de modo que una demanda permanente por encima de la oferta se convierte en medio seguro de maximizar precios y beneficios. En ello coinciden los intereses tanto de los flotistas andaluces como de los almaceneros mexicanos y mayoristas limeños. ${ }^{183} \mathrm{La}$ aparición del capital líquido del perulero en los mercados hace emerger principios cercanos al libre comercio, y opuestos a los del sistema de regulación y exclusivismos que intenta imponer el monopolio comercial de la Corona. Aquél discute el oligopolio de la oferta que usufructúa en exclusividad el sevillano, filipino o novohispano y el carácter estático de la demanda. ${ }^{184}$ Los efectos causados por la movilidad perulera en los mercados externos son inmediatos. Veamos desde el plano fáctico estos postulados.

\section{Eje transatlántico}

La arremetida perulera sobre la ruta transatlántica y hasta el mismo centro neurálgico sevillano es un fenómeno ampliamente reconocido por la historiografía. ${ }^{185}$ Nos valemos de las aportaciones realizadas por estos importantes trabajos con la intención última

183 Bernal, 1992, pp. 223-224 y 298.

184 Este cambio cualitativo que García Fuentes descubre en la ruta transatlántica de los galeones de Tierra Firme es un fenómeno que se podría generalizar en todo espacio donde participa el perulero. García Fuentes, 1997b, pp. 161-162.

185 Los clásicos trabajos sobre el fenómeno son Chaunu, 1955-59; García Fuentes, 1997b; Lorenzo Sanz, 1979; Suárez, 1995. 
de inscribir el fenómeno en el contexto de la emancipación de la economía peruana.

Los desplazamientos marítimos entre Lima y Sevilla, salteando el monopolio de los cargadores españoles, no es un hecho coyuntural sino un elemento estructural de la carrera transatlántica entre 1580 y 1630 . Los peruleros desconocen la relación de "subordinación" con el mercader español porque con disposición de su metálico en Sevilla deciden cuándo movilizar la flota, cuánto y qué tipo de mercaderías enviar al mercado peruano. Ellos logran evadir fácilmente el radio de acción de Portobelo que le ordena la disposición y se inmiscuye de lleno en el comercio transatlántico y en el mercado sevillano y europeo. Evitan cualquier tipo de mediador, fundamentalmente al cargador de flotas sevillano, reduciendo los costos de comercialización de los productos y desconociendo los principios mercantiles que España diagrama para la ruta Sevilla-Tierra Firme. En los mercados europeos consiguen créditos de mercaderes con la promesa de saldarlos en Lima o Portobelo, por lo que la función de plaza central de intercambio en Portobelo con los cargadores peninsulares fue perdiendo su sentido y naturaleza. La presencia perulera en Sevilla genera un efecto tan gravitante que en el primer cuarto del siglo XVII precisan a la Casa de Contratación a despachar una flota cargada con los bienes que ellos mismos compraron, a pesar de la resistencia de los sevillanos. ${ }^{186}$

Los peruleros condicionan el mercado sevillano, algo de extrema gravedad para los intereses de los peninsulares, que pierden la capacidad de controlar la oferta-demanda de bienes $y$, por ende, la balanza de los precios en el mercado peninsular. El perulero no sólo compra bienes en Sevilla (lencería, lana y vino) sino que también invierte sus capitales en la compra de textiles europeos por "el señorío de Vizcaya y otras partes de España, Portugal, Génova y Milán”. El caso del banquero limeño Juan de la Cueva, sacado a la luz por Margarita Suárez, es el más representativo del fenómeno perulero por actuar en varios mercados 
de Europa. Entre 1615 y 1635 el dinero enviado a Sevilla por De la Cueva supera las inversiones hechas en la propia feria de Portobelo: 305032 pesos contra $247890 .^{187}$

Lorenzo Sanz es uno de los primeros historiadores que documenta la aparición en fechas tempranas de los agentes peruleros, ubicándolos desde la segunda mitad del siglo Xvi. ${ }^{188}$ Aunque le debemos al excelente trabajo de García Fuentes la exacta trascendencia que alcanzan estos agentes en la carrera de Tierra Firme entre 1590 y 1620, décadas donde inciden con peso significativo en el mercado español. Atendiendo el peso relativo (\%) de la carga de los galeones en sus viajes hacia Panamá, García Fuentes encuentra que en 1591 el valor de las mercancías que pertenecen a los peruleros es de $56 \%$; en $1605,46 \%$, y en 1615,37 por ciento. ${ }^{189}$ En la década de 1590 se alcanza la cota más alta de peruleros que, al operar en Sevilla: cargan en los galeones una media de 30 peruleros por las cuatro flotas que se envían. García Fuentes logró localizar, entre 1580 y 1620, más de medio millar de ellos en Sevilla (527), el grupo de peruleros logra cargar más de un millón de pesos en valor de mercancías hacia Portobelo. Las cifras son realmente extraordinarias e inéditas en 1624 y 1626, cuando la media de pasajero perulero supera los 73000 y 71000 pesos respectivamente; pero, en 1595, es un poco más de 45000 pesos y, en 1616, 53583 pesos..$^{190}$ Estos datos terminan por demostrar una presencia perulera sistemática y de efectos prolongados en el mercado peninsular de precios y productos.

187 La lista de peruleros que participan en el comercio transatlántico sería extensísima. Remitimos aquí a la lista que García Fuentes ofrece en su libro. García Fuentes, 1997b, p. 167. Para el caso de Juan de la Cueva: Suárez, 1995, pp. 62-65.

188 "En la segunda mitad del siglo Xvi, la flota de Tierra Firme cada vez se ve más abastecida por los propios habitantes de Indias, Se les conoce con el nombre de indianos, pasajeros que vienen a emplear o simplemente peruleros. La mayor parte de ellos eran mercaderes peruanos o peruleros y su número crecía a medida que transcurría el reinado de Felipe II", Lorenzo Sanz, 1979, p. 208.

189 García Fuentes, 1997b, p. 58.

190 García Fuentes, 1997b, pp. 158-159. 
Los datos de García Fuentes ponen en juicio la hipótesis de Chaunu, uno de los primeros en atender la intromisión perulera en suelo sevillano. El historiador francés afirma que en 1607 inician su intromisión en España con letras de cambio y numerario, a raíz del decreto de Felipe III que clausura el comercio desde Perú hacia Nueva España para la adquisición de textiles extranjeros. ${ }^{191}$ La apuesta perulera al comercio transatlántico se explica, según Chaunu, por la clausura legislativa de movilizar sus capitales por el Pacífico. Los registros de García Fuentes dan cuenta, por el contrario, de que la movilización perulera es previa al cierre oficial del mercado novohispano. Nos topamos aquí con una rica discusión historiográfica en torno al momento en que los limeños apuestan a la vía del Pacífico o del Atlántico para invertir sus capitales. Latasa y Fariñas sugieren que los peruleros invierten sus capitales por la vía del Pacífico hasta 1634, año en que los comerciantes sevillanos junto con la Corona logran cerrar de manera absoluta la ruta con México para garantizar los tratos transatlánticos. Por su parte, Ramiro Flores nos dice que los peruleros priorizan el comercio asiático con México entre 1590 y 1610, y a partir de las riquezas obtenidas por esta vía se colocan como competidores exitosos de los sevillanos en la vía transatlántica. Por su parte, Suárez aduce que la ofensiva perulera en el Atlántico y la saturación de bienes que ya registra el mercado peruano en el segundo cuarto del siglo XVII obliga a los propios mercaderes limeños a legitimar (y hasta apoyar) el cierre comercial con México para mantener el control del mercado virreinal. Aquí sostenemos que el perulero actúa de manera simultánea en los mercados del Pacífico y del Atlántico. Esto se podrá confirmar al atender su injerencia por el Pacífico mexicano y las Islas Filipinas de la que enseguida nos ocuparemos. ${ }^{192}$ 
Cuadro I.5. Valor total de los galeones y participación perulera

\begin{tabular}{cccc} 
Año & Valorgaleón & Valor peruleros & Porcentaje \\
\hline 1583 & 2454364 & 57492 & 2.5 \\
1589 & 3720846 & 431547 & 15.8 \\
1591 & 2865277 & 1627410 & 56.7 \\
1594 & 2562049 & 323714 & 20.7 \\
1605 & 1728202 & 807707 & 46.7 \\
1610 & 1383113 & 373850 & 27.0 \\
1612 & 590713 & 110317 & 18.6 \\
1615 & 468090 & 172633 & 36.8 \\
1618 & 644376 & 174622 & 27.0 \\
1619 & 346644 & 27936 & 8.0 \\
\hline
\end{tabular}

Fuente: García Fuentes, 1997b, p. 58.

Gráfica I.7. Valor total de los galeones y participación perulera (en pesos)

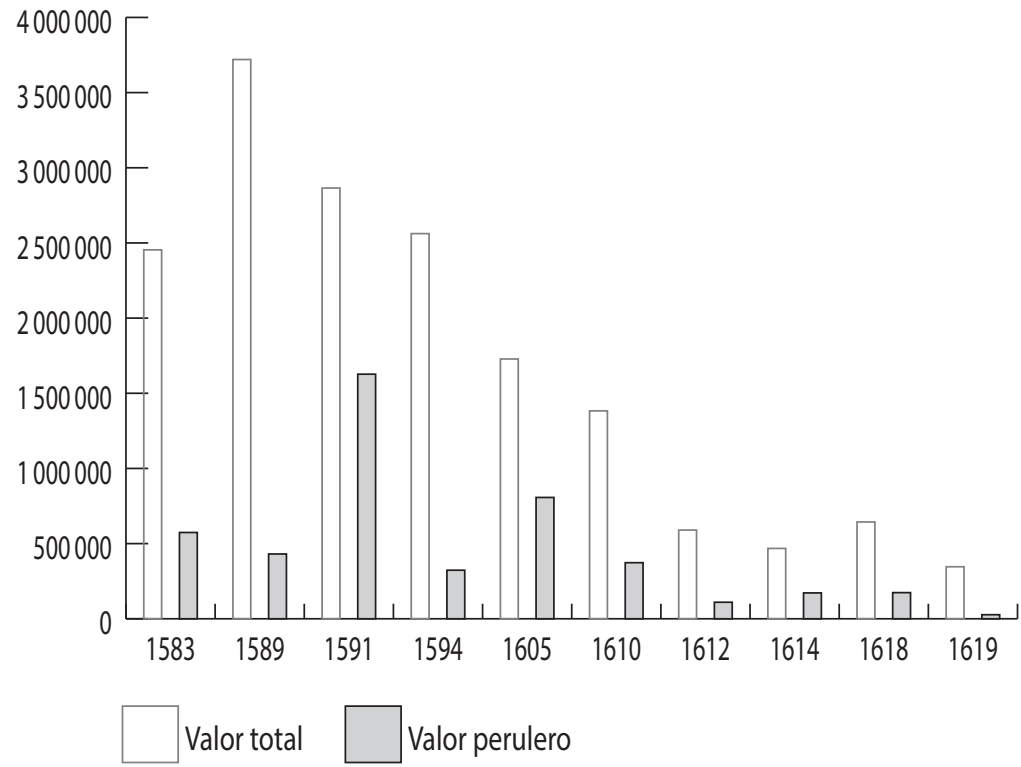

Fuente: Cuadro I.5. 
Ahora bien, atendamos la gráfica I.7 sobre la participación perulera en los galeones y relacionémosla con los datos ofrecidos por la Audiencia de Panamá en 1607 sobre la crisis de los intercambios en Portobelo. Ambas evidencias dan cuenta de que, incluso con cifras realmente elevadas de intercambio por Panamá, el inicio de su decaimiento se inicia en los últimos años del siglo $\mathrm{XVI}$, tendencia que se agudiza ya como crisis, conforme avanzan las primeras décadas del siglo XVII. Entre 1590 y 1600, el comercio peruano, aun con el notable auge de los intercambios que se vive por el frente del Pacífico, mantiene niveles importantes de operatividad comercial por la vía transatlántica.

El desplome comercial obedece tanto al cargador sevillano como a las operaciones de los peruleros. Pero todo indica que la marcada desaceleración en los tratos por Portobelo recae en una mayor responsabilidad de los cargadores españoles que aminoran la participación de los embarques de los galeones. La disminución de peruleros es resultado de una desaceleración de la producción de plata de Potosí y de la decisión de continuar desviando sus capitales comerciales por el eje del Pacífico, a pesar de la legislación prohibitiva. Aún con menor intensidad, la persistencia de los agentes limeños en el eje transatlántico se mantendrá con la consolidación de redes constituidas entre los comerciantes extranjeros instalados en Sevilla, en particular los flamencos. Portobelo termina por ser una pantalla en calidad de centro de intercambios ultramarinos. Las operaciones en plata, bienes, letras de cambio o simplemente al fiado se negocian en otros espacios, como en Lima o en el mercado europeo. En 1612, el reporte de Gallardo de Céspedes, funcionario del Consejo de Hacienda, expresa el escenario de la siguiente manera. Hay "peruleros que vienen a emplear en España":

y esto se tiene por dañoso para el comercio de ella y también para las Indias y aun para las rentas reales de acá y de allá, porque considerando que cada año vienen 4 a 6 mercaderes del Perú y Tierra Firme que llaman peruleros y traen cada uno 150 a 200000 ducados para emplear y compran con este contado otra tanta y aun doblada can- 
tidad fiada a pagar en Portobelo, sólo ellos llevan toda la ropa que es menester para abastecer y llegados a ella, no les falta dinero ni caudal con que pagar lo fiado porque están en su provincia y tienen crédito. ${ }^{193}$

Ciertamente, la calificación de "crisis" de Portobelo puede ser válida si se piensa en los intereses de los cargadores sevillanos o incluso en las arcas reales. La movilización de peruleros esquiva el fisco y emprende el intercambio por vías no oficiales. Sobre este último aspecto, las lógicas de intercambio generadas entre estos últimos y los mercaderes extranjeros provocan que los impuestos al Estado español se vean disminuidos. En el $\mathrm{Me}$ morial de Gallardo de Céspedes, de 1612, se dice que:

este comercio [flota de Portobelo] ya no puede durar ni continuarse sino es por Peruleros o extranjeros que por su trato se han alzado con él, con tanto daño de las cuentas reales hasta que una flota de Tierra Firme que solía valer de derechos de almojarifazgo más de 70 cuentas aquí no llega ya a 20 y así la avería no puede ya continuar los despachos de la armada y flotas, y se puede temer que muy en breve se arruinen todos los tratos y vengan a gran disminución las alcabalas que de ellos resultan porque todo esto esta eslabonado con el consumo y comercio de Indias. ${ }^{194}$

Por su parte, si los cargadores sevillanos hablan de una verdadera tragedia en los intercambios por Portobelo es porque se ven desplazados por los peruleros y por las casas comerciales holandesas ubicadas en la Península. La actividad de la flota de Portobelo, se encuentra condicionada a la acción de los comisionistas del Perú. Con toda la parcialidad que pueda contener la apreciación, el virrey novohispano Velasco reporta, en 1609, que la crisis de Portobelo está asociada a que:

193 Citado en Chaunu, 1955-59, t. Iv, p. 395.

194 Citado en Chaunu, 1955-59, t. IV, p. 463. En 1610, el Consejo de Indias envía una orden en el que "se prohibiese totalmente a los peruleros el poder venir a España a emplear, porque desde que venían se había reconocido atrasamientos [sic] y fraudes en los derechos", en Veitia Linage, 1945, libro II, XVII, 11, p. 517. 
Los mercaderes del Perú envían ahora hombres propios a Sevilla con sus haciendas a emplearlos que de ordinario llevan toda la gruesa de aquel reino con que los de Sevilla ya no cargan para Tierra Firme ni pueden hacer las gruesas ganancias que hacían en años pasados siendo ellos los señores de cuanto se cargaba para aquel reino y esto era lo que tenía rica de dinero y llena de gente a Panamá y como todo esto ha faltado suspiran los unos y los otros por el tiempo pasado con deseo de volverlo a entablar y es imposible. ${ }^{195}$

La presencia de los peruleros por el circuito transatlántico y en el mercado peninsular, ¿explicaría la decisión del consulado sevillano por orientar sus capitales hacia Veracruz? Es posible, al menos el virrey novohispano lo soslaya. De ahí, es sugerente recordar el postulado de la Audiencia de Panamá en 1607, en éste apunta a México como principal centro de importación hispanoamericano de los textiles europeos. Tan influyente es el dominio perulero por la vía de Panamá que los cargadores sevillanos buscan incluso impedir el despacho de su flota al mercado peruano. Así lo dice el Consejo de Indias en 1617.

estándose despachando la flota de Tierra Firme a razón que poco antes había llegado la antecedente y venida en ellos peruleros de gruesos caudales, se resolvió por buen gobierno el prohibirles que no se embarcasen entonces, considerando que sus empleos y cargadores ocasionarían dilación en el despacho y salida de flota, que no puedan quejarse de novedad los peruleros en obligarles a suspender su embarcación. ${ }^{196}$

Incluso en los años en que los peruleros no visitan el mercado hispalense y los mercaderes peninsulares no disponen de suficiente plata del Perú, las flotas enviadas a Portobelo ven reducidos significativamente su tonelaje. En 1619, el Consulado de Sevilla reluce la consciencia que van tomando los mercaderes del

195 AGI, México, 27, núm. 66, f. 4.

196 Veitia y Linage, 1945, libro I, capítulo xxx, p. 319. 
Perú de poder vivir sin depender de los sevillanos. Advierte que "nunca estuvo con tanta gente ni con tanta riqueza en el reino" y que ellos sólo se podían enviar cuatro o cinco navíos y que, aún así, los cargadores estaban en bancarrota. ${ }^{197} \mathrm{La}$ presencia de peruleros en el mercado sevillano se extiende, cuando menos, hasta 1626. En ese año, la Casa de Contratación planea la construcción de una aduana en Portobelo no sólo para registrar los "vinos, aceites, hierro y clavazones" que se defraudan por entonces, sino también por la necesidad de contar los fardos de lencería que se llevan desde España "y que viene de Francia”. Pero la Contratación reconoce que "esto es impracticable respecto de los peruleros que hacen sus fardos surtidos de diferentes géneros conforme a la orden de sus encomenderos" ${ }^{198}$ La cita de la institución pone al descubierto que la movilización de los peruleros en Sevilla hace mutar un patrón comercial del principio de monopolio. Si la carrera monopólica está planeada para que la oferta de bienes se imponga sobre un mercado escaso de mercaderías y de precios altos, los peruleros se ocupan de oponerse al principio de regulación y monopolio, siendo la demanda, es decir, lo que realmente se quiere consumir en el mercado del Perú, el bien demandado en los mercados de Sevilla y Europa.

\section{Pacífico novohispano}

Los protocolos notariales ubicados en el Archivo General de la Nación de Perú nos permiten aproximarnos a la movilidad de los peruleros en su viaje hacia Acapulco y lo que las fuentes denominan "provincias de China y Filipinas". En el cuadro I.6 presentamos a varios de esos agentes limeños que se mueven por esos espacios, así como también los principales comerciantes y autoridades políticas que deciden invertir en el comercio novohispano y transpacífico. 


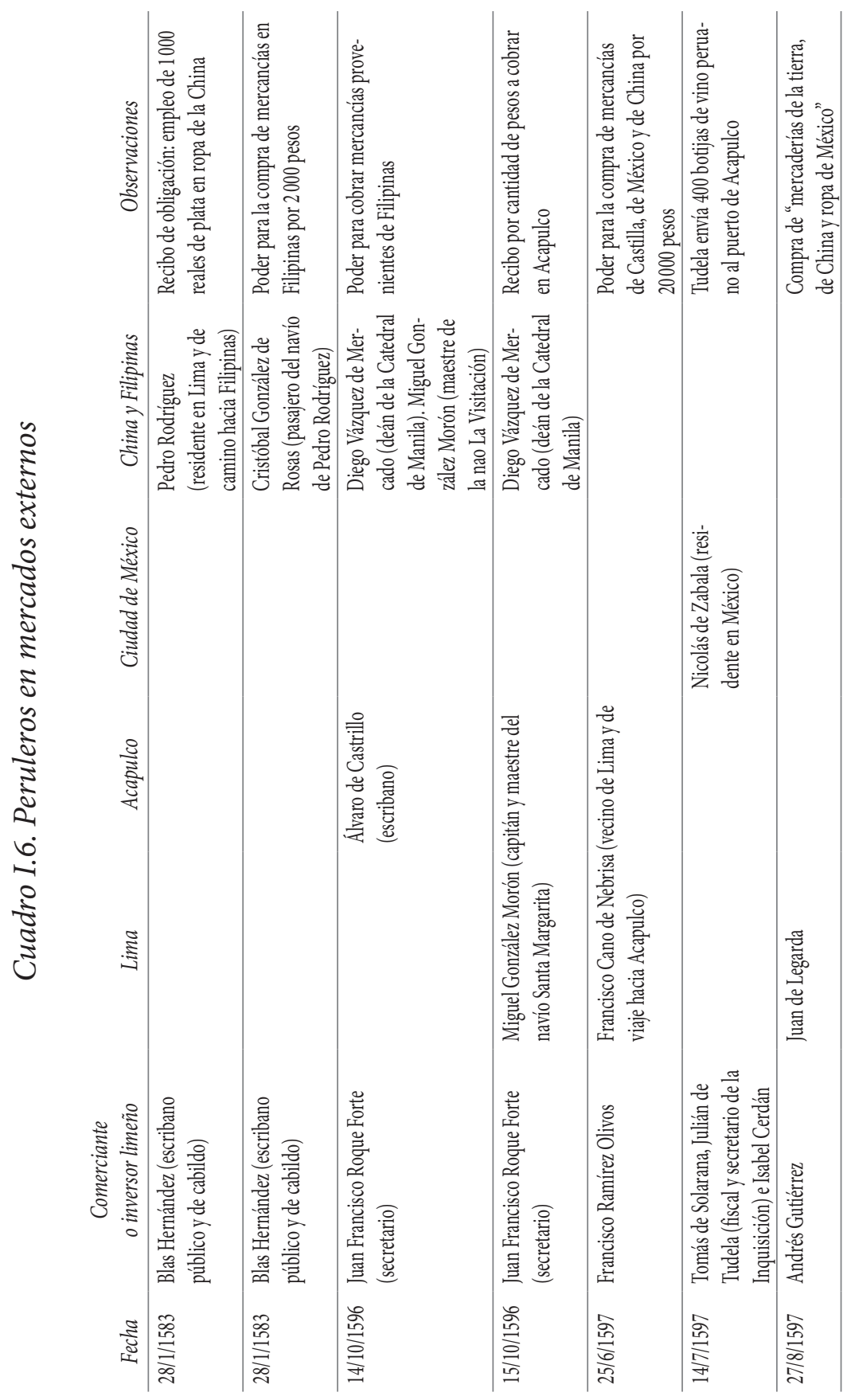




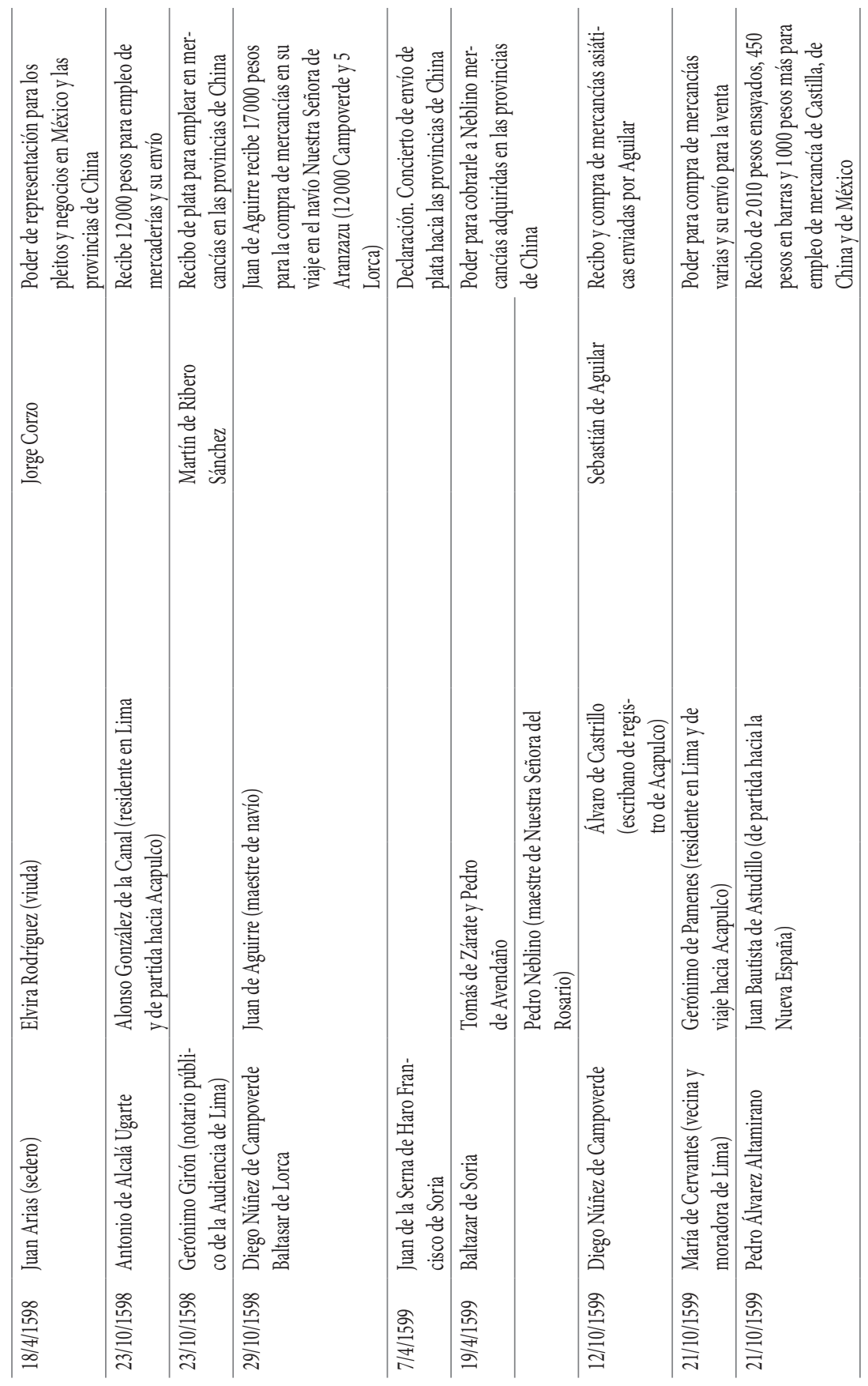




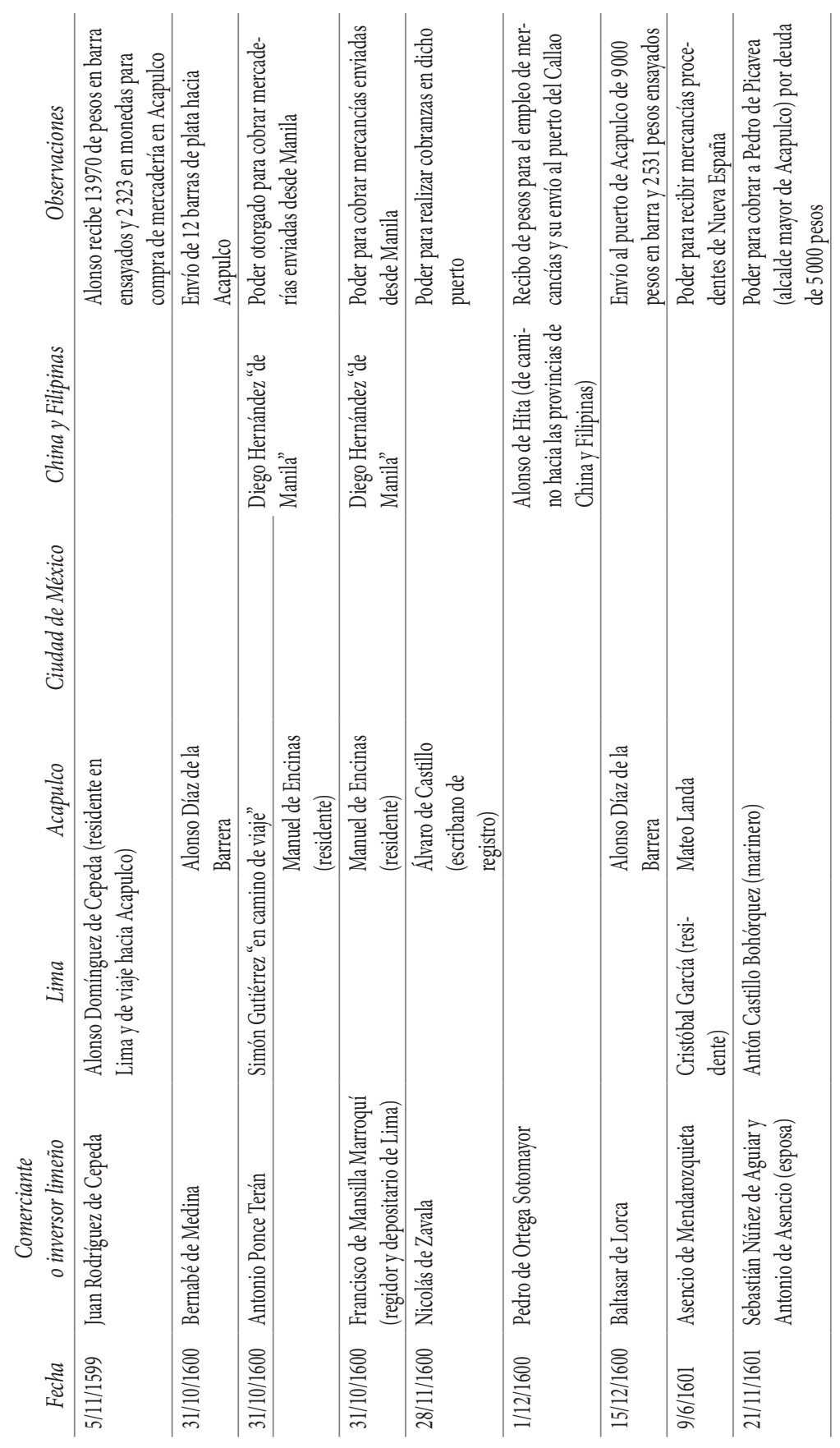




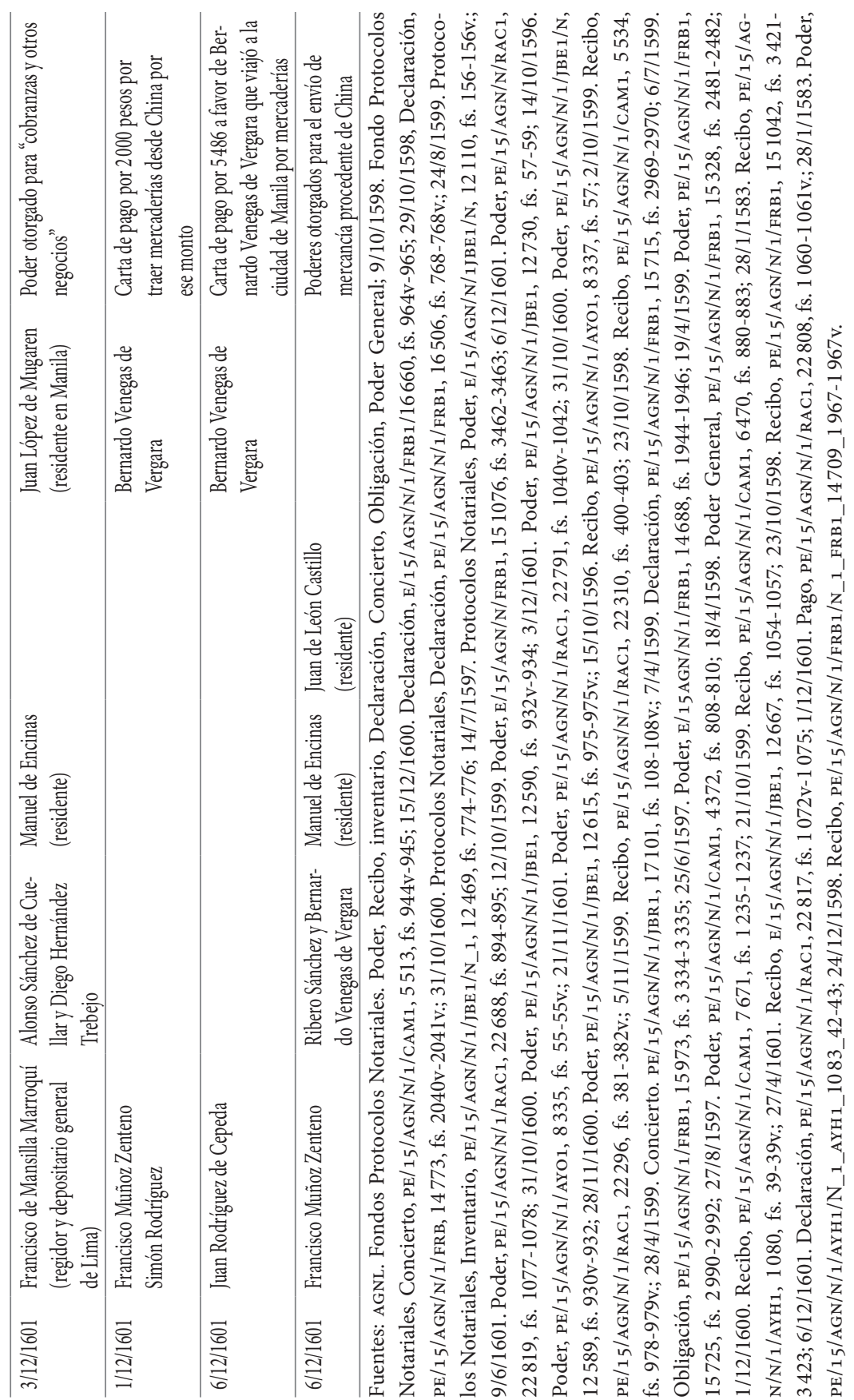


En primer lugar, la intensidad de la movilización perulera por el Pacífico que figura en el cuadro I.7 se ciñe al periodo 1580-1601, cuando aún se encuentra vigente la autorización real para el comercio entre Perú y Acapulco. Nuestro relevamiento documental muestra una clara compatibilidad con las fuentes rastreadas por Ramiro Flores, para quien el auge del comercio con México abarca desde 1590 hasta 1610. ${ }^{199}$ Durante esos veinte años la movilidad alcanza mayor frecuencia que los viajes de los comisionistas y factores limeños hacia el área transatlántica y el mercado hispalense. El sentido común podría explicarlo: el perulero prioriza atender los flujos que presentan menor fiscalización $\mathrm{y}$, sobre todo, de los que obtiene una rentabilidad inmediata $\mathrm{o}$, al menos, en un corto plazo. En gran medida, todos estos atributos se cumplen en el área mercantil del Pacífico.

En segundo lugar, reiteramos que la lista de los interesados y principales accionistas en el comercio con México no se limita a reconocidos comerciantes limeños, también aparecen funcionarios políticos y religiosos. En el cuadro I.6 aparecen el escribano y secretario del Cabildo de Lima, Blas Hernández y Juan Francisco Forte; el fiscal y secretario del Santo Oficio de la Inquisición, Tomás de Solarana y Julián de Tudela; el notario público de la Audiencia de Lima, Gerónimo Girón, y el Regidor de Lima, Francisco de Mansilla. Lo que resulta importante es que los reconocidos mercaderes de la ciudad pueden programar sus negocios ya sea desde su escritorio en Lima o, venturosos, emprendiendo ellos mismos el viaje hacia la Nueva España como un verdadero "perulero". Entre los inversores asentados en Lima sobresale Diego Núñez de Campoverde, un reconocido mercader que incluso llega a invertir su capital en la compra de esclavos asiáticos. ${ }^{200}$ Entre los segundos, más numerosos, aparecen Alonso González de la Canal, Juan de Legarda, Alonso Domínguez de Cepeda, Bernardo Venegas de Vergara, Alonso Sánchez Cuellar y Baltasar

199 Flores, 1995, p. 398.

200 Llega a contar con cuatro esclavos “indios chinos” en su casa de Lima. Para una aproximación a la población asiática durante el periodo: Bonialian, 2015, pp. 205-236. 
de Lorca. Es posible que las ganancias obtenidas en las empresas mercantiles del Pacífico, incluso para Campoverde, consolidasen sus posiciones de poder en el Tribunal del Consulado de Lima (1613). La decisión de los mercaderes de movilizarse por cuenta propia o ampararse en peruleros dignos de su confianza es un fenómeno que confirma el caso analizado por Ramiro Flores. ${ }^{201}$

La otra alternativa ideada por el inversor limeño es confiar y declarar como fiel representante mercantil a los capitanes o maestres de los navíos que hacen el derrotero por el Mar del Sur. Los responsables de las navegaciones hacia y desde Acapulco cumplen así la función perulera de llevar los capitales en metálico para comprar "mercadería china, castellana y de México". Figuran en el cuadro I.6, el capitán y maestre del navío Santa Margarita (1596), Miguel González Morón, que tiene un recibo a nombre del secretario Roque para cobrar saldos mercantiles en Acapulco; el maestre Juan de Aguirre (1598) que lleva hacia el puerto novohispano 12000 pesos pertenecientes a los mercaderes Campoverde y Baltasar de Lorca para invertirlos en la compra de textiles de China, España y México; un poder otorgado por Baltazar de Soria al maestre de la nave Nuestra Señora del Rosario, Pedro Neblino (1599), quien dispone de mercancía procedente de China.

Además, están los agentes que viajan encubiertos como simples marineros en las embarcaciones, permitiendo la movilización de la encomienda de los comerciantes limeños. Muchos de los "vecinos de Lima" que aparecen en el listado acompañando la frase "de partida" o "de viaje" hacia Acapulco forman parte del cuerpo de tripulación de las naves. Si el poderoso mercader limeño le otorga un poder al maestre, éste celebra a su vez un nuevo poder con los marineros. En 1598 se celebra un contrato entre el maestre de navío de Nuestra Señora de Aranzazu, Juan de Aguirre, con un marinero de la nave llamado Francisco Jorge para que descargue mercancías en Acapulco. Un caso muy peculiar que no

201 Flores también descubre la movilización de reconocidos mercaderes limeños como Gerónimo Justo de Porras, Gabriel Recio de Castilla, Francisco de Ibarraíncua, Juan Bautista Crespo y Jácome de Quesada. Flores, 1995, pp. 400-407. 
integramos al cuadro I. 6 es el contrato celebrado el 28 de abril de 1599 entre Juan de la Isla, maestre del navío Nuestra Señora de Asunción con Alonso Bombón y Agustín Manila, "indios marineros de la China”, para participar de la tripulación del viaje hacia el puerto del Realejo. ${ }^{202}$ ¿Caso excepcional? No lo sabemos. Puede suponerse que muchos "indios chinos" llegados al Perú durante esas décadas, sean en calidad de esclavos o libres, se involucraron en la actividad de la marinería y como factores de los grandes mercaderes del Perú.

Panamá, Centroamérica, México y las Islas Filipinas conforman un gran espacio visitado por los peruleros, ya sea en estancias prolongadas o breves. El caso de Manuel de Encinas registrado para los años 1600 y 1601 parece ser la clásica vida del perulero: cargador de plata, opera casi exclusivamente en Acapulco por un tiempo relativamente prolongado y responde a los intereses de los grandes mercaderes limeños. Encinas participa en la feria de Acapulco al momento de la llegada del galeón de Manila, o celebra contratos mercantiles con los mercaderes de la Ciudad de México; es el mediador entre el novohispano y el gran comerciante limeño. Hay otros casos de peruleros que asumen una práctica más arriesgada: internarse tierra adentro del virreinato novohispano, como los casos Nicolás Zavala (1597), Jorge Cozo (1598) o Juan de León Castillo (1601). Así como hemos visto que los viajes de los peruleros por el Atlántico generan flancos de conflictos con el cargador sevillano, la presencia peruana en los puertos del $\mathrm{Pa}$ cífico novohispano puede ocasionar serios problemas económicos al mercader mexicano. El perulero será bienvenido siempre y cuando no se adentre "tierra adentro" del virreinato, buscando cuestionar el monopolio y la circulación de bienes que detenta el gran comerciante de la Ciudad de México. No podemos saber con precisión si el problema fue recurrente y grave o sólo transitan la advertencia: lo cierto es que los comerciantes, como los funcionarios políticos, se muestran atentos de que la presencia perulera no altere la posición ventajosa novohispana para negociar con

202 AGNL, Protocolos Notariales, FRB 1, vol. 15, exp. 973, fs. 334-335. 
el cargador español. Por ejemplo, en 1625, el virrey novohispano marqués de Cerralvo obliga a Juan Bautista Espíndola, natural de Génova y vecino del Perú a pagar una fianza por ser extranjero y estar residiendo por tiempo indeterminado en Acapulco, realizando intercambios sin autorización. ${ }^{203}$

El relevamiento documental (cuadro I.6) manifiesta una brusca desaparición de la actividad del perulero hacia 1601. Es evidente que las estipulaciones prohibitivas que comienzan a cobrar fuerza en los primeros años del siglo XVII tienen efectos, pero de ninguna manera logran hacer desaparecer la presencia perulera en el occidente novohispano. A partir de 1604, se los puede ver en otros puertos menores como Huatulco, Zacatula o Zihuatanejo, realizando intercambios de manera clandestina con mercaderes locales. Reyes García descubrió que en 1610 llegan a la costa de Acapulco y Zacatula las naves peruleras Nuestra Señora de la Candelaria y Nuestra Señora de los Remedios procedentes del puerto del Callao. Los navíos presentan una numerosa tripulación de agentes y comisionistas limeños con cargas importantes de metálico (oro y plata). ${ }^{204}$ Sobresale el maestre y capitán de Diego de Simancas, quien comanda numerosos navíos en años sucesivos, convirtiéndose en uno de los peruleros más reconocidos en la movilización de las fortunas de las casas comerciales limeñas. ${ }^{205}$ Las autoridades portuarias logran sancionar a la tripulación y decomisan gran parte de la plata y efectos. Pero no hay duda de que el caso representa uno de tantos de navíos peruleros que terminan, por el contrario, con mayor fortuna. Decíamos que la presencia y movilización perulera se mantiene hasta la tercera década del siglo XVII. En noviembre de 1629, al momento en que se despacha el navío de permiso a México (barco que hasta 1634 estará permitido) que "no es más de 200000 duros de Castilla, por cosa muy sabida hay 70 cargadores contados que pretenden ir a emplear a México". ${ }^{206}$

203 AGN, Gobierno Virreinal, Reales cédulas originales y duplicados, vol. D50, exp. 213, f. 126.

204 Reyes García, 2015, pp. 113-121.

205 Flores, 1995, pp. 400-407.

206 Suardo, [1629-1639] 1936, p. 36. 
En momentos de apogeo de la economía peruana, la presencia perulera en el occidente novohispano es, para el cargador español de flotas, tan importante como la del almacenero novohispano. Los peruleros con disposición de metálico en las costas occidentales novohispanas no hacen más que incrementar la demanda y subir los precios de las mercaderías que trae el español. No resulta extraño ver el escenario opuesto en 1609, momentos en que la movilidad perulera hacia Acapulco ya se encontraba prohibida. En ese año, los comerciantes sevillanos que invierten en la flota capitaneada por Gutiérrez Garibay se lamentan que "estando cerrada la puerta de Acapulco por el Perú por donde había mucho consumo las ventas serían muy inferiores a lo común". ${ }^{207}$

\section{China y las Islas Filipinas}

La emancipación peruana por los mercados globales también se manifiesta con lo que las fuentes llaman "peruleros en las provincias de China y Filipinas". Antonio de Morga, en calidad de gobernador de Filipinas en 1609, subraya el fenómeno: "los hombres de negocios del Perú tratan y contratan en Filipinas por medio de sus encomenderos y factores". ${ }^{208}$ El cuadro I.6 confirma la presencia de los peruleros por tierras orientales. Ya desde los primeros años de la década del 80 del siglo XVI, llegan peruleros a Filipinas como Pedro Rodríguez y Cristóbal González de Rosas (1583), entre otros. Registramos en 1598 a un tal Marín de Ribero Sánchez que cuenta con un recibo del notario de la Audiencia de Lima para invertir metálico en la compra de mercancías asiáticas. Hacia 1600 otro perulero con actividad considerable en el archipiélago es Diego Hernández "de Manila”; comisionista y factor de Antonio Ponce Terán y del Regidor de Lima Mansilla Marroquí. Alonso de Hita, un residente en Lima, viaja en ese año hacia el Oriente. Suponemos que lo hace a través de la ruta con escala en 
Acapulco porque los viajes directos entre Perú y Filipinas sólo se logran concretar en el último cuarto del siglo XVI. Hacia 1601, encontramos dos casos más: el de Juan López de Mugaren, perulero con residencia en las islas, y el del conocido comerciante limeño Bernardo Venegas de Vergara, que por su propia cuenta viaja a Filipinas para intercambiar su plata por mercancías asiáticas.

La carta que envía al Rey hacia 1601 el gobernador de Filipinas, Francisco Tello, resulta una suerte de "caja de pandora" para inscribir la actuación de los peruleros en las islas. Informa la carta que, a pesar de que el derecho imperial insta que las mercancías traídas por los chinos en sus juncos deben ser adquiridas sólo por los vecinos residentes en las islas, "compran ahora la mayor los peruleros que pasan a ellas a emplear con cantidad de dineros". La entrada de peruleros al archipiélago oriental es posible por dos vías o mecanismos: a) con autorización y beneplácito de los virreyes de la Nueva España y $b$ ) con "plazas de marineros sin serlo a fin de hacer su empleo y volver a su plaza y otra parte emplean". Nuevamente, al igual que en el caso de peruleros en Nueva España, son los maestres de navíos u oficiales mayores de los galeones de Manila los que "llevan mucha suma de plata y de encomiendas de personas de México y los que contratan a peruleros". Tanto factores o comisionistas de la Nueva España o del Perú son los que: "compran a los vecinos de las dichas islas parte del repartimiento que se les da por premio de sus servicios por mandado de su majestad. Y cargan ellos mismos y así vienen ahora peruleros y mexicanos este aprovechamiento". ${ }^{209}$

El repartimiento de mercancías en el galeón termina en manos de los peruleros "que viven en cierto tiempo vecindad en estas islas", pero siendo "que esta gente no es la que esta tierra ha menester porque ninguno es casado y no guardan más de cumplir su vecindad y aún muchos vuelven sin ser vistos antes de cumplirla". Francisco Tello saca a la luz que son los virreyes de la Nueva España y no los gobernadores de Filipinas los que en la

209 "Capítulo carta de Tello, gobernador de Filipinas, sobre licencias a peruleros", 6-7-1601, AGI, Filipinas, 6 r. 9, núm. 178, fs. 1. 
práctica deciden quiénes tienen acceso a los espacios del galeón: el perulero es uno de los beneficiados." 110

Más evidencia de peruleros en Filipinas: con probable fecha de 1602 aparece un documento titulado "Puntos de lo que tiene suplicado las Islas Filipinas, sobre la contratación de ellas". El mencionado obispo Martín Ignacio de Loyola, junto con su colega de Nueva Segovia que no sabemos su nombre, parecen ser los autores del breve informe presentado al Consejo de Indias. ${ }^{211} \mathrm{De}$ los cinco puntos que contiene, el tercero dice:

Que se mande al virrey de Nueva España, no de licencia para que pasen mercaderes del Perú a las islas Filipinas, con nombre de que se van avecindar a ellas, por el daño que en ello reciben las islas, por traer como traen gran suma de dinero, suyo y ajeno, y de compañías, y sólo vienen a emplearlo y volverse y con esto se suben las mercaderías más del 50 por 100 . Y habiendo empleado: los generales y cabos porque se lo pagan les vuelven a llevar a Nueva España, sin que se pueda remediar. Los obispos dicen que conviene no pasen, sino es para avecindarse de todo punto. ${ }^{212}$

Resulta notable el universo social que viaja cada año en los galeones de la ruta transpacífica. Por ejemplo: en el año 1610 se embarcan más de 600 personas en las naos capitana y almiranta en la ruta Acapulco-Filipinas. El ejemplo, que parecería algo rutinario, no puede soslayar el notable número de la tripulación que anualmente se moviliza en el eje transpacífico. El contingente está compuesto por los llamados oficiales "galeotes", soldados, forzados, gente de mar, marineros, arzobispos y religiosos. ${ }^{213} \mathrm{De}$

210 "Capítulo carta de Tello, gobernador de Filipinas, sobre licencias a peruleros", 6-7-1601, AGI, Filipinas, 6 r. 9, núm. 178, f. 2.

211 Informe impreso de Alonso Fernández de Castro [relator del Consejo]: "Puntos de lo que tienen suplicado las Islas Filipinas sobre la contratación de ellas", (fecha probable 1602) AGI, Filipinas 35, núm. 47, fs. 832-833.

212 AGI, Filipinas 35, núm. 4, f. 833.

213 El 25 de marzo de 1610 sale desde Acapulco la nao capitana con 197 soldados, oficiales y forzados, 130 gentes de mar y marineros, y 99 como arzobispos o religiosos. 
acuerdo a las citas anteriores, en este universo social marítimo se encuentran "disfrazados" de alguno de estos oficios identificados, los peruleros.

La última cita evidencia los notables efectos que ocasiona la presencia perulera en las plazas mercantiles. La subida de precios de las mercaderías orientales, dada la presencia de capital perulero en Filipinas, termina constituyéndose en un patrón común, reiterado, en cada uno de los espacios mercantiles que visitan. ${ }^{214}$ Lo vimos en el mercado hispalense, también en México y ahora en Filipinas. Es notable la visión global del obispo Martín Ignacio de Loyola a la hora de ubicar la contratación asiática como un elemento fundamental del quiebre de la "subordinación” del reino del Perú con relación a España. Antes de llegar a ser obispo de la Gobernación de Buenos Aires, Loyola vivió en el puerto de Cantón para llevar a cabo la política de conversión cristiana de los chinos. Allí fue nombrado hacia 1585 como primer custodio de la orden de franciscanos y atendió con interés el intercambio comercial realizado por el eje transpacífico. ${ }^{215} \mathrm{De}$ hecho, navegó a través del galeón de Manila para llegar a China. Como testigo ocular de los hechos que se vivían en el galeón, Loyola adoptó para el caso de los peruleros en Filipinas una posición muy vanguardista. Propone en 1602 la creación de un Consulado de Manila como corporación para frenar el ingreso de peruleros y mexicanos con su plata. Recordemos que tal corporación se fundará recién hacia 1769.

Esta nave traslada un total de 426 pasajeros. Por su parte, la almiranta lleva 71 de aquella primera categoría, 92 en la segunda y 27 en la tercera. Número total de pasajeros: 616 . "Carta del virrey Luis de Velasco, el joven”, 25-3-1610, AGI, México, 28, núm. 2, fs. 70-71.

214 En el clásico libro de Schurz se advierte de la presencia perulera en las Islas Filipinas, la cual genera la subida de los precios en los bienes orientales. El autor ubica la participación perulera en cierta competencia con el mercader novohispano y bien recibido por el manilense. Aquí proponemos una visión casi opuesta: resistencia de los filipinos por ser desplazados de los derechos de carga del galeón y en alianza con los novohispanos, al ser quienes permiten al peruano realizar el derrotero transpacífico. Schurz, [1939]1992, pp. 134-151.

215 Tellechea, 1989. 
El remedio propio que tengo consiste en que se haga un consulado en Manila y que allí se proveen los oficiales, y allí se señale a cada vecino de las islas las toneladas de ropa que han de embarcar, con cuanto se pondrá el remedio total a este mal y los de las islas por su bien propio y por su interés procurarán tratar ellos solos y estorbar que no traten ni envíen plata los de México ni Perú. El tratar de enviar su plata los de México y del Perú a las Filipinas en gran detrimento de los vecinos de ellas, [...] que como los mexicanos y peruleros envían tanta plata ha subido el precio de las sedas y mercaderías de la China de tal suerte que han aumentado a mil por ciento las mercaderías, con harto de las filipinas. ${ }^{216}$

Con una presencia breve y esporádica, los peruleros inyectan de monedas de plata el mercado del Oriente. Hacen subir los precios de las mercaderías que se ofertan y desplazan al vecino filipino que cuenta con el derecho exclusivo para participar en el intercambio.

El caso más resonante sean los viajes entre Perú y el Oriente del comerciante limeño Juan de Mendoza. En 1583, Mendoza se embarca en el navío Nuestra Señora de la Cinta rumbo a Filipinas. Según el estudio de Iwasaki Cauti, Juan de Mendoza recorre durante un año, junto con otro grupo de factores limeños, el archipiélago oriental, Cantón, Macao y otros puertos de China. ${ }^{217}$ El navío Cinta había partido dos años antes desde Manila. El registro que se le realiza en el puerto filipino en 1581 supone que los factores que viajan hacia Lima con mercadería china son peruleros que responden a reconocidos comerciantes limeños. Llevan un gran caudal de plata con el objetivo de adquirir mercadería asiática para el mercado peruano (cuadro I.7).

216 AGI, Filipinas, 35, núm. 47, fs. 823-825. Véase apéndice documental, capítulo I documento I.

217 Producto de su derrotero, Juan de Mendoza, nos deja su diario Relación del viaje que hizo don Juan de Mendoza desde la ciudad de Lima del Perú a la Manila de las Filipinas y a la China. Iwasaki Cauti, 1992, pp. 70-85. 


\section{Cuadro I.7. Navío Nuestra Señora de la Cinta. Viaje de las Islas Filipinas a Lima en 1581}

Cargador en Manila

\begin{tabular}{ll}
\hline Juan Pacheco Maldonado (regidor) & Diego Núñez de Figueroa (regidor) \\
Álvaro de Medina (alguacil) & Hernando de Medina (vecino) \\
Cristóbal Santos (alguacil) & Blas Hernández (escribano del \\
& Cabildo) \\
Blas Hernández (piloto) & Garci Jaime de Flandes (mercader) \\
Pedro de la Parrilla (vecino) & Francisco de la Hoz (mercader) \\
Salvador de Aldave (tesorero) & Martín de Rivera (vecino) \\
Juan de Ozina (piloto) & Licenciado Recalde (oidor de Lima) \\
Gabriel de la Cruz (vicario) & Domingo de Azpitia (vecino) \\
Diego Ronquillo (maestre de campo) & Pedro Mercado de Peñaloza (vecino) \\
\hline
\end{tabular}

La presencia perulera en las Islas Filipinas se extiende hasta 1633, año que se avecindan "vecinos de Nueva España y Perú" con un capital estimado entre los tres y los cuatro millones de pesos para comprar mercadería asiática. La referencia corresponde al alférez Jerónimo de Fuentes Cortés que sugiere, al igual que décadas atrás lo hacía el gobernador Tello, que los vecinos de las Islas Filipinas sean facultados con el derecho real al repartimiento de carga del galeón y no el perulero y el novohispano como ocurría desde finales del siglo anterior. ${ }^{218}$ 



\section{NUEVA ESPAÑA Y LA SEGUNDA \\ PACIFICACIÓN DEL ATLÁNTICO, 1680-1740*}

Hemos visto que entre los años 1580 a 1620 la economía marítima del Pacífico impone su fuerza y gravita decisivamente sobre el Atlántico. Es el primer momento donde el Atlántico sufre su pacificación. Veíamos que el Perú, con su notable producción y circulación de la plata potosina, aparecía como el motor de aquel mundo económico occidental, funcionando con gran cuota de autonomía e independencia comercial con relación a España. La presente comunicación reconoce un similar fenómeno para un periodo posterior. En este caso se valora la trascendente función que tiene México como principal centro de acopio y espacio redistributivo de bienes extranjeros por toda Hispanoamérica. Dicha función novohispana, aun con un significativo retroceso de la producción y circulación de plata peruana por el Pacífico, tiene la fuerza para reimpulsar la contratación asiática y de efectos europeos entre México y Perú, recondicionando la economía atlántica peninsular entre 1680 y 1740 . Como lo expresa el título de este segundo capítulo, sería la "segunda pacificación del Atlántico".

Si en el primer ciclo la economía peruana impulsa la gravitación del Pacífico sobre el Atlántico (1580-1620), en el segundo (1680-1740) la iniciativa recae en el espacio novohispano, particularmente en la poderosa corporación del Tribunal del Consulado de la Ciudad de México. El inicio del crecimiento de la producción de plata, un sólido sistema de finanzas; el aumento del tráfico

* El presente capítulo representa una revisión y ampliación del ensayo "México: epicentro semiinformal del comercio hispanoamericano, 1680-1740", publicado en 2011 en la revista América Latina en la Historia Económica (ALHE), núm. 35, pp. 1-35. 
comercial internacional como regional, y el fortalecimiento de una oligarquía criolla cuyos intereses se encuentran distanciados de los de la Península son algunas de las características fundamentales de una Nueva España con gran autonomía económica con relación a la Monarquía ibérica. El responsable de ese escenario es el Consulado de la Ciudad de México, que centraliza el movimiento de bienes y plata por el Virreinato y, al mismo tiempo, extrae el máximo provecho de la política económica monopólica. ${ }^{1}$

¿Cuáles son las razones del renovado impulso por el área del Pacífico? Gran parte de la responsabilidad recae en China y en la necesidad de su economía por monetizarse. Entre 1540 y 1640, Japón se erige en el principal proveedor de plata a China, pero para mediados del siglo XviI el gobierno japonés se ve obligado a poner un alto a las exportaciones de plata porque las minas locales se encuentran prácticamente agotadas. Hasta entonces China era una suerte de esponja del metal nipón. El cierre hacia el exterior de la plata nipona aumenta la necesidad del imperio celeste por la plata americana, ya sea la que ingresa por el frente de los circuitos euroasiáticos, como de los transpacíficos. ${ }^{2}$ La medida del gobierno japonés no vino más que a redoblar el interés asiático por las monedas de plata de Nueva España, lo que se traduce en mayores importaciones de sedas y tejidos orientales por el puerto de Acapulco. La plata americana y la seda china que se mueven por el Pacífico requieren observaciones particulares.

Plata amonedada. ¿Cómo comprender el fenómeno de revitalización del comercio por el Mar del Sur y el transpacífico en un periodo en el que la producción de plata por el Perú se encuentra en una situación crítica, en los niveles mínimos de todo el perio-

1 Ante el notable poder económico de la Nueva España, algunos estudios revisan de manera crítica la tradicional periodización de un "reformismo borbónico" que se inicia en la segunda mitad del siglo xviII. Se propone, por el contrario, que la "primera acometida borbónica" sobre el virreinato comienza a principios de la centuria, Escamilla, 2011. Por su parte, el denominado “autogobierno" de la Nueva España con respecto a la Corona es una gran problemática que supera los marcos del presente ensayo. Para un acercamiento sobre el protagonismo de los grandes comerciantes de la Ciudad de México, véase la clásica obra de Hoberman, 1991.

2 Prakash, 2001, pp. 59-76. 
do colonial? En la gráfica II.4 que aparece al final de este capítulo se logra visualizar claramente que desde 1640 la minería del Perú ingresa en un ciclo de constante descenso en su producción del que logrará salir a flote apenas en la segunda mitad del siglo XVIII, aunque sin llegar a los niveles registrados en su periodo de auge (1580-1640). ${ }^{3}$ Un hecho representativo: en la primera década del siglo XVII, sólo el Cerro Rico de Potosí produjo más de 72000000 de pesos; entre 1711 y 1720 la producción del Perú alcanza tan sólo el tercio de aquella cifra $(27000000){ }^{4}$

\section{Gráfica II.1. Producción de plata en la Nueva España (en millones de 292 maravedies)}

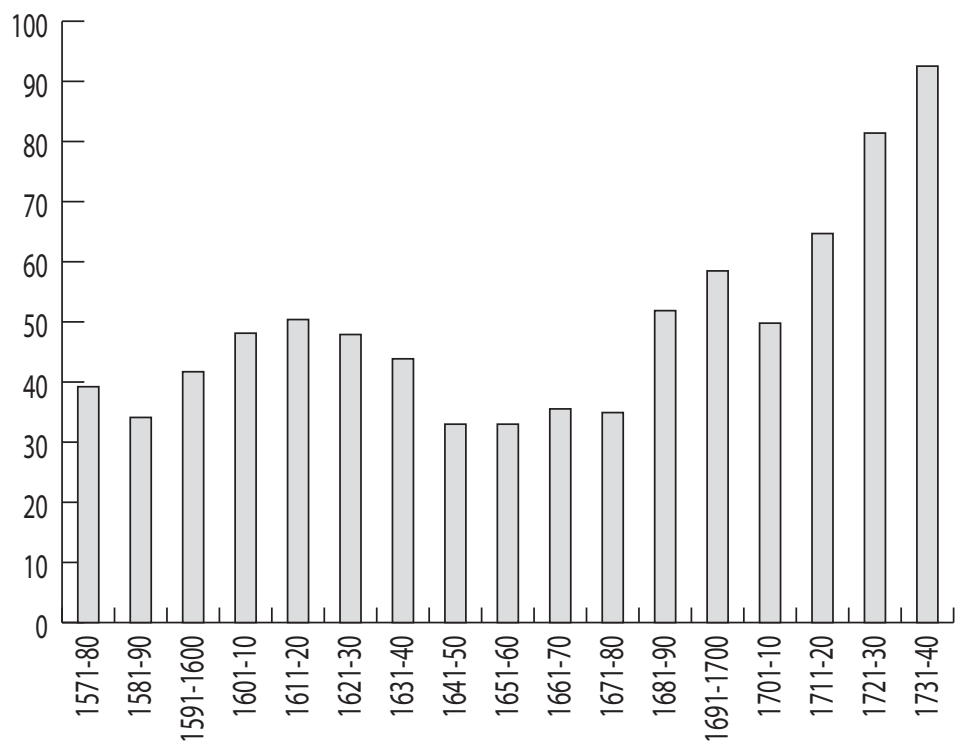

Fuente: TePaske y Brown, 2010, p. 112.

${ }^{3}$ ¿Cuáles son las razones de la estrepitosa declinación? El anegamiento de las labores en las minas, el insuficiente abasto de azogue de Huancavelica a los centros productores de plata del Perú y la escasez y el encarecimiento de la mano de obra indígena, dada su caída demográfica, aparecen como los factores centrales de la merma en la producción de plata. Contreras, 1999, pp. 13-18.

${ }^{4}$ Por ejemplo, en la década 1671-1680 Zacatecas produce más de 21000000 de pesos, un poco menos de la mitad de toda la plata en Nueva España (51 870000 pesos). TePaske y Brown, 2010, pp. 112-114. 
Las gráficas II.1 y II.4 reflejan, a la vez, que desde 1670 se inicia un crecimiento sostenido de la producción de plata en la Nueva España, en especial del centro minero de Zacatecas. ${ }^{5}$ Desde entonces, Nueva España comienza a desplazar al Perú como principal productor de plata en Hispanoamérica. Estamos en presencia del primer ciclo de crecimiento de la minería novohispana que antecede al boom de la segunda mitad del siglo XviII y principios del XIX, cuando México se convierte en el principal productor de plata a nivel mundial. A diferencia del primer periodo (15801640), la plata novohispana tomará desde 1670 un claro predominio con respecto a la peruana en los embarques de los galeones de Manila.

El virreinato del Perú ofrecerá en los puertos del Pacífico novohispano el cacao que produce Guayaquil como principal medio de cambio para saldar sus compras de los bienes chinos y europeos. En este segundo periodo, el cacao de Guayaquil se alza como el principal excedente mercantil que sale desde el espacio del Perú rumbo a México, superando incluso a la plata, al azogue y a los vinos. Se ha reconocido que el fruto guayaquileño se erigió como unidad de cambio en el mercado mexicano desde la segunda mitad del siglo XvIII, momento en que se legaliza su comercio. ${ }^{6}$ Sin embargo, todo indica que su función como valor de cambio viene desde antes. Lo enunciado no supone pensar en la inexistencia de flujos de plata desde el Perú hacia Nueva España. Seguirá fluyendo, pero en menores proporciones con relación al primer periodo. De momento, anticipemos la comprometida situación para el comercio transatlántico. Si hay una crisis minera peruana y una parte de la poca plata existente se destina a la compra de seda asiática y textiles europeos hacia el Pacífico novohispano, el galeón español procedente de Portobelo perderá interés en las ferias atlánticas, pues vaticina un fracaso de sus intercambios. Si la escuadra española se ausenta en el istmo, los agentes del Perú tendrán que acudir a México para adquirir tex-

5 Bakewell, 1976, pp. 259-312.

6 Valle Pavón, 2010, pp. 181-206. 
tiles europeos y asiáticos. El círculo parece cerrarse con nefastos resultados al comercio transatlántico español.

Seda asiática. El reimpulso del eje transpacífico también se explica por la necesidad de disponer de seda, ya sea elaborada o bruta, en los mercados de la Nueva España y del Perú. Si bien a finales del siglo XVI, la Corona hispánica establece algunas estrategias para limitar la cría del gusano de seda en la Nueva España, un siglo más tarde, concretamente en el año 1679, refuerza la medida, ordenando arrasar las plantaciones de morera en el virreinato. El propósito inmediato de la legislación es la venta y consumo de la seda peninsular granadina, alpujareña, murciana y levantina y de los centro de producción de Toledo y Sevilla en el mercado indiano; algo que, en cierta medida, parece haber sucedido. Pero un efecto más profundo y paradójico termina generando la prohibición: redobla el interés de la Nueva España, de Centroamérica y del Perú por la seda asiática. No resulta raro que el comercio de importación por Acapulco a través del galeón de Manila registre un aumento exponencial de las piezas ingresadas de China y Filipinas. Por lo menos desde 1690, vemos a mercaderes mexicanos y peruanos viajando en la nao de China con ejemplares de tejidos europeos y castellanos para que los tejedores asiáticos copiaran sus diseños y los despachen hacia Acapulco. En el caso de la ropa confeccionada que viene de China, tiene necesariamente que familiarizarse, habituarse a los patrones de consumo y uso de las familias hispanoamericanas. ${ }^{7}$

\section{MÉXICO: “CORAZÓN" DE LA ECONOMÍA MARÍtIMA DE LA MONARQUía}

Entre 1680 y 1740, el nuevo crecimiento de la economía marítima del Pacífico con epicentro en México renueva un modelo comercial, alternativo al oficial. Lo caracterizamos en su momento como modelo semiinformal porque en él existen y se articulan

7 Álvarez de Abreu, [1736] 1977, t. II, pp. 328-335; Pérez Herrero, 1983, p. 109. 
flujos tanto legales como ilícitos. ¿Cómo opera el esquema? Nos atrevemos a presentarlo de manera esquemática, reconociendo la complejidad que presenta cada fenómeno que lo compone. México se posiciona en el centro de la red; hacia él confluyen los tres circuitos que hacen al esqueleto del tejido. Dos son reconocidos legalmente por España y otro funciona de manera ilícita. Uno de los flujos oficiales e interoceánicos es el de la flota Atlántica, que conecta a España con el puerto de Veracruz. El otro es el eje transpacífico, que por medio de las navegaciones del galeón de Manila une a Filipinas con el puerto de Acapulco. Ambos flujos presentan un notable fraude; es decir mueven un volumen de mercancías y metales que supera el tope permitido por la legislación peninsular.

La dinámica de ambos circuitos de larga distancia y la gran concentración de sus bienes en la Ciudad de México resultan ser la "chispa" para la creación de un flujo entre México y Perú por el Pacífico, constituyendo el tercer circuito del modelo. Gracias al sobreabastecimiento de mercancías que se hace por ambos circuitos, México logra responder satisfactoriamente al conjunto de los mercados regionales del virreinato, y tiene la capacidad por su eje terrestre México-Acapulco de irradiar un tercer flujo, en este caso intercolonial e ilícito, que va hacia el espacio peruano por el Mar del Sur. Navíos peruanos se movilizan hacia la costa novohispana para adquirir los productos europeos y asiáticos a precios más bajos que los ofrecidos por la vía oficial de los galeones y ferias en Portobelo. En el intercambio, los peruanos entregan a los comerciantes novohispanos plata, azogue, cacao, aceite y vinos. Vale señalar que la reexpedición de efectos extranjeros también es una realidad del circuito del Caribe, desde Veracruz hacia Cartagena y Portobelo. ${ }^{8}$ Pero el gran desarrollo del contrabando europeo por el área del Atlántico caribeño, más la presencia del galeón español, contribuyen a que la ruta de bienes ultramarinos hacia Cartagena sea relativamente delgada, sin alcanzar la intensidad ni la frecuencia que sí adquiere

8 Bonialian, 2014. 
la vía del Pacífico. ${ }^{9}$ Este capítulo también analiza la otra cara del modelo: la circulación de la moneda peruana hacia Nueva España, con destino a China y a España. Luego de internarse en México, la moneda peruana acompaña a la novohispana por sus reconocidas vías de exportación. Se destina hacia Oriente, a través del galeón filipino y la otra corriente metalífera va hacia Cádiz, embarcándose en las flotas españolas.

El capitán francés Jean de Monségur, en sus Nuevas Memorias, de 1709, brinda una notable y lúcida síntesis de lo que ocurre por el Pacífico y sus efectos sobre el escenario económico novohispano:

Resultaría grato al lector que se aclarara cómo es posible que tantas mercaderías de Asia puedan consumirse en México, lo que satisfaremos diciendo que, cuando hay más de lo necesario para el consumo de México o las mercaderías están a precios bajos, se despachan para el Perú por la vía de la Mar del Sur; y aunque este comercio está severamente prohibido, esto no impide que, mediante negociación secreta, se pasen con seguridad, libre y decididamente, todas las mercancías que son tan estimadas en el Perú como en México. Cada año no dejan de llegar a las costas de México algunas naves del Perú en espera del galeón de Manila, a fin de hacer compras de las mercancías que trae. Ocurre a menudo que compren también de las de Europa, cuando escasean en el Perú y están a precios razonables en México. A México llevan cacao de Guayaquil con mucha plata en monedas y barras. Este comercio que allí se hace a pesar de estar terminantemente prohibido por las leyes, es un buen negocio, y resulta de gran provecho para los virreyes y otros ministros del Rey. ${ }^{10}$

El mapa II.1 es un espejo ilustrado del testimonio del capitán francés. Agregamos en él el trayecto final de este gran comercio despuntado desde la Nueva España hasta los territorios australes

9 Sobre la problemática del contrabando por el Atlántico sur: Suárez, 2001; Vila Vilar, 1982.

10 Monségur, 1994, p. 219. 
del virreinato del Perú. El tramo final del lago indiano termina por "confundirse" con el circuito oficial que unía a Panamá con el Callao, a través de la Armada del Sur. Los bienes europeos y asiáticos llegados a las plazas del occidente sudamericano desde la Nueva España se definen en calidad de bienes legales del galeón de Portobelo. Ya sea por Nueva España o por Panamá, la ciudad de Lima se posiciona en el principal centro de acopio y de redistribución de bienes asiáticos y europeos por la Sudamérica hispana.

El segundo punto de redistribución es Quito, con la puerta de acceso de Guayaquil. De hecho, cabe la posibilidad de que los bienes que llegan a la ciudad ecuatoriana se reexpidan a la ciudad de Lima. ${ }^{11}$ Desde donde, una considerable porción de mercaderías extranjeras continúan el circuito vía terrestre hacia la parte más austral del continente, alcanzando el centro de Santiago de Chile o el puerto atlántico de Buenos Aires vía Tucumán-Córdoba.

Por lo dicho hasta aquí, la perspectiva que proponemos en cuanto a la interpretación del comercio por el Pacífico se distancia de aquella lectura galeonista que impera en gran parte de la historiografía dedicada al estudio del comercio hispanoamericano. ${ }^{12}$ Es cierto que el galeón filipino es una pieza importante del espacio marítimo, el motor que le da vida al Pacífico, pero no es el único elemento mercantil. Por ello, es necesaria una nueva definición del Pacífico imperial que intente contemplar el circuito legal que unía Acapulco con Manila, el dudoso término de "comercio de cabotaje" que utiliza reiteradamente la historiografía para referirse al tráfico entre México y el Perú. En efecto, el espacio peruano ha sido una variable descuidada en los estudios y esta carencia nos ha llevado a pensar que en el espacio marítimo occidental de América existieron sólo los pesados y lentos movimientos de bienes y metales realizados a través del galeón de Manila. Por el Mar del Sur existe un riquísimo, pero a la vez desconocido mundo

11 Ulloa y Juan, [1747] 1953, pp. 205-206.

12 Existe una enorme literatura dedicada al galeón de Manila. Los trabajos más representativos son: Chaunu, 1974; Pérez Herrero, 1983, pp. 77-182; Schurz, [1939] 1992; Valdés Lakowsky, 1987; Yuste, 1984 y 2007. 


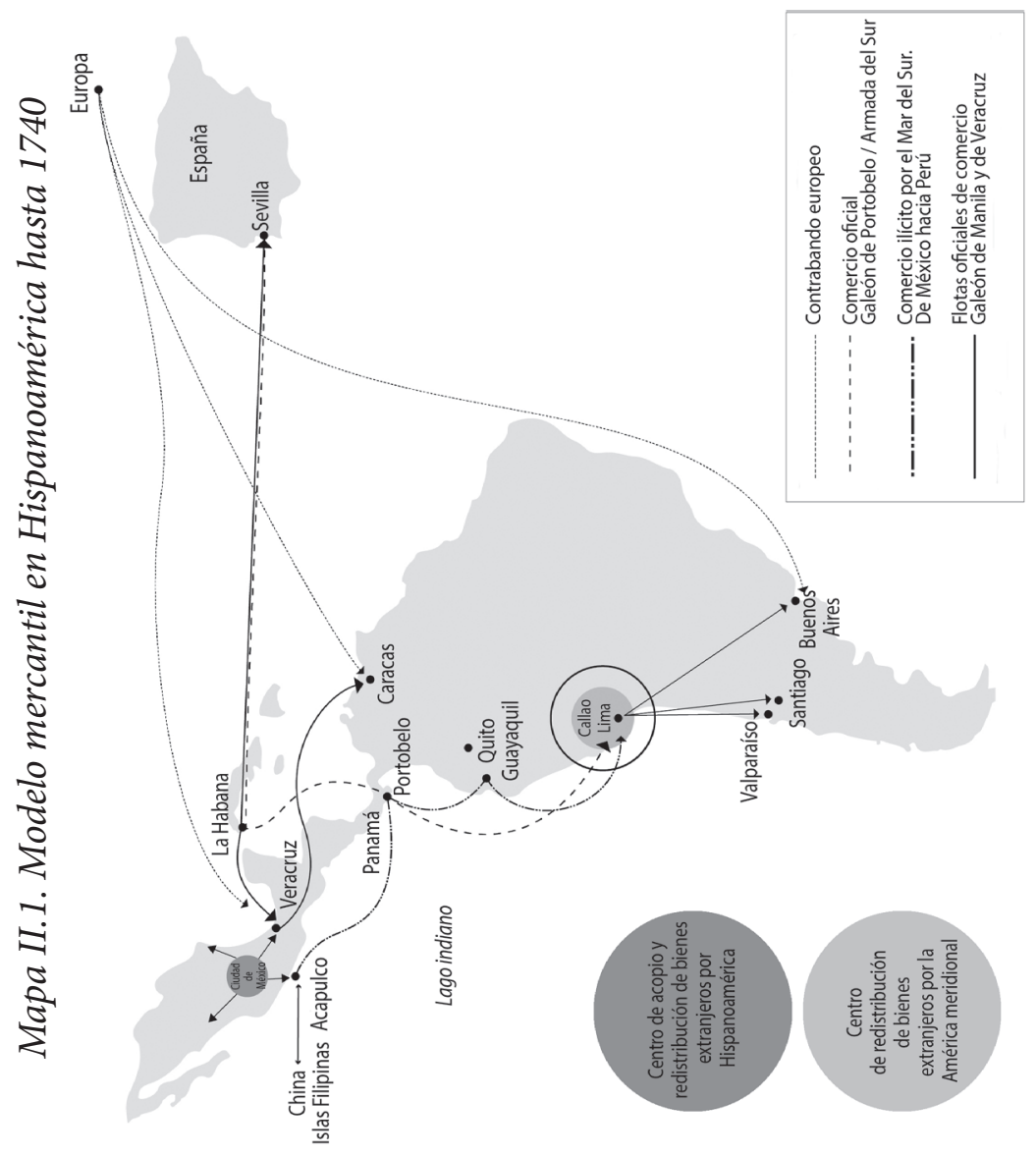

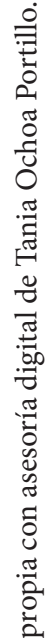


mercantil que supera los constreñidos marcos de la carrera filipina. Perú y todo lo que representa su movimiento mercantil con México es una problemática de enorme trascendencia; un fenómeno que no se reduce al ámbito del Pacífico, sino que alcanza a generar importantes efectos en el conjunto de las relaciones comerciales por el Imperio y más por la carrera de Indias.

Así entendida, la economía marítima del Pacífico se aleja de la tradicional caracterización de Spanish Lake (lago español) o más aún de la de un "Pacífico extranjero".13 Más bien, todo indicaría que estamos en presencia de un lago indiano, un área y economía marítima plenamente americana. Los argumentos son numerosos. En primer lugar, la definición alcanza su justificación al notar que los circuitos comerciales, legales e informarles, que se desarrollan por el área son controlados de forma muy temprana, por lo menos desde el último cuarto del siglo XVI, por los mercaderes asentados en las grandes ciudades de México y de Lima que pertenecerán, unas décadas después, a sus respectivos consulados. ${ }^{14} \mathrm{El}$ eje transoceánico entre Acapulco y las Islas Filipinas mueve capitales, bienes y agentes que responden a los más acaudalados comerciantes novohispanos. La extensión de rutas que van desde Acapulco hasta los puertos del virreinato del Perú se construye sobre una red de mercaderes mexicanos, centroamericanos y peruanos; un tejido de relaciones que, a pesar de las prohibiciones estipuladas por la Corona española, logran movilizar una cantidad ingente de bienes extranjeros y locales entre los puertos del Pacífico hispanoamericano y Filipinas.

La identidad del Pacífico como un espacio específicamente americano no puede trazarse desde una cuestión genealógica. No se podría discutir el origen peninsular de gran parte del cuerpo de mercaderes instalados en México o en el Perú, sean vascos o

13 Para la primera categorización, véase Spate, 1979-88; Schurz, [1939] 1992; Romano, 1998, pp. 41-49; Bernabéu, 1992. Para la segunda: Yuste, 1984, p. 14; Hoberman, 1991, pp. 211-217. No desconocemos el fenómeno de la piratería y de corsarios ingleses y holandeses por el Pacífico, pero en términos de tiempo prolongado no pasa de ser un fenómeno coyuntural, una actuación coyuntural motivada por el saqueo y el pillaje.

14 Bonialian, 2012, pp. 340-350. 
montañeses. Nos inclinamos al término de lago indiano por razones de carácter geopolítico; es decir, por prácticas de agentes que orientan sus capitales hacia el Pacífico que condicionan, estimulan o perjudican el desenvolvimiento de la vida mercantil transatlántica-peninsular. Durante casi los doscientos años en que funcionó el lago indiano, desde 1576 hasta 1740, notamos que los flujos comerciales que lo integraban gravitan en las rutas comerciales características del régimen monopólico español de flotas y galeones. Lo que en verdad se constata es que el modus operandi de los agentes peruanos y novohispanos goza de una relativa autonomía con relación a los cargadores peninsulares y de las arcas reales de la Monarquía hispánica. La capacidad de intervención del poder real y de los comerciantes peninsulares sobre el lago indiano resulta, en efecto, nula o por lo menos mínima. El Pacífico monárquico, titulado como un mare clausum, carece de sentido al notar la especificidad de las prácticas de los hispanoamericanos.

Ahora bien, pensar el Pacífico como una economía marítima americana nos lleva necesariamente a afrontar un gran dilema historiográfico que desafortunadamente ha sido descuidado en los últimos años. Nos referimos al tipo de articulación que existe entre la economía marítima del Pacífico y del Atlántico. La relación ha sido interpretada de diferente manera por trascendentes estudios. Aquí merecen enfatizarse las dos posiciones más contundentes. La primera obedece a Hamilton, para quien una de las claves para entender la caída de las importaciones de metal precioso en España durante el segundo cuarto del siglo XviI reside en el flujo ilícito de plata que se desvía hacia Filipinas a través del galeón de Manila. ${ }^{15}$ La sola mención de esta premisa supone que él concibe al tráfico transpacífico en directa oposición a la coyuntura atlántica. Por el contrario, ya como hipótesis generalizada para todo el periodo colonial, Pierre Chaunu sugiere un Pacífico con falta de autonomía, que vino a representar "la simple prolongación en la lógica de intercambios del comercio atlántico,

15 Hamilton, 1975, pp. 48-49. 
coordinado por Sevilla y luego Cádiz”. Lo que implica, según el parecer de Chaunu, que: "el estudio del galeón de Manila conduce a una conclusión decepcionante: la negación del Pacífico como un espacio económicamente autónomo, dotado de dinámica propia, susceptible de alterar y de influenciar el destino de la Europa del Atlántico". ${ }^{16}$

De esta manera, los índices del comercio por el Pacífico reproducen los ciclos de crecimiento y contracción registrados sobre el ámbito atlántico; esto es: expansión hasta 1620, una tendencia de ligera caída para los años próximos, que llevarán a la fuerte depresión de los años 1650-1680 y su posterior recuperación desde esta última fecha hasta fines del siglo XVIII. ${ }^{17}$

Aquí nos distanciamos de la postura del historiador francés. Al menos en lo que respecta al periodo 1680-1740, todo el Pacífico - la conexión Manila-Acapulco y el tráfico por el Mar del Sur - resulta, sin lugar a dudas, un ámbito de comercialización y navegación no sólo dotado de una dinámica propia y económicamente autónomo, sino también un espacio marítimo que logra repercutir y alterar de manera opuesta los dos ejes fundamentales del comercio oficial transatlántico: $a$ ) al alentar y promover el comercio por las flotas españolas de Veracruz, y b) al contrarrestar el eje Lima-El Callao-Portobelo-Cádiz impulsado por los galeones de Tierra Firme.

Efectivamente, este capítulo finaliza en 1740. La intensidad del tráfico de géneros asiáticos y castellanos desde México hacia el Perú desciende a partir de 1739, en el contexto de la guerra entre España e Inglaterra. De ahí en adelante, se oficializa el navío de registro como transporte dominante en el comercio ultramarino

16 Esta categórica afirmación entra en contradicción con una premisa que dará el propio historiador en páginas posteriores de su gran obra. Él dirá que simplemente "no existió un Pacífico de los ibéricos”. Me pregunto entonces, ¿cómo es posible que el eje transpacífico sea la simple prolongación de los intercambios atlánticos cuando dicho espacio marítimo no estuvo controlado por los españoles sino por los propios mexicanos? Chaunu, 1974, pp. 19-23.

17 Chaunu, 1974, pp. 249-266. 
español y comienza una paulatina apertura de puertos sudamericanos en el comercio directo con España. Estos nuevos canales abastecedores de mercadería europea y castellana por toda la región sudamericana harán que el circuito ilícito por la Mar del Sur que llamamos lago indiano vaya perdiendo fuerzas. Los comerciantes ya no tendrán interés por invertir sus capitales en un circuito de bienes internacionales que ya no asegura rentabilidad por la competencia impuesta desde el frente atlántico. De esta manera, a partir de la cuarta década del siglo XVIII, el esquema que posicionaba al Pacífico como espacio gravitante en la estructura imperial de comercio va cediendo hasta desaparecer. Evidentemente, la hipótesis será tema de análisis de las próximas páginas.

\section{INTENTO DE NUEVA ESPAÑA POR OFICIALIZAR SU CENTRALIDAD Y LA DEL PACÍFICO}

Un excelente mirador para rastrear la función mercantil central de la Nueva España es la correspondencia que circula en 1711 entre el virrey duque de Linares y el Consejo de Indias. ${ }^{18}$ El expediente consta de dos cartas. La primera pertenece al propio virrey novohispano en la cual se recomiendan dos cambios fundamentales, en primer lugar, la apertura comercial entre México y Perú por el Mar del Sur y, en segundo lugar, la libre circulación de bienes y metales por las vías intercontinentales como era el galeón de Manila por el Pacífico y la flota española del Atlántico. La solicitud de liberalizar ambos flujos es la condición para la reexpedición de los efectos castellanos, europeos y asiáticos desde México hacia el Perú. ${ }^{19}$ La segunda carta representa el rotundo rechazo del Consejo de Indias a la propuesta del virrey. ${ }^{20}$ Comienzo con

18 AGI, Lima, vol. 480, s/n de exp., f. 7.

19 Véase en el Consejo de Indias la "Carta adjunta del Duque de Linares y sobre que en ella representa me consultara el Consejo lo que se ofreciera y pareciere", AGI, Lima, vol. 480, s/n de exp., fs. 1-3.

20 "Respuesta que da el Consejo de Indias a la petición del virrey de Nueva España de abrir el comercio entre México y Perú”, AgI, Lima, vol. 480, s/n de exp., fs. 4-7. 
una exposición sintética de la propuesta de Linares, para luego intentar comprender las razones que llevan al Consejo de Indias a desacreditarla.

Decíamos que el virrey Linares sugiere la apertura de las comunicaciones mercantiles por el Mar del Sur entre ambos virreinatos. Era una medida necesaria en el contexto de la guerra de Sucesión porque el comercio legal español con las Indias se ve interrumpido. Particularmente, los efectos de la guerra se sienten sobre el espacio peruano. Los galeones de Portobelo prácticamente desaparecen. Desde principios del siglo, el galeón de Tierra Firme logra ingresar a Portobelo tan sólo en una oportunidad (1707). ${ }^{21}$ El contrabando francés lo reemplaza. Navíos franceses surcan el Cabo de Hornos y arriban a las costas peruanas llenos de mercaderías europeas para vender. También importan al Perú géneros asiáticos. Linares reconoce que los barcos franceses, luego de su primer ciclo de intercambio en puertos peruanos, extienden su navegación atravesando el Pacífico, con el objetivo de arribar al puerto de Cantón, uno de los astilleros más importantes del reino de China. Desde allí retornan al Perú para despachar las mercaderías orientales. ${ }^{22}$ Bajo este poco prometedor escenario mercantil español, caracterizado por

21 Dice Linares: "No hallo motivo que más precise mi obligación cuanto el de representar reservadamente los muchos y graves perjuicios que he reconocido se le siguen de la prohibición de comercio entre este reino y el del Perú, mayormente después de quedar suspendido el curso de los galeones que, en el espacio de diez años, atento a los riesgos de enemigos no han podido ejecutar una sola navegación, con grave detrimento de la real hacienda y notable perjuicio de los comercios", AGI, Lima, vol. 480, s/n de exp., f. 1 .

22 Con palabras del virrey: "Se ha seguido el abuso de la frecuente introducción de franceses en su vasta dilatación, no pudiendo permanecer sin comercio por faltarle el regular de España, ha debido admitir al extraño en tanta copia por ambos mares del norte y sur, que pasan de cien navíos los que en pocos años han aportado en aquellas costas, con muy limitada conveniencia de los reales derechos que solo por razón de ellos debía percibir su Majestad dos millones y otros dos de quintos de plata en pasta, sacada por alto, como es notorio y que pareciéndoles no dejaban bastantemente abastecidas aquellas provincias con los géneros de Francia, introdujeron en ellas los de China por medio de dos navíos cargados de ellos, sabiéndose han despachado al mismo efectos otros dos, sin embargo de la rigurosa prohibición que disponen las últimas órdenes de su majestad", AGI, Lima, vol. 480, s/n de exp., f. 2. 
la ineficacia de los galeones y el contrabando francés por el Pacífico, el virrey novohispano le propone al Consejo de Indias un giro verdaderamente transformador en su política comercial con las Indias:

Para evitar este daño nada conviene tanto como el que su Majestad mandase abrir el comercio [por la Mar del Sur] aunque fuese esto solo durante la guerra, y mientras vuelva a tomar su curso la navegación de galeones con cuya providencia pudieran duplicarse las cargazones de las flotas para la Veracruz y pasando los peruleros a estos reinos a emplear en ropas de la Europa, en otras de la tierra y de la china, quedará aquel reino bastantemente socorrido y no en tanta necesidad del comercio de franceses, resultando a beneficio de los vasallos de su majestad los intereses que estos logran actualmente con notable aumento de sus reales derechos y beneficio común de ambos reinos. ${ }^{23}$

La apertura del comercio entre México y Perú por el Pacífico exige para el virrey Linares una nueva planificación del régimen comercial oficial. Los requisitos serían: 1) dejar de apostar a la reactivación de los galeones de Portobelo; 2) duplicar el volumen de mercancías que llevan las flotas españolas a México o, en otros términos, cargar en ellas más mercaderías del nivel de consumo que presentara el mercado americano; 3) aumentar el comercio por el eje transpacífico anulando sus topes de comercio, y 4) autorizar el movimiento de mercancías europeas, castellanas y asiáticas desde México hacia Perú con su correspondiente reflujo de plata peruana hacia el virreinato novohispano.

El nuevo esquema que propone Linares es, sin lugar a dudas, un notable fortalecimiento a la centralidad mercantil de los comerciantes de la Ciudad de México: son los que controlarían todo el tejido de flujos que se trazan por el Imperio español. Monopolizarían las importaciones de ambas carreras: la del Atlántico y la transpacífica, y desplazarían a los cargadores sevillanos del papel

23 AGI, Lima, vol. 480, s/n de exp., f. 3. 
de abastecedores de mercaderías sobre el espacio peruano. En resumen, el modelo mercantil sugerido por Linares no es sino un intento por oficializar el proceso de relativa autonomía mercantil que por entonces vive el virreinato de la Nueva España con respecto a la metrópoli española.

Si la carta de Linares es recibida por el Consejo de Indias en junio de 1711, seis meses después, en noviembre, el máximo órgano español en asuntos americanos envía su respuesta a México. El Consejo de Indias rechaza la propuesta por "inadmisible ni tratable". Pero por fortuna para nosotros ofrece las razones de la negativa. La carta oficial comienza diciendo que: "abierto el comercio de los dos reinos había de crecer y aumentarse el comercio de las naos de Filipinas en el puerto de Acapulco que se ha opuesto siempre a la permisión y tolerancia de arribadas del Perú a la Nueva España" ${ }^{24}$

La apertura del comercio por el Mar del Sur implica una serie de transformaciones que el Consejo de Indias no desea aceptar de ninguna manera. Habría que suspender los topes de comercio permitidos por el eje transpacífico, una medida peninsular diseñada para garantizar el desenvolvimiento de las flotas españolas en Veracruz. Una posible autorización a las arribadas peruleras sobre el puerto de Acapulco llevaría al espacio peruano a participar no sólo en el giro asiático sino a priorizar sus intercambios con las mercancías traficadas por las flotas de Veracruz, en detrimento del propio régimen de galeones de Portobelo. Más aún, desde el Consejo de Indias se deduce que los mercaderes peruanos abandonarían su participación en la feria de Portobelo e inclinarían sus capitales mercantiles hacia México, por el Pacífico.

Ahora bien, el informe del Consejo no sólo no acepta la propuesta, sino que al mismo tiempo la denuncia. En efecto, en sus últimas fojas reconoce que gran parte del modelo sugerido por Linares funciona clandestinamente desde décadas atrás. Inicia su descargo tocando un elemento clave: las salidas de plata americana hacia Oriente.

24 AGI, Lima, vol. 480, s/n de exp., f. 4. 
con cuanto dolor se sabe y está observado que un comercio como el de la china tan discurrido y limitado a solo 350 mil pesos que solo puedan volver a aquellas islas de retorno, es hoy ya el que tanto del Perú como de Nueva España arrastra para la china un retorno de tres y más de cuatro millones cada año y que cada día ha de ser más en paz y en guerra. ${ }^{25}$

Los topes permitidos para la exportación de numerario hacia Filipinas son, según el Consejo, insistentemente violados. No sólo porque se embarca más plata mexicana de la que está permitida, sino porque ingresa ilícitamente por Acapulco moneda peruana. Esto se debía a que, según el Consejo de Indias: "no hay carrera más frecuentada de navíos que la del Perú a Acapulco y demás puertos de la Nueva España que están en el Mar del Sur" ${ }^{26}$

Las arribadas peruleras a México cuentan con la complicidad de las autoridades aduaneras. El mismo Consejo de Indias cuestiona el proceder del virrey que, con la propuesta, no sólo parece defender los intereses particulares de los novohispanos sobre el interés real, sino que busca propiciar aún más el proceso de autonomía mercantil novohispana que se está viviendo desde las últimas décadas del siglo XVII y primera mitad del siguiente. La intención de oficializar el plan esconde en el fondo la intención del virrey de concentrar un notable poder centralizador que termina por superar los atributos de la propia Corona española: "el virrey y ministros de la Nueva España lograrán más útiles tesoros que V. M. misma, y éstas han sido siempre las ansias de todos los virreyes, con celo de las imaginarias conveniencias que proponen". ${ }^{27}$

Por supuesto, el principal responsable de los envíos de mercancías internacionales hacia el Pacífico meridional es el gran mercader novohispano, ya que "son tan considerables los cargazones de china que no las pudiendo consumir la Nueva España

25 AGI, Lima, vol. 480, s/n de exp., f. 6.

26 AGI, Lima, vol. 480, s/n de exp., f. 7.

27 AGI, Lima, vol. 480, s/n de exp., f. 8. 
es preciso la saca transporte al Perú" ${ }^{28}$ La denuncia constituye el "nervio" principal de los intercambios ilegales. En México descienden los precios de las mercaderías importadas y el mercader del Perú, deseoso de obtener una gran rentabilidad, decide arriesgarse a operar en un tráfico ilegal lleno de sanciones. Las importaciones de artículos orientales que se hacen por Acapulco superan los niveles de consumo que presenta el mercado novohispano; una lógica comercial que, como vimos, funcionó en toda su magnitud en el periodo comprendido entre 1580-1620. Los rezagos, el excedente de mercancías, se reservan para su reexpedición hacia el Perú por medio de navíos peruleros que llegan a Acapulco, Zihuatanejo, Huatulco y otros puertos menores del Pacífico septentrional.

La condena del Consejo de Indias no se queda en denunciar el tráfico teñido de fraude y de ilegalidad sobre el triángulo marítimo Filipinas, México y Perú: va más lejos y bosqueja que una tentativa oficialización del circuito por el Pacífico llevará a que los excedentes mercantiles del espacio peruano, como el cacao y el azogue, fluirán con total naturalidad hacia Nueva España. El cacao guayaquileño terminará por arruinar el circuito legal del grano caraqueño que se conduce hacia Veracruz. ${ }^{29}$ Nuevamente, los diagnósticos sobre el quiebre de la relación transatlántica vía Portobelo que vimos para la primera pacificación del mundo atlántico (1580-1620) comienzan a renovarse en estos tiempos. Lo cierto es que, según el Consejo, la aplicación del proyecto de Linares conduce inevitablemente al camino de emancipación de las

28 AGI, Lima, vol. 480, s/n de exp., f. 7.

29 La sugerencia del virrey "produce no menores consecuencias que abierto aquel comercio con igual libertad pasaría de Guayaquil las abundantes cargazones de cacao, con cuyo abasto, necesariamente se excluya el que dan de este género por la Veracruz las provincias de Caracas, Maracaybo y Cumaná que únicamente se mantienen de este útil, el cual faltándoles necesariamente vendrán a experimentar su ruina, pues quedaba en términos de la mayor necesidad, y precisados por esta razón a comerciarlos con los enemigos" [...] "el perjuicio de lo trascendente que sería el comercio fraudulento de los azogues del Perú, que desquiciaría los mayores intereses de la real hacienda, en el producto de los que se conducen de estos reinos y que se repitan cédulas las más estrechas y rigurosas", AGI, Lima, vol. 480, s/n de exp., f. 8. 
economías del Pacífico hispanoamericano: "la provincia de tierra Firme se perdería, faltándole el curso de la navegación antigua de estos reinos para aquellos puertos". ${ }^{30}$ La carta finaliza exhortando por el cumplimiento de las órdenes reales y medidas punitivas que alientan la restricción del tráfico transpacífico y la total prohibición del comercio por el Mar del Sur.

Ahora bien, deseamos demostrar que el plan de comercio hispanoamericano propuesto por el virrey Linares no es una idea novedosa; es un intento oficial de blanquear lo que clandestinamente ocurre en el Pacífico. Más que un innovador régimen comercial a inaugurar, la propuesta de Linares resulta una instancia por oficializar un modelo de comercio alternativo que ya se desarrolla de manera clandestina desde tiempo atrás. Lo intentaré comprobar a partir de un abanico de testimonios emitidos por los verdaderos protagonistas que juegan en este esquema: los cuerpos mercantiles de Cádiz, México, Perú y el comercio de Manila.

\section{El ATLÁNTICO PACIFICADO Y LA GARANTÍA} DE LAS CORPORACIONES MERCANTILES

En un principio, podríamos confirmar la denuncia del Consejo de Indias acerca de la alta intensidad de barcos peruanos que se movilizan entre México y Perú por el Mar del Sur. La documentación que he revisado sobre decomisos y denuncias arroja que, entre 1670 y 1740, un total de 80 embarcaciones limeñas se dirigen hacia los puertos novohispanos y centroamericanos. ${ }^{31}$ Subrayamos que es una cifra mínima, puesto que son sólo los casos registrados. La red de corrupción que se teje entre autoridades y comerciantes me hace suponer que sólo estamos en presencia de la mancha visible de un gran fenómeno mercantil oculto, de una corriente mercantil sistemática. Las embarcaciones que salen del puerto del Callao o de Guayaquil llegan a los

30 AGI, Lima, vol. 480, s/n de exp., f. 8.

31 Bonialian, 2012, pp. 274-277. 
puertos de Acapulco, Zihuatanejo, Huatulco, Realejo y Sonsonate para despachar al mercado novohispano cacao, azogue, vino y plata. Al evaluar con detalle la composición de los cargamentos, vemos que el cacao guayaquileño es el principal producto importado (ilegalmente o con permisos excepcionales) a un mercado novohispano muy interesado en su consumo. En razón de un menor costo de producción y comercialización, su precio final resulta más barato que el cacao de Caracas, canal oficial y atlántico que promueve la Corona. La mayoría de estas naves aprovechan los recurrentes permisos concedidos para proveer de azogue de Huancavelica a las minas novohispanas y envían el cacao de Guayaquil. La exportación de mercurio peruano resulta curiosa, pues la capacidad productiva del centro productor del mercurio se encuentra casi a la mitad de los niveles registrados un siglo antes. De hecho, las importaciones de azogue de Almadén desde España al Perú no son infrecuentes. En el periodo que estudiamos, es posible pensar que la Corona busca garantizar la producción de plata novohispana antes que de las decaídas minas del Perú. El azogue de Huancavelica termina por suministrar a las minas de México antes que a los centros mineros propios del espacio del Perú. ${ }^{32}$

Los navíos regresan desde México hacia los puertos del Callao, Paita y Guayaquil con cargamentos de efectos asiáticos, castellanos, europeos y efectos de la tierra (tabaco, brea y alquitrán). En esta segunda orientación norte-sur, calculo un total de 25 navíos entre 1672 y $1748 .^{33}$ Prácticamente la totalidad de

32 Durante la década de 1690 se envía hacia México la considerable suma de 3000 quintales por año de azogue producido en Huancavelica. El virrey del Perú conde de Monclova, que había sido anteriormente virrey de la Nueva España, sabe perfectamente de la necesidad de azogue en México y se esmera por enviar esta importante suma cada año. En 1695 disminuye tanto la extracción del mineral, que Monclova suspende los envíos hacia Acapulco. No obstante, es tan evidente la política oficial de promocionar las minas de México que en 1697 una cédula real obliga a Monclova a garantizar la provisión de azogue a pesar de la baja productiva, manteniendo al precio de costo que arroja el flete Callao-Acapulco y el transporte Acapulco-Ciudad de México. Lohman, 1999, pp. 430-431.

${ }^{33}$ Lohman, 1999, pp. 302-303. 
ellos son comisos (22 de los 25). Se podría pensar que no estamos en presencia de una corriente mercantil de alta intensidad. Pero cuando sabemos que los comisos de mercaderías asiáticas y castellanas son excepcionales en el Perú por el alto índice de corrupción entre funcionarios y mercaderes, los casos se interpretan de manera inversa. En otros términos, si el contrabando era una práctica sistemática el decomiso era un hecho excepcional por dos razones: "porque los oficiales reales quieren vengarse de algún sujeto por haberles engañado antes o que tengan enemigos declarados y resueltos a denunciarlos", ${ }^{34}$ y porque el tráfico de partidas asiáticas y rezagos de flotas de México hacia el Perú se había convertido en una práctica institucionalizada que "parecía haberse borrado la idea de que era trato ilícito ni que estaba sujeto a castigo, al contrario, este negocio se hacía como cosa establecida". 35

Los datos de embarcaciones limeñas navegando de forma recurrente entre México y Perú vienen a confirmar la acusación que ofrece en 1725 el virrey marqués de Castelfuerte. En una carta que le dirige a Felipe $V$ señala que será imposible celebrar alguna feria en Portobelo porque: "se ha sacado porción de plata de estos reinos para los de la Nueva España a emplearlos en ropa de China y Castilla, de la que viene en la flota, en tan grande cantidad que se han descaminado varias porciones que importan crecida suma". ${ }^{36}$ Castelfuerte llega a definir a la ruta Perú-México como "de libre circulación de los géneros de Castilla y China". Y este es uno de los elementos, según el virrey del Perú, que impiden la salida de la Armada del Sur y de los "cortos caudales" que se presentan en la feria de Portobelo.

Ahora bien, concentremos la atención en el segundo ciclo de este gran flujo mercantil, el de las partidas asiáticas y castellanas que se reexportan de forma ilícita desde México hacia el Perú. Valdría preguntarse qué mecanismos hacen posible que estas

\footnotetext{
34 Ulloa, [1747] 1953, pp. 161 y 163.

35 Ulloa, [1747] 1953, pp. 161 y 163.

36 AGI, Lima, vol. 411, s/n de exp.
} 
mercaderías, luego de ingresar al espacio novohispano (las asiáticas a través de la feria de Acapulco y las castellanas con las ferias de Jalapa), logren ser reexportadas hacia el Perú por las aguas del Pacífico. En un memorial que el consulado de Sevilla le envía al Consejo de Indias en 1714 podemos encontrar lúcidas pistas para responder al interrogante:

el reino de Nueva España abunda de ropas de Castilla que conducen las flotas, de ropa que les llevan los extranjeros y de todas cuantas sedas llegan todos los años del Asia y las Filipinas, y así es menester formar el juicio sobre la forma en que se hallará aquel reino porque consumirlo todo es imposible, y no hay sustancia anualmente para poder digerirlo y así perdiendo con la poca reputación de los precios para deshacerse de tanta carga les es preciso introducir gran parte de ella en todo el reino y costas del Perú. ${ }^{37}$

Estamos en presencia de una cita de enorme importancia porque nos expresa la pieza clave que representa Nueva España en la articulación de los flujos comerciales; el "nervio" principal de un esquema comercial alternativo al oficial que tiene su epicentro en la Ciudad de México y su extensión sobre el área del Pacífico. El cuerpo mercantil español es claro en su juicio: las importaciones ultramarinas son superiores a los niveles de consumo que registran los mercados novohispanos. Los rezagos asiáticos y de flotas se van acumulando en los depósitos de los grandes mercaderes de la Ciudad de México y sus precios comienzan a descender significativamente. Desde el último cuarto del siglo XVII hasta mediados de la centuria siguiente, las importaciones de piezas orientales que introduce el galeón de Manila al puerto de Acapulco superan en varios años el tope ordenado por la Corona de 4000 piezas anuales. Sólo por brindar unos datos representativos de los muchos que existen. En 1699 el galeón importa más de 6700 piezas; en 1713 más de 5300 piezas, y en 1723 más de 6100 . Estos

37 "Memorial del Consulado de Sevilla, 30 de enero de 1714", en AGI, México, vol. 2501, s/n de exp. Las cursivas son mías. 
números dan cuenta de que el galeón no sólo satisface el consumo de la Nueva España; también considera al mercado consumidor peruano. ${ }^{38}$

Entonces, surge un nuevo interrogante: ¿cuál es la fuerza principal que alienta a los barcos peruanos a ir hasta México? Debemos reconocer que el motivo principal de las arribadas peruanas a las costas novohispanas occidentales está en el hecho de conseguir los sobrantes de las partidas asiáticas y castellanas, que se encuentran almacenadas en los depósitos de los comerciantes de la Ciudad de México, a muy bajo precio ${ }^{39} \mathrm{El}$ almacenamiento de mercaderías extranjeras en la capital novohispana es un claro ejemplo de peso reducido que tiene el poder metropolitano en el presente esquema comercial. Durante el siglo XVII prácticamente no se organiza ninguna feria ni en Veracruz ni en Jalapa. Como efecto automático, con la llegada de la flota peninsular al puerto atlántico de la Nueva España, las mercaderías se movilizan sin escala a la Ciudad de México, en razón de que el mercader capitalino logra comprar la totalidad de la carga que trae el flotista. Sumado al carácter sobrante de los bienes, hay otra razón previa de su baratura con relación a los que llegan en Portobelo. Los mercaderes del Consulado de la Ciudad de México demoran sus compras hasta la fecha de partida de la flota para obligar al peninsular a bajar los valores de las mercaderías y obtener descuentos sustanciosos. El peninsular nada podía hacer para evitar este "chantaje"; más cuando los novohispanos encuentran su aliado en el virrey, el sostén legal y político para cumplir sus objetivos. Todo indica que los grandes almaceneros

38 Álvarez de Abreu, [1736] 1977, t. I, pp. 235-237; “Certificación dada en el tribunal y Real Hacienda de cuentas de nuestra Nueva España de los 10 últimos galeones que han venido de las Islas Filipinas a este reino y carga que han traído", 1721, en AGI, Filipinas, 208, s/n de exp. En el siguiente capítulo se brinda una serie de larga duración del siglo XVIII exponiendo las entradas de piezas orientales por Acapulco a través del galeón de Manila.

39 El término rezagos se define al menos por dos elementos: hace referencia a la mercadería invendible ya sea en la feria de Veracruz-Jalapa o en la de Acapulco y, en segundo lugar, por ser un excedente de los niveles de consumo del mercado mexicano. 
de la Ciudad de México tienen esta notable capacidad de monopolizar el comercio porque controlan la producción de plata mediante el avío, impidiendo que el peninsular entable un contacto directo con el productor. ${ }^{40}$

El flujo ilegal con México le ofrece al mercader limeño altos márgenes de rentabilidad. Por unas "mordidas" o coimas a los agentes aduaneros y a las autoridades, logran evadir la fiscalidad por ser conducto clandestino ( cabala, entre otros impuestos). También, pueden controlar - junto con los almaceneros novohispanos - un flujo de mercancías y bienes que se encuentra bien lejos de la influencia peninsular. Adquieren a precios inferiores las mercaderías castellanas que les eran ofrecidas más espaciadamente y a más elevado precio por el conducto legal de Portobelo. Por último, no sólo consiguen los artículos asiáticos, un producto que les es prohibido pero de gran estimación en sus mercados, sino que también lo logran adquirir a un precio inferior, de rezago e invendible, y no al precio que previamente había sido fijado por la feria oficial de Acapulco al momento de su inmediata importación.

La función central de la Nueva España en este tejido de flujos también es reconocida por el propio consulado de Lima. En 1706, su Junta de Comercio le comunica a la Real Hacienda los obstáculos que existen para un exitoso funcionamiento de las ferias de Portobelo. El cerco más importante, según el cuerpo mercantil limeño, reside en la puerta de abastecimiento desde México. Dice al respecto:

pública está en la ciudad la noticia de que la flota de la Nueva España llegó a Veracruz compuesta de 17 bajeles de carga entera [...] pero menos carga para abastecer a México era suficiente y se tiene por cierto que de las memorias que compraren los mercaderes de aquel reino y de las que no vendieron los cargadores de España pasarán a éste [al Perú] la mayor parte. De suerte que cuando se supone que había de volver este comercio de celebrar la feria de Portobelo hallaría

40 Walker, 1979, pp. 39-74; Carmagnani, 2012a, pp. 345-346. 
sin duda en esta costa o navegando para ella los cargadores mexicanos, o sus factores con cargazón igual a la de Tierra Firme. ${ }^{41}$

Una nueva cita con notable riqueza informativa: la Junta de Comercio de Lima dice en 1706 lo mismo que dirá el Consulado de Sevilla en 1714, mención que he reproducido más arriba. Todas las voces muestran un consenso en que las flotas españolas cargan más de lo que es posible consumir en México. El excedente de mercancías, los rezagos, "pasarán al Perú".

La Junta de Comercio de Lima anexa inéditas problemáticas a la cuestión. Como ya hemos anticipado, nos muestra la función de los grandes mercaderes de la Ciudad de México como agentes promotores de las reexportaciones de los géneros europeos hacia el Perú. Nos dice también que la iniciativa para navegar por el Mar del Sur parte de los "cargadores mexicanos" o "sus factores". Es posible pensar que el Tribunal del comercio limeño intenta ocultar aquí la responsabilidad de sus miembros en el contrabando y extender la culpa hacia los mercaderes novohispanos. En su momento, hemos identificado que la mayoría de los promotores del contrabando son o fueron cónsules y priores del Consulado de Lima. ${ }^{42}$ Lo cierto es que los integrantes de ambos cuerpos mercantiles están involucrados en el comercio ilegal. La primera decisión corre a cuenta de los peruanos, al navegar a las costas mexicanas con una buena porción de plata y otros efectos de la tierra. Para los comerciantes de la Ciudad de México, la orientación del flujo hacia el Perú también trae sus beneficios y no tiene por qué suprimirse. Pero para ello se les debe garantizar un principio fundamental: el monopolio de la circulación de mercancías por el interior del virreinato, en este caso, de costa a costa (Veracruz-Acapulco), evitando tanto la internación peruana desde las costas occidentales novohispanas, como también de los propios flotistas españoles por el Atlántico.

41 El informe es una respuesta a la Real Audiencia con respecto a las serias dificultades que existen en el reino para despachar con una buena porción de caudal la Armada del Sur hacia Portobelo. Véase Moreyra, 1956, p. 21.

42 Remitimos aquí al cuadro 16 del libro Bonialian, 2012, pp. 342-343. 
La segunda problemática que menciona la Junta de Comercio de Lima es que el aprovisionamiento de mercancías desde México hacia los mercados del Perú se ubica como una variable determinante para entender la evolución dispar que vive el comercio transatlántico español; esto es, la vitalidad de las flotas españolas que van hacia México y el proceso de crisis del eje mercantil El Callao-Portobelo-Cádiz. Llegamos así al escenario del Atlántico. Hasta aquí hemos reseñado algunos elementos que nos dan una idea aún fragmentaria de los efectos que provoca el flujo ilícito entre México y Perú sobre el régimen transatlántico del comercio español. Si los convoyes españoles de Veracruz gozan de una mayor demanda de sus productos, los galeones de Portobelo sufren un total abandono. Veamos con mayor detalle cómo las reexportaciones hechas desde México al Perú por el Pacífico provocan una notable gravitación desestabilizadora en la carrera de Indias.

Desde la ciudad de Manila se reconoce el hecho. En pleno conflicto sobre los efectos que ocasiona en las ferias de Jalapa las excesivas entradas de mercancías orientales por el puerto de Acapulco, el comercio de Manila le replica en 1733 al comercio de Andalucía lo falaz que resulta culpar al galeón de Manila de un supuesto descenso y crisis de las ferias de Jalapa y Orizaba. Afirman desde el archipiélago oriental:

como es notorio, no logran mejores ferias los comerciantes de Cádiz en el reino del Perú que en el de Nueva España, antes bien en éste son mayores las utilidades [...] y así quéjense los comerciantes de Cádiz de la copiosa introducción de géneros que hacen aquéllos en estos reinos y que a las Indias envían más de lo que puede consumirse. ${ }^{43}$

Todos los "comercios" de la Monarquía van armando el "rompecabezas" del modelo mercantil que aquí se presenta; un tejido que, ante todo, conduce a la centralidad del Pacífico gravitando en la economía atlántica. Manila, con su descarga, pone a relucir que el galeón filipino no provoca ninguna contracción en las

43 Álvarez de Abreu, [1736] 1977, t. I, p. 145. 
flotas de Veracruz porque éstas envían más mercaderías de lo que consume Nueva España. Desde el silencio, España también tiene conocimiento del fenómeno. Los cargadores sevillanos comienzan a depositar su confianza en las flotas mexicanas y lentamente van renunciando a su interés por los galeones panameños. En un informe enviado al Consejo de Indias en 1705, con motivo de los preparativos para enviar los galeones y flotas al año entrante, el consulado sevillano expone abiertamente: "que el común del comercio tiende a interesarse en el de la Nueva España que no en el de Tierra Firme". ${ }^{44}$

Desde el último cuarto del siglo XVII y de forma paralela al auge del comercio ilícito por el Mar del Sur, las flotas mexicanas empiezan a ser más periódicas y numerosas que la carrera hacia Portobelo. En los 20 años que van de 1680 a 1700 se envían nueve flotas a Nueva España y tan sólo cuatro galeones a Tierra Firme. El proceso se puede ver también en la evolución comparativa del tráfico de ida hacia ambos virreinatos.

Cuadro II.1. Evolución comparativa de los viajes realizados por las flotas y galeones

\begin{tabular}{lccccc} 
& $1650-59$ & $1660-69$ & $1670-79$ & $1680-89$ & $1690-99$ \\
\hline Nueva España & $38 \%$ & $36 \%$ & $39 \%$ & $40 \%$ & $42 \%$ \\
Tierra Firme & $30 \%$ & $36 \%$ & $20 \%$ & $24 \%$ & $25 \%$ \\
\hline
\end{tabular}

Fuente: García Fuentes, 1980, pp. 164 y 215.

El cuadro II.1 deja entrever que el tráfico hacia Nueva España permanece muy estabilizado durante toda la mitad de la centuria, con una ligera tendencia al incremento a partir de la década de 1670 y alcanza la máxima cota en el decenio de finales del siglo. En cambio, se observa una tendencia contraria en el tráfico hacia Tierra Firme. Se nos puede objetar que la mayor frecuencia de flotas no se traduce en un más alto volumen de comercio, pero la 
relación existe: J. Everaert ha descubierto, a la luz de registros oficiales, que las remesas mexicanas crecen de forma espectacular, sobre todo a partir de 1685, año en que pasan de los 10000000 de pesos hasta los 30000000 en la flota que regresa a España en $1697 .{ }^{45}$ La tendencia continúa en los tiempos de la Guerra de Sucesión. Durante el periodo 1699-1713, Sevilla envía cinco flotas a México cargadas hasta el tope de mercaderías y cuatro pares de navíos cargados de azogue. ${ }^{46}$

Por el contrario, los efectos que produce el tráfico entre México y Perú por el eje sudamericano concentrado en Portobelo son bastante diferentes. En 1706 el Consulado de Lima deja entrever que el comercio por el Mar del Sur de los primeros años del siglo XVIII es el factor crucial que impide vender los artículos europeos ingresados al mercado peruano con la última feria de Portobelo de 1697:

Desde el año referido empezó a viciarse la contratación con el reino de México introduciéndose en éste sin limitación, considerables cargazones de ropa así de Castilla como de la China que han remitido los vecinos de aquella, en que sus intereses han sido sin ponderación de las diez partes las nueve; y se ha continuado con tan irregular exceso que hasta el día de hoy se ven intactos algunos géneros del empleo de la última Armada en las tiendas públicas sin que haya quien ofrezca por ellos ni el tercio de lo que costaron en Portobelo. $^{47}$

Hay una total indiferencia por parte de los comerciantes españoles y limeños en invertir sus caudales en los galeones españoles. De 1697 a 1713 se despacha tan sólo un galeón, la comandada por

45 Vale reproducir la tabla del autor que expresa el notable incremento de la plata enviada a España a través de las flotas: En 1679, 12 millones (patacones); 1681, 10; 1685, 15; 1688, 24; 1690, 10, y 1697, 37.5. Citado en Oliva, 2005, p. 26.

46 Alcedo, 1883, p. 8.

47 "En 24 de septiembre de 1706, Junta General de Comercio en la que se confirieron varios puntos y de común acuerdo se resolvió responder a la Real Audiencia”. Moreyra, 1956, p. 14. 
el conde de Casa Alegre de $1706{ }^{48}$ No sólo es la única por varios años, sino que cuando arriba a Portobelo la reciben los mercaderes limeños con gran decepción, porque: "apenas eran nueve, que vienen a media carga y otros al tercio siendo lo regular y antecedente diez y seis y a carga entera". ${ }^{49}$

El cuadro II.2 y la gráfica II.2 expresan de manera clara cómo el galeón de Portobelo pierde fuerza y frecuencia conforme avanzan las décadas finales del siglo XVII y las primeras del XVIII. La mayor espacialidad en el tiempo de sus arribos va acompañada de una disminución de su tonelaje total de mercancías transportadas hacia Portobelo.

Cuadro II.2. Galeones de Portobelo (1672-1737)

\begin{tabular}{clc} 
Año & \multicolumn{1}{c}{ Capitán } & Toneladas \\
\hline 1672 & Diego de Ibarra & 6000 \\
1675 & Fernández de Córdoba & 2000 \\
1678 & Enrique de Guzmán & 4500 \\
1681 & Marqués de Brenes & 4500 \\
1684 & Gonzalo Chacón & 4000 \\
1690 & Marqués del Vado & 4000 \\
1695 & Fernández de Zaldívar & 4000 \\
1706 & Fernández Sacristán & 3452 \\
1713 & Antonio de Echaberz & 1290 \\
1715 & Conde de Vegaflorida & 556 \\
1721 & Baltasar de Guevara & 2047 \\
1723 & Carlos Grillo & 3127 \\
1730 & Manuel López Pintado & 3962 \\
1737 & Blas de Lezo & 1891 \\
\hline
\end{tabular}

Fuente: Malamud, 1982, p. 77.

48 Alcedo, 1883, p. 8; Walker, 1979, p. 44.

49 Moreyra, 1956, p. 19. 
La indiferencia hacia el comercio de los galeones es mutua: los cargadores españoles reconocen lo difícil que resulta vender la mercadería en la feria de Portobelo. Desde el otro lado, los mercaderes de Lima estarán más ocupados en abastecer su mercado interior por un abanico de vías ilegales. Se sabe que existieron diferentes canales de comercialización que "alimentan" los mercados peruanos. Ingleses y holandeses desde sus bases en Jamaica y Curazao trafican por las costas aledañas a Portobelo. Particularmente, los ingleses aprovechan para ingresar mercadería con el manto legal del Asiento de esclavos y el navío de permiso de 500 toneladas.

Gráfica II.2. Galeones a Portobelo, 1672-1737

(en toneladas de mercadería)

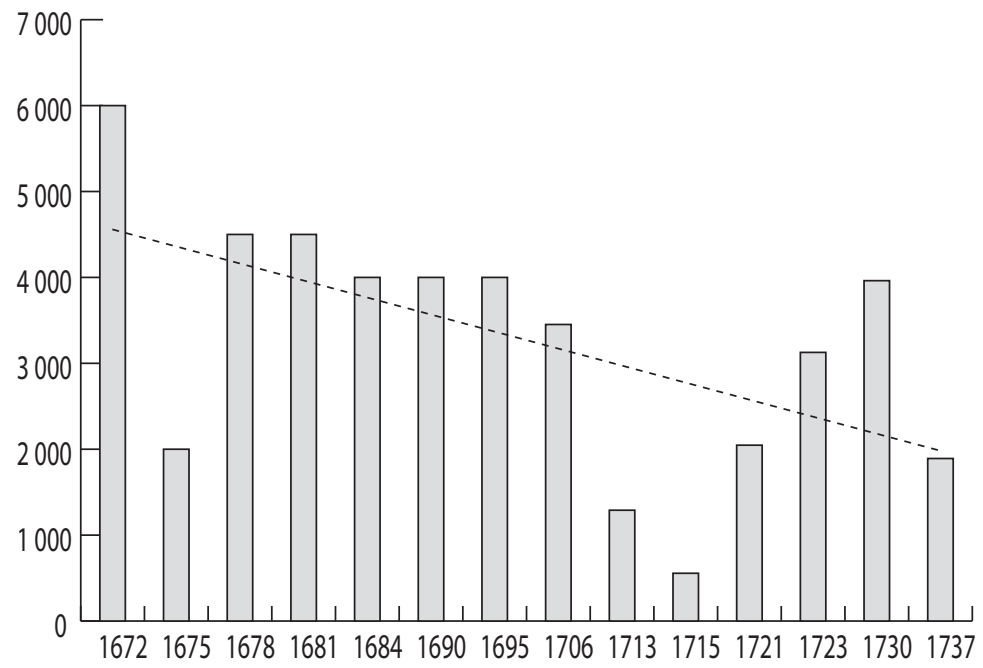

Fuente: Cuadro II.2.

Con un peso coyuntural propio está también, como lo anticipamos en el estudio de la propuesta del duque de Linares, el contrabando de los navíos franceses que surcan el Cabo de Hornos y abastecen de mercaderías europeas a los mercados del Pacífico sudamericano. Tal magnitud tiene el movimiento francés generado con los mercados de Chile y del Perú que alcanzó a supe- 
rar, con creces, las exportaciones de metálico peruano registradas desde Portobelo hacia España. La gráfica II.3 muestra que, durante 30 años, desde 1701 a 1731, las extracciones de plata por el Cabo de Hornos que logran los franceses alcanza un total de 54602765 pesos; mientras que los pocos galeones que navegan desde el istmo hacia Cádiz (1707, 1722, 1726 y 1731) no llegan a los 36000000 en total; tan sólo 65\% de lo obtenido por los franceses por la vía austral.

\section{Gráfica II.3. Exportaciones de metálico del Perú, 1701-1731}

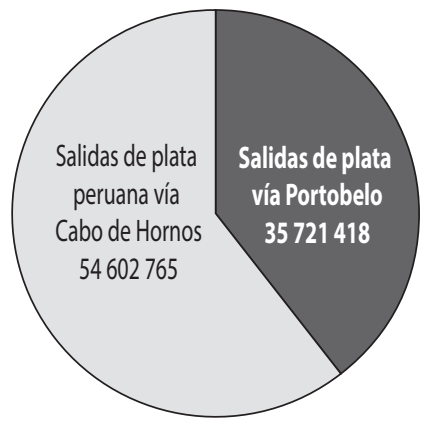

Fuente: Comercio francés: Malamud Rikles, 1986, pp. 126-170. Para el caso de Portobelo: AGNP, Real Tribunal del Consulado de Lima, caja 122, doc. 698 y Walker, 1979, p. 333.

Por su parte, el puerto de Buenos Aires será una pieza central como punto ilegal para las importaciones de bienes y las exportaciones de plata. Aquí valdría detenernos en una variable de explicación del proceso de crisis y colapso de las ferias oficiales de Portobelo, que curiosamente la historiografía la ha marginado de la explicación y es la vía de comercialización con México, por el Mar del Sur. Insistimos: no la consideramos como la única causa de la decadencia del galeón, pero sí como una fuerza determinante a la hora de explicar la crisis y desaparición de la plaza de recambio oficial de Portobelo. Según Alcedo y Herrera, desde 1678, el eje mercantil entre Perú y México comienza a desestabilizar la celebración de las ferias oficiales en Portobelo. Dice Alcedo: 
con la ocasión de dos navíos de particulares a quienes concedió el virrey [del Perú] licencias para hacer viaje a los puertos de Nueva España, habían introducido tan crecida cargas de ropa y tejidos de China que descaecieron [sic] con grandísima pérdida de su estimación las mercaderías de Castilla de los empleos de feria. ${ }^{50}$

Sucede algo similar en la última feria, en 1731. Desde un principio, la organización para celebrarla no da señales alentadoras. La Armada del Sur llega tarde a Panamá con un caudal de 10000000 de pesos. $^{51}$ El virrey Castelfuerte promete el doble de dinero - unos 20000000 - porque piensa que, a raíz de la desaparición del tráfico ilícito francés por las costas del Pacífico peruano, se lograría convencer a los limeños de invertir su capital en la feria de Portobelo. De hecho, el galeón sale hacia Tierra Firme con la plena confianza de que los 20000000 de plata peruana prometidos por el virrey alcanzarían para despachar la mercadería y retornar lo más rápido posible a España. Sin embargo, nuevamente el enlace intercolonial por el Mar del Sur hace fracasar el compromiso asumido por Castelfuerte y, desde luego, los sueños de los cargadores españoles. ¿Por qué?, por:

la circunstancia de haber dado en aquel intermedio licencias y viajes a navíos de algunos particulares para pasar por la Mar del Sur a los puertos de Nueva España; y convertidas aquellas porciones en el expediente de flota que también tenía adyacente de la nao de permiso La Isabel en la Veracruz y faltaron en Tierra Firme para poder celebrar la feria de Portobelo. ${ }^{52}$

Alcedo agrega aquí un dato todavía no señalado. Perú se abastece desde México, pero no sólo de rezagos de flotas sino también del navío de permiso inglés que llega periódicamente a las costas de la Nueva España.

\footnotetext{
50 Alcedo, 1883, p. 152.

51 AGNP, Real Tribunal del Consulado de Lima, caja 122, doc. 698.

52 Alcedo, 1883, p. 278.
} 
Ahora bien, la plata peruana se envía hacia México, particularmente a sus costas occidentales, con el propósito de emprender dos tipos de operaciones muy compatibles: adquirir mercancía europea y castellana que desembarca la flota por Veracruz y comprar los géneros asiáticos que llegan a Acapulco a través del galeón de Manila. De ahí que no toda la plata peruana que se envía a México se exporta a Oriente por la vía de Filipinas. Una gran porción se interna en el virreinato novohispano para proseguir su viaje en las flotas atlánticas. Valdría preguntarse por qué razón la historiografía esquiva el análisis del movimiento de metálico peruano por el eje Acapulco-Ciudad de México-Veracruz. Así como existe una escasa documentación que condena al tráfico de rezagos de flotas entre México y Perú, también carecemos de denuncias sobre el escape de plata peruana desde el atlántico novohispano. Sin embargo, las pocas referencias no parecen corresponderse con la alta intensidad que adquiere el movimiento de bienes. Más bien, la desatención de los contemporáneos tiene claros propósitos porque en torno a este circuito de rezagos de flotas giran numerosos intereses de autoridades políticas de las Indias, consulados situados a ambos lados del Atlántico e, incluso la propia Corona. En un contexto bélico de gran intensidad como es la Guerra de Sucesión española y el gran contrabando directo que las potencias europeas gozan en estos tiempos con América, la Corona española no se siente con el privilegio de denunciar la "violación" a los drenajes formales de metálico. Más bien, debe sentir satisfacción porque, a fin de cuentas, la plata americana llega a puerto español, sea por flota o galeón. En última instancia, se pierde más de lo que se gana en denunciar el flujo.

Uno de los pocos testimonios que "destapa" la salida de plata peruana hacia España vía México es el de Alcedo y Herrera. Éste identifica las consecuencias que generan las reexpediciones de rezagos de flotas desde Acapulco hacia el Perú con el consiguiente drenaje de metálico peruano hacia Nueva España, Alcedo sintetiza de manera lúcida los problemas que afronta el capitán López Pintado en Portobelo con los últimos galeones que llegan a Tierra Firme en 1731: 
el año de 1730 fueron al cargo del mismo comandante y jefe de escuadra, López Pintado, y tuvieron por distinto modo la misma o mayor desgracia que los dos [galeones] antecedentes: porque con la ocasión de no haber concurrido el comercio del Perú por la banda del sur, con la gruesa de caudales que había ofrecido, por haberse convertido en el largo intermedio de los segundos a éstos una gran parte al trato de los puertos de Nueva España, Realejo, Sonsonate y Acapulco, que llaman de la otra costa, faltó aquella crecida porción para efecto de la feria. Así lo atestiguó judicialmente el general comandante de los galeones y lo comprobó en Cádiz, con la diferencia en la copiosa cantidad de monedas del Perú que condujo aquel mismo año la flota de Nueva España. ${ }^{53}$

La cita de Alcedo y Herrera nos invita a abordar el problema en su justa y compleja dimensión. Los galeones de Tierra Firme de 1731 sufren el boicot o la indiferencia de los mercaderes limeños al no llevar la plata a la feria oficial de Portobelo. La feria es un verdadero fracaso. Pero al llegar a Cádiz, el comandante López Pintado encuentra que una gran porción de moneda perulera había ingresado a Cádiz con la flota de México ¡Notable suceso! Vemos así que la gravitación y los efectos que produce el comercio ilegal por el Pacífico son de corte imperial afectan a todo el régimen de comercio transatlántico. El flujo de metal peruano hacia Acapulco es la principal causa de que falte "crecida porción para efecto de feria [de Portobelo]". Así, la plata peruana que debería ir a España a través del eje Lima-Callao-Panamá-Portobelo se conduce en las flotas novohispanas.

53 Alcedo, 1883, p. 515. Similar denuncia nace del autor anónimo de Estado Político del Reino del Perú; manuscrito contemporáneo al de Alcedo y Herrera: "la tercera puerta es la del reino del México por donde continuamente entran a el Perú crecidas partidas de ropa de china y está computada esta saca por 3 millones con lo que el Perú aumenta el crédito de riquezas a el reino mexicano, como se ha examinado esta realidad de las mismas flotas que al manifestarse sus registros en Cádiz se halla gran porción de moneda del perulero, no obstante de el oro, que el que carga para el uso de esta relajada puerta”, en BPRM, Miscelánea de Ayala, vol. II, exp. 2888, fs. 154-155. 
Con todo, tendríamos que partir de la premisa de que el tráfico de rezagos de flotas entre México y Perú no resulta para España un fenómeno tan dramático como el que provoca el comercio peruano con China vía México. El espacio peruano se abastece, en el último de los casos, por la carrera de Indias, sobre todo por medio de los cargadores españoles. Mal que bien el metal de las minas andinas llega a España, aunque eso pone al descubierto la exigua funcionalidad de los galeones de Tierra Firme y sus ferias de Portobelo. ¿Por qué esperar una denuncia peninsular a un flujo de metal que a pesar de su ilegalidad terminaba en el puerto español de Cádiz? Por el contrario, la salida de plata perulera hacia Oriente implica la pérdida total del metal que, de otra manera, y respetando los canales oficiales de los galeones de Tierra Firme, tendría que ser enviada a España. De ahí la permanente y enfática denuncia al tráfico ilegal de monedas peruanas hacia México y su correspondiente reexportación hacia Filipinas a través del galeón de Manila.

Con notable perspicacia, la distinción se explicita en un interesante manuscrito anónimo de 1735. Apartando de la problemática el comercio de la China, el autor sostiene que:

aunque entre dos reinos [México y Perú] hubiera crecido comercio, no disminuiría nada al de España, pues en saliendo armada de cualquiera de los dos, lo deja sin un real, porque en ello está el interés de sus moradores, de lo cual buena prueba es que llevando todo el año moneda tierra adentro, en estos casos se remite gran parte de ella a México y Veracruz, con que lo más que sucedería es que produciendo la Nueva España 9 millones de plata y oro vendría lo más que este comercio le hubiera comunicado, y si los galeonistas lo perdían por Cartagena lo lograban los flotistas para la Veracruz y para Su Majestad y sus derechos de Cádiz era igual el beneficio. ${ }^{54}$

54 "Breve relación en que se describe el puerto de Veracruz y su castillo, salida de flotas y azogues, armada de Barlovento, Campeche, Habana y Cuba, Astillero de Alvarado, Puebla de los Ángeles, los Juzgados de bienes de difuntos, fiscales de México y Lima, Universidad y Hospitales, Casas de Moneda, comercio de Nueva España, variedad de gentes... situación de México, Acapulco, su comercio" [...] 1735, BPRM, Miscelánea de Ayala, vol. II, exp. 2868, fs. 315v-316r. 
Una mención más completa e ilustrativa de estos caminos alternativos pero oficiales por donde transita la plata americana la ofrece hacia 1720 el propio Consulado de la Ciudad de México:

la prohibición del comercio de este reino con el de Perú total no parece que conviene porque el estar cerrado por ambos Mares más parece monstruosidad que buena política [...] Por la parte del Sur será conveniente el que esté abierto por muchas causas pues el que pase alguna plata de este a aquél y de aquél a este no se viene a perder nada pues la que estuviere en el Perú se la liberarán los galeones y la que estuviere en este reino será para la flota. ${ }^{55}$

Si hay plata peruana en México o, a la inversa y más inusual, plata mexicana en el Perú, inevitablemente el metal debería continuar su ruta hacia España con la flota o con el galeón. Naturalmente, lo que no dice el Consulado son todas las implicaciones negativas que trae para España la apertura del tráfico por el Pacífico entre ambos virreinatos que ya hemos señalado: salida de plata peruana hacia Oriente, reexportación de los productos castellanos y europeos desde México hacia el Perú y las terribles consecuencias que ocasiona todo ello a los intereses peninsulares depositados en el galeón de Portobelo.

Lo reseñado hasta aquí nos permite interpretar el comercio transpacífico y el interamericano en un nuevo marco de reposiciones territoriales dentro del tejido de los flujos mercantiles imperiales entre 1675 y 1740. Las funciones que cumplen cada uno de los bloques territoriales en el nuevo mapa mercantil dan cuenta de un esquema mercantil que tiene a la Ciudad de México y su conexión con Acapulco como el área céntrica del sistema mercantil imperial y aun global. El régimen funciona a la par y en detrimento del comercio transatlántico de flotas y galeones diseñado desde España. Estamos en presencia de un fenómeno

55 AGNM, Consulado, vol. 269, exp. 2, Manuscrito sin título, sin fecha y sin número de fojas. El informe enviado al Rey consta de 3 fojas. y se ubica dentro de este extenso expediente. 
transcontinental muy similar al visto en el capítulo inicial de este libro, al analizar el caso peruano en el periodo 1580-1620. Es decir, nuevamente la fuerza del Pacífico se impone sobre el Atlántico. Es una segunda ola en la que el Atlántico se ve pacificado.

A México lo situamos como centro neurálgico de las importaciones del comercio exterior, tanto de las transpacíficas (efectos asiáticos) como de las transatlánticas (europeos y de Castilla). Conecta ambas carreras, la de Indias y la del Pacífico, alcanzando así una inédita red de intercambios verdaderamente mundial, que interrelaciona la economía de tres continentes. Su papel central se extiende al monopolizar la reexportación de los géneros hacia el espacio peruano por la vía del Pacífico. Por sus costas occidentales - particularmente por Acapulco- circula una incalculable pero significativa cantidad de plata americana. México importa plata peruana. Una porción de ella parte hacia Filipinas, junto con plata mexicana, y otra cantidad de desconocida estimación se embarca en las flotas españolas de la costa Atlántica.

El espacio peruano, entonces, tiende a un notable abastecimiento de artículos asiáticos, castellanos y europeos por la vía mexicana del Pacífico. Es tan elevada la cantidad de mercaderías importadas al mercado peruano que hacia la década de 1740 se le define como la "feria de Pekín". ${ }^{56}$ El conducto se ubica como un factor significativo, pero no exclusivo, para que los comerciantes limeños abandonen el interés de la vía de importación oficial por Portobelo. En este marco, España intenta mantener su política comercial bipolar del Atlántico, revitalizando la carrera de galeones con el fin de impedir que un espacio americano, en este caso México, se ubique como eje comercial, arrastrando hacia sí todos los circuitos exteriores (de metales y bienes) existentes en el imperio español en América. En otros términos, la resistencia peninsular a oficializar la propuesta del virrey Linares es, en última instancia, evitar un posible proceso de independencia económica del virreinato, de alentar un proceso de autonomía. Estamos en presencia de una economía marítima del Pacífico que hace tam-

56 Bonialian, 2012, p. 347. 
balear - y en el caso de América del Sur contribuirá a modificarlo- al régimen oficial transatlántico español. Para 1740, un nuevo esquema de tráfico y navegación de larga distancia terminará por suplantar al sistema de galeones y ferias de Portobelo. Llegará el turno del sistema de navíos de registro que enlazará de manera directa y con mayor frecuencia cada mercado local de la América meridional con la cabecera peninsular. Desde entonces, el eje transoceánico por el Cabo de Hornos concretará el antiguo y, por varios siglos, truncado proyecto español de acercar los mercados del Pacífico hispanoamericano a su economía metropolitana.

\section{Gráfica II.4. Producción de plata. México, Perú y total de la América hispana, 1571-1810 \\ (en millones de pesos de 272 maravedies)}

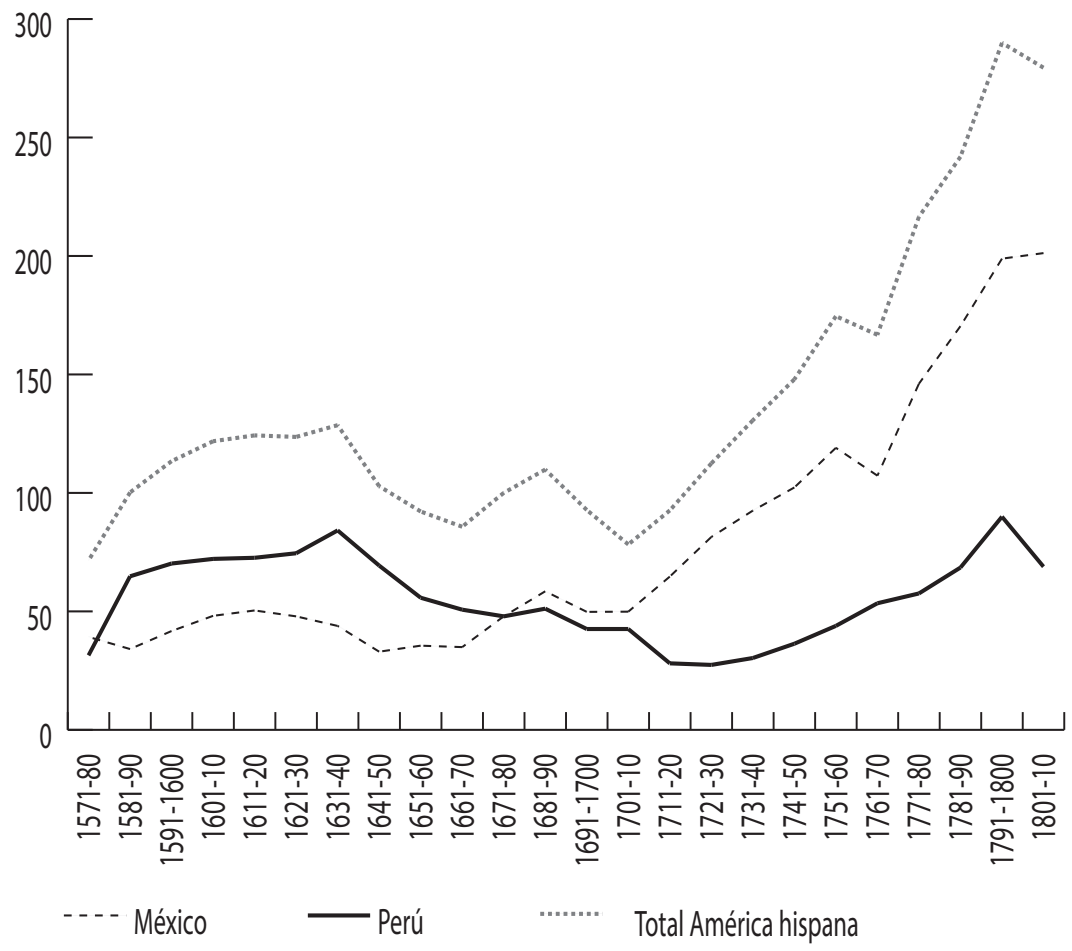

Fuente: TePaske y Brown, 2010, p. 112. 
El cuadro II.3 es una síntesis de los grandes problemas históricos de la economía marítima americana en la historia prolongada. En él se intenta identificar y presentar las transformaciones y cambios más trascendentes que ocurren en el mapa hispanoamericano tanto del lado del atlántico como del Pacífico. Asumimos los riesgos de vacíos y simplificaciones que una historia macroespacial y de larga duración presenta. Lo primero que debemos advertir es que el quiebre histórico, el parteaguas, lo situamos hacia la mitad del siglo XVIII, concretamente en 1750. Las primeras medidas económicas del llamado "Reformismo borbónico", particularmente las referidas al comercio, comienzan a configurar un nuevo mapa económico que establecerá las condiciones para el ingreso y desarrollo en Hispanoamérica del liberalismo europeo y angloamericano. Según nuestro enfoque de análisis, las reformas borbónicas representan una continuidad y no una instancia rupturista que una lectura política de Estado-nación podría proponer, del escenario económico marítimo de principios del siglo xix. Una multiplicidad de variables y criterios analíticos desarrollados en este libro podrían explicar la razón del gran fenómeno de transformación que vive la economía marítima de la América española hacia mediados del siglo xviII. Es verdad: el esquema tiende a generar interpretaciones rígidamente esquemáticas de procesos con elevado grado de especificidad. No todos los cambios ocurren hacia 1750; algunos de ellos son bruscos y otros paulatinos, se explicitan en su plena dimensión hacia finales del siglo XVIII o principios del siglo xIX. Asumimos el riesgo y lo intentaremos evitar con la presentación del tercer y último capítulo del libro. 


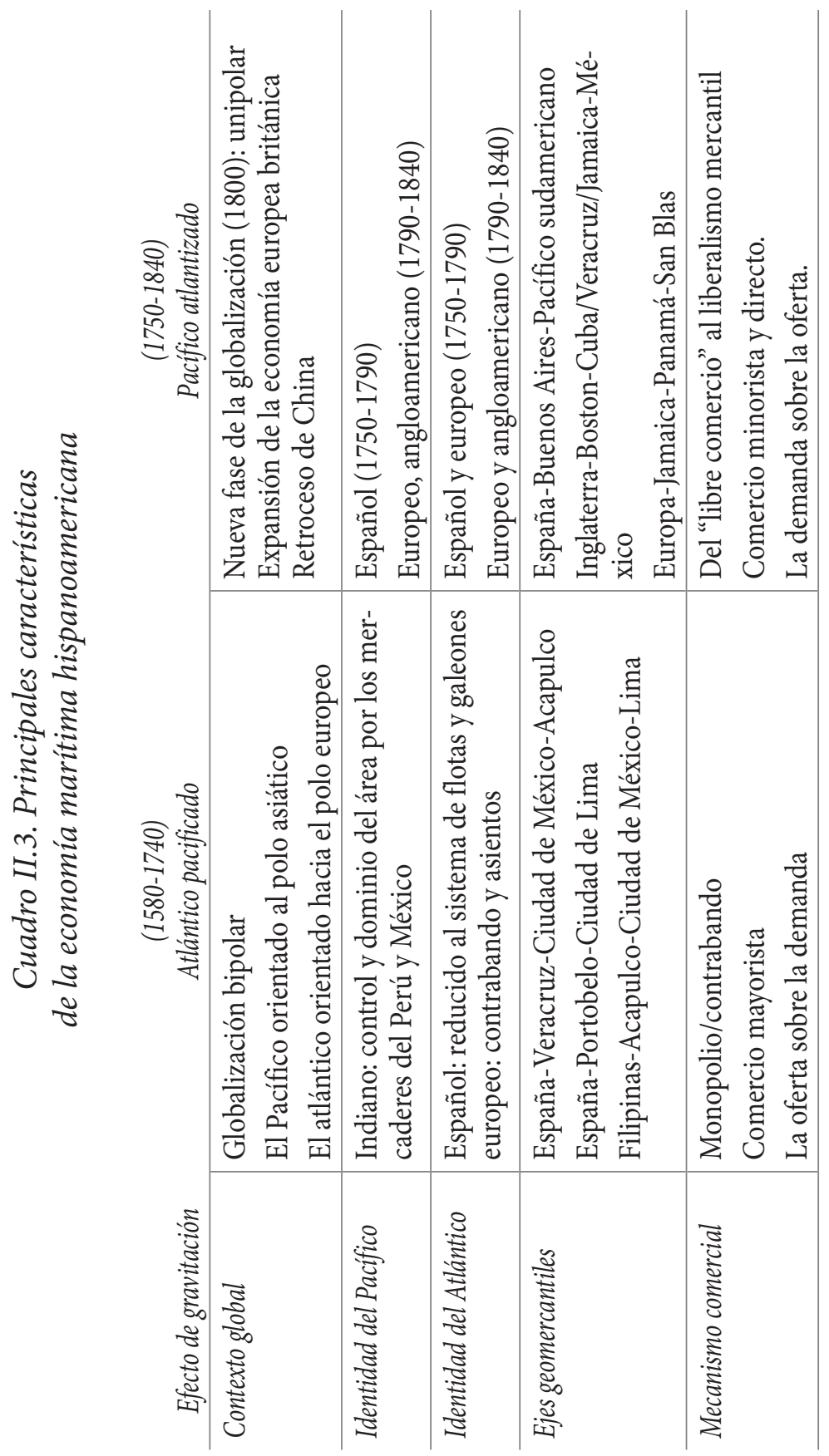




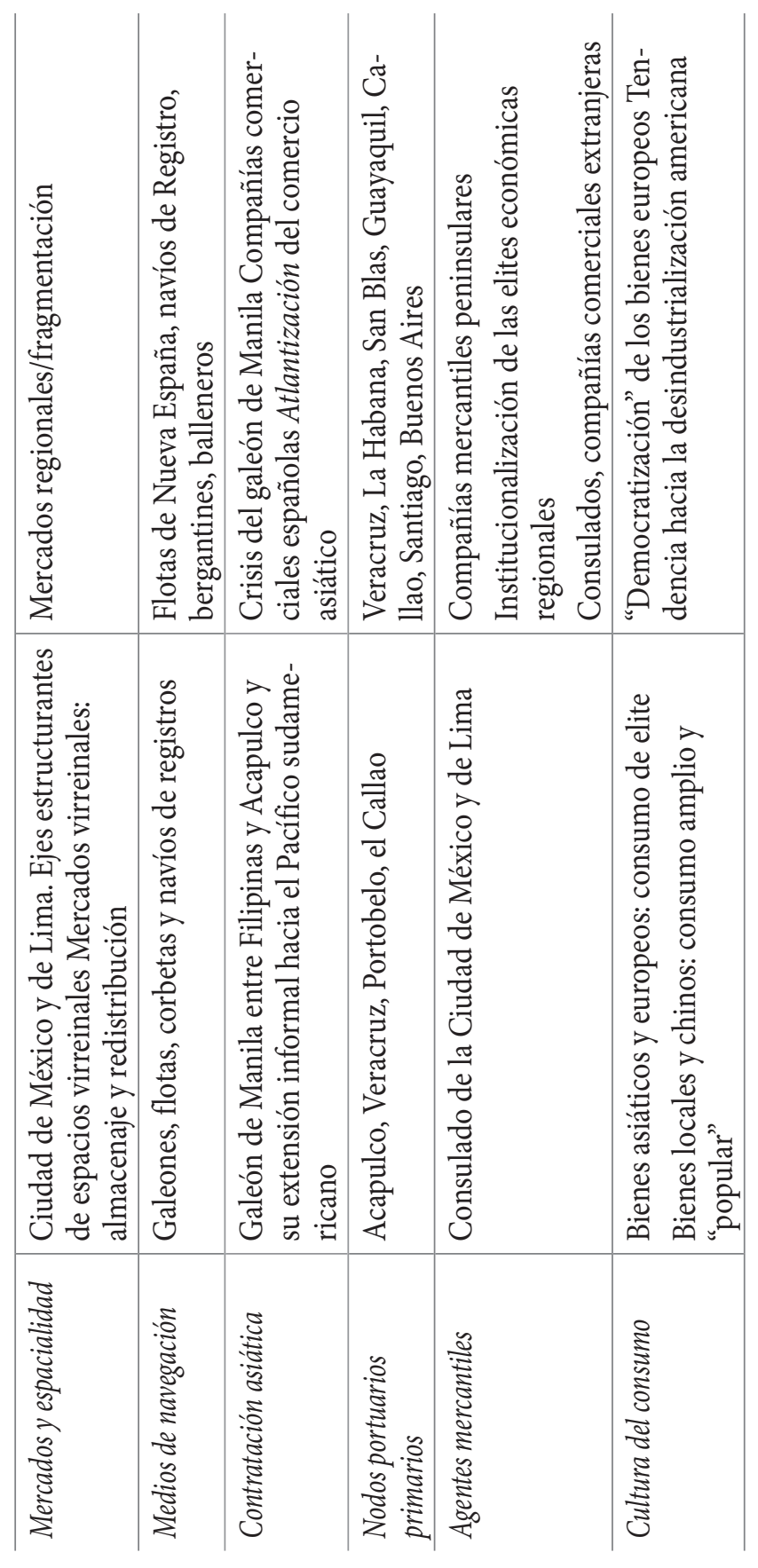




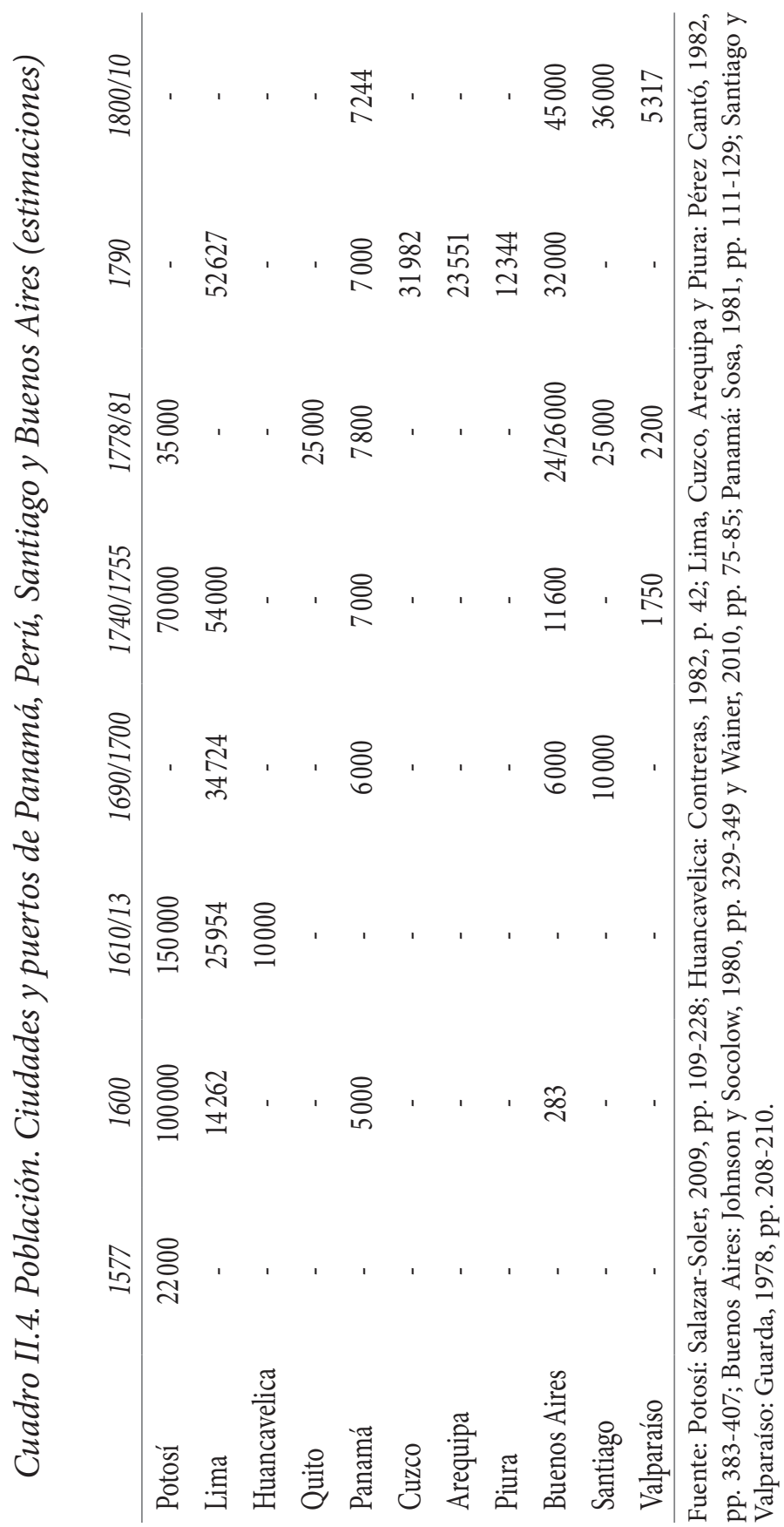



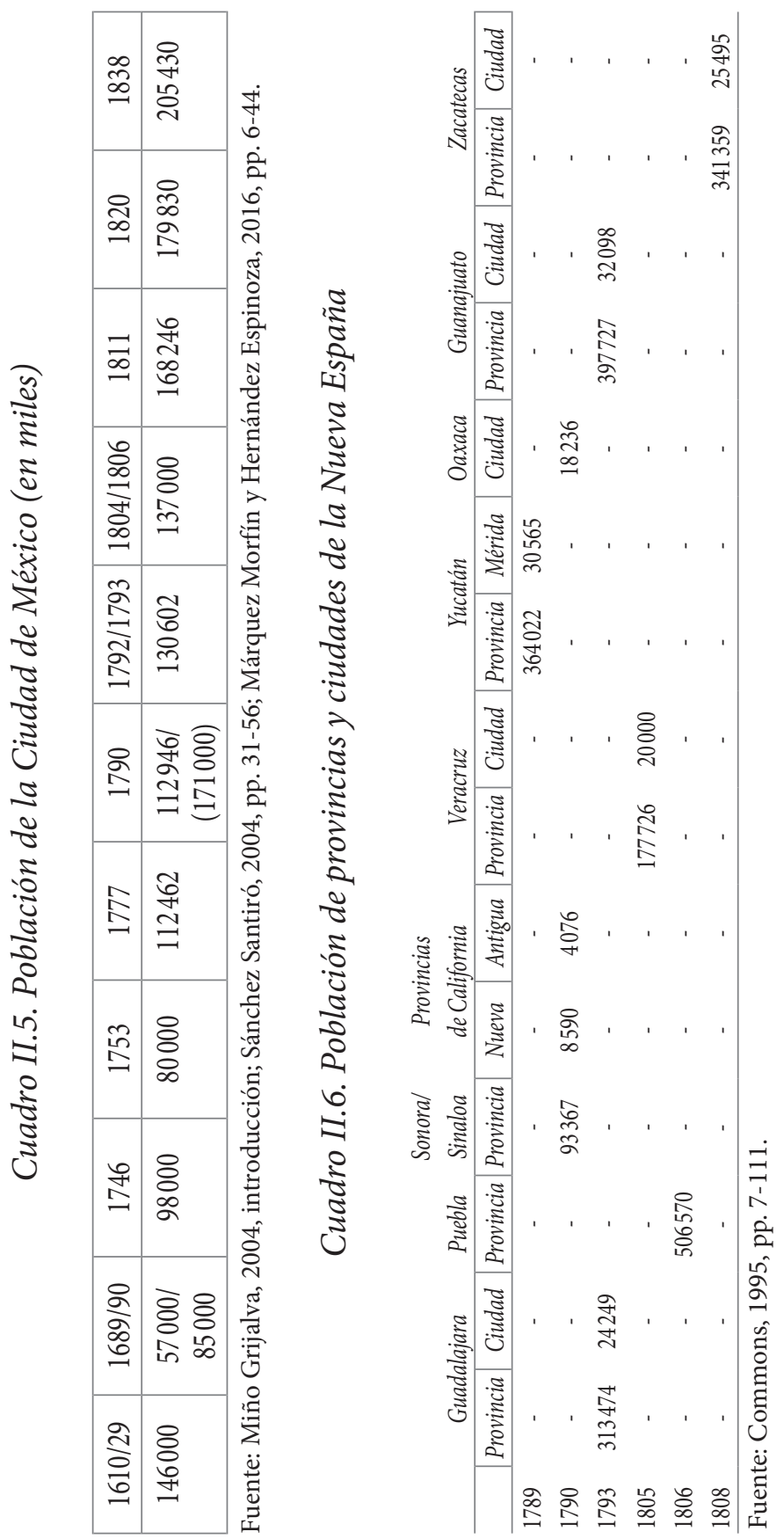

2

EL PACÍFICO ATLANTIZADO 



\section{GEOPOLÍTICA Y ECONOMÍA MERCANTIL EN LA AMÉRICA ESPAÑOLA, 1740-1840}

El Pacífico en las postrimerías del Siglo xViII ¿BAUTISMO GLOBAL O ATLANTIZACIÓN?

La literatura clásica dedicada a la historia del Pacífico mexicano parece no distinguir lo que llaman "el inicio de la internacionalización" de las últimas décadas del siglo xviıI con lo que en realidad es su atlantización. ${ }^{1}$ Pensar que la economía marítima, no sólo de México sino también la de Sudamérica, inicia por esos tiempos reformistas una inédita participación en la economía global supone desmerecer las antiguas y globales relaciones transpacíficas que se tejen entre América y el Oriente desde el siglo Xvi. Hemos visto en los dos primeros capítulos que el Pacífico novohispano opera en una temprana globalización gracias a la vida del galeón de Manila.

Ciertamente, pensar que el "bautismo internacional" del Pacífico mexicano le llega con el libre comercio y con la presencia de agentes y capitales europeos no hace más que apoyar una lectura eurocéntrica del fenómeno; posición de la que nos intentamos distanciar. La aproximación general que se ofrece en este libro demuestra una lectura alternativa, donde la economía marítima del occidente hispanoamericano juega un papel sustancial en esa temprana globalización bipolar, que tenía a China como uno de sus polos fundamentales y donde la economía europea tenía por el área una débil participación. El término Pacífico indiano con que la definimos para épocas previas a 1750 es representativo al respecto.

De todos modos, la existencia de un Pacífico hispanoamericano globalizado desde finales del siglo Xvi no implica desmerecer

1 Trejo Barajas, 2006a, pp. 11-48; Valdés Lakowsky, 1985, pp. 58-81. 
su proceso de atlantización u occidentalización, más al saber que sus efectos perduran hasta la actualidad. Un ingrediente fundamental de dicho fenómeno es la revolución atlántica del comercio y del consumo que se expande y absorbe el universo del Pacífico. Es el inicio de la entrada sistemática y dominante de la economía europea sobre un ámbito oceánico que hasta 1750 se muestra resistente a incorporarse a la economía occidental. Antes de la segunda mitad del siglo XVIII, la participación de Occidente en el Pacífico hispanoamericano puede categorizarse como esporádica y circunstancial, cuyo modus operandi se basó en el pillaje, el saqueo o aun en la práctica del contrabando.

La occidentalización del Pacífico sería, según nuestra interpretación, un componente fundamental de la segunda fase de la globalización ahora con un perfil unipolar. El Pacífico hispanoamericano ya no se puede definir como un área independiente, indiana o americana, sino que muta hasta convertirse en una importante pieza de una economía global dirigida por Europa, en particular por la economía británica y su revolución industrial. La atlantización del Pacífico es también la manifestación de otro componente de la globalización unipolar: el retraimiento de China. Desde la perspectiva americana, el suceso se vislumbra con la decadencia del galeón de Manila, el descenso de productos chinos (principalmente la seda) en los mercados consumidores americanos y en la movilización transatlántica de los textiles de la India, espacio que desplaza paulatinamente a China como centro de la región asiática.

Dos excelentes casos ilustran el retroceso de la economía China sobre el mercado americano. En 1803, la provincia de Guadalajara comunica los bienes no americanos importados para el consumo de su población. En su estadística resume que el "consumo en valores de productos de efectos de Castilla es de 1299472 pesos, mientras que lo correspondiente a bienes asiáticos ronda los 288720". ${ }^{2}$ Pensemos que en esa época San Blas, puerto oficial del mercado de Guadalajara, dispone asiduamente de la llegada

2 Silva-Herzog, 1944, vol. III, p. 116. 
del galeón de Manila que reemplaza al surgidero tradicional de Acapulco. Sin embargo, aun siendo el mercado mexicano de mayor influencia en el comercio transpacífico, el comercio asiático representa tan sólo $22 \%$ del valor total de los bienes castellanos que ingresan. El informe de Guadalajara llega a señalar que la mayoría de los bienes orientales que llegan a su mercado proceden de Veracruz o de la Ciudad de México y no de sus puertos del Pacífico. ${ }^{3}$ El segundo caso lo atestigua Lucas Alamán, para quien la gravitación de la economía asiática en México en el primer cuarto del siglo xix era sólo un recuerdo, dado el avance irremediable de la economía británica: "con el comercio de Asia ha sucedido lo mismo, pues la perfección, buen gusto y baratura de las manufacturas inglesas y francesas, ha hecho que se estimen menos las de China y de la India, que se recibían por la vía de Manila y que apenas son y conocidas en los mercados mexicanos". ${ }^{4}$

El presente capítulo busca identificar y explicar las razones que contribuyen a la desaparición de este tejido comercial colonial que posiciona en el largo acontecer colonial a la Ciudad México como centro y del que nos hemos ocupado en los anteriores capítulos. Nos encontramos lejos de presentar un acabado esquema mercantil constituido en Hispanoamérica a partir de 1750; problemática de notable magnitud e imposible de sintetizar aquí. Pero, si el objetivo es reconocer los factores que propician la desintegración del escenario geopolítico y mercantil que hemos comunicado en los capítulos I y II, debemos atender los nuevos "hilos", las transformaciones en las conexiones y el nuevo mapa que se configura a nivel continental desde la segunda mitad del siglo. La interpretación que presentamos sólo es posible si se toma como referencia tanto los estudios dedicados a los cambios económicos y políticos ocurridos en regiones y virreinatos durante las reformas borbónicas, como a los trabajos de política

3 "El comercio de Europa y Asia se ejecuta comprando los géneros de la primera en Veracruz y los de la segunda en México, a excepción de una y otra vez que se hace la feria de Acapulco y entonces acuden allí a proveerse de primera mano", Relaciones estadísticas, 1944, vol. III, p. 111.

4 Alamán, [1850] (1985), vol. III, p. 38. 
económica que bajo un abordaje de Estado-nación se ocupan del periodo de las emancipaciones iberoamericanas. ${ }^{5}$

Un abanico de interrogantes se presenta como una excelente caja de herramientas para nuestro análisis. ¿Cuáles fueron las causas que provocan los cambios estructurales en los circuitos imperiales y globales en torno a Hispanoamérica a partir de 1750? ¿Cómo explicar la pérdida de la centralidad de México, de haber sido punto de confluencia para los contactos con Asia, Europa y Sudamérica a pasar a ser un punto marginal del esquema económico? ¿Qué identidad cobró el Pacífico novohispano si notamos que los agentes de Lima y de la Ciudad de México pierden protagonismo en el área marítima? ¿Podemos seguir sosteniendo aquella definición del Pacífico indiano, ese espacio autónomo más vinculado al espacio asiático que al europeo? $\mathrm{O}$, por contrario, ¿el Pacífico se verá envuelto y condicionado por la revolución del comercio y consumo promovido por las potencias europeas, en particular, por Gran Bretaña y Norteamérica en un contexto de expansión del liberalismo económico? ¿Qué ocurrió hacia 1750 para que el galeón de Manila inicie su decadencia y se desvanezca como correa principal en la relación entre Asia e Hispanoamérica? Este capítulo es un primer acercamiento a estas grandes problemáticas, sabiendo que cada una ellas merecen en el futuro un estudio independiente.

Desde 1750 aparecen contundentes señales de la situación terminal de aquel tejido comercial visto en el capítulo I y II que ubicaba al Pacífico y a la Ciudad de México como epicentros. Identificamos, en principio, cuatro causas de su desvanecimiento; todas ellas elementos constitutivos de la atlantización del Pacífico: a) la apertura peninsular de la vía mercantil por el Cabo de Hornos para alcanzar los mercados del Pacífico hispanoamericano y China, debido al fin del sistema de galeones por Portobelo; $b$ ) la crisis del galeón y las ferias de Acapulco, con la consecuente desapari-

5 Sería injusto citar aquí la enorme lista de los trabajos consultados. El lector podrá encontrar en el apartado final de bibliografía las investigaciones consideradas en el armado del presente capítulo. 
ción del entronque de bienes extranjeros desde Acapulco hacia el Perú; c) el paquete de medidas borbónicas aplicado durante la segunda parte del siglo para un "libre comercio" entre Europa e Hispanoamérica, y d) la penetración y dominio efectivo de la economía europea en todos los mercados hispanoamericanos.

Si el objetivo es analizar cada uno de los factores que llevaron a la descomposición del modelo comercial colonial, el análisis debería extenderse hasta las primeras décadas del siglo XIX. La mayor parte de los fenómenos que ocasionan la crisis de la centralidad de la ciudad de México no parecen detenerse ni en las vísperas, ni en el momento en que se produce la independencia. La emancipación política vendría, más bien, a profundizar el papel de periferia de la Ciudad de México en la economía internacional; un proceso que se anticipa con las reformas borbónicas.

¿Cuál es la razón de extender nuestro análisis hasta la cuarta década del siglo XIX? Es que es hasta entonces continúan vigentes los factores que provocan la descentralización del espacio mexicano. En la segunda mitad de la centuria reinará una nueva estructura comercial que envolverá al Pacífico mexicano en su función de espacio mediador entre Europa, Panamá y la ciudad de San Francisco. La nueva red estará propiciada, en gran medida, por la fiebre de oro de California (1840) y la construcción de la vía férrea por el istmo de Panamá (1855). ${ }^{6}$

\section{CRIsis y DeSCOMPosición Del PACífico INDIANo}

El mundo económico independiente y gravitante, concretamente americano, que resulta ser el Pacífico desde finales del siglo XVI inicia su fase de crisis a partir de 1750, con las políticas del reformismo borbónico. La crisis del Pacífico indiano se manifiesta en

${ }^{6} \mathrm{El}$ análisis del nuevo tejido económico de la segunda mitad del siglo xIX supera la atención de esta comunicación. Pero vale mencionar que, desde entonces, el Pacífico mexicano, que contará con Mazatlán como puerto nodal, se subsume a un nuevo eje de la economía mundial, reemplazando o, más bien, desplazando el derrotero transcontinental por el Cabo de Hornos como punto interoceánico dominante. Busto Ibarra, 2008. 
el desmoronamiento de sus dos grandes "columnas": el comercio del galeón de Manila y la nueva modalidad que asume la relación entre México y el Pacífico sudamericano. No habría que perder de vista que ambos fenómenos son reflejo de un hecho histórico a escala global: la atlantización o europeización de la economía marítima del Pacífico.

\section{Agonía del galeón de Manila y de la feria de Acapulco}

A partir de una lectura monárquica hispanista, devenida en una interpretación histórica sobre la emergencia de los Estados-nación, la literatura clásica asoció el quiebre del enlace transpacífico de la nao del Oriente con la independencia política mexicana y el conflicto bélico con la Francia napoleónica. Quizá la interpretación más emblemática sea la que ofreció Pierre Chaunu en su clásica obra Las Filipinas y el Pacífico de los ibéricos. Su hipótesis sería la siguiente: "más que las empresas capitalistas gaditanas del siglo XVIII es la emancipación política de México y de toda Hispanoamérica y la convulsión del Atlántico lo que termina por quebrar el venerable enlace transpacífico del Galeón, del cual dependió a lo largo de más de dos siglos la existencia política de las Filipinas españolas".

Una lectura alternativa, anclada en una perspectiva de Estado-nación sobre la declinación y desaparición del galeón de Manila, la ofrece Valdés Lakowsky, para quien la toma de Acapulco y del tradicional navío transpacífico por parte de los insurgentes al mando de Morelos en los últimos meses de 1810 obliga al definitivo cierre del eje transpacífico para la Monarquía hispánica, suponiendo que décadas atrás no había abandono de facto en el circuito y su feria. ${ }^{8}$ Aportaciones más recientes hacen énfasis en coyunturas precisas, asociando su crisis al conflicto bélico entre España e Inglaterra de mediados del siglo. Las fortunas que se

7 Chaunu, 1974, p. 26. Véase también el clásico libro de Díaz Trechuelo, 1965.

8 Valdés Lakowsky, 1987, p. 213-231. 
transportaban en la nao oriental habrían sido objeto de interés de las demás potencias europeas, particularmente por Inglaterra, dueña de mares y océanos en ese tiempo. De esta manera, se dice que el debacle del galeón de Manila comenzaría con la captura en el año 1743 de los tesoros en plata de la nao Covadonga por el pirata inglés Anson. ${ }^{9}$ La crisis vendría a agudizarse veinte años después, en 1762, con la invasión y ocupación de los ingleses de la ciudad de Manila. Siguiendo la línea de proposición, se dice que la ocupación extranjera llevaría a que los agentes novohispanos y filipinos muestren un desinterés por invertir sus caudales sobre una ruta riesgosa y poco segura. ${ }^{10}$ Ciertamente, la ocupación británica del archipiélago genera fuertes repercusiones no sólo en el plano comercial, sino que reformula la tradicional política económica sobre el archipiélago: de su función meramente comercial se comienza a atender sus potencialidades a nivel de producción agrícola y de centro geopolítico ligado a los intereses de la Monarquía. ${ }^{11}$ Sin embargo, sería apresurado pensar en una coyuntura conflictiva como explicación de la crisis de la nao de China, una crisis que se prolonga hasta su definitiva desaparición entre los años 1813 y $1815 .^{12}$

Aquí proponemos una explicación estructural de su caída. Todos los factores serán tema de análisis en el capítulo, pero vale enunciarlos. En primer lugar, la institucionalización del eje mercantil por el Cabo de Hornos, producto de la desaparición de las flotas de Portobelo (1739), es una causa fundamental para que el galeón de Manila no goce del auge mercantil y de la capacidad

9 Desde 1766 hasta 1780, Manuel García fue obispo del Convento de San Esteban de las Islas Filipinas, en AGI, Filipinas, 1029, núm. 13, s/n de fs. En su Representación de Comercio señala que Anson logró capturar tres millones y medio en plata que salieron desde Acapulco hacia Manila. AHCIs, film 220, García, Representación del comercio, f. 6. Agradezco al Dr. Jean Sánchez por brindarme el acceso del documento del obispo.

10 Álvarez, 2007, pp. 206-207; Yuste, 2007, pp. 149-150.

11 Alfonso Mola y Martínez Shaw, 2013, pp. 307-340; Bonialian, 2012, pp. 398-400.

12 Contamos con un documento que expresa la suspensión del galeón de Manila en septiembre de 1813 y el permiso para realizar un comercio directo con China a través de barcos particulares entre Filipinas, Acapulco y San Blas, véase AGNM, Instituciones coloniales, Reales Cédulas originales, vol. 209, exp. 166, f. 1. 
para gravitar sobre el mundo atlántico que, como vimos en capítulos anteriores, lo había logrado (1580-1740). El mercado del virreinato del Perú, que antes de 1750 se posiciona como un mercado consumidor por excelencia de los bienes asiáticos traídos por el galeón hacia Acapulco, ahora tendrá respuesta por la vía directa de los navíos de registro españoles a través del Cabo de Hornos. Estos nuevos barcos españoles le causan gran daño al eje Ciudad de México-Acapulco al comprometer su función histórica de eje reexportador de bienes asiáticos y europeos al mercado peruano.

En segundo lugar, la presencia de agentes mercantiles peninsulares con sus respectivas compañías de comercio desde 1760, año en que se inician las medidas borbónicas de "libre comercio" por el Pacífico, no hacen más que cuestionar el papel dominante de los comerciantes novohispanos en el eje transpacífico. Los órganos mercantiles tienen la autorización de importar bienes asiáticos por todos los puertos del Pacífico hispanoamericano a cambio de la plata del Perú y de la Nueva España, cuyas minas registran niveles de producción elevados, inéditos para el caso de la Nueva España (gráfica II.4). ${ }^{13}$ Si bien es cierto que muchos comerciantes peninsulares depositan sus capitales en la nao de China, también compiten de manera exitosa con el galéon usando sus propios navíos, acción que compromete el antiguo monopolio novohispano de las empresas españolas. ${ }^{14}$

13 Los estudios reconocen que la producción de plata americana registró un boom durante la segunda mitad del siglo xviII. En la primera mitad de la centuria, Perú continúa registrando un estancamiento de su producción, que repunta en las décadas finales. Nueva España, tomará la vanguardia como espacio productor metalífero del mundo hacia 1770. Véase Cross, 1983, p. 403.

14 ¿Cuáles son estas corporaciones mercantiles peninsulares que se fundan en la segunda mitad del siglo? Aparece la línea de navíos de guerra el Buen Consejo y Venus (1765); posteriormente, vemos actuar a la compañía de los Cinco Gremios Mayores de Madrid (1776) y la compañía que nace en 1779 de Uztáriz, San Ginés y Compañía, con su navío el Hércules que circula por el Pacífico novohispano, el Callao y Filipinas. Pero sin lugar a dudas, entre las compañías españolas que se fundan para el trato transpacífico, la Real Compañía de Filipinas, fundada en el año 1785, es el proyecto más ambicioso y la que tuvo mayor importancia en el comercio. 
Un tercer fenómeno que ocurre de manera simultánea al proceso de libre comercio por el Pacífico es lo que denominamos aquí la atlantización del comercio asiático. El quebranto del galeón de Manila y de su feria en Acapulco obedece también al proceso de rotación de la contratación asiática y a la introducción de bienes orientales por la vía de Veracruz, de Panamá y otros puertos hispanoamericanos. El tráfico de mercancías británicas y, en menor medida asiáticas, desde Jamaica, pasando por Panamá hasta San Blas y Acapulco comprime de manera significativa el surtimiento de algodones de la India que el galeón de Manila movilizaba décadas atrás. Filipinas irá perdiendo su papel de centro abastecedor de textiles hindúes para el mercado mexicano y será remplazado por el canal de surtimiento Panamá, acometiéndole el último golpe a la tradicional navegación transpacífica. El fenómeno de la atlantización del comercio asiático intensifica sus efectos en las primeras décadas del siglo XIX. Así, la economía del Atlántico despoja al Pacífico de aquella pieza dominante que le otorgaba dinámica y autonomía. Serían estos tres acontecimientos los que propician el declive del comercio asiático a través del galeón de Manila. Cada uno de los fenómenos apuntados merecerá un apartado particular de análisis.

De momento, veamos la evolución que registra la importación de piezas orientales en los cargamentos del galeón de Manila durante el transcurso del siglo XVIII. El cuadro III.1 y la gráfica III.1 tratan sobre las cantidades de fardos orientales que importa la nao de China por Acapulco para su consumo en México durante el periodo comprendido entre 1709 y 1788. De ellas se desprenden varias observaciones significativas.

La gráfica III.1 ilustra que desde los inicios del siglo XVII hasta 1744 el galeón de Manila introduce por Acapulco una enorme cantidad de piezas chinas y del Oriente. Son tiempos en que opera el Pacífico indiano. Con sólo atender sus niveles y cantidades, se percibe el estado de esplendor del cargamento del navío y del enorme apetito del mercado indiano por los productos orientales. En capítulos anteriores hemos argumentado que el número elevado de piezas importadas por Acapulco no responde exclusivamente al 


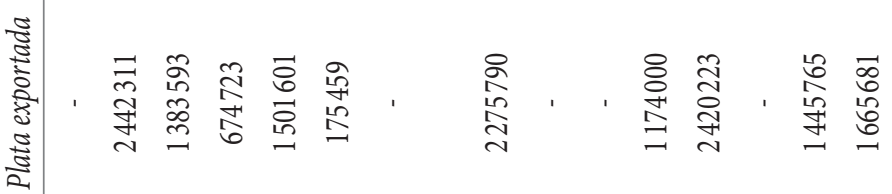

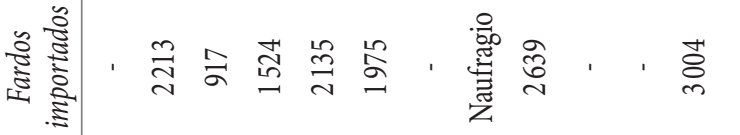

$$
\begin{aligned}
& \text { รี कี }
\end{aligned}
$$

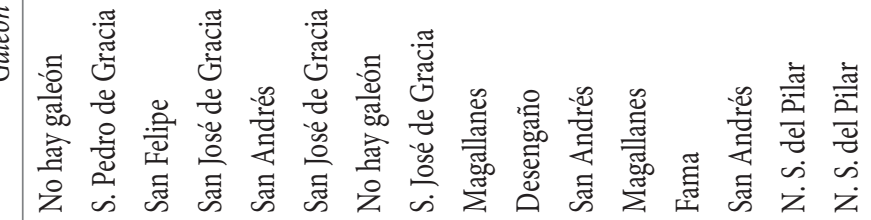

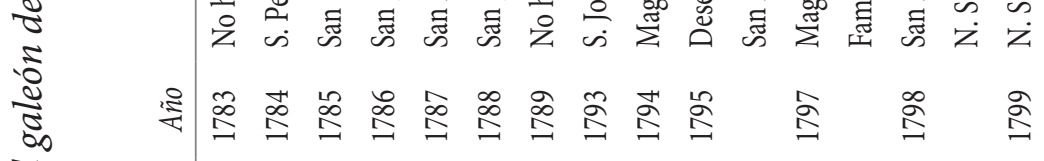

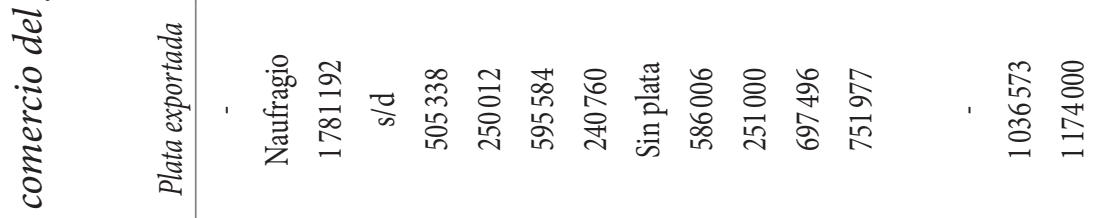

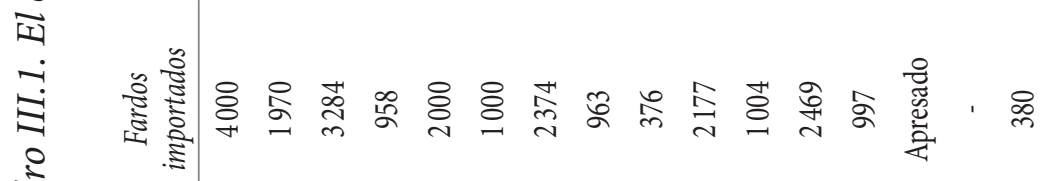

$$
\begin{aligned}
& \text { 촣 }
\end{aligned}
$$

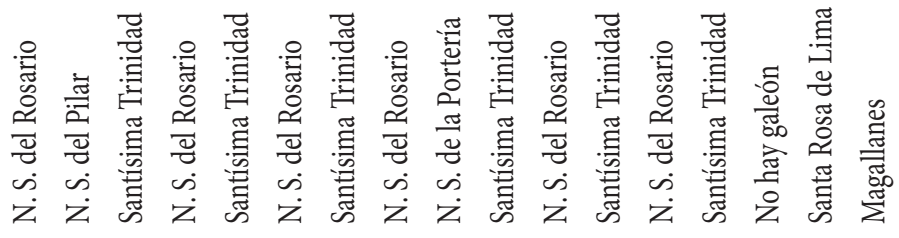

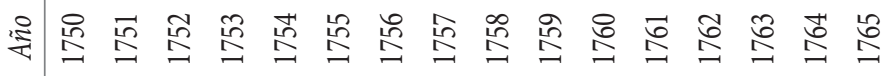

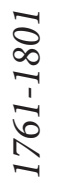$$
\text { 音 }
$$ 


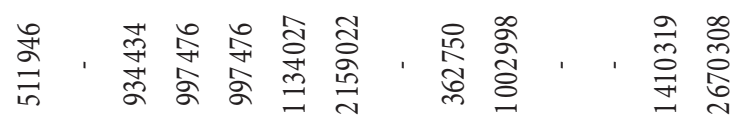

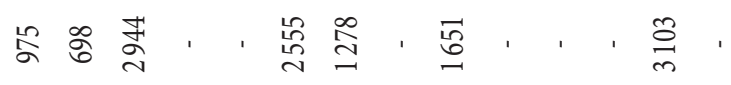

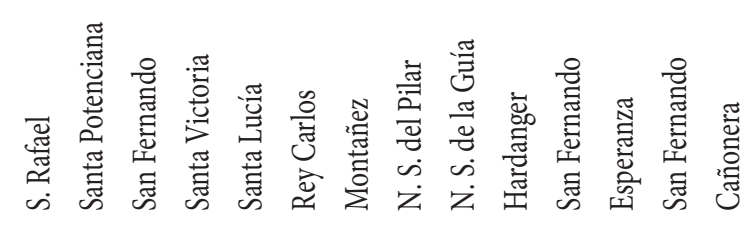

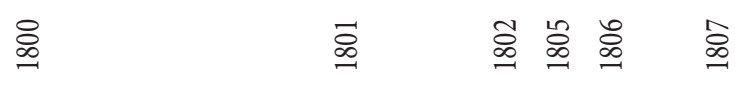

突

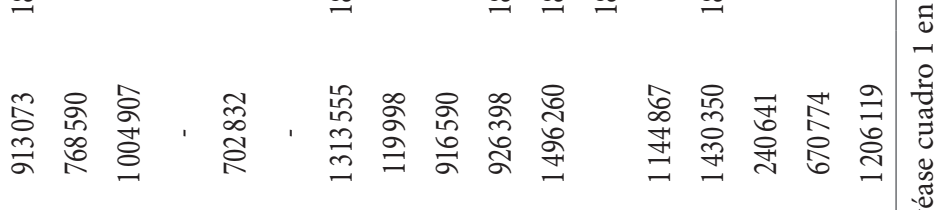

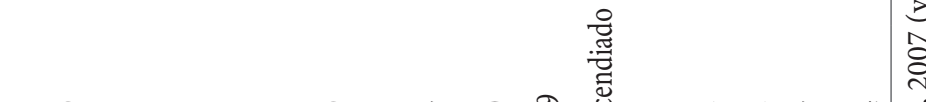

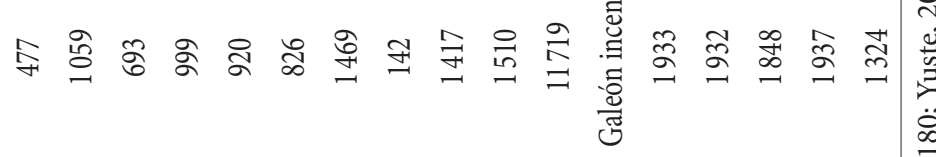

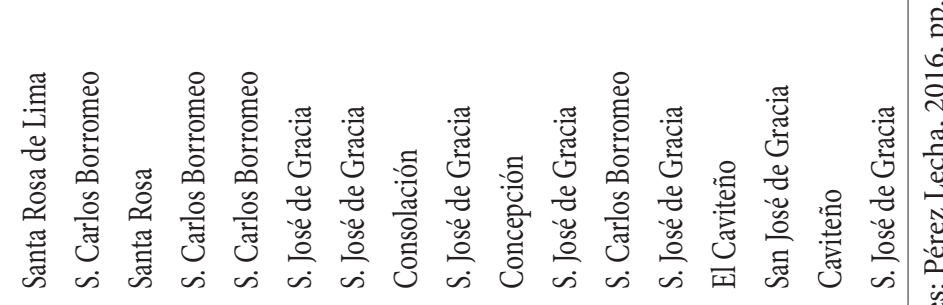

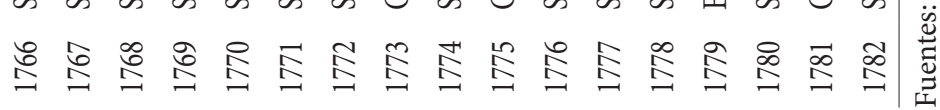


mercado novohispano, sino también a las plazas de Centroamérica y del Perú. Mucho de ello se expresa en la gráfica III.1. Al inicio del segundo cuarto del siglo xviII, la Corona intenta controlar sus ingresos con medidas de restricción y regulación. En 1720, el poder metropolitano ordena un tope máximo de 4000 piezas por cada viaje. ${ }^{15}$ No obstante, los cargamentos superan lo estipulado por la legislación. En 1699 se presenta por Acapulco la nao del Oriente con un cargamento de 6754 piezas de efectos asiáticos que corresponden a los "vecinos de México". ${ }^{16}$ En 1713, el Santo Cristo de Burgos desembarca 5359 piezas orientales. Ese mismo galeón, una década después, vuelve a superar las expectativas: ofrece en la feria de Acapulco la increíble suma de 6135 piezas. Los casos abundan: unos superando las 5000 y casi nunca bajan de las 3000 piezas. La gráfica pone de relieve que en varios años se registran cargamentos que respetan las 4000 piezas. Pero esos registros máximos son expresión de una adicional carga que ingresa informalmente. El piso de importación en esta primera mitad del siglo también es elevado: las cantidades de piezas asiáticas desembarcadas por Acapulco no bajan de las 3000 anuales.

Ahora bien, un escenario opuesto se registra al iniciar la segunda mitad del siglo. La caída de las importaciones de bienes asiáticos es notable y no parece detenerse ni recuperarse hasta su desaparición. Aunque entre 1750 y 1790 existen coyunturas de recuperación, los tibios impulsos obedecen a fenómenos coyunturales y contextuales que no pueden disimular el descenso y la agonía estructural. En contados años que van de 1750 a 1788 la carga supera las 2000 piezas, una cifra que representa tan sólo la mitad o menos del promedio anual del primer periodo. Estas cantidades se encuentran muy por debajo de los 4000 fardos que la ley permite transportar hacia Acapulco o San Blas. En 1756, el galeón de Manila moviliza la ínfima cantidad de 376

15 Bonialian, 2012, p. 43.

16 Hecho mencionado en el capítulo anterior. Álvarez de Abreu, [1736] 1977, t. I, pp. 235-237. 

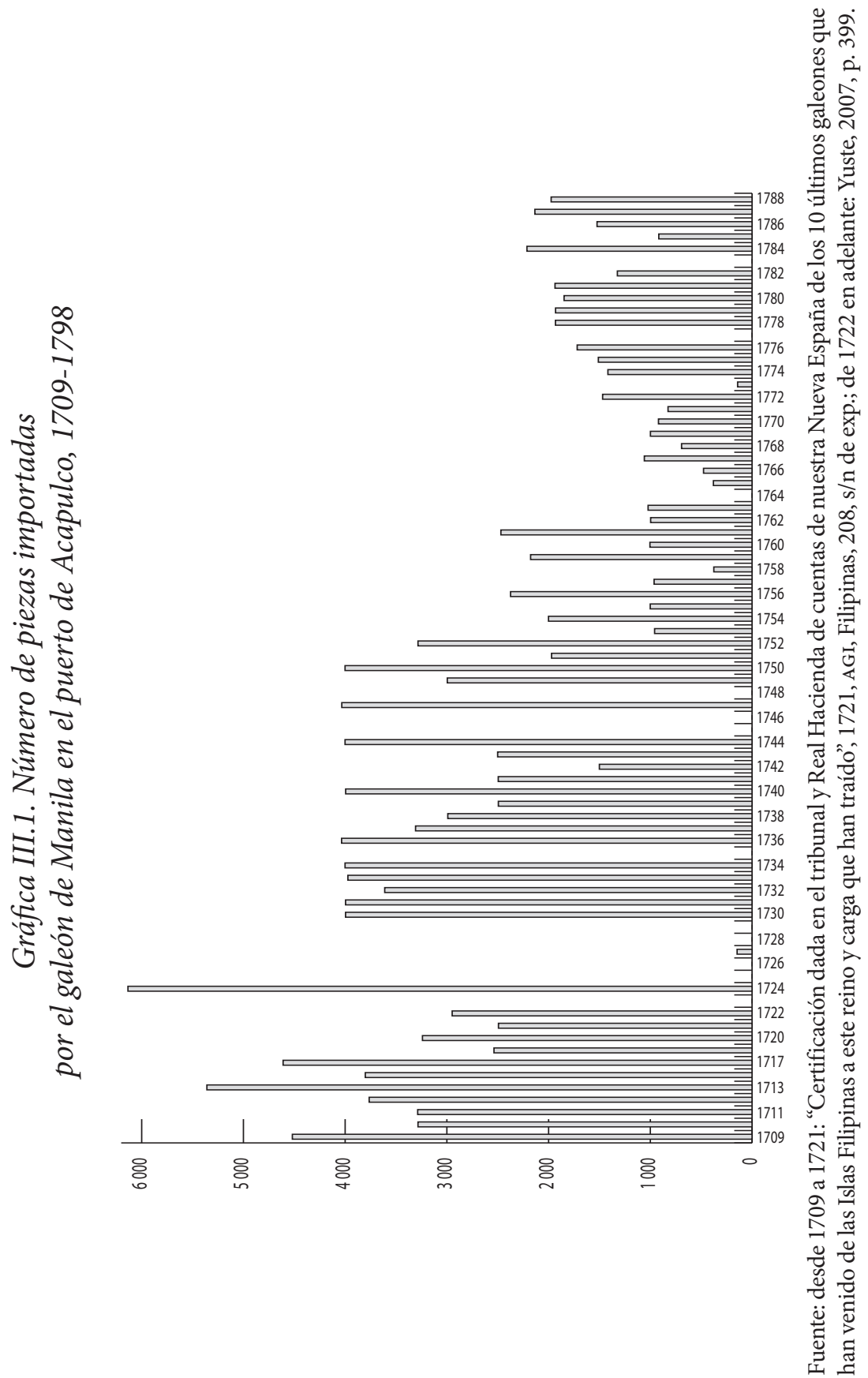
piezas. ${ }^{17}$ La técnica náutica para la construcción de barcos por el Pacífico avanza en estos tiempos, logrando que los galeones sean más sofisticados y con bodegas más amplias. Nuevos barcos permiten llevar entre 18 y 20000 piezas, que pasan de una capacidad de tonelaje de 1000 a más de $2000 .{ }^{18}$ Sin embargo, los progresos tecnológicos náuticos no se ven acompañados por el ritmo comercial: el galeón parece operar con 10 o 15\% de su capacidad.

Por otro lado, y como fiel espejo del descenso de sus importaciones, el cuadro III.1 manifiesta la significativa disminución de las cantidades de plata peruana y novohispana que la nao exporta hacia las Islas Filipinas. Más adelante se verá la nueva modalidad de circulación del metálico peruano. De momento, digamos que es una rareza ver plata peruana en los cargamentos de los galeones de la segunda mitad del siglo xvir. Si entre 1560 y 1740 la plata peruana fue algo común en los envíos transpacífico, desde la segunda mitad del siglo iniciará su circulación con dirección hacia el sur, destinándose a España y a Europa a través de la vía del Cabo de Hornos. Hay una salvedad: la Real Compañía de Filipinas que extrae desde el puerto de el Callao monedas de plata para intercambiar en los puertos de Cantón y de Cavite por productos del Oriente en algunos años desde su fundación (1785). ${ }^{19}$ Pero, como veremos más adelante, la gran masa de metálico peruano fluye hacia el Atlántico vía Cabo de Hornos.

Lo cierto es que si el galeón exporta más de un millón y medio de pesos en cada viaje hacia el Oriente será todo un éxito; lejos de las expectativas de las primeras décadas del siglo XVIII, cuando lo común se estimaba entre los tres y cuatro millones de pesos por año. Valdría precisar que el total de las cantidades anuales de plata que figuran en el cuadro III. 1 incluyen otros rubros y no sólo dinero de comercio; comprende, además, el dinero enviado

17 Para mayores detalles y datos sobre la decadencia del galeón, véase "Informe del 'comercio de Manila' al Consejo de Indias sobre alteraciones de comercio, 1753", AGI, Filipinas, 268, s/n de exp. Véase también el informe del fiscal Leandro de Viana de 1767, "Informe de los abusos de este comercio, 1767"; AGI, Filipinas, 941, s/n de exp.

18 Schurz, [1939] 1992, p. 188; Valdez-Bubnov, 2017, pp. 73-74.

19 Díaz Trechuelo, 1965. 
por la Corona para el mantenimiento de los galeones, el valor en plata de otros productos movilizados para Filipinas (ejemplo: barajas, salitre, cacao, etcétera), la plata para fundaciones piadosas u obras pías, entre otros rubros. De esta manera, las exportaciones de plata en concepto exclusivo de comercio son en realidad menores a esos totales que de por sí son reducidos. El caso de los galeones el Montañez y el Rey Carlos de 1801, presentado en el cuadro III.2 es representativo. Entre ambos, trasladan más de tres millones de pesos hacia Filipinas; pero en concepto de dinero de comercio la sumatoria alcanza un poco más de dos millones.

\section{Cuadro III.2. Carga que conducen a las Islas Filipinas el navio el Montañez y la nao Rey Carlos (1801)}

El Montañez

Rey Carlos

\begin{tabular}{|c|c|c|c|}
\hline $\begin{array}{l}\text { Para la escuadra en } \\
\text { dinero de su Majestad }\end{array}$ & 490267 & $\begin{array}{l}\text { De misioneros en } \\
\text { dinero }\end{array}$ & 19333 \\
\hline $\begin{array}{l}\text { Para las atenciones de } \\
\text { su Majestad }\end{array}$ & 360117 & $\begin{array}{l}\text { De la obra pía de la } \\
\text { Madre Paula }\end{array}$ & 300 \\
\hline $\begin{array}{l}\text { De las monjas de la } \\
\text { Concepción }\end{array}$ & 2000 & Del comercio en dinero & 999098 \\
\hline Del comercio en dinero & 1257818 & Del comercio en frutos & 115295 \\
\hline Del comercio en frutos & 48819 & 29 cajones de medicina & \\
\hline $\begin{array}{l}46 \text { cajones de barajas } \\
\text { de su Majestad }\end{array}$ & & $\begin{array}{l}500 \text { cajones de salitre } \\
\text { sencillo de su Majestad }\end{array}$ & \\
\hline \multicolumn{4}{|l|}{$\begin{array}{l}500 \text { cajones salitre sen- } \\
\text { cillo de su Majestad }\end{array}$} \\
\hline Total & 2159022 & Total & 1134027 \\
\hline \multicolumn{4}{|l|}{ Total: 3293049} \\
\hline
\end{tabular}

Fuente: AGNM, Indiferente virreinal, industria y comercio, caja 4322, exp. 4111, fs. 13-15.

La mesura nos llama a no caer en simplificaciones. El descenso de las exportaciones de plata por parte del galeón de Manila no significa una caída general de las exportaciones de metálico por el Pacífico mexicano, sea en su escape hacia el Oriente o hacia 
Europa por el Atlántico. Si sumamos todas las modalidades de comercio que se gestan desde finales del siglo xviII y principios del xix - compañías peninsulares, balleneros británicos y angloamericanos, y navíos centroamericanos y británicos desde San Blas hacia Panamá- ${ }^{20}$ se concluye que los volúmenes de plata mexicana que salen desde el espacio occidental son más elevados con relación a la primera mitad de la centuria, expresando el crecimiento de la producción de metálico que se vive en la Nueva España.

También se debe reconocer que el descenso de la exportación de plata novohispana a través del galeón de Manila rumbo a Filipinas obedece a sus nuevos destinos. Es decir, la plata novohispana que sale desde el Pacífico no tiene como único destino el Imperio Celeste. Apenas comenzada la guerra de independencia de Estados Unidos (1779) y Gran Bretaña, los pesos de plata empiezan a circular intensamente y llegan a ser la moneda oficial en el mercado interno. La plata mexicana se convierte en la reserva metálica de su nuevo papel moneda, el dólar. El flamante Congreso Nacional estadounidense sólo acepta letras de cambio en "dólares de acuñación española”, declarando al peso mexicano como la unidad monetaria nacional para los intercambios; un medio de cambio dominante que se mantendrá hasta $1857 .{ }^{21}$ De esta manera, la caída de las exportaciones de metálico del galeón de Manila obedece a la aparición de nuevos mercados externos que desean contar con la moneda novohispana.

Los reiterados conflictos bélicos del último cuarto del siglo no generan el mismo efecto en el comercio del galeón. En una tendencia secular a la baja, la guerra puede "oxigenar" o agudizar el descenso de su comercio; depende de las particularidades del conflicto y del espacio en que se suscita. La toma de Manila por los ingleses en 1763 impide que el galeón parta hacia Acapulco en ese año. Pero en años previos, cuando la guerra está presente, como es 1759 o 1761, el galeón alcanza un número de piezas 
superior a las 2000; una cantidad alta para la segunda mitad del siglo y que en pocas oportunidades se llega a igualar o superar. Desde que España logra recuperar Manila y en los años subsiguientes de paz, el comercio del galeón vivirá su peor momento: el cargamento ocasionalmente llega a las 1000 piezas hasta no poder embarcar más de 500. La guerra con Inglaterra en el contexto de la independencia de las trece colonias produce un hecho singular. Entre 1780 y 1784 el galeón muestra una breve revitalización: introduce 2000 o más piezas al puerto de Acapulco. En este caso, pensamos que el bloqueo inglés en el Atlántico permite "liberar" el comercio del galeón para cubrir las necesidades que no sólo necesita Nueva España sino también el Perú. Es decir, la incorporación oficial y circunstancial de la economía peruana al comercio transpacífico "oxigena”, al menos hasta 1784, el tráfico del galeón.

Si bien nuestra gráfica finaliza en 1788, podríamos extender el análisis sobre el declive del galeón durante la guerra con Francia, entre 1793 y 1795. Sólo un galeón llega a Acapulco en esos años, el San Fernando, con 2639 piezas en 1794. La guerra del Rosellón no parece influir en su declive. Pero la respetable carga trasladada se explicaría porque en años previos y posteriores no arriba ningún galeón al puerto de Acapulco. El último conflicto del siglo que España mantiene con Inglaterra (1796-1805) produce una breve revitalización de la nave transpacífica hasta su desaparición definitiva (1815). En esos años, aparecen galeones escoltados por otros convoyes que trasladan más de 3000 piezas anuales hacia Acapulco o San Blas. El inconveniente del suministro por la vía Atlántica, producto del bloqueo y de la presencia británica, hace ensanchar el surgidero de abastecimiento de la tradicional nao.

Lo fundamental en nuestro argumento es que el galeón de Manila, como pieza clave del lago indiano - esto es, como el lazo que unía los intereses de los grandes comerciantes de la Ciudad de México con la economía asiática-, ingresa a una fase de declinación. No es casual que los caudales de plata del galeón de Manila que figuran en el cuadro III.1 correspondan, en su mayor 
parte, a los mercaderes del flamante consulado de Manila, en 1769, cuando antes eran los comerciantes novohispanos quienes controlaban los envíos de metálico hacia las Islas Filipinas. ${ }^{22}$

Tampoco resulta casual que el puerto de Acapulco padezca la decadencia del galeón. Su famosa feria, que le inyectaba vida al puerto, perderá fuerza, sumergiéndose en un prolongado estado de inestabilidad económica y pobreza social. Suspensión de ferias, galeones semivacíos o con cargas invendibles serán las noticias más recurrentes del periodo. Así lo dirá Manuel García, obispo del convento de San Esteban de las Islas Filipinas entre 1766 y 1780. En su Representación del Comercio señala que "en el año 86 salió de Manila el navío San Andrés con dos millones de pesos de principal: el año siguiente salió el San Joseph con otra carga más interesada y ninguno de los dos hicieron feria, ya por lo exorbitante de sus cargas o ya por estar abastecido el reino de México con motivo del libre comercio". ${ }^{23}$

Si la carga de la nao de China no se consume o es poco estimada se debe a que el mercado novohispano se encuentra importando objetos asiáticos por otros puertos u otras vías comerciales, con el acelerado ritmo que impone la política de "libre comercio". Las medidas de libre comercio erosionan la exclusividad que tenía el puerto para la contratación asiática. "Decadencia", "falta de fondos", "subsistencia", "estado deplorable", "quiebra", "precios abatidos" son sólo algunas de las tantas referencias negativas apuntadas por los funcionarios y mercaderes sobre el galeón y su feria. ${ }^{24}$ En 1767, el contador general de Indias Tomás Ortiz de Landazuri afirma que "la nao de Filipinas no produce por sí ni puede la introducción de ropas de China al Perú ni Tierra firme;

22 Pérez Lecha, 2016, pp. 163-180.

${ }^{23}$ AHCIs, film 220, García, Representación, f. 7; AGI, Filipinas, 1029, núm. 13, s/n de fs.

24 Sobre el informe del marqués de Ovando de 1754, véase AGI, Filipinas, 335, leg. 16, f. 436. Sobre los informes de su sucesor, Manuel de Arandía, véase AGNM, Instituciones Coloniales, Filipinas, vol. 3, exp. 18, f. 316v; "Cartas al virrey referentes al tráfico comercial de las Islas Filipinas, 1755”, AGNM, Instituciones Coloniales, Indiferente virreinal, caja 3693, exp. 18, f. 18. 
que por el contrario aún no presta las necesarias para los parajes adonde vienen destinadas a México". ${ }^{25}$

Enseguida nos ocuparemos de lo que ocurre en el espacio peruano. De momento, atendamos lo que el contador madrileño apunta de la poca resonancia del galeón de Manila en el propio mercado novohispano. Como sistema comercial, los galeones y las ferias de Acapulco sufren desde la segunda parte del siglo XviII un fuerte cuestionamiento desde el poder peninsular. En lo que respecta al área del Pacífico hispanoamericano, los puertos de San Blas y el limeño de el Callao son autorizados a participar en el comercio asiático. Se quiebra así el eje mercantil tradicional que unía a Filipinas y la Ciudad de México, a través de la exclusividad del puerto único que históricamente residía en Acapulco. La crisis de Acapulco golpea la centralidad de la Ciudad de México.

En 1796, el virrey de la Nueva España, Branciforte, le advierte a la Corona que la política más adecuada para recuperar la vitalidad del galeón de Manila es desplazar su punto oficial de salida y de destino a San Blas y celebrar una feria en Tepic. El traslado ayudaría no sólo a reimpulsar el comercio del galeón dada la respuesta que daría el mercado de Guadalajara, sino también a posicionar el surgidero de Tepic como punto dinamizador de las economías del área noroccidental novohispana. ${ }^{26}$ La propuesta

25 García Fuentes, 1980, p. 41.

26 Para el virrey Branciforte, resulta de suma urgencia que el galeón de Manila recalara en San Blas y organice su feria en Tepic, en la medida que forzaría a la comandancia de las Provincias Internas a una mayor relación con el centro político en México, consolidaría la sede central de Marina en el apostadero de San Blas y promovería la apertura comercial entre el Pacífico mexicano con la América meridional. Para el virrey, estas medidas llevarían a la restauración e integración de un área occidental de la Monarquía hispánica que se encuentra fragmentada. Para el virrey los tres fenómenos se encontraban íntimamente relacionados. Facilitarían la población de la provincia de California y el aumento de la de Sonora y Sinaloa en las que ésta era escasa. Obligando a la nao de China a recalar en San Blas (y ya no en Acapulco), el centro de Tepic lograría convertirse en un importante centro de acopio y abasto para los mercados de las provincias internas, mucho más cercano que Acapulco y que la Ciudad de México. Fomentaría la producción de minerales, la actividad de extracción de perlas preciosas en sus aguas y el beneficio de la peletería. Reanimaría la economía del reino de Nueva Vizcaya, de la Nueva Galicia y la expansión monárquica hacia tierras abandonadas de 
no es más que institucionalizar un hecho existente, pues los propios barcos de las compañías españolas o la propia nao de China priorizan el contacto con el mercader de Guadalajara antes que de Acapulco. Al mismo tiempo, el pensamiento del virrey pone al descubierto la vulnerabilidad y el aislamiento que sufren los mercados internos noroccidentales. ${ }^{27}$ La respuesta llegará con cierta tardanza, con la construcción del enlace directo entre San Blas y Panamá que promueven los británicos en los años iniciales del siglo XIx; tema del que trataremos más adelante.

El proceso de crisis del galeón de Manila y del eje Acapulco-Ciudad de México puede que no sea el golpe "mortal" que reciben los mercaderes capitalinos. Al fin de cuentas, reconstruyen y reformulan sus redes a los nuevos tiempos de "libre comercio" de la política borbónica. ${ }^{28}$ Pero en el nuevo escenario de competencia en el trato oriental, la corporación entra en una disputa mercantil en la que no siempre saldrá beneficiada. Sobre los conflictos corporativos que se suscitan en la Nueva España nos ocuparemos más adelante. Por el momento, puntualicemos que el libre comercio, la participación de las elites regionales en el nuevo y múltiple entramado de circuitos y los nuevos ejes espaciales que se gestan por el virreinato son sólo algunos de los resultados desencadenantes del proceso de desmoronamiento de los antiguos ejes mercantiles.

Aquella centralidad asumida por la Ciudad de México en tiempos previos al reformismo borbónico, operando como un

Nuevo México. Véase "Branciforte acusa recibo R.O” (septiembre de 1796), AGI, Estado, 25, núm. 43 (1), s/n de fs.

27 Decía Branciforte: "De todo esto se deduce por natural consecuencia que como llevo indicado por fundamento de mi indicación a las descargas de la nao de Filipinas en San Blas, casi no hay otro medio que este para reanimar el comercio, la agricultura y la industria en los importantes establecimientos de California y demás provincias internas. La necesidad de facilitar las provisiones de ropas de China la reconoció $\mathrm{Su}$ Majestad [...] sería necesario aumentar el permiso de los 500000 pesos al comercio de Filipinas y el de su correspondiente regreso porque el mayor consumo de sus Provincias Internas ha de escasear los efectos a los comerciantes y pueblos del gobierno de Nueva España”, "Branciforte acusa recibo R.O” (septiembre de 1796), AGI, Estado, 25, núm. 43 (1), s/n de fs.

28 Álvarez, 2007, pp. 187-213; Yuste, 1987, pp. 189-217. 
"corazón bombeador" de mercaderías asiáticas y europeas hacia mercados internos del virreinato novohispano, de Centroamérica y de la América meridional perderá operatividad y significancia. De ahora en adelante, sus agentes no tendrán otra alternativa que ingresar al juego de la competencia con las nuevas elites comerciales regionales del virreinato, donde sobresalen los cuerpos mercantiles de Veracruz y de Guadalajara. ${ }^{29}$ La apertura portuaria y las conexiones directas entre puertos asiáticos con los hispanoamericanos permite que los agentes regionales relajen la rígida e histórica subordinación que hasta la primera mitad del siglo mantenían con la Ciudad de México para adquirir las mercancías asiáticas.

San Blas es el caso más representativo de cómo se desvanece el eje Acapulco-Ciudad de México, pues se convierte no sólo en bastión costero de la política borbónica, sino en el principal punto de intercambio del Pacífico gracias a la constitución del mercado consumidor Tepic-Guadalajara de los productos asiáticos. ${ }^{30}$ Hacia las primeras décadas del siglo XIX, cuando los británicos consolidan su dominio por las costas del Pacífico mexicano, San Blas seguirá siendo el punto elegido para los contactos directos con China o con la región norteña de California. Una de las primeras casas comerciales británicas que se instalaron en San Blas (1831) promueve un tráfico directo desde dicho puerto hacia Cantón, llevando grandes cantidades de plata para pagar productos chinos y del Oriente. ${ }^{31}$

Ahora bien, desde 1750 la crisis por Acapulco debería interpretarse con cierta mesura. El diagnóstico resulta válido si se le define como puerto global o por su incapacidad de posicionarse como "punta de lanza" de las políticas borbónicas de protección, poblamiento y desarrollo económico sobre el espacio noroccidental. Es decir, su declive como punto costero internacional se verifica por una doble crisis: de su relación con el Oriente asiático y

29 El problema se aborda en el apartado: "Fragmentación y disputa corporativa por los mercados regionales".

30 Ibarra, 2000; Ibarra, 2007, pp. 1017-1041.

31 McMaster, 1959, p. 382. 
como punto de redistribución informal de bienes de Asia y Europa hacia los restantes mercados del Pacífico hispanoamericano. ${ }^{32}$ Sería muy apresurado hablar de una crisis general de Acapulco al ver su respetable actividad en el intercambio de bienes locales entre la malla de puertos que van desde Chile hasta el norte de México desde 1760 hasta los años de la Independencia de México.

\section{Una nueva relación entre México y el Pacífico sudamericano}

Si el galeón de Manila pierde incidencia en la economía mexicana, será mucho más sensible sobre la realidad del Perú. Parece cierto que la nueva reorientación que asume la economía exterior del Perú es el factor clave para entender la agonía del galeón oriental y del proceso de desvanecimiento del eje Ciudad de México-Acapulco-Sudamérica. Vale precisar: a partir de la segunda mitad del siglo XVIII, el tradicional flujo de bienes asiáticos y europeos que veíamos deslizarse como una suerte de cascada y con escalas desde Acapulco hacia el espacio peruano comienza a ser un recuerdo. La definición de la ciudad de Lima como una histórica feria de Pekín no podría representar el escenario de la segunda mitad del siglo. ${ }^{33}$ El entronque comercial por el Mar del Sur, en su orientación norte-sur de productos extranjeros (asiáticos y europeos) y que definimos como uno de los "nervios principales" del lago indiano, prácticamente se extingue. ${ }^{34}$

¿Por qué se quiebra la conducción norte-sur de mercaderías asiáticas y europeas por el Pacífico hispanoamericano? La Real Compañía de Filipinas, fundada en 1785, abastece de bienes

32 Acapulco tendrá un reimpulso al comercio global hacia 1848, cuando su producción de carbón le permitirá colocarse como punto de escala de los barcos europeos y estadounidense en su viaje hacia puntos portuarios más significativos como Mazatlán y San Francisco, arrastrados por la fiebre del oro californiana. Véase al respecto: Busto, 2016, pp. 267-288.

33 Bonialian, 2014, p. 128.

34 El hecho lo podremos confirmar al analizar más adelante la información que aparece en el apéndice documental, cuadros AIII.1 y AIII.2. 
orientales al Perú, ya sea con procedencia europea o directamente desde el espacio asiático. ${ }^{35}$ Sin embargo, hay un hecho previo que también debería atenderse: Chile, Perú y Guayaquil y otros mercados menores de la franja pacífica se abastecerán de mercadería europea y asiática por la vía del Cabo de Hornos. Si antes de 1750 estas plazas importaban bienes europeos y asiáticos desde México, en comercio de escala y cabotaje desde Panamá o por la vía de Acapulco (con posibles escalas en Huatulco, Realejo o Sonsonate), comenzada la segunda parte del siglo la participación en el tráfico global del Pacífico sudamericano tomará una clara orientación hacia el sur. La nueva configuración de las rutas transatlánticas resignifica la relación entre México y el Pacífico sudamericano. La nueva orientación del circuito se verá notoriamente fortalecida al reproducir en una escala mayor desde 1790, con los barcos balleneros angloamericanos y británicos; problemática de enorme interés que desarrollaremos más adelante. Ambos fenómenos conforman el proceso de la atlantización del Pacífico sudamericano. Otra expresión de la atlantización del Pacífico se visualiza en el caso de Panamá, problemática a la que también le dedicaremos un apartado especial. Vale anticipar aquí que su histórica y tradicional gravitación en las economías y los mercados del Pacífico sur comienza a debilitarse desde 1740. En los años iniciales del siglo xix y luego de numerosas medidas que surgieron de las reformas borbónicas y que poco le beneficiaron, Panamá, a través de sus agentes mercantiles y funcionarios políticos, tomará una decisiva orientación para influir en los mercados del Pacífico mexicano, movilizando textiles ingleses y asiáticos que le llegan previamente desde Jamaica, el principal centro de distribución británico en Hispanoamérica.

Ahora bien, reconocemos dos esferas de circulación mercantil entre México y el Pacífico sudamericano que a la vez derivan en dos niveles de análisis. Por un lado, está lo que denominamos "primer ciclo comercial": el movimiento de mercancía, mayoritariamente de bienes locales, promocionado por los agentes 
regionales con sus propias embarcaciones. Por otro lado, el "segundo ciclo" está representado por el tráfico de bienes internacionales, alentado por mercaderes y barcos europeos que surcan el Cabo de Hornos. Esta segunda plataforma mercantil presenta a la vez dos fases: 1) 1750-1790: navíos de registro españoles, y 2) desde 1790 en adelante: balleneros ingleses y norteamericanos. Ambas fases de circulación mercantil entre México y el Pacífico sudamericano, particularmente la propiciada por los británicos y estadounidenses, constituyen tan sólo una pieza del gran derrotero transcontinental. La distinción se presenta como un hecho novedoso para el periodo pues, como se advirtió en los capítulos I y II, los intercambios internacionales y de cabotaje, en tiempos del Pacífico indiano, confluían en un único circuito; es decir, los bienes globales y bienes de la tierra se movilizaban de forma simultánea por iniciativa de los agentes mexicanos y peruanos.

El tráfico de producciones locales: primer nivel comercial

Los testimonios de la época y algunos estudios clásicos que atienden el tráfico entre México y el Pacífico sudamericano de finales del siglo XVIII coinciden en describirlo como pobre, corto, de poco valor, etcétera. ${ }^{36}$ En 1797, el Consulado de Lima señala que el tráfico mercantil que va desde la costa de Chiloé hasta San Blas "no corresponde ni a la décima parte de los que debía haber" ${ }^{37} \mathrm{El}$ consulado responsabiliza a la carga impositiva que sufre el circuito de productos locales. Al año siguiente, el virrey del Perú, Ambrosio O'Higgins, dice estar enterado del "poco y poquísimo" tráfico de efectos y buques que se emplean entre el Perú y México. Si los navíos de por sí son: "pocos y de pequeño valor se hace más visible su cortedad por la cantidad exigua en que se verifica, pues

36 Humboldt, [1811] 1953; Alamán, [1850] 1985, vol. III.

37 "Carta del Tribunal del Real Consulado de Lima" (1797), AGI, Lima, 718, núm. 67, f. 776 . 
estoy asegurado que le absorben cuatro buques en doce o catorce viajes que entre todos hacen cada año" ${ }^{38}$

¿Cómo fundamentan los contemporáneos la "cortedad del comercio" entre México y Perú?, ¿lo estarían cotejando con el precedente y rico movimiento de bienes internacionales que ocurría por el área?, ¿ o es por el tráfico que realizan los extranjeros que en forma paralela están moviendo un mayor número de productos y riquezas?, ¿lo comparan con la movilización de bienes y plata que se vive en estos tiempos por el Atlántico?, ¿los funcionarios del Perú suponen una disminución de sus relaciones con el Pacífico novohispano al notar que el comercio exterior peruano redirecciona sus rutas hacia otros mercados de destino?, ¿será que existe otro puerto y mercado que va tomando predominancia por el Pacífico sudamericano? Según O’Higgins, México solicitaba de la economía peruana tan sólo una cuarta parte de lo que históricamente enviaba. ${ }^{39}$ Ofrecemos, en suma, algunas respuestas a este abanico de interrogantes, para acercarnos al nuevo perfil que asume el primer ciclo de movimiento de bienes locales entre México y Sudamérica por el Pacífico.

En el apéndice documental, cuadros AIII.1 y AIII.2 se presentan dos listados que constituyen una excelente "caja de herramientas" para analizar el tráfico local entre México y el Pacífico sudamericano entre 1798 y 1819. El cuadro AIII.1 se refiere a los navíos que transitan con orientación desde el sur hacia el norte, mientras que el $\mathrm{v}$ al movimiento inverso de los barcos, de norte a sur. La totalidad de los documentos fueron extraídos del Archivo General de la Nación de México, ubicados en los ramos Indiferente Virreinal y Marina. Los expedientes ofrecen los nombres de los barcos, su maestre o capitán, los puertos y fechas de salida y de destino y la canasta de mercadería movilizada. Ciertamente, no estamos en presencia de listados completos, aunque entre

38 Carta núm. 203 de Ambrosio O’Higgins, Marqués de Osorno, Virrey del Perú", 23/12/1798, AGI, Lima, 718, núm. 67, f. 771.

39 "Carta núm. 203 de Ambrosio O’Higgins, Marqués de Osorno, Virrey del Perú", 23/12/1798, AGI, Lima, 718, núm. 67, f. 771. 
1811 y 1816 las investigaciones especializadas encuentran más de 53 buques que llegan a las costas del Pacífico mexicano provenientes de Panamá, Guatemala y Lima. ${ }^{40}$ No obstante, la serie es por demás representativa.

La primera observación que arroja es la respetable actividad comercial de Acapulco, que se mantiene como el surgidero occidental más importante en el tráfico de bienes locales con el Pacífico sudamericano. Reiteremos que su escenario de crisis sólo sería aceptado al pensarlo como puerto internacional transpacífico, no así al cotejar su operatividad en el tráfico local y regional. El cuadro III. 3 muestra que de un total de 37 embarcaciones registradas que parten desde el Pacífico mexicano, 35 de ellas notifican su salida desde Acapulco; sólo dos comunican su salida desde San Blas. En dirección inversa, de un total de 49 embarcaciones identificadas que parten desde los puertos de Sudamérica, 95\% (46) reconoce la llegada de su cargamento en Acapulco. Desde ahí, cabe la posibilidad de que se dirijan a San Blas o a puertos más al sur como Sonsonate o Realejo, pero Acapulco concentra la fiscalidad y la gran mayoría de las mercaderías desembarcadas.

Cuadro III.3. Salidas y destinos de navíos por el Pacífico entre 1798 y 1819

\begin{tabular}{|c|c|c|c|c|}
\hline & \multicolumn{2}{|c|}{ De norte a sur } & \multicolumn{2}{|c|}{ De sur a norte } \\
\hline Salida & $\begin{array}{l}\text { Acapulco } 35 \\
\text { San Blas } 2\end{array}$ & & $\begin{array}{l}\text { Guayaquil } 39 \\
\text { El Callao } 4 \\
\text { Paita/Sonsonate } \\
\text { o Sonsonate } 6\end{array}$ & \\
\hline Destino & $\begin{array}{l}\text { Guayaquil } 22 \\
\text { El Callao } 6 \\
\text { Valparaíso } 4 \\
\text { Sonsonate/Realejo } 4\end{array}$ & & $\begin{array}{l}\text { Acapulco } 46 \\
\text { San Blas } 3\end{array}$ & \\
\hline
\end{tabular}

Fuente: Apéndice documental, cuadros AIII.1 y AIII.2. 
Los estudios hacen énfasis en la importancia que asume San Blas durante las últimas décadas del siglo XVIII. Esto es cierto. Pero su valoración termina por opacar el papel significativo que sigue asumiendo Acapulco en el tráfico local y de cabotaje. No puede desconocerse el ascenso de San Blas, sea en su calidad de puerto internacional para los contactos transpacíficos, en su conexión con Panamá para adquirir algodón británico o como punto oficial de partida en las expediciones científicas y comerciales hacia el norte californiano. Pero el surgidero más importante de Guadalajara no tiene mayor fortuna con respecto al tráfico de producciones locales con Sudamérica.

El virrey novohispano Branciforte pone de manifiesto el poco efecto de las autorizaciones emitidas para la conexión directa entre San Blas con los puertos sudamericanos desde el último cuarto del siglo XVIII; una iniciativa recomendada años antes por el visitador del Perú, Antonio de Areche, buscando desarrollar las aisladas economías de Sonora, Sinaloa y California. ${ }^{41}$ Branciforte comunica que en 1795 la Corona autoriza a un tal Víctor Ibáñez de Cordeza realizar una expedición de comercio a San Blas "con frutos del reino de Chile y provincia de Guayaquil". En ese mismo año, también se le otorga el permiso a la compañía de los Cinco Gremios Mayores de Madrid para el enlace entre Guayaquil, Valparaíso y el Callao con el puerto de San Blas. Sin embargo, dice Branciforte: "no movió a otros a emprender la comunicación [...] por lo que a partir de todo esto, creo que el suceso no corresponda a las esperanzas aún después de alzadas las prohibiciones $3^{\circ} \mathrm{y}$ $5^{\circ}$ de la Real Cédula de 1774 ". 42 Aún con la flexibilidad de un "co-

41 Branciforte advierte en septiembre de 1796 sobre la concreta "independencia y autonomía” de la Comandancia General de las Provincias Internas con relación al mando del virrey. Dice que por "incidencia" desea tocar "las dificultades advertidas para el cumplimiento de dos reales órdenes sobre el abrir el comercio de la América meridional con la Nueva España, no sólo con San Blas sino los que yo hallase a propósito en la costa del Sur", "Branciforte acusa recibo R.O", septiembre de 1796, AGI, Estado, 25, núm. 43 (1), s/n de fs.

42 "Respecto a los caldos del Perú y Chile podrían no ser de mucho consumo en las Provincias Internas porque ya hay vino en Sonora y en la capital de Nueva Vizcaya hay un almacén del vino que llaman de "parras". Para el virrey Branciforte, levantar 
mercio libre", la fortuna de San Blas parece estar más ligada a los contactos del norte californiano o al trato con las Islas Filipinas que a su enlace con el Pacífico sudamericano.

Las alteraciones que ocurren en las costas occidentales de Sudamérica son más visibles. El centralismo marítimo que por mucho tiempo caracterizó al punto costero oficial de la ciudad de Lima, el Callao, parece resquebrajarse. Guayaquil crece en protagonismo, convirtiéndose en el puerto primario para las comunicaciones con el puerto de Acapulco. Como se expresa en el cuadro III.3, de los 49 navíos que salen desde los puertos sudamericanos hacia México, 39 lo hacen desde el puerto ecuatoriano, sólo cuatro de el Callao y el resto del Realejo, Paita o Sonsonate. Los puertos de destino de los navíos procedentes de México muestran mayor variación, pero mantienen la dominancia de Guayaquil: de los 37 casos identificados, 17 registran su destino hacia el puerto principal de Quito, sólo seis a el Callao, tres a Valparaíso y los restantes a Realejo, Sonsonate y San Blas. Ciertamente, sería apresurado pensar que los navíos sólo arriban al apostadero que registran. Su derrotero estaría extendiéndose a otros puertos, operando en escalas. Pero no hay dudas de que la notificación oficial de puntos de salida y de llegada dilucida las jerarquías portuarias del momento.

La importancia de Guayaquil se ve confirmada por otros estudios: entre 1806 y 1808 Lerdo de Tejada encontró un total de 17 navíos procedentes de Guayaquil en Acapulco, y tan sólo un navío que salió desde el puerto de Lima. ${ }^{43}$ Por su parte, Ramírez Cabañas nota un total de nueve navíos procedentes de Guayaquil en San Blas entre 1811 y 1814 , y tan sólo tres con origen desde el tradicional surgidero limeño. ${ }^{44}$ Esto no significa que el Callao abandone o suspenda su movimiento con Acapulco o San Blas. Pero, como veremos en el próximo apartado, la apertura institucional

los artículos de prohibiciones estipuladas en la real cédula de 1774 no tendría mayor efecto. El comercio desde América meridional hacia el norte de la Nueva España continuaría siendo pobre, "Branciforte acusa recibo R.O", septiembre de 1796, AGI, Estado, 25, núm. 43 (1), s/n de fs.

43 Lerdo de Tejada, [1853] 1967, Documentos 19, 20 y 21.

${ }^{4}$ Ramírez Cabañas, 1944, p. 75. 
del circuito por el Cabo de Hornos hace que el comercio exterior del Perú reoriente gran parte de su economía exterior hacia otras plazas mercantiles, como el puerto más cercano de Valparaíso y, fundamentalmente, con España y Europa vía cabo austral.

En lo que se refiere al primer nivel mercantil, el lazo Guayaquil-Acapulco se constituye como el eje estructurante que mantiene ligado a México con Sudamérica desde los últimos años del siglo xVIII y primeras décadas del siglo XIx. El boom del comercio de cacao guayaquileño destinado al consumo de la plaza novohispana es emblemático al respecto. ${ }^{45}$ En los capítulos dedicados al Pacífico indiano se comprobaron los significativos envíos del grano ecuatoriano a la Nueva España, ya sea en forma de permisos o de modo informal. Pero la real cédula de 1774, que libera la movilización de producción local entre México y Perú, no hace más que impulsar y sistematizar su ingreso por Acapulco. ${ }^{46} \mathrm{El} 5$ de junio de 1789 se anula la disposición que limita sus salidas de 8000 a 10000 fanegas de cacao. El 18 de noviembre de 1794 se decreta la libertad absoluta del comercio de frutos, mercaderías y efectos de Europa por todo el Mar del Sur. ${ }^{47}$ Aún siguen prohibidos los bienes asiáticos en el mercado sudamericano; traba que será eliminada en el año $1803 .{ }^{48}$ Incluso con una notable diversificación de los destinos de exportación de cacao y de los permisos otorgados por la Corona a San Blas para enlazarse con Sudamérica, Acapulco seguirá siendo el conducto portuario por excelencia para abastecer de cacao a la sociedad novohispana. ${ }^{49}$

45 Miño, 2013; Contreras, 1990.

46 AGNM, Instituciones coloniales, Reales cédulas, volumen 104, exp. 10, fs. 1-5; AGNM, Instituciones coloniales, Indiferente virreinal, caja 2790, exp. 10, fs. 1-8.

47 AGNM, Instituciones coloniales, "Real Orden que permite la extracción e introducción de frutos, mercaderías y efectos de Europa entre este reino y el del Perú por los puertos del Sur", abril de 1795, Bandos, vol. 18, exp. 10, f. 44; AGNM, Bandos, vol. 20, exp. 87, f. 191; AGNM, Instituciones coloniales, Real Hacienda, vol. 130, exp. 9, 1800, f. 1. "Carta 279 de Francisco Gil de Taboada y Lemos, Virrey del Perú, a Diego Gardoqui, secretario de Estado de Hacienda”, AGI, Lima, 711, 21, f. 1.

48 Miño, 2013, pp. 72-73.

49 Desde la segunda mitad del siglo, el cacao guayaquileño tendrá como principales puertos de destino Acapulco, el Callao y Cádiz por la ruta del Cabo de Hornos, 
Si atendemos el estudio especializado de Miño, en 1774 el puerto de Acapulco absorbe 18.55\% del total del cacao exportado; en $1779,43.66 \%$, y en 1791, 62.55\%. Entre 1779 y 1783 , Acapulco recibe $63.71 \%$ de lo que sale de cacao desde Guayaquil. ${ }^{50}$ La dominancia del grano ecuatoriano en el circuito por el $\mathrm{Pa}$ cífico explica por qué Acapulco continúa con una operatividad comercial significativa. A diferencia de San Blas, donde el peso del Consulado de Guadalajara es ya decisivo, Acapulco sigue bajo la órbita del Consulado de la Ciudad de México, corporación que controla la importación y redistribución del grano en México. ${ }^{51}$ Contabilizamos unas 212579 cargas de cacao por Acapulco en los 21 años considerados. A partir de 1810, las importaciones de cacao por Acapulco muestran un marcado descenso, debido a la inestabilidad política del virreinato de la Nueva España y el notable aumento de su comercialización hacia Cádiz por el derrotero del Cabo de Hornos.

Si bien dominante, nótese en el cuadro AIII.1 del apéndice documental que no sólo llega cacao guayaquileño al puerto de Acapulco. En un segundo nivel de jerarquía aparece una canasta de productos compuesta por estaño, cobre, lana de vicuña bruta o elaborada en sombreros, vino y los sombreros de jipijapa o de paja que se producen en la Audiencia de Quito. El cobre, extraído de las minas de Coquimbo y Aconcagua de Chile, también se moviliza desde Guayaquil hacia Acapulco. Conforme avanzan los primeros años del siglo XIX, la canasta de exportación de Guayaquil se diversifica: se suman el aceite de almendra, la manteca de cacao, la cascarilla, el aguardiente de Pisco, aceitunas, arroz, harina, azúcar, carne de cecina, pasas, frijoles, nueces y garbanzos y

de la que enseguida nos ocuparemos. Si bien México se mantendrá como uno de los más importantes centros para su consumo, el mercado europeo tomará cada vez mayor protagonismo. Contreras, 1994, pp. 189-250.

50 Miño, 2013, p. 112. Corroborando la primacía de Guayaquil en su relación con Acapulco, sabemos que en un año entre marzo de 1780 y marzo de 1781 ingresaron a Acapulco ocho naves peruleras, de las cuales seis proceden de Guayaquil y las dos restantes de Lima, AGNM, Industria y comercio, vol. 13, exp. 1, fs. 47-48.

51 Miño, 2013; Contreras, 1994, pp. 189-250; Contreras, 1990. 
la yerba mate de Paraguay. La canasta exportadora de Guayaquil, compuesta de productos elaborados en el Alto Perú, Quito, Chile y en menor medida de Asunción, da cuenta de algunas débiles "réplicas" de lo que fue en su momento el espacio peruano relatado en los capítulos anteriores, con capacidad de enviar excedentes mercantiles hacia México.

El virrey Osorno del Perú presenta una idéntica canasta exportadora que opera entre el Callao con todos los puertos del $\mathrm{Pa}$ cífico y no sólo con Acapulco (cuadro III.4).

Cuadro III.4. "Estado que manifiesta los frutos y los efectos de las Provincias de este Virreinato que exportan del puerto del Callao los buques de su comercio a los de Guayaquil, Panamá, Sonsonate y Realejo y los que retornan al primero de su salida" (1798)

\begin{tabular}{|c|c|c|}
\hline Extracción para Panamá & $\begin{array}{c}\text { Extracción para } \\
\text { el Realejo y Sonsonate }\end{array}$ & $\begin{array}{c}\text { Extracción } \\
\text { para Guayaquil }\end{array}$ \\
\hline $\begin{array}{l}\text { Vinos, aceitunas, harina, } \\
\text { aceite y pasas }\end{array}$ & $\begin{array}{l}\text { Pellones, aguardientes, } \\
\text { vinos, aceitunas, aceites, } \\
\text { pellejo de carnero, ropa } \\
\text { de la tierra, pasas, higos } \\
\text { sueltos y miel }\end{array}$ & $\begin{array}{l}\text { Harina, vinos, pasas, } \\
\text { aceitunas y aceite }\end{array}$ \\
\hline Retorno al Callao & Retorno al Callao & Retorno al Callao \\
\hline $\begin{array}{l}\text { Cacao de superior } \\
\text { calidad, caobas [sic], pi- } \\
\text { ñuelas o mangles, cedros, } \\
\text { pitilla torcida y escobas }\end{array}$ & $\begin{array}{l}\text { Añil, brea, alquitrán, } \\
\text { bálsamos medicinales, } \\
\text { cedros, caobas, cacao } \\
\text { de Soconusco, petates y } \\
\text { sombreros de palma }\end{array}$ & $\begin{array}{l}\text { Cacao, suelas, pita } \\
\text { torcida y floja, paños de } \\
\text { Quito, maderas, café, } \\
\text { piedras pomas y sombre- } \\
\text { ros de paja }\end{array}$ \\
\hline
\end{tabular}

Fuente: “Carta n 203 de Ambrosio O’Higgins, Marqués de Osorno, Virrey del Perú”, 26 de diciembre de 1798, AGI, Lima, 718, núm. 68 b, f. 777.

Aún más diversificada se presenta la canasta de exportación de Guayaquil hacia el Callao que informa José de Baquíjano en su Disertación sobre el comercio del Perú en $1790 .^{52}$ Atendiendo 
los cargamentos de navíos, muestra la llegada permanente de cacao, cuero de vacas, paños ordinarios, sayal, pita floja y torcida, sombreros de paja, ajonjolí, canoas de madera y otras mercaderías locales. Un comentario especial merece el vino peruano que, como vimos en el primer capítulo, desde finales del siglo XVI es trasladado en importantes cantidades para el consumo de la Nueva España, Panamá y Realejo. El flujo de la bebida parece no tener freno, continuando su consumo hacia finales del siglo XVIII.

Ahora bien, en nuestro listado de navíos en su dirección norte-sur sobresale la plata acuñada y los llamados "efectos de la tierra”. El metálico es el medio de pago fundamental que ofrecen los comerciantes de la Ciudad de México para obtener el cacao de Guayaquil. Vemos aquí el quiebre de una histórica pauta de intercambio: si entre 1580 y 1740 el flujo de metálico peruano en barra, pasta o en moneda fluye de manera continua hacia México, como pago de los bienes internacionales, en la segunda parte del siglo XVIII se registra el drenaje hacia el Perú de plata mexicana. El cambio obedece a que México fue desplazado como centro de redistribución de los bienes internacionales. Antes el comercio de México podía saldar los envíos clandestinos de cacao con esos bienes. Al liberarse el tráfico de cacao, México saldará sus envíos con moneda de plata, pues dispone de muy contados bienes (tejidos de Puebla) que solicita el espacio sudamericano. El flujo de moneda mexicana hacia Sudamérica será explicitado por el virrey Revillagigedo: en 1794, al llegar a Acapulco 30000 cargas de cacao guayaquileño tasadas en 300000 pesos, dice que se pagan "en dinero casi enteramente". ${ }^{3}$

Por su parte, el metálico andino, que para la década de 1770 registrará un franco ascenso en su producción (gráfica II.4), encontrará su escape por otras vías mercantiles, ya sea con los agentes comerciales europeos que vendrán por el Cabo de Hornos o por la Real Compañía de Filipinas que lo canalizará hacia el Oriente o Europa. ${ }^{54}$ En gran medida, Perú se verá en la

53 Hamerly, 1973, p. 125.

54 Alfonso Mola y Martínez Shaw, 2009, p. 534. 
necesidad de saldar las importaciones de bienes europeos que llegan con los navíos españoles con su moneda de plata o con la plata mexicana que llega, como vimos, como pago del cacao exportado.

Otro aspecto a destacar del cuadro AIII.2 del apéndice documental es la movilización de las "cajas de efectos de la tierra" o "del reino". Los términos apuntan a la loza, el rebozo, la ropa y el vidrio, todos ellos elaborados en la ciudad de Puebla. Sin duda, los textiles que se confeccionan en Puebla son uno de los rubros principales de este tráfico. Completan los cargamentos la brea, el alquitrán (productos también mencionados por el virrey Osorno), la cera de La Habana y, menos usual, el tabaco, el hierro y el chocolate. ${ }^{55}$ Aún sigue arraigada en la historiografía la idea de que las fábricas de Puebla entran en una fase de crisis desde 1740, cuando Perú reorienta su economía exterior hacia el Cabo de Hornos. En las primeras páginas del libro se señaló que los obrajes de Puebla disponían de una considerable demanda de tejidos del mercado peruano. El caso más emblemático sobre esta visión es la ofrecida por fray Villa Sánchez, en su obra Puebla sagrada y Profana de 1746. Allí, el religioso brinda un escenario de decadencia de la ciudad de Puebla, en tanto centro textil y exportador de bienes locales elaborados. La miseria se explicaba por la falta de trato y comercio con el Perú. Grandes cantidades de producción de vidrio, textiles y loza (conocida por las imitaciones que realizaban de la loza de China) se habían destinado al mercado del Perú. Si bien desde 1580 hasta 1630 fue su esplendor comercial, Puebla se mantuvo como exportador de bienes elaborados hasta la primera mitad del siglo XVIII. Según Villa Sánchez, desde el momento en que Perú reorientó su comercio hacia España, los obrajes de paños se habrían paralizado, provocando miseria y falta de empleo en la ciudad. En ese contexto, el padre solicita a la Corona la reapertura del comercio desde Nueva España hacia el Perú para evitar

55 Este abanico de bienes también se confirma en el estudio de Ramos Pérez, 1970, p. 266. 
el contrabando inglés, que desde su centro de Jamaica inicia sus operaciones hacia el Pacífico sudamericano y mexicano. ${ }^{56}$

Para tiempos más cercanos, hacia 1850, Alamán ofrece similares apreciaciones. La "manufactura de Puebla, encontraba buena salida en el Perú por la escasez y carestía de los europeos”. La llegada espaciada de la flota de Panamá cada tres años permite, según Alamán, no sólo que los efectos de China ingresen al Perú, sino también los productos que se elaboraban en los "centros manufactureros y obrajes de Puebla y extendidos hasta Cholula". ${ }^{7}$ Desde mitad del siglo, todo el crecimiento de la ciudad "había desaparecido y los obrajes estaban en ruinas". ${ }^{58}$ La apertura del tráfico de mercancías de producción local entre México y Perú en 1774 no había logrado recuperar el esplendor de su pasado comercio, minimizándose a "casi sólo el cacao de Guayaquil”. La llegada de manufactura europea a través del "libre comercio" impedía su renacimiento. Nada había cambiado con la independencia; por el contrario, el escenario había empeorado:

Sin mira política alguna y sólo por seguir principios mal aplicados, la independencia no hizo más que desconocer la política económica de compatibilidad peninsular para el desarrollo novohispano. El tráfico de manufactura inglesa destruía cualquier intento de industrialización local. Sólo lograba que la miseria en México fuera espantosa. ${ }^{59}$

Quizá, las referencias más negativas y desalentadoras sobre lo que ocurre en el tráfico por el Mar del Sur se encuentren en el Ensayo político de Humboldt. Entre sus líneas se plantea que el comercio desde Acapulco hacia Guayaquil y Lima es "casi nulo",

56 Villa Sánchez, [1746] 1835, pp. 43-48.

57 Alamán, [1850] 1985, vol. III, p. 37.

58 Alamán, [1850] 1985, vol. III, p. 37.

59 Alamán, [1850] 1985, vol. I, p. 109. La cita de Alamán nos sumerge en un sinfín de problemáticas que superan el caso de Puebla. Muchas de ellas, como el comercio de telas británicas, las rutas de Panamá y la desindustrialización mexicana serán temas de análisis más adelante. 
reducido a "géneros de lana de las fábricas de Querétaro, un poco de grana y a mercancías de las Grandes Indias". ${ }^{60}$

Pues bien, la información que brinda el cuadro AIII.2 del apéndice documental relativiza esa imagen de crisis de la industria poblana. Las cantidades de loza, rebozos y vidrios poblanos que se movilizan por el Pacífico nos alejan de una imagen desoladora de Puebla. En casi la totalidad de los navíos registrados se encuentran productos de Puebla que se exportan, vía Acapulco, hacia el Pacífico sudamericano. Una mención final sobre el caso de Puebla. Su ejemplo de buena salud mercantil se contrapone a los planteamientos de la época que hablan de una industria mexicana en situación crítica, en razón del libre comercio de las telas de algodón británicas que desde finales del siglo Xvin ingresan de manera sistemática al espacio. Quizá Puebla logre atrasar su caída industrial hasta la cuarta década del siglo XIX, gracias a la salida de su producción hacia el Perú.

En un completo análisis sobre la nueva modalidad del comercio de cabotaje entre México y el Pacífico meridional se alcanzaría al ver la relativa importancia del movimiento de bienes extranjeros (tanto asiáticos como europeos), valdría recordar su marco jurídico. En 1794, la Corona autoriza la libre movilización de bienes europeos por el circuito y con la real cédula de 1803 la absoluta libertad para la circulación y consumo de las mercancías orientales en otros espacios hispanoamericanos que no sean México. ${ }^{61}$

Pues bien, el cuadro AIII.2 del anexo documental desprende consideraciones reveladoras. Incluso con el beneficio de la autorización de 1794, la reexpedición de mercancía europea desde Acapulco hacia Guayaquil o el Callao es reducida o poco significante. Resulta imposible saber con exactitud de qué tipo son los pocos productos europeos que se envían, porque los registros sólo anotan el calificativo de "géneros de Europa" o "de España". Posiblemente sean textiles. Sean tejidos o no, lo cierto es que están lejos de ser el motor del intercambio del comercio por el Mar del Sur. Ellos

60 Humboldt, [1811] 1953, p. 250.

61 Valdés Lakowsky, 1985, pp. 241-242. 
acompañan, casi de modo anecdótico, la plata mexicana y los tejidos locales de Puebla, que son los que constituyen el cargamento más importante de los barcos. Es cierto: Acapulco parece recobrar tibiamente aquella función de puerto reexportador de bienes extranjeros en particulares años de conflicto bélico, como en tiempos de la guerra entre España y Gran Bretaña (1779-1783) y (18041809). ${ }^{62}$ En esos años, prácticamente todos los navíos identificados que salen de Acapulco hacia Guayaquil o el Callao llevan "tercios", "cajones", "efectos" o simplemente textiles "de Europa” o "de España" ${ }^{63}$ La coyuntura bélica genera un bloqueo para el abastecimiento transatlántico de bienes europeos hacia Sudamérica. Sin embargo, hay que insistir: los reenvíos de bienes internacionales desde el norte hacia el sur por el Pacífico no son de ninguna manera el rubro significativo de los cargamentos.

La descomposición del eje Ciudad de México-Acapulco como abastecedor de bienes europeos hacia el mercado centroamericano y sudamericano cobra mayor sentido cuando atendemos el flujo inverso. El canal mercantil con dirección sur-norte también moviliza loza y tejidos europeos. Así, el tráfico de efectos extranjeros, siempre nimios, viajan por ambas direcciones. Contamos con otros casos que no aparecen en nuestro cuadro. En 1802, el paquebot Mart que viaja desde el Perú ingresa efectos europeos al puerto de Acapulco sin pagar derechos. ${ }^{64}$ En 1806, Juan de Antepara, vecino y comerciante de la Ciudad de México, solicita la

62 El modelo que posiciona a México como centro se legaliza entre 1779 y 1784 . El bloqueo atlántico, producido por el conflicto entre España e Inglaterra en el marco de la independencia norteamericana, obliga a que la Corona autorice las operaciones de reexpedición de bienes chinos y europeos desde el Pacífico mexicano hacia el Perú. Pero hay que subrayar que durante esos años la ruta del Cabo de Hornos estuvo clausurada, lo que permitió que, en una coyuntura excepcional, se lograra reconstruir el tejido antecedente. Para un mayor detalle sobre las características comerciales de este particular periodo: Bonialian, 2012, pp. 420-422 y 426-441.

63 Véase en el apéndice documental, cuadro AIII.2. Los casos de Nuestra Señora de Guadalupe (1804); el bergantín San José El Diligente (1805) y, sobre todo, el de las fragatas Guadalupe, Primera, Veloz, Jesús María (todas ellas de 1806).

64 AGNM, Instituciones coloniales, Reales Cédulas originales, vol. 183, exp. 1, enero de 1802 , f. 4. 
devolución de la alcabala que se le había exigido de la primera venta de "efectos y frutos de Europa, de Guatemala, Santa Fe y Perú recibidos por los puertos del mar del Sur" ${ }^{65}$ Hacia 1818, según el gobernador de Nueva California, se presenta por las costas californianas la fragata Hermosa Mexicana, propiedad del comercio de Lima, al mando del capitán Gaspar Yllas, con textiles de algodón inglés procedente de el Callao. ${ }^{66}$ Los casos relatados ponen al descubierto que los mercados del Pacífico sudamericano ya reciben los bienes europeos por la vía del Cabo de Hornos. Posiblemente, en momentos de sobreabasto, estos bienes se reexportan hacia el Pacífico mexicano.

La centralidad histórica de la Ciudad de México como centro de acopio de bienes chinos pierde funcionalidad. Son tiempos en que las compañías comerciales españolas tienen la posibilidad de realizar el tráfico directo desde Filipinas o China hacia el Pacífico sudamericano. Nuestro registro confirma el hecho: de las 37 naves que salen desde el Pacífico mexicano hacia el sur tan sólo dos embarcaciones llevan efectos del Oriente hacia Guayaquil o el Callao; cargas que resultan intrascendentes. En 1802 el bergantín Príncipe de Asturias lleva desde San Blas al Perú un "cajón de loza de China". En 1811, la fragata La Fama moviliza de Acapulco a Realejo y Sonsonate " 12 tercios de efectos asiáticos". ${ }^{67}$ El acotado flujo de mercancía del Oriente por el área del Pacífico puede tomar también la dirección inversa: desde Guayaquil hacia Acapulco. Lo confirman los casos del año 1809, con los navíos Aranzazu, Nuestra Señora de Guadalupe y Nuestra Señora del Pilar. El primero traslada "2907 bolsitas de canela de China" y "20 tercios con 10 docenas pañuelos azules corrientes de China"; Nuestra Señora de Guadalupe, "un tercio de canela de China" y el Pilar "61 cajones de canela de China y tan sólo un bulto de tinta corte de China".68

65 AGNM, Instituciones coloniales, Indiferente Virreinal, caja 2292, exp. 20, 1806, f. 18.

66 AGNM, Instituciones coloniales, Indiferente Virreinal, caja 3915, exp. 33, 1818, f. 3.

67 17/12/1803: AGNM, Indiferente virreinal, caja 4322, exp. 4106, f. 5; 15/4/1811: AGNM, Marina, caja 3782, exp. 10, f. 2.

68 AGNM, Marina, caja 3782, exp. 19, f. 8. Marina, caja 3782, exp. 17, f. 7; Marina, caja 3782, exp. 15, f. 3. Cuadro AIII.2 del apéndice documental. 
Llegamos así al interrogante inicial de nuestro apartado: ¿qué ocurre con el histórico flujo de bienes asiáticos que, desde 1580, veíamos caer como una suerte de cascada desde Acapulco hacia Sudamérica?, ¿perdura su circulación en nuestro registro?, ¿deberíamos pensar en una "explosión” del comercio de bienes asiáticos desde México hacia el Perú con la autorización para su circulación en 1803? Todo indica que nada de esto ocurrió. La autorización de 1803 para su libre circulación llega en pleno contexto de políticas de libre comercio, cuando una multiplicidad de flujos y puertos del Atlántico y del Pacífico participan en el tráfico de textiles asiáticos. De esta manera, la libertad que se le concede a un alicaído galeón de Manila no representa ningún peligro para el comercio de España, como sí lo había sido en las primeras décadas del siglo XVIII. ${ }^{69}$ Desde 1750 el panorama es bastante diferente.

Los textiles de seda y algodón del Oriente no tienen lugar en el comercio interamericano por el Pacífico. El trato asiático en Hispanoamérica se inscribirá en las nuevas lógicas del comercio mundial e imperial y de aperturas portuarias. Los textiles de la India o aun de China ya no tendrán el canal transpacífico novohispano como única vía de circulación. Estamos en presencia, de la atlantización del comercio oriental en Hispanoamérica; tema al que le dedicaremos enseguida un apartado especial.

\section{LA ATLANTIZACIÓN DEL PACÍFICO SUDAMERICANO Y MEXICANO}

El primer nivel mercantil, sustentado en el comercio de efectos de producción americana, no es la única modalidad de tráfico que opera por las aguas del Pacífico. Existe un segundo nivel de naturaleza internacional y transcontinental, promovido por agentes $y$

69 Recordemos que en 1712 se prohíbe el ingreso de sedas chinas por Acapulco para garantizar la venta de la ropa de seda española que conducen las flotas de Veracruz. La medida, de escaso éxito, es no obstante una clara exposición de cómo el Atlántico se veía condicionado por el Pacífico. 
corporaciones europeas procedentes del Atlántico. Ciertamente, la distinción se vuelve rígida a la hora de pensar en la constitución de redes comerciales, donde juegan agentes locales y europeos en los intercambios. Sin embargo, la diferenciación resulta útil si atendemos las fuerzas o corrientes oceánicas donde la impronta atlántica logra reinsertar al Pacífico hispanoamericano en las nuevas lógicas de una globalización de impronta occidental.

¿Cuándo se inicia el cambio? El punto de arranque lo situamos con la oficialización del paso por el Cabo de Hornos (1739), con los llamados navíos "de registro" o "particulares". A partir de 1790, el patrón comercial iniciado por los navíos españoles será reproducido por las embarcaciones británicas y angloamericanas, los balleneros - como se les nombra en los documentos-. Estas grandes embarcaciones que se ocupan de la actividad de la caza de ballenas, también encontrarán rentabilidad al vender bienes extranjeros en los mercados del Pacífico, particularmente textiles de algodón británicos, a cambio de la plata.

\section{El eje Europa-Cabo de Hornos-Pacífico sudamericano}

Primera fase: navíos de registros españoles desde 1749

La ruta entre el Atlántico y el Pacífico por el Cabo de Hornos, formalizada hacia 1739 pero que comienza a operar con fuerza desde 1749, viene a suplantar el tradicional sistema de galeones y ferias de Portobelo. Recordemos que la vía del cabo austral había sido utilizada por los europeos desde finales del siglo XVI. A modo de título, mencionemos el temprano contrabando holandés; la piratería inglesa y, como vimos en el capítulo II, los navíos franceses de Saint-Maló de las primeras décadas del siglo XVIII. De esta manera, el "viejo" paso transoceánico de circulación no pasó del carácter ilícito, accesorio y hasta marginal. Es verdad que los problemas climáticos y geográficos impidieron entonces que la ruta adquiriera sistematicidad. A su vez, España se mostraba resistente a su apertura para garantizar la carrera de Indias 
transatlántica. Si se abría el paso austral, los galeones de Portobelo tendrían una competencia no deseada. ${ }^{70}$

Pero su significancia toma un rumbo radicalmente diferente después de la guerra con Inglaterra (1739-1748) y de los convenios de Paz firmados entre 1748 y $1749 .{ }^{71}$ Desde entonces, la percepción mercantil y geopolítica de la Monarquía sobre el paso transoceánico del sur cambia de sentido. Del carácter pirático y de pillaje, se le empieza a concebir como el principal eje institucional para el movimiento de los barcos de registro o navíos particulares con la finalidad de alcanzar no sólo los mercados del Pacífico sino también las Islas Filipinas. ${ }^{72}$ La decisión española es clara: controlar un universo marítimo que históricamente le había pertenecido a los agentes de México y del Perú. La mayoría de las fragatas harán escala de descanso o de intercambio en los puertos de Sacramento o Buenos Aires; cruzarán el Cabo de Hornos con el objetivo de vender en los puertos de Valparaíso, Concepción, La Serena, Arica, el Callao, Huanchaco, Paita y Guayaquil las mercaderías europeas y, en menores proporciones, las asiáticas a los comerciantes locales. Los navíos, recibirán, como forma de pago, productos de la región y la plata del Perú, cuya producción está en crecimiento luego de tantas décadas de estancamientos (gráfica III.4). Los comerciantes españoles utilizarán la plata para posteriores operaciones por el Pacífico hispanoamericano y Asia o para retornarla por la misma vía austral hacia España.

Veamos algunas estadísticas ofrecidas por especialistas para reconocer la magnitud que alcanza el trayecto por el Cabo de Hornos. Entre 1740 y 1750, década en la que aún el circuito transatlántico se ve bloqueado por los ingleses, Lamikiz apunta que el número de navíos oscila entre uno y tres por año. ${ }^{73}$ En el año 1748, luego de los tratados de paz con Gran Bretaña, arriban unos 18 navíos españoles tan sólo al puerto de el Callao. Desde 1760, el movimiento

70 Bonialian, 2016a, pp. 37-58.

71 Del Cantillo, 1843, pp. 409-412.

72 Lamikiz, 2010, pp. 81-83; Ramos Pérez, 1970, pp. 264-267; Alfonso Mola y Martínez Shaw, 2013, pp. 307-340.

73 Lamikiz, 2007, p. 238. 
de barcos irá en pleno crecimiento, registrándose para el año 1761 la presencia en el Callao de 56 embarcaciones. En el periodo 17681776, la media de registros que llegan a Perú procedentes de Cádiz alcanza los 4.5 por año. ${ }^{74}$ En 1786, arriban sólo a la costa de Lima 16 navíos de registro; cuando numerosos puntos costeros cercanos al Callao ya se encuentran con una intensa actividad mercantil. Para los años finales del siglo XVIII, Villalobos calcula un promedio de 60 embarcaciones por año que llegan al puerto del Río de la Plata; de las cuales muchas de ellas extienden su travesía hacia el Pacífico. ${ }^{75}$ Por su parte, Parrón Salas muestra que entre 1742 y 1778 encallan a las costas del Perú 108 navíos de registro procedentes de España. ${ }^{76}$ Entre 1778 y 1796 circulan de Cádiz al Callao unos 153 barcos, y entre 1809 a 1820 unos $90 .{ }^{77} \mathrm{El}$ conteo de Alfonso Mola es levemente inferior: entre 1778 y 1809 transitan desde Cádiz hacia el Pacífico (no sólo al Callao) 120 buques españoles, lo que representa una media de cuatro barcos anuales. También señala que entre 1810 y 1828, años turbulentos por las independencias, la media es de seis embarcaciones por año, considerando un total de 116 navíos. La inestabilidad bélica, resultado de los conflictos independentistas, no hace disminuir, según Alfonso Mola, la intensidad del circuito de las fragatas peninsulares hacia y desde el Pacífico. ${ }^{78}$

Desde el momento en que se abandona el régimen de flotas y se abre la puerta del Cabo de Hornos, no sólo el enlace oficial de España con Panamá entra en franco declive, sino también el contrabando inglés desde Jamaica, Curazao o Portobelo hacia los puertos de Nueva Granada, Ecuador y Perú. ${ }^{79}$ Ambos flujos encuentran una fuerte competencia de los navíos de registros españoles procedentes del cabo austral. Tan sólo como ejemplo

74 Lamikiz, 2007, p. 238.

75 Villalobos, 1965, pp. 40-56.

76 Parrón Salas, 1995, pp. 508-510.

77 Parrón Salas, 1995, p. 320.

78 Alfonso Mola, 2014, p. 508. Habría que señalar que algunos navíos del segundo periodo registran como destino Manila, por lo que se puede suponer la alternativa de viajar por el Cabo de Buena Esperanza.

79 Pearce, 2007, pp. 28-29. 
representativo: hacia 1700, Panamá representa un considerable $6 \%$ del comercio interregional que se desarrolla por el Pacífico. Hacia finales de siglo desciende a un insignificante $1 \%{ }^{80}$ Ciertamente, la decisión por priorizar la ruta del Cabo de Hornos en detrimento del histórico istmo centroamericano tiene también razones fiscales e impositivas vigentes desde el último cuarto del siglo. El famoso Reglamento de Libre Comercio de 1778 dispone que las mercaderías españolas y europeas que lleguen a Portobelo y Chagres sólo sean consumidas en la ciudad de Panamá. El impuesto comercial sobre los productos españoles que transitan por esta vía es inferior a $1.5 \%$ de los que pesan sobre la ruta del Cabo de Hornos. La diferencia es todavía mayor hacia la baja para los bienes extranjeros: 3\%. Pero, en el caso que los agentes centroamericanos que deseen reexportar las mercaderías desde Panamá hacia los puertos del Pacífico sudamericano, deben contribuir con un 3\% adicional en caso de bienes españoles y $7 \%$ para los extranjeros. ${ }^{81}$ Es evidente el mayor costo de comercialización que pesa sobre la vía de Portobelo desde Cádiz con relación a la vía del Cabo de Hornos en el abasto de los múltiples mercados de Chile, Perú y Ecuador. Los mercados del Pacífico sudamericano y las plazas de Montevideo y de Buenos Aires adquieren un renovado impulso económico con la nueva ruta austral beneficiada por las ventajas impositivas promovidas por la política borbónica. Por su parte, la relación entre Panamá con las plazas del Pacífico sudamericano no desaparecerá, pero sí sufrirá un descenso de su actividad. Durante la segunda mitad del siglo xviII, la función mercantil del paso centroamericano vivirá un estado crítico que lo llevará a buscar alternativas. Como veremos más adelante, la conexión con los mercados del Pacífico mexicano, impulsada por los británicos desde Jamaica, será una de las soluciones.

80 León, 2001, pp. 318-329.

81 "Arancel de los derechos señalados por Carlos III, rey de España, para las embarcaciones del comercio libre y las que hacen el comercio interior de unos puertos a otros por los mares del norte y sur de América”. España, 16 de febrero de 1778; AGNM, Instituciones coloniales, Gobierno virreinal, Impresos oficiales, vol. 11, exp. 3, fs. 15-23. 
Según el registro de Alfonso Mola, las navegaciones de las fragatas por el Cabo de Hornos hacia los puertos del Pacífico hispanoamericano entre 1778 y 1809 no presentan una reducción del tonelaje que prima por el Atlántico. Menos peso provoca que los tiempos de espera en los puertos resulten más breves, promoviendo una mayor dinámica en los intercambios. Algunos de los buques del Pacífico pasan las 2500 toneladas y los de menor tamaño no bajan de las 300 toneladas. La media de la carga de los navíos que operan por el Atlántico es notoriamente inferior. ${ }^{82}{ }_{i} \mathrm{La}$ razón de esta diferencia? Pensamos que los elevados cargamentos que se mueven por el Pacífico se explicarían por la multiplicidad de puertos que son visitados. No responden a un solo centro consumidor, los navíos españoles están preparados para realizar intercambios por muchos de ellos. El nuevo patrón de comercio expresa, en última instancia, el paso de un cohesionado mercado peruano a un espacio fragmentado y caracterizado por el regionalismo mercantil. Valdría realizar algunos breves comentarios para cada caso regional.

Valparaíso-Santiago de Chile. Hasta la primera mitad del siglo XVIII, la vida comercial del puerto chileno está sujeta a los ritmos dictados por los dos mencionados ejes históricos: México-Acapulco-Callao y el eje atlántico de Portobelo-Callao. A partir de la segunda mitad de la centuria, Valparaíso, a través de su centro urbano de Santiago, logra disminuir su subordinación respecto de Lima e intensifica su enlace directo con España y con el puerto de Buenos Aires. Tanta importancia habría alcanzado Santiago que algunos especialistas se atreven a afirmar que Valparaíso se convierte durante ese periodo en el puerto dominante del Pacífico sur. ${ }^{83}$ Es cierto que la urbe chilena registra un abastecimiento de textiles británicos y europeos por la vía terrestre de Buenos Aires, gracias al previo arribo al puerto atlántico de los barcos españoles ${ }^{84}$ Pero los estudios de Carmagnani dan cuenta de que el

82 Alfonso Mola, 2014, pp. 538-539.

83 Carmagnani, 2000; Cavieres, 2003, pp. 93-110.

${ }^{84}$ Jumar, 2009, pp. 21-34. 
eje marítimo Buenos Aries-Cabo de Hornos-Valparaíso presenta un mayor dinamismo que el circuito terrestre vía Mendoza. La preferencia de Chile hacia el circuito austral parece prolongarse hasta las primeras décadas del siglo xIX. Entre 1810 y 1819, las importaciones de bienes europeos (casi en su totalidad textiles) representan 33.2\% del total del comercio de Santiago: 32.7\% se mueve por la vía marítima y sólo $0.5 \%$ procede por el camino terrestre desde Buenos Aires. ${ }^{85}$ La selección no se debe únicamente a las luchas por la independencia y los bloqueos inevitables de los circuitos terrestres interregionales. La primacía de la ruta austral para alcanzar el puerto de Valparaíso se debe al comercio de balleneros británicos y europeos que se movilizan desde la última década del siglo xviII. La relación entre Chile y Panamá poco tendrá de componente mercantil; su trayecto tendrá sentido en la logística, a modo de circulación de pasajeros y de inteligencia. ${ }^{86}$

Río de La Plata. Si bien Buenos Aires, desde el siglo XviI y la primera mitad del siglo XVIII, cubrió muchas de sus necesidades gracias al contrabando portugués, inglés y francés, y a la llegada adicional de navíos de permiso peninsulares, fue con la apertura institucional ya decisiva de la ruta del Cabo con la que inundó el puerto de una notable corriente de barcos particulares. La entrada de mercancías no sólo es una respuesta a la demanda portuaria, sino también a los pedidos solicitados desde las plazas de la $\mathrm{Au}$ diencia de Charcas. El comercio directo transatlántico Cádiz-Río de la Plata será crucial para provocar el quiebre del circuito interno que ataba al puerto porteño con el centro limeño. ${ }^{87}$ Es cierto que la creación del virreinato del Río de La Plata en 1776 es una decisión política de la Corona para modificar la administración del espacio austral, pero no es menos cierto que la ruta del Cabo es un precedente comercial que la justifica; mucho más si se piensa en el caso del Reglamento de Comercio Libre promulgado en

85 Carmagnani, 2000, pp. 87-88. Esta primacía no desconoce el efecto de atracción de bienes extranjeros por el mercado consumidor de Buenos Aires y su hinterland.

86 Llorca-Jaña, 2012, pp. 209-210.

87 Moutoukias, 1988; Jumar y Paredes, 2008, pp. 33-99. 
1778. Con todo, la ciudad de Lima, junto con los grandes mercaderes pertenecientes al Consulado, ven disminuir su radio de influencia sobre mercados locales y regionales que antes dependían de su suministro y distribución de bienes.

El Callao-Lima. Quizás sean el mercado limeño, su hinterland y su comercio exterior las que viven mayores transformaciones económicas y, sobre todo, espaciales con la oficialización de la ruta austral del navío de registro. Ante todo, el mercado limeño ve disminuir su facultad de centro estructurante del espacio virreinal, aquél gran mercado interno que situaba a Lima como centro distribuidor tendrá una menor incidencia en los mercados regionales. La nueva ruta propicia la regionalización económica. Si antes la totalidad de la circulación y movilización de bienes y plata pasaba por la ciudad y su puerto, de ahora en adelante los mercados locales, con sus respectivos puertos, disponen de vías alternativas para operar en el comercio externo sin la mediación de la capital virreinal. A modo de ejemplo, vale un brevísimo comentario sobre la aparición de tres "microejes" que promueven el desarrollo de sus espacios locales. ${ }^{88}$

a) Arequipa-Tacna-Arica. Si bien Arica es nombrado "puerto franco o mayor" con el Reglamento de Libre Comercio de $1778,{ }^{89}$ décadas antes, desde la apertura del Cabo de Hornos, numerosos navíos españoles entran y salen del puerto sin sujetarse al eje Lima-el Callao. Si antes el centro de Tacna, el mercado de Tarapacá y la misma ciudad de Arequipa dependían de otros centros de mayor jerarquía como Lima, Valparaíso o Guayaquil para recibir artículos importados, a partir del último cuarto del siglo XVIII contarán con dos vías alternativas de suministro: desde el punto de entrada de Buenos Aires, pasando por el altiplano y desde Arica gracias a los navíos peninsulares que surcan el Cabo de Hornos. El puerto de Tacna también se enlaza directamente con Valparaíso y Guayaquil para la movilización

\footnotetext{
88 Véase mapa III.2.

89 Rosenblitt, 2014, pp. 41-42.
} 
de productos locales, sin que participe el Callao. Buenos Aires, termina por incidir en el mercado de Charcas, por lo que los agentes mercantiles de Tacna y Arequipa reducen su acción a lo que entra y sale de Arica, en respuesta al consumo de las ciudades y enclaves mineros del espacio local. En los últimos años del siglo XVIII se crea una fundición de plata cerca de las oficinas portuarias de Arica, por lo que los mineros de Tarapacá se ven en la necesidad de enviar ahí su producción y acceder al necesitado azogue. Lo cierto es que vemos constituirse una red mercantil tacnoariqueña en competencia o distanciada de la elite limeña. ${ }^{90}$ Arequipa cuenta en esta segunda mitad del siglo con el grupo mercantil más importante del virreinato peruano, después de Lima.

b) Trujillo-Huanchaco-Hualgayoc. El segundo espacio regional es el conformado en torno al centro minero de Hualgayoc, la ciudad de Trujillo y el puerto de Huanchaco. Hualgayoc es uno de los centros mineros responsables del aumento de la producción de plata que Perú registra hacia finales del siglo XVIII. ${ }^{91}$ El cierre de las cajas reales de Piura-Paita y Saña en 1778 obliga a que la mayor parte de la plata de Hualgayoc se registre y pague los impuestos en la ciudad de Trujillo. La monetización de la región establece las condiciones para el surgimiento de un importante sector mercantil dedicado a la importación de bienes europeos con la consiguiente exportación de plata. Sin embargo, a diferencia de Arica, los beneficios impulsados por el gobierno borbón en materia de apertura portuaria llegan tardíamente a Huanchaco. En 1772, el regidor Pedro de Bracamonte solicita que el puerto goce de libertad para realizar el comercio con puertos del Pacífico sudamericano sin la obligación de registro y de control en el Callao. Todo indica que la solicitud no encontró una resolución favorable: en 1793 el puerto trujillano se ve eximido de pagar derechos para la exportación del azúcar, su principal 
producto. La falta de una clara y beneficiosa política peninsular sobre la economía trujillana explica el rechazo de sus terratenientes y comerciantes a un apoyo abierto a la causa realista. De hecho, es la primera ciudad en proclamar la independencia del Perú. Es el escenario opuesto al proceso vivido en Arequipa donde su elite presenta una activa y entusiasta participación en la guerra contrarrevolucionaria. ${ }^{92}$

c) Cuenca-Loja-Piura-Paita. El tercer eje que logra conformar una economía regional con elevado grado de autonomía con relación al eje Lima-el Callao es el espacio comprendido desde el sur de la Audiencia de Quito con las ciudades de Cuenca y Loja como centro, hasta el norte del virreinato del Perú, con puntos en la ciudad de Piura y el puerto de Paita. ${ }^{93}$ El aumento exponencial del comercio exterior de la cascarilla en la segunda mitad del siglo xvin es el elemento que configura el desarrollo del eje. ${ }^{94}$ Paita es el principal punto de salida de la cascarilla y en menor proporción Guayaquil y Tumbes. Puede destinarse a Panamá, ${ }^{95}$ pero la mayor parte se despacha rumbo a España por la ruta del Cabo de Hornos. Cuenca y Loja fungen como zonas productores y Piura como el más importante centro de acopio y procesamiento de la cascarilla. ${ }^{96}$

Con todo, el centralismo limeño se mantiene fuerte. Los órganos de poder de la ciudad de Lima se resistirán a aceptar el regionalismo desde el momento mismo de la apertura de la ruta del Cabo de Hornos. La mayoría de las fragatas peninsulares que

92 Flores, 2011, pp. 75-80.

93 Aldana, 1987, pp. 50-54.

94 La cascarilla o quina es la corteza de un árbol llamado Cinchona officinalis, originario de la región de Loja (Ecuador). Poseía enorme estimación por parte de la sociedad europea gracias a sus facultades medicinales y curativas.

95 Desde Panamá, los navíos europeos, en especial los británicos instalados en Jamaica, alcanzan el producto para responder al consumo de los propios enclaves europeos, para su envío a Estados Unidos y Europa. Para mayores datos sobre la cascarilla, véanse los ensayos especializados de Petitjean y Saint-Geours, 1998, pp. 15-50; Jaramillo Baanante, 1998, pp. 51-94.

96 Jaramillo Baanante, 1998, pp. 51-94. 
hacen la ruta austral buscan arribar como destino final al puerto de el Callao. Tres grandes razones explican la elección: 1) aun con multiplicación de oficinas para el registro de plata por diferentes puertos y ciudades del Pacífico peruano, Lima continúa como el más importante punto de almacenamiento y escape hacia el exterior de la moneda; 2) Lima también se mantiene como la principal plaza consumidora del virreinato de los textiles europeos que se traen en las naves peninsulares, ${ }^{97}$ y 3 ) El Consulado de Comercio de Lima persiste como la más poderosa elite del Perú borbónico; es el ente responsable de la recaudación de los impuestos estatales y derechos aduaneros y proveedor de préstamos forzosos a la Corona. Se comprende, pues, la atracción de los navíos por llegar y salir del Callao. La corporación mercantil defiende a ultranza el centralismo político del espacio, resistiendo cualquier tendencia hacia la autonomía económica de los citados “microejes". Es tal la influencia de la entidad en la vida económica y monárquica durante el periodo borbón, que su poder perdura y se consolida en la época republicana y durante todo el siglo xIX al ser el ente financiero del crédito público y privado. ${ }^{98}$

Por supuesto, la falta de articulación de la economía peruana mencionada da nacimiento a un Estado débil. Pensemos en las economías regionales del guano (1840) o las lanas de Arequipa (1830) que tienen respuesta en el mercado mundial, como el cobre chileno. Pero el Consulado de Lima no cuenta con un competidor como sí lo tuvo el Consulado de la Ciudad de México. Ahí el regionalismo económico se formaliza con la creación de los Consulados en Guadalajara y Veracruz que comprometen el histórico dominio de los comerciantes de la capital desde el temprano periodo colonial..$^{99}$

${ }^{97}$ La producción del virreinato del Perú en oro, plata y frutos ascendía, según Baquíjano, a poco más de 5000000 de pesos anuales y en el año corrido de septiembre de 1785 a 1786 fondean en el puerto del Callao 16 embarcaciones con un valor de carga total estimada en los 24000000 de pesos de textiles europeos. Baquíjano, 1790, núm. 23, f. 239.

98 Mazzeo de Vivó, 2012, pp. 173-214.

99 En las últimas páginas de este capítulo analizaremos la puja entre dichas corporaciones mercantiles por los mercados regionales novohispanos. 
¿Cómo se compone la canasta de importación y exportación de los navíos de registro? En cuanto a la importación de bienes en los puertos del Pacífico meridional, aparece como dominante lo que se conoce en la época con el término genérico de "ropa", es decir, telas crudas o elaboradas en Europa, en la India y, en mucha menor proporción, seda de China. Según estimaciones, los textiles alcanzan $65 \%$ de la canasta importadora. ${ }^{100}$ También ingresa hierro, acero, artículos de ferretería, cera, papel, libros, medicamentos, vidrio y especias del Oriente; productos que antes fluían desde Panamá o desde México.

El cuadro III.5 expresa, a modo ilustrativo, la canasta de exportación de los navíos de registro que salen desde el Callao hacia España. Allí se comprueba que en un contexto del descubrimiento de nuevas minas y de la producción por el Perú (gráfica II.4), la plata es la principal mercancía que se exporta hacia España. La amonedada es la prioritaria, pero también se lleva plata labrada o en pasta. De acuerdo con los casos encontrados, podríamos suponer un promedio de un millón de pesos en plata por cada navío que sale del Perú.

El flujo de cacao guayaquileño hacia España por el Cabo de Hornos cobra especial significancia en las bodegas de los navíos. Estas cantidades son poco representativas si se compara con décadas posteriores, cuando su circulación y consumo se expande en el mercado peninsular y europeo. En 1786, José de Gálvez ordena que las cargas del fruto se envíen hacia España vía Cabo de Hornos y que los envíos hacia el puerto de Acapulco frenen. ${ }^{101}$ En cierta manera, la orden tendrá sus efectos. Según los datos brindados por Miño, desde 1793 la importación de cacao de Guayaquil en España alcanza un monto de 45500 pesos; cifra bastante distante de los 15895 pesos que arroja el tráfico

100 Lamikiz, 2010, pp. 83-84.

101 “Carta nº 698 de D. Juan José de Villalengua a D. José de Gálvez diciendo dará cumplimiento a la orden de que los cosecheros de cacao de Guayaquil no envíen sus cargas de modo independiente por el puerto de Acapulco, sino que lo hagan por el cabo de Hornos según está establecido", en "Petición de cosecheros de Guayaquil”, 1786, AGI, Quito, 244, núm. 45, s/n de fs. 
general con Acapulco. En 1808, Cádiz es el puerto que concentra el mayor ingreso del fruto con casi 250000 pesos, más del doble de lo que registra Acapulco (donde se tenían alrededor de 100000$).{ }^{102}$ Por otro lado, la economía regional del norte, con el eje Piura-Paita, también aporta su producto regional: la cascarilla. La quina representa, luego del cacao, el producto no metálico más importante de la canasta exportadora. Se suman otros productos a la canasta de exportación: el cobre de Chile y la lana de vicuña.

Si la nueva ruta por el Cabo de Hornos explica el descenso de actividad mercantil por Panamá, poca atención mereció en la historiografía el nuevo circuito sobre la economía comercial novohispana. En otros términos, ¿la corriente mercantil de navíos españoles que opera en la costa del Pacífico hispano extiende sus actividades hacia las costas de Huatulco, Acapulco, San Blas o Mazatlán? Aquí ingresamos en una gran confusión metodológica, derivada de fuentes que nada dicen al respecto. Si se es mesurado en las interpretaciones, todo indicaría que las fragatas españolas tienen una nula o débil participación sobre el Pacífico novohispano. Alfonso Mola asegura que, de las 120 embarcaciones gaditanas que salen hacia el Pacífico hispanoamericano durante el periodo 1778 a 1809, tan sólo dos registran al puerto de San Blas como puerto de destino; ${ }^{103}$ ninguna manifiesta dirigirse hacia Acapulco, Huatulco u otro puerto de la costa novohispana Por su parte, en 1796, el propio virrey novohispano Branciforte señala "la nula concurrencia en Sonora, San Blas o Acapulco de los barcos procedentes del Cabo de Hornos", su operatividad llega hasta el límite costero de la América meridional. ${ }^{104}$

Luego de abastecer de textiles y otras mercancías las plazas de la América meridional, las fragatas españolas no parecen contar

102 Miño, 2013, pp. 124-126.

103 Uno de ellos registra "San Blas de California" y el segundo "Callao/San Blas". Alfonso Mola, 2014, p. 542.

104 “Branciforte acusa recibo R.O”, septiembre de 1796, AGI, Estado, 25, núm. 43 (1), s/n de fs. 
con la fuerza ni la capacidad suficientes para extender sus operaciones en los puertos del Pacífico mexicano. La captación de la plata peruana, junto con otros bienes muy estimados en Europa como el cacao de Guayaquil, el cobre chileno o la cascarilla resultan retribuciones que conforman a los mercaderes con sus navíos peninsulares. $\mathrm{Si}$ a eso se le suma que los bienes producidos en Chile, Perú o Ecuador se envían hacia México con navíos locales, la operatividad del navío peninsular termina por circunscribirse al Pacífico meridional.

Es cierto, la incidencia de la apertura por el paso austral en la economía mexicana no se visibiliza en los documentos. Sin embargo, creemos que es contundente su gravitación: a) termina por eliminar la función centralizadora de la Ciudad de México como núcleo abastecedor de bienes internacional en el mercado del Pacífico sudamericano y $b$ ) desplaza la importante injerencia que antes tenían los grandes comerciantes del Consulado de la ciudad de México en dicho mercado.

No sería apresurado pensar que las nuevas relaciones económicas que se establecen desde 1749 entre España y el Pacífico hispanoamericano crean efectos tan importantes como los generados por el famoso Reglamento de Libre comercio de 1778. La historiografía ha concentrado el debate sobre el éxito o el fracaso de esta última disposición en el tráfico ultramarino y ha puesto poca atención sobre la nueva ruta. ${ }^{105}$ Nuevamente, valoramos aquí los estudios de Lamikiz que señalan la institucionalización del paso por el Cabo de Hornos como medida responsable de las principales transformaciones económicas y mercantiles en el comercio imperial, tanto por el área del $\mathrm{Pa}$ cífico como del Atlántico, superando incluso las que genera el famoso reglamento. ${ }^{106}$ 


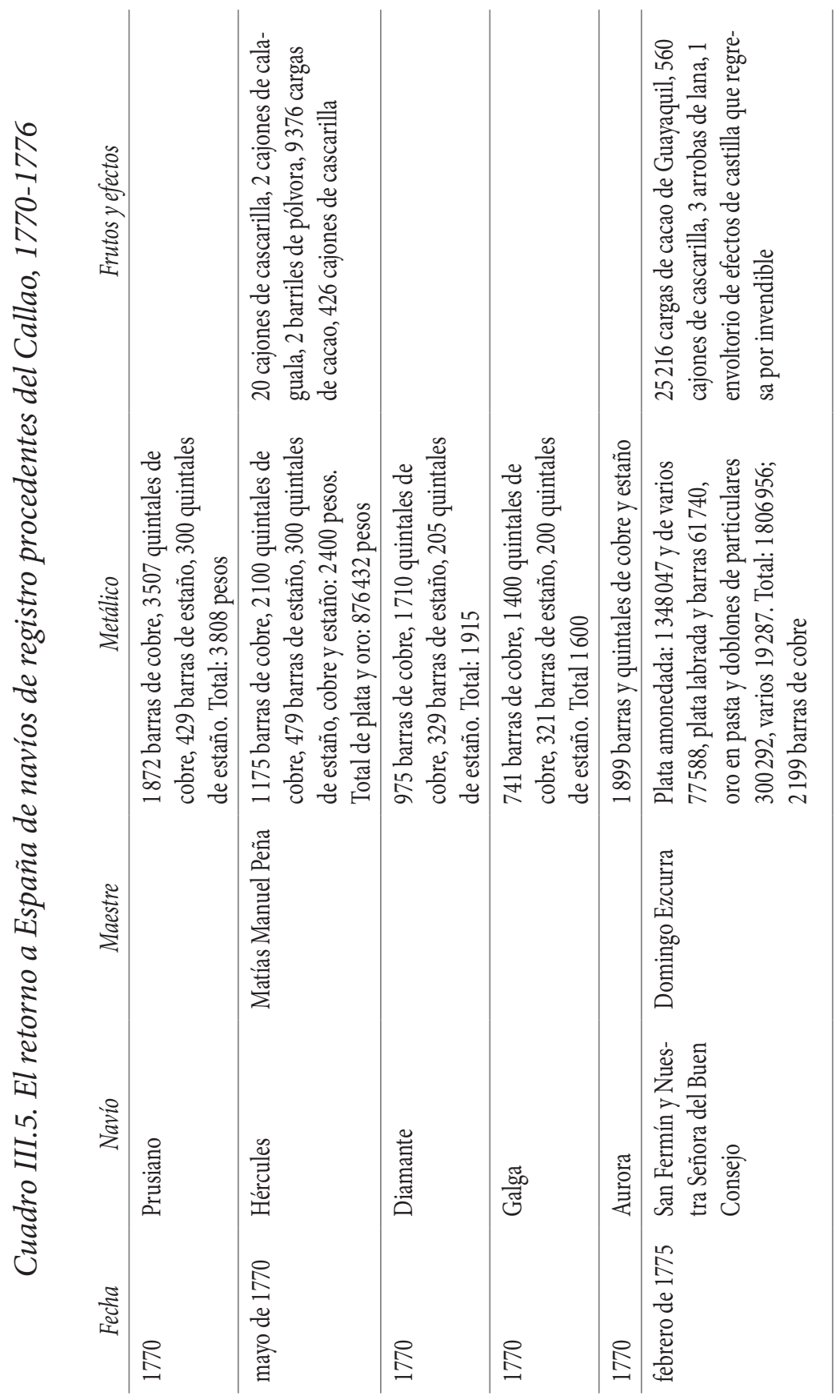




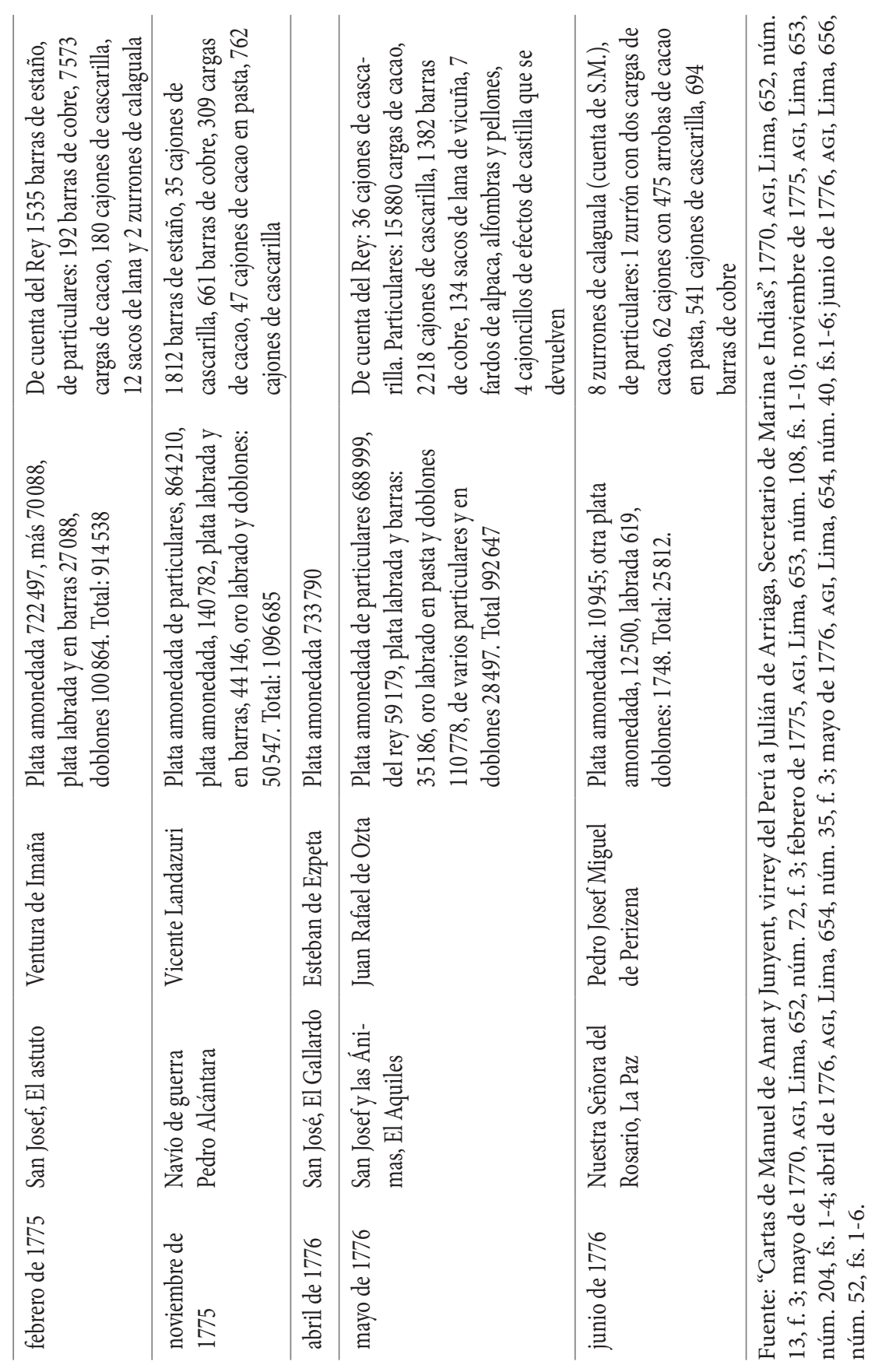


Mapa III.1. Economía marítima en la América española (1750-1840)

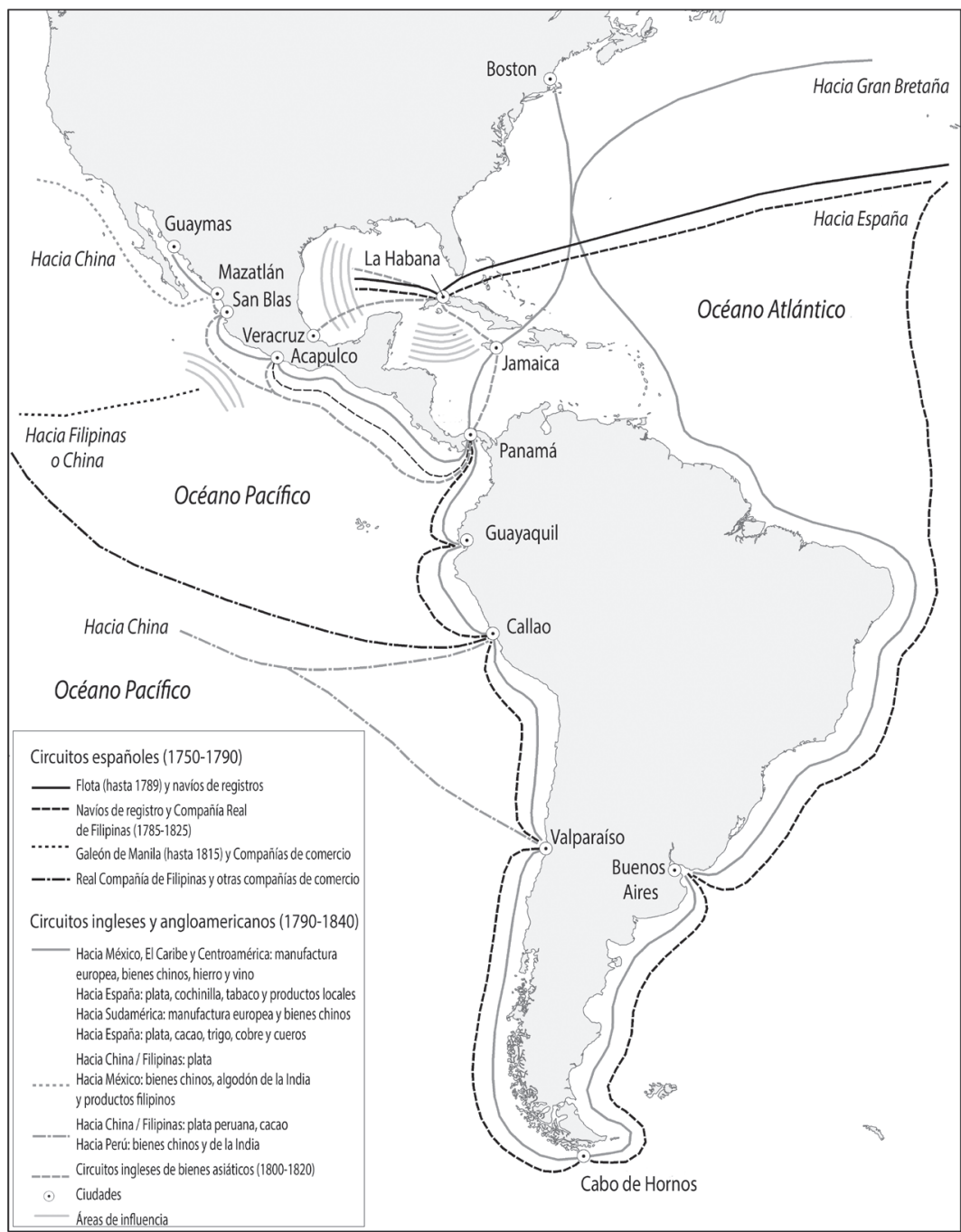

Fuente: Elaboración propia con digitalización de Emelina Nava García.

En definitiva, no estamos en presencia de un mero cambio de orientación de rutas mercantiles. Su apertura, acompañada de la nueva modalidad de transporte como son los navíos particulares, 
acarrea efectos que superan el plano económico de los circuitos. Los estudios de Parrón Salas, especialista en la materia, sugieren que la adopción del comercio directo entre España y el Perú a través de los navíos de registro sólo representa un cambio en la ruta de los intercambios y no en el funcionamiento del sistema. Por el contrario, Lamikiz nota una profunda modificación del patrón comercial. ${ }^{107}$ Recordemos también aquí, la innovadora hipótesis de García Baquero y que continuaron otros estudios sobre la apertura del Cabo de Hornos en tanto fenómeno económico igual o más trascendental que el reconocido Reglamento de Libre comercio de $1778 .{ }^{108}$ Aquí sostenemos que la apertura del Cabo de Hornos constituyó, no sólo un hecho revolucionario en materia económica, sino un parteaguas en la geopolítica de la América española. En términos macroespaciales, se puede apreciar una circulación de navíos y promedio de tonelaje desde España hacia Sudamérica que se equipara a la dinámica mercantil que recibe el mercado novohispano. Como vimos en el capítulo II, antes de 1750 Nueva España concentra buena parte del total del tráfico ultramarino. Entre 1740 y 1778, el porcentaje de tonelaje es de 39\% hacia México y 31.6\% hacia Tierra Firme. En cantidad de navíos: $33.8 \%$ hacia y desde Nueva España y 35.2\% para Tierra Firme. ${ }^{109}$ En segundo lugar, a pesar de las distancias espaciales y de las realidades ajenas, el eje austral termina por descomponer el papel centralizador del que históricamente gozó la Ciudad de México en cuanto a centro redistribuidor de bienes internacionales. La relación se encuentra omitida por quienes intentan rastrear los reposicionamientos geopolíticos y económicos de los espacios hispanoamericanos desde el reformismo borbónico hasta la emergencia de los Estados nacionales. El sistemático abastecimiento directo desde España de mercaderías europeas y asiáticas hacia los mercados de Chile, Perú y Quito provoca la parálisis de una de las "arterias" que le inyectaban de vida y sentido al Pacífi-

107 Parrón Salas, 1997, p. 469; Lamikiz, 2007, pp. 231-258.

108 García Baquero, 1976.

109 García Baquero, 1976, p. 268. 
co indiano. La estructura económica-mercantil asentada en el eje Acapulco-Ciudad de México se verá todavía más comprometida a partir de 1790, cuando los balleneros británicos y angloamericanos reproduzcan, a una escala mucho mayor, el comercio por el Cabo que inauguran 50 años antes los navíos de registro de la época borbónica.

Segunda fase: balleneros ingleses y angloamericanos desde 1790

Las economías de la América española occidental vivirán una segunda ofensiva de la economía atlántica a partir de 1790. La nueva oleada tendrá otros protagonistas, pero el eje geomercantil por el Cabo de Hornos continuará teniendo un papel fundamental. La renovada ofensiva europea, considerada aquí como la segunda fase de la atlantización del Pacífico por el estrecho austral, supera las fuerzas que desde décadas atrás venía presentando la economía peninsular borbónica. La aparición de los balleneros por el área denota un renovado control europeo comandado por Gran Bretaña y la nueva nación estadounidense. Al analizar esta segunda fase de comercio europeo por el Cabo de Hornos, el concepto de balleneros no parece ser tan representativo de lo que en realidad sucede en el escenario económico. El comercio legal e ilícito que practican los ingleses y norteamericanos por el eje se ejecuta tanto con embarcaciones de gran porte dedicadas a la actividad de pesca de ballenas, focas y lobos marinos, vital para la industria dedicada a la elaboración de esperma y aceite destinados a alumbrar y cocinar, como en navíos dedicados exclusivamente a la venta de productos europeos, en especial de textiles.

No se pueden pasar por alto las particularidades de esta segunda fase mercantil, tema que se abordará más adelante. De momento, atendamos las notables continuidades históricas en materia de comercio y geopolítica con la primera fase de la atlantización del Pacífico: a) la trascendencia histórica del Cabo de Hornos como eje transoceánico; b) la agudización de la crisis de los ejes geohistóricos tradicionales: Acapulco-Ciudad de 
México-Pacífico sudamericano y Panamá-Pacífico sudamericano; c) la vía de abastecimiento de textiles europeos, en especial el algodón inglés; d) la apropiación de la plata y de otros minerales (como el cobre chileno) por los puertos del Pacífico hispanoamericano; $e$ ) el fortalecimiento de las elites mercantiles locales como Sacramento, Buenos Aires, Chile, Perú, Ecuador y Panamá, ${ }^{110}$ y $f$ ) la consolidación de la fragmentación de los mercados hispanoamericanos.

Cada una de las problemáticas mencionadas encierra una enorme complejidad de fenómenos que se irán abordando seguidamente. Vale iniciar el análisis del nacimiento y desarrollo del fenómeno ballenero desde el plano legislativo. La guerra y el conflicto entre naciones europeas explica, quizá como pocos sucesos mercantiles del momento, el nacimiento y desarrollo de la navegación y el comercio de los navíos balleneros ingleses y estadounidenses. Los acuerdos diplomáticos que España negocia con Inglaterra y Estados Unidos en 1790 y 1795, más la real orden para el "comercio de neutrales" de 1797 constituyen un excelente "combo normativo" para el notable despliegue de la incursión extranjera desde el Atlántico hacia el Pacífico.

El punto de partida es la Convención de paz celebrada en San Lorenzo entre Inglaterra y España el 28 de octubre de $1790 .{ }^{111} \mathrm{La}$ presencia efectiva de buques ingleses en las costas del noroeste novohispano efectuando el comercio de pieles de nutria y aceite de ballena obliga a la Corona española a sentarse en la mesa de negociación. ${ }^{12}$ Cabe recordar que desde 1767 la Corona reconoce la presencia de los rusos en la práctica del comercio peletero en el

110 Villalobos, 1965, pp. 90-96.

111 "Convención celebrada entre España e Inglaterra transigiendo varios puntos sobre pesca, navegación y comercio en la costa N.O. de América, hecha en San Lorenzo el Real el 28 de octubre de 1790", AHNM, Estado, 3370, exp. 4, s/n de fs. Véase también la completa transcripción del tratado en: Del Cantillo, 1843, pp. 623-633.

112 Entre 1788 y 1789 dos buques de la marina española a cargo del comandante José Martínez viajan entre San Blas y el puerto de Nootka para asegurar y fortalecer los puntos costeros de una descuidada frontera monárquica. La comitiva española se encuentra con un lucrativo comercio extranjero entre China y la región costera del noroeste novohispano. 
norte del Pacífico, pero no presenta una seria amenaza con relación al avance británico. ${ }^{113}$ Lo cierto es que el Pacífico borbónico se encuentra presionado por varios frentes. La alternativa peninsular se reduce a la negociación diplomática. La pesca británica y angloamericana es un hecho evidente desde 1780 con incursiones esporádicas, sin ningún tipo de marco jurídico o normativo que legitime su accionar. Compuesto de ocho artículos y una cláusula secreta, sintetizamos con nuestros términos los artículos de la Convención de 1790 que más nos interesan: $3^{\circ}, 4^{\circ}, 5^{\circ}$ y $6^{\circ}: 114$

$1^{\text {o }}$ Se reconoce la navegación y pesca inglesa en el océano Pacífico, permitiéndoles operar en parajes no ocupados por España para facilitar escalas de descanso, establecimiento y "comercio con los naturales".

$2^{\circ}$ Que la navegación y pesca británica no sea excusa para promover "el comercio ilícito", por lo cual navíos ingleses deben sujetarse a 10 leguas marítimas de distancia de la costa.

$3^{\circ} \mathrm{La}$ libre movilización de súbditos ingleses y españoles por el noroeste de la América septentrional.

$4^{\circ}$ Los súbditos británicos se comprometen a no formar asentamientos en la costa occidental y oriental de la América meridional; exceptuando la construcción de cabañas u otras obras temporales para su exclusiva actividad de pesca.

¿Dónde se encuentra el límite entre la prohibición al "comercio ilícito" $\left(4^{\circ}\right)$ y la posibilidad de construir "enclaves" y escalas?, ¿dónde está el punto que divide la prohibición a su "comercio ilícito" con la autorización al "comercio con naturales"? Con una redacción que roza la confusión, las ordenanzas transitan por un hilo muy fino entre lo que está permitido y lo prohibido. Al mis-

113 AGI, Estado, 47, núm. 1; Vila Vilar, 1966; Barratt, 1944.

114 En los dos primeros artículos la Corona española se compromete a restituir los asentamientos británicos en la costa noroeste de la América septentrional, producto del acontecimiento conflictivo del año anterior y, en segundo lugar, a indemnizar a Inglaterra por los daños causados en terrenos, edificios, navíos y mercaderías; véanse todos los artículos en Del Cantillo, 1843, pp. 623-633. 
mo tiempo, las estipulaciones denotan el desequilibrio de fuerzas que existe en la mesa de negociación y los enormes beneficios que España concede a Inglaterra. Se termina por reconocer el desenvolvimiento informal del comercio inglés por todo el Pacífico, no sólo por el Pacífico septentrional. Cualquier modalidad de comercio ballenero se consiente ante el amplio margen de manipulación que brinda el cuerpo de disposiciones. La ambigüedad de las cláusulas expresa el triunfo británico, pues dispone del manto jurídico que legitima la navegación de los balleneros. Muestra, a la vez, la debilidad española como potencia marítima, que no tiene más alternativa que reconocer mecanismos múltiples de penetración del comercio inglés en los mercados hispanoamericanos.

Valdría un paréntesis acerca de la identidad que asume el $\mathrm{Pa}$ cífico. No hay duda de que el Tratado de Nootka de 1790 marca un quiebre en la identidad económica del Pacífico. De un perfil fuertemente hispánico que adquiere desde 1750 (con la disolución del Pacífico indiano), tan sólo cuatro décadas después asume una identidad extranjera o lo que algunos especialistas llaman la "desnacionalización". ${ }^{15}$ El Pacífico español es fruto de la crisis del galeón de Manila, del desarrollo de compañías mercantiles peninsulares y, sobre todo, de la proliferación de los navíos de registro por el Cabo de Hornos. Pero en 1790, aquella "refundación ibérica del Pacífico"116 se verá profundamente cuestionada a raíz de la concesión otorgada a los navíos británicos y angloamericanos para la explotación del aceite de ballenas, de pieles de nutrias y de focas.

115 Para Ramiro Flores, la convención de 1790 "representa un hito clave en el proceso de desnacionalización del comercio peruano, pues legaliza la presencia de naves extranjeras en aguas territoriales españolas, dando el ejemplo a otros empresarios foráneos que buscaban penetrar el infranqueable mercado colonial hispanoamericano". Flores, 2010, p. 41. Quizá sea apresurado hablar de "desnacionalización", una noción que corresponde a otra circunstancia histórica. En una visión más hispanoamericana, parece más pertinente el concepto de extranjerización.

116 El término, muy pertinente para otorgarle una identidad muy breve al Pacífico como verdaderamente ibérico, aparece en Vives Anzacot, 1991, pp. 245-257. 
Las Islas Filipinas vivirán un proceso similar, pero con importantes diferencias políticas con relación al Pacífico hispanoamericano. Desde 1789, año en que la Corona decreta a Manila puerto franco al comercio internacional, el archipiélago vivirá una época de esplendor en calidad de centro geopolítico y mercantil de esta segunda fase de la globalización netamente occidental. Aumentará de manera notable la presencia de los juncos chinos y de buques españoles, pero lo novedoso será el crecimiento exponencial de embarcaciones europeas (mayormente británicas) y estadounidenses. Por ejemplo, entre 1798 y 1801 llegan y salen de Manila tan sólo 8 y 6 buques españoles, mientras que los buques de aquella procedencia son 54 y 53, respectivamente. ${ }^{117}$ De esta manera, aunque las Islas Filipinas se mantendrían políticamente hispánicas hasta finales del siglo XIX (1897-1898), pasarían inmediatamente al dominio estadounidense; hay que reconocer la extranjerización de su economía exterior en tiempos simultáneos al caso hispanoamericano.

En efecto, para el caso del Pacífico hispanoamericano, notamos una identidad extranjera en vísperas de los procesos de emancipación iberoamericana que se profundizará conforme avancen las décadas del siglo XIX. La autorización peninsular para el "comercio de neutrales" permitirá que las elites económicas locales del Pacífico comiencen a realizar intercambios directos con los agentes europeos; una presencia extranjera que décadas más tarde se materializará en la creación de compañías y unidades políticas consulares extranjeras en los Estados nacientes de la América española. Hacia 1820 ya están establecidas renombradas casas de comercio norteamericanas y británicas en Santiago y en Lima, promovidas por el comercio ballenero y lobero. Sobresalen la Casa de Alsop de Nueva York fundada en Valparaíso en 1824 y en Lima en 1828 y otras tantas en Santiago (Wessel-Duval y Cía. en 1827). La penetración de estas empresas foráneas cultiva y difunde ideas de independencia hispanoamericana. ${ }^{118}$ 
Lo cierto es que año tras año se irá diluyendo la presencia española. En mayo de 1793, las débiles regulaciones que seguían vigentes del tratado de 1790 terminan por esfumarse. Un nuevo convenio otorga una notable apertura y libertad para los balleneros ingleses en sus descansos y escalas que realice por cualquier punto del Pacífico meridional y septentrional. Como retribución, España sólo solicita un simple pago en efectivo por todas sus compras de víveres. ${ }^{119}$ La nueva cláusula no hace más que dejar sin efecto el único límite al avance que establecía la Convención de Nootka: el artículo $4^{\circ}$ que obligaba a Gran Bretaña a sujetarse a 10 leguas de distancia de la costa. Desde entonces, el contrabando inglés tendrá vía libre para realizar la actividad de pesca y el contrabando de bienes y plata por toda la franja del Pacífico.

Ambas disposiciones jurídicas, las de 1790 y 1793, brindan el sustrato legal que alienta la sistematicidad del flujo comercial de los británicos como de los estadounidenses, de los que enseguida nos ocuparemos. Compartamos algunos datos cuantitativos generales. Desde 1788 hasta 1809 navegan por el Cabo de Hornos y llegan a los puertos comprendidos entre Valparaíso y California unos 165 buques ingleses y norteamericanos. ${ }^{120}$ Jorge León contabiliza para el año de 1800 unos 80 barcos balleneros y cazadores de pieles, los cuales participan en un activo contrabando por la gran demanda de bienes europeos que presentan los mercados de Chile, Perú y México. ${ }^{121}$ Entre 1817 y 1818, en las costas peruanas hay más de 100 balleneros norteamericanos que estarían alcanzando el occidente mexicano. ${ }^{122}$

119 “Convenio provisional de alianza defensiva entre su Majestad Católica y el Rey de la Gran Bretaña con motivo de los sucesos ocurridos en la república francesa: firmado en Aranjuez el 25 de mayo de 1793", en Del Cantillo, 1843, pp. 646-657

120 Pereira Salas, 1971, pp. 315-353. Villalobos nos ofrece una cifra más elevada. Durante ese periodo estarían surcando el paso austral 257 barcos (sólo estadounidenses). Villalobos, 1965, p. 94.

121 León, 2001, p. 326.

122 Burne Goebel, 1938, p. 304; Flores, 2010, p. 85. No resulta casual que el primer nivel de comercio de bienes de producción local que hemos analizado en el primer apartado de este capítulo muestre un descenso desde 1815. La explicación parece estar en la consolidación de los balleneros ingleses y estadounidenses en los circuitos 
Veamos lo que informan las fuentes testimoniales de la época. El 6 de marzo de 1795, el virrey del Perú, Francisco Gil, expone "los perjuicios que se siguen de la falta de cumplimiento del artículo $4^{\circ}$ de 1790 sobre de la Convención de pesca”. Anota el caso de un conjunto de fragatas que en 1794 arriban al puerto de Coquimbo, Chile: dos inglesas, Alderney y Belisarius, y dos estadounidenses, Ruby y Favorita. ${ }^{123}$ Las cuatro fragatas, junto con muchas más, son apenas una pequeña muestra de la injerencia extranjera por los mercados del Pacífico. Notifica el virrey que:

han sido tan frecuentes las arribadas de estos pescadores a nuestros puertos [...] que esa condición de convenio ha sido abolida en la práctica desde su mismo principio [...] su repetición y frecuencia exigen toda la atención [...] hay poca protección y dilatada costa en que los balleneros aprovechan para realizar el tráfico clandestino. ${ }^{124}$

La carga de cada barco ballenero supera las 200 toneladas. Un testimonio de uno de los capitanes señala la presencia de barcos balleneros muy cercanos a la costa de Chile, con el objetivo de dirigirse al puerto de Pisco para abastecerse de aceite, necesario para la travesía de dos años. Sólo una de ellas, Ruby, contiene mercaderías por valor de 8000 libras esterlinas. Lo preocupante para el virrey es cómo los balleneros compensan los auxilios recibidos, de acuerdo a la cláusula del año 1793, con la propia plata del Perú, lo que supone la existencia de tratos mercantiles previos, vendiendo algodón inglés y toda mercancía europea que los mercaderes locales solicitan: "el pago hecho por aquellas dos fragatas inglesas en satisfacción de los auxilios recibidos fue en moneda acuñada de esta capital que no pudieron adquirir sino

del Pacífico. Los balleneros no sólo efectúan el tráfico interoceánico de bienes europeos por el Cabo de Hornos, también el comercio de cabotaje, al movilizar bienes locales de consumo básico entre los diferentes puntos del litoral.

123 "Virrey del Perú da cuenta de la arribada de unos balleneros", AGI, Estado, 73, núm. 25.

124 "Virrey del Perú da cuenta de la arribada de unos balleneros", AGI, Estado, 73, núm. 25. 
en estos mares según sus fechas" ${ }^{125}$ La poca resistencia o, mejor dicho, la bienvenida que les ofrecen los propios comerciantes locales y regionales a los balleneros ingleses en cada puerto y mercado del Pacífico sudamericano hacen inviable cualquier medida de regulación estipulada. ${ }^{126}$

En 1794, Francisco Gil insiste nuevamente "sobre la frecuencia que entran en los puertos del virreinato". Menciona nuevos casos, como la fragata inglesa York y de otras "muchas embarcaciones que han arribado" y "haber vendido con ventaja grandes cantidades de efectos comerciables". ${ }^{127}$ Las arribadas y el contrabando británico por toda la franja occidental hispanoamericana, desde Chile hasta México, no se detendrá en los siguientes años. En 1800, balleneros británicos y estadounidenses realizan el contrabando por los puertos de San Blas y Loreto con cargas estimadas al millón de pesos cada una. ${ }^{128}$ Simultáneamente, se presentan "cinco o seis buques ingleses entre Paita y Santa Elena”; una suerte de crucero militar y comercial que captura navíos locales traficando por el Pacífico con pérdidas estimadas al millón de pesos, pero que, según la apreciación del virrey marqués de Osorno: "ha sido poco sensible el daño en esta capital porque se ha dividido entre muchos o repartido con los comerciantes de las provincias y reinos de Chile, Quito, Panamá y otras partes". ${ }^{129}$

El virrey reitera algo ya visto: ante la incapacidad de las fuerzas hispánicas para contrarrestar la arremetida inglesa, se suma

125 "Virrey del Perú da cuenta de la arribada de unos balleneros", AGI, Estado, 73, núm. 25, fs. 5-6.

126 "[...] y lo que acaso es peor a tolerar que cada día se vean en nuestras costas navegar tranquilamente flotas de pescadores aún armados sin poder hacerles separar de ella a la distancia convenida con falta de fuerzas con que hacerles respetar lo estipulado". "Virrey del Perú da cuenta de la arribada de unos balleneros", AGI, Estado, 73, núm. 25, f. 11.

127 “Sobre entradas de embarcaciones inglesas", 23-8-1794, AGI, Estado, 73, núm. 113.

128 "Correspondencia sobre los balleneros ingleses y americanos", AGNM, Instituciones coloniales, Archivo Histórico de Hacienda (008), vol. 839, s/n de exp.

129 "La codicia y el descuido de nuestras embarcaciones mercantes ha hecho que navegando separados y sin armas caigan en sus manos y las pérdidas se calculen ya en cerca de un millón de pesos"; "Disposiciones por desalojar a los balleneros", El Callao, 22-1-1800, AGI, Estado, 73, núm. 101. 
la complicidad de los mercaderes regionales de Chile, Ecuador, Panamá y de la misma ciudad de Lima, quienes ven en el comercio inglés una excelente oportunidad para generar rentabilidad en unos negocios que no parecían aumentar con el tráfico de navíos españoles o autorizados. Más evidencias: en 1804, el gobernador de Panamá, Juan de Urbina, relata la frecuencia "con que llegan a los puertos del espacio, navíos ingleses y angloamericanos", que si bien muestran "dedicación a la pesca de ballena en el Mar del Sur, no están exentos de realizar el contrabando". ${ }^{130}$ En ese mismo año, se encuentran cometiendo "excesos de comercio ilícito" en el puerto de Talcahuano (puerto de Chile) dos balleneros ingleses; misma cantidad de navíos vemos aparecer en el mes de noviembre por el puerto de Pisco (Perú), "montadas con 18 cañones cuyos capitanes saltaron a tierra pidiendo víveres y haciendo contrabando." ${ }^{13}$

Hemos ofrecido cálculos generales acerca del número de balleneros que circulan por el Pacífico. Valdría ahora inscribir esas generalidades con un pequeño ejemplo de 1793. Sabemos que en tan sólo un mes, del 22 de mayo hasta el 26 de junio de aquel año, llegan a la costa del Callao cinco embarcaciones británicas con procedencia de Londres, con la excusa de "víveres y bastimentos" (cuadro III.6). Es nuevamente Francisco Gil, el virrey, quien advierte que "no serán las últimas, pues en este año se hallan en la pesca y el comercio la mayor parte de las 33 que se hallan matriculadas para estos fines". ${ }^{132}$ Parecen ser balleneros con amplias bodegas, cuyo tonelaje va entre los 175 a los casi 380. Si bien la carga que reconocen es la de aceite de ballena y lobos marinos, el virrey delata las importantes "cajas de textiles europeos que no se pueden medir" para intercambiarla por monedas de plata. El tiempo que lleva recorrer el circuito transcontinental desde Gran Bretaña al Perú es de un año, pero dos de ellas eligen un preciso punto de escala: Río de Janeiro.

130 AGI, Estado, 51, núm. 17, (13/9/1804).

131 "Virrey del Perú sobre los excesos de embarcaciones extranjeras", AGI, Estado, 73, núm. 32.

132 AGI, Estado, 73, núm. 37, f. 9. 
La actuación británica sólo puede sustentarse en un escenario con alto nivel de militarización, proclive a intervenciones en suelo hispánico. Conscientes de los flacos recursos militares que cuenta la armada española para defender sus fronteras y mercados, los ingleses declararán la guerra en toda coyuntura precisa que lo vean conveniente. El virrey del Perú lo dice explícitamente hacia 1800, en pleno conflicto (1796-1802): "se armaron para sostener y comerciar confiados en la falta de fuerzas navales para resistirlo". ${ }^{133}$ El comercio a gran escala y la política militar geoestratégica son fenómenos estrechamente vinculados.

Cuadro III.6. Balleneros ingleses apostados en el Callao del 22 de mayo al 26 de junio de 1793

\begin{tabular}{llllll} 
Nombre & $\begin{array}{c}\text { Corbeta } \\
\text { Grenssuh }\end{array}$ & $\begin{array}{c}\text { Fragata } \\
\text { Guillermo } \\
\text { Enrique }\end{array}$ & $\begin{array}{c}\text { Fragata } \\
\text { Rasper }\end{array}$ & $\begin{array}{c}\text { Fragata } \\
\text { Príncipede } \\
\text { Wales }\end{array}$ & $\begin{array}{l}\text { Corbeta } \\
\text { Libelly }\end{array}$ \\
\hline Capitán & Jorge & Benjamin \\
Quened & Swif & Thomas & Gage & $\begin{array}{l}\text { Federic } \\
\text { Boton }\end{array}$ & $\begin{array}{l}\text { Richard } \\
\text { Brown }\end{array}$ \\
\hline Procedencia & Londres & Londres & Londres & Londres & Londres \\
\hline Salida & $6 / 6 / 1792$ & $16 / 5 / 1792$ & $10 / 8 / 1792$ & $20 / 7 / 1792$ & $5 / 9 / 1792$ \\
\hline Llegada & $22 / 5 / 1793$ & $26 / 5 / 1793$ & $30 / 5 / 1793$ & $31 / 5 / 1793$ & $26 / 6 / 1793$ \\
\hline Escala & Río de & Río de & Isla de & Valparaíso & sin escala \\
& Janeiro & Janeiro & Lobos & & \\
\hline Carga & Aceite de & 3500 & 3000 & 2000 & 330 ba- \\
& ballena & lobos & lobos & lobos \\
& marinos & marinos y & marinos y & grasa \\
& y000 & maceite de & \\
& lobos & y 1700 & aceite de & ballena & \\
& marinos & barriles de & ballena & ballena \\
& & aceite de & & & \\
\hline Tonelaje & 256 & - & 175 & 376 & - \\
\hline Tripulación & 22 & 22 & 22 & 23 & - \\
\hline
\end{tabular}

Fuente: AGI, Estado, 73, núm. 37, fs. 6-20.

133 "Disposiciones por desalojar a los balleneros", El Callao, 22-1-1800, AGI, Estado, 73, núm. 101, f. 1. 
Los británicos disponen de al menos dos flancos militares para la amplia área sudamericana. Por el lado atlántico, está el puerto de Río de Janeiro, por el frente del Pacífico, concentran sus fuerzas militares en la ratio ubicada entre Paita y Santa Elena; lugar con mucha densidad en el movimiento del comercio de cabotaje. Como ilustra el cuadro III.6, el puerto de la colonia portuguesa se convierte durante esas décadas en el punto geoestratégico fundamental a la hora de planificar embates militares y mercantiles para el avance de los balleneros británicos hacia el Pacífico por el Cabo de Hornos. Hablamos de un prolongado asentamiento británico con epicentro militar en Río de Janeiro porque los vemos operar desde 1780 hasta al menos 1808 . Antes de cruzar el estrecho austral está Buenos Aires, que no es un puerto indiferente para los objetivos británicos. En 1780, se encuentran la notable cantidad de 22 navíos ingleses navegando entre Río de Janeiro, Montevideo y Buenos Aires para realizar el contrabando. Las autoridades porteñas perciben una posible invasión. La presión inglesa desde Río de Janeiro sobre el comercio de Montevideo y Buenos Aires es, cuando menos, asfixiante. ${ }^{134}$ En 1800, el virrey de Buenos Aires recibe una orden real para liberar un contingente de marinos británicos que habían caído prisioneros a raíz de 11 buques balleneros que operaban por la costa. ${ }^{135}$ En 1798, el virrey del Río de La Plata, Olaguer, le notifica a su par peruano, marqués de Osorno, que se encuentran ingresando al Pacífico: "dos fragatas inglesas de 28 y 30 cañones armados en corso y mercancía de géneros y destino determinado de introducirlas por los mares del Sur, siendo comandante de uno de dichos buques oficial de Marina"..$^{136}$

Las fragatas llegan al Pacífico sudamericano con procedencia de Río de Janeiro: una de ellas lo hace con 20 cañones y 70 tri-

134 Si la invasión militar británica a Buenos Aires de 1806 no tiene éxito, al menos logran que las autoridades porteñas reconozcan la necesidad de su comercio. Burne Goebel, 1938, pp. 311-313.

135 "Carta no 23 Agustín de Jáuregui, Virrey de Perú, a José de Gálvez, Secretario de Indias”, 1780-84, AGI, Lima, 659, núm. 119.

136 "Sobre entrada en el Mar del Sur de dos fragatas inglesas", 26, 4-1798, AGI, Estado, 73, núm. 81. 
pulantes; la otra con 8 y 40. Están preparadas para el comercio clandestino con "ricas mercaderías de textiles británicos para introducirlos por los puertos intermedios y del Mar del Sur". Ya entrado el siglo xix, Río de Janeiro se institucionaliza como punta de lanza británica en su expansión mercantil e intervención sobre los espacios de Sudamérica, tanto por el Atlántico, pero sobre todo por el Pacífico. En 1808, se establece la estación naval británica en Río de Janeiro, como parte de una estrategia global de control inglés sobre los mares. Como bien lo explicita Flores, la estación no es otra cosa que "un escudo seguro" para comerciantes y balleneros, con lo que les es posible aumentar sus actividades comerciales. ${ }^{137}$

Ahora bien, hemos advertido que junto a los balleneros británicos circulan navíos estadounidenses. Su reconocimiento llegará casi de manera simultánea a la presencia británica, el 27 de octubre de 1795, con el Tratado de amistad, límites y navegación entre su Majestad Católica y los Estados-Unidos de América, compuesto de 23 artículos y firmado en San Lorenzo. ${ }^{138}$ A pesar de que el Tratado de 1795 presenta la excusa por convenir los límites de la América meridional entre la nueva nación norteamericana y España, la mayoría de los acuerdos giran en torno a la presencia y comercio de las naves angloamericanas en las áreas atlántica y pacífica de la América española. Los artículos comprendidos entre el $7^{\circ}$ y el $15^{\circ}$ se refieren, de manera contundente y sin ambigüedades, a la absoluta libertad que disfrutarán los navíos angloamericanos para navegar y comerciar, no sólo por la ratio de los puertos de la América española, sino también para aquellos que escalan, proceden u operan con puertos "enemigos". ${ }^{139} \mathrm{Si}$ es-

137 La estación es un dispositivo de defensa naval compuesto por un conjunto de buques de guerra estacionados de forma permanente en Río de Janeiro para proteger a la familia real portuguesa residente en aquella ciudad. Flores, 2010, p. 57.

138 Del Cantillo, 1843, pp. 665-671.

139 Vale reproducir algunos de ellos. Artículo 7: "se ha convenido que los súbditos y ciudadanos de una de las partes contratantes, sus buques o efectos, no podrán sujetarse a ningún embargo o detención de parte de la otra". Artículo 8: los buques de ambas partes, sean públicos o privados, de guerra o de comercio "serán recibidos y tratados 
tas permisiones resultan de por sí llamativas, más notable y revolucionaria nos parece la cláusula $16^{\circ}$ :

Esta libertad de navegación y de comercio debe entenderse a toda especie de mercadería, exceptuando sólo las que se comprenden bajo el nombre de contrabando o mercaderías prohibidas, las cuales son: armas, cañones, bombas [...] pero los géneros y mercaderías que se nombrarán ahora no se comprenderán entre los de contrabando o cosas prohibidas, a saber: toda especie de paños y cualquiera otra tela de lana, lino, seda u algodón u otras cualquiera materia, toda especie de vestidos con las telas que se acostumbran hacer, el oro o la plata labrada en moneda o no [...] todas las cosas que se acaban de nombrar deben ser comprendidas como mercaderías libres. ${ }^{140}$

El artículo modifica todo principio de lo que, hasta entonces, se considera como acto de contrabando. De ahora en más, las mercaderías prohibidas se constriñen a los objetos militares y de guerra. A partir de la ampliación de la canasta de bienes permitidos, el navío angloamericano tendrá el libre derecho de comerciar el más estimado rubro existente por los mercados hispanoamericanos: el algodón británico y todo tipo de textil bruto o confeccionado de Europa. El Tratado podría definirse, en de-

con humanidad, gozarán de todo favor, protección y socorro y les será lícito proveerse de refrescos, víveres y demás cosas necesarias". Artículo 12: "a los buques mercantes de las dos partes que fueran destinados a puertos pertenecientes a una potencia enemiga de una de las dos, cuyo viaje y cargamento diese justas sospechas se les obligará a presentar no sólo sus pasaportes sino también los certificados que probaran expresamente que su cargamento no es de la especie de los que están prohibidos como de contrabando". Artículo 15: "se permitirá a todos de una y otra parte que puedan navegar con sus embarcaciones con toda libertad y seguridad sin que haya la menor excepción al respecto, aunque los propietarios de las mercaderías cargadas en las referidas embarcaciones vengan del puerto que quieran, y las traigan destinadas a cualquier plaza de una potencia enemiga [...] se permitirá igualmente a todos los súbditos navegar con sus buques y mercaderías y frecuentar con total libertad y seguridad las plazas y puertos de las potencias enemigas de las partes contratantes, y comerciar no sólo desde los puertos del dicho enemigo a un puerto neutro directamente, sino de uno enemigo a otro tal". Del Cantillo, 1843, pp. 665-668.

140 Artículo 16. Del Cantillo, 1843, pp. 668-669. 
finitiva, como una clara antesala al reglamento de comercio de neutrales que se decreta al siguiente año, en 1796.

La guerra anglo-española (1796-1802) deviene en un efecto inevitable: la declaración española como enemiga a toda embarcación británica, con la facultad de ser apresada y embargada por las autoridades españolas en América. Se suspenden las cláusulas de 1790 y 1793 donde se autorizaba el auxilio, escalas o incluso intercambios con los mercaderes locales en la América española. Cualquier acto de comercio ilícito de (o con) los ingleses se sanciona con la pena de muerte. ${ }^{141}$ Se piensa que en esos años conflictivos la presencia de buques ingleses cae en intensidad por las costas de Chile y Perú, dado el peligro de verse capturados. ${ }^{142}$ Sin embargo, los estudios demuestran una tendencia contraria. El conflicto permite una mayor circulación de navíos ingleses y de sus textiles hacia unos mercados del Pacífico tan necesitados de sus bienes. ¿Cómo lo hacen?

La declaración de guerra por parte de España, aunado a la autorización del comercio de neutrales, hace que los británicos conciban los puntos de la costa este de Estados Unidos como sitios de almacenamientos de sus tejidos y productos para su posterior transporte hacia zonas comerciales del Caribe y del Golfo de México. Estados Unidos se convierte en un punto de reexpedición de textiles británicos hacia el Pacífico sudamericano, luego de transitar por todo el Atlántico. Esta función reexpeditiva parece haber funcionado aun después de la coyuntura conflictiva: en 1805 y 1806, las mercancías europeas reexportadas por Estados Unidos alcanzan $60 \%$ de las exportaciones totales de Estados Unidos. ${ }^{143}$ El sistema de puertos libres que establece el libre comercio aun

141 “Cartas del virrey Ambrosio O’Higgins, Marqués de Osorno, acusando recibo de la Real Orden reservada sobre denegar toda habilitación y auxilio a los ingleses pescadores de la Mar del Sur; avisa de las que ha dirigido a las Intendencias de Arequipa y Trujillo para su cumplimiento y del bando sobre la pena de muerte por contrabando". 1796-8-8. AGI, Lima, 713, núm. 39, s/n de fs.

142 Flores, 2010, pp. 53-62.

143 De 29 barcos norteamericanos que llegan a los puertos de Chile entre 1788 y 1796, se pasa a 226 en el periodo de 1797 a 1809. Whitaker, 1941, pp. 7-12. 
con los enemigos por parte de Gran Bretaña en sus dominios por las islas del Caribe en las últimas décadas del siglo XVIII (punto que enseguida detallaremos) es, sin duda, el "trampolín" que les otorga impulso a las navegaciones de los estadounidenses en sus travesías transcontinentales.

Por su parte, el convenio firmado entre España y los estadounidenses en 1795, junto con la apertura al comercio de neutrales, conforman las herramientas legislativas para que los balleneros británicos prosigan con sus actividades, tanto por el Atlántico como por el Pacífico vía el Cabo de Hornos. La estrategia de los británicos pasa o bien de utilizar la bandera de otra nación, particularmente la angloamericana en sus propias embarcaciones o de operar con naves norteamericanas enarbolando la bandera británica. ${ }^{144}$ El virrey del Perú marqués de Osorno, en una carta enviada hacia 1800 al Ministro de Estado, informa que "en esta larga carrera encontrará su majestad muchos buques que son o se dicen angloamericanos. El concepto del pueblo se fija en que no siendo en realidad sino ingleses toman la denominación que los acomoda [...] es difícil distinguirlos claramente porque traen dos patentes". ${ }^{145}$

El uso de pasaportes falsos es una práctica constante de los británicos en tiempos de conflictividad militar. El abanico de posibilidades se abre notablemente: pueden utilizar barcos inscriptos como españoles, llevar documentos norteamericanos y ser en realidad de propiedad británica. Todas las estrategias son utilizadas desde el momento en que son declarados enemigos o cuando los navíos angloamericanos gozan de notables beneficios a partir del convenio firmado en 1795 . Hacia 1798 , se realiza una inspec-

144 Whitaker, 1941, p. 5; Flores, 2010, p. 53.

145 "Disposiciones por desalojar a los balleneros", El Callao, 22-1-1800, AGI, Estado, 73, núm. 101, f. 10. Parrón Salas brinda otros interesantes testimonios. El primero lo hace el Consulado de Lima porque desconfía de que los buques de Boston sean realmente de ahí, "en la realidad son corsarios ingleses en la mayor parte". El segundo testimonio lo realizan los funcionarios al señalar que si los buques ingleses se encuentran frente a frente con alguna armada marítima española enarbolan la bandera americana. Pero si se percatan de que tal armada resulta militarmente débil, enseguida se posicionan como enemigos para enfrentarla. Parrón Salas, 1995, p. 430. 
ción en las bodegas de navíos británicos que llegan al puerto de Lima. Resultó imposible embargar su carga porque disponen y presentan "patente americana". ${ }^{46}$ El comercio ilícito británico termina por tener un escudo legal. La disposición de "pasaportes" falsos termina garantizando el desarrollo del comercio británico en cualquier puerto español.

El tráfico de balleneros ingleses y angloamericanos, al que consideramos como tráfico a gran escala por el Pacífico, genera significativos efectos en el primer nivel del tráfico efectuado por navíos peruanos, centroamericanos y novohispanos, movilizando en gran medida mercaderías de producción local. Los efectos son, en principio, paradójicos. Por un lado, el dominio extranjero produce serias amenazas y limitaciones al comercio de cabotaje, por lo que cualquier beneficio impositivo que el tráfico local quisiera obtener resulta en vano. En 1798, el propio virrey del Perú Ambrosio O'Higgins desistirá de rebajar los derechos impositivos a los mercaderes de Lima que realizan el tráfico de bienes locales con México, porque "no creyendo oportuno de innovar sobre esto en tiempos en que, cortada toda comunicación mercantil con Europa, no quedara a este erario otro recurso de esta clase que los productos de aquél tráfico, bien molestado hoy por los balleneros ingleses que inquietan este mar Pacífico". ${ }^{17}$

Las cargas fiscales que asume el comercio de cabotaje se destina a la defensa militar española, dada la ofensiva británica. El propio Consulado de Lima, al reconocer que los circuitos de corta y media distancia por el Pacífico se encuentran en serio riesgo, se encargará de financiar una fragata de guerra con 120 marineros y soldados para combatir el "crucero militar" inglés en el norte de Perú que mencionamos líneas anteriores. ${ }^{148}$

146 "Sobre entrada en el Mar del Sur de dos fragatas inglesas", AGI, Estado, 73, núm. 81.

147 “Carta núm. 203 de Ambrosio O’Higgins, Marqués de Osorno, Virrey del Perú”, 23/12/1798, AGI, Lima, 718, núm. 67, f. 770 (las cursivas son mías).

148 La decisión consular es inmediata por el inminente arribo de las fragatas Bárbara y Guadalupe procedentes de México con importantes cargas de plata y bienes. AGI, Estado, 73, núm. 101, f. 1 
¿Cuál es la lógica mercantil de los balleneros? El mapa III.1, presentado en páginas anteriores, es un ejercicio ilustrado de las sucesivas operaciones que realizan los balleneros. Cargan en sus puertos de origen manufacturas particularmente textiles de algodón inglés. Algunas de ellas pueden recalar en Boston, Nueva York y Baltimore en su derrota transatlántica. Posteriormente, los vemos dirigirse hacia el sur por el Atlántico hispanoamericano haciendo intercambios en el Caribe y Jamaica hasta llegar a puertos sudamericanos, como Río de Janeiro y Buenos Aires. Cruzan el Cabo de Hornos y despachan bienes orientales y europeos en los puertos de Chile, del Perú, de Ecuador, de Panamá o los del Pacífico mexicano. En estos derroteros adquieren productos locales para realizar el comercio de cabotaje por toda la costa occidental del continente (trigo chileno, vinos y aceite del Perú, cacao de Guayaquil, entre otros). Prolongan su comercio hacia las Islas Filipinas y costas de Asia para adquirir algodones y especias de la India, sedas y porcelanas de China. En su retorno, esos mismos productos se intercambian por pieles de nutria y focas, ya sea para venderlos en las costas norteñas de México y de Estados Unidos o destinarlos al mercado europeo donde gozan de estima y elevados precios. Hacia 1830, el guano del Perú y de Bolivia se integra a la compleja y rica red mercantil, inyectándole a la ruta austral un renovado impulso para su desarrollo. ${ }^{149} \mathrm{El}$ conjunto de estos intercambios expulsan importantes volúmenes de plata mexicana hacia los mercados de Estados Unidos, China y Europa, logrando romper los conductos metalíferos con impronta monopólica en poder de las tradicionales corporaciones consulares.

Antes de finalizar el apartado, valdría hacer algunas conclusiones. No cabe la menor duda de que Gran Bretaña es la principal potencia marítima por estos tiempos. Sin embargo, no deberíamos desmerecer, sea en competencia o en colaboración, la presencia de los navíos de compañías estadounidenses que, en las últimas décadas del siglo, se posicionan como la segunda flota mercante más importante a nivel global. La débil capacidad 
armamentística hispánica, agudizada por los conflictos políticos internos que germinan en el contexto de las luchas por las independencias iberoamericanas, se encuentra muy lejos de ser resistencia para el avance británico.

En este contexto deberíamos comprender la evolución de la política económica que se aplica sobre el gran espacio del Pacífico hispanoamericano durante las primeras décadas del siglo XIX. La inauguración de un tráfico plenamente libre entre México y Perú aparece con una real cédula expedida por Carlos IV el 18 de septiembre de 1803. Esta busca "el fomento de la navegación y el comercio entre los reinos del Perú, Nueva España, Granada y Guatemala y los puertos del mar del Sur". ${ }^{150}$ Tres décadas después, hacia 1833, el gobierno mexicano firmaba el "tratado de amistad, comercio y navegación entre México y la República del Perú". ${ }^{151}$ A pesar de las profundas transformaciones políticas que se vivieron y se vivían en esos años por el espacio latinoamericano, percibimos un patrón de orientación común entre las medidas dictadas durante el periodo de antiguo régimen e independiente que tiende a una política de libre comercio e injerencia europea. ${ }^{152}$

150 AGNM, Instituciones coloniales, Gobierno Virreinal, Impresos oficiales, contenedor 22, vol. 54, exp. 41, 18 de septiembre de 1803, fs. 212-215.

151 AGNM, Instituciones Gubernamentales, Gobernación (127-128), Circular del Ministerio de Relaciones Exteriores, Gobernación y Policía, volumen 160, exp. 18, s/n de fs.

152 Vale revalorizar aquí el pensamiento de Amaral. Nos dice que los contactos entre los espacios americanos por el Pacífico son responsabilidad de empresas extranjeras más que de agentes locales, quienes dependen de suministros europeos. Desde el "comercio libre", las relaciones entre Nueva España y el Perú por el Mar del Sur se ven reducidas "a sólo el cacao de Guayaquil y entre las otras provincias a pocos artículos". Poco ha cambiado con la independencia, según Amaral. La emancipación, "quitando todas las trabas, ha venido a poner más en claro la verdad de estos principios". El contacto por el Pacífico, que ahora se ve promovido por "repúblicas independientes, no por esto ha tomado mayor actividad y antes bien ha disminuido". Los efectos europeos ingresaban de contrabando por "los puertos del mar del Sur de México", cuyos responsables eran, ante todo, los británicos, quienes con sus barcos depositaban previamente los "tejidos y otras mercaderías en Valparaíso en Chile o en el Realejo en Guatemala”. La baratura de las manufacturas inglesas y francesas que venían desde el Sur hacia el Pacífico mexicano constituía un hecho paradójico con el principio de promoción de las artes y manufacturas decretado por las Cortes de Cádiz. Amaral, [1850] 1985, t. III, pp. 37-38. 


\section{Mapa III.2. La atlantización del Pacífico, circuitos y centralidades espaciales}

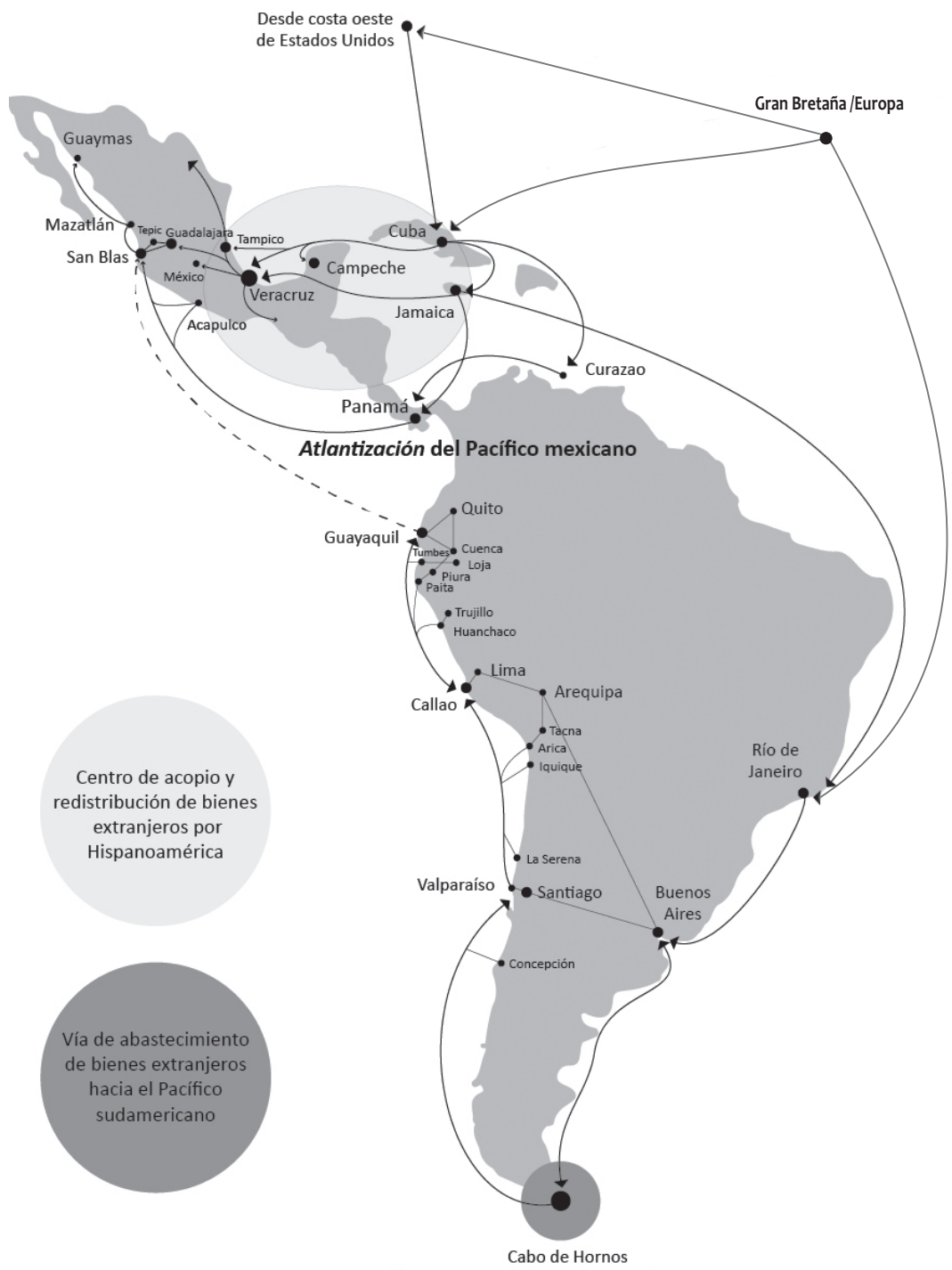

Atlantización del Pacífico sudamericano

Fuente: Elaboración propia con digitalización de Tania Ochoa Postillo. 
En el contexto nacional, hacia 1840, llegan más de 32 naves europeas y norteamericanas a San Blas procedentes del Pacífico sudamericano. La mayoría de ellas cruzan el Cabo de Hornos, luego de haber partido desde el Atlántico europeo o norteamericano. ${ }^{153}$ Sabemos también que en el año 1839 recalan al menos dos barcos procedentes de Hamburgo al puerto de Mazatlán, luego de cruzar el Cabo de Hornos, una travesía que dura entre cuatro y seis meses, ${ }^{154}$ cuando vimos que los balleneros de fines del siglo XIX navegan casi un año entre océano y océano (cuadro III.6). Es muy posible que estos cálculos en el movimiento de barcos sean un piso mínimo, más al considerar que, según las estadísticas de Jorge León, las travesías que hasta la década de 1830 no superan un promedio de 50 al año, a partir de 1840 se cuadruplicaron. ${ }^{155}$ De esta manera, continuando con nuestra aproximación a una historia macromercantil de larga duración, podemos decir que las independencias políticas hispanoamericanas no parecen representar un fenómeno de cambio en el escenario; en todo caso, maximizan un fenómeno que viene registrándose desde las décadas previas.

Hay que reconocer, no obstante, que estamos en presencia de un Pacífico fragmentado y diversificado, resultado de años turbios, por conflictos externos e internos del proceso emancipador que se vive por cada espacio de Hispanoamérica. Pero los pocos estudios dedicados a la historia económica mercantil de las primeras décadas del siglo Xıx adoptan una perspectiva de Estado-nación, que concentra la atención en el horizonte del comercio de cabotaje o en los movimientos expedicionarios hacia el norte californiano. En verdad, el Pacífico mexicano continúa siendo un área permeable y móvil, con fuertes influencias de los cambios que se viven no sólo en el espacio del Pacífico sudamericano, sino también en el Atlántico. Tanto el Pacífico septentrional como

153 Meyer, 2008.

154 Dane, 1967, p. 86. Según Llorca-Jaña, el tiempo que duraba el viaje desde Inglaterra hasta el Pacífico Sudamericano era de 120 a 180 días. Recién en la segunda mitad del siglo xIX, se logró reducir el tiempo de derrotero gracias a las mejoras en las técnicas náuticas y la utilización de los barcos de vapor. Llorca-Jaña, 2012, p. 213.

155 León, 2001, p. 335. 
el meridional son, en definitiva, piezas de una economía global que se unifica gracias a la revolución de la tecnología marítima a una velocidad sorprendente. Si antes de 1750 los mercados occidentales de Hispanoamérica se veían fuertemente orientados al polo asiático, uno de los principales centros de la globalización bipolar, desde finales del siglo XVIII la unidad del Pacífico parece apuntalarse por las economías europeas y estadounidenses.

Finalmente, como telón de fondo de esta historia comercial de larga duración, debemos advertir que el aumento del tráfico por el Pacífico mexicano y estadounidense, de la segunda mitad del siglo XIX, se debió más a la apertura de la vía férrea de Panamá que al paso por el Cabo de Hornos. Desde entonces, la circulación de navíos europeos por el eje austral pierde sistematicidad. La construcción de la vía férrea interoceánica por Panamá (1855) provocó que la movilidad de barcos y hombres por la ruta transcontinental del Cabo de Hornos iniciara su ciclo secular de descenso. ${ }^{156}$ Si bien el derrotero permaneció en operación, será el istmo centroamericano el que se posicione, por costos de comercialización y tiempo de navegación, como el paso transoceánico dominante del continente para la interacción entre las economías del Atlántico y del Pacífico. A partir de 1840, el descubrimiento y explotación del oro de las minas de California configurará un nuevo tejido de redes comerciales internacionales; problemática que supera el análisis de nuestro ensayo.

\section{El eje Jamaica-Panamá-San Blas, 1810-1820}

Hemos apuntado que la apertura del Cabo de Hornos es la primera ola económica que atlantiza el Pacífico. Se presenta como una ofensiva prolongada, primero hispánica y luego británica, quebrando desde sus estructuras la lógica del universo del lago indiano. También se sugirió que dicho embate, comprendido en

156 Un recorrido de 77 kilómetros de rieles unía por esos tiempos la ciudad de Colón con la ciudad de Panamá. Busto Ibarra, 2008, pp. 125-129. 
el periodo 1750-1840, registra mucha más intensidad en la franja sudamericana que en la costa occidental mexicana. Aún con lo poco que sabemos por el momento, todo indica que la globalización mercantil europea presenta, incluso hasta los años iniciales del siglo XIX, un flanco débil: el Pacífico mexicano. ${ }^{157}$

En efecto, la economía del Pacífico mexicano inicia su primera ola contundente de atlantización a partir de 1810, casi medio siglo después de aquella primera intromisión europea por el eje austral. Lo logra a partir del comercio ilícito que enlaza a Jamaica, Panamá y San Blas. Posiblemente antes, pero con fuerza desde 1810 , se registra una notable "invasión" de naves británicas, panameñas y de Guadalajara que movilizan textiles ingleses y de la India hacia el punto de San Blas y desde ahí se redistribuyen hacia el mercado de Guadalajara, Acapulco, Mazatlán y Guaymas. La segunda atlantización, impulsada desde el Caribe atlántico, especialmente desde la colonia británica de Jamaica, crea una nueva forma de inserción de Hispanoamérica en el tablero global y continental. En primer lugar, es el último golpe a un galeón de Manila alicaído, lo cual es una fiel expresión del retroceso de China en la economía novohispana y en la globalización. El fenómeno puede leerse de manera inversa; esto es, como la cristalización del proceso de occidentalización de las economías del occidente hispanoamericano. ¿La relación Panamá y San Blas no podría leerse como el antecedente directo de la plataforma construida en la segunda mitad del siglo XIX (1855), cuando las economías de Estados Unidos y Gran Bretaña alcanzan las minas de oro de California, mediante la construcción de la vía férrea que une las costas del Atlántico y del Pacífico de Panamá? La función de escala que logró tener México en este último eje tiene arraigo en el tejido construido por los británicos desde principios del siglo.

157 A pesar de los inconvenientes metodológicos y la ausencia de documentación ya subrayada, resulta necesario conocer con mayor profundidad las características que asume el tráfico de balleneros ingleses y angloamericanos por Acapulco, San Blas o en puertos más al norte, como Mazatlán, Guaymas o California. No contamos con una investigación particular sobre el tema. 
Desde la perspectiva virreinal, regional y nacional, el eje $\mathrm{Pa}$ namá-San Blas explicaría la crisis del histórico eje terrestre Ciudad de México-Acapulco-Veracruz y la descomposición de la importante centralidad que supo tener Nueva España como nervio principal de la economía mexicana. El abastecimiento de textiles de algodón británico desde Jamaica al mercado de Guadalajara y otras plazas más al norte contribuye a la regionalización y autonomía del espacio. También el nuevo eje es responsable de que la relación entre México y Sudamérica se vuelva menos estructural y dependiente, dada la nueva orientación de Panamá con el Pacífico mexicano. A la vez, la relación Panamá-San Blas es una pieza clave del proceso de rotación y remplazo del centro de acopio y redistribución de bienes extranjeros por la América española: de la Ciudad de México hacia el espacio atlántico caribeño. La posibilidad de abastecerse de textiles desde Panamá hace que Guadalajara logre una mayor autonomía, no solo en relación al histórico punto de acopio de la Ciudad de México, sino también, pero en menor grado, con el puerto atlántico de Veracruz.

Ubicada en el Atlántico, Jamaica gravita también en los mercados del Pacífico. Se coloca como centro de acopio de bienes británicos que permite alcanzar la demanda del mercado de Guadalajara y del septentrión mexicano. La centralidad del área atlántica, cuyas cabeceras son Cuba, Veracruz y Jamaica, se constituye a partir de una malla tupida de complejos circuitos oficiales e ilegales, de una infinidad de escalas isleñas o puertos menores que "confunden" el comercio oficial del prohibido. ${ }^{158}$ De hecho, Curazao, bajo el dominio holandés, no debería dejarse de lado. Pero hay que retroceder décadas atrás para ver el proceso de gestación del Golfo de México y el Caribe antillano como epicentro mercantil (mapa III.2).

Desde 1760, el Caribe y la costa atlántica de México evidencian transformaciones trascendentales en materia comercial. Un conjunto de puertos accede a la categoría de puerto franco o de 
comercio "más libre"; esto es, la autorización para movilizar bienes y metales con otros puertos y espacios de Hispanoamérica en manos de otras potencias, aun declaradas enemigas en determinadas coyunturas. Por ejemplo, en 1763, Francia concede el estatus de puerto libre a los puntos de Martinica, Guadalupe y Santo Domingo. Si bien con limitaciones, en un decreto del 16 de octubre de 1765, España abre el comercio de Cuba, Santo Domingo, Puerto Rico, Margarita y Trinidad con una malla de puertos peninsulares que van desde Alicante, Cartagena, Barcelona, Gijón, Sevilla, Santander, Málaga, La Coruña y por supuesto Cádiz. ${ }^{159}$ Cuba adquiere una mayor libertad mercantil en los años finales del siglo, al autorizarse el libre tránsito de bienes hacia Veracruz y Tampico. ${ }^{160}$ La consolidación de la isla española como depósito y centro redistribuidor de mercancías lo refuerza un decreto de 1807 de Carlos IV, con la permisión de que el comercio de La Habana suministre de bienes europeos a los puertos del Golfo de México. Veracruz se convierte en una verdadera plaza de consumo, almacenamiento y redistribución hacia otros mercados perdiendo aquel histórico papel de puente mercantil hacia la Ciudad de México. ${ }^{161}$

Ahora bien, dentro del área caribeña Jamaica termina por gozar de una intensísima actividad mercantil. Junto a Dominica, la Corona británica le concede la categoría de puerto franco en 1766, con el objetivo de posicionarla como una de las principales fuentes de aprovisionamiento de textiles británicos hacia los puntos costeros de La Habana, Yucatán, Panamá y de la intendencia de Venezuela. Para esos años, se estima que Jamaica realiza un comercio oculto de textiles hacia diferentes plazas de la América española en la fabulosa cifra de seis millones pesos anuales. ${ }^{162} \mathrm{Si}$ bien el contrabando británico está presente en Veracruz, es de

159 Una explicación más detallada del proceso de gestación y de las características de estos reglamentos puede verse en García Baquero, 1992, pp. 49-53; Muñoz Pérez, 1947, pp. 615-643; Fisher, 1996, pp. 109-122.

160 Souto Mantecón, 2001; Nakamura, 2007, pp. 53-59.

161 Souto Mantecón, 2000, pp. 110-139.

162 Christelow, 1942, pp. 309-343. 
menor intensidad por el control oficial. ${ }^{163}$ Con todo, el enclave británico y su comercio de textiles hacia los mercados de la América hispana aspira también a fungir como la correa de succión de la plata y el oro de la América española, incluso desde el frente del Pacífico. Lo interesante de esta revolucionaria medida de libre comercio no sólo está en el sorprendente contrabando que emprenden los británicos desde Jamaica, sino en la posibilidad de que las propias embarcaciones locales y peninsulares de regiones cercanas visiten la isla británica para aprovisionarse de bienes. Panamá es un "bombeo" de contrabando, pero también es una "esponja" que absorbe navíos extranjeros, peninsulares y de América.

Muy poco se sabe sobre el papel de Jamaica y Panamá en las economías del Pacífico mexicano. Un puñado de ensayos y libros reconocen la relación, pero son menciones dispersas y fragmentarias. ${ }^{164}$ Resulta importante conocer con mayor precisión la naturaleza y las características de la conexión económica entre el Atlántico caribeño y el Pacífico mexicano. Sobre Jamaica ya hemos ofrecido algunos comentarios introductorios. El otro punto de enlace, Panamá, requiere una observación general. El cuerpo político y mercantil del istmo se muestran desde principios del siglo XIX muy dispuestos a fungir como puente mercantil entre Jamaica y el Pacífico mexicano. "A pesar de las incesantes representaciones hechas y exigencias de pago que necesita", Panamá no cuenta con el situado que le debe proveer Santa Fe o Perú. Para suplir la falta de recursos, el istmo solicita "el comercio libre por los habitantes de este reino con las colonias inglesas"; ya aliadas en esos tiempos. ${ }^{165}$ Todo indica que el rey aprueba la solicitud en 1809. La finalidad de Panamá es evidente: mediar el comercio para abastecer el mercado de Guadalajara.

${ }^{163}$ La investigación más seria sobre el proceso de erección de Jamaica y de las otras islas británicas del Caribe como puertos libres es, sin duda, la de Adrian Pearce, 2007. Para cuestiones más generales, puede consultarse: Romano, 1998, pp. 60-83.

164 Ramírez Cabañas, 1944; Cárdenas de La Peña, 1988, pp. 235-240. Pardo Hernández, 1994; Valdés Lakowsky, 1987, pp. 241-260. El estudio que otorga identidad propia al fenómeno es el de Olveda, 2003.

165 AGI, Guadalajara, 532, f. 59. 
Antonio de San Felices (del que nada sabemos) envía hacia 1813 una carta al Secretario de Estado español. En ella cuestiona el reclamo de los panameños de abrir su tráfico con los ingleses (apéndice documental, capítulo III, documento I). Según él, el principal motivo de la solicitud de la elite centroamericana es que, desde la apertura del Cabo de Hornos y con el consecuente abandono del régimen de galeones de Portobelo, Panamá perdió la función central asumida en el mapa mercantil hispanoamericano. La sistematicidad y alta frecuencia del eje austral para enlazar directamente los mercados del Pacífico sudamericano le quitaron su actividad mediadora entre Perú y Europa. Sólo la vía de contrabando mantiene en pie a Panamá. La carta oficial que envía San Felices, con su necesaria cuota de parcialidad, confirma muchas apreciaciones que hasta aquí hemos ofrecido. Desde finales del siglo XviII, la elite de Panamá nota que la histórica incidencia que tenía su economía en el mercado sudamericano decae. Buscará una nueva alternativa, rotando el beneficio que arroja su privilegiada posición geopolítica transoceánica hacia el Pacífico norte, es decir, hacia el occidente mexicano.

Al menos desde los inicios del siglo xix una corriente de barcos panameños arriba a San Blas con textiles ingleses para su distribución y consumo, no sólo en la feria de Tepic y en la ciudad de Guadalajara, también en los mercados del septentrión mexicano y californiano. Los textiles ingleses llegan por medio de fragatas, coletas o bergantines cuyos propietarios son en su mayoría comerciantes locales panameños. Para ellos, resulta un negocio muy rentable establecer redes con las casas comerciales $y$ agentes ingleses que operan desde Jamaica. En los primeros años que se desarrolla este comercio, no vemos naves ni capitanes ingleses que se presenten en San Blas. El comercio de textiles de procedencia inglesa vía Panamá hacia San Blas se realiza, en un principio, con navíos y agentes centroamericanos. A partir de 1820 podemos identificar la llegada de comerciantes y barcos ingleses por el puerto de Nayarit. El cuadro III.7 expresa cada caso identificado: navío, capitán y fecha. Su publicación nos resulta necesaria pues la historiografía especializada sólo reconoce de 
manera genérica y sin mayores precisiones el enlace de bienes británicos desde Panamá hacia el Pacífico mexicano. Hay que reconocer, en un principio y con bases sólidas, la magnitud que adquiere el flujo de comercio de bienes extranjeros, en su mayoría de tejidos británicos y salidas de moneda mexicana, que se practica entre Panamá y San Blas. También disponemos de documentación sobre los cargamentos de mercaderías transportados por la gran mayoría de estos navíos en su viaje de ida y vuelta entre Panamá y San Blas. ${ }^{166}$

La decisión de omitir las cargas de los navíos en el cuadro III.7 se debe a los múltiples inconvenientes metodológicos que se presentan. Por un lado, la mayoría de los registros no brinda el cargamento general y total de cada embarcación, sino que se ve discriminado por "pólizas", una suerte de registro individual sobre cada comisionista y comprador de los bienes y plata que participan en la operación. Así, al momento de explorar un expediente que lleva por título el cargamento de un determinado navío, nos encontramos con un extensísimo documento (a veces de más de 300 fojas) en el que se individualizan cada una de las "pólizas" de los consignadores. Es decir, un mismo navío cuenta con numerosas pólizas. Sumado a ese inconveniente metodológico, existe un garantizado fracaso al momento de unificar (y sumar) cada una de las "pólizas" de cada navío. No siempre hay un único criterio de medición; las mercaderías pueden ser valuadas como tercios, arrobas, valor en pesos o simplemente por el número de cajas. Esa es la principal razón que impide incorporarlas con un criterio uniforme en la serie. Cuando las referencias documentales se muestran genéricas y concisas, las vamos a reproducir. También ofrecemos la transcripción de algunos casos detallados de los cargamentos en las siguientes páginas.

166 Un análisis minucioso e independiente acerca de la composición de los cargamentos requiere, sin duda, una comunicación independiente a futuro. 


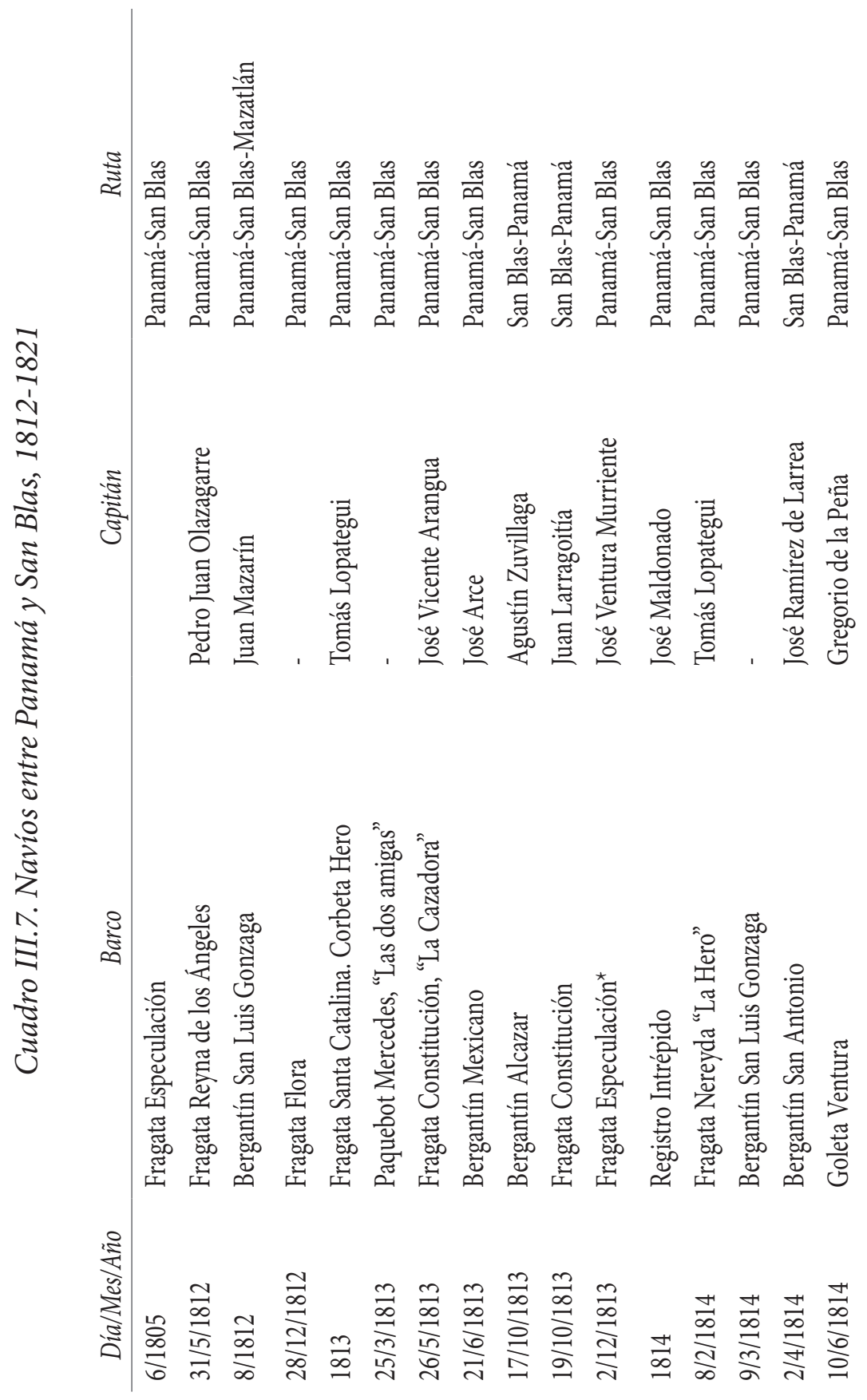




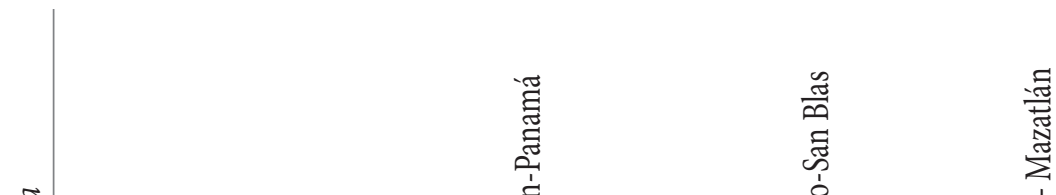

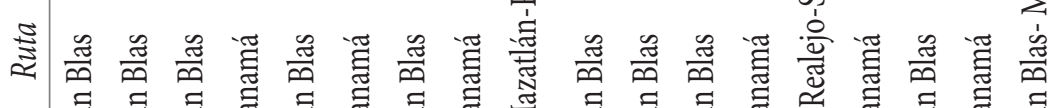
品 步

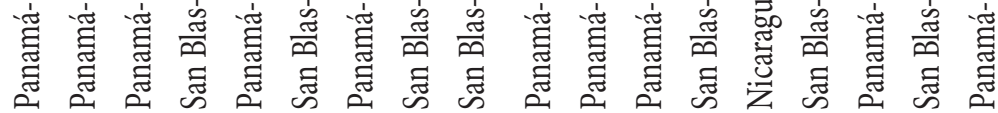

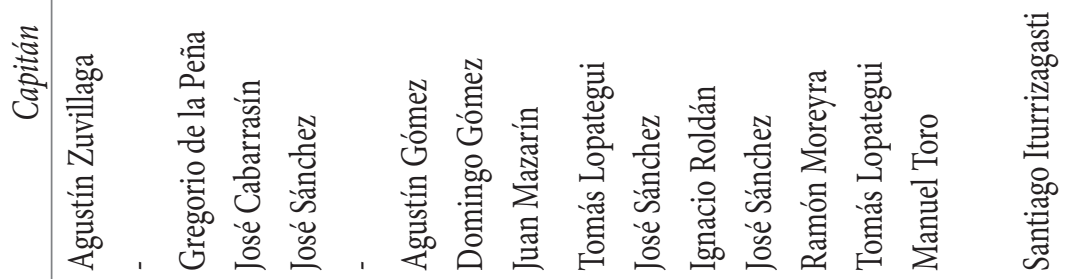
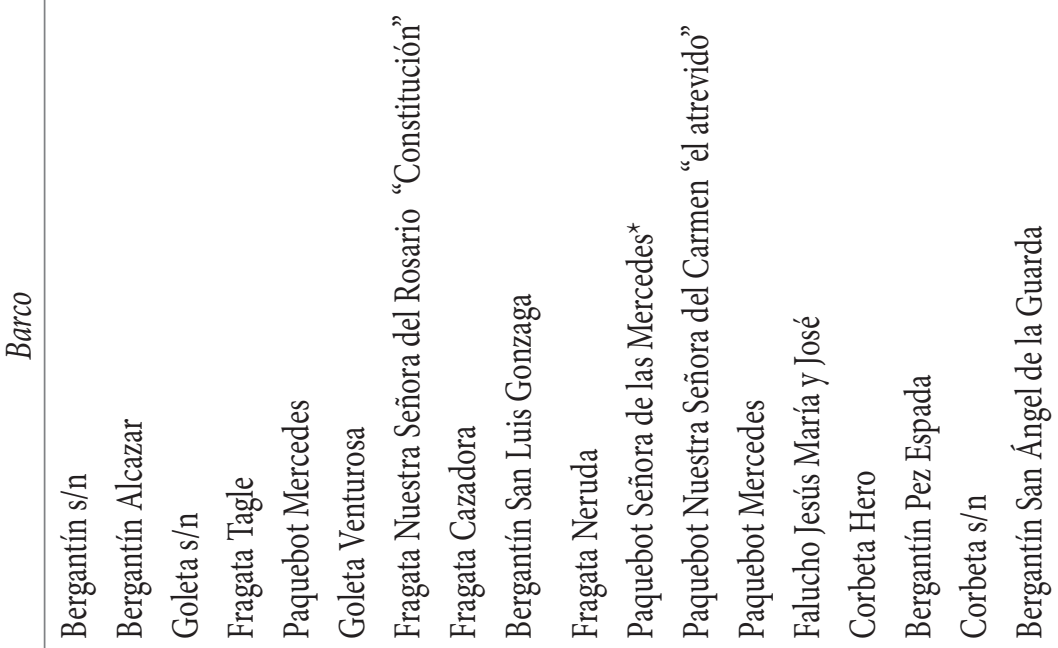

운

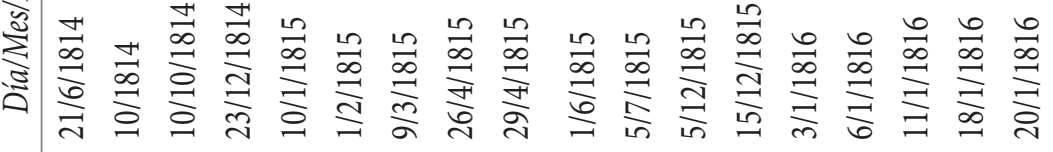



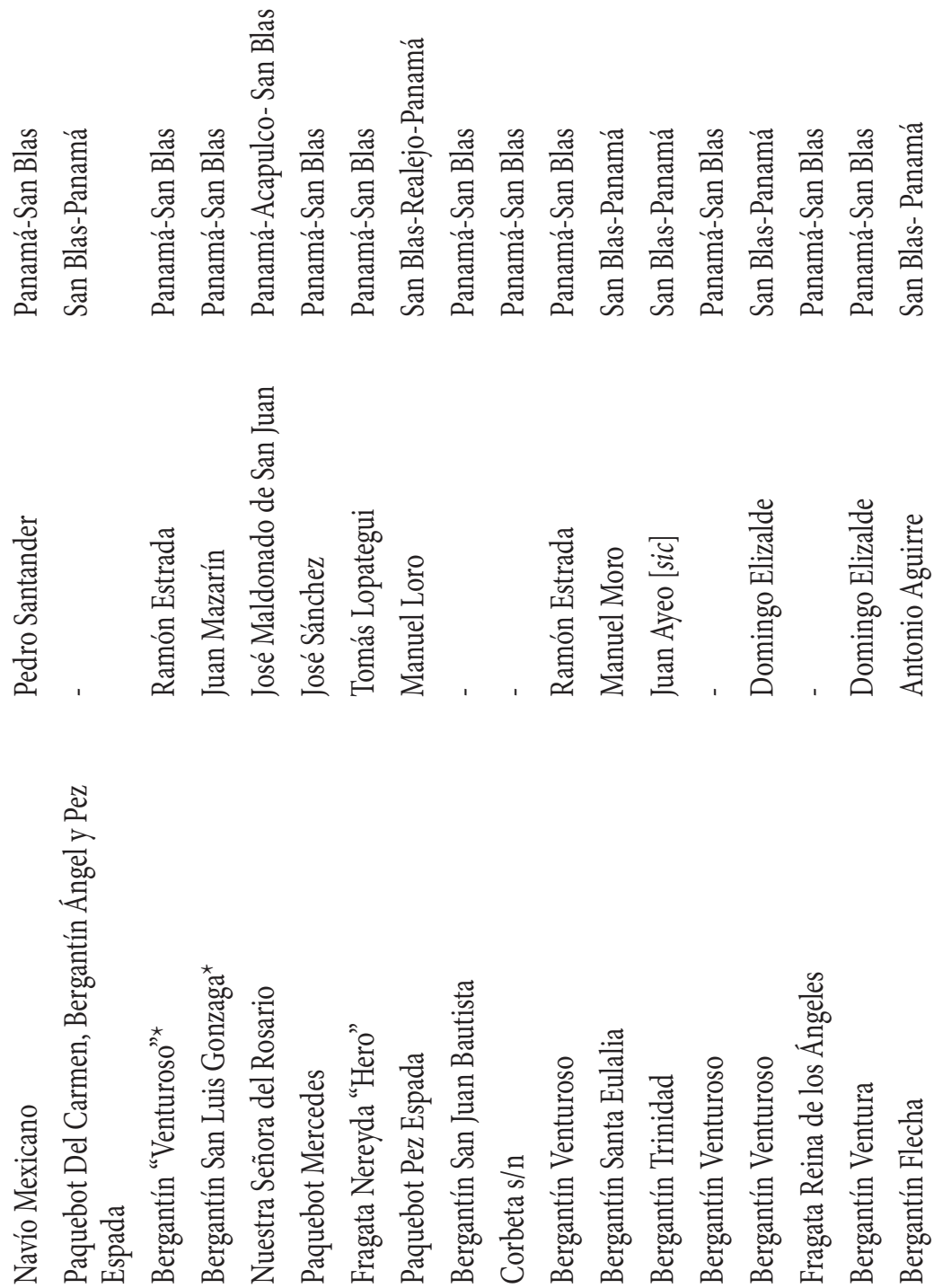

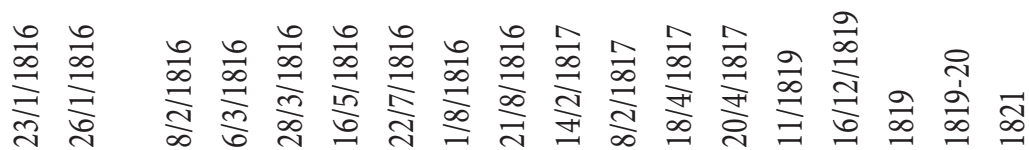




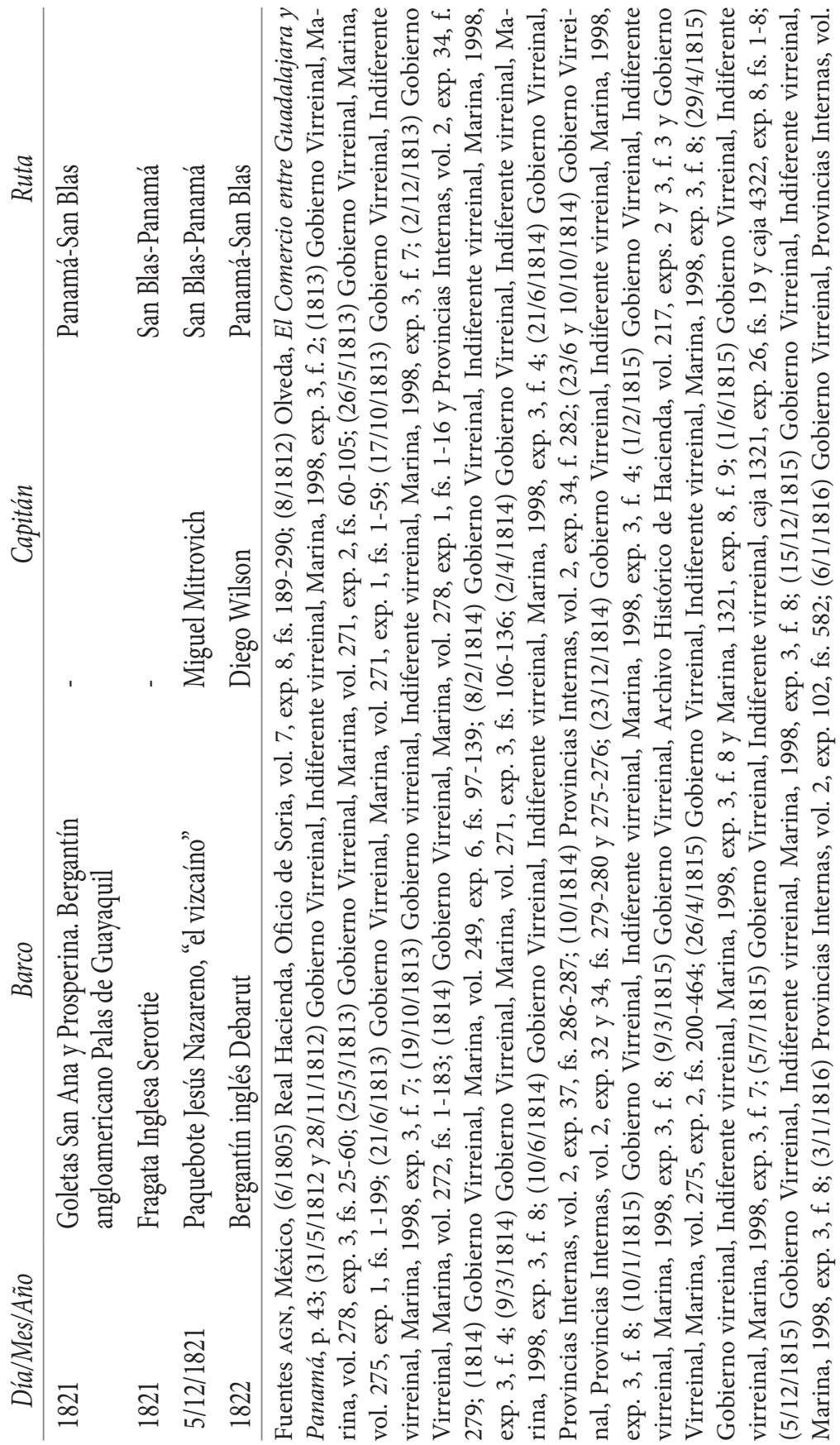




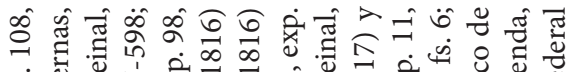

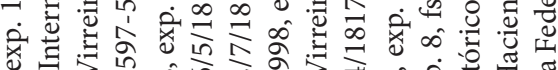
4ी

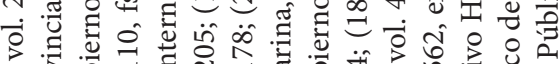

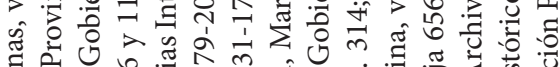

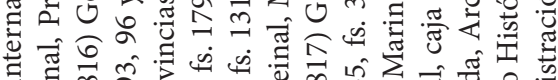

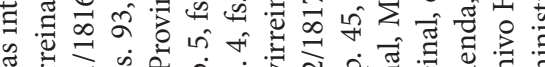

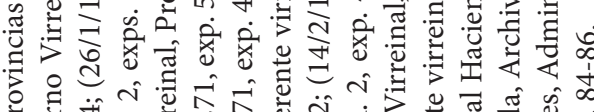

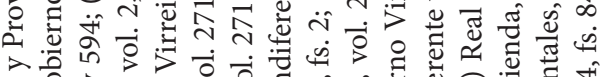

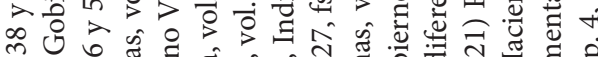

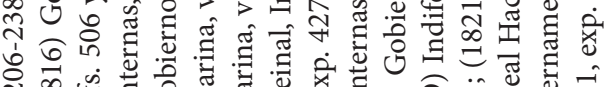

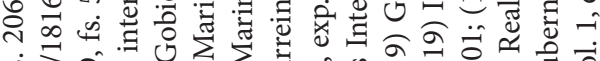
ஸे

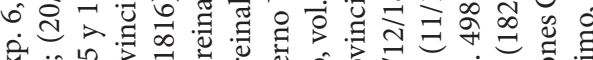

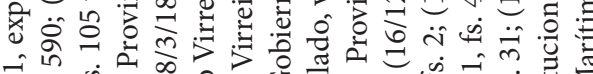

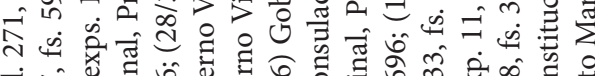

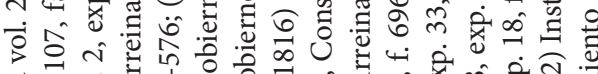

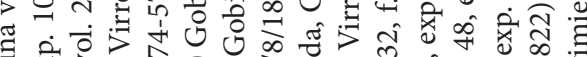

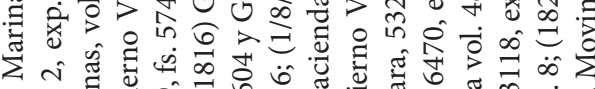

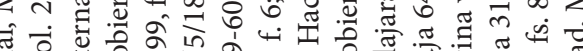

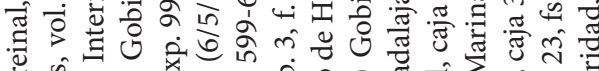

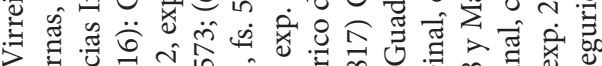

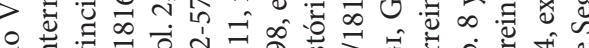

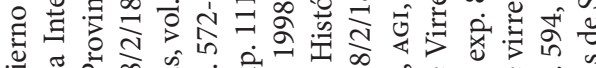

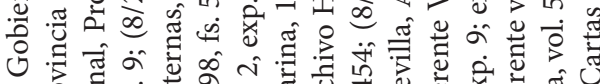

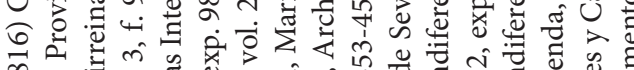
को

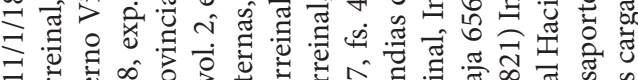

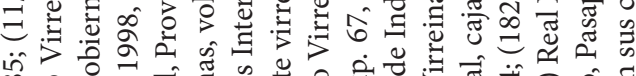
भि

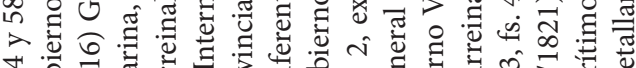

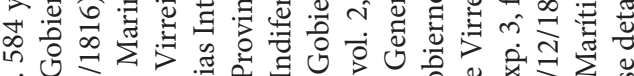

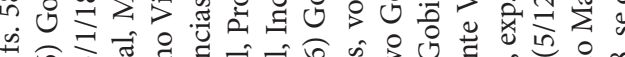

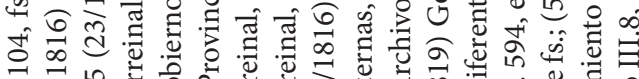

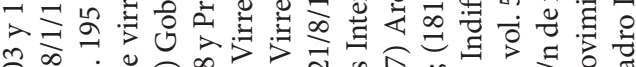

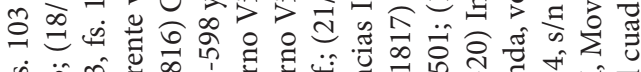

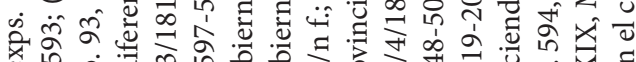

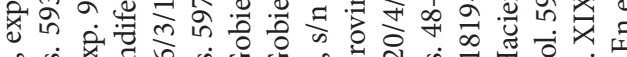

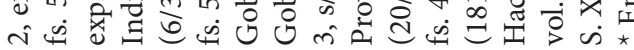


La segunda observación es que nuestro listado de navíos no es completo. Si bien representativo, hay que reconocer su imagen recortada con relación al número real de navíos que circulan entre Panamá y San Blas. El carácter mayormente ilícito del tráfico nos advierte, ante todo, de los límites de las fuentes oficiales, cualitativas y cuantitativas. Comencemos por lo cuantitativo. El listado no ofrece navíos hacia 1810, año en que, según los estudios de Pardo Hernández, se presentan efectivamente en el puerto de San Blas navíos centroamericanos descargando algodón de la India y textiles ingleses. ${ }^{167}$ Según el Consulado de México, en tan sólo tres años, entre 1811 y enero de 1814, arriban al puerto de San Blas 25 buques procedentes de Panamá. ${ }^{168}$ El cuadro III.7 sólo arroja 11 navíos en ese periodo. Tercer testimonio: según el apoderado del comercio de Manila, durante el año 1817 fondean en San Blas 35 naves panameñas y 15 en la primera mitad del año 1818. ${ }^{169}$ Nuestros registros son mucho menores: tan sólo dos navíos para el primer año y ninguno para el siguiente. Al margen de la cuota de exageración que pueden contener las afirmaciones desde Filipinas, es evidente que el cuadro III.7 es incompleto. De esta manera, la serie que se presenta es tan sólo "la punta del iceberg" de un oculto y gran fenómeno mercantil.

La naturaleza de las fuentes consultadas también obliga a tener mesura sobre nuestras estadísticas. La gran mayoría de los expedientes nacen por la "presión" que ejercen las autoridades centrales sobre el Consulado de Guadalajara o sobre las autoridades aduaneras de San Blas para que informen lo que verdaderamente está ocurriendo en la relación mercantil con Panamá. Evidentemente, los actores locales buscan ocultar los excesos y el contrabando fuera de registro. Como caso emblemático señalemos que, en 1817 , le llega al virrey un listado de "los registros de los buques procedentes de Panamá que han entrado y salido del Puerto de

167 Pardo Hernández, 1997, pp. 131-142.

168 AGNM, Real Hacienda, Archivo Histórico de Hacienda, vol. 8, exp. 5, f. 8.

169 "Representación del apoderado del Consulado de Manila quejándose del diferente trato que recibían las naos de Filipinas respecto de los barcos de Panamá". Véase Ramírez Cabañas, 1944, pp. 166-167. 
San Blas, entre 1811 y 1813 ". ${ }^{170}$ La lista se origina desde la "presidencia de Guadalajara", pasa por su Consulado y luego transita al "Real Tribunal de Cuentas" (quien advierte la "curiosa" ausencia de los cargamentos de los navíos enlistados) y finalmente llega a manos de la máxima autoridad. Esta suerte de "posta" en la correspondencia se encuentra viciada desde su origen, los propios mercaderes de Guadalajara y los funcionarios locales son los menos interesados en relucir la magnitud real del flujo, la cantidad de navíos en operación y qué tipo de mercancías se están movilizando. Nuestra serie descansa en gran medida sobre esta última fuente que, como queda claro, contiene una enorme parcialidad.

Vistas las limitaciones, atendamos la composición de los cargamentos de los navíos descargados en San Blas. Algunos expedientes ofrecen referencias generales, otros son más detallados, como los apuntados sobre las pólizas. El bergantín San Luis Gonzaga que llega al puerto de San Blas en agosto de 1812 lleva como carga "ropa europea y asiática". ${ }^{171}$ El registro realizado el 10 de junio de 1814 sobre la goleta Ventura apunta 202 tercios de ropa de "toda clase", más algunos productos locales como azúcar, cacao de Maracaibo, vinagre y tabaco. El informe sobre el bergantín Alcázar del mes de octubre del mismo año da cuenta de "ropa de Europa”. El barco capitaneado por Agustín Gómez, llamado Nuestra Señora del Rosario arriba a San Blas el 9 de marzo de 1815 con una carga compuesta de: "2076 fardos de varios efectos extranjeros y del país". La misma referencia genérica presenta "Nuestra Señora del Carmen" que, con fecha del 5 de julio de 1815, registra "339 fardos de varios géneros europeos, más un paraguas y bas-

170 José Beltrán, Real Tribunal de Cuentas y Audiencia de Cuentas, el 13 de junio de 1817 solicita "el número de embarcaciones que han entrado y salido del puerto de San Blas con motivo del tan crecido comercio que en el tiempo de la rebelión se abrió por el puerto de Panamá, que ha parecido a este tribunal conveniente hacer sacar las dos listas que pasa a manos de V. E. para que se sirva mandar que por la secretaría de cámara y virreinato se anote el paradero de los registros de que tuviere constancia y que los demás se reclamen a la presidencia de Guadalajara”, AGNM, Gobierno Virreinal, Indiferente virreinal, Marina, 1998, exp. 3, fs. 1-17.

171 Olveda, 2003, p. 43. 
tones”. El 3 de enero de 1816, arriba desde Nicaragua (pero con bienes procedentes de Panamá) el falucho Jesús María y José con 140 tercios de cacao de la región, 70 tercios de añil, algo de coco, cacao y una carga de “300 tercios de algodón inglés”. El Pez Espada, que ancla el 11 de enero de ese año, comunica " 599 tercios de efectos ingleses”. El bergantín San Ángel de la Guarda lleva desde Panamá hacia Mazatlán y San Blas "184 fardos de ropa inglesa”. Quizá sea el navío El mexicano del 23 de enero de ese año el que registra el cargamento más sorprendente: “778 tercios de géneros ingleses y de mercería”. El 28 de marzo de 1816, Nuestra Señora del Rosario inscribe como carga " 307 tercios de cajones de algodón y de lino inglés; 4 barriles de aguardiente y ron de Jamaica". ${ }^{172}$

Ya sea en las referencias genéricas como en los registros de póliza, lo cierto es que hasta mediados de 1816, los expedientes explicitan los cargamentos de estos navíos. Posterior a esa fecha, las menciones se vuelven, como mínimo, infrecuentes. La ausencia se debe al bando real del 12 de julio de 1816, cuyo artículo $4^{\circ}$ "ordena el cese del comercio entre Panamá y San Blas de mercadería británica e ilícita" ${ }^{173}$ No es casual que desde esa fecha nuestra búsqueda sobre la composición de los cargamentos no tenga éxito. Sólo podemos mencionar, por un lado, el caso del bergantín Venturoso del 8 de febrero de 1817, que llega a San Blas con sólo una carga de "mercancías de Panamá" y, por otro lado, el mismo navío que arriba en noviembre de 1819 , donde en una sola póliza de las 34 que contiene figuran " 8 tercios con 2400 percales y muselinas ordinarias, 24 tercios con 2520 piezas de zarazas, 30 tercios con 6840 libras de panas". ${ }^{174}$

El cuadro III.8 presenta los cargamentos particulares de cuatro navíos: la fragata Especulación de 1813, el bergantín San Luis Gonzaga, el Venturoso y el paquebot Mercedes. Los tres últimos

172 Todas las referencias se encuentran en las fuentes que apoyan el cuadro III.7.

173 "Bando sobre la prohibición del comercio que ha estado haciendo de efectos extranjeros desde Panamá con esta Nueva España por los puertos del Mar del Sur, y arreglo del que se ejecuta por las costas laterales de Veracruz", noviembre de 1817, en Ramírez Cabañas, 1944, p. 66.

174 AGNM, Indiferente virreinal, caja 6562, exp. 8, f. 6. 
operan durante la primera mitad del 1816, previo al bando real prohibitivo de julio. La elección de los casos tiene sus razones: los navíos de 1816 son los únicos casos encontrados de "carga general", mientras que el expediente de "especulación" se ofrece como ejemplo típico de las cargas de cada una de las pólizas. En el último caso, el número de ellas sobrepasa las 20 pólizas individuales, pero en el cuadro sólo se presentan tres. Con todo, lo que interesa ver de los casos apuntados es la composición de la carga, el tipo de mercaderías y su jerarquía en tanto expresión general del tráfico.

Lo primero que salta a la vista de las cargazones es la notable dominancia de las telas y los tejidos ingleses que se importan por el puerto de San Blas. Las plazas comerciales del Pacífico mexicano no son para nada una excepción de la sorprendente corriente de textiles británicos que en el siglo XIX constituyen el rubro de importación dominante en los mercados sudamericanos. ${ }^{175}$ Las menciones sobre "ropa de Europa", "géneros ingleses" o la aún confusa calificación de "ropa de Panamá" apuntan a todo tipo de tejido de algodón y de otras telas elaboradas en tierras y colonias británicas. Las cargas generales y los detallados registros de pólizas otorgan plena veracidad realizada por el Consulado de la Ciudad de México en 1815. En efecto, los intereses de la corporación capitalina se encuentran comprometidos pues el circuito transoceánico evita su mediación y centralidad:

Examínese las pólizas de todos estos buques remitidos de San Blas a nuestra solicitud y se verá que a vueltas de uno u otro fruto de la industria de los lugares de su procedencia todos los demás gruesos cargamentos que asombran y valen millones son tejidos de algodón y extranjeros, como cotonías, sarasas, panas, casimires, rengues, irlandas, estopillas, medias, pañuelos de Madrás, percales, etc. ${ }^{176}$

175 Llorca-Jaña, 2012, pp. 4-10.

176 "Sobre el recurso hecho al Rey contra el comercio de efectos extranjeros que se hace por Panamá a San Blas y puertos de Tampico y Tuxpan”, AgnM, Real Hacienda, Archivo Histórico de Hacienda, vol. 8, exp. 5, f. 8. 


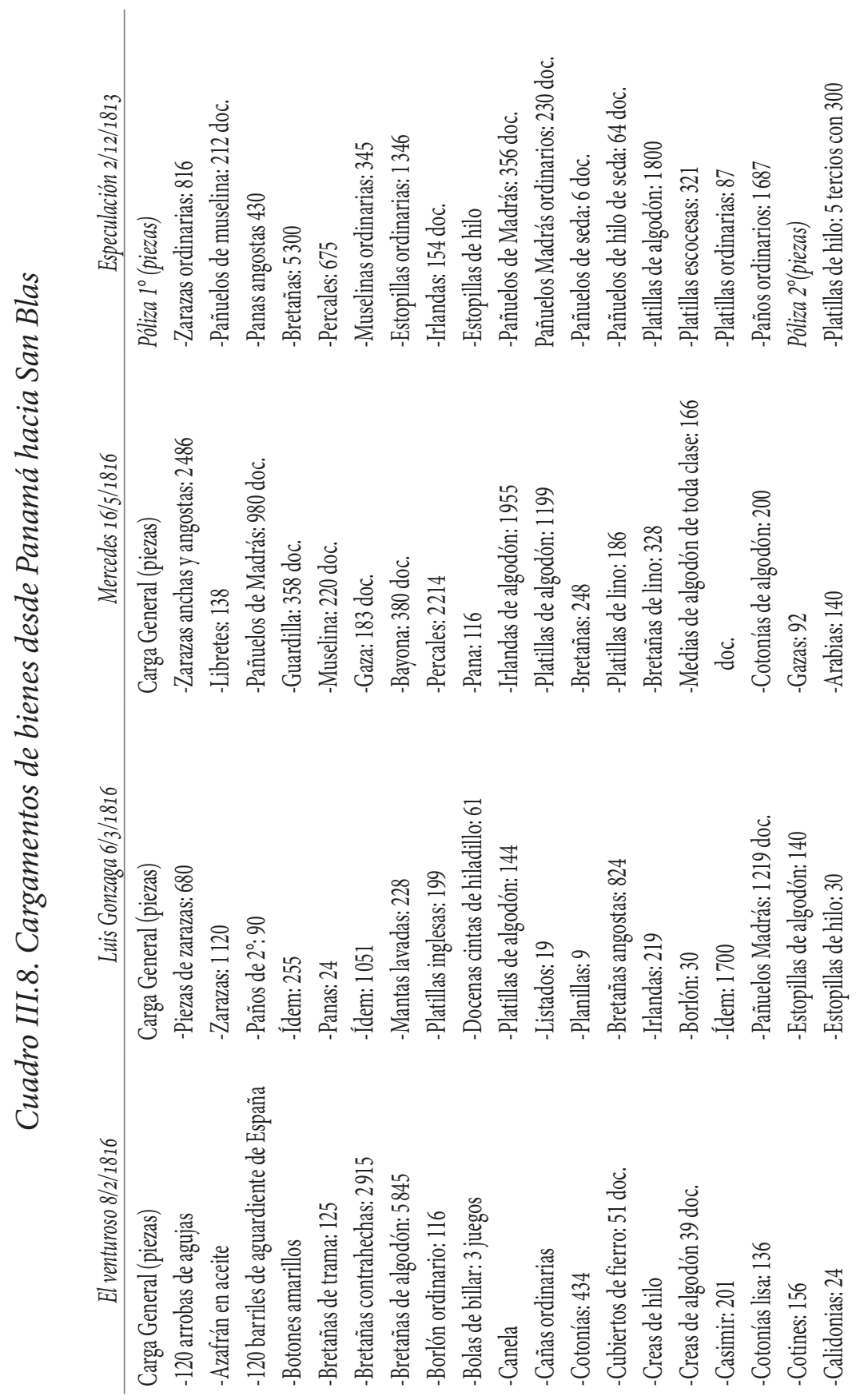




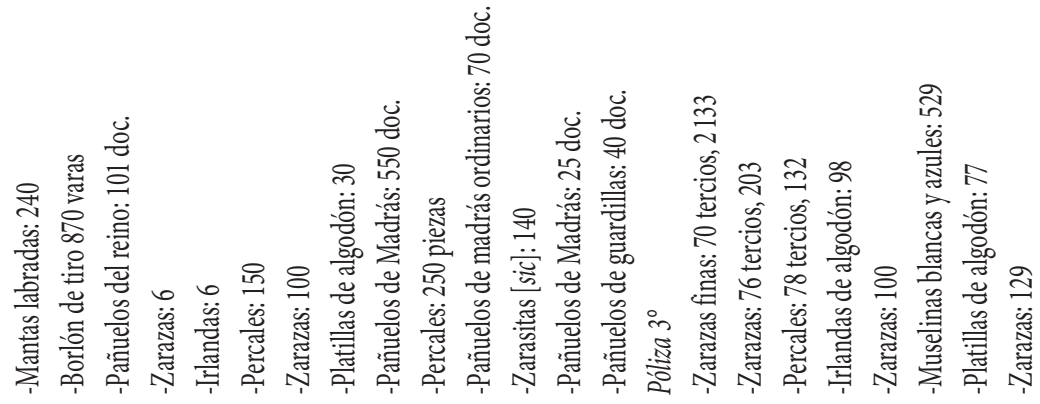

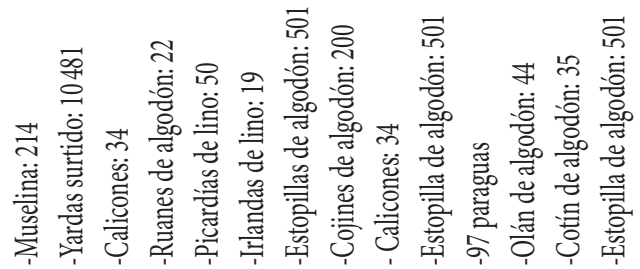

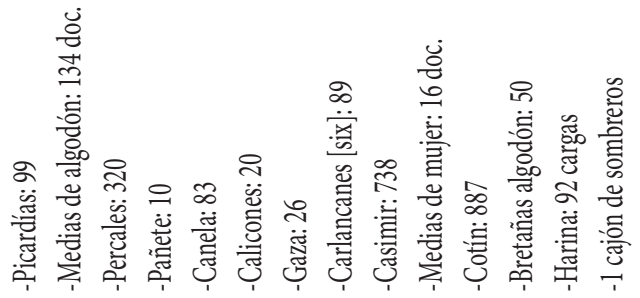

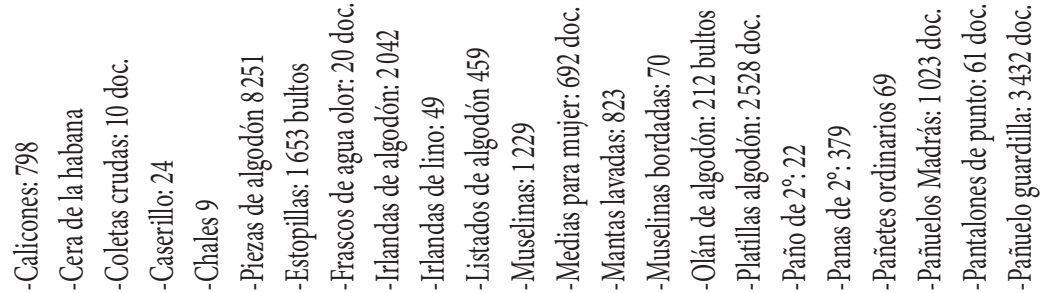




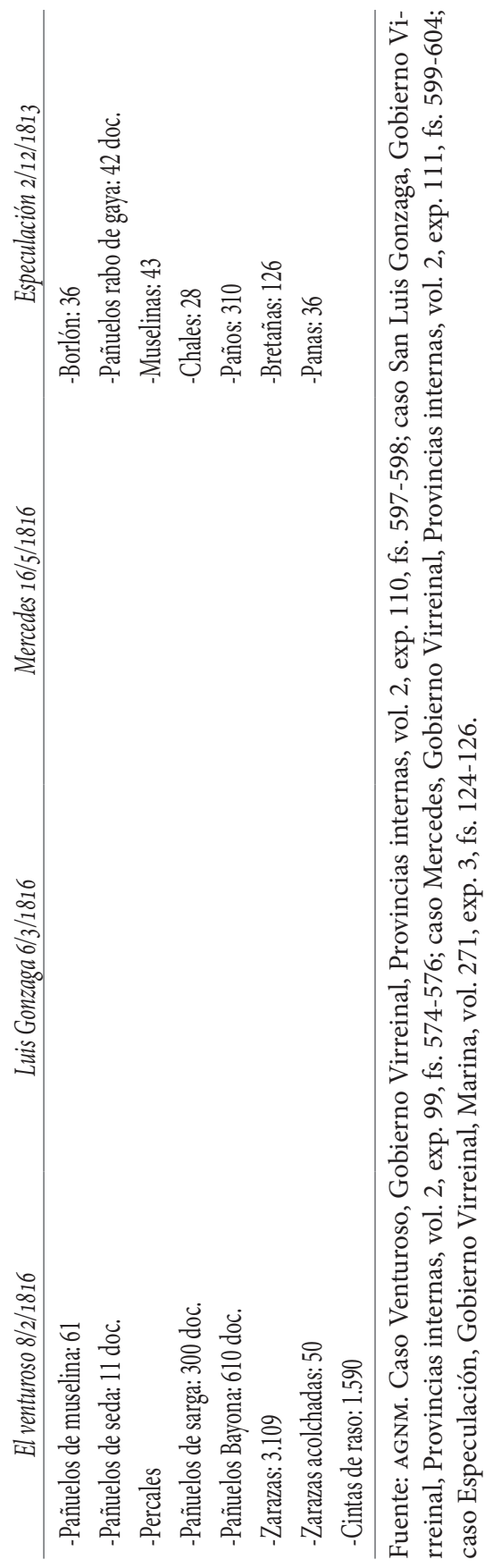


Todos los tipos de tejidos ingleses mencionados por el Consulado no sólo aparecen en los registros consultados, sino que constituyen los productos primordiales que movilizan los navíos desde Panamá hacia el puerto de San Blas. Enumeremos: el algodón británico (cotton) más transportado son las cotonías, cotines, cojines, cotín, coletas, irlandas (tejidos de algodón hechos en Irlanda). La zaraza, un algodón más refinado, es otro tipo de tela que aparece en los cargamentos. Se importa en grandes cantidades la pana, un tejido de algodón grueso semejante al terciopelo. También está el casimir, una tela realizada con lana de cabra.

Entre las producciones textiles de la India británica se encuentra la muselina, una tela fina de algodón, y las famosas medias de Madrás, presentes y en gran cantidad en cada uno de los cargamentos; cada navío lleva cientos de docenas de ellas. Si continuamos en la India británica, no se puede omitir los calicones o calidonias, que son los conocidos tejidos calicó (en francés: calicot), un tejido de algodón, realizado con tafetán de textura rústica. Es un tejido originario de la ciudad de Calcuta, centro situado en el suroeste de la India. El olán constituye otro tejido muy presente en los cargamentos. No sabemos si esta tela plega$\mathrm{da}$, que parece adecuarse a adornos y decoraciones, es de algodón, de seda o de otro tipo de telas. Tampoco puede identificarse si es de Holanda, de Cambray o de la propia Madrás. Lo cierto es que se traslada en grandes cantidades hacia el mercado de Guadalajara. El casimir (cashmere), también con notable presencia en los cargamentos, es la lana de cabra que puede ser originaria del Tíbet de la India o de la región de Xinjiang en China. ${ }^{177}$ Lamentablemente, no podemos registrar su precisa procedencia.

Las características de los textiles británicos y de la India oriental también nos ofrecen sugerentes pistas sobre su universo consumidor. Esas grandes porciones de textiles de segunda calidad, toscas y ordinarias parecen destinados a una población de la ciudad en aumento constante. Hacia 1792, en la ciudad de Guadalajara viven un poco más de 24000 habitantes y luego de 30 años, hacia 
1821, un censo registra 38000 personas residiendo en la urbe. ${ }^{178}$ No es casual ver un aumento poblacional de más de $63 \%$ en tiempos que el comercio de textiles ingleses entre Panamá y San Blas está en apogeo. Guadalajara es en sí un mercado consumidor en expansión y también un espacio de concentración para que su flamante elite mercantil distribuya las telas británicas y asiáticas importadas por regiones lindantes. Hay un mercado socialmente amplio que consume esas telas y que supera una demanda de elite. Nos referimos a las panas, paños e incluso a las medias de Madrás con precios accesibles. Todo indica que esta amplia demanda social, plenamente diversificada, impulsa el tráfico que, a la vez, su libre importación no hace más que competir de manera favorable con cualquier intento manufacturero local. ${ }^{179}$

La significativa cantidad de telas de la India y de China traídas desde Jamaica a Guadalajara indudablemente nos remite a la atlantización del comercio asiático, que termina por eclosionar el tradicional comercio transpacífico y la centralidad detentada por la Ciudad de México. El galeón de Manila, pilar del lago indiano, recibe el último coletazo por la avanzada y la movilización de bienes y plata bajo la órbita de británicos y panameños. Dedicaremos un apartado independiente a la rotación del comercio oriental, en especial a lo que ocurre con la movilización de bienes orientales por canales legales desde España hacia Veracruz. Pero por el momento vale anticipar que el circuito británico entre Jamaica, Panamá y San Blas es una expresión sustancial de la nueva modalidad ilegal de tráfico asiático hacia Hispanoamérica.

No resulta casual, por lo tanto, que el flujo mercantil entre el istmo centroamericano y el puerto de Guadalajara se vea fuertemente cuestionado desde el comercio y las autoridades de Manila, con un galeón, que como vimos, viene en caída libre desde mitad del siglo XVIII. Enseguida, nos ocuparemos de ofrecer una controversia

178 Anderson, 1983, p. 45.

179 Véase, al respecto, la transcripción completa en el apéndice documental, capítulo III, documento II: "México. Sobre las manufacturas de seda, algodón y lana que se fabrican en Nueva España”, AGNM, Indiferente virreinal, caja 5909, exp. 109, fs. 1-18. 


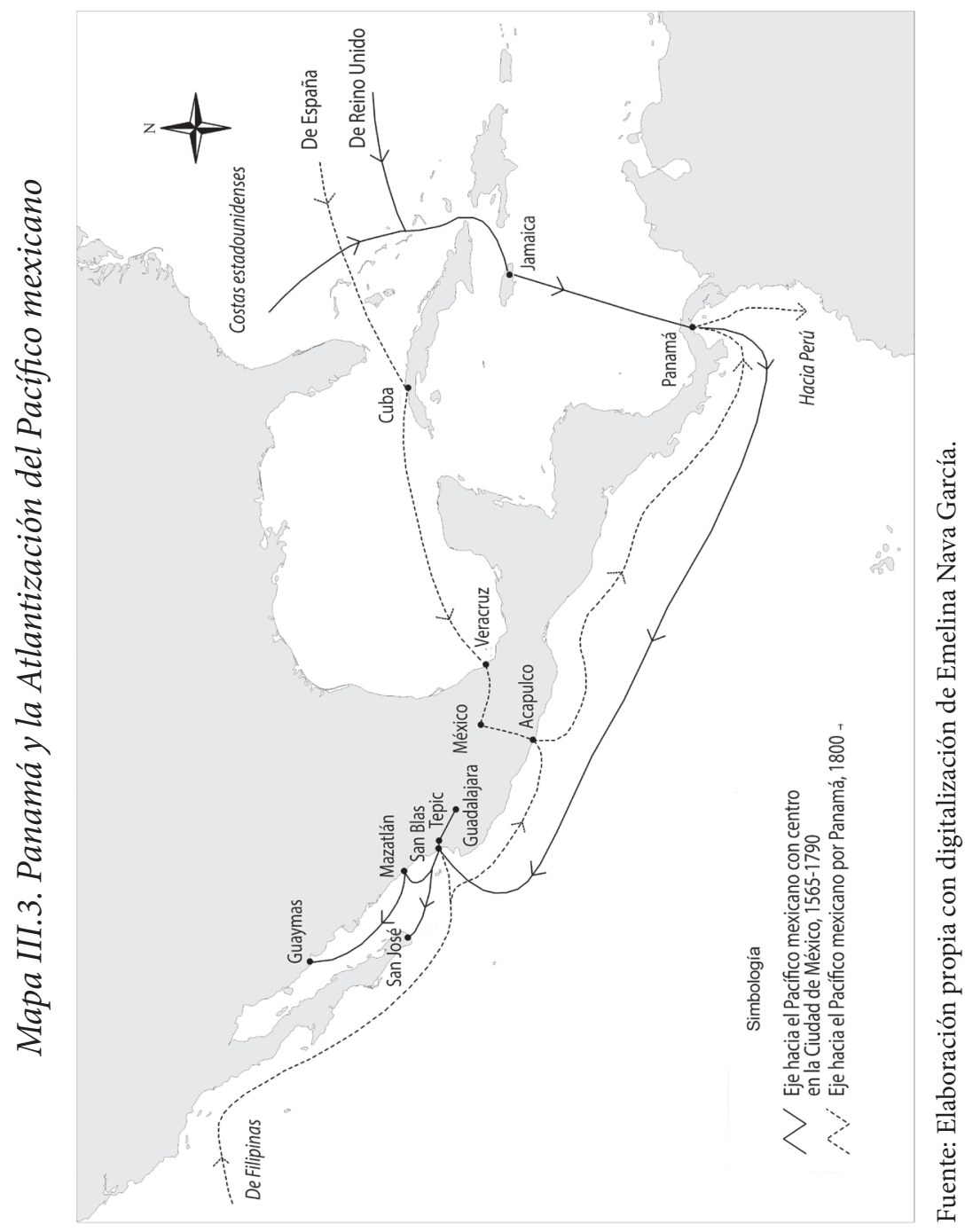


concreta que sucede hacia 1810 entre el Consulado de Guadalajara y sus pares de Manila; conflicto, en definitiva, que viene a expresar la tensión global entre el eje del Pacífico y del Atlántico en torno al comercio de China y del Oriente.

La extensión del flujo hacia el septentrión mexicano

La decisión de inscribir el comercio Panamá-San Blas como parte sustancial del gran fenómeno de atlantización del Pacífico mexicano adquiere una mayor trascendencia al notar que su influencia no se limita al espacio entre el puerto de San Blas, Tepic y Guadalajara. Si bien la densidad del comercio se concentra allí, observamos una frecuente extensión del circuito marítimo desde el puerto de San Blas hacia los puntos costeros del norte, como San José del Cabo, Mazatlán e incluso Guaymas. En estos casos, San Blas es utilizado como "trampolín" portuario para alcanzar los mercados del septentrión.

La amplia respuesta del circuito hacia la Baja California, Sinaloa y Sonora da cuenta del notable depósito de textiles y algodón británico que presenta Jamaica en esas décadas, así como la importante exportación de plata mexicana como forma de pago. Según el informe de 1815 que realiza el Consulado de la Ciudad de México, la venta de algodón británico traídos por las naves procedentes de Panamá alcanza, tan sólo por el puerto de Guaymas, una suma total de 20000000 de pesos entre 1811 y $1814 .^{180}$ Sin interés en las producciones locales, el flujo de bienes británicos parece aceptar exclusivamente el metálico que se produce en San Luis Potosí, Zacatecas, Sinaloa, Sombrerete y Sonora. Veamos dos casos específicos: el barco La Cazadora (1813) y Cruz de Mayo (1819), que importan en Guaymas y Baja California los siguientes textiles ingleses procedentes de Panamá, con escala en San Blas.

180 AgNM, Real Hacienda, Archivo Histórico de Hacienda, vol. 8, exp. 5, f. 8. 


\section{Cuadro III.9}

Fragata La cazadora (1813)

2 tercios con 59 zarazas

7 pañuelos de manta de color

4 docenas de pañuelos de Madrás

60 tercios de algodón

40 muselinas lisas

2 muselinas de color

34 docenas de medias de algodón
Balandra Cruz de Mayo 1819
25 piezas de zarazas
4 piezas de guingas
12 docenas de pañuelos ordinarios
10 piezas de percales
11 piezas de cotines
12 piezas de calicones [sic]
4 libras de seda
30 piezas de listón
12 piezas de Ninfas
6 quintales de azogue
2 tercios de cacao

Fuente: AGNM, Gobierno Virreinal, caso La Cazadora, Marina, vol. 275, exp. 1; fs. 3-4; Caso Cruz de Mayo: Marina, caja 1321, exp. 26, f. 2.

Por otro lado, la correspondencia que circula entre los mercaderes regionales de Sonora, Los Álamos y Guaymas nos advierte del aislamiento y falta de abasto para sus mercados locales. Éstos comunican que "en estas remotas regiones todo es tranquilidad y quietud", que sólo se ve interrumpida cuando llegan "fragatas de las colonias inglesas con efectos de Europa y China”. Un comerciante del Real de Los Álamos menciona el arribo en octubre de 1814 de una fragata inglesa al puerto de Guaymas con un cargamento de textiles británicos valuado en un millón de pesos, "a cuyas compras han concurrido comerciantes de Chihuahua de Arispe y de toda la provincia de aquí para tierra adentro, hasta los pobres prelados han ido cual 200 pesos, otros con 50". ${ }^{181}$ En

181 "los precios a que se dice venden en dicha fragata los efectos son los siguientes: bretañas contrahechas finas entre 3 a 4 pesos; ruan entre 4 a 6 reales la vara: paños de primera entre 4 a 5 pesos vara; bretañas legítimas superfina anchas entre 8 a 10 pesos pieza; quimones finos de China a 6 pesos: indianillas especiales inglesas en todas calidades entre 12 a 14 reales vara: pañuelos de muselina de todas calidades de 7 a 8 pesos la docena", "Expedientes del comercio de San Blas de California con Panamá", AGI, Guadalajara, 532, fs. 715-118. ¿Estamos en presencia de un navío extranjero que cruza el Cabo de Hornos o resulta un barco local (panameño o de San Blas) procedente del istmo? Difícil de saberlo. No se puede olvidar algo visto: en estos tiempos, arriban al Pacífico mexicano balleneros ingleses y angloamericanos desde el Cabo de Hornos. 
septiembre de 1809 visita el puerto de Guaymas una fragata estadounidense "con un cuantioso cargamento de ropas que pasa su valor de un millón de pesos siendo, la mayor parte géneros de ilícito comercio". La "vecindad y comercio de las provincias internas de Sonora", que es el informante de su llegada, dice que es tanta la cantidad de textiles británicos que se importan que se logra celebrar una feria en Guaymas y otra en Mazatlán por más de dos meses. El navío accede a la plata de los reales de mina de la zona, gracias a la "muchísima gente que fue a comprar". ${ }^{182}$ El flujo originado desde Jamaica, vía Panamá, abastece la región septentrional de manera más intensa y frecuente que la vía austral de los balleneros. La cantidad de evidencia documental lo confirmaría.

Se disponen más referencias de navíos que salen desde Panamá y llegan al Pacífico septentrión con textiles británicos. El 23 de febrero de 1815 sale la balandra Flor de Mayo, capitaneada por Juan Antonio Cambra, desde San Blas hacia el puerto de San José del Cabo con partidas "de registro de ropas procedentes de Panamá y del país". ${ }^{183}$ Ciertamente, el concepto "ropas de Panamá" se refiere a tejidos y algodones británicos. El 6 de enero de 1816 el bergantín El Silencio, al mando de Antonio Lopategui, registra en San Blas para transportar al puerto de Guaymas "103 tercios de géneros de Europa y del Reino, chocolate, guangoches y azúcar". ${ }^{184}$ A pesar del bando de prohibición de julio de 1816, desde esa precisa fecha hasta noviembre de 1817 habrían ingresado al puerto de Guaymas procedentes de Panamá, pero con inevitables escalas por San Blas, los bergantines Resolución, San Luis Gonzaga y Nuestra Señora de la Merced (El Tenerife). ${ }^{185}$

Por lo visto, los textiles británicos se pagan con plata y, en menor medida, con oro. Así lo sintetiza, en tono de reclamo, la

182 AGI, Guadalajara, 532, f. 714.

183 AGNM, Marina, caja 1321, exp. 86, fs. 8-9.

184 AGNM, Gobierno Virreinal, Provincia interna, vol. 2, exp. 108, fs. 593.

185 "Bando sobre la prohibición del comercio que se ha estado haciendo de efectos extranjeros desde Panamá con esta Nueva España por los puertos del Mar del Sur y arreglo del que se ejecuta por las costas laterales de Veracruz", Consulado de México, 1817, en Ramírez Cabañas, 1944, p. 65. 
corporación mercantil de la Ciudad de México en 1815: “es innegable que se haya abastecido este reino de Nueva España de toda clase de efectos y frutos procedentes de Jamaica e islas vecinas extranjeras y que ellas en precio de sus mercaderías se absorben los preciosos metales de la plata y el oro". ${ }^{186}$ En algunos casos, los metales preciosos van acompañados con un puñado de mercancías locales, como la harina, fideos y dulces, pero no más que eso. Las casas británicas y los mercaderes panameños y británicos que operan en este comercio reclaman, ante todo, la plata mexicana. Recordemos aquella cita del Consulado de México de 1815 donde dice que son "gruesos cargamentos que valen millones". Posiblemente haya una cuota de exageración en la apreciación, pero sí una medición que nos habla de "cientos de miles" de plata que extraen los navíos panameños.

Contamos con cinco casos que expresan los topes mínimos, regulares y máximos. Las cargas mínimas se ilustran con el caso del bergantín San Luis Gonzaga, que el 29 de abril de 1815 sale desde Mazatlán-San Blas hacia Panamá con un cargamento compuesto de "68000 pesos en plata, dos cajones de loza de Tonalá, 9 cajones de fideos y dulces". ${ }^{187}$ Un segundo caso de cantidades mínimas le corresponde al paquebote Jesús Nazareno, que en diciembre de 1821 traslada casi 80000 pesos "y 1 cajón barato de China”. La plata va hacia Panamá, mientras que lo chino se destina a algún mercader de Nicaragua. ${ }^{188}$ Estamos ante casos mínimos, de poca monta, pero que sería el patrón común de exportación de plata que opera por el circuito. Por su parte, la tendencia máxima le corresponde al barco Hero, que sale de San Blas hacia Panamá el 6 de enero de 1816. Capitaneada por Juan Mandarín, la corbeta lleva en su bodega nada menos que "894147 pesos en oro y plata quintada y numerario". ${ }^{189}$ Por la cantidad de textiles que ingresan

186 AGNM, Real Hacienda, Archivo Histórico de Hacienda, vol. 8, exp. 5, f. 8.

187 AGNM, Gobierno Virreinal, Indiferente virreinal, Marina, 1998, exp. 3, f. 8.

188 AGNM, Gobierno Virreinal, Archivo Histórico de Hacienda, vol. 594, exp. 23, fs. $1-25$.

189 AGNM, Gobierno Virreinal, Provincias internas, vol. 2, exps. 103 y 104, fs. 584 y 585 . 
en estas naves al mercado mexicano, se puede deducir que lo que extrae la corbeta Hero no es lo más regular.

El patrón común rondaría el medio millón de pesos por cada navío. Dos pruebas vendrían a corroborarlo, junto a un testimonio de denuncia. El 18 de abril de 1817 parte desde San Blas con destino a Panamá el bergantín Santa Eulalia (alias Resolución) con 448200 pesos en moneda acuñada. Dos días después, idéntica ruta realiza el bergantín Trinidad con 415723 pesos, "contando entre esta cantidad 69383 pesos en barras quintadas, 790 en efectos y el residuo en moneda acuñada". ${ }^{190}$ Un año después, desde Manila, calculan que en los 7 años anteriores a 1817, el valor de los textiles ingleses transportados alcanza un total 55 millones de pesos. ${ }^{191}$ La estimación de medio millón de pesos por navío sale a cuenta si partimos de que en un año salen desde el Pacífico mexicano hacia Panamá un total de 15 a 18 navíos.

Estamos en presencia de un cambio en la orientación de la exportación de plata por el Pacífico mexicano. Con evidencias que enseguida presentaremos, no parece haber dudas de que la succión de metálico desde los puertos del occidente mexicano hacia Jamaica compromete seriamente las salidas de plata del histórico, pero ahora débil, eje transpacífico que finaliza en China. El nuevo cauce de plata que va al área del Caribe británico constituye una pieza más del gran fenómeno de la atlantización del Pacífico y también una fiel representación de cómo el eje tradicional Ciudad de México-Acapulco termina desplazado por el entronque San Blas-Panamá. Evidentemente, el gran perdedor del cambio recae en el Consulado de la Ciudad de México.

Lo que ocurre en 1816 es una magnífica expresión de cómo priman las fuerzas económicas de la globalización en la economía de la América española. Aún con resistencias legislativas que in-

190 "Real Orden de 3 de enero de 1818 con carta del virrey dando cuenta de las considerables sumas de plata que se extraen por San Blas", 1789-1818, AGI, Guadalajara, 532, f. 696.

191 "Representación del apoderado del Consulado de Manila quejándose del diferente trato que recibían las naos de Filipinas respecto de los barcos de Panamá, en Ramírez Cabañas, 1944, p. 168. 
tentan promocionar la relación de México con el oriente asiático, la victoria de las fuerzas atlánticas británicas resulta inevitable. En ese año la Corona borbónica promulga leyes que exponen el tenso juego de las fuerzas oceánicas mercantiles que vienen del Atlántico y del Pacífico. Por el frente de la América española occidental, el 28 de mayo de ese año México acusa recibo del bando real que ordena la "supresión de la nao de Acapulco". A partir de entonces, los buques particulares tendrán la posibilidad de continuar el giro con China desde los puertos de Acapulco y San Blas. ${ }^{192}$ Para dinamizar el eje transpacífico, el rey da una prórroga de 4 años más a la rebaja de derechos en el comercio de los vecinos de Manila en el trato con la Nueva España. En la otra orilla, por el frente atlántico, el 12 de julio de ese mismo año, apenas dos meses después del abandono oficial del tradicional galeón, se expide un bando real que exhorta al cese del comercio entre los puertos del Pacífico mexicano con Panamá. ${ }^{193}$ Las ordenanzas con relación al Pacífico tienen efectos relativos: si bien el decreto que ordena la suspensión definitiva del tradicional galeón termina por concretarse a raíz de una economía china que a escala global está en retroceso, las intenciones de incentivar las relaciones económicas directas entre Nueva España con Filipinas a través de navíos particulares o, como lo dice la fuente, "nacionales" tendrá pocas repercusiones. Por su parte, el bando del 12 julio de 1816 no logra anular, ni siquiera minimizar el tráfico de textiles británicos y plata mexicana del circuito Jamaica-Panamá-San Blas. Por el contrario, la realidad demuestra que a partir de ese año el flujo se intensifica. Es, en definitiva, la excelente muestra de la victoria de la economía europea atlántica en su control del Pacífico del denominado proceso de su atlantización.

El auge de San Blas se inicia desde finales del siglo XVIII, pero alcanza su perfil plenamente globalizante en las décadas iniciales

192 AGNM, Indiferente virreinal, caja 3142, exp. 24, 2 fs.

193 "Bando sobre la prohibición del comercio que ha estado haciendo de efectos extranjeros desde Panamá con esta Nueva España por los puertos del Mar del Sur, y arreglo del que se ejecuta por las costas laterales de Veracruz", noviembre de 1817, en Ramírez Cabañas, 1944, p. 66. 
del siglo posterior. Desde entonces, se logran hilvanar relaciones regulares con China y consolidar las inversiones mercantiles británicas desde el Atlántico. San Blas seguirá siendo el punto elegido para los contactos directos con China, con la región norteña de California y con la Jamaica británica. Hacia 1831, una de las primeras casas comerciales británicas que se instalaron en San Blas promueve el tráfico directo desde el puerto mexicano hacia Cantón, llevando grandes cantidades de plata para pagar productos chinos y del Oriente. ${ }^{194}$

Lo dicho nos remite al inicio del proceso de consolidación del comercio inglés por el Pacífico mexicano. Desde 1790 hasta 1820, las navegaciones británicas vía Cabo de Hornos o las realizadas desde Panamá establecieron las condiciones para el asentamiento definitivo de agentes y compañías inglesas en la economía mexicana. El caso más emblemático es la fundación en el año 1830 de la compañía Barron and Forbes en San Blas y con centro de operación en Tepic. Sin duda, hemos analizado aquí la antesala o el antecedente histórico más inmediato del eje ya plenamente internacional Panamá-Pacífico mexicano-San Francisco, constituido desde 1848 con el descubrimiento del oro californiano. Allí San Blas, si bien mantiene su actividad en el comercio de altura, pierde su dominancia en manos de Mazatlán, que será el puerto más importante del Pacífico mexicano durante toda la segunda mitad del siglo XIX. ${ }^{195}$

\section{La occidentalización de los circuitos de plata del Pacífico}

Los nuevos ejes transoceánicos del Cabo de Hornos y de Panamá no son sólo las puertas de paso de los textiles británicos y europeos en los mercados del Pacífico hispanoamericano. Hemos ofrecido algunas referencias aisladas sobre las cantidades de plata que extraen los navíos de registros peninsulares, las 
embarcaciones estadounidenses e inglesas e incluso los barcos panameños y de Guadalajara en su vuelta hacia el istmo centroamericano luego de expender el algodón británico. De esta manera, vemos que esos ejes logran fungir como corredores de plata en el control de su circulación por parte de los europeos y norteamericanos.

En estas líneas ofrecemos una breve reflexión sobre las salidas de plata por el Pacífico hispanoamericano en el contexto de la globalización de finales del siglo XVIII y principios del siglo XIX. Si tuviéramos que sintetizar con un concepto, nos parece pertinente hablar de un proceso de occidentalización de los flujos. Se reconocen, como mínimo, cuatro características principales que dan contenido al fenómeno de la occidentalización: 1) captación y orientación europea hacia el Atlántico de los flujos de plata que se exportan desde los puertos hispanoamericanos del Pacífico; 2) control, en un primer momento, por los agentes peninsulares $y$, más tarde, por los británicos y norteamericanos de los circuitos metalíferos que se exportan desde el Pacífico y el Atlántico hispanoamericano. Los circuitos de exportación de plata desde el Pacífico se anexan y refuerzan los flujos atlánticos, ya con destino hacia Norteamérica y Europa; 3) circulación y monetización de la plata americana en los mercados europeos y estadounidense, y 4) freno y descenso de China como principal importador y depósito mundial de la plata americana.

En los capítulos I y II vimos de las incalculables, pero sin duda significativas, cantidades de moneda peruana y novohispana que fluían vía directa a China desde los puertos del Pacífico hispanoamericano. Notamos, a la vez, que una de las características singulares del flujo transpacífico era el de no contar con la mediación europea; es decir, estábamos en presencia de una modalidad de envíos con exclusiva iniciativa de los comerciantes peruanos (peruleros) y novohispanos para acceder a la seda y otros productos orientales. Como derivación, concluíamos que el flujo directo de metálico que salía desde la Nueva España hacia China se constituyó como un ingrediente no menor para que China se posicionara como el depósito mundial de la plata americana desde el siglo XVI 
hasta la primera mitad del XVIII. ${ }^{196}$ En esa gran corriente de plata, que ligó a la temprana América hispana con la economía oriental, se distinguían dos fases que explican el dispar protagonismo asumido por las espacialidades indianas: a) 1580-1640, el ciclo de Perú, cuya responsabilidad recayó en las primeras décadas en el rico cerro de Potosí, y b) 1680-1740, el ciclo novohispano, con el ascenso de la producción de plata de varios centros mineros: el evidente resurgimiento de Zacatecas, el inicio del crecimiento sostenido de Guanajuato, Durango, y el crecimiento de Sombrerete poco atendido en los estudios (gráfica III.2). ${ }^{197}$

Sostenemos que, de manera paulatina pero sin pausa, la masa de metálico americano que fluía hacia China como pago de sus sedas, cerámicas y especias aminora hacia la segunda mitad del siglo xVIII. El estancamiento se convertirá en una ligera tendencia hacia su descenso, profundizándose conforme avancen las primeras décadas del siglo XIx. Los ejes transoceánicos del Cabo de Hornos y de Panamá logran reorientar hacia el Atlántico gran parte de las exportaciones de plata que antes viajaban hacia las Islas Filipinas para su almacenamiento en China. En una visión de tiempo prolongado, se podría sostener que la vía del cabo austral termina por suplantar el tradicional circuito metalífero peruano en dirección a Panamá, a Nueva España y como destino final China. Por su parte, las exportaciones de plata mexicana que se movilizan por el circuito de San Blas hacia Panamá y Jamaica se insertan en los múltiples circuitos atlánticos con destino hacia la costa oeste de Estados Unidos o hacia Europa. Ciertamente, las exportaciones de plata mexicana desde San Blas hacia el istmo se inician con sistematicidad hacia $1810 \mathrm{y}$, unos años después, el flujo transpacífico de metálico hacia China disminuirá consi-

196 Claro está que la "silverización" asiática de la temprana globalización se sustenta, más que nada, en la reexportación europea de la plata americana a través de sus compañías orientales, tema que supera nuestro marco espacial.

197 Nuestra propuesta se corresponde a grandes rasgos con la que en su momento ofrecieron Flynn y Giráldez, al identificar dos ciclos de plata americana en China. El primero “The Potosi/Japana Silver Cycle (1540-1640)" y el segundo “The Mexican Silver Cycle (1700-1750)”. Flynn y Giráldez, 2002, pp. 391-427. 
derablemente con la suspensión definitiva del galeón de Manila. Una gran porción de la plata americana que antes se destinaba a la "conexión asiática", se redirecciona desde 1750 hacia el Atlántico. ¿Estamos en presencia de una transformación de los circuitos mercantiles hispanoamericanos que refleja y se corresponde con la evidente transformación del patrón de comercio exterior de China desde el último cuarto del siglo xvin? Creemos que sí. La atlantización de los circuitos de plata marca el freno de China atesorando el metálico.

\section{Gráfica III.2. Producción de plata en la Nueva España} según cajas regionales, 1571-1810 (en millones de pesos de 272 maravedíes)

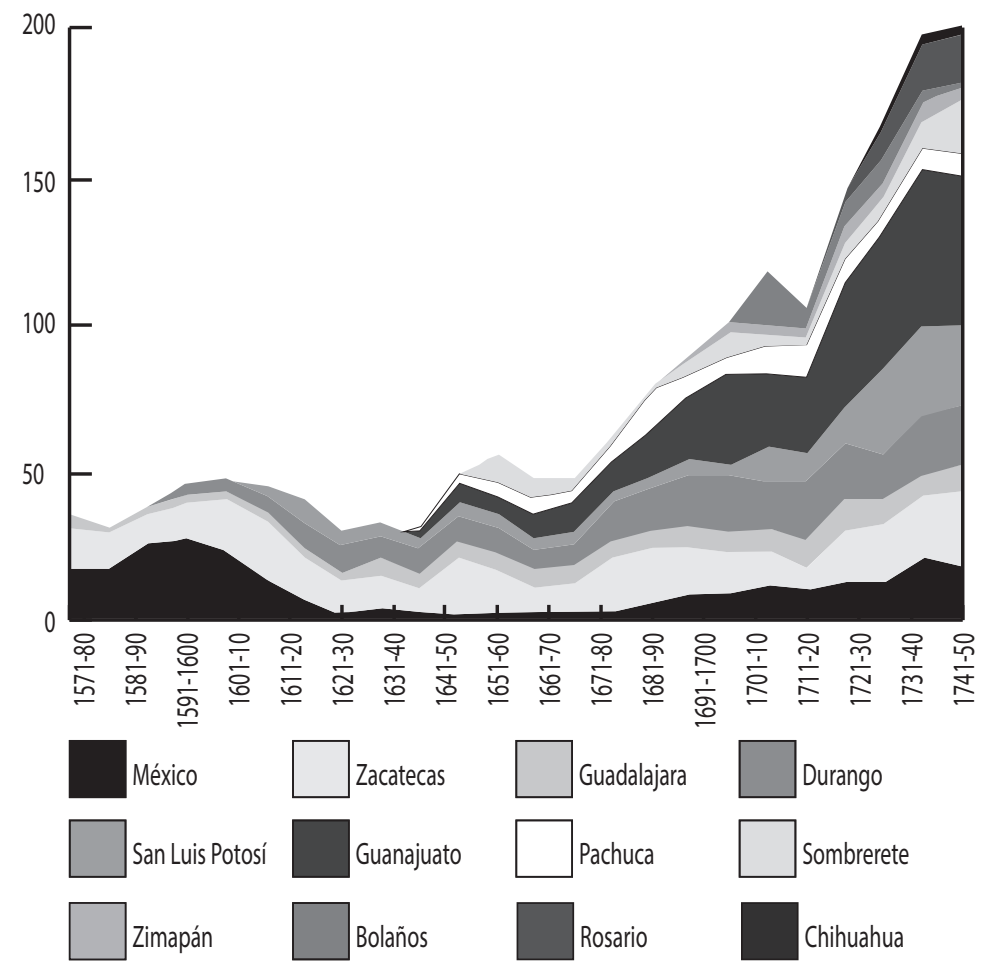

Fuente: TePaske y Brown, 2010, p. 114. 
Ahora bien, el planteamiento puede ser sugerente, pero tienta a caer en exageraciones. Lo que llamamos una occidentalización de los circuitos de plata no debería traducirse automáticamente en su atlantización. La reorientación hacia el Atlántico de las salidas de plata por los puertos del Pacífico sería sólo una pieza (quizá la más importante) del proceso de europeización. Esta última conceptualización intenta también demostrar un acontecimiento histórico más amplio al contemplar los importantes envíos de plata americana hacia China, realizados por los agentes europeos. En otros términos, aun en menores cantidades que antes, no cabe duda que China continúa recibiendo plata por la ruta transpacífica durante la segunda mitad del siglo XVIII. La diferencia con el ciclo 1580-1740 es que desde 1750 vemos que los flujos se encuentran bajo la órbita y dominio de los agentes comerciales europeos y estadounidenses. Pensemos en lo ya anunciado al principio del capítulo sobre las compañías comerciales peninsulares que surgen por el Pacífico compitiendo con el galeón. Sobresale aquí la Compañía Real de las Islas Filipinas, una empresa mercantil de capitales privados, en su mayoría de peninsulares, que desde 1785 hasta los momentos de la independencia mexicana envía plata a los puertos de Cavite, Cantón o Calcuta para la compra de los productos orientales, principalmente de textiles de la India. Esto es posible porque la corporación insular opera en el Perú para conseguir su metálico y estar en condiciones de adquirir telas y otros productos orientales. ${ }^{198}$ También recordemos a los agentes mercantiles británicos y estadounidenses que viajan en sus embarcaciones balleneras por el Cabo de Hornos y en sus operaciones iniciales adquieren plata peruana y mexicana por los puertos del Pacífico para continuar realizando intercambios en las costas occidentales de Estados Unidos y de China.

La gráfica III.3 resulta esclarecedora al inscribirla en las nuevas reorientaciones de los flujos del Pacífico en la economía global. Notamos que hacia 1750 se producen varios de los cambios que ya anticipamos. Primero: incluso con un crecimiento 
sostenido de las salidas de plata desde la América hacia Europa, la corriente denota un fuerte salto y explosión en el comercio transatlántico desde la segunda mitad del siglo XVIII. El boom de las importaciones de metálico a Europa se ve acompañado por una mayor retención del metálico dentro de los mercados europeos; elemento que lo distingue del anterior ciclo de la globalización bipolar (1580-1750), cuando China absorbía gran parte de la moneda hispanoamericana que llegaba en un primer momento a Europa. Segundo: si vemos que desde la segunda mitad del siglo XVIII, Europa atesora una mayor cantidad de metálico americano con relación a épocas anteriores, los volúmenes de plata americana que salen por la vía euroasiática a través de los trayectos del Cabo de Buena Esperanza, el Báltico o el Cáucaso, y por el camino directo transpacífico inician un descenso. La tendencia polinómica que muestran estas dos últimas corrientes de metales resultan muy convincentes. Europa acumula y monetiza sus mercados; China, por el contrario, parece estar iniciando un proceso inverso: desmonetización y ruralización de su economía.

Desde 1780 el peso de plata mexicano se convierte en moneda de cambio en la flamante nación estadounidense. La plata la consiguen gracias al comercio que emprenden con los puertos del Golfo de México y Cuba, y del que practican con los puertos de Mazatlán, Guaymas y el Cabo de San Lucas en California. La plata que importan por estos conductos les sirve como reserva y garantía del nuevo papel moneda, el dólar. Como bien decíamos al principio de este capítulo: el nuevo Congreso Nacional estadounidense no considera otra letra de cambio que la moneda de acuñación mexicana, declarándola hasta 1857 la unidad monetaria nacional de sus intercambios. ${ }^{199}$ ¿La apropiación y control de la plata americana de la nueva nación constituye un elemento causal de la desaceleración de las importaciones de metálico en China?, ¿es posible pensar que mucha plata mexicana que antes fluía hacia China ahora se quede en Estados Unidos? Algunos estudios sostienen que sí, relativizando la incidencia que habría 
tenido el ascenso comercial del opio en el mercado chino y sus cambios en el sistema monetario, financiero y comercial. ${ }^{200}$ Es un debate abierto y con plena vigencia en la actualidad.

Gráfica III.3. Exportación y reexportación de plata americana en la globalización temprana. Ejes transpacífico, transatlántico y euroasiático, 1651-1800 (promedio anual en toneladas)

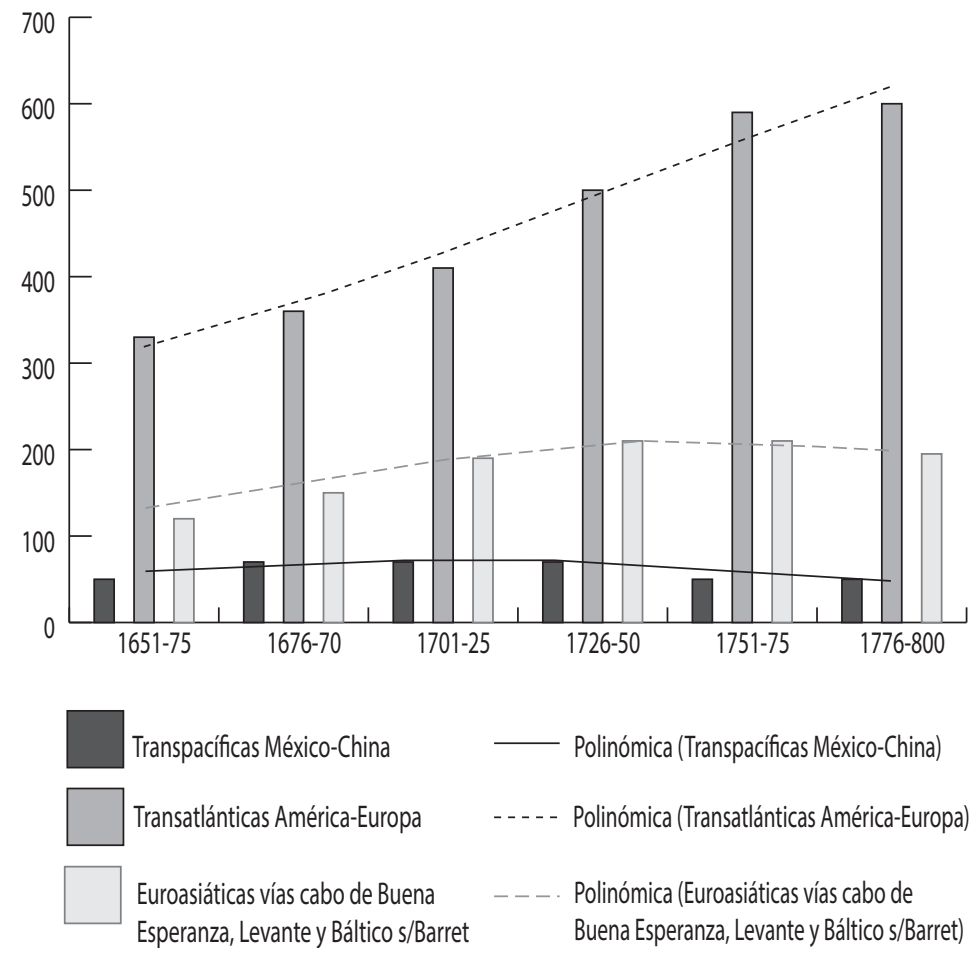

Fuente: Barret, "World bullion flows", tabla 7.7, p. 251; Morineau, Incroyables gazettes, tabla 70, pp. 474-476; Attman, “The Bullion Flow”, Hang-Sheng, “Trade”, pp. 845-853.

La desaceleración de China como “esponja” absorbente de metálico no parece explicarse sólo con la monetización de pesos mexicanos que atesora la naciente nación de Estados Unidos. Así 
como Gran Bretaña controla el gran mapa del comercio exterior hispanoamericano, su expansión y dominio se extiende hacia los mercados de la amplia región del Oriente, desde la India hasta China. Su asentamiento en Bengala (colonia británica en la India) desde 1757 termina por ubicar al opio como una mercancía significativa que los británicos ofrecen a los chinos a cambio de su té y, en menor medida, de sus sedas y porcelanas. Dermigny nos dice que las importaciones británicas por Cantón para el periodo $1775-1795$ se componen de $65 \%$ en plata y $35 \%$ en opio y algodones de la India, cuando en la primera parte del siglo la plata acaparaba $90 \%$ de la canasta comercial. ${ }^{201} \mathrm{El}$ cambio de patrón de la balanza comercial Gran Bretaña-China ya es evidente. Pierre Vilar señaló que entre 1733 y 1766, 65\% de las exportaciones británicas hacia Asia eran en forma de plata acuñada o en barra. Desde 1765, el algodón de la India y en menor medida el opio, tendrá un papel más importante en su canasta de exportación. ${ }^{202}$

Por su parte, Peer Vries sugiere un panorama de deflación en los precios de los bienes en China durante la primera mitad del siglo XIX, dada la escasez de moneda en la circulación interna del espacio. ${ }^{203}$ La plata americana es retenida por los europeos y norteamericanos, disminuyendo su entrada en China. Las importaciones chinas de opio que realizan los británicos terminan por reemplazarlas en la primera mitad del siglo xix. ${ }^{204}$

En 1809, China reconoce oficialmente sus salidas de plata al emitir un edicto prohibiendo su salida, merced a la introducción del opio traficado por los ingleses desde la India. La política monetaria de China se encuentra en graves problemas puesto que su gobierno, al margen del edicto de 1809 , no estableció mecanismos oficiales y de largo plazo para evitar la fuga de plata. ${ }^{205}$ La nueva operatividad de la Compañía británica de las Indias

201 Recordemos la definición cycle of tea que brinda Dermigny para describir el comercio británico en Cantón de 1760 en adelante. Dermigny, 1964, vol. II, pp. 68-69.

202 Vilar, 1982, p. 410.

203 Vries, 2015, pp. 238-240.

204 Furber, 1976, p. 257.

205 Vries, 2015, pp. 233-240. 
Orientales es frenar los envíos de plata a China y ofrecer a cambio de sus productos el opio de la India. La primera famosa Guerra del opio entre China y Gran Bretaña (1839-1842) es el desenlace de un proceso comercial conflictivo que viene gestándose desde mediados del siglo XVIII. En definitiva, el atesoramiento de plata por las nuevas potencias como Inglaterra y Estados Unidos, el freno a las importaciones de metálico en China y la atlantización de los circuitos de plata constituyen elementos en íntima relación del nuevo escenario de la globalización económica occidental.

Nos parece útil presentar el notable planteamiento que Marx realizó sobre la circulación de la plata a escala global y en el tiempo prolongado. La circulación de la plata entre Asia y Occidente tuvo "periodos alternados de altibajos que dependían de las fluctuaciones de la balanza de comercio". Marx nota que los cambios en el patrón de los intercambios explican los tres grandes periodos del movimiento de la plata a escala planetaria. El primero empieza en el siglo XVII y termina más o menos en 1830. El segundo, más breve, comprende los años entre 1831 y 1848 . El último, de 1849 hasta el momento en que Marx escribe. ¿Cómo los caracteriza?: "En la primera época la exportación de plata al Asia iba generalmente en aumento; en la segunda, la corriente de exportación iba disminuyendo hasta que, al final, una corriente opuesta empezó y por primera vez Asia arrojó de regreso a Europa parte del tesoro que absorbió durante dos siglos y medio". ${ }^{206}$

Es cierto la vigencia y el consenso que actualmente existe con la periodización de Marx. Pero por lo que hasta aquí venimos apuntando, parece necesario precisar con mayor claridad los cortes de las etapas. El punto de partida del primer periodo, cuando la plata se deposita como destino final en China, sería desde el último cuarto del siglo XVI y no en el siglo siguiente, como lo presenta Marx. El inicio más temprano del primer periodo considera los inicios de auge de Potosí como proveedor y fuente de suministro de metálico a China. Pero lo que reclama mayor aten- 
ción es la finalización del primer periodo y el inicio del segundo. Según Marx, la exportación de plata hacia China disminuye en la cuarta década del siglo XIX (1831). ¿No resulta un corte tardío? La presencia del opio desde finales del siglo xviII, la atlantización de los circuitos del Pacífico hispanoamericano y el control europeo de los flujos mundiales de la plata son elementos que aquí nos inducen a pensar un proceso de disminución mucho más temprano.

\section{La rotación del comercio oriental: del Pacífico al Atlántico}

La atlantización del Pacífico es un concepto que no sólo comunica la expansión de la economía noratlántica sobre el área marítima occidental de América. También demuestra cómo fenómenos mercantiles que hasta 1750 constituían la columna vertebral del Pacífico indiano se trasladan hacia la propia área atlántica. El movimiento de la contratación oriental parece ser la expresión más cabal de este segundo acontecimiento. Si antes se veía claramente concentrado en el Pacífico, a partir de la segunda mitad del siglo comienza su viraje hacia el Atlántico. Continuando con una perspectiva global, la atlantización del comercio oriental es otra prueba del retroceso de China y la emergencia de la India como espacio asiático representativo de la economía global.

En efecto, el descenso del movimiento de bienes orientales por Acapulco y la comentada crisis del galeón de Manila a partir de la segunda mitad del siglo xviII obedece, en gran medida, a su circulación e importación por los puertos del Atlántico hispanoamericano. Nuestras evidencias sobre la traslación del tráfico oriental son, para la segunda mitad del siglo borbónico, cualitativamente dispares y, vale reconocerlo, débiles. Por el contrario, para las primeras décadas del siglo XIX aparecen evidencias con un marcado carácter cuantitativo. Esta diferencia es entendible en la medida en que la circulación y consumo de bienes asiáticos tienen el peso de la prohibición hasta 1803, por lo que antes de esa fecha su ocultación es un hecho habitual. A partir de los pri- 
meros años del siglo xıx, las mercaderías comienzan a ser explicitadas en los registros con total normalidad, aunque la visibilidad no implica suponer, por todo lo que venimos argumentando, que el comercio y consumo de artículos asiáticos se incrementa en los mercados hispanoamericanos; todo lo contrario. El giro espacial de la contratación asiática, del Pacífico hacia el Atlántico, refuerza nuestra consideración acerca de que a partir de la segunda mitad del siglo XVIII se producen los cambios más significativos en la economía hispanoamericana.

En 1778, año en que se emite el famoso decreto de "libre comercio", un funcionario aduanero de La Habana muestra perplejidad y desconocimiento sobre cómo proceder ante "las embarcaciones del comercio libre que vienen a este puerto de los de España y que conducen muchas veces géneros de China”. Se pregunta si son "legítimos de introducción, aunque no conste su especial habilitación”. Advierte el funcionario que en el caso de que se considerara mercadería legítima "serán muchos los fraudes que se cometerán contra la Real Hacienda, porque teniendo los reinos extranjeros mucho comercio con los de China, introducirán sus géneros a la sombra de los que vienen a España, por el giro suyo, perjudicándose las fábricas del reino". ${ }^{207}$ Siete años antes, en 1771, había llegado el navío Oriflama al puerto chileno de Valparaíso procedente de Cádiz navegando por la flamante ruta del Cabo de Hornos. Al inspeccionarse el cargamento se descubrió la presencia de una gran porción de tejidos asiáticos rotulados como sedas de Bretaña, de Francia y Cantabria. ${ }^{208}$ En las costas peruanas sucede algo similar. Dos años después, de la llegada del Oriflama, el Tribunal del Consulado de Lima comprueba el ingreso de manufactura en seda asiática y extranjera en navíos de registro español que venían por el Cabo de Hornos. La entrada sale a la luz porque el Tribunal dudaba si dichos géneros estaban permitidos o no, si existiría alguna norma fiscal para su

207 "Expediente del comercio libre (1778-1779)", AGI, Indiferente, 2415, s/n de fs.

208 Real Tribunal del Consulado de Lima, AGNL, subsección Resguardo al comercio-Naufragios y arribadas, caja 137, documento 932, f. 50. 
gravamen. ${ }^{209}$ No hay sustento jurídico que anticipe y encuadre el fenómeno real de la atlantización del comercio asiático. Son tiempos donde las referencias muestran gran ambigüedad por un proceso real que no se considera en la legislación. La situación se repite en el puerto del Río de La Plata. Más de 22000 pesos en valor de géneros asiáticos buscan ingresarse en 1802 por medio del navío francés L'Osterley. El funcionario del puerto no sabe cómo proceder: si debe confiscar la mercadería por ser de contrabando o debe permitir su ingreso. Finalmente, decide por su subasta, un procedimiento regular para recaudar dinero. ${ }^{210}$

Donde se expresa claramente la atlantización de la contratación asiática es en el espacio de la Nueva España. El ilustrado eclesiástico Agustín Iñigo Abbad y Lasierra (1745-1813), que vivió unos años en las islas del Caribe y en la Cartagena venezolana, nos comparte en su obra Comercio de Filipinas de 1784 un relato revelador. Nos dice que las compañías europeas que operan en el Oriente "reciben todos los años muestras de los dibujos de moda que se inventan en la Europa". Las corporaciones orientales pasan los diseños a los chinos, para que los "tejan, imitando los modelos y el ancho que se les prescribe". Los textiles confeccionados "se traen a Europa y los pasan a Cádiz por telas de Francia e Inglaterra"; desde allí circulan por la vía transatlántica "en las flotas y registros a México". De manera que:

Dichos cargamentos de China hechos a gusto de Francia e Inglaterra se presentan en la feria de Jalapa, corren por toda la América y como son todas más anchas de mejor calidad y gusto que los que lleva la Nao de Filipinas se ven estos despreciados, vendiéndose aquellos a precios muy subidos, pues en materia de lujo, el americano rico, no conoce límites y el extranjero que entiende su fantasía aprovecha todos medios de extraerles la plata. ${ }^{211}$

209 AGNL, Tribunal del Consulado, caja 11, doc. 476, f. 14.

210 Bonialian, 2014, pp. 75-76.

211 Abbad y Lasierra, “Comercio de Filipinas”, AGI, Estado, leg. 47, exp. 10, fs. 26-27. 
La "ropa de China” que, aún en esos años y por disposiciones legislativas debería movilizarse por el eje transpacífico, se envía a la Nueva España por la vía transatlántica, gracias al pacto entre los mercaderes extranjeros y gaditanos. Esto lo logran a través de la transformación del bien: una imitación oriental de lo occidental. Abbad explicita que las entradas de textiles de China y de algodón de la India por Jalapa terminan perjudicando las importaciones de similares productos por Acapulco para la celebración de sus ferias. ${ }^{212}$ Otros informes y memoriales de la época, como el que realiza el pensador económico Bernardo de Ulloa, denuncian la negociación existente entre las casas comerciales españolas y europeas para movilizar sedas, algodones de la India, de China y porcelana asiática desde el Atlántico rumbo a los mercados hispanoamericanos. $^{213}$ Los géneros asiáticos, todavía ilegales para su comercialización por toda América hasta los primeros años del siglo XIX, se etiquetan como producción europea, con vistas a evadir cualquier intento de sanción o confiscación.

Ahora bien, los mecanismos de imitación de los bienes es un juego de ida y vuelta entre Oriente y Occidente. Recordemos aquí lo visto en el capítulo I, sobre las solicitudes de textiles chinos con dibujos y diseños occidentales en los tempranos viajes transpacíficos emprendidos por los mercaderes novohispanos y peruanos. Se copia lo occidental desde el Oriente y se imita lo oriental desde el Occidente. Todo indica que lo segundo se torna regular con posterioridad. Por lo menos desde finales del siglo XVII los centros de consumo europeos consumen bienes que llevan consigo los diseños y estilos orientales. ${ }^{214}$ El fenómeno de la cultura material nos remite al proceso de occidentalización de lo oriental llega con fuerza al mercado hispanoamericano más tarde, un siglo después. Así lo confirman los inventarios de bienes de la época, que demuestran, en todo el arco hispanoameri-

212 Abbad y Lasierra, “Comercio de Filipinas”, AgI, Estado, leg. 47, exp. 10, fs. 26-27.

213 Ulloa, [1740] 1992, p. 343.

214 Algunas referencias sobre las imitaciones chinas fabricadas y consumidas en Europa puede verse en: Roche, 2003; McKendrick, Brewer y Plumb, 1982. 
cano que va desde la Nueva España hasta Buenos Aires, el consumo de los llamados bienes "chinescos" o "chinoiserie"; esto es, tejidos y cerámica europea producidos en serie con diseños y formatos orientales. ${ }^{215}$

Hacia 1767, el contador de Madrid Landazuri responsabiliza la reducción del comercio del galeón de Manila por los ingresos de las imitaciones europeas de los bienes orientales promovidos por el puerto de Veracruz.

No puede negarse que las ropas y demás efectos que actualmente se traen de Filipinas según los últimos reglamentos de permisión tienen su avío y despacho en Nueva España, sin que no sólo resulte exceso que pueda dar lugar a su introducción en el Perú ni Tierra firme, sino es que no bastando al surtimiento de aquellas provincias, tiene acreditado la experiencia que es muy común el uso de las ropas que de esta clase [China] se introducen clandestinamente los holandeses y otros extranjeros desde sus colonias, como también otras imitadas a aquellas, pintadas en lienzo de lino, que los mismos extranjeros han inventado y van ya por lícito canal de flotas y registros de Nueva España. ${ }^{216}$

Si bien los testimonios indican que los textiles asiáticos transitan por todos los puertos atlánticos, hay que reconocer que el puerto de Veracruz funge como el nodo portuario de arrastre más importante de Hispanoamérica. En 1787 una representación del Consulado de Manila expresa su queja de las incesantes entradas de bienes orientales por el surgidero de Sotavento que hasta hace poco se surtían de manera exclusiva por Acapulco. La crisis comercial del comercio del galeón es, según esta fuente, producto:

de la concurrencia de los mismos efectos de China y costa en el reino mexicano, pues introduciéndose [aquellos con los] que surtimos nuestro permiso por los comerciantes de la Península, o por la Real 
Compañía, por Veracruz u otro cualquier puerto en la América septentrional será causa de un total descalabro a ambos comercios. ${ }^{217}$

Por su parte, el permiso otorgado desde su nacimiento a la Real Compañía de Filipinas (1785) para importar por el puerto de Veracruz los tejidos de China y el algodón de la India aminora el tradicional flujo transpacífico. Así lo dice en ese mismo año el provincial de los religiosos de San Agustín, fray Francisco González, que responsabiliza en la concesión real otorgada a la corporación insular la inactividad que vive la feria de Acapulco.

público y notorio que en cuanto tuvieron noticias los mercaderes del reino de México de que la nueva Compañía de Filipinas había de introducir por la vía de Veracruz los mismos efectos de que antes los surtía el barco de Acapulco, comenzaron a mirar con extraña indiferencia la carga de dicho barco, que tan grata le era antes, ofreciendo por ella precios tan bajos e ínfimos que se han visto sus dueños en la precisión de no abrir feria. ${ }^{218}$

Disponemos de abundantes documentos que muestran ingresos importantes de "géneros de la China" por la real aduana de Veracruz. ${ }^{219}$ La rotación de la contratación asiática sigue plenamente vigente durante las primeras décadas del siglo XIX a través del comercio británico. Hacia 1811, el editor de la Gaceta de México, Juan José Cancelada, pone al descubierto su movilización. El artículo muestra un lamento sobre la falta de una política proteccionista en México que proteja el desarrollo de la industria textil local. El embate mercantil británico sólo es efectivo ante las situaciones frecuentes de guerra, que obligan a bloquear los circuitos transatlánticos y establecer políticas de regulación so-

217 Citado por Alonso Álvarez, 2007, p. 205.

218 Citado por Alonso Álvarez, 2007, p. 207.

219 AGNM, Instituciones coloniales, Indiferente virreinal, caja 6154, exp. 10, fecha: 1791, f. 218. El proceso también puede rastrearse en el pago de las alcabalas. Véase al respecto AGNM, Instituciones coloniales, Indiferente virreinal, caja 6527, exp. 22, fecha: 1795 , f. 24. 
bre las importaciones. Pero continúa argumentando que "hecha la paz con la Gran Bretaña, volvieron de nuevo las introducciones de la Europa y por los mismos mares muchas del Asia".220

Las casas comerciales de Veracruz disponen en sus depósitos de significativos cajones de seda China y algodón de la India. En la coyuntura de los conflictos por la independencia, cuando los buques directos desde Asia hacia el Pacífico mexicano son muy esporádicos, la compañía de Gabriel Manuel de Iturbe e Iraeta no encuentra otra solución que recurrir a las casas comerciales proveedoras, como Malsan y Follin, instaladas en los puertos de Veracruz y Alvarado para surtirse de aquellas telas. ${ }^{221}$ Es más, una buena porción de los textiles asiáticos desembarcados por esos puertos atlánticos durante la tercera década del siglo xix alcanza, incluso, la plaza de Acapulco.

El comercio de los ingleses ya no sólo viene a propinarle los últimos golpes al moribundo comercio del galeón de Manila, sino también a la Compañía Real Española de Filipinas, cuyas operaciones concluirán en 1820 , fecha en que los procesos de emancipación hacen inviable la continuidad de sus operaciones. Los comerciantes de la Ciudad de México hacen evidente que estas introducciones de tejidos de algodón de la India y de China tienen un efecto devastador sobre la estructura textil local. ${ }^{222} \mathrm{El}$ fenómeno de las imitaciones y reproducciones europeas, particularmente las emprendidas por los ingleses, no se limitan a convertir sus productos en formato oriental, sino que se constituye como una estrategia económica general, para que los productos europeos, sean una imitación o no, tengan despacho y venta en los mercados americanos. Desde finales del siglo xviII, el textil inglés que llega a México es etiquetado como textil de producción local para evitar los impuestos que sufren las mercaderías extranjeras en los puertos mexicanos. ${ }^{223}$

220 López Cancelada, 1811, p. 110.

221 Gabriel fue nieto del famoso comerciante Francisco Ignacio de Yraeta de la segunda mitad del siglo xviII. González Villanueva, 1997, pp. 158-165.

222 Valdés Lakowsky, 1987, pp. 241-247.

223 Bernecker, 1994, pp. 69-70. 
Analicemos la evidencia más consistente que aparece en los primeros años del siglo XIX. El siguiente listado sobre las importaciones de bienes asiáticos por Veracruz y sus reenvíos hacia otros puertos americanos se sustenta con información extraída del clásico libro Comercio exterior de Lerdo de Tejada (cuadro III.10). Las consideraciones que haremos no alcanzan una reflexión general sobre todo el comercio exterior mexicano, sino circunscripta a la atlantización del comercio de géneros asiáticos. El reciente trabajo de Sandra Kuntz, que corrige pero sobre todo legitima la fuente presentada por Tejada entre los años 17961820 , nos ahorra varios comentarios preliminares. ${ }^{224}$

Desde un principio, habría que reconocer las limitaciones metodológicas de la serie. En primer lugar, sólo considera el comercio permitido por el puerto de Veracruz, tanto en la modalidad de buques españoles como de los navíos neutrales de las potencias europeas. Así se escapa del análisis cualquier ponderación del gran contrabando de las mercaderías asiáticas que ingresarían a México por el mismo puerto de Veracruz y por otros puertos menores en alza, como Sisal, Tampico y Campeche. Tampoco reconoce las entradas ilícitas de productos asiáticos promovidas por otros puertos de México, de Panamá, de Cuba o de otro enclave británico del Caribe, cuando sabemos, por lo visto en apartados anteriores, que Panamá es un coladero de bienes de la India para su despacho hacia San Blas.

De esta manera, la fuente de Lerdo no permite ilustrar de forma cabal y completa la atlantización del comercio asiático. Son cifras que deberían tomarse con suma prudencia, como elemento representativo del fenómeno. ${ }^{225}$ Un segundo punto a recordar es

224 Es la fuente estadística que ofrece cifras completas para el periodo. Kuntz, 2015, pp. 35-59. Para nuestro preciso objetivo de rastrear la atlantización de bienes asiáticos, aspecto que no resulta nada fácil de identificar en las fuentes, de ser una porción menor y no representativa del comercio exterior mexicano, las cifras de Lerdo de Tejada resultan, en definitiva, una herramienta fundamental de considerar en el análisis.

225 En sus "Notas", Sandra Kuntz pone de manifiesto que la gran disparidad entre importaciones y exportaciones existente en la serie de Lerdo apunta a la gran existencia del contrabando. Particularmente, al hecho de ingresos de mercaderías no declarados. Kuntz, 2015, pp. 43-45. 
que la serie de Tejada constituye una estadística sostenida en los reportes del Consulado de Veracruz, corporación interesada en ofrecer una imagen parcial y mínima del comercio a raíz de motivos fiscales. ${ }^{226}$ En tercer lugar, los productos orientales movilizados desde Europa hacia Veracruz corresponden exclusivamente al "comercio neutral"; no hemos identificado bienes asiáticos en los buques españoles que salen desde los puertos peninsulares con "efectos europeos o extranjeros".

El registro relativamente frecuente y en serie de mercadería del Oriente parece corresponder a la relativa simultaneidad de dos autorizaciones: el comercio en navíos neutrales (1797) y la posibilidad de movilizar libremente géneros asiáticos en Hispanoamérica (1803). En 1806 toma fuerza el "comercio neutral" y se explicita lo asiático, dada la caída del comercio bilateral entre Nueva España y la metrópoli. ${ }^{227}$ No menos importante y a modo de comentario final, hay que decir que varios de los productos anotados en los registros de Lerdo no comunican el lugar de origen de elaboración, por lo que muy posiblemente algunos de ellos sean de origen asiático, aunque nos impide identificarlos como tales.

Ante todo, habría que resaltar el notable ingreso por el puerto de Veracruz del textil de algodón de China y de la India en especial, el mahón, el lienzo y la zaraza. El lienzo y la zaraza, telas de algodón que pueden o no estar estampadas, nos resultan familiares. Pero, ¿qué es el mahón? Según el Diccionario de la Real Academia Española, el mahón es una "tela fuerte y fresca de algodón, de diversos colores, que primeramente se fabricó en la ciudad de Nanquín, en China”. El lienzo ancho asiático y el mahón de Nanquín son los artículos orientales de mayor ingreso por Veracruz. En el año 1807, se importan por Veracruz más de dos millones en varas de lienzo de China, casi 400000 varas de mahón asiático y más de 11000 docenas de pañuelos de Madrás. No sabemos si el mahón era de origen indio o chino, posiblemente con proceden- 
cia de la colonia británica de la India. La importación de algodón "asiático" es realmente significativa al considerar el rubro general de textiles que traen los buques extranjeros. En 1807 representa 21\% (1 382340 pesos) del rubro total de algodón (6351464) que ingresa por Veracruz. También es sustancial el registro de 1806. El valor que suman los lienzos, mahonés y zarazas de Asia alcanza los 484113 pesos; cifra que representa $31.13 \%$ del valor total de algodones (1554647) que se importan por el puerto atlántico mexicano. En 1808 las comparaciones porcentuales fueron menos importantes: el valor del lienzo ancho asiático y las varas de mahón de China llegan a los 219884 pesos; $8.5 \%$ del total de algodones ingresados (2583 160).

Cuadro III.10. La atlantización del comercio asiático (1804-1828). Importaciones (I) por Veracruz y sus reenvios a otros puertos

\begin{tabular}{rlr} 
Año & \multicolumn{1}{c}{ Mercadería } & \multicolumn{1}{c}{ Pesos } \\
\hline 1804 & Menudencias del reino y de China & 22788 \\
\hline 1805 & Menudencias del reino y de China & 1593 \\
\hline 1806 & (I) Algodón & 82000 \\
& 26800 piezas mahonés de China & 68580 \\
& 3895 piezas mamodíes y lienzos anchos de la India & 333533 \\
& 6507 piezas zarazas de Asia & 484113 \\
& Suma total de algodón asiático & 1554647 \\
& Valor total del rubro de algodón & 17168 \\
& bejucos de China & 15000 \\
\hline & menudencias del reino y de China & \\
\hline 1807 & (I) Algodón & 1071665 \\
& 2143330 varas de lienzo de Asia & 149339 \\
& 398238 varas Mahón de China & 161336 \\
& 11524 doc. de pañuelos de Madrás & 1382340 \\
& Suma total del algodón asiático & 6351464 \\
& Valor total rubro de algodón & 3240 \\
\hline
\end{tabular}




\begin{tabular}{|c|c|c|}
\hline$A \tilde{n} o$ & Mercadería & Pesos \\
\hline \multirow[t]{5}{*}{1808} & Algodón & \\
\hline & 17851 piezas de lienzo ancho de India & 184334 \\
\hline & 94800 varas Mahón de China & 35550 \\
\hline & Suma total del algodón asiático & 219884 \\
\hline & Valor total rubro de algodón & 2583160 \\
\hline \multirow[t]{2}{*}{1809} & (I) 6400 varas de lienzo de China & 4000 \\
\hline & 1511 libras de peines de marfil & 7555 \\
\hline \multirow[t]{4}{*}{1810} & (I) 118 piezas de lienzo de China & 1888 \\
\hline & 1863 libras peines de marfil & 9315 \\
\hline & 208 libras de peines de marfil & 1040 \\
\hline & 90 libras de peines de marfil & 540 \\
\hline \multirow[t]{2}{*}{1811} & (I) 84 libras peines de marfil & 840 \\
\hline & 20 mantos de China & 700 \\
\hline 1812 & 1812 doc. de pañuelos de Madrás & 23582 \\
\hline \multirow[t]{2}{*}{1816} & 20117 doc. de pañuelos de Madrás & 160932 \\
\hline & 1817 pañuelos de seda india & 27255 \\
\hline 1817 & 9467 doc. de pañuelos de Madrás & 56982 \\
\hline \multirow[t]{3}{*}{1823} & 61750 varas de lienzo de China & 11578 \\
\hline & 3450 libras de pimienta de China & 862 \\
\hline & 780 piezas de muselinas de la India & 3900 \\
\hline \multirow[t]{7}{*}{1824} & por Alvarado & \\
\hline & 680 varas de manta de China & 170 \\
\hline & 289 pañuelos de Madrás & 1300 \\
\hline & 1600 varas de lienzo de China & 400 \\
\hline & por Veracruz & \\
\hline & 1106 varas de muselina de la India & 2362 \\
\hline & 160 doc. de pañuelos muselina de Madrás & 640 \\
\hline
\end{tabular}

Fuente: Lerdo de Tejada, [1853] 1967, Documentos, núm. 15-31, s/n de fs.

A la par del mahón de China, también ingresa a México el mahón inglés. Si comparamos sus cantidades y valores se desprenden interesantes observaciones. Al considerar la evolución 
del rubro desde 1805 hasta 1824, se logra visualizar lo que, quizás, fuera el elemento distintivo de la revolución comercial atlántica: conforme avanzan los primeros años del siglo va tomando dominio el tráfico y el consumo del algodón inglés por sobre el de Asia y posiblemente - aunque los registros lo impidan-del que produce México. Los registros de ingreso de algodón expresan la avanzada del tejido inglés por sobre el textil asiático en el mercado mexicano. En 1806, las importaciones de los mahones ingleses representan la mitad de los de China: 10979 varas para el primero con un valor de 8580 pesos, contra las 26800 varas con un valor total de 82000 pesos para los asiáticos. ${ }^{228} \mathrm{Al}$ año siguiente la relación es de 398238 varas para el mahón chino contra 28513 del inglés. ${ }^{229}$ Sin embargo, para el año 1824, ya se puede constatar cómo se invierten las importaciones: no se documenta ingreso de mahón asiático, mientras que el "mahón inglés ancho" registrado alcanza las 108336 varas a un total de 62381 pesos. En 1826, el dominio del mahón inglés es absoluto. Entre "ancho, blanco y angosto" se documenta 121790 piezas de mahones de la India, cuando el mahón inglés casi lo cuadruplica: 485774 piezas por un valor de 121444 pesos. El ejercicio comparativo con un solo producto es, claro está, arbitrario. Posiblemente, al realizar similar tarea con el "lienzo" o "liencecillo" los resultados serían aún más contundentes, pero al no contar con números frecuentes y anuales sobre la entrada del lienzo asiático se hace imposible su comparación. No obstante sí vale mencionar los notables volúmenes y valores de la Bretaña inglesa en estos cargamentos por Veracruz durante el primer cuarto del siglo XIX. Como ejemplo ilustrativo subrayemos las más de 200000 piezas de Bretaña (anchas, angostas, contrahechas y entreanchas) con una suma total que acariciaba los dos millones de pesos. ${ }^{230}$ La seda china, un artículo de gran trascendencia en el comercio transpacífico y en el patrón de consumo hispanoame-

228 Lerdo de Tejada, [1853] 1967, documento 19, s/n de fs.

229 Lerdo de Tejada, [1853] 1967, documento 20, s/n de fs.

${ }^{230}$ Lerdo de Tejada, [1853] 1967, documento 22, s/n de fs. 
ricano durante el periodo 1580-1750, ya no figura en los registros de estos cargamentos, su ausencia por Veracruz no se traduce automáticamente en su desaparición como artículo de consumo. Posiblemente, sea un producto que continúa comercializándose directamente desde el oriente hacia el Pacífico mexicano. Pero la omisión por Veracruz llama la atención de manera especial. La calificación que aparece como "muselina de la India" no permite saber si se refiere a seda o algodón. Por otro lado, no se puede dejar de mencionar los altos cargamentos de pañuelos de Madrás y de los peines de madera y de marfil de China, prácticamente presentes en todos los años.

Los envíos de mercadería oriental desde Veracruz hacia otros puertos americanos o hacia la propia España son insignificantes, que se reducen a unas pocas mantas de China, peines o con el genérico calificativo de "menudencias de China". Son entendibles estas bajísimas reexportaciones. A diferencia de lo que ocurre hasta 1750, cuando los reenvíos de mercancía asiática desde Veracruz hacia España y a otros mercados del Caribe se movilizan de manera clandestina y en significativas proporciones. Desde finales del siglo XVIII los navíos de registro y los buques de los neutrales tienen la posibilidad de abastecer a los restantes puertos de América de forma directa y legal las mercancías asiáticas. Por lo que el comercio intercolonial de productos asiáticos, más entendible para el lado Atlántico, resulta un hecho excepcional para este periodo atendido. En 1804, el valor de las reexportaciones de "menudencias del reino y de China" desde Veracruz hacia otros parajes de Hispanoamérica representaron tan sólo $0.66 \%$ (22 788 pesos) del total de los reenvíos (3 424511 pesos). Al año siguiente, el valor de esas "menudencias" es de 1593 pesos; 0.48\% del valor total: 330 540. En 1806, el rubro asiático tiene un valor de 32168 pesos, lo que arroja 5.6\% del total del valor: 565791 . Por último, en 1807 lo asiático es $17 \%$ de los reenvíos totales de Veracruz que van cayendo sostenidamente: 18725 pesos. 


\section{Cuadro III.11. Importaciones de bienes asiáticos por la República Mexicana (1825-1828)}

\begin{tabular}{|c|c|c|}
\hline Año & Mercaderías & Pesos \\
\hline \multirow[t]{5}{*}{1825} & 98 millares de cohetes de China & 392 \\
\hline & 18697 varas de muselina de India & 11685 \\
\hline & 66 piezas de pañuelos de Madrás & 91 \\
\hline & 44930 docenas de pañuelos de Madrás & 202184 \\
\hline & 150 millares de peines de China & 2250 \\
\hline \multirow[t]{16}{*}{1826} & 26 cajitas y 3750 paquetes de cohetes de China & 565 \\
\hline & 188 esteras de la India & 141 \\
\hline & 190 piezas de "carranclanes" de la India & 1520 \\
\hline & 3091 lienzos de Cantón & 1546 \\
\hline & $\begin{array}{l}46200 \text { lienzos asiático angosto (comparar lienzo } \\
\text { europeo) }\end{array}$ & 23100 \\
\hline & 34342 piezas de mahón ancho de la India & 51513 \\
\hline & 68501 piezas de mahón angosto de la India & 68501 \\
\hline & 17095 piezas muselina de la India & 10684 \\
\hline & 96 varas de olán de China & \\
\hline & 11 millares de peines de China de caña & 173 \\
\hline & 977 docenas de peines de marfil de China & 2932 \\
\hline & 946 docenas de pañuelos de Madrás & 4259 \\
\hline & 8391 varas de tul de China & 8391 \\
\hline & $\begin{array}{l}\text { Valor total de la importación de bienes asiáticos por } \\
\text { los puertos de México }\end{array}$ & 173325 \\
\hline & $\begin{array}{l}\text { Valor total de las importaciones por el Pacífico } \\
\text { mexicano }\end{array}$ & 969757 \\
\hline & $\begin{array}{l}\text { Total comercio de importación por los puertos de } \\
\text { México }\end{array}$ & 15450508 \\
\hline \multirow[t]{4}{*}{1827} & 334 cajitas de cohetes de China & 1337 \\
\hline & 312 piezas carranclanes de la India & 2496 \\
\hline & 1890 varas de lienzo de Cantón & 570 \\
\hline & 96696 piezas de mahón ancho de la India & 145044 \\
\hline
\end{tabular}




\begin{tabular}{|c|c|c|}
\hline \multirow[t]{2}{*}{ Año } & \multirow{2}{*}{$\begin{array}{c}\text { Mercaderías } \\
64868 \text { varias mahón angosto de la India (comparar) }\end{array}$} & \multirow{2}{*}{$\begin{array}{l}\text { Pesos } \\
64868\end{array}$} \\
\hline & & \\
\hline & 20989 varas de muselina de la India & 13118 \\
\hline & 432 varas de pañuelos de Madrás & 416 \\
\hline & 1818 varas de olán de China & 1819 \\
\hline & $\begin{array}{l}7084 \text { docenas, } 28 \text { millares y } 30 \text { cajones de peines de } \\
\text { madera de China }\end{array}$ & 8543 \\
\hline & 75 docenas de peines de marfil de China & 225 \\
\hline & 636 petates de la India & 318 \\
\hline & 2779 docenas de pañuelos de Madrás & 12506 \\
\hline & 35 docenas de pañuelos de lienzo de cantón & 105 \\
\hline & 600 piezas de quimones & 900 \\
\hline & 10422 varas de tafetán de China & 10442 \\
\hline & $\begin{array}{l}\text { Valor total de la importación de bienes asiáticos por } \\
\text { los puertos de México }\end{array}$ & 262707 \\
\hline & $\begin{array}{l}\text { Valor total de las importaciones por el Pacífico } \\
\text { mexicano }\end{array}$ & 1081810 \\
\hline & $\begin{array}{l}\text { Total comercio de importación por los puertos de } \\
\text { México }\end{array}$ & 14889016 \\
\hline \multirow[t]{10}{*}{1828} & 2640 varas y 30 piezas carranclanes [sic] de la India & 1271 \\
\hline & 217 cabo de China & 326 \\
\hline & 1600 petates de la India & 400 \\
\hline & 26116 docenas de pañuelos de Madrás & 61845 \\
\hline & 500 varas de ruan de China & 781 \\
\hline & 28 varas de ruan negro de China lanquin & 51 \\
\hline & 13 varas de tafetán de China & 12 \\
\hline & $\begin{array}{l}\text { Valor total de la importación de bienes asiáticos por } \\
\text { los puertos de México }\end{array}$ & 64686 \\
\hline & $\begin{array}{l}\text { Valor total de las importaciones por el Pacífico } \\
\text { mexicano }\end{array}$ & 577544 \\
\hline & $\begin{array}{l}\text { Total comercio de importación por los puertos de } \\
\text { México }\end{array}$ & 14488786 \\
\hline
\end{tabular}

Fuente: Lerdo de Tejada, [1853] 1967, documentos, núm. 15-31, s/n de fs. 
Desde 1825, los registros comerciales presentados por Lerdo de Tejada no atienden solamente las importaciones por Veracruz, sino que consideran las entradas de bienes por "los puertos de la República mexicana”. Desconocemos qué puertos son considerados y cuáles son marginados con el generalizado calificativo. En el cuadro III.11 se listan los bienes asiáticos que fueron registrados por "todo" el territorio mexicano, tanto por los puertos del Pacífico como del Atlántico; por lo que resulta imposible continuar realizando el ejercicio de ingresos de mercadería asiática exclusivamente por Veracruz. Con todo, tomando los recaudos metodológicos mencionados, la contabilidad propuesta por Lerdo de Tejada para los años comprendidos entre 1825 y 1828 nos permite realizar ejercicios, para continuar analizando: 1) la importancia del comercio asiático por México en los inicios del segundo cuarto del siglo xIx, y 2) el peso relativo que dicho trato adquiere en el área marítima occidental mexicana y las mercancías de origen asiático que por esos años circulan y se consumen por el país.

Lo primero que salta a la vista del cuadro III.11 es el bajísimo valor que habrían alcanzado para el periodo 1826-1828 el conjunto de las importaciones de mercadería asiática por México en relación al valor total de comercio de importación. Para el año 1826 el valor de las importaciones asiáticas representa solamente 1.12\% (173325 pesos) del total de importaciones mexicanas (15450508 pesos) que incluyen bienes europeos, españoles, americanos y los propiamente asiáticos. Al año siguiente, el valor importado de mercadería de origen asiático alcanza 1.76\% (262 707 pesos) del total (14889016 pesos) y para el año 1828 el valor total de la canasta importadora de lo asiático es de tan sólo $0.44 \%$ (64686 pesos) de la suma general de bienes que ingresaron a México (14488786 pesos). En conjunto, para el periodo 1826-1828 el comercio de importación de bienes asiáticos se estima en $1.11 \%$ de las importaciones totales por México. Estos cálculos ponen de manifiesto el notable descenso de la gravitación del comercio asiático en los inicios de la república independiente, no sólo con relación al largo periodo colonial, sino también con los importantes valores de tex- 
tiles de algodón de la India y China que ingresan por el puerto de Veracruz en los primeros años del siglo XIX.

No se puede saber si los ingresos de bienes asiáticos se están efectuando sólo por los puertos del Pacífico o también participan los puertos del Atlántico. Puede que parte de los ingresos de esta canasta de importación asiática se hagan por Veracruz y otra porción por el puerto de San Blas u otro punto costero occidental. A pesar de este interrogante de difícil resolución, nos atrevemos a pensar un hecho hipotético o contrafáctico. Si partimos del hecho de que toda la importación de bienes asiáticos se hace por el Pacífico (fenómeno difícil de suponer por todo lo que estamos sosteniendo), obtendríamos que para el año 1826 la importación asiática representó $17.87 \%$ (173325 pesos) del total de comercio de importación por el occidente mexicano (969757 pesos en 25 buques con 3851 toneladas); en 1827, el 24 y 28 \% (1 081810 pesos en bienes importados por el Pacífico en 32 buques de 5242 toneladas) y al año siguiente sólo $11.20 \%$ (577544 pesos, 17 buques por el Pacífico, con 2298 toneladas). ${ }^{231}$

Estos porcentajes, que de por sí reflejan un comercio asiático notablemente aminorado, serían topes máximos, porque no todas las mercaderías ingresan por el Pacífico. Tampoco estarían representando el rubro de importaciones asiáticas, ya que más de tres cuartas partes del total de entradas por el Pacífico son bienes procedentes de Europa, vía el Atlántico. De ahí una segunda conclusión, no menos notable, que arroja el ejercicio: la economía mercantil del Pacífico ya no puede definirse como el espacio singular de la contratación asiática. Si durante el largo periodo colonial que va de 1580 a 1740 las importaciones de bienes del Oriente en Acapulco, vía Islas Filipinas, por medio del galeón de Manila constituyen una pieza central del esquema general del comercio hispanoamericano, a partir de 1750, con el inicio de la atlantización del Pacífico, los textiles, mayormente británicos, comienzan a dominar el rubro de las importaciones por los puertos del Pacífico mexicano. El comercio de mercade-

${ }^{231}$ Lerdo de Tejada, [1853] 1967, documentos núm. 32, 33, 34 y 35. 
ría británica desde Panamá a San Blas es un caso emblemático de este fenómeno: expresa, en un inicio, el retroceso del comercio asiático; también la crisis del enlace transpacífico entre América y el Oriente y, por último, el cambio en las prácticas de consumo que vive el mercado americano que va del protagonismo de los textiles asiáticos a lo frecuente del uso del algodón británico.

Pues bien, ¿qué mercaderías asiáticas vemos ingresar durante 1825 y 1828 ? Continúan apareciendo el mahón y la muselina de la India y el lienzo de Cantón. Sin embargo, como fiel reflejo de un tráfico en declive, sus cantidades y valores resultan insignificantes comparados con los textiles ingleses de diferente composición. Durante esos años, el valor total de los textiles asiáticos ronda una suma total que va desde los 50000 pesos hasta, excepcionalmente, como lo es en 1827, los 200000 pesos. Son cifras realmente mínimas que muestran su papel secundario y complementario, si se compara con los más de siete millones de pesos de textiles de lienzo, hilo, algodón y seda de origen europeo (mayormente británicos) que ingresan a México en aquel año. ${ }^{232} \mathrm{~A}$ pesar de continuar comercializándose, la seda asiática pierde importancia con relación al predominio de los textiles ingleses. Lo que sí llama la atención en el rubro del comercio de importación asiática es la aparición de nuevos productos, de considerable peso: nos referimos a la entrada por México de los cohetes y fuegos de artificio chinos como a las grandes cantidades de peines de madera y de marfil de mismo origen.

\section{FRAGMENTACIÓN Y DISPUTA CORPORATIVA POR LOS MERCADOS REGIONALES}

La aparición de puertos francos junto a la multiplicidad de circuitos que produce el libre comercio gestan una nueva radiografía espacial en toda Hispanoamérica: la fragmentación y regionalización de los mercados. Recordemos de manera muy breve - pues el pro- 
ceso ya fue advertido en anteriores capítulos- lo que sucedía antes de esas revolucionarias medidas mercantiles, cuando los mercados se encontraban articulados e integrados en la unidad virreinal, gracias a la capacidad estructurante de la Ciudad de México, monopolizadores del circulante amonedado. La Ciudad de México, mediante su consulado, controló con exclusividad las importaciones de bienes por Veracruz y Acapulco y fungió como centro de acopio y redistribución de bienes en el espacio virreinal. Los comerciantes regionales y locales contaron con muy poco margen de acción para participar en las ferias que se celebraban anualmente en Jalapa y en Acapulco. En gran medida, los agentes locales dependieron del suministro de mercancías extranjeras que les enviaban sus colegas desde la Ciudad de México para surtir sus mercados regionales. Situación similar ocurrió en el espacio del Perú. Los comerciantes de Lima controlaban las importaciones de mercancías extranjeras en el virreinato: ya fuera la procedente de México como la canalizada desde España vía Portobelo. Por ejemplo, hasta las primeras décadas del siglo XVIII los comerciantes de Chile o de Buenos Aires, sin desconocer las permisiones y el comercio ilegal que se practicaba durante el periodo colonial, estaban sujetos a las cargas de bienes que se enviaban desde el centro de Lima. ${ }^{233}$

Pues bien, las lógicas de intercambio y redistribución comienzan a mutar hacia la segunda mitad del siglo xviII. Las reformas borbónicas desmantelan o, en el mejor de los casos, readecuan las antiguas redes comerciales trazadas por Nueva España, debilitando el papel central de los comerciantes de la Ciudad de México. Los tradicionales mecanismos secundados en el control de la circulación de la plata dejan de funcionar y, como efecto de arrastre, los propios almaceneros novohispanos ven desvanecer su capacidad exclusiva en el manejo de las importaciones y la intervención-regulación que antes generaban en la oferta y demanda

${ }^{233}$ La afirmación no supone en lo absoluto desconocer el contrabando que se realizaba por Buenos Aires, práctica que beneficiaba a los comerciantes porteños en detrimento de los limeños. Sin embargo, nadie podría dudar que, hasta la mitad del siglo xVIII, los limeños tuvieron la capacidad para mantener su predominancia comercial por el virreinato. 
sobre el mercado. ${ }^{234}$ Así, sufren la pérdida de su lugar económico central, pues el comerciante regional interviene activamente en los intercambios sin su mediación, alentados por las perspectivas alentadoras del libre comercio. De esta manera, el Consulado de la Ciudad de México se debilita como agente conector entre las economías del Atlántico y del Pacífico. ${ }^{235}$

El libre comercio, junto con la apertura de nuevos puertos al tráfico externo, ofreció nuevas oportunidades para que los mercados internos regionales gozaran de un directo abastecimiento de bienes de primera mano por parte de los comerciantes extranjeros, sin tener que mediar con los almaceneros. Las movilidades de agentes hacia las tiendas, almacenes y depósitos capitalinos acaban por ser una práctica excepcional. Desde entonces, los mercaderes locales evitarán la práctica de "tierra adentro"; una movilidad que los obligaba a viajar desde el interior regional o de cada puerto periférico hacia el centro capitalino. Para disponer de mercancías europeas y del Asia, el agente regional, al tener disponibilidad de plata, comienza a surtirse desde los diferentes puertos autorizados. En 1792, la corporación mercantil capitalina brinda el escenario del virreinato:

el principal motivo del atraso del comercio de México consiste en que los mercaderes de tierra adentro no vienen ya a surtirse a esta Capital de lo que necesitan para el giro de sus comercios, como lo ejecutaban antes, sino que bajan en derechura a Veracruz para el efecto. Y este hecho se comprobará con evidencia si se cotejan las pocas Guías que se despachan en Veracruz con destino a esta capital, con las muchas que se dirigen en derechura a los lugares de la tierra adentro, de modo que en el día sólo vienen a México lo que necesita para su consumo, careciendo los comerciantes de

${ }^{234}$ La historiografía demuestra con creces que, al perder gran parte del poder mercantil, los integrantes del Consulado se replegaron hacia otras actividades económicas, como la agricultura, minería y finanzas. Pérez Herrero, 1983, pp. 97-182.

235 No fue casual que apenas comenzó el funcionamiento del libre comercio, los tradicionales consulados de la Ciudad de México y de Lima reclamen la restauración del antiguo sistema de monopolio que tanto los había beneficiado. 
la capital de las utilidades que antes le rendían los negocios de la tierra adentro. ${ }^{236}$

El movimiento "tierra adentro" no debe confundirse con las "internaciones" de los peninsulares. Si a partir de la segunda mitad del siglo XVIII, la circulación de agentes locales hacia la capital novohispana es infrecuente, las “internaciones" peninsulares son regulares. Con legislación a su favor, los comerciantes españoles que arriban con sus navíos de registro o con la propia flota de Veracruz se internan en los mercados regionales, rompiendo con el blindaje monopólico que hasta entonces imponían los grandes mercaderes de México. Ahora, el agente español establece negociación directa con el mercader local.

Ahora bien, decíamos en páginas previas que a partir de la segunda mitad del siglo XVIII las importaciones de bienes extranjeros a la Ciudad de México se limitaron al consumo interno de la plaza capitalina. El sobreabasto o el excedente de mercaderías en manos de los comerciantes capitalinos, principio rector del anterior modelo comercial, dejó de funcionar, pues los mercados regionales se vieron abastecidos gracias a las operaciones directas entre europeos y comerciantes locales generados desde los diferentes puertos autorizados del Atlántico y del Pacífico. De esta manera, los principales beneficiarios de las políticas borbónicas de libre comercio y posteriormente del liberalismo económico promovido por los ingleses y norteamericanos fueron, ante todo, las elites económicas locales y regionales de Hispanoamérica. Las internaciones españolas, que se veían institucionalizadas y protegidas por el reformismo borbónico, se vuelven un excelente antecedente para que, en las primeras décadas del siglo XIX, los comerciantes británicos y de otras naciones europeas se movilicen por cada plaza mercantil hispanoamericana. En efecto, las internaciones de los agentes extranjeros constituyen una práctica muy reiterada en las primeras décadas del siglo XIX. Gran parte 
de los mercaderes panameños que llegan a San Blas con textiles ingleses lograron internarse en la Ciudad de México para el intercambio. ${ }^{237}$

La fractura de grandes zonas económicas a partir de la segunda mitad del siglo XVIII anticipa la configuración de las nuevas demarcaciones espaciales político-administrativas. Piénsese en las intendencias y en perspectiva mayor en los Estados nacionales. El declive de la capacidad estructurante de la Ciudad de México y de Lima es resultado, en gran medida, de la liberalización comercial y de la apertura de puertos, medidas que tienden a la pérdida de los monopolios en la circulación de plata y bienes de los tradicionales consulados. ${ }^{238}$ El nuevo escenario económico que lleva a la pérdida de poder de la Ciudad de México y de Lima, como espacios estructurantes de grandes zonas, alentó el proceso de institucionalización de corporaciones mercantiles en cada una de las regiones. En este marco, deberíamos comprender la "catarata" de fundaciones consulares por Iberoamérica: Manila (1769), ${ }^{239}$ Caracas (1793), Guatemala (1793), Buenos Aires (1794), Montevideo (1794), La Habana (1794), Veracruz (1795), Santiago de Chile (1795), Guadalajara (1795), Cartagena de Indias (1784) y, más tarde, Puebla (1821). Para el caso de México, la fragmentación y autonomía económica regional se verá agudizada inmediatamente por la proliferación de nuevas casas de moneda para la acuñación del metal. ${ }^{240}$

237 "Dictámenes presentados al Tribunal de Cuentas, sobre que no se permitiese desembarcar en Tampico y puertos del Pacífico géneros excluidos de América”, en Ramírez Cabañas, 1944, pp. 23-44.

238 Para el caso de descenso de la importancia del eje el Callao-Lima y el ascenso de puertos y grupo de mercaderes regionales como es el caso de Arica, véase; Cheesman, 2011.

239 AGI, "Remisión del Reglamento a la ciudad y comercio de Manila", 1769, Filipinas, 36, 1. 18, fs. 95-96.

${ }^{240}$ Lejos nos encontramos de abordar el complejo fenómeno de acuñación de plata en México durante las primeras décadas del siglo XIX. La calidad y valor de las monedas de plata de México que se acuñan son notablemente diversas. Algunas con vida bastante breve y creadas en el contexto del conflicto de emancipación, nombremos algunas de ellas: Casa de Moneda de Chihuahua (1810), Durango (1810), Sombrerete 
La institucionalización de los intereses comerciales regionales manifiesta al menos tres fenómenos que se suscitan de manera simultánea: 1) el descenso de la Ciudad de México y de Lima como nodos que articulan grandes espacios económicos; 2) la concentración de capitales mercantiles en elites regionales en ascenso, apoyadas y en alianza con los mercaderes europeos (primero peninsulares y más tarde ingleses y estadounidenses); 3) los puertos consagrados como puerto franco o beneficiados con el libre comercio se convierten en puentes generadores de mercados locales y regionales. La fragmentación de los virreinatos con la consecuente división político-administrativa y la regionalización mercantil son relevantes para comprender aquellas titánicas navegaciones transcontinentales que desde finales del siglo xviII realizan los navíos ingleses y estadounidenses saliendo desde Europa o Boston, costeando cada puerto del Atlántico, cruzando el Cabo de Hornos y ascendiendo por cada surgidero del Pacífico sudamericano y, en menor medida, mexicano.

La política de reforma administrativa aplicada por el gobierno borbónico (como era el caso de las intendencias) y posteriormente las luchas y conflictos generados por las emancipaciones hispanoamericanas profundizaron los problemas para las conexiones de los mercados regionales, desvaneciendo la integración mercantil que caracterizó a la Nueva España y el Perú hasta la primera mitad del siglo xvirI. Ciertamente, en el segundo cuarto del siglo XIX las características económicas y sociales que fueron una regla general en la Nueva España borbónica se agudizaron en el México independiente, producto de las guerras de emancipación. Nos referimos a la desintegración del mercado, su autarquía y la contracción económica. ${ }^{241} \mathrm{El}$ sistema de transporte interno mexicano colapsó, lo cual aumentó sus costos y fragmentó aún más el mercado interno y aisló las di-

(1810), Zacatecas (1810), Guadalajara (1811), Guanajuato (1813), Oaxaca (1812), Valladolid-Michoacán (1813) y Real de Catorce en San Luis Potosí (1811).

241 Cárdenas, 2003, pp. 72-90. Hacia 1830 la situación de caos económico continúa. Véase al respecto Tutino, 2015, pp. 1119-1124. 
versas regiones del país. ${ }^{242}$ Cada mercado regional y local tendrá su respuesta de abasto desde los puertos autorizados. En perspectiva continental, digamos, por último, que los circuitos terrestres para las comunicaciones interoceánicas recién podrán materializarse con la construcción de la vía férrea de Panamá. Hasta entonces, el conducto del Cabo de Hornos será el punto dominante para las relaciones entre el Atlántico y el Pacífico.

Pues bien, en el contexto de fragmentación mercantil, alentado por el fenómeno de expansión de la economía atlántica sobre el Pacífico, se inscribe la infinidad de pleitos que aparecen entre viejas y flamantes corporaciones mercantiles. Nos concentraremos en el área de México y sobre los nuevos circuitos que surgen a raíz del libre comercio ya apuntados. En anotaciones previas sugerimos que el flamante enlace entre Panamá y el Pacífico mexicano le propina el último mazazo a la ruta transpacífica del galeón de Manila. Sugerimos también que el tradicional galeón de Acapulco sufre una aguda y prolongada crisis a partir de la segunda mitad del siglo XVIII, con las ya analizadas reformas borbónicas comerciales. En una tendencia decreciente del eje transpacífico, vemos que la disposición de los mercaderes de Guadalajara al tráfico de textiles británicos desde Panamá le termina por dar el último golpe al tradicional eje que México mantenía con el archipiélago oriental. Recordemos una simultaneidad histórica que parece no ser para nada casual: en el mismo instante en que la Corona española decreta la desaparición oficial del galeón de Manila (1815-1816), el enlace entre Panamá y Guadalajara vive su momento de apogeo, movilizando textiles británicos y plata mexicana. La simultaneidad histórica de ambos fenómenos con resultados opuestos resulta ser la mejor ilustración para el caso mexicano de la victoria de la economía atlántica sobre la del Pacífico.

Quizás sea el año 1810, el último intento desde Manila por recomponer su ruta directa con México. El apoderado del Tribunal insular, Alonso Terán, le solicita al virrey y al consulado de 
Guadalajara enviar tres expediciones mercantiles hacia el puerto de San Blas, para abastecer de textiles de China y de la India los mercados del occidente de la Nueva España. ${ }^{243}$ La iniciativa no tiene eco en los comerciantes de Guadalajara, quienes ya están preparando la entrada de la economía británica en la región. Los argumentos oficiales para desechar la propuesta manilense pasan por un discurso proteccionista; es decir, por los efectos perjudiciales que genera la importación de mercaderías del Oriente para el fomento y producción de bienes locales. A pesar de alzar la bandera en defensa de la producción local, el rechazo de Guadalajara debería comprenderse por intereses mercantiles bastante alejados del proteccionismo y muy cerca del libre comercio: nos referimos a la comentada importación indiscriminada de textiles británicos y asiáticos que en la segunda década del siglo XIX establece con Panamá. ${ }^{244}$

La elección de Guadalajara de promocionar el tráfico de textiles británicos con Panamá no sólo se confirma al recordar la incesante llegada de navíos panameños en los años posteriores a 1810, sino por un acontecimiento concreto que sucede en 1815 . En diciembre de ese año, llega a San Blas la nao Magallanes, uno de los últimos galeones de Manila. Simultáneamente, llega al puerto oficial de Guadalajara un buque de Panamá cargado de mercaderías británicas. Según el testimonio del apoderado de Manila, mientras que el navío transpacífico sufre un rígido control, hasta el punto de ser decomisada gran parte de su carga, el navío de Panamá es "recibido en clase de amigo".245 Lo que se trae de

243 "El apoderado general del Real Tribunal del Consulado de Manila, Francisco Alonso Terán, solicita permiso de armar dos a tres expediciones comerciales a la Nueva España”, AGNM, Instituciones Coloniales, Consulado, vol. 193, exp. 5, f. 121.

244 En palabras del propio apoderado de Manila, Terán: "la entrada frecuentísima de buques panameños que le llevan en tanta abundancia no sólo efectos extranjeros de algodón inglés sino de todas clases que perjudican la industria de aquel reino", "Representación del apoderado del Consulado de Manila quejándose del diferente trato que recibían las naos de Filipinas respecto de los barcos de Panamá", en Ramírez Cabañas, 1944, p. 171.

245 "Representación del apoderado del Consulado de Manila quejándose del diferente trato que recibían las naos de Filipinas respecto de los barcos de Panamá, en Ramírez Cabañas, 1944, p. 166. 
Panamá consiste en toda clase de algodón "con el nombre propio de sanas, garras, bayetas, sarampures [sic] y elefantes, permitidos exclusivamente al comercio de filipinas". ${ }^{246}$

La situación parece repetirse en los años siguientes: mientras en 1816 y 1817 hacen fila en el puerto de San Blas "barcos panameños, siempre con la misma libertad que los anteriores", al bergantín procedente de Manila, San Ruperto alias el Aventurero, vive una sanción a pesar de que "el cargamento ha sido el más miserable que han exportado los buques de Manila”. El trato desigual y prioridades de flujos se hace evidente en San Blas; la importación de textiles orientales y británicos desde Panamá se "había naturalizado" entre los comerciantes de Guadalajara hasta el punto de provocar no sólo el descenso del comercio directo entre México y China, sino también grandes pérdidas a la Real Compañía de Filipinas, que funciona, por entonces, gracias a los privilegios de exención de impuestos y de inyección de capitales otorgados por el poder peninsular. ${ }^{247}$

La posición política e institucional de Guadalajara no es lo único que paraliza definitivamente el eje transpacífico. Hay una simple lógica económica: en cada arribo del galeón de Manila y de cualquier otro navío que opera con el Oriente al mercado de Guadalajara se encuentra lo suficientemente abastecido que hace imposible sus intercambios. Los intentos desde Manila están condenados al fracaso, "pues lo que trae ya no se necesita”. La situación aduanera y fiscal también condiciona: mientras que los flujos de Panamá "no satisfacen derechos, reglamentados ni provinciales, sino la escasez que está a su arbitrio”, la vía transpacífica sufre un peso de $42 \%$ de cargas impositivas, y "a proporción de estos gravámenes regulan el valor de sus ventas". Para la corporación manilense, el escenario es realmente desalentador, hasta el

246 "Representación del apoderado del Consulado de Manila quejándose del diferente trato que recibían las naos de Filipinas respecto de los barcos de Panamá", en Ramírez Cabañas, pp. 166-167.

247 "Representación del apoderado del Consulado de Manila quejándose del diferente trato que recibían las naos de Filipinas respecto de los barcos de Panamá", en Ramírez Cabañas, 1944, p. 179. 
punto de preguntarse, no sin una cuota de ironía, ¿cómo podrá subsistir este desagraciado comercio? Evidentemente, la vida del circuito directo Manila-México tenía los días contados. ${ }^{248}$

Ahora bien, existe una segundo frente que desacredita la solicitud manilense de 1810: el Consulado de Veracruz. ${ }^{249}$ El rechazo no debe resultar extraño: gran beneficiario de las políticas de libre comercio, la corporación veracruzana cuestionará todo circuito comercial o centro de acopio que esté por fuera de su puerto e hinterland. El Consulado de Veracruz exige, siempre, que su puerta atlántica sea el exclusivo sitio de confluencia de todos los barcos procedentes de la Península. Critica el papel de Cuba como punto de almacenamiento oficial y clandestino, pues el arribo de barcos peninsulares como extranjeros le está generando una férrea competencia en su papel de redistribuidor de bienes europeos y orientales hacia los mercados hispanoamericanos. ${ }^{250}$ Idéntica denuncia realiza sobre Campeche, que comienza a dar respuestas a los mercados internos de México, sin pasar por el control de Veracruz. ${ }^{251} \mathrm{Al}$ disponer de otros centros de almacenamientos en el Caribe mexicano y centroamericano, los puertos vecinos como Tampico y Soto ejecutan un tráfico de alta mar que

248 "Representación del apoderado del Consulado de Manila quejándose del diferente trato que recibían las naos de Filipinas respecto de los barcos de Panamá", en Ramírez Cabañas, 1944, p. 170.

249 Capítulo III, documento III, del apéndice documental. AGNM, Instituciones coloniales, Consulado, vol. 193, exp. 5, fs. 121- 125.

250 Hacia 1814 el Consulado de Veracruz puntualiza: "que los efectos que recibe la isla de Cuba en barcos nacionales y extranjeros por el equivalente valor de los grandes productos de su agricultura exceden muchísimo de lo que pueden consumir las poblaciones de su comprensión, sin contar los que entran de contrabando, y procuran dar salida a los sobrantes para donde pueden, permutar por la plata y oro que necesitan para fomentar sus labores y lograr su engrandecimiento con detrimento de los intereses generales de la Nación", Expediente sobre los abusos que se cometen, 1814, AGI, Guadalajara, 532, f. 24.

251 “[...] que el ejemplo de La Habana excitó la codicia de la provincia de Mérida de Yucatán [...] con lo cual se prometen sin duda formar grandes almacenes en Campeche de géneros de Europa y extranjeros y surtir a Laguna, Tabasco, Veracruz y principalmente las costas laterales de este puerto, arruinando su tráfico de cabotaje y perjudicando al comercio y navegación directa de la metrópoli”, Expediente sobre los abusos que se cometen, 1814, AGI, Guadalajara, 532, f. 25. 
evita el registro por la aduana veracruzana. Los reclamos de Veracruz no paran ni tienen límite: recaen sobre los puertos vecinos y menores de Tampico y Soto que terminan por ejecutar un tráfico de alta mar con aquellos almacenes sin registrarse en Veracruz; ${ }^{252}$ asimismo, alza la voz sobre las mejoras de exenciones impositivas que tiene el comercio por el Pacífico hispanoamericano ${ }^{253} \mathrm{y}$, por último, desecha cualquier intento por recomponer el lazo transpacífico con China-Islas Filipinas.

La ruta directa de México con el Oriente no escapa al reclamo del Consulado de Veracruz, constituyendo, sólo en el caso específico y de coyuntura, una alianza con sus pares de Guadalajara. El propósito final es evidente: debilitar la relación directa con la economía oriental desde el Pacífico que representa, históricamente, los intereses del gremio mexicano. Precisemos el conflicto discursivo entre los frentes económicos del Pacífico y del Atlántico. En 1810, Manila busca que se reconozca el ingreso de textiles orientales a México por dos rutas atlánticas: los que proceden desde Panamá hacia San Blas y los que importa Veracruz, en gran medida con las naves que vienen desde la Península. Expone, a fin de cuentas, que ésas son las razones de anular la vía manilense. ${ }^{254}$ El Consulado de Veracruz responde inmediatamente: en el caso de que existan este tipo de importaciones "son de ningún momento, pequeñas, en comparación de las que se pretenden extraer del puerto de Manila”. En el caso que fuese cierto la circula-

252 " [...] que el comercio de cabotaje que se hace desde esta plaza para sus costas laterales hasta Tampico y el Soto de la Marina, se limite precisamente a los barcos playeros que se despachen por esta aduana nacional sin que por ninguna causa pretexto ni motivo entren ni descarguen en sus ríos y calas ningunas embarcaciones de alta mar", Expediente sobre los abusos que se cometen, 1814, AGI, Guadalajara, 532, f. 17.

253 " [...] derogar todas las exenciones concedidas al giro de la mar del Sur; igualando sus derechos con las que se pagan en Veracruz, pues sobre los inconvenientes y quebrantos que ofrece la concurrencia de los mismos efectos, cuando los unos están muy recargados y los otros aliviados", Expediente sobre los abusos que se cometen, 1814, AGI, Guadalajara, 532, f. 17.

254 "Representación del apoderado del Consulado de Manila quejándose del diferente trato que recibían las naos de Filipinas respecto de los barcos de Panamá, en Ramírez Cabañas, 1944, pp. 164-179. 
ción de bienes orientales por las rutas transatlánticas, el flujo termina por beneficiar al comercio de España "porque son mayores los derechos que se pagan [que] los que se reciben en el Veracruz de los que vienen por Acapulco". El segundo motivo veracruzano para rechazar la posición de Manila es similar al sostenido por Guadalajara: lo oriental perjudica tanto a las fábricas de España "como de las potencias amigas de Europa que se conduzcan de la Península", anulando cualquier posibilidad de desarrollo de las industrias locales. ${ }^{255}$ Tercero: el comercio transpacífico no protege a los negociantes de España. "Si se le concediese la solicitud a Manila, los ramos de comercio del Consulado de Veracruz, que tanta protección, socorros y de urgencias hace para mantener los ejércitos reales en el virreinato, dejarían de enviarse". ${ }^{256}$

La economía informal supera todo tipo de presiones que afloran en los pleitos institucionales. El argumento corporativo sobre los perjuicios que propicia la importación de bienes asiáticos al desarrollo de la industria local es, cuando menos, infundado. No hay duda de que las importaciones indiscriminadas de textiles británicos a los mercados de México desalientan cualquier proceso industrialista en los albores el siglo XIX. El consulado de la Ciudad de México escribe en 1815 sobre los nefastos efectos que producen, en la industria local y española, los ingresos de algodón inglés "de la misma India Oriental y manufacturado" que se hace desde Panamá o de los puertos atlánticos del virreinato como Tampico y Tuxpan. ${ }^{257}$ Con todo, estamos lejos de una razón "industrialista" si deseamos comprender la alianza entre Guadalajara y Veracruz contra la petición de Manila. Creemos que la

255 "La expedición anual del galeón de Acapulco que hace ingresar los lienzos de la India generan notables perjuicios a los cosecheros de algodón del reino tocantes a las telas ordinarias", AGNM, Instituciones coloniales, Consulado, vol. 193, exp. 5, f. 122.

256 AGNM, Instituciones coloniales, Consulado, vol. 193, exp. 5, fs. 121-125.

257 Dice la corporación: “¿Cuál sería la consecuencia de estos comercios? La disminución y paralización del tráfico e industria española [...] Los campos de Granada y Valencia se ven sustituidos por el algodón inglés de la misma India Oriental y manufacturado por su industria en tantas clases de tejidos, como muselinas, cotonías, panas, cocos, cambray”, AGNM, Real Hacienda, Archivo Histórico de Hacienda, vol. 8, exp. 5, f. 9. 
respuesta se encuentra en los cambios globales que se viven en la circulación mercantil, en la rotación hacia el atlántico del comercio asiático; esto es, la forma en que la economía atlántica busca apropiarse de un comercio que históricamente le perteneció al Pacífico indiano. Enseguida analizaremos en detalle este apasionante problema.

Los defensores de la atlantización del Pacífico no pueden evitar entrar en conflictos entre sí. La posición de "alianza" o de común acuerdo entre las corporaciones de Guadalajara y de Veracruz se quiebra al momento en que esta última cuestiona la conexión ilícita entre Panamá y San Blas. ${ }^{258}$ La movilización de textiles británicos desde Panamá hacia San Blas se impone como camino alternativo y ventajoso ante la vía terrestre y más costosa, en términos impositivos, que enlaza a Veracruz con Guadalajara. Precisemos: sabemos que al menos desde el último cuarto del siglo XIX, Veracruz se convierte en el principal punto importador de bienes no sólo hacia el mercado de la ciudad de Guadalajara, sino también hacia la región occidental más amplia y hacia el septentrión. Antonio Ibarra ha demostrado esa notable función de radiación de Veracruz hacia el distrito de Guadalajara con el rastreo de los registros de avería, aquel impuesto que grava los bienes en circulación (0.5\%) y que en 1795 es concedido al propio Consulado de Guadalajara como derecho de recaudación. Entre 1798 y 1818, señala Ibarra, entran por Veracruz más de 26 milones de pesos de mercancías con destino para el distrito de Guadalajara, cifra que representa $37.5 \%$ del total de su mercado consumidor. Por Acapulco tan sólo 237 mil pesos, mientras que por San Blas-Tepic un valor cercano a los 15 millones de pesos (21.7 por ciento). ${ }^{259}$

Estamos en presencia de contundentes cifras que confirman no sólo una fuerte dependencia de Guadalajara a las importacio-

258 "El $1^{\circ}$ de septiembre y el 30 de octubre de 1813 el Consulado de Veracruz expone los perjuicios de tolerar la puerta del istmo centroamericano", Ramírez Cabañas, 1944, pp. 77-78.

259 Ibarra, 1996, p. 23. 
nes que se hacen por Veracruz, sino también la insignificante participación de Acapulco. También es relevante que una gran parte de ese conjunto de mercancías que van desde Veracruz hacia la plaza de Guadalajara no pasan necesariamente por la mediación del comercio de la Ciudad de México, sino que transitan por circuitos alternativos; dato contundente de la pérdida de centralidad de la capital como redistribuidor regional y de la resistencia de Veracruz a reproducir la funcionalidad del Consulado de la Ciudad de México como entre y espacio de almacén redistributivo por todo el espacio novohispano.

Desde 1810, fecha en que comienza a adquirir fuerza el movimiento de textiles extranjeros y plata por la ruta Panamá-San Blas, el Consulado de Veracruz percibe una marcada disminución de los volúmenes y valores de mercancías por el puerto. A partir de 1812, la drástica caída del flujo de bienes desde Veracruz hacia Guadalajara se manifiesta en las cuentas de alcabala del puerto de Sotavento. En las cuentas se manifiesta que los efectos enviados al distrito de Guadalajara alcanzan los 3628429 pesos para el periodo 1812-1815. Si en los dos primeros años la cifra anual reportada superaba el millón de pesos, desde 1814 no llegaba al medio millón. ${ }^{260}$ Dato contundente que nos habla de una estrepitosa caída del flujo Veracruz-Guadalajara a raíz del auge del comercio de Panamá hacia San Blas.

En este sentido, Antonio Ibarra puntualiza que el descenso de Veracruz como centro de almacenamiento "es explicable por los bloqueos de rutas terrestres y el alto riesgo del tráfico interior" ${ }^{261}$ La hipótesis resulta correcta, pero valdría revisar que el descenso relativo de Veracruz, como centro de almacenamiento de bienes, también obedece a que en 1814 surge, en su máxima expresión, el flujo de importación de textiles británicos hacia San Blas, procedente de Panamá. No resulta casual que desde 1811 las cuentas de avería de las mercaderías que provienen de este puerto expresen un cambio en la composición de su canasta importadora: desde

260 Para mayor detalle véase Trejo Barajas, 2006b, p. 721.

261 Ibarra, 1996, p. 29. 
1798 hasta 1811 fueron efectos mayormente del país y entre 1811 y 1818 extranjeros, predominantemente no españoles. Así, en términos de valor, en ese amplio periodo de 20 años, la tendencia en el movimiento de bienes importados de efectos extranjeros a Guadalajara se revela inversamente proporcional al monto de los ingresos de mercaderías locales. Antes de 1810, San Blas recibía no más de $3 \%$ del valor de lo averiado para el distrito de Guadalajara, lo cual representa 70\% de lo introducido en la región (más de 11 millones de pesos entre 1814 y 1818).

La declinación del enlace comercial entre Guadalajara y el puerto de Veracruz a partir de la segunda década del siglo xix es definida por Ibarra como "el fin del control atlántico de ultramar" para la región de Guadalajara. ${ }^{262}$ Correcta definición, más si tomamos en cuenta: 1) la consolidación de San Blas como uno de los puertos principales del Pacífico e incluso, del conjunto del territorio mexicano, y 2) la representación de un caso que ilustra la emergencia de espacios económicos regionales con capacidad de autonomía y en competencia con relación a la Ciudad de México y Veracruz. Pero si retomamos nuestra principal hipótesis acerca del fenómeno de la atlantización del Pacífico en su larga duración, podríamos llegar a una lectura, sino opuesta, al menos alternativa.

El conflicto espacial y corporativo entre Panamá (Jamaica) y Veracruz, en cuanto al abastecimiento del eje triangular San Blas-Tepic-Guadalajara y del septentrión mexicano, podría conceptualizarse como un conflicto suscitado entre dos nodos económicos propiamente atlánticos, que compiten entre sí por el control del comercio y de las plazas de los mercados del Pacífico. En este sentido, más que el fin del control atlántico de ultramar, estaríamos en presencia de la consolidación y perduración de ese control, que se expresa en el conflicto entre dos centros de acopio y redistribución de bienes del Atlántico americano.

En este contexto histórico, cobran sentido los fenómenos ya enunciados en el presente capítulo: a) la crisis y abandono del tráfico del galeón de Manila; $b$ ) el descenso de los volúmenes de

262 Ibarra, 1996, p. 29. 
carga operados en los años finales de la flota de Veracruz, y c) la insignificante carga o prácticamente la ausencia de bienes asiáticos y europeos en los intercambios entre México y Sudamérica, con embarcaciones locales, desde la segunda mitad del siglo XVIII y las primeras décadas del xix. La apertura del Cabo de Hornos junto con la nueva orientación del eje panameño hacia el Pacífico mexicano representan un hito en la geopolítica hispanoamericana; fenómenos trascendentales que explican las nuevas dinámicas espaciales y el nuevo perfil occidental de la globalización mercantil. Estamos en presencia de un momento de inflexión en la historia económica de México y de Hispanoamérica: se desvanece el eje terrestre Veracruz-Ciudad de México-Acapulco como punto de confluencia americana entre las economías de China y de Europa, para reubicarse, en un contexto de fragmentación y regionalización económica, en una simple "periferia" del capitalismo mercantil europeo, una suerte de enclave económico del mundo noratlántico en plena expansión.

\section{Nuevo PATRÓN DE CONSUMO:}

POBLACIÓN, TEXTILES BRITÁNICOS Y CONSUMO MASIVO

Hemos visto que la expansión de la economía atlántica hacia los mercados del Pacífico de la América española es posible por una revolución comercial sustentada en decisiones de política económica reformistas y liberales. Pero la revolución parece no sólo superar el plano meramente de la circulación, sino que alcanza otras esferas de la economía. Desde la mitad del siglo XVIII, aparecen significativas transformaciones en los parámetros de consumo. Con el arribo sistemático de los buques españoles por el Cabo de Hornos y ante la multiplicidad de puertos francos por el Pacífico y por el Atlántico, se percibe que la variable consumidora adquiere un papel determinante en el plano comercial y aún productivo.

Recordemos lo visto en los capítulos I y II acerca del rol pasivo, casi de espectador, que tenían los sujetos al patrón del régi- 
men de flotas y galeones o al propio fenómeno de contrabando. Si bien la legislación buscaba lograr la frecuencia anual del régimen de monopolio, la realidad arrojaba una situación inversa; esto es, de una presencia espaciada y esporádica de las escuadras. Vale recordar la notoria espacialidad de la actividad de los galeones de Portobelo desde finales del siglo xvir. Entre 1690 y 1739 sólo partieron siete galeones desde España (1691, 1696, 1708, 1722, 1726, 1731 y 1739). El "desperfecto" temporal se traducía en un marcado escenario de desabastecimiento de mercancías por las plazas y mercados. Los más beneficiados de esta lógica de los intercambios eran los grandes mercaderes de la Ciudad de México y de Lima quienes, al disponer de grandes caudales, terminaron por acaparar y adquirir prácticamente la totalidad de los cargamentos llegados a las ferias. En un contexto de escasez y con el consiguiente aumento de los precios de los bienes ultramarinos, los comerciantes de las grandes urbes decidían el momento más conveniente para redistribuir las mercancías, disponibles en sus almacenes, hacia comerciantes regionales y sus respectivos mercados locales.

La historiografía es clara al respecto: hasta mediados del siglo XVIII, el tráfico ultramarino atlántico se encuentra regulado, no tanto por los cargadores españoles, sino "por la demanda mayorista" de los grandes comerciantes de la Ciudad de México y del Perú. Así debería comprenderse la nota de Antonio Bernal sobre "una demanda que impera sobre la oferta". Una demanda permanente por encima de la oferta constituye, en esta primera etapa, el medio seguro para maximizar precios y beneficios. En ello coinciden y muestran armonía la comunidad de mercaderes de la Península, de México y de Lima. ${ }^{263}$ Sobre el poder del gran mercader limeño que maneja a discreción el comercio, el consumo y el precio de los productos, el pensamiento del peruano José Baquíjano en su Disertación de 1791 es iluminador: "el buque de los galeones y naves era regulado en el pasado siglo para el consumo del Perú y Tierra Firme en 15 mil toneladas y en 1740 se 
hallaba reducido a 2 mil. La facilidad de estancar el comerciante poderoso un solo ramo lo hacía árbitro del precio, aumentando a un exceso que sólo se reglaba por la necesidad". ${ }^{264}$

Pocos o mínimos márgenes de intervención cabían al mercader regional y de poco caudal. Entendemos por "regla de la necesidad" el deber del consumidor de someterse al poder redistributivo de los agentes monopólicos. Resulta difícil encontrar en el esquema tradicional de intercambios, una iniciativa del consumidor; una elección sobre qué comprar y consumir. Pues bien, a partir de la segunda mitad del siglo XVIII se percibe un cambio en la relación oferta-demanda de mercancías, el surgimiento de un nuevo paradigma consumidor. La importancia del consumo obedece a la nueva forma de comercio que, a la vez, considera el incremento poblacional mostrado por las distintas urbes de la América española. Veamos brevemente el fenómeno demográfico.

Los índices de un crecimiento sostenido de la población son claros desde 1750, pero su salto significativo se concentra en las décadas finales del siglo XVIII y primeros años del siglo xIx. El cuadro II.4 que aparece antes del presente capítulo, referido a la población de las principales ciudades y puertos de Panamá, Perú, Santiago y Buenos Aires, y el siguiente (II.5), que atiende la Ciudad de México, confirman el sostenido ciclo secular de aumento de la población. ${ }^{265}$ Precisemos: Buenos Aires cuenta con 6000 habitantes hacia finales del siglo Xvir y en 1750 casi duplica la cifra (11600). En 1790 triplica su número de habitantes (32000) y en vísperas de la independencia se consagra definitivamente como una de las ciudades con mayor población de Hispanoamérica (45 000). Por su parte, la ciudad de Santiago de Chile registra 10000 habitantes hacia 1700. En momentos en que se decreta el libre comercio (1778), la población de la ciudad presenta un incremento de $150 \%$ (25000) y hacia 1800 cuenta con 36000 habitantes. La población de su puerto, Valparaíso, también se ve estimulada: ha-

264 Baquíjano, 1790, núm. 23, fs. 245-246.

265 Todos los datos apuntados en las próximas líneas se apoyan en la bibliografía de los cuadros II.4 y II.5. 
cia 1740 cuenta con un reducido número de 1750 residentes. En 1800 la población fija del puerto chileno alcanza más de los 5000 habitantes; acercándose al número que por esos años presenta una importante ciudad como Panamá (7244). Cobra especial relieve el considerable número de habitantes de ciudades que registran algunas de las ciudades del interior peruano, beneficiadas por las políticas borbónicas de apertura portuaria y comercio directo. Para 1790 Cuzco registra 31982 habitantes, mientras que Arequipa, que funge por esos tiempos como la segunda ciudad económica más importante del virreinato del Perú, alcanza los 23551 pobladores. Si bien con un ritmo menor, la población de la ciudad de Quito también crece: para 1778 se estima en 25000 habitantes, densidad similar a la de Buenos Aires y Santiago de Chile. Hay que tener en cuenta que la población española, en particular, asentada en estos centros aumenta de forma considerable. A grandes rasgos y como piso mínimo, $60 \%$ de las cifras ofrecidas son españoles, sin duda, el grupo social predominante.

Lima continúa siendo el más importante punto de concentración demográfica en Sudamérica hispana. Hacia los años finales del siglo XVII habitan 32724 personas, 54000 en 1740 y 52627 en 1790, de los cuales casi 20000 son españoles. La evolución demográfica de Lima reviste singularidad, pues si bien no decae, tampoco crece a ritmos acelerados como lo hacen las ciudades anteriormente mencionadas. Hay que recordar el terremoto de 1746 , donde fallecen, según registros oficiales, por lo menos 3000 personas. Incluso considerando la tragedia, podría sugerirse que el lento andar demográfico de Lima responde al profundo proceso de descentralización económica del virreinato. Por su parte, como puede verse en el cuadro II.5 que la población de la Ciudad de México crece sostenidamente durante el siglo XVIII y a un ritmo mucho mayor que las ciudades de Sudamérica. En 1689 cuenta con 57000 habitantes, en 1746 con 98000 y en 1777 con más de 112000 , cifra que representa el doble de la población de los años finales del siglo XVII. El crecimiento adquiere una escalada más veloz cuando nos asomamos al siglo XIX: de los 112000 habitantes que había hacia 1777, en 1820 se registran casi 180000 , un incre- 
mento de poco menos de $60 \%$ en 43 años. En 1790, sólo en la capital de la Nueva España viven más de 60000 habitantes españoles y europeos, de los más de 1050000 que habitan en todo el reino. ${ }^{266}$

Pues bien, ¿el crecimiento poblacional es una condición o, mejor dicho, contribuye a provocar un nuevo patrón de consumo en Hispanoamérica? Si esto fuera así, ¿qué impacto tendría en el comercio global y en la dinámica de la economía mundial? El cuadro III.12 que aparece a continuación nos obliga a ser prudentes con la conclusión. Allí se evidencia que hacia 1800 el total de la población hispanoamericana sólo representa $2 \%$ del total de habitantes de Asia; 7.5\% de Europa y 19.2\% de África. El total de habitantes registrados en ese año para la Nueva España representa 37.5\% del total de la población de Gran Bretaña; 20.6\% de Francia y 52\% de España. Si el porcentaje es de por sí bajo, las proporciones se hunden aún más al comparar con Perú o con la zona austral integrada por Chile, Buenos Aires, Montevideo y Paraguay. La población total del virreinato del Perú representa la mitad de los habitantes que hay en Brasil, un poco más de 10\% de la población española y $8 \%$ de la que existe en Gran Bretaña. Se podría continuar con más cálculos, pero todo conduce a una inicial conclusión: la mínima incidencia del mercado poblacional-consumidor de la América española en el mapa mundial del comercio y de la economía.

Ahora bien, el postulado inicial sobre el poco efecto del mercado consumidor hispanoamericano en la economía global vendría a relativizarse al considerar dos elementos. Aunque parezca evidente, digamos que el régimen de comercio tradicional monopólico no fue ideado para responder a grandes, numerosas ni dispersas plazas consumidoras. La fragmentación es un escenario incómodo para su actuación. Inclusive con los bajos números poblacionales en Hispanoamérica, comparados con otros espacios globales, el innegable proceso de crecimiento demográfico descentralizado hace incompetente e insuficiente cualquier sistema de monopolio exclusivo y centrífugo. El comercio directo, la 
promulgación de puertos francos y el renovado tráfico en navíos particulares y de registro constituyen, en definitiva, el nuevo plan oficial para responder a la emergencia de elites locales y de mercados regionales; con lo cual se reubica a la cultura consumidora en una nueva posición de primacía.

Cuadro III.12. Población de Hispanoamérica y espacios mundiales en 1800 (en millones)

\begin{tabular}{|c|c|c|c|}
\hline Asia & 625 & HISPANOAMÉRICA & 13.5 \\
\hline China & 330 & Nueva España & 6 \\
\hline EUROPA & 180 & $\begin{array}{l}\text { Las Antillas } \\
\text { y Venezuela }\end{array}$ & 0.8 \\
\hline Gran Bretaña & 16 & Centroamérica & 1.1 \\
\hline Francia & 29 & Los Andes & 3.5 \\
\hline España & 11.5 & Quiteños & 0.5 \\
\hline ÁFRICA & 70 & Neogranadinos & 1.1 \\
\hline $\begin{array}{l}\text { Estados Unidos y } \\
\text { Canadá }\end{array}$ & 6.5 & Peruanos & 1.3 \\
\hline \multirow[t]{2}{*}{ Brasil } & 2.5 & Altiplano & 0.6 \\
\hline & & Zona austral & 1.3 \\
\hline
\end{tabular}

Fuente: Caso Hispanoamericano: Sánchez Albornoz, 1994, pp. 37-38. China: Maddison, 1998, p. 24. Restantes casos: McEvedy y Jones, 1978.

Por otro lado, la variable demográfica o poblacional no es determinante, pues termina por minimizarse al notar que la América española sufre, como veremos más adelante, un escenario crítico en la producción obrajera textil. El proceso de desindustrialización hispanoamericana, con la clausura de los tradicionales pulmones obrajeros de México, de Quito o del Perú, magnifica el papel del mercado consumidor hispanoamericano, que coloca en una posición preeminente el comercio exterior de las economías europeas, en especial de Gran Bretaña y sus textiles. ${ }^{267}$ En 
síntesis, el crecimiento demográfico, la descentralización espacial y la crisis de la producción textil local configuran el escenario más ideal para que la cultura consumidora adquiera un protagonismo que hasta entonces no había tenido.

Puntualicemos lo que sucede en el caso del Pacífico sudamericano desde la segunda mitad del siglo XviII. En un muy sugerente ensayo sobre la evolución del comercio exterior en los mercados del Perú, Lamikiz nota el papel fundamental que alcanza la cultura del consumo para la dinámica del nuevo régimen de los navíos de registro que surcan el Cabo de Hornos. ${ }^{268} \mathrm{La}$ "regla de la necesidad" que había reinado comienza a desaparecer. La fuerza dominante que tenía la oferta, va retrocediendo poco a poco hasta verse reemplazada por la fuerza del consumo; es decir, a partir de las peticiones de bienes y gustos que exigen los consumidores. Las reglas del mercado, el juego de la oferta y demanda, se invierten. El consumidor adquiere, desde entonces, una gran cuota de decisión sobre qué productos deben ofrecer los comerciantes españoles, en un escenario mercantil donde prima la abundancia y la competencia. ${ }^{269}$ Los específicos pedidos de prendas y diseños de ropas que solicita el consumidor final a los centros de producción europea pasan a ser un medio de garantía del éxito. Hasta los propios peninsulares se sienten obligados a aprender y conocer el vocabulario específico de las prendas y ropas exigidas por el público. Ser un buen conocedor de lo que falta, de lo que se desea de la moda se vuelve una condición para el triunfo en el intercambio.

La importancia de la demanda en la práctica de intercambio genera que los mercaderes más importantes de Lima vean disminuir su predominio en el conjunto de las operaciones comerciales. El principio de competencia, política económica compatible con los decretos de "puerto franco" en el Pacífico meridional, permite que las elites mercantiles locales participen en el intercambio con compras directas, minoristas que requieren poco o mediano 
caudal. Los elevados cargamentos de buques españoles, que algunos investigadores ven operando por el Pacífico, ${ }^{270}$ no implican necesariamente ventas al mayoreo. El gran tonelaje se explica, como vimos, por las múltiples visitas en varios de los puertos del espacio, pero, sobre todo, porque dicha carga corresponde a un elevado número de pólizas; esto es, pequeñas porciones de mercancías que terminan en manos de muchos consignatarios y comerciantes. De ahí que los registros rara vez superan los 100000 pesos; muy lejos de los 500000 o 600000 pesos que se invertían en el anterior sistema de ultramar. ${ }^{271}$

La elección y el deseo de lo que se quiere usar y consumir resultan elementos fundamentales al momento de decidir qué productos deben cargarse en las fragatas. Los inventarios de mercancías o los informes de stock específicos, cortos, concretos y detallados se convierten en testimonios indispensables para garantizar el éxito de futuros retornos a las plazas del Pacífico. Muy lejos están esos nuevos informes con los que se hacían para la partida o la entrada de un galeón. Baquíjano lo explicita de manera clara:

Cuando en 1748 se permitió la navegación por el Cabo de Hornos en las embarcaciones llamadas de Registro: las relaciones con la Metrópoli se hicieron más directas y frecuentes [...] insensiblemente se extienden los usos, gustos y comodidades que podían recibirse de Europa. Los precios se moderan, logrando hoy vestirse una familia de los más exquisitos tejidos con la misma cantidad con que antes no alcanzaba a conseguirlo de las groseras manufacturas del país. ${ }^{272}$

La cita es esclarecedora en varios aspectos. En primer lugar, da cuenta de que el gusto, los usos y las necesidades constitu-

270 Alfonso Mola, 2014, pp. 538-539.

271 Lamikiz, 2007, pp. 239-240.

272 Baquíjano, 1790, núm. 23, f. 246. La cita fue publicada también en Lamikiz, 2007, p. 250. 
yen componentes decisivos de las mercaderías movilizadas. Hay que respetar la elección del público consumidor para el desenvolvimiento armónico del nuevo régimen de comercio. Pero la reflexión de Baquíjano a la vez invierte las causas y los efectos. La nueva modalidad de navíos particulares es responsable de los cambios en el universo consumidor. En otros términos, es la sistematicidad, la asiduidad y frecuencia y, sobre todo, la competencia entre navíos lo que provoca una renovada atención sobre lo que se quiere consumir. En segundo lugar, la cita de Baquíjano nos remite el acceso de textiles importados, en especial de los españoles y británicos, de sectores sociales que antes consumían telas y prendas locales, producidas por el obraje hispanoamericano. Estaríamos en presencia de un proceso de "democratización" del consumo de textiles extranjero, cuyos precios compiten exitosamente con el sector textil local.

En efecto, en la Gobernación de Tucumán se inicia durante la segunda mitad del siglo xviII un proceso de popularización del consumo de nuevas telas inglesas y del Oriente que, como una suerte de invasión, comprometen la producción local manufacturera. La tradicional indumentaria de los mestizos, compuesta de ropa de la tierra, lienzos, cordellate y bayetas, se reemplaza por los lienzos, bretañas, angaripolas y otros textiles europeos y orientales que presentan precios accesibles. El consumo del algodón inglés rompía los cánones de la sociedad jerárquica y, en un contexto de libre comercio, se propaga sobre el mercado popular masivo. ${ }^{273}$ Para el caso del mercado rioplatense, en pleno ascenso mercantil durante la segunda parte del siglo XVIII, los estudios de Jumar ponen de manifiesto que el contrabando y comercio por navíos de registro por Buenos Aires y puertos adyacentes de la costa atlántica importan una gran porción de bretañas y telas francesas con precios realmente accesibles para la mayoría de la sociedad rioplatense. ${ }^{274}$

Quito no es la excepción. Los textiles británicos inundan y presionan a la baja la histórica producción de paños, bayetas

273 Arcondo, 1992, pp. 103-227; Assadourian, 1982, pp. 191-207.

274 Jumar, 2002, t. I, pp. 147-155. 
y lienzos locales. Al rastrear las causas de esta decadencia en la industria local, el presidente de la Real Audiencia de Quito, el barón Carondelet no duda en responsabilizar al textil británico: "ocasionada por la grande introducción de los paños de segunda, lienzos y demás ropas en estos reinos por el Cabo de Hornos, con los cuales no pueden competir sus géneros en los mercados de Lima”. ${ }^{275}$ La cita no puede ser más adecuada para nuestro argumento. El corredor austral convierte a Quito en un terreno invadido por el textil británico de segunda calidad. Barato y accesible a un amplio público, desalienta y pone en crisis el sector obrajero, de telares y de otros ramos de la economía, como ollerías y sombrererías. Quito, histórica plaza manufacturera de Hispanoamérica padece así una crisis de su aparato productivo local.

Valdría superar el caso del Pacífico sudamericano y ampliar la mirada al espacio hispanoamericano. El cambio de la canasta exportadora peninsular, puesta en marcha con los navíos de registro desde la segunda mitad del siglo XVIII, es sintomática sobre la ampliación del arco consumidor de textiles europeos, mayormente ingleses. Durante el mandato del marqués de Ensenada (1748-1753), años de paz y sin conflictos militares por los océanos, los buques y las fragatas transportan hacia América un porcentaje casi insignificante de los tradicionales textiles suntuosos; de hierro, y de los bienes derivados como vino, aceite y aguardiente. Estas mercancías constituían el cargamento principal de las flotas de Veracruz y de los galeones de Portobelo. Comenzada la segunda parte del siglo, los artículos históricos llevados hacia México representan 6\% del valor total exportado por España. Se ven desplazados por las manufacturas, en su gran parte "ropas" o textiles de origen extranjero, que se convierten en el artículo dominante de la exportación española. ${ }^{276}$ Los datos ofrecidos por

275 Citado en Miño Grijalva, 1984, p. 76.

276 Supera aquí abordar la incapacidad que muestra la industria manufacturera española por abastecer con sus productos los mercados hispanoamericanos. Estamos ante uno de los fundamentos que permiten hablar del fracaso borbónico y pensar en el libre comercio como motor del crecimiento económico y la industrialización nacional. Véase al respecto Delgado Rivas, 1982, pp. 99-169. 
Bernal son elocuentes. En ese periodo y para la Nueva España, el textil europeo alcanza $68 \%$ del total de las importaciones de los navíos españoles, en el Perú nada menos que 94\%, y 96\% para Buenos Aires. ${ }^{277}$ A partir del reglamento de Libre comercio de 1778, la exportación de telas españolas hacia América se minimiza aún más ante el dominio del textil británico. Antes de esa fecha el textil gallego constituía $50.2 \%$, mientras que para el periodo 1778-1818 sólo llega a 26.8\%. Para el mismo periodo, las reexportaciones españolas de textil europeo con destino a los diferentes puertos hispanoamericanos pasan de 49.8 a 73.2 por ciento. El cuadro gallego es extensible a otros puertos españoles autorizados. Al menos, hasta los últimos días del imperio, casi la mitad de lo exportado desde España proviene de los centros industriales europeos, mayormente británicos. ${ }^{278} \mathrm{La}$ ventaja de las telas británicas sobre otras de elaboración europea no sólo se encuentra en los costos de producción, sino también en la permanente innovación y disposición británica de perfeccionar géneros muy demandados por los consumidores americanos. Si la cuestión es actualizarse en la moda, los de origen británico toman la delantera. De hecho, los españoles recurren a copiar y a imitar los tejidos ingleses para evitar su quiebra. ${ }^{279}$

Los testimonios cualitativos son igual de contundentes que los cuantitativos. En 1791, el informe enviado al virrey Revillagigedo, cuyo responsable es Ángel Puyade, uno de los más importantes comerciantes de la Ciudad de México, pone al descubierto las limitaciones de la industria española para competir con Gran Bretaña. La clave está en que Inglaterra ofrece a México paños “de segunda" y de "tercera clase" que es el "miserable consumo de los pobres". España no cuenta con nada equivalente a esa clase de tejidos ordinarios. ${ }^{280}$ Como enseguida veremos, el juicio de Puyade toca el centro del problema: ese comercio británico beneficiado

277 Bernal, 1992, p. 352.

278 Bernal, 1992, p. 414.

279 Bernal, 1992, p. 414.

280 "Testimonio del expediente formado sobre averiguar si hay o no decadencia en el comercio” (1791), AGI, México, 1554, fs. 94-102. 
por unos costos productivos menores, no sólo compromete a la manufactura española sino al propio sector manufacturero hispanoamericano, sumergiéndolo en una profunda crisis. ${ }^{281}$

No se puede pasar por alto la íntima relación que existe entre el fenómeno de expansión del comercio libre, la importación de algodón británico y la confirmada crisis obrajera hispanoamericana durante el siglo XVIII. Un especialista en la materia como Miño Grijalva advierte, ante todo, que el apogeo de la industria obrajera en Hispanoamérica se comprime, para el caso de la Nueva España, entre 1570-1630 y para la real Audiencia de Quito, a 1590-1620. La conclusión nos remite innegablemente a lo visto en el capítulo I cuando los textiles producidos en Quito, Puebla y de la Ciudad de México fluían por circuitos interregionales y marítimos, aun de larga distancia, recorriendo los mercados de ese Pacífico indiano independiente e influyente. Con el proceso de atlantización del Pacífico del siglo XVIII el panorama cambia radicalmente. Si bien es difícil simplificar con la idea "apocalíptica" del sector manufacturero hispanoamericano, la tendencia decreciente y generalizable no puede soslayarse. En efecto, hay casos que muestran cierto desarrollo. Para el caso de la Nueva España, Miño insiste en la estabilidad de los obrajes de Querétaro y de Acámbaro. Aunque bien nos recuerda Salvucci, ambos centros "sufrieron mucho por la introducción de paño inglés de segunda" que sustituye el consumo del paño local. ${ }^{282}$ Para el área andina, Miño puntualiza señales de expansión de los obrajes de tejidos ordinarios de lana en las áreas de Cuzco (17151770) y de Huamanga (1660-1760). ${ }^{283}$ Pero no hay que perder de vista el evidente proceso de caída de los tradicionales pulmones

281 Salvucci, 1992, pp. 234-241; Miño Grijalva, 2016, pp. 361-381.

282 El precio del textil de "segunda" inglés en México habría partido de 21 reales por vara en 1778 a 10 reales por vara en 1818. El obraje de Querétaro no podía competir con esos precios pues no podía ajustar su textil por menos de 18 reales por vara. Salvucci, 1992, p. 235.

${ }^{283}$ Los tejidos de lana producidos en Hispanoamérica parecen tener mejor fortuna que los tejidos locales de algodón que no tienen elementos para competir con el algodón europeo. Miño Grijalva, 2016, pp. 365-370. 
industriales de Texcoco, Puebla, San Miguel el Grande y, para la región andina, el emblemático caso de Quito, donde el valor de la industria se redujo en $75 \%$ de 1700 a 1800 . Su crisis deriva en formas más precarias de producción textil conocidas como el trabajo a domicilio (el trapiche en México y los chorillos en los Andes). ${ }^{284}$

La caída de la producción manufacturera durante el siglo XVIII puede que sea paulatina, pero resulta innegable. La importación de textiles europeos y la apertura de nuevas rutas comerciales se convierte en un factor central para que ocurra. La exportación de la plata hispanoamericana que sale como pago de las importaciones del textil británico durante la segunda parte del siglo xviII logra alterar el histórico bombeo de plata que financiaba el desarrollo de los obrajes. Es cierto que el sector logra breves respiros en coyunturas bélicas y con el bloqueo los circuitos comerciales transatlánticos. ${ }^{285}$ Pero son sólo "tanques de oxígeno" que se ago$\tan$ muy pronto.

En suma, existen señales contundentes para pensar que desde 1740, el comercio por la América meridional vive una revolución del consumo que en Europa se inicia en el siglo xvir. La construcción de una sociedad consumidora va tomando forma con los cambios en el comercio de larga distancia implantados por el reformismo borbónico y previo al proceso de industrialización británica. De hecho, las transformaciones en materia de comercio y consumo son las condiciones para el acelerado ingreso de la revolución industrial británica en esta parte del globo. Los efectos del "libre comercio" implementado por los Borbones fue el primer golpe para el descenso de la producción local hispanoamericana. La crisis y el debilitamiento de la producción local son factores que propician el ingreso a menor costo y sin resistencia del textil inglés. ${ }^{286}$

284 Miño Grijalva, 2016, pp. 366-367.

285 Véase, al respecto, apéndice documental, capítulo III, documento II: "México. Sobre las manufacturas de seda, algodón y lana que se fabrican en Nueva España”, 1800.

286 Fenómeno similar podría pensarse desde la perspectiva del consumo. Como variable macroeconómica, el consumo es visto por la reciente historiografía europea 
Lo que ocurre en las primeras décadas del siglo XIX profundiza el proceso que se viene gestando desde la segunda mitad del siglo XVIII. Ciertamente los efectos de las luchas por la independencia que recorren por todo el espacio hispanoamericano a partir de 1810 son claramente determinantes para el definitivo hundimiento de la industria textil, hasta el punto en que los especialistas en la materia nos hablan del "fin de los obrajes"287 o de un parteaguas de la historia manufacturera hispanoamericana. Atisbos de resurgimiento, pero con un marcado perfil artesanal de textiles domésticos y no industrial, aparecerán hacia la cuarta década del siglo Xıx. ${ }^{288}$

Lo importante es que se intensifica y se consolida por la América hispánica la "democratización" del consumo popular del textil inglés. En su clásico libro, Empire of Cotton, Beckert muestra que en esas iniciales décadas la importación del algodón inglés cobra un salto significativo. ${ }^{289}$ Lo económico va de la mano con la política al percibir una fuerte presencia de ideas proteccionistas en contra del libre comercio para salvar la industria local. Vale un repaso esquemático de lo que ocurre por cada espacio. Comencemos por México. Hacia 1807, el valor de los tejidos europeos, casi en su totalidad ingleses, importados por Veracruz alcanzan la extraordinaria suma de 10 millones de pesos, cuando dos años antes era de apenas un millón. ${ }^{290}$ Por su parte, hacia 1803 la provincia de Guadalajara comunica la ausencia absoluta de fábricas textiles que den respuestas al consumo local. Expresa que "no hay un obraje o fábrica formal en toda la Provincia, y por su falta vienen aún de México, Querétaro y otros pueblos todos los paños y bayetas ordinarias que se

como la chispa que encendió los motores para la constitución de la sociedad industrial del siglo xviII. De Vries, 2009; Berg, 2005.

287 Salvucci, 1992, pp. 238-241.

288 Miño Grijalva, 2016, pp. 385-389.

289 Beckert, 2014.

290 Un caso representativo de la composición de los cargamentos de estos barcos es el del navío Mensajero. Por esos años descarga la mercadería en el puerto de Veracruz. Su valor total es de 1200000 reales y el grueso se compone de bretañas, zarazas, medias de algodón, muselinas y panas de algodón, todo inglés, pero también textiles de China. Marichal, 1999, pp. 206-207. 
consumen". ${ }^{291}$ No resultaría casual pensar que el textil británico que vimos ingresar desde Panamá y Jamaica hacia el mercado de Guadalajara unos años después a esta insatisfecha demanda que presenta la región. Hacia 1811, las casas inglesas ubicadas en Jamaica introducen por Panamá nada menos que 45 millones de pesos en textiles manufacturados, porque ya son productos "acostumbrados a su consumo". ${ }^{292}$ En 1818, Basilio de Arrillaga, asesor y secretario del consulado de la Ciudad de México, señala que una vara de paño inglés cuesta en Veracruz diez reales, por lo que se pregunta: “¿cómo han de subsistir las fábricas de Querétaro, de México, de Guadalajara y de otros lugares valiendo los similares que allí se producen 18 ?" ${ }^{293}$ No hay duda de que el movimiento insurgente de 1810 profundiza el descalabro manufacturero que se venía sufriendo por el espacio. El debate entre industria versus libre comercio en México es un fenómeno que ocurre antes de la independencia, aunque las discusiones tomaron mayor relieve hacia $1830 .{ }^{294}$ Las fábricas de Querétaro, que como vimos lograron sobrevivir a las políticas borbónicas, tienen un diagnóstico desastroso en tiempos de la revolución insurgente. Antes de la segunda década del siglo, venían operando en Querétaro 19 obrajes con 291 telares. Para diciembre de 1811, sólo funcionan ocho unidades productivas y en 1812 quedan cuatro, que desaparecen al poco tiempo. La parálisis de Querétaro no fue breve, se extendió hasta entrada la década de $1830 .{ }^{295} \mathrm{La}$ ciudad de Puebla, histórico centro manufacturero, termina por ingresar al desolador panorama de las demás provincias. Hacia 1835, un vecino de Puebla, Javier de la Peña, lo sintetiza de manera elocuente.

291 Relaciones estadísticas, 1944, vol. III, p. 110.

292 Correo de Londres, septiembre de 1817, Florescano y Castillo, 1975, pp. 250 251 y 270.

293 De Arrillaga, “Informe que dieron los señores José Ruiz de la Barcena; José María de Echabe y Gregorio Sáenz de Sicilia, prior y cónsules del Real Tribunal del Consulado de México, a Juan Ruiz de Apodaca, virrey, gobernador y capitán general de Nueva España”, 1818, Florescano y Castillo, 1975, pp. 295-296.

294 Véase al respecto Tutino, 2015, pp. 1119-1192.

295 Salvucci, 1992, pp. 238-239. 
Las ventajas son todas para la Gran Bretaña, y ningunas o casi imperceptibles para México. Londres poblado, industrioso y con una marina la primera de Europa; precisamente ha de tenerlo bajo su tutela, especialmente cuando le trae manufacturados lienzos ordinarios de algodón, que con tanta abundancia producen nuestras costas y han sido y pueden ser ocupación de infinitos brazos; de esta funesta introducción se ha originado la destrucción completa de esta ciudad, antes opulenta y floreciente como tengo probado, pues anualmente entraban cuatro o seis millones de pesos, valor de toda clase de tejidos de lana y algodón, sombreros, etc. Por lo que, en esta población hoy tan pobre y falta de recursos, rebosaban por todas partes la abundancia, el gozo y el bienestar, no bajando sus habitantes de setenta a ochenta mil; hoy no tiene la mitad indudablemente y todos sus barrios se arruinan de día en día y casi tocan el de su exterminio. ${ }^{296}$

En Centroamérica y Sudamérica el algodón inglés se consolida como el principal rubro de la canasta de importación con la correspondiente exportación de metálico. ${ }^{297}$ En su meticulosa investigación, Manuel Llorca-Jaña comunica que si bien el textil británico ocupa un lugar importante en los mercados hispanoamericanos del periodo preindependiente, su consumo "explota" hacia el segundo cuarto del siglo XIX. ${ }^{298}$

En 1812, la editorial del periódico El Peruano, apunta que el comercio y el consumo de algodón inglés son las razones del estancamiento de la producción textil local. Las consecuencias eran evidentes:

50 mil familias que antes se ocupaban y mantenían en manufacturar tocuyos, bayetas de tierra, bayetones y otras telas ordinarias de

296 Apreciación de Javier de la Peña, vecino de Puebla, en 1835, Villa Sánchez, [1746] 1835, pp. 112-113.

297 Irigoin y Schmit, 2003, pp. 20-22.

298 Llorca-Jaña, 2012, pp. 3-47. No nos parece para nada curioso que Llorca brinde una idéntica composición de textiles consumidos en Sudamérica que al ofrecido aquí para el caso de Guadalajara: calicós, bretañas, todo tipo de paños, etcétera. 
gran consumo, tanto en el virreinato como fuera de él, se vean hoy reducidas a la indigencia y a la desesperación [...] al país aniquilado del todo, sin que experimente otra ventaja que la aparente suma baratura y abundancia de los géneros de algodón ingleses. ${ }^{299}$

Para el caso de Buenos Aires, señalemos lo dicho por Halperin Donghi sobre los productos británicos importados de un puerto rioplatense que no sólo funge como un mercado consumidor independiente, sino que también se consolida como principal punto redistribuidor de textiles británicos hacia el interior de lo que será Argentina. Entre 1814 y 1819, los porcentajes anuales de textiles británicos al puerto oscilan entre $60.3 \%$ y $42.3 \%$ (único año en que se ubica por debajo de 50\%). ${ }^{300}$ Por medio de un análisis cuantitativo, Assadourian y Palomeque demuestran que en las primeras tres décadas del siglo xix los textiles de algodón, lana y lino inglés importados a la ciudad de Córdoba desde el puerto de Buenos Aires rondan entre 70\% y $85 \%$ del total de la canasta importadora de productos ultramarinos. De esa manera, apenas iniciado el nuevo siglo los tejidos británicos corrompen cualquier intento de ingreso de los tejidos de la localidad de Cochabamba, ciudad de la actual Bolivia. ${ }^{301}$ Un proceso similar vive Chile. Aunque no disponemos de una cuantificación tan precisa, el trabajo de Llorca-Jaña muestra sólidas pruebas de que el algodón británico (particularmente las muselinas y el calicó) es, por lejos, el rubro dominante de la canasta de importación destinada a la población popular de Chile en las primeras décadas del siglo XIX. ${ }^{302}$

Las reflexiones sobre el cambio en el patrón de consumo nos permiten presentar una interpretación en la larga duración. Para ello, es necesario retomar lo planteado en los capítulos I y II. Sin duda, la propuesta tiene mucho que afinar y no poco qué corregir,

299 Florescano y Castillo, 1975, p. 294.

300 Halperin Donghi, 2005, pp. 91 y 127-128.

301 Assadourian y Palomeque, 2003, pp. 177-178 y 209-210.

302 Llorca-Jaña, 2012, pp. 96-114. Hacia la cuarta década del siglo, las importaciones de textiles británicos representaban $40 \%$ de las importaciones para el consumo nacional de Chile. 
pero vale la comunicación como primera y esquemática aproximación para su discusión. El "comercio libre" con la correspondiente introducción del algodón de la India británica o propiamente de Gran Bretaña quiebra la matriz consumidora que desde el siglo XVI había regido en la sociedad hispanoamericana. El consumo hispanoamericano entre 1580 y 1740 , etapa histórica donde el Atlántico se ve pacificado, parece regirse por el principio de complementariedad en dos particulares niveles. Por un lado, como lo advirtió en su momento Assadourian, la política peninsular combatió toda producción local de textiles suntuarios que comprometiera el abastecimiento transatlántico español de consumo de elite. Vimos en el capítulo I el caso de la restricción peninsular que pesó sobre la producción y consumo de vino peruano para garantizar el despacho y venta de bebida etílica española. También mencionamos en el capítulo II la decisión peninsular por arrasar las plantaciones de moreras en México, dedicadas a la cría de gusano de seda. Más evidente aún es la prohibición para la importación de seda asiática al Perú, que obliga a su población a consumir la fina seda elaborada en las tierras de Granada. Pero la política económica se mostraba tolerante con la producción local de textiles ordinarios para el consumo amplio. Recordemos el caso de Quito, con sus bolsones manufactureros en la elaboración de paño o la tolerancia y aún la promoción de los centros obrajeros de Puebla para la confección de paños y algodones novohispanos. Éste sería el primer principio de complementariedad consumidora que caracteriza a la temprana sociedad de Antiguo Régimen.

Ahora bien, identificamos un segundo nivel de complementariedad en el consumo social de carácter más amplio y exclusivamente sobre bienes internacionales. Nos referimos a lo que se importa y se consume por los mercados de Hispanoamérica desde el frente pacífico-chino y desde el atlántico-europeo. Sin desacreditar el foco de conflicto y la competencia suscitados en torno al reducido grupo de elite, sugerimos dos perfiles consumidores disímiles entre el eje transpacífico y el transatlántico, que propician el desarrollo de un comercio exterior novohispano con relativa armonía. En los anteriores capítulos tuvimos la oportunidad 
de relativizar aquella premisa historiográfica que apunta a una permanente rivalidad, una férrea competencia entre el galeón de Manila y la flota de Veracruz por cuál de los ejes logra imponer sus productos en el mercado de elite de Nueva España. ${ }^{303}$

Sugerimos que la complementariedad, antes que la competencia, fue la clave para que ambas vías de importación gozaran de un notable desenvolvimiento. Detectamos que la mayor parte del cargamento que ingresaba por Acapulco, en particular el textil bruto o semielaborado, se destinó a un consumo social amplio y popular. Por el contrario, los productos europeos que llegaban a México con las flotas de Veracruz, con mayor costo, de calidad con valor agregado y exquisitos, se destinaron a la elite, a los estratos más pudientes y reconocidos de la población novohispana.

Una de las evidencias más contundentes del modus operandi de la complementariedad lo veíamos en la composición equitativa de textiles de China y efectos de Castilla u otros europeos en los navíos peruanos procedentes de México. Una considerable porción de los textiles chinos que componen la carga respondían o bien a una demanda popular o para darles un valor agregado, "industrial", ya sea en los centros manufactureros novohispanos o, en menor grado, en los obrajes del Perú. Los segundos, más elaborados y terminados, fueron los solicitados por los sectores privilegiados. ${ }^{304}$ Las partidas de tela semielaborada, de tejidos de algodón y de sedas producidos en Filipinas, China o, más tarde, en la India constituyeron, junto con la vajilla y los textiles de producción local americanos (los llamados efectos de la tierra), en los artículos estimados por un amplio sector de la sociedad hispanoamericana. Sostenemos que una importante porción de los artículos importados en Hispanoamérica con el galeón de Manila acompañó a los efectos de la tierra en su propósito de responder a un universo consumidor amplio y diversificado, incluso a los grupos sociales medios y pobres. 


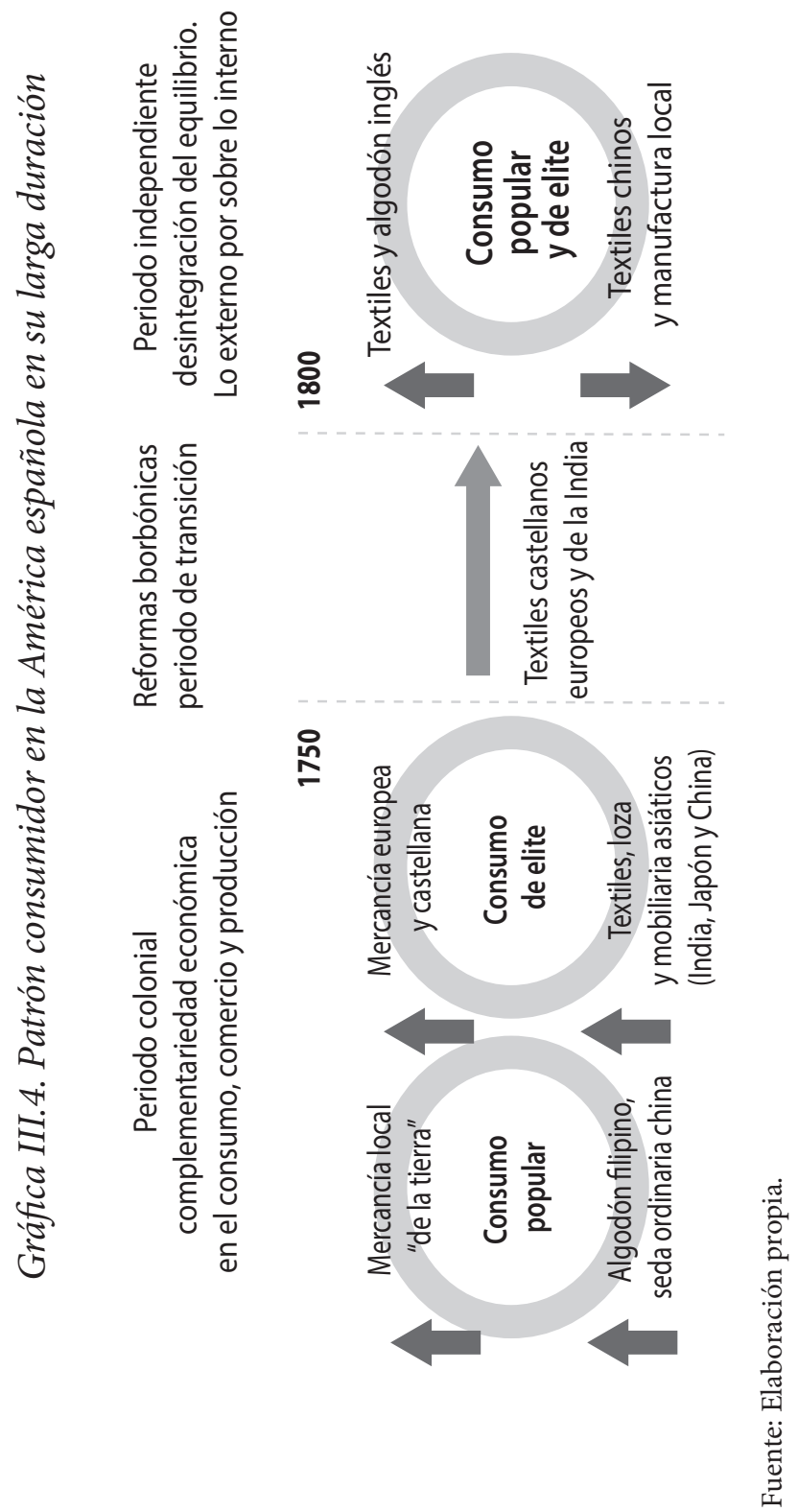


Ahora bien, los dos componentes que daban sentido al principio de complementariedad inician su descomposición hacia 1750, con el proceso de las Reformas borbónicas. El retroceso de China en la economía global, visibilizada en el caso Hispanoamericano con la notoria disminución en la importación de seda china por el eje transpacífico del galeón de Manila, no es más que el reflejo de la nueva fase global unipolar donde la economía atlántica absorbe al universo mercantil del Pacífico. Desde entonces, la Ciudad de México, que antes se veía beneficiada como centro de almacenamiento de los textiles chinos y europeos, ve perder su centralidad ante el avance de la economía británica y sus telas de algodón, para el consumo amplio en el escenario de descentralización y fragmentación de los mercados. El nuevo periodo, caracterizado como la etapa donde el Pacífico se ve atlantizado, es la victoria de los textiles británicos de algodón en los mercados amplios y populares de Hispanoamérica.

La seda china ordinaria que llegaba a Hispanoamérica desde China vía Manila, una de las columnas del eje transpacífico, sufre un severísimo retroceso en los mercados consumidores de Hispanoamérica. Vale recordar aquí, la mención de Lucas Alamán hacia mediados del siglo XIX, donde las telas del Oriente eran ya un recuerdo en el mercado mexicano a raíz de la baratura y la calidad para diferentes sectores sociales de los tejidos británicos y europeos importados en el espacio ${ }^{305}$ De ser, junto con la plata, uno de los productos que vitalizaba al galeón de Manila, la seda china termina por representar un rubro anecdótico, insignificante y marginal en los cargamentos de los navíos de finales del siglo xviII y principios del siglo xIX. Aun con el fenómeno de la atlantización del comercio oriental, la seda de China no pasa de ser un rubro excepcional en el tráfico ultramarino. Desde la segunda mitad del siglo XviII el textil procedente de Asia será el algodón de la India, cuya circulación será controlada por los británicos por los flujos transatlánticos.

305 "la perfección, buen gusto y baratura de las manufacturas inglesas y francesas, ha hecho que se estimen menos las de China y de la India que apenas son ya conocidas en los mercados mexicanos", Alamán, [1850] 1985, vol. III, p. 38. 
La canasta amplia y variada de textiles británicos, caros, baratos, de diferentes calidades y precios no hace más que propiciar la declinación de una producción local hispanoamericana cuya tarea era responder el consumo amplio y popular. La industria local sólo toma respiro en los momentos excepcionales de conflicto bélico y de bloqueos en el atlántico (1790-1810). Sólo allí logran un leve y coyuntural resurgimiento. El obraje hispanoamericano, que durante el largo ciclo 1530-1750 fue relativamente tolerado y hasta en ciertos momentos promocionado por la Corona española, ingresa en la segunda mitad del siglo XviII en un proceso prolongado de crisis. Sólo el sector artesanal y doméstico tendrá posibilidades de sobrevivir al responder a mercados locales y reducidos. 


\title{
APÉNDICE DOCUMENTAL
}

\section{Capítulo I}

\begin{abstract}
I
"Carta de Martín Ignacio de Loyola, obispo del Río de la Plata, al presidente del Consejo de Indias, adjuntándole memorial sobre Filipinas", 1602, en Documentos sobre el comercio de Filipinas, AGI, Filipinas, 35, núm. 47, fs. 823-825.
\end{abstract}

Para que las Indias no se pierdan conviene estén pendientes y subordinadas a España y haya grande correspondencia de la una a otra parte. Esta subordinación y correspondencia consiste en dos cosas. La primera en lo que toca al gobierno político y espiritual y temporal; y así conviene que los virreyes, gobernadores y obispos y vicarios y comisarios generales vayan de España. Verdad es que los que de aquí han ido y allá dan buena cuenta conviene sean mejorados, pues ellos han trabajado y merecido este tal favor [...] Por faltar esta subordinación y correspondencia sabemos que nuevos reinos que están convertidos a la fe, se volvieron al paganismo; de lo que tenemos ejemplo en la India Oriental donde el apóstol Santo Thome convirtió innumerables almas en el reino de Ceylán, Cochín y Cazahuete [sic], pero muerto el santo apóstol, como no hubo correspondencia desde Palestina ni Roma, en tres o cuatro generaciones no quedó cristiano alguno, hasta que ahora 200 años [después] acudieron allá obispos babilonios y ahora hay muchos portugueses.

La otra cosa que consiste la correspondencia entre las Indias y España es que haya comercio y trato entre estos reinos, lo que es 
precisamente necesario, so pena de que, cesando el comercio, cesará la correspondencia y cesando cuenta en pocas generaciones no habrá cristiano alguno. Para que tenga comercio y comunicación lo que hace más daño es el divertir el comercio que tenían de las Indias a España a otros reinos que no son Su Majestad, sino de gentiles y paganos, como ahora pasa entre la Nueva España, Perú y Filipinas, que llevan cada año 3 o 4 millones de plata lo que todo va a poder de los chinos; y se deja de tratar a España, con daño de los derechos reales, daño de los vecinos de las Filipinas y el mayor daño andando el tiempo será el que redundaría a las mismas Indias.

Todas cuantas trabas y prohibiciones que se hacen para remediar este daño no sirven de nada sino para dar más y más y echarlo todo a perder. Mientras el virrey de Nueva España prohibiese los capitanes y oficiales de las naos que van a las Filipinas no se podrá poner remedio debido, porque como los tales oficiales van de México es claro que no dejarán de llevar dinero suyo y de sus amigos, y aunque se les pongan más prohibiciones no lo dejarán de hacer.

El remedio propio que tengo consiste en que se haga un consulado en Manila y que allí se proveen los oficiales, y allí se señale a cada vecino de las islas las toneladas de ropa que han de embarcar, con cuanto se pondrá el remedio total a este mal y los de las islas por su bien propio y por su interés procurarán tratar ellos solos y estorbar que no traten ni envíen plata los de México ni Perú [...] El tratar de enviar su plata los de México y del Perú a las Filipinas en gran detrimento de los vecinos de ellas [...] que como los mexicanos y peruleros envían tanta plata ha subido el precio de las sedas y mercaderías de la China de tal suerte que han aumentado a mil por ciento las mercaderías, con harto de las Filipinas; y así es ciertísimo que concediéndoles que sólo ellos traten con una limitación justa, ellos solos querían ser los gananciosos y procurarán que no envían plata los mexicanos y peruleros [...] y procurarán que no envíen plata alguna los mexicanos y así los filipinos ganarán provecho a todo porque bajarán el precio de las mercaderías en Manila y subirán en México. Si esta razón se considera con atención se conocerá claramente lo que digo 
[...] Lo mismo digo del puerto de Buenos Aires que lo que ahora se ha ordenado entiendo fue ordenación divina. La razón de lo que es ahora como se les prohibía que no hubiese trato alguno entraban y salían y trataban de Brasil a Potosí y de Potosí al Brasil y España [...]

Martín Ignacio de Loyola, obispo del Río de La Plata.

\section{II}

Loyola, Martín Ignacio, "Que se tripliquen los despachos tocantes a la contratación con las Filipinas y a las mercaderías y ropa de la China que se prohiben en el Perú", Buenos Aires, 6 de mayo de 1605, AGI, Charcas, 135, f. 1.

Por la obligación que tengo al servicio de Su Majestad y descargo de mi conciencia me parece que tengo obligación de dar aviso de algunas cosas; la primera es que ha entrado tanta ropa de la China en el Perú de contrabando y contra toda razón que no hay provincia por acá que no esté llena de ella, y tan buena y barata que las cosas de España ya no valen nada, lo cual es en grandísimo daño de los derechos reales pertenecientes a Su Majestad en España y en los puertos donde [...] se despachan, y es grande la independencia que se va siguiendo al Perú y México, de España que es un inconveniente muy grande, y tal que el día que las Indias no estuvieren pendientes de España en todo sin duda se destruirá toda la política espiritual y temporal.

La centésima parte de la ropa que este año ha entrado en el Perú, es más que cuanta ha entrado por este puerto [Buenos Aires] en 50 años y estoy admirado de algunos ministros de Su Majestad que tanto procuran cerrar este puerto siendo una minoría cuanto viene por él, y se les da tan poco de esa puerta tan grande donde van cada año tantos millones [...] De Buenos Aires, 6 de mayo de 1605. CR [Capellán Real] de Su Majestad

Fray Martín Ignacio de Loyola, obispo del Río de la Plata 
Cardenal de Sevilla, "Copia de carta original del cardenal arzobispo de Sevilla al rey sobre el remedio de la contratación de las islas Filipinas con la Nueva España y el Perú", Colección de Documentos inéditos para la historia de España, tomo LII, pp. 565-572.

Una carta de V. M. recibí el tenor siguiente: Muy Reverendo en Cristo Padre cardenal arzobispo de Sevilla, de mi Consejo de Estado, mi muy caro y muy amado amigo: El Rey, mi señor, que haya gloria, deseando que las Islas Filipinas se poblasen de españoles y que se plantase la fe en los naturales indios de ellas, y con las esperanzas que se tienen de que con la comunicación que de aquellas islas hay en la China, sería Dios Nuestro Señor servido de que se abra puerta para que se extienda su Santa Fe en aquellos reinos, permitió y dio licencia para que de ellos contratase con las dichas islas y que ellas se trajese cada año a la Nueva España hasta en cantidad de doscientos y cincuenta mil pesos de mercaderías de la China en dos navíos que anduviesen por cuenta de la hacienda real, y que del retorno de las dichas mercaderías se pudiesen llevar de la Nueva España hasta quinientos mil pesos en reales, y que esta contratación se hiciese solamente por vecinos de las dichas Islas Filipinas y no por otras personas algunas, y que de la dicha Nueva España no pudiesen pasar al Perú ni a Tierra Firme ninguna de las dichas mercaderías, y se diesen las órdenes que conviene sobre aquella navegación y contratación, de las cuales se ha excedido mucho, según se ha entendido por cartas de mis virreyes, audiencias y gobernadores y relación de otras personas y que es grande la cantidad de mercaderías que traen a la Nueva España demás de la permisión y que pasan de dos millones en plata y reales lo que se lleva de ellos cada año y la mayor parte de ello a los reinos de infieles y que tampoco se ha cumplido la prohibición que está hecha de que no se pasen al Perú desde la Nueva España las dichas mercaderías y que van allí por ellos los mercaderes con gran cantidad de plata cada año proveyéndose las dichas provincias del Perú y de estas y otras mercaderías de 
China, de lo cual resulta enflaquecerse el trato y comercio con estos reinos y tener poca salida y venta lo que se lleva de España en flotas y haberse venido a acortar e imposibilitar su despacho. Y habiéndose representado por parte del prior y cónsules de la universidad de los mercaderes de esa ciudad los dichos inconvenientes, y suplicándoseme mandase prohibir de todo punto aquella contratación de Filipinas, y quejándose las mismas islas de que no se cumplen las órdenes que están dadas y que se hace aquella contratación por mano de otras personas de la Nueva España y el Perú, que atraviesan las mercaderías y hacen gruesos empleos sin que gocen aquel beneficio los vecinos de las islas [...] he querido ver vuestro parecer sobre ello, y así os encargo que habiéndose enterado e informado muy bien de lo que hay y pasa en lo susodicho y qué causa es la principal por donde se va enflaqueciendo el trato y comercio de estos reinos con las Indias, y en lo que está el daño, y el que resulta de la contratación de Filipinas, y habiendo discurrido sobre todo muy atentamente, me enviéis relación muy particular de todo lo que os ocurriese y se ofreciere con vuestro parecer, y lo que se debe ordenar y proveer para el remedio de ello, y dar el mejor asiento que convenga, así cuánto a la dependencia que conviene que haya de las Indias con estos reinos por el remedio de trato y comercio y que éste se conserve y aumente, como asimismo para las dichas Islas Filipinas y la cristiandad de los indios, que hay en ellas, se sustente y acreciente [...] Yo el Rey, 21 de septiembre de 1603 .

Que para que haya bastante número de naves y gente en este trato y comercio, conviene que haya ganancias conocidas, cuya codicia sufren los cargadores de trabajo y riesgo de una tan larga y peligrosa navegación. Que este trato y comercio anda ahora tan flaco y quebrado que si V. M. con mucha brevedad no manda poner remedio en él, se puede creer que dentro de pocos años se acabará de todo punto. Que, aunque el daño de esta disminución se entiende que ha procedido y procede de diversas causas, en las que más concuerdan todos son cinco. En la poca seguridad que ha habido en la mar. En los muchos y excesivos derechos que se pagan. En el trato y comercio de las Indias con las Filipinas. En 
haberse dejado plantar tantas viñas en el Perú. En haber dejado ir naves a las Indias fuera de flota y llevar en ellas mercaderías.

La primera de la Filipinas, tienen por las más dañosa y perjudicial de todas, porque es gran suma la que dice que en reales se lleva todos los años a aquella provincia, sin que vuelvan jamás sino empleados en las peores y más inútiles cosas y mercaderías que hay, de que demás de sacarse el dinero, y dejarse de traer a estos reinos, como antes que hubiese ese trato y comercio se solía hacer, resultan dos daños e inconvenientes de mucha consideración. El primero, hinchen de sedas y lienzos de poco valor a Nueva España y el Perú en tanta cantidad que cuando llegan las flotas a España, no hallan salida de lo que llevan y así no hay quien se atreva a cargar. Y el segundo, que si las Indias con la abundancia que el Perú tiene ya de viñas y con las sedas, lienzos, hierro y otras cosas que les proveen las Filipinas, pueden vivir sin necesidad de España, no habrás seguridad de ellas, pues lo que se entiende que hasta aquí las ha conservado es la dependencia de estos reinos y la necesidad que hasta ahora han tenido de estos reinos y del trato de ellos [...] y así les parece que por ahora se remediará el daño que de esta primera causa procede, sin intentar nuevas navegaciones, con mandar V. M. al gobernado y audiencia de filipinas que de ellas no pudiesen venir cada año más de dos navíos, que el mayor no excediese de 50 toneladas, que es capacidad bastante para que los vecinos de aquellas islas envíen a la Nueva España sus mercaderías, donde se podrá consumir esta cantidad sin que sobre para enviar cargazones de ellas al Perú; y no teniendo las mercaderes de la Nueva España navíos en que les puedan traer de las Filipinas tan grandes cargazones y empleos, como ahora hacen, no enviarán más reales de los que pueden volver empleados, y con esto aún no se llevarán los 500 mil pesos que el rey nuestro señor, que está en el cielo, les hizo merced de permitir que pudiesen llevar [...]

Cuanto lo segundo punto de las viñas del Perú, aquí tienen por muy dificultoso el remedio de él, por ser interesados en ellas muchas personas de quien se podría temer algún desasosiego muy perjudicial, si se las quitasen y mandasen decepar, y sería 
en alguna manera crueldad hacer eso, habiéndolas plantado con licencia, o a lo menos con permisión de V. M., y estando ya aquel reino hecho a gastar a un moderado precio un mantenimiento tan necesario y forzoso como éste, se les haría de muy de mal comprarlo a tan caro y excesivo precio como valdría el que se llevase de acá; pero todavía les parece se remediaría mucho si se mandase con grandes penas no se pudiesen plantar más viñas de nuevo, y que esto se ejecutase sin excepción de persona alguna con mucho rigor, y que todas las viñas que se vendiesen se comprasen a costa de la real hacienda de V. M. y se decepasen, y que aunque este remedio parece costoso, sería dentro de muy poco tiempo muy provechoso, pues costará mucho más si acaso se perdiese la contratación del Perú [...]

Dios guarde la católica persona de V. M. de Sevilla 28 de octubre de 1603. El Cardenal Obispo.

"Descripción de Panamá y su Provincia, sacada de la Relación que por mandato del Consejo hizo y envió aquella Audiencia”, 1607, Biblioteca Digital Hispánica, Descripción de Indias, tomo I, clasificación Mss/3064, fs. 67-69.

Advierten estas relaciones que los vecinos de Panamá tuvieron a los principios grandes aprovechamientos y ganancias por la frecuencia de las flotas que venían cada año con número de más de cuarenta navíos con cargazón de todos géneros. Ocupábanse las recuas y los barcos del trato del río Chagres y los navíos y barcos del mar del Sur; ganaban en los alquileres de las casas, en los jornales de los negros, en las granjerías del ganando, porque se vendía bien la carne; en las contrataciones de mercaderías y en mil menudencias, porque ninguna cosa había ociosa ni sin ganancia. Lucía la ganancia y medraban las haciendas con el poco gasto, porque todo lo necesario para armazón de recuas, barcos y navíos, valía menos. No se pagaban alcabalas de cosa ninguna, 
ni de las harinas y bastimentos que venían del Perú se cobraban derechos. Daban gran provecho las minas de Veragua, que ocupaban dos mil negros en su labor. En las islas del Rey pescaban treinta bergantines ordinarios. Pero después las flotas comenzaron a tardar dos años y a veces tres y venir menores en número de navíos e importancia cargazón.

Las causas de esta disminución son: Primera, que una parte de las mercaderías que vienen de España para el Perú, toman su derrota por Nueva España. Segunda, y más importante, el haberse introducido la navegación de la China, que ha engrosado con daño general de España y de esta provincia, y consume muchos millones de plata que se llevan a perder para siempre entre aquellos bárbaros; Tercera, que el Perú tiene vino de cosecha para sí y para cargar a Nueva España. Coge también el Perú aceitunas, labra cordobanes; en Sana, Guayaquil y Nicaragua se labra jabón; dan cera Campeche y Santa Cruz de la Sierra; Guayaquil, Riobamba y Puerto Viejo dan jabón; Nicaragua, brea; téjense paños en Quito, Huánuco y Chuquiagon; Nueva España da paños y sedas. De la China vienen sedas, lienzos, hierro, cera, loza y otros géneros. Cuarta, la plata que solía pasar por aquí para España se divide y divierte, parte a la China, parte a la Nueva España.

Por estas razones, las recuas, barcos y navíos son en Panamá en muy menor número, tienen que hacer menos tiempo y ganan menos fletes; no trabajan sino los siete u ocho meses al año. Consiguientemente, todos los tratos y granjerías han menguado. Por el contrario, todos los gastos son e iban siendo mayores. La ciudad, con fuerzas tanto menores, ha de sustentar cinco monasterios y un hospital, como cuando podía mucho. Las minas de Veragua se han desamparado por el mal trato de los gobernadores. Los bergantines no pescan porque las costas son mayores que las ganancias. Junto con estas causas de disminución de ganancia, la pérdida grandísima que tocó a los vecinos de esta ciudad por los dos incendios de Nombre de Dios en el año de 1596: uno por Francisco Draque, y otro casual, en la flota del cargo de Don Francisco de Eraso. De todo se ha seguido que la ciudad no tiene el tercio de los vecinos, ni en haciendas, que solía y todo decrece día a día. 
"Carta a S. M. del virrey de la Nueva España marqués Villamanrique", 1585-12-17, México, AGI, México, 20, núm. 119, fs. 14-19.

[...] y las cosas que tocan a la navegación de las Filipinas como negocio nuevo y que hasta aquí ha sido menester esforzarlas, no se han puesto en el estado que es razón y aunque todavía es bien disimular con algunas, hay otras que de remediarse no traen inconvenientes como fue de la que a V. M. tengo dado cuenta en la carta de 16 de diciembre en el capítulo 9 de que las mercaderías de China que se sacasen fuera de este reino se pagasen derechos que ha sido de mucha importancia porque es grande la saca que de aquí hay de estas mercaderías para el Perú. Porque la contratación va creciendo y la gente se ha aficionado de pocos años a esta parte. A ella respecto de las pocas costas y crecidas ganancias que de ello se les sigue, hasta ahora se ha acostumbrado que a todos cuantos iban en la nao se les daba de comer a costa de V. M. y esto cuando se empezó respecto de ser poca la gente que iba en ellas fuera de la mar y guerra y era de poca consideración. Más ahora que va mucho número de mercaderes y no es menester animarlos a que vayan como antes, parece que es harta comodidad la que se les hace en que V. M. les dé nao y pasaje sin que se les dé bastimento. Y así ordenado que no se dé de comer a otros más de a los que llevan sueldo de V. M. y a los religiosos y que los demás lo lleven por su cuenta. Y también he mandado que todo lo que en la nao de V. M. se metiere por granjería con que sea cosa de bastimento paguen derechos de salida y también que paguen el flete de ello. Porque hasta ahora no se había cobrado, ni le pagaban, sino solamente de las mercaderías que de allá venían y esto es tan poco que no pagar más de nueve ducados por cada tonelada. Y pareciéndome que de todo lo que de allá viene no se pagan otros derechos más que estos fletes, he querido crecerlos al número que se pagan en la Mar del Norte, que es a treinta y treinta y dos ducados por tonelada. Y porque me han advertido que podría tener inconveniente este trato nuevo, lo he dejado de hacer hasta con- 
sultar a V. M. sobre ello para que me envía a mandar lo que es servido se haga. Porque, aunque de aquí se seguirá aprovechamiento a la Real Hacienda de V. M. para ayuda de los grandes gastos de esta jornada, todavía me parece que es temprano para poner esto en el punto que es justo que deben ser en adelante.

El capitán Juan de Chaguya y Baltazar Rodríguez me presentaron una cédula de V. M. fecha en Barcelona a primero de junio del año pasado de ochenta y cinco cuya copia va con esta en que V. M. me remite el darles licencia para que un navío que habían hecho en Tehuantepec pudiesen llevar desde esta tierra mercaderías de las filipinas al Perú. Y habiéndola visto y entendido que la prohibición que V. M. fue servido hacer al tiempo que estaba en el Perú el virrey don marqués Enríquez de que no se llevasen allá mercaderías de China no fue que no se llevasen de aquí, sino prohibir que desde las filipinas no fuesen allá derechas por causa de la contratación de esta tierra, me pareció que no traía inconveniente el darles esta licencia como se ha dado a otros pagando a V. M. los derechos de salida como los pagan los demás, y así se la di. El daño de esta contratación no está en que la mercadería de la China después que llegue aquí se comunique al Perú y a otras partes, sino en la mucha cantidad de dineros que de aquí se lleva cada año allá a emplear en ellas, que es una saca grandísima. Y esto es desecar este reino de la plata y enriquecer el extraño con ella a trueque de brujerías que, aunque no vinieran a esta tierra, no por eso dejará de estar muy bien proveído de todo lo necesario.

\section{CApítulo III}

\section{I}

Juan Antonio de San Felices. Al excelentísimo Señor secretario de Estado y del despacho de hacienda de Ultramar. 
AGI, Guadalajara, 532, Expedientes del comercio de San Blas de California con Panamá. 1789-1818, Cádiz, 27 de febrero de 1813, fs. 98-105.

En cumplimiento de la orden superior de V. E. de 26 de diciembre último ha visto la Contaduría y general de ultramar la carta documento del virrey que fue de Santa Fe, Don Benito Pérez de 20 de julio último $\mathrm{n}^{\circ} 25$ en que acusando el recibo de la orden que se le reiteró en 16 de marzo próximo pasado por la que se le dio facultad amplia para abrir o cerrar el comercio con las colonias amigas, según lo exigieron las circunstancias, manifiesta las causas de la decadencia de aquel istmo y cuan útil sería concederle permiso para comerciar libremente con los mercados de Europa y Asia estableciendo en Panamá una factoría de la compañía de Filipinas, conforme a la exposición que le hizo la diputación de comercio de aquella capital con motivo de haberla pasado copia de la citada ordena y en que se excedió notoriamente el virrey por la calidad de reservada que preveía.

Aunque para puntualizar los daños inferidos y que continúan a la Metrópoli, al reino del Perú y a mucha parte del de Santa Fe, era como indispensable tener a la vista las quejas que parece se han dado por el virrey de Lima y su comercio sobre la libertad concedida a Panamá de introducir géneros europeos por el istmo; sin embargo expondrá esta oficina después de dar alguna idea del antiguo comercio que se hacía por aquel, las razones que califiquen lo irregular y perjudicial de las pretensiones que incluye el presente expediente:

Antes que los españoles se atreviesen a doblar el Cabo de Hornos, se hacía el comercio del Perú por Panamá dirigiéndose los registros o galeones desde Sevilla a Portobelo. De este punto se introducían por tierra los frutos y efectos de sus cargamentos a Panamá, desde donde se conducían por el mar Pacífico hasta Lima. Con el auxilio de pilotos franceses se hicieron algunas expediciones por el Cabo de Hornos por los años de 40 del siglo pasado y con el tiempo se desterró el horror que causaba esta navegación, la cual se ha hecho tan común y corriente como se está 
experimentando. Viendo, pues, el gobierno el gran beneficio que se seguía al estado de fomentar por el Cabo esta contratación y su fácil transporte a Europa de las riquezas del Perú, anuló el sistema de galeones y desde el año de 40 a 50 del siglo citado, se sigue sin interrupción tan favorable proyecto.

Era muy natural que habiendo estado Panamá en posición de proveer al Perú con los cargamentos de galeones y permiso concedido en aquel tiempo a la Inglaterra viniese a sufrir la decadencia que se dice, pues no sólo le faltó este pingüe recurso, sino que también se trasladó su audiencia, o tribunal de justicia al Perú por no ser necesaria.

Como la opulencia a que llegó Panamá era por efecto de su situación y respecto a que se tenía al Cabo la sucedió lo que, a Génova y Venecia, que perdieron en la mayor parte sus inmensas riquezas y temible marina luego que se abrió el comercio con la China por el de Buena Esperanza; pero estas desgracias son consiguientes a aquellos pueblos, cuya riqueza no proviene de la industria, o naturales producciones.

No hay duda que Panamá era el baluarte del mar pacífico, y lograría en el día de la consideración que disfrutó, sino se hubiera practicado la navegación por el Cabo de Hornos, y la nación habría siempre fundado con equivocación en aquella ciudad la seguridad del Perú.

Perdidas por Panamá las consideraciones políticas que merecía, como queda demostrado, conviene pasar a tratar del objeto interesante del comercio que el que mantienen al estado en opulencia y sin el cual ni la agricultura ni las artes pueden progresar.

Cuando los ingleses tomaron injustamente la isla de Jamaica bien conocían las grandes ventajas que les había de producir esta adquisición, pues su situación topográfica les proporcionaba surtir clandestinamente con sus efectos no solo el reino de Nueva España, más también toda la costa firme y hacer a Panamá un segundo almacén que, surtido abundantemente por los ingleses proveyese desde allí todo el Perú. Así se verificó todo el tiempo que corrió, desde la pérdida de Jamaica, y que permaneció el sistema de los galeones. De modo que sólo el tráfico por el Cabo de 
Hornos puedo impedir aquel escandaloso contrabando en una gran parte.

Panamá no tiene producciones naturales, por consecuencia conseguida sus actuales pretensiones era lo mismo que acabar de arruinar el Perú, porque no puede dar salida a sus cobres, quinas, cacaos, lanas, estaños y otros frutos propios de su suelo, que hacen la felicidad de aquel reino y se conducen a Europa, cuya exportación no es factible hacer por Panamá en razón de sus enormes costos y otros inconvenientes invencibles que son bien notorios a V. E.

Privado el Perú de su comercio por el Cabo, no puede sostener obligaciones porque los estados son pudientes siempre que sus habitantes o ciudadanos sean ricos, y ésta es una verdad incontestable. En el día se ve el comercio de Lima en una total inacción por las introducciones que hace Panamá. La agricultura en la mayor decadencia. Su navegación paralizada enteramente. Aquel virrey tocando los mayores apuros para las atenciones más urgentes de justicia. Y la metrópoli careciendo de los productos que debería producir el giro y re-giro del comercio directo cuando más lo necesita. Mas si por desgracia se concediese a Panamá la factoría que pretende, es menester contar con que no llegaría a la Península un solo peso del Perú, porque todo el que se acuñase en él pasaría por una forzosa consecuencia a Panamá, y de allí al Asia y potencias extranjeras de Europa. Según el estado presente de cosas, no pueden sostenerse las coronas sin el metálico y cuanto han discurrido en contrario los políticos equivocan los verdaderos principios de la ciencia económica porque es indudable que el valor de las manufacturas y producciones naturales ha de ir a parar indefectiblemente al estado, provincia, ciudad o pueblo que los produzca, dejando beneficiados los conductos por donde gire en favor de aquella potencia que haga la contratación.

Puede calcularse que el Perú en tiempos de tranquilidad amonede cinco millones de pesos fuertes, de los cuales se deben destinar muy cerca de la mitad para el tráfico de aquél país y la otra mitad extraerse, la cual ha de ir a parar precisamente a Panamá que suerte de efectos a aquél virreinato. Y como la importación 
de Europa debemos suponerla anualmente en ocho millones de pesos, se observa un déficit contra el Perú que no puede suplir con sus frutos, por no permitirlo su tosquedad y crecidos gastos de su exportación por Panamá como queda manifestado. De aquí resulta necesariamente la ruina de la agricultura del Perú y que el importante cuerpo de minería abandone las labores de sus minas por faltarle el auxilio del comercio que le vivifica y fomenta.

Deben mirarse quiméricas las protestas que hace Panamá y su virrey para evitar el contrabando, y exhibir religiosamente los derechos nacionales, pues estando en posesión por tantos años del lucro que les proporciona el contrabando que hacían impunemente, no es fácil desviarlos de sentimientos tan envejecidos. Lima manda situado a Valdivia y establecida en Panamá la factoría quedará aquella plaza sin auxilio y sin apoyo alguno para sostener aquellas vastas regiones de las agitaciones interiores, e invasión extranjera. Lima se surte de Chile de todo el trigo que necesita y su pago lo hace en efectivo. A Guayaquil también le paga, en el mismo, la mayor parte de sus ricas y diferentes producciones, y faltando a Lima el numerario, tocará infaliblemente su ruina en premio de su distinguida lealtad e importantes servicios y a que deberá seguirse la de todo el virreinato.

Algunas otras reflexiones pudieran añadirse sobre la gravedad de la materia de que se trata. Pero la contaduría a beneficio de la brevedad las omite, persuadida que con las ya expuestas deja satisfecha la idea que se propuso. Bajo de este concepto entiende que no es de acceder a las solicitudes de la Diputación del comercio de Panamá apoyadas por su virrey, ya por evitar los nuevos males que causarían como queda demostrado, o cuanto porque esta clase de privilegios particulares están en contradicción con lo resuelto por las Cortes generales y extraordinaria. Así parece a la Contaduría que puede declararse previniendo al virrey lo conducente sobre la falta de reserva con que procedió al recibo de la orden citada de 16 de marzo último que publicó y ha excitado el presente expediente, con lo demás que parezca oportuno acerca del tino y prudencia con que ha debido y debe proceder en el uso de la facultad con que le autorizó la consideración de S. A. para el 
loable fin que se reconoce de dicha real orden. Sin embargo V. E. con sus luces hará de todo el mérito que estime y añadiendo las que conduzcan al acierto lo hará presente a S. A. para la determinación que tuviere a bien.

\author{
II \\ "México. Sobre las manufacturas de seda, algodón \\ y lana que se fabrican en Nueva España", \\ AGNM, Indiferente virreinal, caja 5909, exp. 109, fs. 1-18.
}

\title{
ExMO. SEÑOR
}

Por encargo particular que la bondad de V. E. se ha dignado hacerme en virtud de su Oficio superior de 15 de enero último, he colocado en el adjunto Libro de muestras reunidas de las manufacturas que se fabrican actualmente en este reino, dividendo por clases todos los géneros con sus respectivos precios originales, para que a una hojeada pueda hacerse un juicio compartido con los de igual calidad y ancho de Europa y del Asia. Si a V. E. no le agradare este método, que es el que a mi ver simplifica la facilidad de su cabal inteligencia pondré luego en práctica otro cualquiera que se sirva insinuarme en prueba de los verdaderos deseos que tengo de emplearme en obsequio de V. E.

Estas fábricas son susceptibles de mucha mejora por la fertilidad de la tierra, por la aptitud de sus naturales, por ser propios los tintes, por el uso de nuevas máquinas, por la moderación de los derechos, y en fin porque la experiencia que todo lo perfecciona, produce ciertas economías hijas nativas de la suma carestía. Ha llegado ésta a ser efectivamente tan extremada, que sin embargo de haberse dado por purísima necesidad y conmiseración entrada a varios barcos colonos que recalaron a Veracruz, comunicó rápidamente a la industria del país tal energía, que a poco tiempo los efectos de lana y algodón de la tierra competían en baratura con los de Europa y del Asia, de manera que según me ha asegurado un sujeto fidedigno que está continuamente atareado en 
estampar indianillas de lienzo trabajado en la tierra, solo él pintó de azul cien mil cortes de enaguas de a cuatro varas en el inmediato año de 1799. Estos hechos notorios acreditan de un modo indudable la seguridad de la máxima, de que en todos los lugares progresarán las manufacturas del país, al paso que se encarezcan las que se le introduzcan de fuera.

A esto se ha seguido, como se sabe V. E., el gran poder que por grados ha ido adquiriendo el reino de Nueva España, tanto por haberse duplicado la labor anual de la Real Casa de Moneda, como por los visibles valores que le han rendido los azúcares que se han extraído para Europa y el Aguardiente de caña que se está fabricando para el consumo de la tierra. Ninguno que haya vivido algunos años en ella podrá negar la certeza de estos sencillos datos, ni tampoco que esta misma opulencia rezagada, es la que ha motivado el extraordinario lujo que se ha propagado en cuantos objetos necesitamos para nuestra subsistencia. Este consumo ha de ir forzosamente subiendo más cada día, a proporción que bajen de precio los géneros que vayan viniendo de Europa y del Asia, pues es una verdad acreditada por la experiencia que todos (absolutamente todos) gastamos el dinero con más bizarría en tiempo de abundancia que en el de escasez y carestía.

Si a juicio mío es cierto lo que dejo dicho hasta ahora, lo es también que jamás podrán prosperar las fábricas de la América, siempre que vengan copiosos surtimientos de géneros de la Europa y del Asia, porque la equidad de sus jornales no permitirá que tome nuestra industria más vuelo que el que escasamente necesita para hacer mantas, rebozos, y cotones de algodón y paños, frezadas y bayetones de lana. Para darme a entender con alguna más claridad sobre esta materia, hablaré a V. E. primeramente de los géneros de algodón para seguir después con los de lana.

Pero antes diré con beneplácito de V. E. que a mí me parece ilusorio el decantado raciocinio de los que fincan la felicidad pública, únicamente en el prurito de acumular la riqueza, o por mejor decir, la redundancia de la moneda gradúo por uno de los mayores males que al presente se padecen en ésta felicísima tierra. Porque si no me equivoco de medio a medio, ella ha sido la 
principal causa de que paso a paso nos hayan alzado los precios corrientes de cuantos artículos necesitamos para nuestra existencia. Ésta es una de aquellas verdades de que puede dar entera fe uno de cada casa, si reflexiona que en el discurso de pocos años ha subido al doble el valor de los consumos precisos de sus familias; pues a mí ver no puede ofrecerse argumento más plausible sobre la materia, que el del asombroso cercen de cien mil carneros que se matan menos en el día, respecto de los que se gastaban en el abasto anual de esta ciudad populosa, sin que haya habido en substancia otro motivo que el de la carestía, para una rebaja de tanta consideración e importancia. Este daño irreparable es uno de los muchos que se nos han seguido del exceso de la riqueza estancada, como lo sabe muy bien V. E.

Al que sintiese repugnancia en prestar ascenso a esta noticia, le presentaré otra más obvia, urgente y extensiva que tengo a la vista: de 4996664 pesos que han tenido de incremento los diezmos de las seis iglesias catedrales de México, Puebla, Valladolid, Guadalajara, Durango y Oaxaca en el decenio de 81 a 90 comparado con el de 71 a 80 . Digo más que no hubiera ciertamente en el mundo reino más miserable que el de la Nueva España, si sus fábricas fueran capaces de absorberse los veinticinco millones de pesos anuales que produce la Minería; porque faltando objetos en que invertir los caudales sobrantes que progresivamente se amontonarían en la tierra, al cabo valdría un sentido cualesquiera cosas de las que indispensablemente necesitase cada individuo para su decente permanencia.

$\mathrm{Si}$ alguno me objetase que éstos principios son trascendentales a cualquiera paraje donde abunde la riqueza, no tendré reparo en adherir redondamente a la fuerza de esta réplica, como en cambio se me conceda que en ninguna parte serán tan funestas las resultas como en América. La razón es clarísima. Porque no pudiéndose dar todo en todas las partes, ha dispuesto las cosas con tal economía, orden y justicia la inefable amorosa providencia que lo que se halla en una provincia, no se encuentra en otra, para impeler a los hombres a que mutuamente se socorran con equidad en las necesidades que cada cual tenga. Esta concertada 
regla no sólo está acreditada entre las naciones más laboriosas y cultas de la Europa, sino entre nosotros mismos se halla también confirmada; pues en vano se buscará a alguno que sea tan afortunado, que no haya menester de otra persona para su descanso, regalo y conveniencia.

De estos antecedentes deduzco consecuencias una en pos de otra. La primera que a proporción de los frutos privativos que coseche la América, serán los progresos que tenga en la balanza mercantil de la Europa. Y la segunda que cuántos más caudales se vayan acopiando de una mano a otra, tanto más breve han de malear las particulares de la causa pública. En esta inteligencia diré, en suma, que tanta afición mostraré a las fábricas ordinarias que puedan difundir la industria popular de la tierra, como aversión a las que temporalmente sean capaces de promoverse en ella; porque las primeras a par que conducen a que se vista tanta gente desnuda, contemplo que sólo sirven las segundas para encarecernos cuanto penda de la carcoma de la codicia: de la codicia, que cuanto mayor sea, suele aspirar a más inmoderada ganancia.

Bajo de este concepto hago presente a V. E. que no se puede poner en disputa que jamás se ha tejido en el reino tanto algodón como el que se está laboreando en el día, para suplir la notable falta de dos años consecutivos que ha dejado de venir a Acapulco la Nao de Manila. Esta proposición se halla apoyada en 20091 tercios de algodón en greña que entraron de más en México en los cuatro años de 96 a 99; respecto de los que se introdujeron en el de 92 a 96. De donde colegirá acertadamente V. E. que ésta es y ha de ser la causa radical que influya para que a medida que se acaben los pocos géneros que existen de la Europa y del Asia, se vaya reconociendo que cada vez va tomando más cuerpo la industria de América; pues no se ha descubierto móvil de tanto poder, como el del interés para comunicar celeridad a las ruedas de todo género de Fábricas, haciéndonos de camino demostración palmaria, que pueden surtirse de cuánto han menester siempre que no sean provistos oportunamente de mar en fuera.

Pero a mi entender luego que se ponga en corriente la navegación que se halla casi interrumpida, regulo que estas fábricas se 
debilitarán aún con más presteza de la que han necesitado para adquirir su mayor fuerza. Muéveme a pensar de esta manera la consideración naturalísima de ser todos los lienzos que se trabajan en la tierra parecidos a los que se conocen en el comercio con los nombres de elefantes, garras, Jamanes y Bayetas que vienen del Asia, que cuando en México se venden encima del mostrador a cuatro reales vara a vara, apenas pueden costearse en el país, dándolos a seis reales con poquísima diferencia. De este cotejo inferirá sin duda V. E. que si no es imposible está muy cerca de que lo sea, que las manufacturas del país ahora ni nunca puedan emular a las de China. Esta ha sido en todos tiempos la triste suerte que han experimentado las fábricas de América.

No me aventuro a hablar con igual resolución a V. E. en orden al éxito que puedan tener las cotonías que se hacen en la tierra, porque si por una parte veo que ellas se acercan en calidad y precio a las extranjeras, por otra reconozco que fomentan muchísimo la introducción furtiva de las inglesas, que hace años que están justamente prohibidas. Digo que están justamente prohibidas tanto en lo político como en lo moral; porque además de haberse generalizado su uso para chupas y calzones que hace disminuir enormemente el consumo de otros géneros nacionales, han observado muchos sujetos suspicaces, y concienzudos que la ropa ajustada que gastan de este vistoso lienzo los hombres impudentes, sirve de tropiezo a las incautas mujeres para hartas caídas lastimosas.

En esta atención ya por la inseparable volubilidad caprichosa de la moda, que sólo se contenta de lo exquisito, raro y costoso para singularizarse del resto de los demás hombres, o ya porque en realidad esta manufactura no es dable que preste ocupación sino a personas muy contadas; confieso abiertamente a V. E. que me holgará que en su lugar se amparasen las desatendidas fábricas ordinarias, que son las que con menos fondos de caudal participan más socorros a la causa pública; pues sin que preceda la dulce esperanza de lograr de algún alivio, es incapaz que a ninguno se le inspire amor a las penosa tarea diaria. Por ellas y no por la finas, es por donde contemplo que pueda tener feliz 
principio la industria de las Indias, si se pretende de veras que sucesivamente hagan algún progreso las otras maniobras. Porque además de ser mucho más difícil de connaturalizar cualquiera fábrica costosa en el país por las ganancias que de ella se propone sacar el que anticipa el dinero para sostenerlas, es punto de hecho que no admite la menor disputa que en ninguna tierra como en la de América, hay tan extrema necesidad de que se ocupe y vista la muchedumbre de gente pobre, desnuda y ociosa. Cuando esta palpable verdad exigiese alguna comprobación me aprovecharía de la noticia de estarse mandando cada año de sola la jurisdicción de Villa alta 600 tercios de a 124 piezas de a 5 varas de mantas de tributo para surtir la indigencia de los miserables trabajadores de tierra adentro, sin hacer cuenta con 4248 tercios de ropa ordinaria que con el propio destino vinieron de varias partes a esta Real Aduana en el cuatrienio de 96 a 99 respecto de los que se remitieron en el inmediato anterior de 92 a 96.

Ya la penetración de V. E. se hará cargo que, si no es capaz que prosperen las fábricas de algodón, menos esperanzas se podrán fundar de que florezcan en el país las de lana; pues que son aún más victoriosas las razones que militan para asegurar la segunda parte, que las de la primera. Ruego a V. E. que tenga un poco de más paciencia en oír lo que me falta. Porque aún dado y no concedido, que las manufacturas de la tierra llegaran a hacer competencia a las de Europa, nos encontrábamos con la dificultad insuperable de no haber en la América la cantidad competente de lana para abastecer de tanta ropa cuanta necesita para vestirse la gente que en ella habita; como evidentemente lo demuestra la experiencia inconcusa que habiéndose apurado el consumo total de sus lanas, han quedado parados toda la vida los telares del reino por falta de más materiales.

Esta reflexión se corrobora con otra que ya habrá ocurrido a V. E. El comerciante experto que no tiene otro oficio que el de estar alerta para aprovechar las ocasiones de enriquecerse a poca costa, motu proprio hubiera ya presentado auxilios eficaces a las fábricas de la tierra, si en su concepto le brindarán ellas con mayores utilidades de las que le ofrecen las manufacturas de Europa. 
Esta observación sencilla disipa cualquier duda que pueda caber sobre la materia; porque es innegable que cada individuo de por sí, prescinde del paraje donde se ha trabajado el género cuando en comprarlo y venderlo no lleva otra mira que la de su propia ganancia.

Una verbigracia aclarará todavía más mi idea. El paño azul de segunda inglesa que tiene una y media varas de ancho, trae tres o cuatro reales de plata de principal costo de España: se vende en México por lo común en tiempo de paz de 17 a 18 reales y al presente lo compran de 32 a 34 reales vara. Confronte este paño con el más fino que se fabrica en la tierra, que cuesta en su origen de 18 a 20 reales y se vende aquí de 26 a 28 reales para deducir naturalmente que los géneros de lana que se hacen en América no pueden perjudicar a los que vienen de Europa. Mas la angaripola o indianilla de Barcelona que trae de principal costo de Cádiz de $4 \frac{1}{2}$ a 5 reales de plata se vende en tiempo de paz de 6 a $6^{1 / 2}$ reales y en el presente de 17 a 18 reales; que comparadas con las que se hacen en el país vengo a sacar igual consecuencia para los géneros de algodón que para los de lana; pues cuestan dentro de México de 12 a 121/2 reales no siendo ni sus colores, ni sus dibujos tan apreciables como los de España. Atendida la realidad de estos supuestos, cualquiera caerá en cuenta que si en tiempo de guerra apenas pueden costearse las fábricas de la tierra, en el de paz volverán a reducirse a los estrechos límites en que siempre se han mantenido desde su Conquista.

En esta firmísima persuasión, tan lejos estoy de comprender que se ha disminuido el consumo regular de las manufacturas de Europa por las de la tierra, que gradúo se ha aumentado considerablemente el despacho de las que de poco tiempo a esta parte produce la industria española; como lo justifica ya la remesa doble de caudales que se manda hoy en día respecto de lo que antes se enviaba, y ya el visible incremento que ha adquirido el comercio activo de aquel reino con el de América. En que de paso diré lo que sabe V. E. que si el año 62 que fue cuando escribió Don Bernardo Ward, su recomendable obra del Proyecto económico expresa al folio 228 que apenas la veintena parte de lo que 
consumen nuestras Indias es de los productos de España ya en el día gracias a Dios no aporta, ni puede aportar barco alguno a Veracruz que deje de traer a lo menos la tercia parte de su carguío en frutos y efectos pertenecientes a nuestra Península. Esta idea placentera me excita el deseo patriótico de que los señores intendentes representen sin dilación a V. E. cuán conducente sería que a ejemplo de la feria libre de San Juan de Lagos, se entablasen en sus respectivas provincias otras parecidas a ella, para vigorizar la agricultura, minería, comercio e industria peculiar del reino de Nueva España; porque en realidad percibo que esta providencia unida a otras de igual naturaleza, podría exaltar brevemente la felicidad general de la tierra.

Confiado en los fundamentos que he exhibido, no temo proferir animosamente, que las manufacturas del país, tienen y han de tener sus flujos y reflujos a correspondencia de la abundancia o escasez de las que entren de mar en fuera; o como nos lo pone de claro en claro el dilatado transcurso de los siglos enteros que han pasado desde su dichosa agregación a la Corona de Castilla. Ésta es la primera parte de mi conclusión y la segunda consiguiente a ella que a nivel que se reconcentren las riquezas en manos de pocos sujetos adinerados de la tierra, crecerá de día en día la dificultad de poderse adoptar en ella ningún ramo de industria forastera, pues que es cosa lisa y llana que al paso que al pobre jornalero le cueste su comida, vestido y casa encarecerá necesariamente el estipendio por lo que cada día trabaja.

Este raciocinio Sr. Exmo. me decide por último a creer que tan errada irá la Europa en querer abarcar la industria propia de América, como la América en pretender dar alcance a la de Europa. A cada país privilegió benignamente el autor de la naturaleza con sus especiales gratuitos dones. A nosotros nos cupo en herencia el rico patrimonio del cultivo de las minas, granas, añiles cacaos, azúcares, tabacos, algodones y otros provechosos renglones que debemos dar en permuta por los que recibimos de fuera. Es verdad (no quiero disimular) que en un caso tan deplorable como el actual, podrán tener algún progreso efímero las fábricas finas de algodón y lana de la tierra, porque verdaderamente quie- 
bra el corazón ser testigo forzoso de un sin número de personas de todas esferas que tienen que comprar géneros precisos para vestirse por dos, tres y cuatro veces más caros de lo que valen y deben valer en tiempos regular. Pero tampoco se podrá cuestionar que en el momento en que se renueva este obstáculo, nos convenceremos plenamente, que la equidad de las manufacturas de América no ha influido en el detrimento de las de Europa, y la baratura de las de Europa ha de demostrar que no pueden prevalecer en auge las de América.

Hubiere añadido a V. E., de buena gana, la curiosa e interesante noticia del mayor número de individuos que se ocupan en las artes, y oficios del año de 96 hasta el presente; si no fueran tan inexactas las que hallo preparadas en varias contestaciones de la que han dado a V. E. algunos subdelegados, que ni aun prudentemente es posible de conjeturarse a cuantos miles ascenderán las personas que se hallan empleadas con este motivo. Un ejemplar que vale por muchos, me relevará de dar otra prueba. El hilado, tejido y pintado de los lienzos de algodón que se trabajan sólo en esta capital, mantiene a algunos millares de más almas de las doscientas cincuenta y seis que se le avisa a V. E.; como lo persuade eficazmente ya la reflexión del aumento de algunos miles de tercios de algodón en rama que han entrado en ella cada año; y ya el estampado de 400 mil varas de indianillas azules que únicamente despachó Don Francisco Iglesias, en lo inmediato de 1799; sin hacer caudal de la consideración de ser México el centro de donde se reparten las habilitaciones de memorias para el surtimiento general de todo este reino.

Iba por remate a alabar el santo zelo con que la amabilidad de V. E. procura el bien común de la patria, cuando la religiosa modestia de V. E. me trajo a la memoria que ningún homenaje le es tan grato como el del humilde ruego que dirijo al todo poderoso, para que guarde a V. E. en las mayores felicidades muchos años. México, de marzo de 1800. Exmo Señor. José de Azarragoitia

Exmo. Señor Virrey Don Miguel José de Aranza. 
Real Tribunal del Consulado de Veracruz, 10 de octubre de 1810 AGNM, Instituciones Coloniales, Consulado, vol. 193, exp. 5, fs. 121-125.

Exmo. Señor., el Consulado de Veracruz ha recibido en fecha de 6 de agosto último, copia de la solicitud que ha entablado el apoderado del de Manila, pretendiendo se le conceda permiso para armar dos o tres expediciones mercantiles con destino a este reino que la Real Audiencia gobernada se sirvió dirigir a este cuerpo, a fin de que exponga de que se le ofrezca y parezca según lo pedido por los Señores Fiscales. Cumpliendo este Tribunal con dicha superior determinación y conferenciándose sobre este importante asunto en Junta de gobierno celebrada en 7 del pasado, con cuanta reflexión exige una materia de tanta gravedad, manifiesta a V. E. atentamente lo que sigue:

En primer lugar, que aun cuando se introdujesen a este reino en las naves procedentes de la Península algunos géneros asiáticos, es de considerarse que son de ningún momento, en comparación de las que se pretenden extraer del puerto de Manila; que por esta vía producen algún fomento al comercio de España, y que son mayores los derechos que pagan los que se reciben en el Veracruz, que los que vienen por Acapulco.

Lo segundo que surtiéndose esta Nueva España de la gran porción de lienzos y demás géneros asiáticos procedentes de $\mathrm{Ma}$ nila de que habían de componerse sus cargamentos, perjudicarían al consumo tanto de las fábricas de España como de los de las potencias amigas de Europa que se conduzcan de la Península, arruinando enteramente su comercio, resentido ya en la presente triste época, con los quebrantos que le ha hecho experimentar a las consecuencias de una guerra tan sangrienta, desoladora y tenaz como es la que sostiene la Monarquía en defensa de sus religión, su rey y de su libertad; con el aditamento de los daños que sufre en la navegación a las Américas, por los apresamientos, robos y saqueos, que toleran de los corsarios franceses. 
Tan estrechas y dolorosas circunstancias exigen necesariamente del gobierno que aplique todo el lleno de su protección a favor de los negociantes de España, no solamente porque no se acabe nuestro giro nacional, sino con presencia de que son los únicos que pueden suministrar algunos prontos socorros en las frecuentes urgencias en que se halla el estado para mantener respetables ejércitos que contengan la fuerza de los contrarios y que salven a la patria de la opresión en que la ha puesto la perfidia y tiranía del perverso Bonaparte.

Tercero, que faltaría este Consulado y los demás de la Nueva España a los encargos que les ha hecho el Soberano, si en lugar de proteger la agricultura y la industria de estos dominios se franquease y condescendiese a una solicitud que acabaría con ambos interesantes ramos, que son las fuentes de la prosperidad de este reino y ocupación a sus habitantes que les facilita su precisa subsistencia, que sufren las cargas que les compete y que contribuyen con sus abundantes derechos al Real Erario.

El consulado habla en esta materia con unos conocimientos y datos tan seguros como que no habrá hombre de medianos conocimientos que haya tocado palpablemente por la experiencia lo mucho que perjudica a los cosecheros de algodón, tocantes de las telas ordinarias y de común uso en estos países, para el surtimiento de la que los lienzos de igual clase de la India que vienen en la Nao que anualmente arriba a Acapulco. Bien es general el conocimiento del sumo atraso en que pusieron a las mismas [...] las expediciones agraciadas en el tiempo de la última guerra con la Nación inglesa abatiéndose el precio de los algodones, a términos de no costearse sus siembres y hundido los telares de mantas, rebosos y demás manufacturas de esta clase a un número muy pequeño, en que subsisten hasta del día, condenando a perecer de muchas familias y a unos vasallos laboriosos y útiles a la sociedad y el estado.

Pues si estas fatales consecuencias han resultado de la expedición anual del galeón de Acapulco y de las agraciadas que quedan referidas ¿cuáles serán las que se originasen de la gracia que solicita el apoderado de aquel comercio, para que se multi- 
pliquen los productos asiáticos en dos o tres expediciones cada año? Llevar a su último exterminio el ramo de agricultura e igualmente las fábricas de tejidos de algodón; dejar sin trabajo una gran proporción de brazos sobre los medios que hay sin aplicación en este reino; difundirá por todas partes la pobreza y por último ocasionará que se aumenten los robos y delitos que precisamente conduce la ociosidad popular que tanto perjudica a la pública [...].

Lo cuarto, que los fundamentos en que apoya su pretensión el apoderado de Manila no merecen la menor atención: porque aun dado por [...] haya una real orden que permita a las Islas Filipinas duplicar su expedición a raíz de que la guerra altere el sistema mercantil y la navegación nacional, debería en la mente del Soberano a ampliar aquel comercio esta gracia. Si es así que la que actualmente sostiene la monarquía contra el tirano de la Europa no impide el tráfico de las naves de España y de América, como lo acreditan las expediciones que llegan a este puerto y a los demás de los dominios de Indias; luego no estamos en el caso a que se contrate la expresada real orden: y en cuanto a que no hay ley que prohíba semejante solicitud, es bien notorio y claro que se oponen a ella las del código indiano, cuya observación ha recomendado últimamente el supremo consejo de Regencia por Real Cédula de 27 de junio de este año; a que se agrega que los males que pudiesen experimentar dichas islas no tienen comparación ni el menor átomo de semejanza con los que sufre la Madre Patria; y debiendo poner nuestro mayor cuidado y esmero en proporcionarle los socorros que tan ingentemente necesita, se le privarían de los que puede franquearle el comercio con su América, que se dislocaría y anonadaría si se accediese por el superior gobierno a la indicada solicitud.

Y últimamente que siendo el regular producto de la Nao que de Manila viene anualmente de Acapulco el de tres millones de pesos, los mismos que se extraen de este puerto en plata acuñada; y pasando al Asia se sepultan en aquellos países, sin que vuelvan a salir de ellos. Es visto que si fuesen tres las expediciones se llevarían nueve millones, los cuales se quitaban para siempre 
de la circulación interna de estas provincias; y de las de España, causando un trastorno general al estado, con cuyo golpe fenecería el comercio y la navegación de la Península en su presente y lamentable situación; la que, sin embargo, no impide que se surtan por su conducto esta y las demás colonias de los frutos y efectos europeos que necesita, para sus ordinarios consumos como lo demuestran los ricos cargamentos que se han recibido y están recibiendo con los que se halla surtida esta Nueva España.

Por estas fundamentales, claras y positivas razones, no puede menos este Consulado que suplicar a V. E. se sirva no acceder absolutamente a la pretensión que ha entablado el apoderado de los manilos; y que dignándose aplicar sus vice regias facultades a beneficio de estas dilatadas provincias que ha tenido a bien el rey confiar con acierto a su celo, proteja su agricultura y artes, para que tomen el incremento de que son susceptibles su beneficio general de la Monarquía. Si no teniendo hasta ahora apoyo los fabricantes, en esmerarse en hacer cotonías, mantelerías y otras ropas de toda clase que no pueden todavía entrar en competencia con las inglesas por su abundante baratura. Puede dudarse que sostenidos y ayudados por el Soberano e igualmente por los consulares llevarían sus obras a tal perfección que se evitaría el gasto de las extranjeras y toda especie, disminuyéndose por este medio mucha parte de la extracción de moneda a potencia, quedándose entre nosotros y sirviendo de estímulo y utilidad a las artes. Así lo conoce y cree conveniente este Tribunal y lo eleva a la Superior consulta de V. E. Confiando que será atendida esta genuina exposición, como que en muchos conducirá a la común felicidad de estas Provincias.

Consulado de Veracruz a 10 de octubre de 1810 Excelentísimo Señor virrey Don Francisco Javier Venegas. 


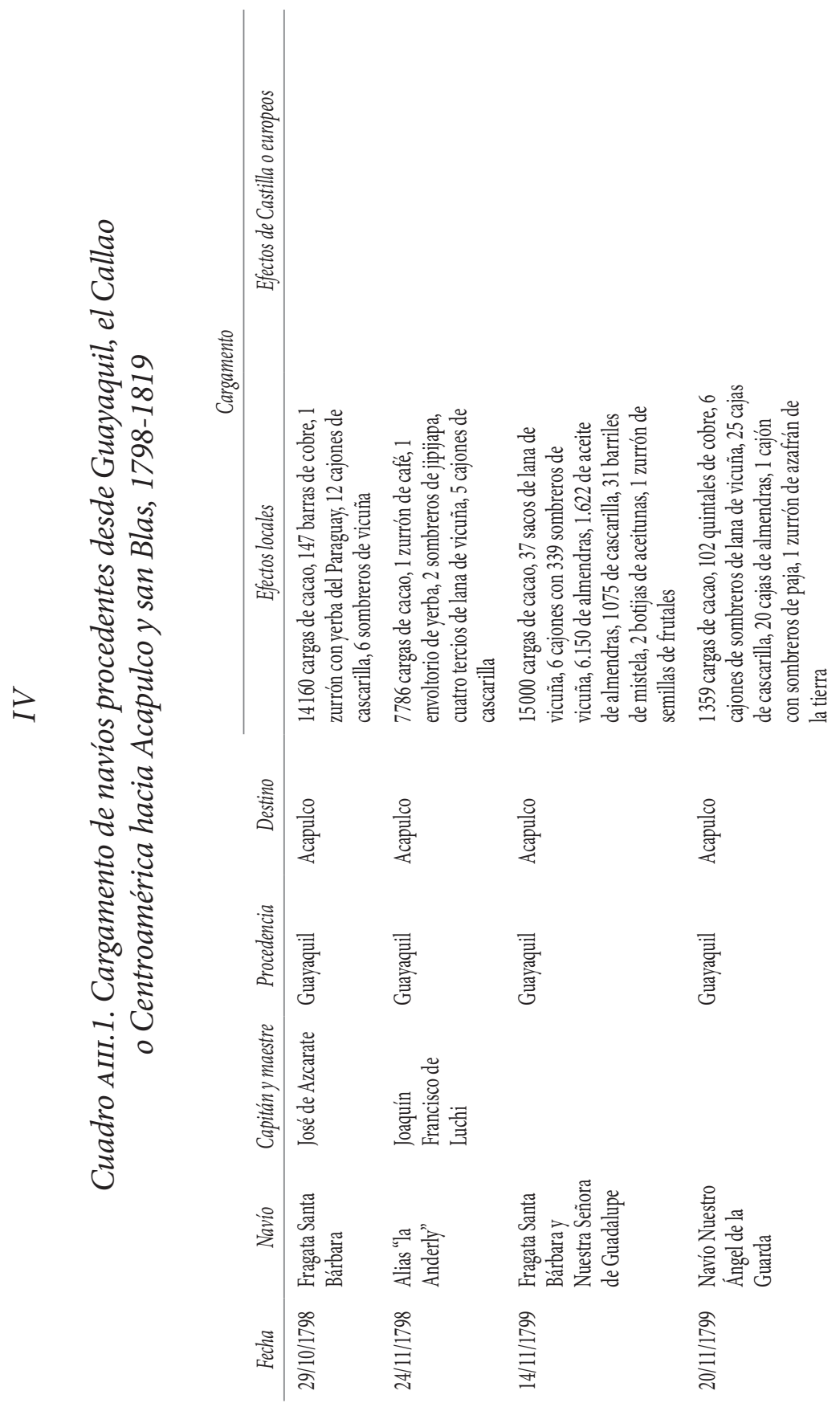




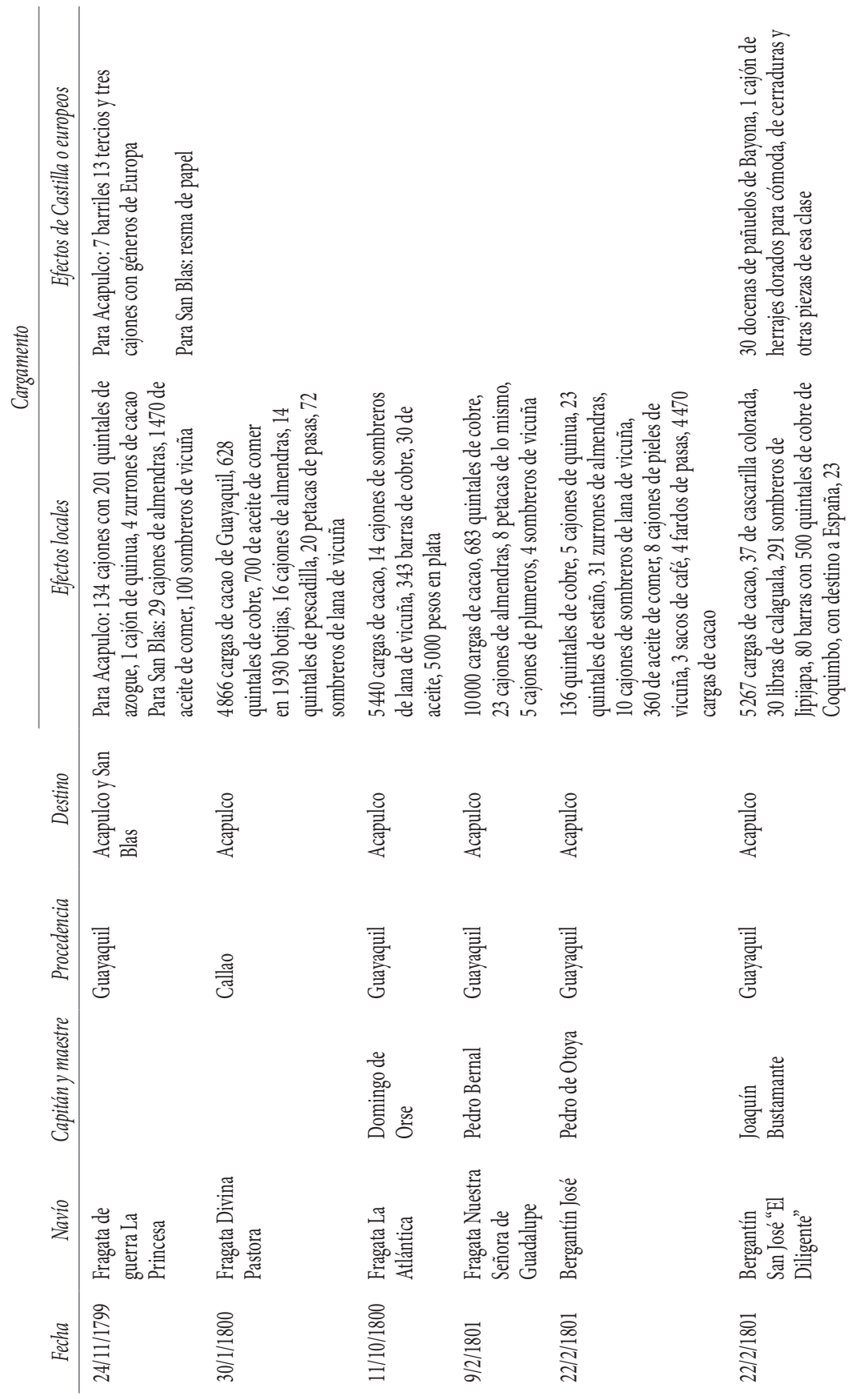




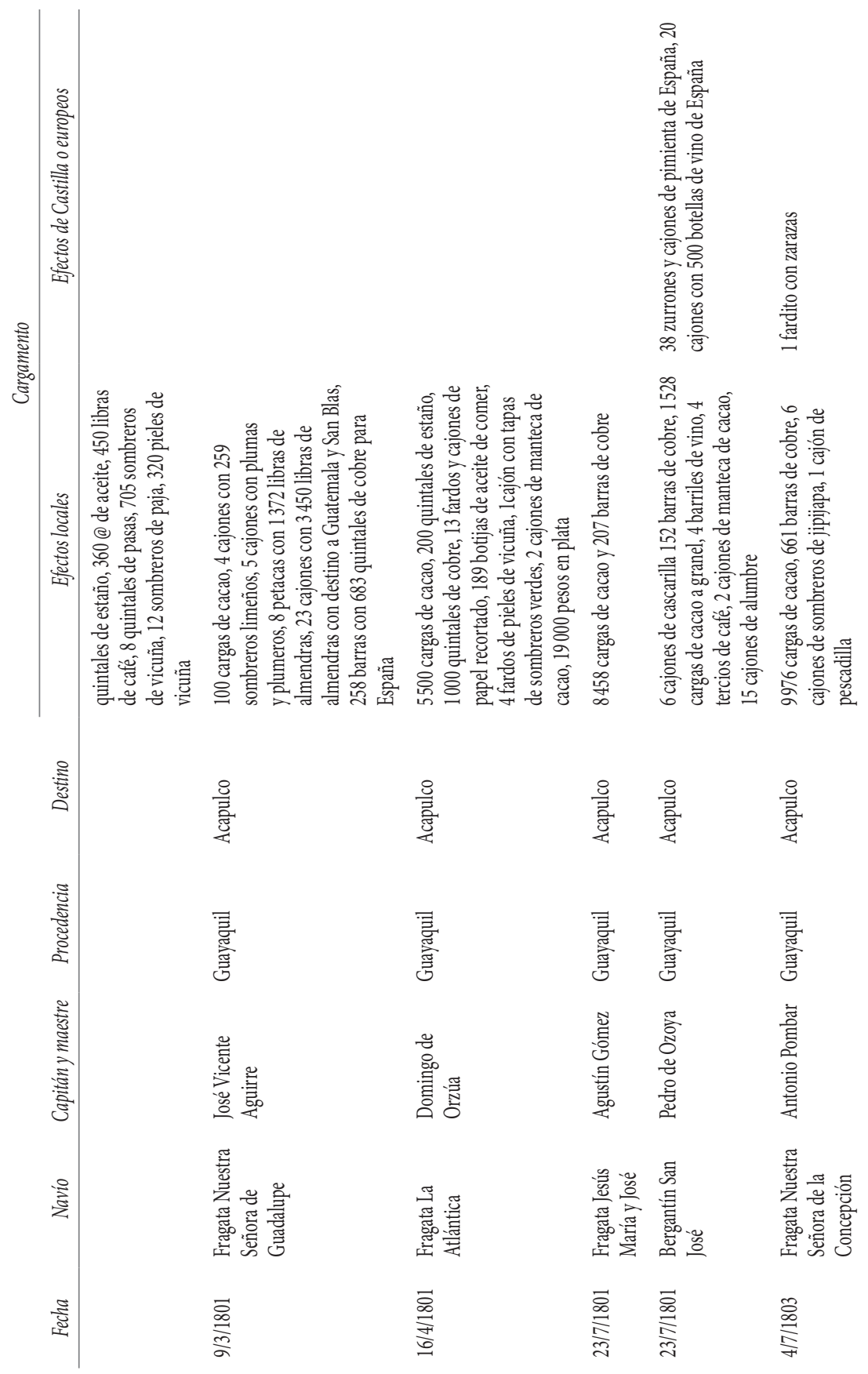




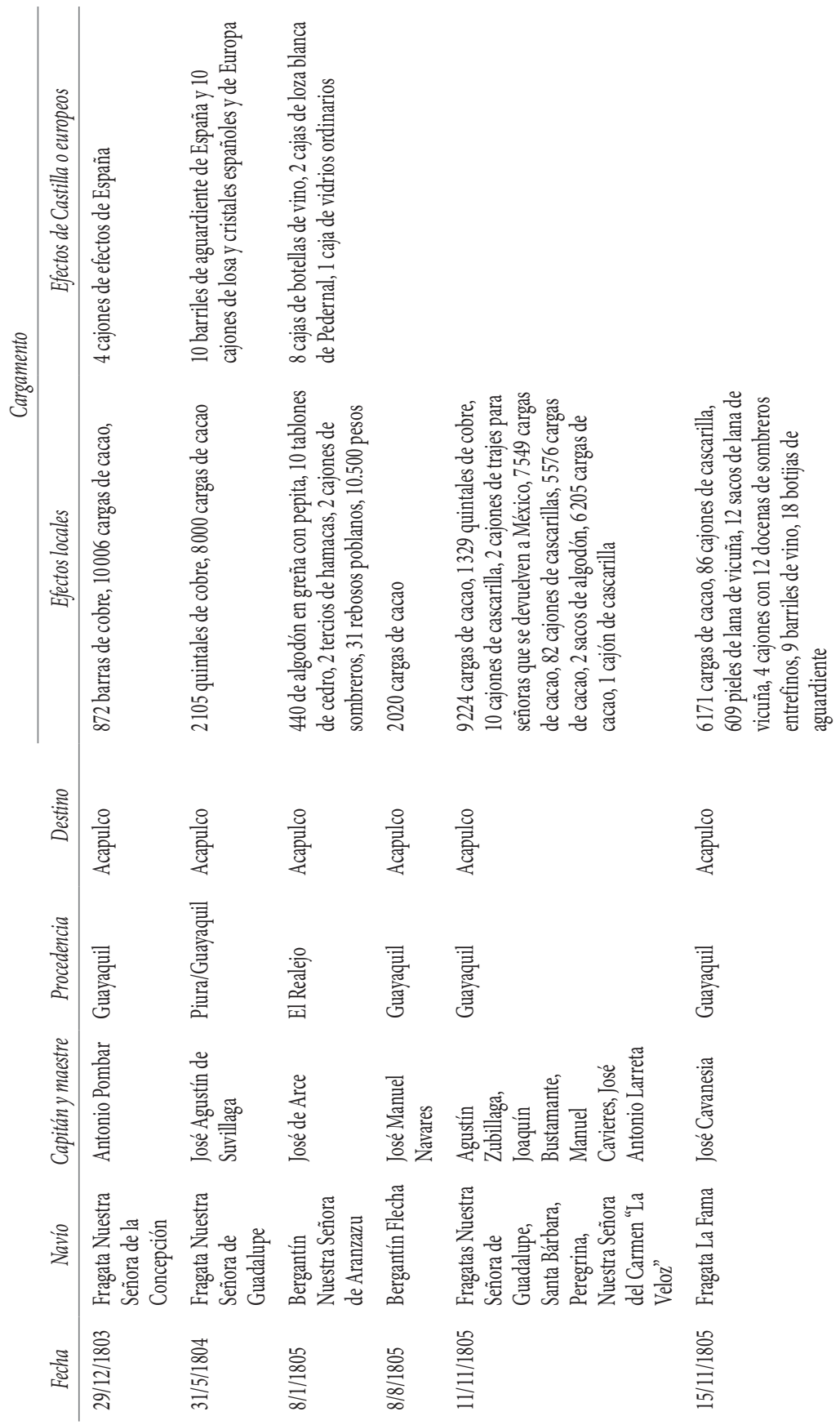




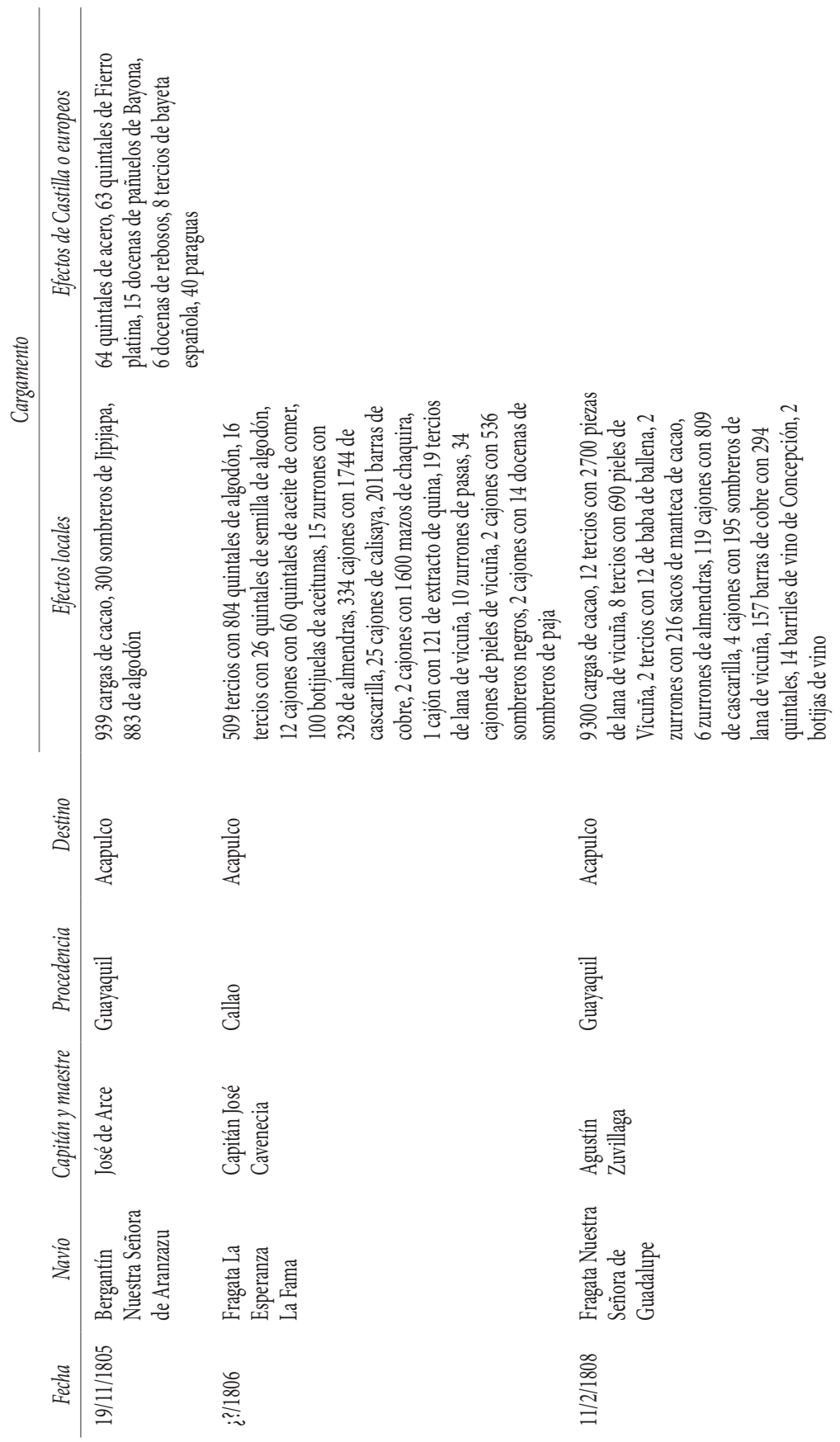




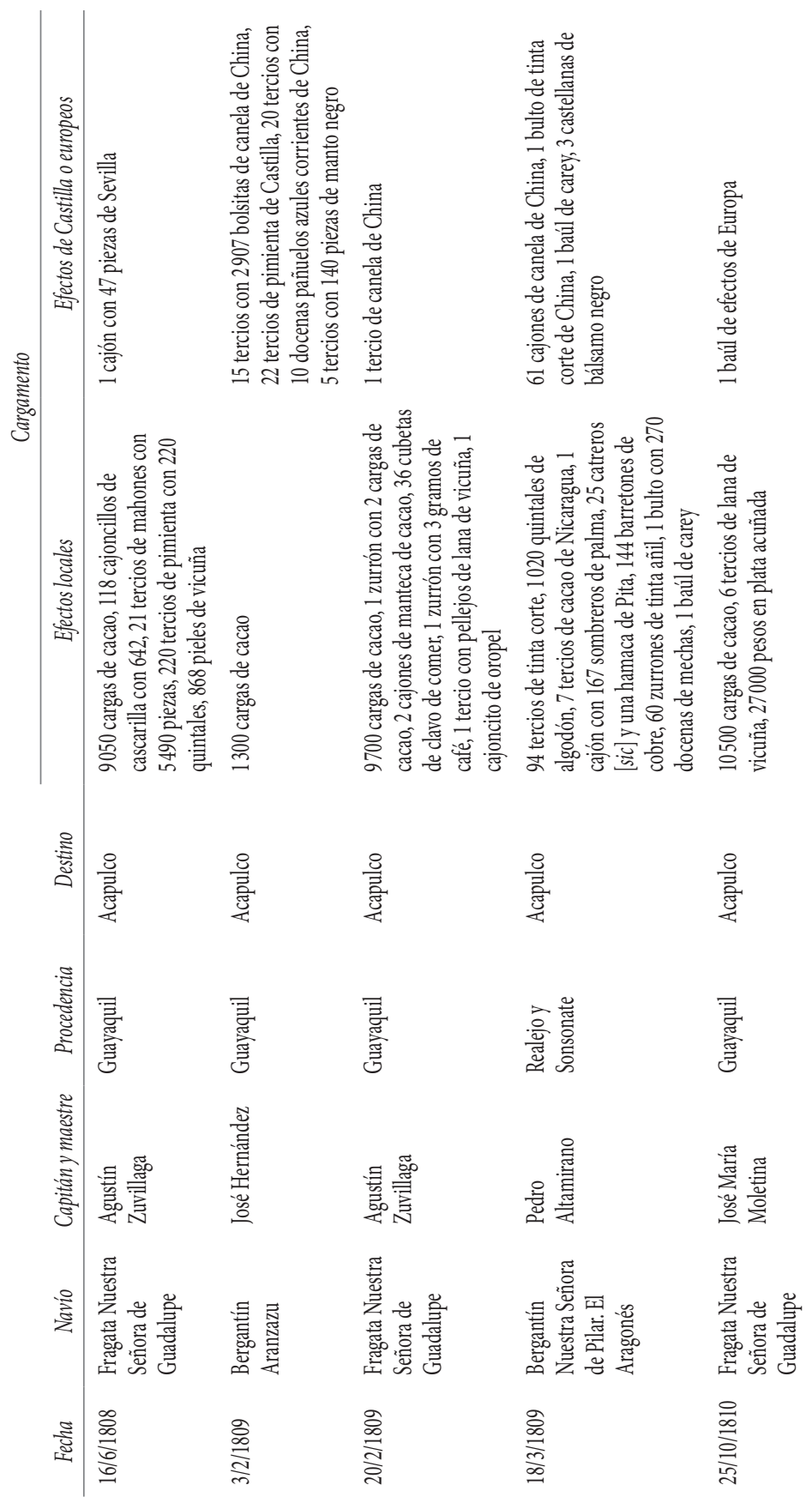




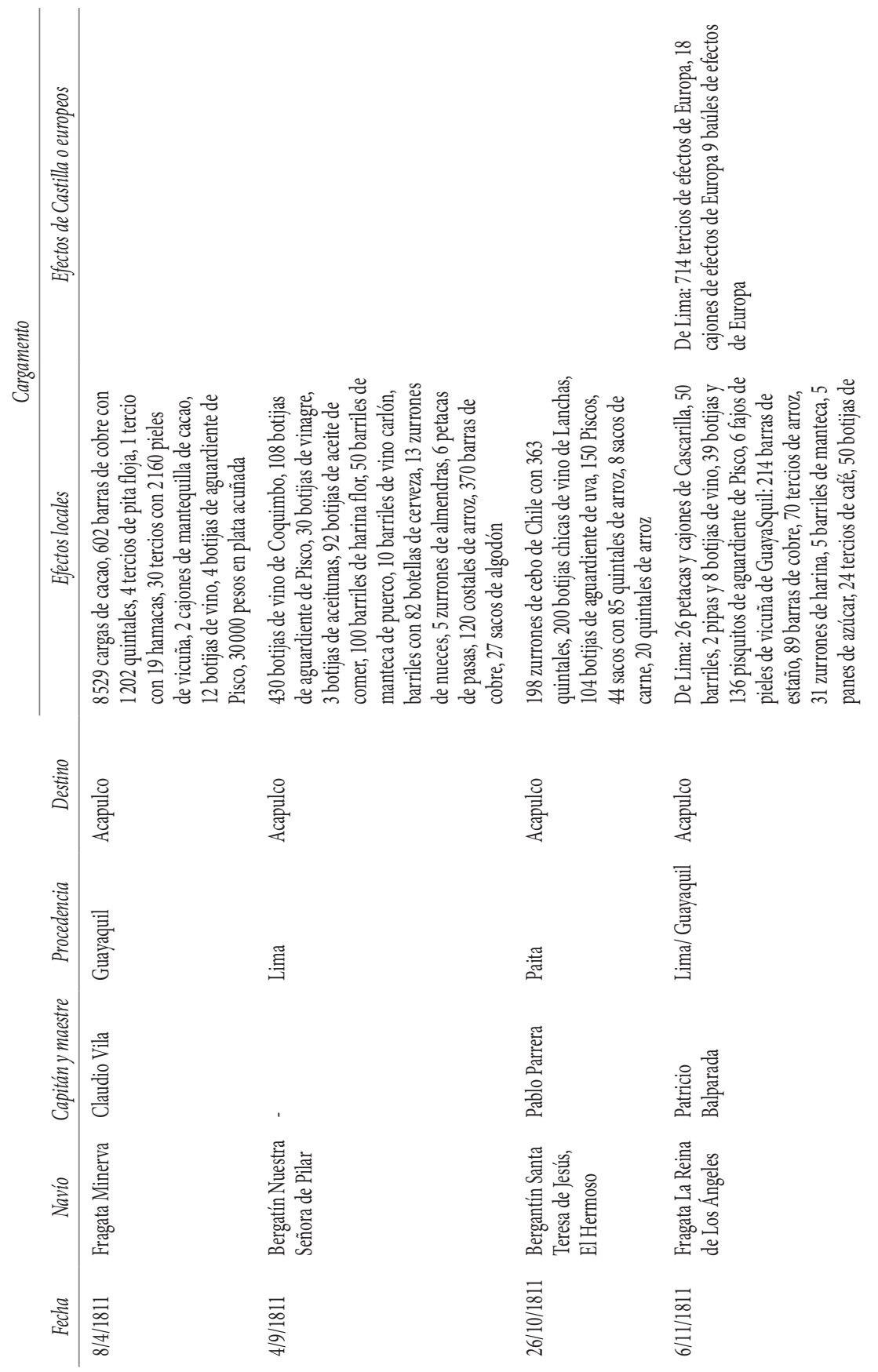




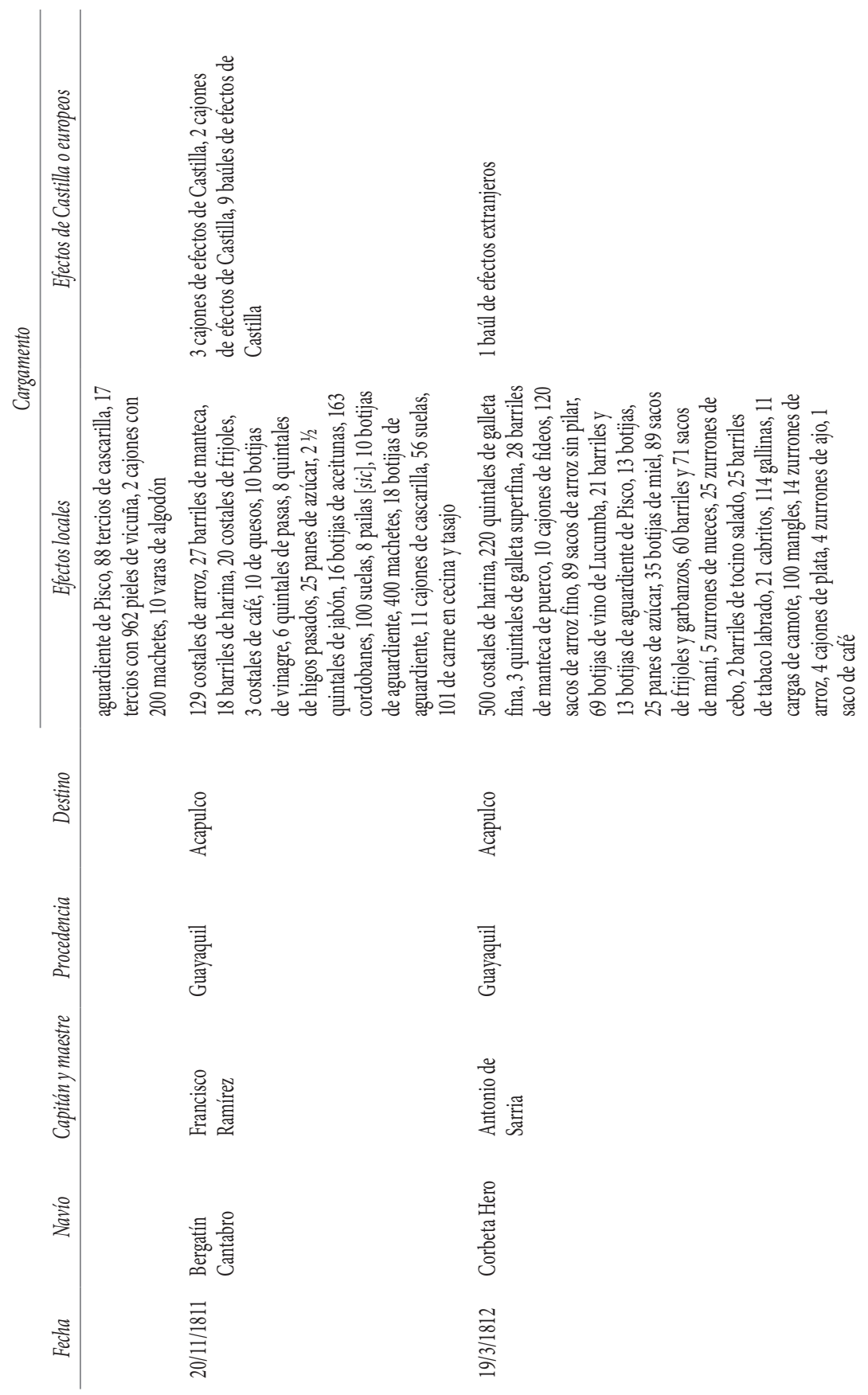




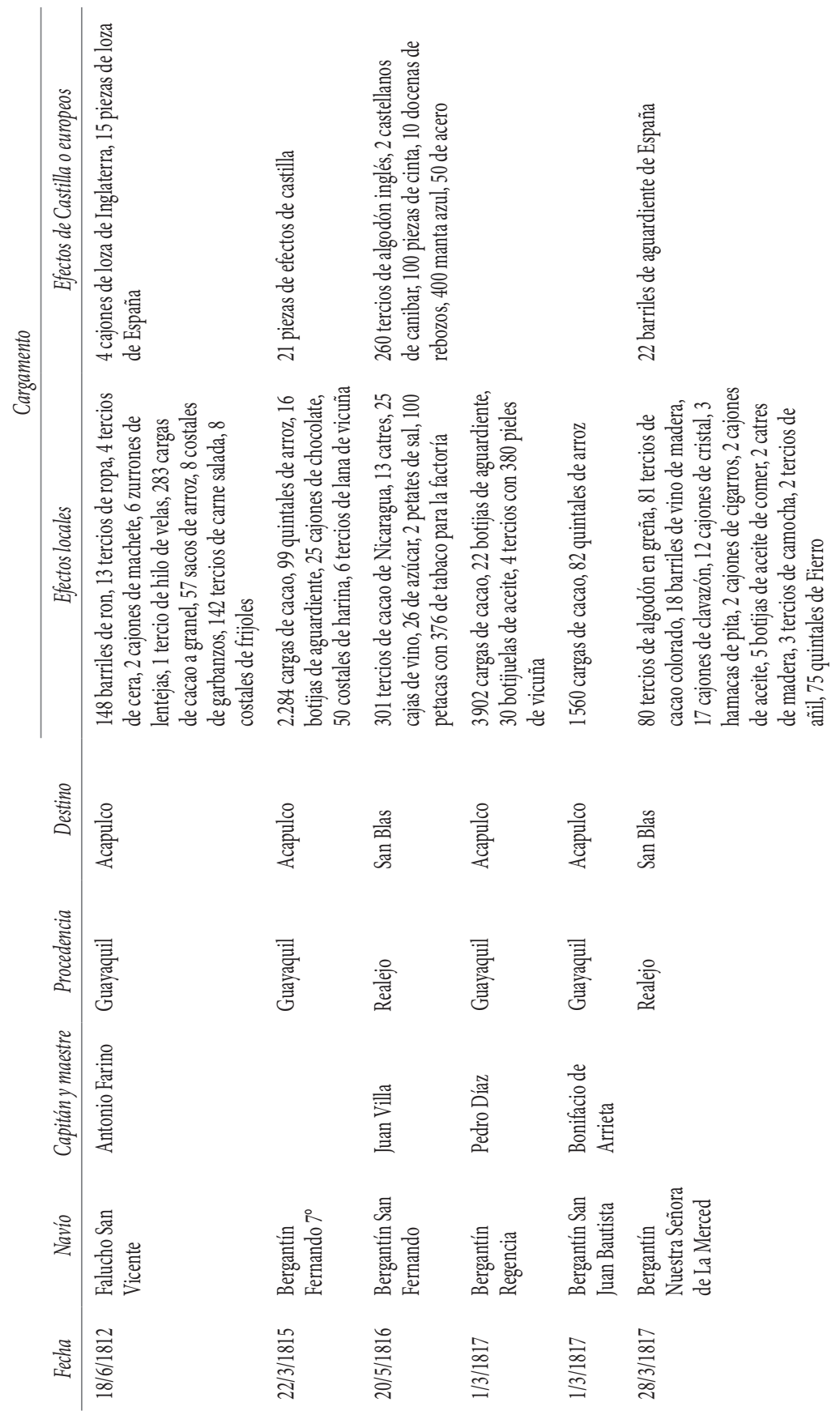




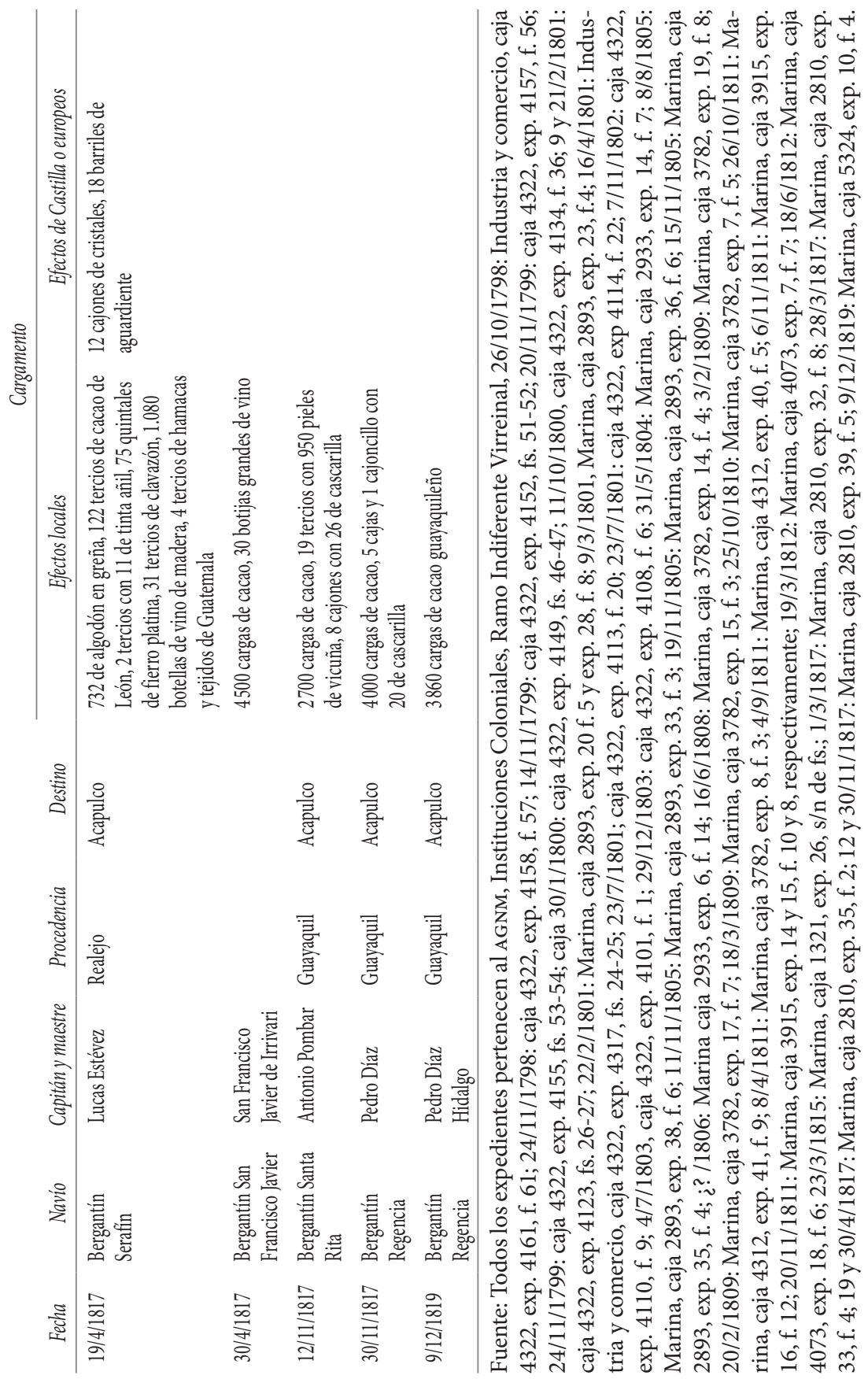




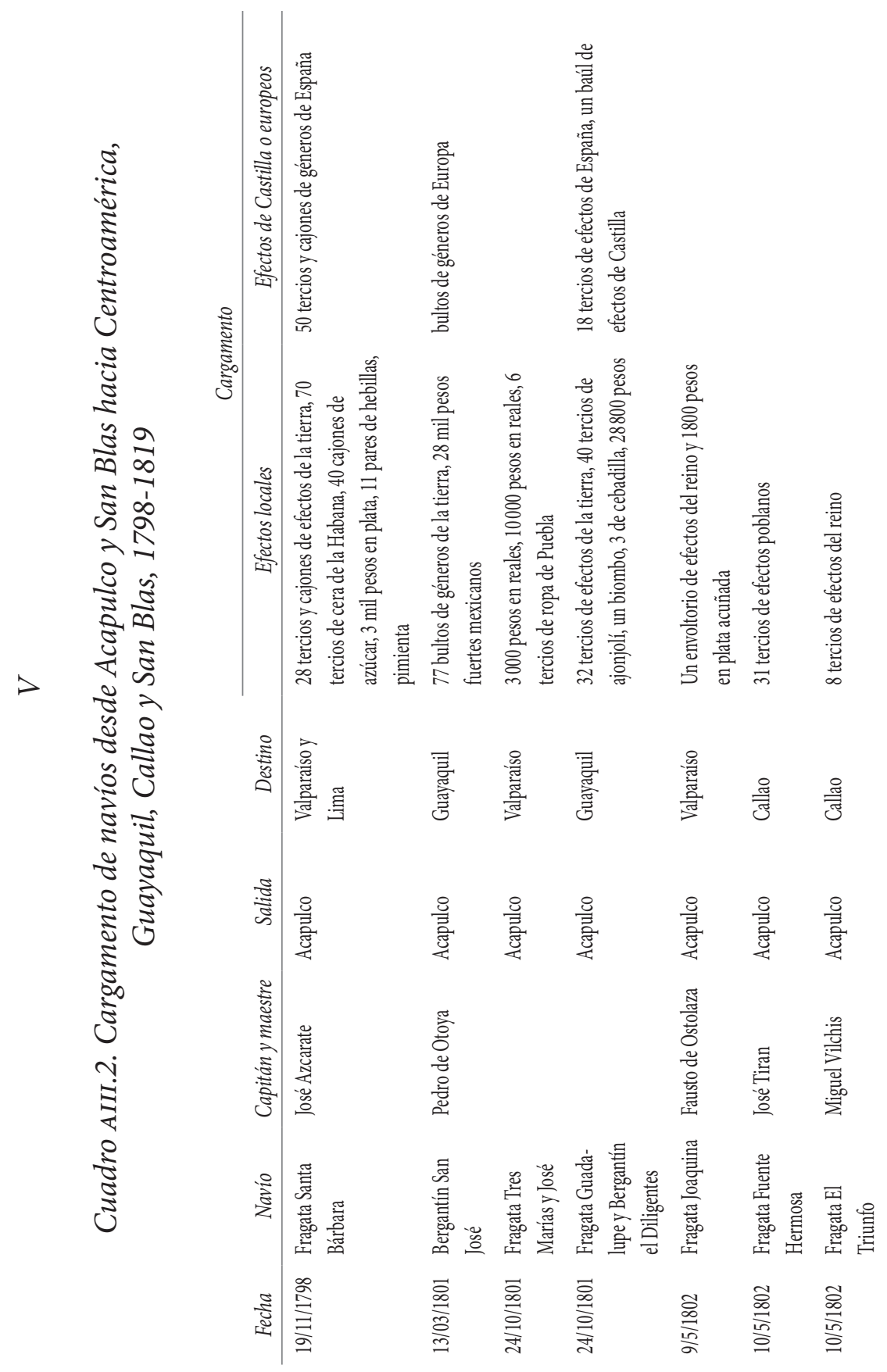




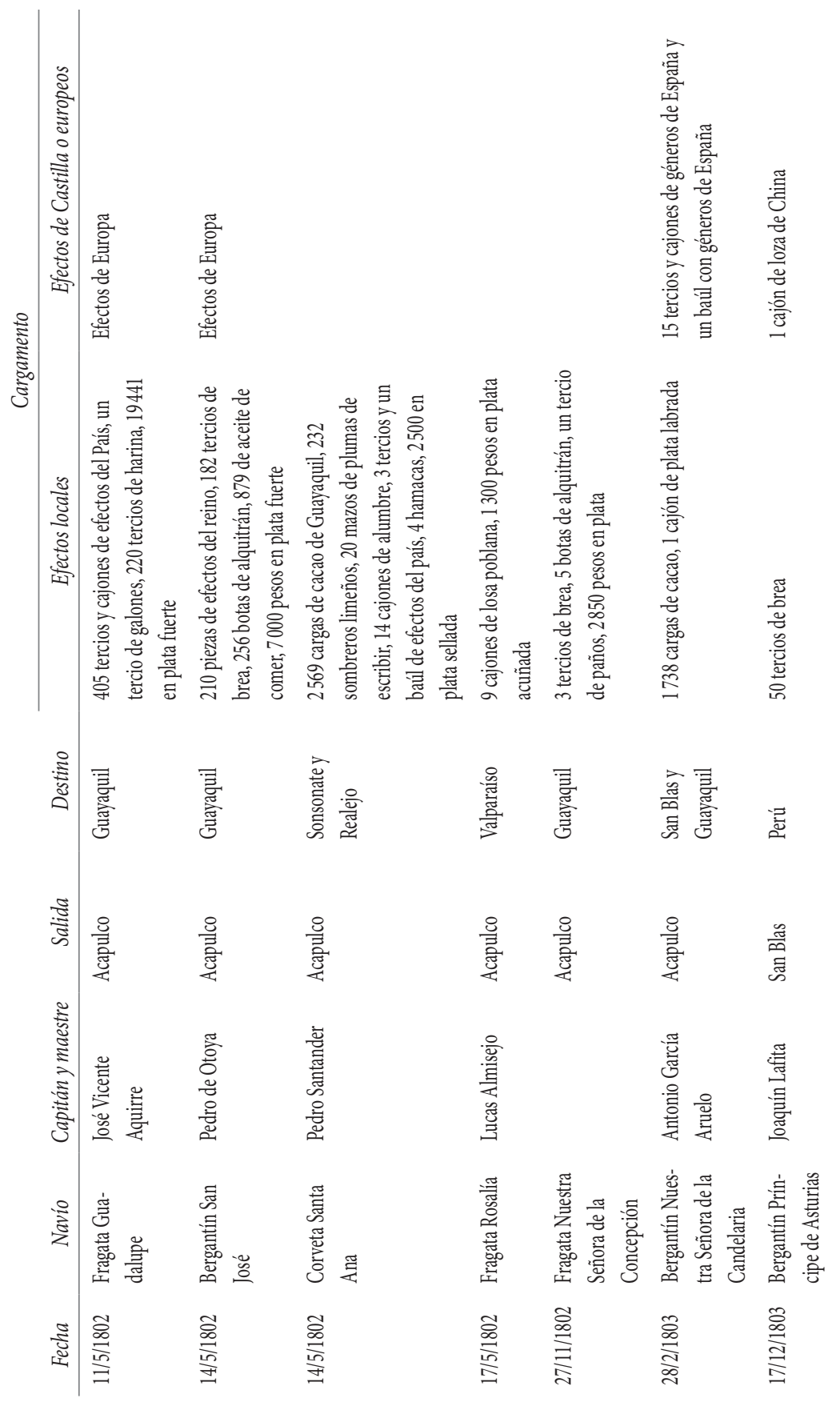




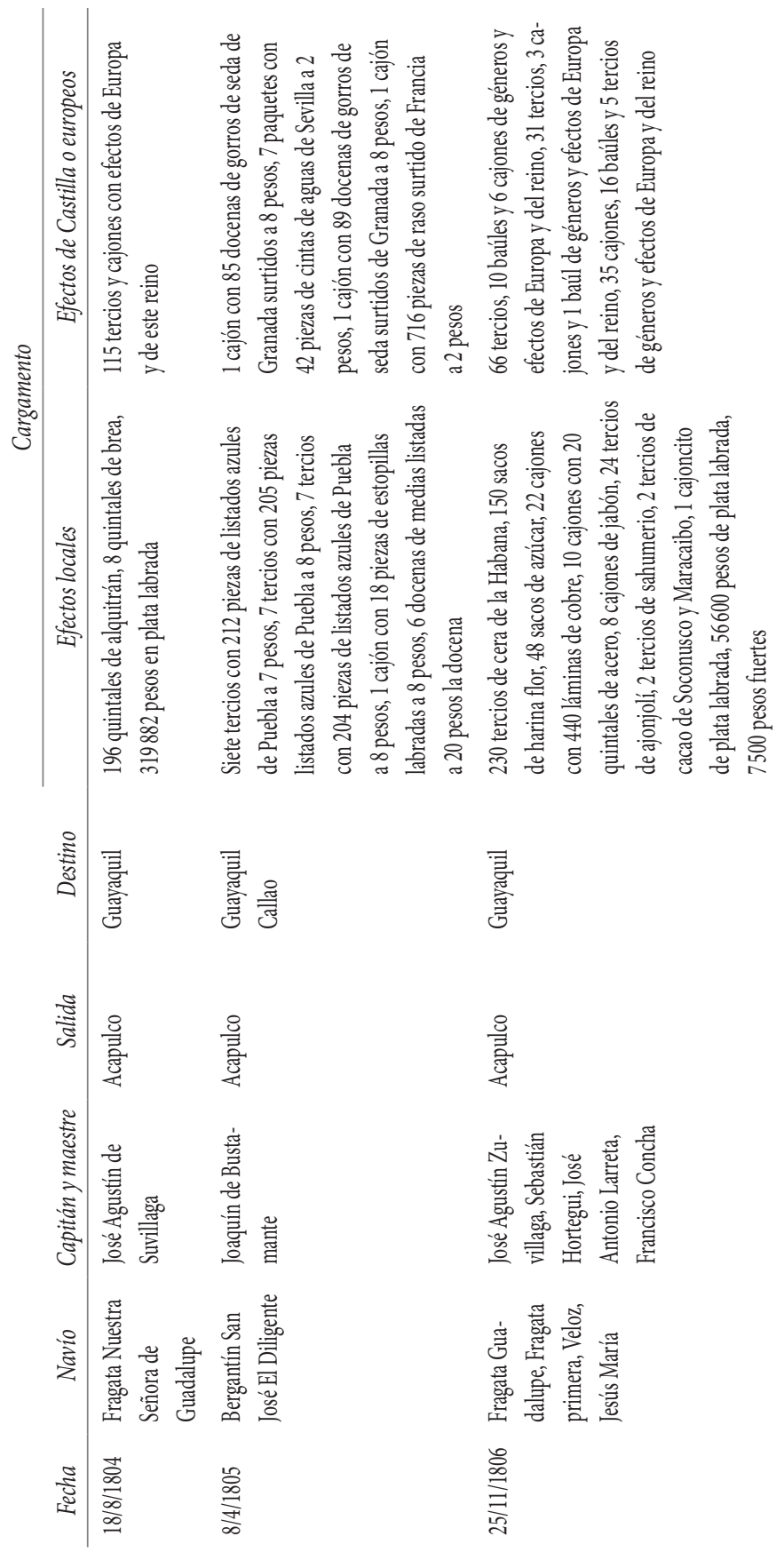




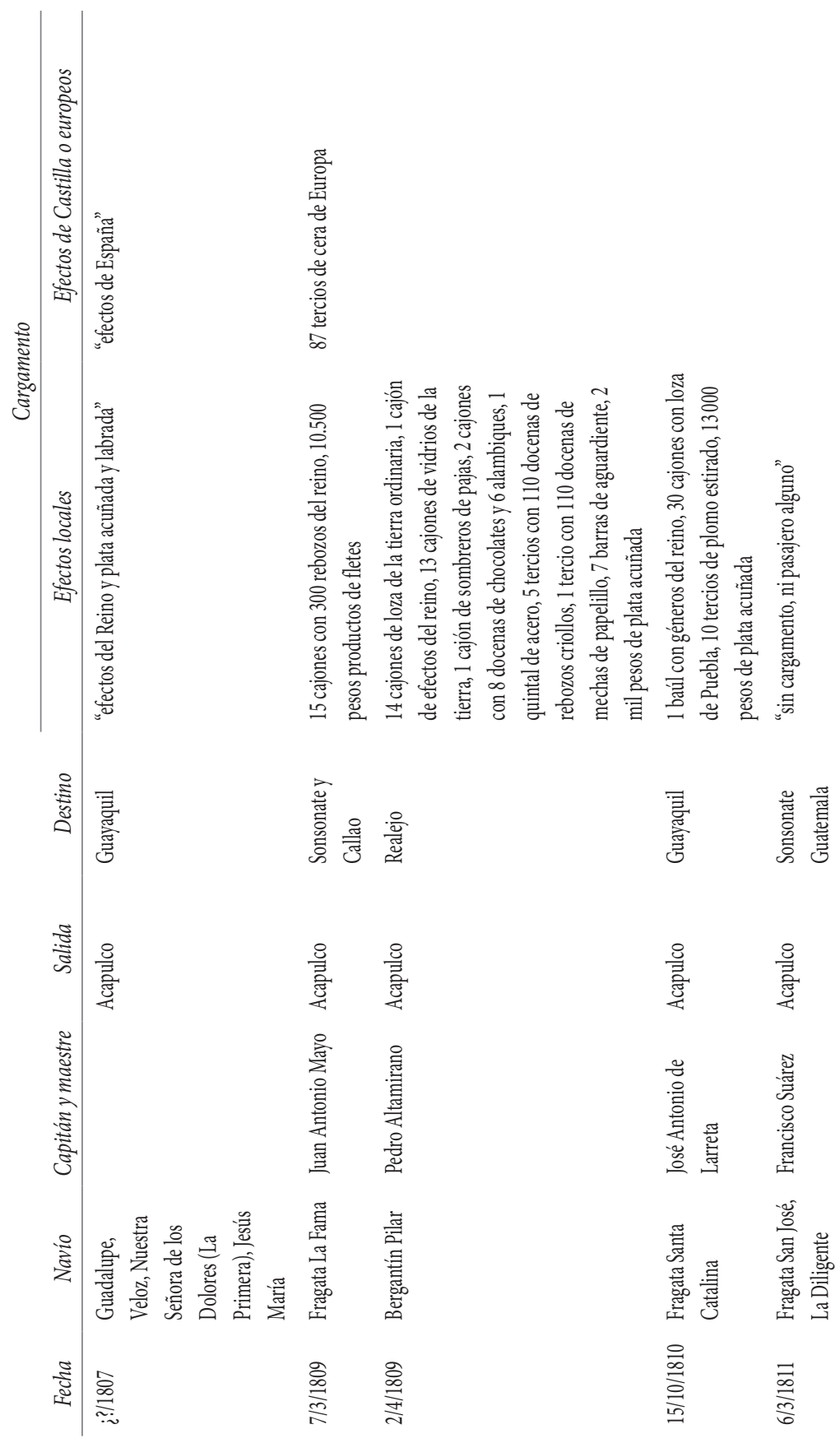




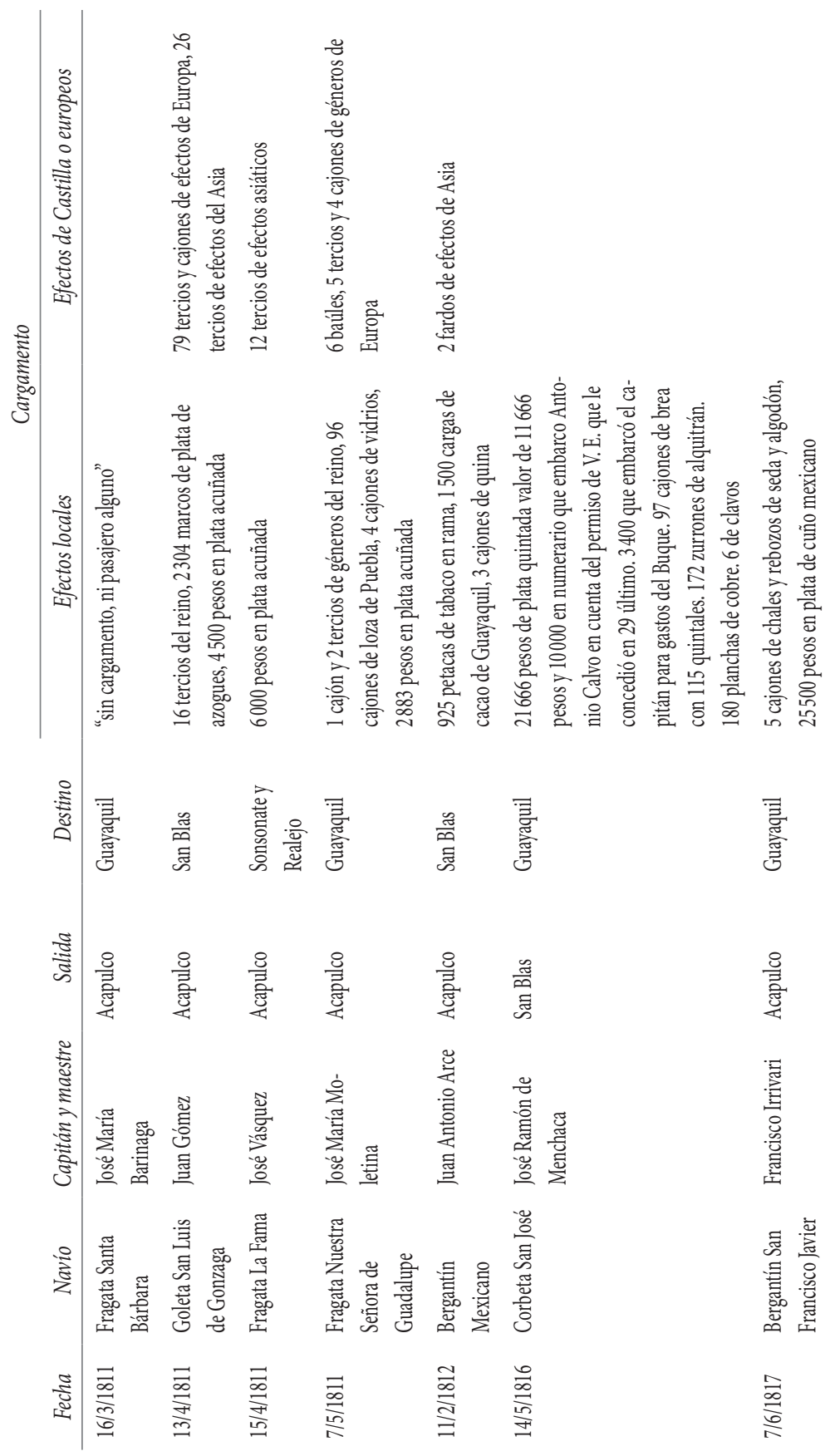




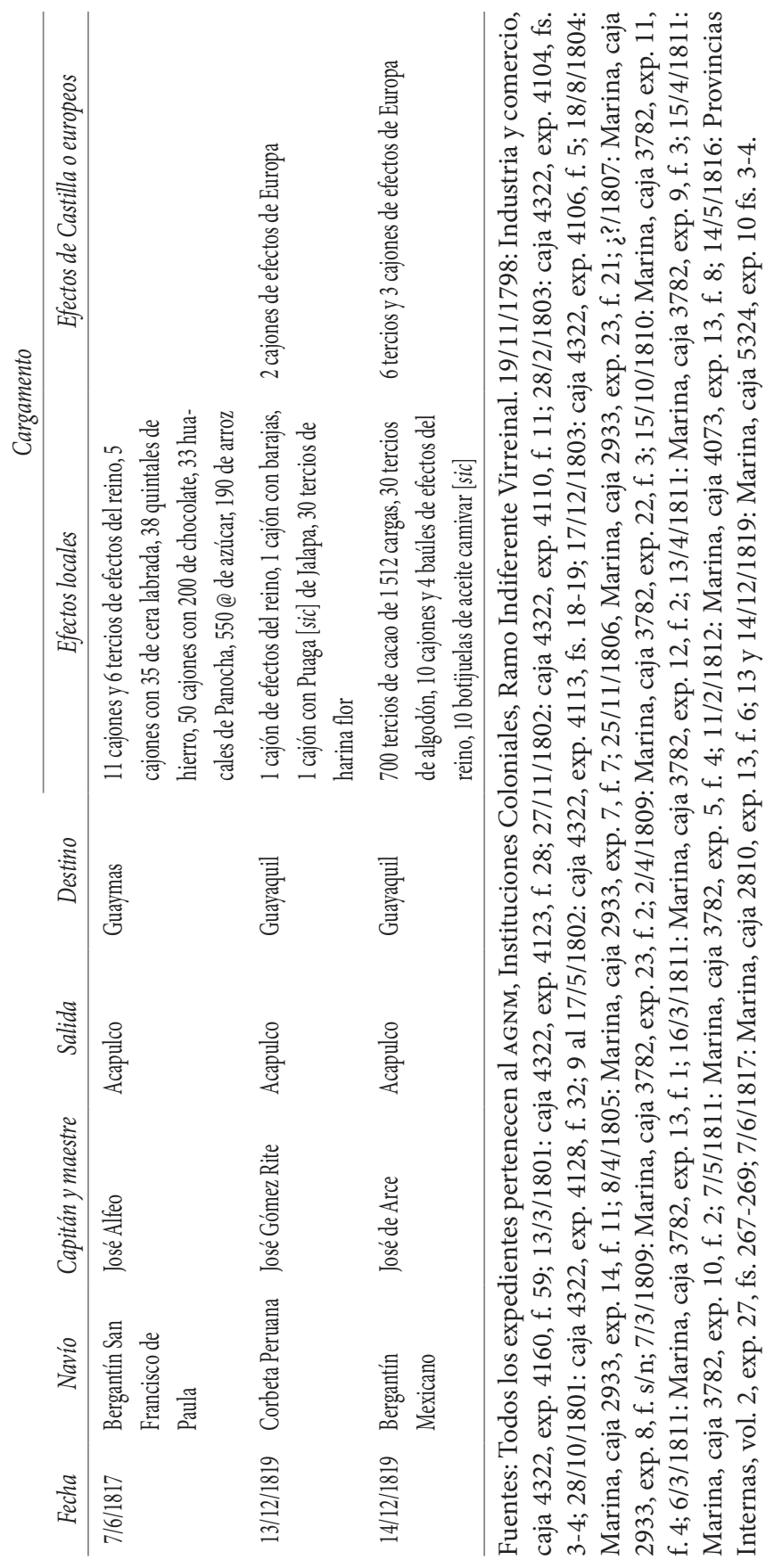





\section{REFERENCIAS}

\section{ArCHivos}

AGI Archivo General de Indias, Sevilla AGNM Archivo General de la Nación de México, Ciudad de México AGNP Archivo General de la Nación de Perú, Lima AHCIS Archivo de los Jesuitas de la Provincia de Cataluña AHNM Archivo Histórico Nacional de Madrid BPRM Biblioteca del Palacio Real de Madrid, Madrid BDHE Biblioteca Digital Hispánica de la Biblioteca Nacional de España

FUENTES PRIMARIAS Y BIBLIOGRAFÍA

Alamán, Lucas [1850] (1985)

Historia de México. Desde los primeros movimientos que prepararon su Independencia en el año de 1808 hasta la época presente, México, Fondo de Cultura Económica/Instituto Cultural Helénico.

Alcedo y Herrera, Dionisio (1883)

Piraterías y agresiones de los ingleses y de otros pueblos de Europa en la América Española. Desde el siglo XVI al XVIII, publicadas por Justo Zaragoza, Madrid, Imprenta Manuel Hernández.

Aldana Rivera, Susana (1987)

"Esbozo de un eje de integración: el comercio Piura-Loja-Cuenca", Ponencia presentada en el $1^{\text {er }}$ Seminario Internacional de 
Historia Latinoamericana del Consejo de Integración Cultural Latinoamericano, Lima, 1987.

Alfonso Mola, Marina (2014)

"El tráfico comercial hispano en el Pacífico en tiempos de las independencias", en Rafael Sagredo Baeza y Rodrigo Moreno Jeria (coords.), El Mar del Sur en la historia. Ciencia, expansión, representación y poder en el Pacifico, Chile, Dirección de Bibliotecas, Archivos y Museos/Universidad Adolfo Ibánez/ Centro de Investigaciones Barros Arana, pp. 493-554.

Alfonso Mola, Marina y Martínez Shaw, Carlos (2013)

"La ruta del Cabo y el comercio español con Filipinas", en Salvador Bernabéu y Carlos Martínez Shaw (eds.), Un océano de seda y plata: el universo económico del Galeón de Manila, Sevilla, pp. 307-340.

(2009) "El comercio exterior de Manila bajo el decreto de Neutrales (1798-1801)", en Carlos Martínez Shaw y Marina Alfonso Mola (coords.), España en el comercio marítimo internacional (siglos XVII-XIX), Madrid, Universidad Nacional de Educación a Distancia, pp. 529-549.

(2000) "El galeón de Manila", La aventura de la historia, Madrid, Editorial Arlanza, núm. 26, pp. 58-65.

Álvarez, Luis Alonso (2016)

"El daño de la tierra en desfrutarla de plata. La polémica de la desmonetización en la carrera del mar del Sur, 1573-1593", en Carmen Yuste López y Guadalupe Pinzón Ríos (coords.), A 500 años del hallazgo del Pacífico. La presencia novohispana en el Mar del Sur, México, Universidad Nacional Autónoma de México, pp. 277-314.

(2013) "E la nave va. Economía, fiscalidad e inflación en las regulaciones de la carrera de la Mar del Sur", en Salvador Bernabéu y Carlos Martínez Shaw (eds.), Un océano de seda y plata: el universo económico del Galeón de Manila, Sevilla, Consejo Superior de Investigaciones Científicas (Colección Universos Americanos), pp. 25-84. 
(2007) "El impacto de las reformas borbónicas en las redes comerciales. Una visión desde el Pacífico hispano, 1762-1815”, en Antonio Ibarra y Guillermina del Valle Pavón (coords.), Redes sociales e instituciones comerciales en el imperio español, siglos XVIII a XIX, México, Instituto de Investigaciones José María Luis Mora/Facultad de Economía-Universidad Nacional Autónoma de México, pp. 187-213.

Álvarez de Abreu, Antonio [1736] (1977)

Extracto historial del comercio entre China, Filipinas y Nueva España, en Carmen Yuste (comp.), México, Instituto Mexicano de Comercio Exterior, 2 tomos.

ANDERSON, Rodney (1983)

Guadalajara a la consumación de la independencia: estudio de su población según los padrones de 1821-22, Guadalajara, Unidad Editorial.

Andrien, Kenneth (1985)

Crisis and Decline: The Viceroyalty of Peru in the Seventeenth Century, Albuquerque, University of New Mexico Press.

Aram, Bethany y Yun-Casalilla, Bartolomé (eds.) (2014)

Global Goods and the Spanish Empire, 1492-1824. Circulation, Resistance and Diversity, Palgrave, Macmillan, 2014.

Arcondo, Aníbal (1992)

El ocaso de una sociedad estamental. Córdoba entre 1700-1760, Argentina, Universidad Nacional de Córdoba.

Armitage, David (2002)

“Three Concepts of Atlantic History", en David Armitage y Michael J. Braddick (eds.), The British Atlantic World, Palgrave, Macmillan, pp. 11-27.

Assadourian, Carlos Sempat (1982)

El Sistema de la economía colonial. Mercado interno, regiones y espacio económico, Lima, Instituto de Estudios Peruanos.

(1979) "La producción de la mercancía dinero en la formación del mercado interno colonial”, en Enrique Florescano (comp.), 
Ensayos sobre el desarrollo económico de México y América Latina (1500-1975), México, Fondo de Cultura Económica, pp. 223-292.

Assadourian, Carlos Sempat y Palomeque, Silvia (2003)

"Las relaciones mercantiles de Córdoba (1800-1830). Desarticulación y desmonetización del mercado interno colonial en el nacimiento del espacio económico nacional", en Alejandra Irigoin y Roberto Schmit (eds.), La desintegración de la economía colonial: comercio y moneda en el interior del espacio colonial, 1800-1860, Buenos Aires, Biblos, pp. 151-209.

Attman, Artur (1989)

“The Bullion Flow from Europe to the East: 1500-1800”, en Eddy Van Cauwenberghe (ed.), Precious Metals, Coinage and the Changes of Monetary Structures in Latin-America, Europe and Asia, Lovaina, Leuven University Press, pp. 65-68.

Atwell, William (2005)

"Another Look at Silver Imports into China, ca. 1635-1644", Journal of World History, vol. 16, pp. 467-489.

(1982) "International Bullion Flows and the Chinese Economy circa 1530-1650", Past and Present, Oxford University Press, núm. 95, pp. 68-90.

BAILly, Felipe (1859)

Memorias de Los Virreyes que han gobernado el Perú durante el tiempo del coloniaje español, Lima, Librería Central de Felipe Bailly, tomo I.

BAKewell, Peter (1989a)

“La maduración del gobierno del Perú en 1560", Historia Mexicana, México, Centro de Estudios Históricos-El Colegio de México, vol. 39, núm. 1, pp. 41-70.

(1989b) Mineros de la Montaña Roja. El trabajo de los indios en Potosí. 1545-1650, Madrid, Alianza.

(1976) Minería y sociedad en el México colonial: Zacatecas 15461700, México, Fondo de Cultura Económica. 
BAquíjano CARrillo, José (1790)

"Disertación histórica y política sobre el comercio del Perú, en Jacinto Calero y Moreira (ed.), Prospecto del papel periódico titulado Mercurio Peruano, Lima, Imprenta Real de los Niños Expósitos, núm. 23, fs. 209-289.

BARratt, Glynn (1944)

Russia in Pacific Waters, 1715-1825, Vancouver/Londres, University of British Columbia Press.

BARRET, Ward (1990)

"World Bullion Flows, 1450-1800", en James D. Tracy (ed.), The Rise of Merchant Empires. Long Distance Trade in the Early Modern World, 1350-1750, Cambridge, Cambridge University Press, pp. 224-254.

BAYLY, Christopher (2010)

El nacimiento del mundo moderno, 1780-1914. Conexiones y comparaciones globales, Madrid, Siglo XXI.

BECKerT, Sven (2014)

Empire Of Cotton. A Global History, Nueva York, Alfred Knopf Publisher.

BERg, Maxine (2005)

Luxury and Pleasure in Eighteenth-Century Britain, Oxford, Oxford University Press.

BERnABÉu, Salvador (1992)

El Pacífico ilustrado: Del lago español a las grandes expediciones, Madrid, Mapfre.

Bernal, Antonio Miguel (2004)

"La carrera del Pacífico: Filipinas en el sistema colonial de la carrera de Indias", en Leoncio Cabrero (coord.), España y el Pacífico, Legaspi, tomo I, Madrid, Sociedad Estatal de Conmemoraciones Culturales, pp. 485-525.

(1992) La financiación de la carrera de Indias (1492-1824). Dinero, crédito en el comercio colonial español con América, Sevilla, Fundación El Monte. 
BERnECKER, Walther (1994)

Contrabando. Ilegalidad y corrupción en el México del siglo XIX, México, Universidad Iberoamericana.

(1989) "El poder de los débiles: acerca del debate sobre el desarrollo 'dependiente' de México en el siglo xix”, Revista Mexicana de Sociología, Visiones de México, México, vol. 51, núm. 2, pp. 377-411.

Bonialian, Mariano (2016a)

"Geopolítica y comercio colonial. El frustrado eje del Cabo de Hornos entre España y China", Jahrbuch für Geschichte, Hamburgo, Böhlau Verlag Köln Weimar Wien, 53, pp. 37-58.

(2016b) "La ropa de la China desde Filipinas hasta Buenos Aires. Circulación, consumo y lucha corporativa, 1580-1620", Revista de Indias, Madrid, Instituto de Historia, vol. LXxvi, núm. 268, pp. 641-672.

(2016c) "La seda China en Nueva España a principios del siglo XVII. Una mirada imperial en el Memorial de Horacio de Levanto", Revista de Historia Económica / Journal of Iberian and Latin American Economic History, I, pp. 1-25.

(2015) "Asiáticos en Lima a principios del siglo XviI", Bulletin de l'Institut Français D’Études Andines, Lima, Perú, 44, núm. 2, pp. 205-236.

(2014) China en la América colonial. Bienes, mercados, comercio y cultura del consumo desde México hasta Buenos Aires, México/ Buenos Aires, Instituto Mora-Biblos.

(2012) El Pacífico hispanoamericano. Política y comercio asiático en el Imperio español (1680-1784). La centralidad de lo marginal, México, El Colegio de México.

(2011) "México: epicentro semiinformal del comercio hispanoamericano, 1680-1740", Revista de Historia Económica, México, Instituto Mora, núm. 35, pp. 7-28.

Bonilla, Heraclio (1972)

"La coyuntura comercial del siglo XIX en el Perú", Desarrollo Económico, Buenos Aires, Argentina, vol. 12, núm. 46, pp. 305331. 
BoraH, Woodrow (1975)

Comercio y navegación entre México y Perú en el siglo XVI, México, Instituto Mexicano de Comercio Exterior.

Boxer, Charles (1970)

"Plata es sangre: Sidelights on the Drain of Spanish-American Silver in the Far East, 1550-1700" Philippine Studies, vol. 18, núm. 3, pp. 457-478.

BRAUdEL, Fernand (1991)

"Historia y ciencias sociales. La larga duración", Escritos sobre Historia, México, Fondo de Cultura Económica, pp. 39-74.

Burne Goebel, Dorothy (1938)

"British Trade to the Spanish Colonies, 1796-1823", The American Historical Review, vol. 43, núm. 2, pp. 288-320.

Busto Ibarra, Karina (2008)

"El espacio del Pacífico Mexicano: puertos, rutas, navegación y redes comerciales, 1848-1927”, tesis de doctorado, México, El Colegio de México.

Canabrava, Alice (1984)

O comercio portugués no Río da Prata. 1580-1644, São Paulo, Universidad de São Paulo.

Cañizares-Esguerra, Jorge y Seeman, Erik (eds.) (2006)

The Atlantic in Global History, 1500-2000, Nueva Jersey, Pearson/ Prentice Hall.

CAPPA, Ricardo (1890)

Estudios críticos acerca de la dominación española en América, parte tercera, Industria agrícola-pecuaria, vol. vi, Madrid, Gregorio del Amo.

Carabarín Gracia, Alberto (1984)

El trabajo y los trabajadores del obraje en la ciudad de Puebla 1700-1710, Puebla, Cuadernos de la Casa Presno. 
Cárdenas de la Peña, Enrique (1988)

Marina mercante, México, Secretaría de Comunicaciones y Transportes.

CÁrdenas Sánchez, Enrique (2003)

Cuando se originó el atraso económico de México. La economía mexicana en el largo siglo XIX, 1780-1920, Madrid, Biblioteca Nueva.

Carmagnani, Marcello (2012a)

"La organización de los espacios americanoss en la monarquía española (siglos XVI-XVIII)", en Óscar Mazín y José Javier Ruiz Ibáñez (eds.), Las Indias Occidentales. Procesos de incorporación territorial a las monarquías ibéricas, México, El Colegio de México, pp. 331-356.

(2012b) Las islas del lujo. Productos exóticos, nuevos consumos y cultura económica europea, 1650-1800, Madrid, Ambos Mundos/Marcial Pons.

(2000) Los mecanismos de la vida económica en una sociedad colonial. Chile (1680-1830), Santiago de Chile, Dirección de Bibliotecas, Archivos y Museos-Centro de Investigaciones Barros Arana, 2000.

Carmichael, W. L., Linton, George y Price, Isaac (1947) Textile Dictionary, La Grange, Callaway Mills.

Cava Mesa, Begoña (2016)

"Mirando hacia el Pacífico. José de la Cruz y la emergencia del puerto de San Blas", en Salvador Bernabéu, Carmen Mena García y Emilio Luque Azcona (coords.), Filipinas y el Pacífico. Nuevas Miradas, nuevas reflexiones, Sevilla, Universidad de Sevilla, pp. 235-258.

Cavieres, Eduardo (2003)

"Comercio, diversificación económica y formación de mercados en una economía en transición. Chile en el siglo XIx", en Alejandra Irigoin y Roberto Schmit (eds.), La desintegración de la economía colonial: comercio y moneda en el interior del espacio colonial, 1800-1860, Buenos Aires, Biblos, pp. 93-110. 
Chaunu, Pierre (1974)

Las Filipinas y el Pacífico de los Ibéricos. Siglos XVI-XVII-XVIII. Estadísticas y Atlas, México, Instituto Mexicano de Comercio Exterior [en francés 1960-1966].

(1960) "Veracruz en la segunda mitad del siglo xvi y primera del siglo xvir", Historia Mexicana, México, Centro de Estudios Históricos-El Colegio de México, vol. 9, núm. 4, pp. 521-557. (1955-59) Seville et Atlantique, 1500-1650, tomos IV, V viII, París, Libraire Armand Colin.

Cheesman, Roxanne (2011)

El Perú de Lequanda. Economía y comercio a fines del siglo XVIII, Lima, Instituto de Estudios Peruanos/Fundación M. J. Bustamante de la Fuente.

Chiaramonte, José Carlos (1981)

"En torno a la recuperación demográfica y la depresión económica novohispanas durante el siglo xvII", Historia Mexicana, México, Centro de Estudios Económicos-El Colegio de México, vol. 30, núm. 4, pp. 561-604.

Christelow, Allan (1942)

"Contraband Trade between Jamaica and the Spanish Main, and the Free Port Act of 1766", Hispanic American Historical Review, vol. 22, pp. 309-343.

Cieza de León, Pedro de [1871] (2005)

Crónica del Perú. El señorío de los Incas, prólogo Franklin Pease, Caracas, Biblioteca Ayacucho.

Clayton, Lawrence (1975)

"Trade and Navigation in the Seventeenth-Century Viceroyalty of Peru", Journal of Latin American Studies, Cambridge, University Press, vol. 7, núm. 1, pp. 1-21.

COATSWORTH, John (1967)

"American Trade with European Colonies in the Caribbean and South America, 1790-1812", The William and Mary Quarterly, vol. 24, núm. 2, pp. 243-266. 
Commons, Áurea (1995)

“La población de Nueva España en 1790", Tempus, México, Facultad de Filosofía y Letras, Universidad Nacional Autónoma de México, núm. 3, pp. 7-111.

Contreras, Carlos (2015)

"Menos plata, pero más papas: consecuencias económicas de la independencia en el Perú", en Carlos Contreras y Miguel Luis Glave (eds.), La Independencia del Perú ¿Concedida, conseguida, concebida?, Lima, Instituto de Estudios Peruanos, pp. 453 484.

(1999) "La minería peruana en el siglo XVIII", en Scarlett O’Phelan Godoy (comp.), El Perú en el siglo XVIII, Lima, Instituto Riva-Agüero, pp. 13-35.

(1994) "Guayaquil y su región en el primer boom cacaotero (17501820)", en Juan Maiguashca (ed.), Historia y región en el Ecuador. 1830-1930, Quito, Facultad Latinoamericana de Ciencias Sociales/Corporación Editora Nacional, pp. 189-250.

(1990) El sector exportador de una economía colonial: la costa del Ecuador entre 1760 y 1820, Quito, Facultad Latinoamericana de Ciencias Sociales.

(1982) La ciudad del mercurio. Huancavelica 1570-1700, Perú, Instituto de Estudios Peruanos.

Cook, David, (1968)

Padrón de los indios de Lima en 1613, Lima, Seminario de Historia Rural Andina, Universidad Nacional Mayor de San Marcos.

"Copia de carta original del Cardenal Arzobispo de Sevilla al rey sobre el remedio de la contratación de las Islas Filipinas con la Nueva España y el Perú" [1603] (1845), Colección de Documentos inéditos para la historia de España, Madrid, Imprenta de la viuda de Calero, tomo LII, pp. 565-572.

Cross, Harry (1983)

"South American Bullion Production and Export 1550-1750", en John Richards (ed.), Precious Metals in the later Medieval and 
early Modern Worlds, Durham, Carolina Academic Press, pp. 397-423.

DANe, Hendrik (1967)

"Primeras relaciones diplomático-comerciales entre Alemania y México", Historia Mexicana, El Colegio de México, México, vol. 17, núm. 1, pp. 72-102.

De Morua, Martín (1946)

Los orígenes de los Inkas, Lima, Pequeños grandes libros de Historia Americana.

De VRIEs, Jan (2009)

La revolución industriosa. Consumo y economía doméstica desde 1650 hasta el presente, Barcelona, Crítica.

Del Cantillo, Alejandro (1843)

Tratados, convenios y declaraciones de paz y comercio que han hecho con las potencias extranjeras los monarcas españoles de la casa de Borbón desde el año 1700 hasta el día de hoy, Madrid, Alegría y Charlain.

Delgado Rivas, Josep (1982)

"El impacto de las crisis coloniales en la economía catalana (17871807)", en Josep Fontana (ed.), La economía española al final del Antiguo Régimen, III. Comercio y colonias, Madrid, Banco de España, pp. 99-169.

DERMIGNY, Louis (1964)

La Chine et loccident. Le commerce á Canton, 1719-1833, 4 vols. París, SEVEN.

Díaz Trechuelo, María de Lourdes (1965)

La Real Compañía de Filipinas, Sevilla, Escuela de Estudios Hispanoamericanos/Consejo Superior de Investigaciones Científicas.

Dilg RoberTson, George (1975)

The Collapse of the Portobelo Fairs; A Study in Spanish Commercial Reform, 1720-1740, tesis de doctorado, Indiana University. 
Dirlik, Arif (1992)

"The Asia-Pacific Idea: Reality and Representation in the Invention of a Regional Structure", Journal of World History, vol. 3, núm. 1, pp. 55-79.

"Descripción de Panamá y su Provincia sacada de la Relación que por mandado del Consejo hizo y envió aquella Audiencia" [1607] (1908), Relaciones históricas y geográficas de América Central, Madrid, Librería General de Victoriano Suárez, pp. 137-218.

Duchesne, Ricardo (2002)

"Between Sinocentrism and Eurocentrism: Debating Andre Gunder Frank's Re-Orient: Global Economy in the Asian Age", Science \& Society, vol. 65, núm. 4, pp. 428-463.

EnCINAs, Diego [1596] (1946)

Cedulario indiano, Madrid, Cultura Hispánica.

Escamilla González, Iván (2011)

Los intereses malentendidos. El Consulado de la Ciudad de México y la monarquía española, México, Universidad Nacional Autónoma de México.

Findlay, Ronald y O'Rourke, Kevin (2007)

Power and Plenty. Trade, War, and the World Economy in the Second Millennium, Princeton/Oxford, Princeton University Press.

FisHer, John (1996)

"Estructuras comerciales en el mundo hispánico y el reformismo borbónico", en Agustín Guimerá (ed.), El reformismo borbónico, Madrid, Alianza, pp. 109-122.

Flores Guzmán, Ramiro (2011)

"La complejidad del proceso de construcción regional: los casos de Trujillo y Arequipa durante la época colonial", en Cristina Mazzeo (ed.), Las relaciones de poder en el Perú. Estado, regiones e identidades locales siglos XVII-XIX, Lima, Pontificia Universidad Católica del Perú, pp. 39-85. 
(2010) "Los balleneros anglonorteamericanos y la apertura comercial del Pacífico sur a fines de la época colonial (17901820)", Histórica, Perú, Universidad Católica del Perú, vol. 34, núm. 2, pp. 63-98.

(1995) "El secreto encanto de Oriente. Comerciantes peruanos en la ruta transpacífica (1590-1610)", en Scarlett O'Phelan Godoy y Carmen Salazar Soler (eds.), Passeurs, mediadores culturales y agentes de la primera globalización en el mundo ibérico, siglos XVI-XIX, Lima, Pontificia Universidad Católica del Perú, pp. 377-409.

Florescano, Enrique y Castillo, Fernando (eds.) (1975)

Controversia sobre la libertad de comercio en Nueva España, 17661818, tomo II, México, Instituto de Comercio Exterior.

FlynN, Dennis (1996)

"China and the Spanish Empire", Revista de Historia Económica, Madrid, Universidad Carlos III, vol. 14, núm. 2, pp. 309-338.

FlynN, Dennis y Giráldez, Arturo (2014)

"Los orígenes de la globalización en el siglo Xvi", en Bernd Hausberger y Antonio Ibarra (coords.), Oro y plata en los inicios de la economía global: de las minas a la moneda, México, El Colegio de México, pp. 29-76.

(2002) "Cycles of Silver: Global Economic Unity through the Mid-Eighteenth Century", Journal of World History, vol. 13, núm. 2, pp. 391-427.

(1995) "Born with a Silver Spoon: The Origin of World Trade in 1571", Journal of World History, vol. 6, núm. 2, University of Hawai'i Press, pp. 201-221.

Fontana, Josep (1982)

La economía española al final del Antiguo Régimen, III. Comercio y colonias, Madrid, Banco de España, pp. 13-34.

Furber, Holden (1976)

Rival Empires of Trade in the Orient 1600-1800, Minneapolis, University of Minnesota Press. 
Ganci, Massimo y Ruggiero, Romano (1991)

Gobernare il mondo. L'imperio spagnolo dal XV al XIX secolo, $\mathrm{Pa}$ lermo, Facoltá di Lettere-Università di Palermo.

Garavaglia, Juan Carlos (2005)

"La cuestión colonial", Nuevo Mundo. Mundos Nuevos, consultado el 29 de septiembre de 2017, [http://nuevomundo.revues. org/441].

GARCía BAQUero, Antonio (1992)

La carrera de Indias: Suma de la contratación y océano de negocios, Sevilla, Algaida.

(1997) Los peruleros y el comercio de Sevilla con las Indias, 15801630, Sevilla, Universidad de Sevilla.

(1976) Cádiz y el Atlántico (1717-1778), vol. I, Sevilla, Escuela Hispanoamericana de Sevilla.

García Fuentes, Lutgardo (1997a)

"Cambios en la demanda y monopolio de la oferta: un nuevo enfoque de las relaciones comerciales entre España y las Indias (1580-1630)", en Carmen Yuste (coord.), Comercio marítimo colonial. Nuevas interpretaciones y últimas fuentes, México, Instituto Nacional de Antropología e Historia, pp. 149-164.

(1997b) Los peruleros y el comercio de Sevilla con las Indias, 15801630, Sevilla, Universidad de Sevilla.

(1980) El comercio español con América, 1650-1700, Sevilla, Escuela de Estudios Hispanoamericanos de Sevilla.

Glave, Luis Miguel (1997)

"La puerta del Perú. Paita y el extremo norte peruano, 16001615”, en Carmen Yuste (coord.), Comercio marítimo colonial. Nuevas interpretaciones y últimas fuentes, México, Instituto Nacional de Antropología e Historia, pp. 101-126.

GoldwERT, Marvin (1957-58)

"La lucha por la perpetuidad de las encomiendas en el Perú virreinal (continuación)", Revista Histórica, Lima, vol. XXIII, pp. 207-245. 
GonZÁleZ De MendozA, Juan [1585]

Historia de las cosas más notables, ritos y costumbres del gran reino de la China, en Félix García (ed.), Madrid, Aguilar, s/f de edición.

Gonzalez Villanueva, Luis Edilberto (1997)

"México-Filipinas en la transformación de las relaciones transpacíficas (1821-1854)", tesis de licenciatura, México, El Colegio de México.

Grau y Monfalcón, Juan (1640)

Justificación de la conservación y comercio de las islas Filipinas, Madrid.

GRUZINSKI, Serge (2010)

Las cuatro partes del mundo. Historia de una mundialización, México, Fondo de Cultura Económica.

GuARDA, Gabriel (1978)

Historia Urbana del reino de Chile, Chile, Editorial Universitaria.

GulLiver, Katrina (2011)

"Finding the Pacific World", Journal of World History, vol. 22, núm. 1, pp. 83-100.

Gunder Frank, Andre (1998)

ReOrient: Global Economy in the Asian Age, Londres, University of California Press.

Halperin Donghi, Tulio (2005)

Guerra y finanzas en los orígenes del Estado argentino (1791-1850), Buenos Aires, Prometeo Libros.

Hamerly, Michel (1973)

Historia social y económica de la Antigua Provincia de Guayaquil, Guayaquil, Publicaciones del Archivo Histórico de Guayas.

Hamilton, Earl (1975)

El tesoro americano y la revolución de los precios en España, 15011650, Barcelona, Ariel. 
HAMneTt, Brian (1978)

Revolución y contrarrevolución en México y el Perú (Liberalismo, realeza y separatismo 1800-1824), México, Fondo de Cultura Económica.

HANG-SHENG, Chuan (1997)

"Trade between China, The Philippines and the Americas During the Sixteenth and Seventeenth Centuries", en Dennis Flynn y Arturo Giráldez (coords.), Metals and Monies in an Emerging Global Economy, Hampshire, Variorum, pp. 845-853.

HANKe, Lewis (1979-80)

Los Virreyes españoles en América durante el gobierno de la Casa de Austria. Perú, tomos III, v, vi, Madrid, Atlas.

HARING, Clarence (1939)

Comercio y navegación entre España y las Indias en la época de los Habsburgos, México, Fondo de Cultura Económica.

Hausberger, Bernd (2018)

La globalización temprana, México, Centro de Estudios Históricos-El Colegio de México, Colección Historia Mínima.

(2007) Reseña de "Latin America and the Atlantic World/Essays in honor of Horst Pietschmann. El mundo atlántico y América Latina (1500-1850)", de Renate Pieper y Peer Schmidt (eds.), Historia Mexicana, Centro de Estudios Históricos-El Colegio de México, vol. LVII, núm. 1, pp. 279-291.

Hausberger, Bernd e Ibarra, Antonio (coords.) (2014)

Oro y plata en los inicios de la economía global: de las minas a la moneda, México, El Colegio de México.

Heckscher, Eli Filip (1943)

La época mercantilista, México, Fondo de Cultura Económica.

Hernández Jaimes, Jesús (2008)

"El fruto prohibido. El cacao de Guayaquil y el mercado novohispano, siglos XVI-XVIII", Estudios de Historia Novohispana, México, Universidad Nacional Autónoma de México, núm. 39, pp. 43-79. 
Herrera, Miguel (2001),

"Gentes de la mar. Marinos y comerciantes en el Pacifico central mesoamericano, 1830-1860", Revista de Historia, Costa Rica, Universidad de Costa Rica, núm. 43, pp. 237-243.

Hoberman, Louisa (1991)

Mexico's Merchant Elite, 1590-1660: Silver, State and Society, Durham, Duke University Press.

Hopkins, Antony (ed.) (2002)

Globalization in World History, Londres, Norton \& Company.

Humboldt, Alexander von [1811] (1953)

Ensayo Político sobre el reino de la Nueva España, México, Compañía General de Ediciones.

IACCARINo, Ubaldo (2011)

"The 'Galleon System' and Chinese Trade in Manila at the Turn of the 16th Century", Ming Qing Yanjiu, Italia, University of Naples l’Orientale, vol. 16, núm. 1, pp. 95-128.

IBARRA, Antonio (2007)

"Redes de circulación y redes de negociantes en Guadalajara colonial: mercado, élite comercial e instituciones", Historia Mexicana, México, Centro de Estudios Históricos-El Colegio de México, vol. 56 (3), pp. 1017-1041.

(2000) "Mercado urbano y mercado regional en la Guadalajara colonial, 1770-1810", tesis de doctorado, Centro de Estudios Históricos-El Colegio de México.

(1996) "Plata, importaciones y mercado colonial. Circulación interior de importaciones: de Guadalajara al septentrión novohispano (1798-1818)", Siglo XIX. Cuadernos de Historia, Universidad Autónoma de Nuevo León, año vi, 16, pp. 7-38.

Ibarra, Antonio y Valle Pavón, Guillermina (coords.) (2007) Redes sociales e instituciones comerciales en el Imperio español, siglos XVII a XIX, México, Instituto Mora/Facultad de Economía-Universidad Nacional Autónoma de México. 
IRIGOIN, Alejandra (2009)

"The End of a Silver Era: The Consequences of the Breakdown of the Spanish Peso Standard in China and the United States, 1780s-1850s", Journal of World History, vol. 20, núm. 2, pp. 207-243.

IRIgoin, Alejandra y Schmit, Roberto (eds.) (2003)

La desintegración de la economía colonial: comercio y moneda en el interior del espacio colonial 1800-1860, Buenos Aires, Biblos.

IsRAEL, Jonathan (1980)

Razas, clases sociales y vida política en el México colonial, 16101670, México, Fondo de Cultura Económica.

Iwasaki Cauti, Fernando (1992)

Extremo Oriente y Perú en el siglo XVI, Madrid, Mapfre.

(1990), "La primera navegación transpacífica entre Perú y Filipinas y su trasfondo económico", Anuario de Estudios Americanos, Sevilla, núm. 47, pp. 123-169.

Jaramillo BaAnante, Miguel (1998)

"El comercio de la cascarilla en el norte peruano-sur ecuatoriano: evolución e impacto regional de una economía de exportación, 1750-1796", en Scarlett O'Phelan Godoy e Yves Saint-Geours (comps.), El Norte en la Historia Regional. Siglos XVIII-XIX, Lima, Instituto Francés de Estudios Andinos-Centro de Investigación y Promoción del Campesinado, pp. 51-94.

Johnson, Lyman y Socolow, Susan (1980)

"Población y espacio en el Buenos Aires del siglo XVIII", Desarrollo Económico, Revista de Ciencias Sociales, Buenos Aires, vol. 20, núm. 79, pp. 329-349.

JUMAR, Fernando (2009)

"La circulación mercantil revelada por las guías de aduana de Buenos Aires, 1779-1783", en José Mateo y Agustín Nieto (comps.), Hablemos de puertos: La problemática portuaria desde las ciencias sociales, Mar del Plata, Grupo de Estudios Sociales Marítimos-Universidad de Mar del Plata, pp. 21-34. 
(2002) Le commerce atlantique au Río de la Plata, 1680-1778, Villeneuve d'Ascq, Presses Universitaires du Septentrion.

Jumar, Fernando y PARedes, Isabel (2008)

"El comercio intrarregional en el complejo portuario rioplatense: el contrabando visto a través de los comisos, 1693-1777", América Latina en la Historia Económica, México, Instituto Mora, núm. 23, pp. 33-99.

Kindleberger, Charles (1989)

Spenders and Hoarders. The World Distribution of Spanish American Silver, 1550-1750, Singapur, Institute of Southeast Asian Studies.

Kuntz Ficker, Sandra (2015)

"Notas sobre las estadísticas del comercio exterior de México, 1796-1820", en José Alberto Uribe Salas y Eduardo Flores Clair (coords.), Comercio y Minería en la Historia de América Latina, México, Universidad Nacional de San Miguel de Hidalgo/ Instituto Nacional de Antropología e Historia, pp. 35-69.

LAMIKIZ, Xabier (2010)

Trade and Trust in the Eighteenth-Century Atlantic World, Spanish Merchants and their Overseas Networks, Londres, The Royal Historical Society/The Boydell Press.

(2007) "Patrones de comercio y flujo de información comercial entre España y América durante el siglo XVIII", Revista de Historia Económica / Journal of Iberian and Latin American Economic History, Cambridge, Second Series, vol. 25, núm. 2, pp. 233-260.

Latasa Vasallo, Pilar y Fariñas de Alba, Maribel (2002)

"Limitaciones legales al comercio transpacífico: actitud del virrey Montesclaros", en Feliciano Barrios (ed.), Derecho y administración pública en las Indias Hispánicas, Cuenca, Ediciones de la Universidad de Castilla-La Mancha, vol. I, pp. 877-897.

(1991) "El comercio triangular entre Filipinas, México y Perú a comienzos del siglo XVII", Revista Naval, vol. IX, núm. 35, pp. 13-35. 
LEMPÉRIÈRE, Annick (2005)

"La cuestión colonial", Nuevo Mundo Mundos Nuevos, consultado el 29 de septiembre de 2017, [http://nuevomundo.revues. org/437].

LEón, Jorge (2001)

“Comercio por el Mar del Sur o Pacífico, 1790-1800", en Revista de Historia, Costa Rica, Universidad de Costa Rica, núm. 43, pp. 289-346.

León de Borja, Dora y SzÁsdi Nagy, Adam (1964)

"El comercio de cacao de Guayaquil", Revista de Historia de América, México, Instituto Panamericano de Geografía e Historia, núms. 57-58, pp. 1-50.

León Portocarrero, Pedro de [1620] (2009)

Descripción del virreinato del Perú, Lima, Universidad Ricardo Palma.

Lerdo de Tejada, Miguel [1853] (1967)

Comercio exterior de México. Desde la conquista hasta hoy, estudio introductorio de Luis Córdoba, México, Banco Nacional de México.

LlORCA-JañA, Manuel (2012)

The British Textile Trade in South America in the Nineteenth Century, Cambridge, Cambridge University Press.

LOHMANN Villena, Guillermo (1999)

Las minas de Huancavelica en los siglos XVI y XVII, Lima, Pontificia Universidad Católica del Perú.

LoosLey, Allyn (1933)

“The Puerto Bello Fairs", Hispanic American Historical Review, Duke University Press, vol. XIII, núm. 3, pp. 315-334.

López Cancelada, Juan (1811)

Ruina de la Nueva España si se declara el comércio libre con los extranjeros, Madrid, Santiago Quintana. 
Lorenzo Sanz, Eufemio (1979)

Comercio de España con América en la época de Felipe II, Los mercaderes y el tráfico indiano, tomo I, Valladolid, Instituto Cultural Simancas.

LYNCH, John (1969)

Spain Under the Habsburgs, Spain and America, 1598-1700, Oxford, Basil Blackwell.

\section{MacLeOd, Murdo (1973)}

Spanish Central America. A Socioeconomic History, 1520-1720, Berkeley/Los Ángeles, University of California Press.

Maddison, Angus (1998)

Chinese economic performance in the long run, París, Organización para la Cooperación y el Desarrollo Económicos.

Malamud, Carlos (1986)

Cádiz y Saint Malo, en el comercio colonial peruano (1698-1725), Cádiz, Diputación de Cádiz.

(1982) "España, Francia y el comercio directo con el espacio peruano (1695-1730: Cádiz y Saint-Maló”, en Josep Fontana (ed.), La economía Española al final del Antiguo Régimen, III. Comercio y colonias, Madrid, Banco de España, pp. 3-95.

Marichal, Carlos (2017)

"El peso de plata hispanoamericano como moneda universal del antiguo régimen (siglos XVI a XVIII)", en Steven Topik, Carlos Marichal y Zephyr Frank (coords.), De la plata a la cocaína. Cinco siglos de historia económica de América Latina, 15002000, México, Fondo de Cultura Económica/El Colegio de México, pp. 37-75.

(1999) La Bancarrota del Virreinato, Nueva España y las finanzas del Imperio, 1780-1810, México, El Colegio de México/Fideicomiso Historia de las Américas/Fondo de Cultura Económica.

(1996) "El comercio, la fiscalidad y el crédito en el virreinato de la Nueva España, 1760-1820: bibliografía reciente”, en Eugenia Romero Ibarra (coord.), Historia y economía: un nuevo 
diálogo, México, Dirección General de Asuntos del Personal Académico-Facultad de Economía-Universidad Nacional Autónoma de México/Claves Latinoamericanas, pp. 247-280.

Márquez Morfín, Lourdes y Hernández Espinoza, Patricia (2016)

"La experiencia de vida en la ciudad de México (siglos XVI al XIx)", Secuencia, México, Instituto Mora, núm. 96, pp. 6-44.

Marx, Karl y Engels, Friedrich (1975)

China ¿fósil viviente o trasmisor revolucionario?, Knauth, Lothar (ed.), México, Universidad Nacional Autónoma de México-Facultad de Ciencias Políticas y Sociales.

Matsuda, Matt (2006)

"The Pacific", The American Historical Review, Oxford University

Press, vol. 111, núm. 3, pp. 758-780.

MAYo, John (2001)

“The Development of British Interests in Chile's Norte Chico in the Early Nineteenth Century", The Americas, vol. 57, núm. 3, pp. 363-394.

(1991) "Imperialismo de Libre Comercio e imperialismo informal en la costa oeste de México durante la época de Santa Anna”, Historia Mexicana, México, El Colegio de México, vol. 40, núm. 4, pp. 672-696.

Mazzeo de Vivó, Cristina (2012)

"Las transformaciones del Estado colonial y el poder de las élites limeñas en la construcción del Perú Republicano", en Cristina Mazzeo (ed.), Las relaciones de poder en el Perú. Estado, Regiones e Identidades locales siglos XVII-XIX, Lima, Pontificia Universidad Católica del Perú, pp. 173-214.

McEvedy, Colin y Jones, Richard (1978)

Atlas of World Population History, Harmondsworth, Penguin.

McKendrick, Neil, Brewer, John y Plumb, John (1982)

The Birth of a Consumer Society. The comercialization of Eighteenth Century England, Bloomington, Indiana University Press. 
McMaster, John (1959)

"Aventuras asiáticas del peso mexicano", Historia Mexicana, México, Centro de Estudios Históricos-El Colegio de México, vol. 8, núm. 3, pp. 372-399.

Mejía Cubillos, Javier (2011)

"Una interpretación neoclásica del fin del Galeón de Manila", Contribuciones a la Economía, Málaga, consultado el 14 de junio de 2018, [https://www.academia.edu/1030495/Una_interpretaci\%C3\%B3n_neocl\%C3\%A1sica_del_fin_del_Gale\%C3\%B3n_de_Manila].

Melitz, Jacques (2017)

"Some Doubts About the Economic Analysis of the Flow of Silver to China in 1550-1820", CEPR Discussion Paper No. DP12427, [https://ssrn.com/abstract=3071059], pp. 1-41.

Melville, Herman (1930)

Mobby Dick, Nueva York, The Modern Library.

Meyer, Jean (2008)

Breve Historia de Nayarit, México, El Colegio de México/Fideicomiso Historia de las Américas (Breve Historia de los Estados).

Miño Grijalva, Manuel (2016)

El Obraje. Fábricas primitivas en el mundo hispanoamericano en los albores del capitalismo (1530-1850), México, El Colegio de México.

(2013) El Cacao Guayaquil en Nueva España, 1774-1812 (Política imperial, mercado y consumo), México, El Colegio de México.

(1998) Obrajes y tejedores de Nueva España, 1700-1810. La industria urbana y rural en una economía colonial, México, El Colegio de México.

(1988) "La política textil en México y Perú en la época colonial", Historia Mexicana, México, Centro de Estudios Históricos-El Colegio de México, 38(2), pp. 283-321.

(1984) La economía colonial. Relaciones socio-económicas de la Real Audiencia de Quito. Quito, Corporación Editora Nacional. 
Miño Grijalva, Manuel, Pérez Toledo, Sonia y Sánchez MiCHEL, Valeria (2004)

La población de la ciudad de México en 1790. Estructura social, alimentación y vivienda, México, Universidad Autónoma Metropolitana-Departamento de Filosofía.

Molina, Raúl (1962)

"La defensa del comercio del Río de la Plata por el Licenciado D. Antonio de León Pinelo", Revista Historia, Buenos Aires, Crisol, núm. 26, pp. 37-112.

MonsÉGUR, Jean de (1994)

Las Nuevas Memorias del capitán Jean de Monségur, en Jean Pierre Berthe (eds.), México, Universidad Nacional Autónoma de México.

Moreyra Paz-Soldán, Manuel (1956)

El Tribunal del Consulado de Lima, Cuadernos de Juntas (17061720), Documentos para la historia económica del Virreinato del Perú, Lima, 1956.

(1944) Estudios sobre el tráfico marítimo en la época colonial, Lima, Librería e Imprenta Gil.

Moreyra Paz-Soldán, Manuel y Céspedes del Castillo, Guillermo (comps.) (1955)

Virreinato Peruano. Documentos para su historia. Colección de cartas de Virreyes. Conde de Monclova, tomos 1, 2 y 3, Lima, Lumen.

Morga, Antonio [1609] (1890)

Sucesos de las Islas Filipinas por el doctor Antonio de Morga. Obra publicada en México en 1609 nuevamente sacada a la luz por José Rizal, París, Librería de Garnier Hermanos.

Morineau, Michel (1985)

Incroyables gazettes et fabuleux métaux, Londres, Cambridge University Press. 
Moutoukias, Zacarías (1988)

Contrabando y control colonial en el siglo XVII: Buenos Aires, el Atlántico y el espacio peruano, Buenos Aires, Centro Editor de América Latina.

MuÑoz PÉrez, José (1947)

"La publicación del Reglamento de Comercio Libre de Indias", Anuario de Estudios Americanos, Sevilla, vol. IV, pp. 615-643.

Murúa, Fray Martín de [1590] (1946)

Los orígenes de los inkas, Perú, Imprenta Bermejo.

[1590] (1962) Historia General del Perú, Madrid, Biblioteca Americana Vetus.

NAKAMURa, Yuko (2007)

"Importación y la demanda de bienes importados de Nueva España, 1767-1810", tesis de doctorado, México, El Colegio de México.

Navarro García, Luis (1965)

"El comercio interamericano por la mar del Sur en la edad moderna”, Revista de Historia, Caracas, núm. 23, pp. 11-55.

Noejovich, Héctor Omar (2009)

"La transición del sistema prehispánico al sistema económico colonial", en Carlos Contreras (ed.), Economía del periodo colonial temprano. Compendio de la Historia económica del Perú, tomo II, Lima, Banco Central de la Reserva del Perú- Instituto de Estudios Peruanos, pp. 23-208.

Oliva Melgar, José María (2005)

"La metrópoli sin territorio ¿Crisis del comercio de Indias en el siglo XVIII o pérdida del control de monopolio?, en Martínez Shaw y Oliva Melgar (eds.), El Sistema Atlántico español (siglos XVII-XIX), Madrid, Marcial Pons, pp. 19-73.

OlvedA, Jaime (2003)

El comercio entre Guadalajara y Panamá, México, El Colegio de Jalisco/Secretaría de Relaciones Exteriores/Unidad de Asuntos Culturales de la Embajada de México en Panamá. 
Orsúa y Vela, Arzans de (1965)

Historia de la Villa Imperial de Potosí, Hanke Lewis y Gunnar Mendoza (eds.), Providence, Brown University Press, tomo I.

Ortiz Hernán, Sergio (1994)

Caminos y Transportes en México. Una aproximación socioeconómica: fines de la Colonia y principios de la vida independiente, México, Fondo de Cultura Económica.

Pardo Hernández, Claudia Patricia (1997)

"El puerto de San Blas en la Nueva Galicia y su población a finales del siglo XVIII", Entorno Urbano. Revista de Historia, núm. 5-6, pp. 131-142.

Parrón SAlas, Carmen (1997)

"Perú y la transición del comercio político al comercio libre, 1740-1778", Anuario de Estudios Hispanoamericanos, Sevilla, Escuela de Estudios Hispanoamericanos, vol. 54, pp. 447-475. (1995) De las Reformas borbónicas a la República: El Consulado y el comercio marítimo de Lima, 1778-1821, España, Murcia, Academia General del Aire.

Pearce, Adrian (2007)

British Trade with Spanish America, 1763-1808, Liverpool, Liverpool University Press.

Peñaloza y Mondragón, Benito de (1629)

Libro de las Cinco Excelencias del español que despueblan a España para su mayor potencia y dilación, Pamplona, Navarra.

Pereira Salas, Eugenio (1971)

Los primeros contactos entre Chile y los Estados Unidos 1778-1809, Santiago de Chile, Andrés Bello.

PÉrez Cantó, Pilar (1982)

"La población de Lima en el siglo XviII", Boletín Americanista, Universidad de Barcelona, Facultad de Geografía e Historia, núm. 32, pp. 383-407. 
PÉrez García, Manuel (2014)

"From Eurocentrism to Sinocentrism: New Challenges in Global History", European Journal of Scientific Research, vol. 119, núm. 3, pp. 337-352.

Pérez Herrero, Pedro (1991)

"Los beneficiarios del reformismo borbónico: metrópoli versus elites novohispanas", Historia Mexicana, México, Centro de Estudios Históricos-El Colegio de México, vol. LXI, núm. 2, pp. 207-264.

(1988) Plata y Libranzas. La articulación comercial del México borbónico, México, El Colegio de México.

(1983) "Actitudes del Consulado de México ante las reformas comerciales borbónicas (1718-1765)", Revista de Indias, Madrid-Sevilla, Consejo Superior de Investigaciones Científicas, vol. XLIII, núm. 171, pp. 77-182.

PÉrez LeCha, Manuel (2016)

"Negocios en tiempos difíciles: comercio transpacífico en el contexto bélico español de finales del siglo Xviı", en Salvador Bernabéu y Carmen Mena García (coords.), Filipinas y el Pacífico: nuevas miradas, nuevas reflexiones, Sevilla, Universidad de Sevilla, pp. 163-180.

Pérez-Mallaina, Pablo (1982)

Política Naval Española en el Atlántico 1700-1715, Sevilla, Escuela de Estudios Hispanoamericanos/Consejo Superior de Investigaciones Científicas.

Perusset Veras, Macarena (2005)

"Élite y comercio en el temprano siglo XVII rioplatense", Fronteras de la Historia, Instituto Colombiano de Antropología e Historia, Bogotá, núm. 10, pp. 285-304.

Petitjean, Martine y Saint-Geours, Yves (1998)

"La economía de la cascarilla en el Corregimiento de Loja (segunda mitad del siglo XVIII-principios del siglo XIX", en Scarlett O’Phelan Godoy e Yves Saint-Geours (comps.), El Norte en la Historia Regional. Siglos XVIII-XIX, Lima, Instituto Francés de 
Estudios Andinos/Centro de Investigación y Promoción del Campesinado, pp. 15-50.

PiePer, Renate y Schmidt, Pee (eds.) (2005)

Latin America and the Atlantic World, Colonia, Böhlau Verlag Köln Weimar Wien.

Pomeranz, Kenneth (2000)

The Great Divergence: China, Europe and the Making of the Modern World Economy, Princeton, Princeton University Press.

Pomeranz, Kenneth y Topik, Steven (2006)

The World that Trade Created. Society, Culture and the World Economy. 1400 to the Present, Nueva York, M. E. Sharpe.

Prakash, Om (2001)

“Global Precious Metal Flows and India, 1500-1750”, en John McGuire, Patrick Bertola y Peter Reeves (coords.), Evolution of the World Ec2001, Economy, Precious Metals and India, Nueva York, Oxford University Press, pp. 59-76.

Rahn Phillips, Carla (2007)

"The Organization of Oceanic Empires: The Iberian world in the Habsburg Period", en Jerry Bentley, Renate Bridenthal y Kären Wigen (eds.), Seascapes. Maritime Histories, Littoral Cultures, and Transoceanic Exchanges, Hawái, University of Hawai'i Press, pp. 71-86.

Ramírez CABAÑas, Joaquín (1944)

Comercio extranjero por el Puerto de San Blas, en los años 1812 a 1817, México, Dirección de Estudios Financieros.

RAMOs PÉREZ, Demetrio (1970)

Minería Comercio interprovincial en Hispanoamérica (siglos XVI, XVII y XVIII), Valladolid, Universidad de Valladolid.

Reyes García, Luis (2015)

"Resultas del viaje de dos navíos peruleros a la Nueva España en 1610", Antropología, México, Instituto Nacional de Antropología e Historia, núm. 100, pp. 113-121. 
RichaRDS, John (ed.) (1983)

Precious Metals in the Later Medieval and Early Modern World, Durham, Carolina Academic Press.

Robles, Antonio (1946)

Diario de Sucesos Notables (1665-1703), 3 tomos, México, Porrúa.

Roche, Daniel (2003)

A History of Everyday Things. The Birth of Consumption in France, 1600-1800, Nueva York, Cambridge University Press.

Rodríguez Vicente, María Encarnación (1960)

El Tribunal del Consulado de Lima en la primera mitad del siglo XVII, Madrid, Ediciones de Cultura Hispánica.

Romano, Ruggiero (1998)

Moneda, seudomonedas y circulación monetaria en las economías de México, México, El Colegio de México.

RosenblitT, Jaime (2014)

"De arrieros a mercaderes. Orígenes de los comerciantes de la región Tacna-Arica, 1776-1794", Revista de Indias, Madrid-Sevilla, Consejo Superior de Investigaciones Científicas, vol. LXXIV, núm. 260, pp. 35-66.

Rubio SÁnchez, Manuel (1975)

Historial de El Realejo, Nicaragua, Fuentes Históricas núm. 4, Colección Cultural Banco de América.

Rueda Ramírez, Pedro (2014)

"Las redes comerciales del libro en la Colonia: 'peruleros' y libreros en la Carrera de Indias (1590-1620)”, Anuario de Estudios Americanos, Sevilla, vol. 71, núm. 2, pp. 447-478.

SAguier, Ernest (1985)

"Political impact of immigration and commercial penetration on intracolonial struggles: Buenos Aires in the early seventeenth century", Jahrbuch für Geschichte Lateinamerikas, Hamburgo, núm. 22, pp. 43-166. 
Salazar-Soler, Carmen (2009)

"Minería y Moneda en la época colonial temprana", en Carlos Contreras (ed.), Economía del período colonial temprano. Compendio de la Historia económica del Perú, tomo II, Lima, Banco Central de la Reserva del Perú/Instituto de Estudios Peruanos, pp. 109-228.

Sales Colín, Ostwald (2007)

"Una coyuntura en el comercio transpacífico: fuentes complementarias para la visita de Pedro de Quiroga en Acapulco, 1635-1640", en Carmen Yuste (coord.), Comercio marítimo colonial. Nuevas interpretaciones y últimas fuentes, México, Instituto Nacional de Antropología e Historia, pp. 127-146.

Salvucci, Richard (1992)

Textiles y capitalismo en México. Una historia económica de los obrajes, 1539-1840, México, Alianza.

SÁnCHez Albornoz, Nicolás (1994)

"La Población de la América colonial española", en Leslie Bethell (ed.), Historia de América Latina. 4. América Latina colonial: población, sociedad y cultura, Barcelona, Crítica, pp. 15-35.

SÁNCHEz SANTIRó, Ernest (2004)

"La población de la ciudad de México en 1777", Secuencia, México, Instituto Mora, núm. 96, pp. 31-56.

Santaella Stella, Roseli (1997)

"Entre a situação legal e a de fato: o comércio de Buenos Aires como Brasil no século Xvi", Cuadernos del Sur, Historia, Bahía Blanca, Argentina, núm. 26, pp. 16-22.

SCHURz, William [1939] (1992)

El Galeón de Manila, Madrid, Edición de Cultura Hispánica.

(1922) "The Spanish Lake", Hispanic American Historical Review, 5(2), pp. 181-194.

Silva-Herzog, Jesús (coord.) (1944)

Relaciones estadísticas de Nueva España de principios del siglo XIX, vol. III, México, Archivo Histórico de Hacienda/Secretaría de Hacienda y Crédito Público/Dirección de Estudios Financieros. 
Sin AUTOR (1944a)

Reales Cédulas, Reales Órdenes, Decretos, Autos y Bandos que se guardan en el Archivo Histórico, Ministerio de Hacienda, Archivo Histórico, Lima, Perú.

(1944b) Relaciones estadísticas de Nueva España de principios del siglo xIx, México, Secretaría de Hacienda y Crédito Público/Dirección de Estudios Financieros, vol. III.

SMith, Robert (1944)

"Antecedentes del Consulado de México, 1590-1594", Revista de Historia de América, México, núm. 15, pp. 300-313.

SosA, Tomás (1981)

"Breve reseña de la evolución demográfica de la ciudad de Panamá", Anuario de Estudios Centroamericanos, Costa Rica, vol. 7, pp. 111-129.

Souto Mantecón, Matilde (2001)

Mar abierto. La política y el comercio del Consulado de Veracruz en el ocaso del sistema imperial, México, El Colegio de México/ Instituto Mora.

(2000) "La transformación del Puerto de Veracruz en el siglo XVIII: de sitio de tránsito a sede mercantil", en Carmen Yuste y Matilde Souto Mantecón (coords.), El comercio exterior de México, 1713-1850. Entre la quiebra del sistema imperial al surgimiento de una nación, México, Instituto Mora/Instituto de Investigaciones Históricas-Universidad Nacional Autónoma de México/Universidad Veracruzana, pp. 110-139.

Spate, Oskar (1979-88)

The Pacific since Magellan, The Spanish Lake, vols. I, II, III, Londres, Cromm Helm.

(1978) "The Pacific as an Artifact”, en Neil Gunson (coord.), The Changing Pacific: Essays in Honor of H. E. Maude, Nueva York, Oxford University Press, pp. 32-45.

SuARDO, Juan Antonio [1629-1639] (1936)

Diario de Lima, en Rubén Vargas Ugarte (ed.), Lima, Universidad Católica del Perú. 
SuÁrez Espinosa, Margarita (2016)

"Metales preciosos, moneda y comercio. La participación del Perú en el mundo ultramarino, siglos XVI-XVIII", en Carlos Contreras (ed.), Historia de la Moneda en el Perú, Banco Central de la Reserva en el Perú/Instituto de Estudios Peruanos, pp. 155-197.

(2015) "Sedas, rasos y damascos: Lima y el cierre del comercio triangular con México y Manila en la primera mitad del siglo xviI", América Latina en la Historia Económica, México, Instituto Mora, núm. 2, pp. 101-134.

(2014) "Reforma, orden y concierto en el Perú del siglo XVII: el arbitrio de Joan de Belveder", Anuario de Estudios Americanos, Sevilla, España, vol. 71, núm. 1, pp. 25-46.

(2009) "El Perú en el mundo atlántico (1520-1739)", en Carlos Contreras (ed.), Economía del período colonial temprano. Compendio de la Historia económica del Perú, tomo II, Lima, Banco Central de la Reserva del Perú/Instituto de Estudios Peruanos, pp. 229-293.

(2001) Desafíos transatlánticos. Mercaderes, banqueros y el Estado en el Perú virreinal, 1600-1700, Lima, Fondo de Cultura Económica.

(1995) Comercio y fraude en el Perú colonial. Las estrategias mercantiles de un banquero, Lima, Instituto de Estudios Peruanos.

TANDETER, Enrique (1991)

"El eje Potosí-Buenos Aires en el imperio español”, en Massimo Ganci y Ruggiero Romano (eds.), Governare il mondo. L'impero spagnolo dal XV al XIX secolo, Palermo, Facoltá di Lettere Palermo, pp. 185-201.

TARDIFF, Guillermo (1968)

Historia General del Comercio Exterior Mexicano (Antecedentes, Documentos, Glosas y Comentarios 1503-1847), vol. I, México, Gráfica Panamericana.

Tellechea Idígoras, Ignacio (1989)

Martín Ignacio de Loyola. Viaje alrededor del mundo, Madrid, Historia 16. 
TePaske, John y Brown, Kendall (2010)

A New World of Gold and Silver, Atlantic world. Europe, Africa and the Americas, Leiden, Boston Brill, vol. 21.

TePaske, John y Klein, Herbert (1981)

"The Seventeenth-Century Crisis in New Spain: Myth or Reality?", Past and Present, núm. 90, pp. 116-131.

Torres Ramírez, Bibiano, Gil-Bermejo García, Juana, Vila Vilar, Enriqueta y Ortiz de la Tabla, Javier (comps.) (1978)

Cartas de cabildos hispanoamericanos, Sevilla, Escuela de Estudios Hispanoamericanos.

Trejo Barajas, Dení (2006a)

"El puerto de San Blas, el contrabando y el inicio de la internacionalización del comercio en el Pacífico Noroeste", Revista de Estudios Históricos, Morelia, Universidad Michoacana de San Nicolás de Hidalgo, núm. 44, pp. 11-48.

(2006b), "Implicaciones del comercio por el puerto de San Blas durante la guerra de Independencia", Revista de Indias, Madrid, vol. LXVI, núm. 238, pp. 711-736.

Tutino, John (2015)

"El debate sobre el futuro de México: en busca de una nueva economía, 1830-1845", Historia Mexicana, México, El Colegio de México, vol. 65, núm. 3, pp. 1119-1192.

UlLOA, Antonio y Juan, Jorge [1747] (1953)

Noticias Secretas de América (1747), Buenos Aires, Mar Océano.

UlloA, Bernardo [1740] (1992)

Restablecimiento de las fábricas y comercio español (1740), Madrid, Instituto de Estudios Fiscales.

VALDÉs LAKowsKy, Vera (1987)

De las minas al mar. Historia de la plata mexicana en Asia, 15651834, México, Fondo de Cultura Económica.

(1985) "Cambios en las relaciones transpacíficas: del Hispanis Mare Pacificum al océano Pacífico como vía de comunicación 
internacional", Estudios de Asia y África, México, El Colegio de México, vol. 20, núm. 1, 63, pp. 58-81.

VALDEZ-Bubnov, Iván (2017)

"El navío de 70 cañones de González Cabrera Bueno (1734): ¿un modelo tecnológico propio de la carrera de Filipinas?", en Jaime Olveda (ed.), Relaciones intercoloniales, México, El Colegio de Jalisco, pp. 63-87.

Valle Pavón, Guillermina del (2010)

"Comercialización del cacao de Guayaquil por los mercaderes del Consulado de México en la segunda mitad del siglo XVIII", Mexican Studies, vol. 26, núm. 2, pp. 181-206.

(2005) "Los mercaderes de México y la transgresión de los límites al comercio Pacífico en Nueva España, 1550-1620”, Revista de Historia Económica. La Economía en tiempos del Quijote, Madrid, vol. XXIII, pp. 213-240.

Veitia Linage, Joseph de (1945)

Norte de la Contratación de las Indias Occidentales, Buenos Aires, Comisión Argentina de Fomento Interamericano.

Vila Vilar, Enriqueta (1982)

"Las ferias de Portobelo: Apariencia y realidad del comercio con Indias", Anuario de Estudios Americanos, España, Escuela de Estudios Hispanoamericanos de Sevilla, xxxix, pp. 275-340. (1966) Los rusos en América, Sevilla, Escuela de Estudios Hispanoamericanos.

Vilar, Pierre (1982),

Oro y moneda en la Historia (1450-1920), Barcelona, Ariel.

Villa SÁnchez, Fray Juan [1746] (1835)

Puebla sagrada y profana. (Informe dado a su muy ilustre Ayuntamiento el año 1746), estudio introductorio de Javier de la Peña, Puebla, Impreso en la Casa del Ciudadano José María Campos. 
Villalobos, Sergio (1965)

Comercio y Contrabando en el Río de La Plata y Chile, 1700-1811, Buenos Aires, Universidad de Buenos Aires.

(1962) "El comercio extranjero a fines de la dominación española”, en Journal of Inter-American Studies, Center for Latin American Studies at the University of Miami, vol. 4, núm. 4, pp. 517-544.

Vives Anzacot, Pedro (1991)

"El Pacífico español: frontera imperial, frontera americana”, en Massimo Ganci y Ruggiero Romano (coords.), Gobernare il mondo. L'imperio spagnolo dal XV al XIX secolo, Palermo, Facoltá di Lettere, Università di Palermo, pp. 245-257.

Von Glahn, Richard (1996)

"Myth and Reality of China's Seventeenth-Century Monetary Crisis", The Journal of Economy History, vol. 56, núm. 2, pp. 429-454.

VRIES, Peer (2015)

State, Economy and the Great Divergence Great Britain and China, 1680s-1850s, Londres, Bloomsbury Academic.

WAINER, Luis (2010)

"La Ciudad de Buenos Aires en los Censos de 1778 y 1810", Población de Buenos Aires, Buenos Aires, Dirección General de Estadística y Censos de la Ciudad de Buenos Aires, vol. 7, núm. 11, pp. 75-85.

WALKer, Geoffrey (1979)

Política española y comercio colonial 1700-1789, Madrid, Ariel.

WALLERSTEIN, Immanuel (1979-99)

El moderno sistema mundial, vols. I, II y III, México, Siglo XXI.

Whitaker, Arthur Preston (1941)

The United States and the Independence of Latin America, 18001830, Baltimore, Johns Hopkins Press. 
Yuste, Carmen (2013)

"De la libre contratación a las restricciones de la permission. La andadura de los comerciantes de México en los giros iniciales con Manila, 1580-1610", en Salvador Bernabéu y Carlos Martínez Shaw (eds.), Un océano de seda y plata: el universo económico del Galeón de Manila, Sevilla, Consejo Superior de Investigaciones Científicas (Colección Universos Americanos), pp. 85-106.

(2007) Emporios Transpacíficos. Comerciantes mexicanos en $\mathrm{Ma}$ nila 1710-1815, México, Universidad Nacional Autónoma de México.

(1987) "Francisco Ignacio de Yraeta y el comercio transpacífico", Estudios de Historia Novohispana, México, Universidad Nacional Autónoma de México, vol. 9, pp. 189-217.

(1984) El Comercio de la Nueva España con Filipinas 1570-1785, México, Instituto Nacional de Antropología e Historia.

ZANIER, Claudio (2004)

"Pre-Modern European Silk Technology and East Asia: Who Imported What?", en Ma Debin, Textiles in the Pacific, 15001900, The Pacific World, vol. 12, Ashgate/Variorum, Aldershot, Hampshire, pp.105-190. 

La América española: entre el Pacífico y el Atlántico.

Globalización mercantil y economía política, 1580-1840, se terminó de imprimir en mayo de 2019, en los talleres de Gráfica Premier, S.A. de C.V., Calle 5 de Febrero 2309, col. San Jerónimo Chicahualco, 52170, Metepec, Estado de México. Portada: Enedina

Morales. Tipografía y formación: Logos Editores.

Dirección de Publicaciones de El Colegio de México. 


\section{CENTRO DE ESTUDIOS HISTÓRICOS}

En la actualidad, prevalece la idea de que la historia colonial hispanoamericana y la historia global constituyen áreas de estudio con poca relación, gestadas en circunstancias historiográficas diferentes. La percepción de mundos distantes se magnifica cuando vemos que el espacio hispanoamericano no goza de una agenda propia en los estudios globales; usualmente, se le contextualiza en una literatura con marcada perspectiva eurocéntrica o sinocéntrica. La América española intenta reconocer la especificidad histórica que adquirió este gran espacio en el lento transcurrir del trascendente cambio global, que va desde la centralidad china a la globalización occidental. En este sentido, los ejes geo-históricos construidos en la América española desde el siglo XVI hasta principios del XIX asumen un papel central en la investigación. La incorporación del gran espacio americano a la globalización no sólo fue viabilizada por estas estructuras espaciales, sino también por su función de puente transoceánico que comunica las economías del Atlántico y del Pacífico. Tal interacción estuvo marcada por efectos de gravitación, complementación y conflicto, un gran fenómeno histórico que en el libro se sintetiza y se periodiza en dos grandes momentos: el del Atlántico pacificado y el de la atlantización del Pacífico.
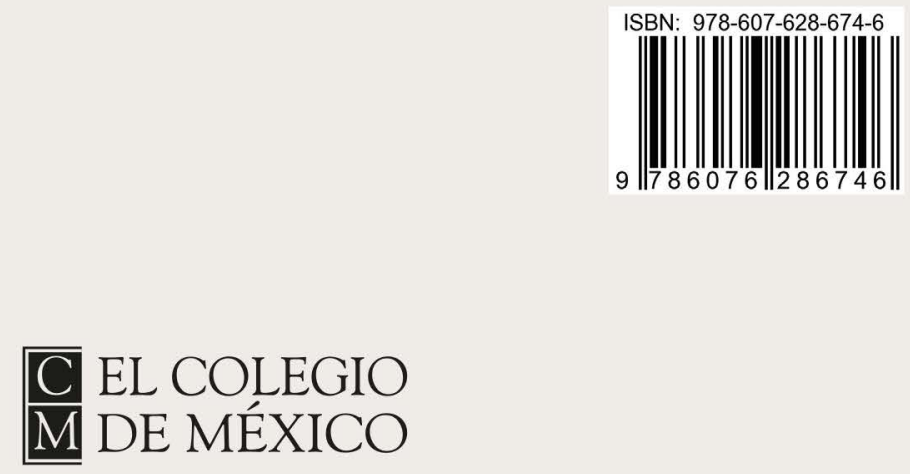